\title{
Simplified Design Guide for Estimating Photovoltaic Flat Array and System Performance
}

\author{
D. L. Evans, W. A. Facinelli, L. P. Koehler
}

Arizona State University, Tempe, AZ 85281 
Istued by Gandia National Laboratories, opezated for the United States Departantat of Energy by sandi Corporation.

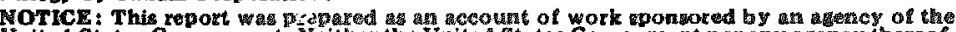

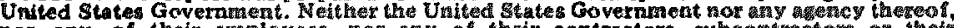
nos any of their employees, nor any of their contractors, subecontractorts or thes

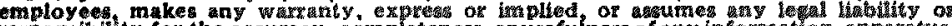

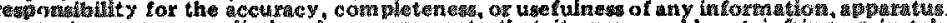

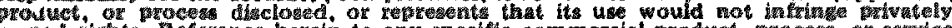

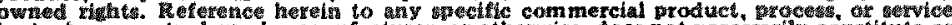

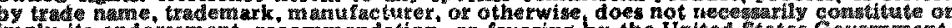

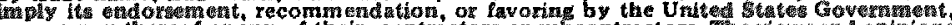

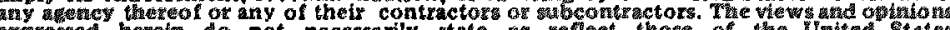
crpressed herein do not necessarily state of rellect thowe of the Unitud Stater Govertinent, any agency thereot or sny of their contractore or guboontracters.

Printed in the United States of Amorica

Available from

National Technical Information Sarvice U. S. Department of Commerce

5285 Port Royal Road

Springfield, VA 22161

NTIS price cades

Printed copy: $\$ 11.00$

Microfiche copy: A01 
SAND80-7185

Unlimited Distribution

Distribution

Printed March 1981

Category UC-63

SIMPLIFIED DESIGN GUIDE FOR ESTIMATING PHOTOVOLTAIC FLAT ARRAY AND SYSTEM PERFORMANCE

\author{
D. L. Evans \\ W. A. Facinelli \\ L. P. Koehler \\ Mechanical and Energy Systems Engineering Department \\ Arizona State University \\ Tempe, Arizona $\mathbf{8 5 2 8 1}$
}

\begin{abstract}
Simplified, non-computer based methods are presented for predicting photovoltaic array and system performance. The array performance prediction methods are useful for calculating the potential output of passively cooled, flat, south facing max-power tracked arrays. A solar/weather data base for 97 different U.S. and U.S. affıliated stations is provided to aid in these calculations. Alsc, performance estimates can be made for photovoltaic systeüls (array, battery, power conditioner) that are backed-up by non-solar reserves capable of meeting the load when the solar system cannot. Such estimates can be made for a total of 41 different sinusoidal, unimodal, and bimodal diurnal load profiles from appropriate graphs included. These allow easy determination of the fraction of the load met by the solar photovoltaic system as a function of array size and (dedicated) battery storage capacity. These performance graphs may also be used for systems without battery storage. Use of array manufacturer's specification sheet data is discussed. Step-by-step procedures, along with suggested worksheets, are provided for carrying out the necessary calculations.
\end{abstract}

Prepared for Sandia National Laboratories under Contract No. 13-0313 


\section{ACRNOWLEDGMENTS}

This guide is an outgrowth of the mork reported in SAND 80-7013 entitled. 'Simulation and Simplified Design Studies of Photovoltaic Systems." Both documents were completed under Contract 13-0313 with Sandia National Laboratories. Mr. Kent Birigger served as technical monitor, his assistance, advice and coments are greatly appreciated.

The authors would like to express their thanks to T.T. Rn1e, of Arizona State University, W.J. Kaszeta of SES, Inc. and F.T.C. Bartels of Energy Analysis. Inc. and Solec International for critiquing the manuscript and offering many helpful suggestions. Most of their idens and recomended changes have been incorporated.

The assistance of Reneo Overbeck and Katty McIntosh in preparing the manuscript is also deeply appreciated. 
Nomenc1ature $\ldots \ldots \ldots \ldots \ldots \ldots \ldots \ldots \ldots \ldots \ldots \ldots \ldots \ldots \ldots \ldots \ldots \ldots \ldots \ldots \ldots$ iv

CHAPTER 1 INTRODUCTION

1.0 Photovoltaics ............................... 1

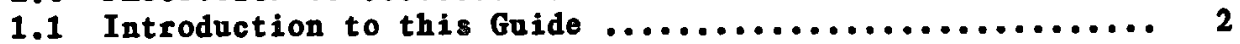

What this Guide Will Do ...................... 6

What this Guide Wi11 Not Do .................... 6

1.2 Order of this Guide $\ldots \ldots \ldots \ldots \ldots \ldots \ldots \ldots \ldots \ldots \ldots \ldots \ldots \ldots \ldots 7$

CHAPTER 2 PREDICTING POTENTIAL ARRAY AND POWER CONDITIONER PERFORMANCE

2.0 Background

2.1 Array Thermal Performance ........................ 9

2.2 Array Reference Efficiency ...................... 10

2.3 Power Conditioning ........................... 12

2.4 Monthly Average Potential Power Conditioner Output ...... 12

2.5 The Procedure for Calculating Monthly Potential Array and Power Conditioner Output ..................... 12

2.6 Departures from Long Term Average Behavior ............ 17

2.7 Corrections to be Applied ........................ 18

2.8 Table I and the Use of Other Data Bases ............... 19

CHAPTER 3 PREDICTING SYSTEM PERFORMANCE

3.0 Background ................................ 23

3.1 Load $\ldots \ldots \ldots \ldots \ldots \ldots \ldots \ldots \ldots \ldots \ldots \ldots \ldots \ldots \ldots \ldots \ldots \ldots \ldots \ldots \ldots \ldots \ldots \ldots . \ldots 23$

3.2 Electrical Storage Capacity ..................... 23

3.3 Solar Fractions ............................... 24

3.4 The Procedure for Estimating Monthly and Annual Solar

Fractions (F's) ............................ 25

3.5 Key to the Graphs of Table III .................... 27

3.6 Use of the Electrical Storage ..................... 29

3.7 Errors in System Performance Predictions ............. 31

Effect of "Noisy" Loads ........................ 31

Dependence of Performance Estimates on KT and

Latitude .............................. 31

CHAPTER 4 EXAMPLES

4.0 Introduction .............................. 37

4.1 Example 1: Harrisburg, PA ..................... 38

4.2 Example 2: Savannah, GA ...................... 39

4.3 Example 3: Honolulu, HI ....................... 42

4.4 Example 4: st. Louis, Mo ........................ 44

4.5 Example 5: F1agstaff, AZ .................... 46

4.6 Example 6: 0akland, CA ...................... 48

4.7 Example 7: Madison, WI ..................... 51

REFERENCES $\ldots \ldots \ldots \ldots \ldots \ldots \ldots \ldots \ldots \ldots \ldots \ldots \ldots \ldots \ldots \ldots \ldots \ldots \ldots \ldots \ldots \ldots \ldots$ 


\begin{tabular}{|c|c|c|}
\hline Symbo 1 & Significance & $\begin{array}{l}\text { Comon Uaits } \\
\text { this Guide }\end{array}$ \\
\hline B & $\begin{array}{l}\text { Capacity of the dedicated electrical energy } \\
\text { storage (see oq. } 3.1 \text { ) }\end{array}$ & wa:t-honrs \\
\hline $\mathrm{B} / \mathbf{A}_{\mathbf{T}}$ & 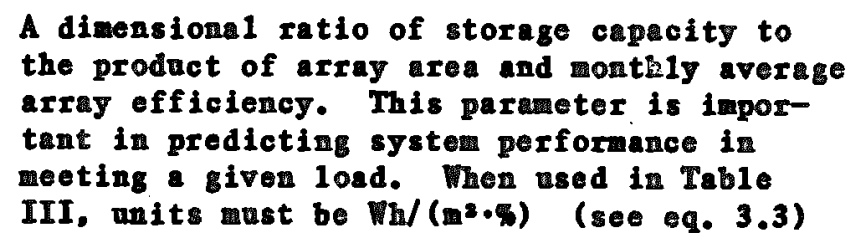 & $\mathrm{m} /\left(\mathrm{m}^{2} \cdot \mathrm{p}_{\mathrm{n}}\right)$ \\
\hline $\mathbf{F}$ & $\begin{array}{l}\text { Monthly average soler fraction or fraction } \\
\text { of the load that is met by the solnr system. } \\
\text { The back-up energy source must meet (1-F) } \\
\text { of the load }\end{array}$ & $\begin{array}{r}\text { dimensionless } \\
\text { decinal }\end{array}$ \\
\hline $\mathbf{K T}$ & $\begin{array}{l}\text { The clearness number or ratio of nonthly } \\
\text { total radiation (beam and diffuse) on a hor- } \\
\text { izontal surf ce to what would fall on that } \\
\text { surface if the surface were } 1 \text { oceted sbove } \\
\text { the atmosphere (the latter is roferred to } \\
\text { a the extraterrestrial radiation) }\end{array}$ & dimersionless \\
\hline $\mathbf{I}$ & Current & ares \\
\hline $\mathbf{L}$ & Monthly average iaily load & $\mathbf{k T h}$ \\
\hline NOCT & $\begin{array}{l}\text { Nominal Operating Ce11 Temperature or the } \\
\text { temperature of the cell in an res or mod- } \\
\text { ule under specified irradiation, } \\
\text { temperature and wind speed conditions }\end{array}$ & C \\
\hline $\mathbf{a B} / \mathbf{A}$ & $\begin{array}{l}\text { Monthly everage daily electrical outpot } \\
\text { from the power conditioning wat per unit } \\
\text { array area if the instantaneous array output } \\
\text { conld always be used to meet the load or soae } \\
\text { part of the load }\end{array}$ & $\mathrm{kWh} / \mathrm{se}^{2}$ \\
\hline $\mathrm{QR} / \mathrm{L}$ & $\begin{array}{l}\text { The ratio of the daily potential power con- } \\
\text { ditioniag electrical output (for the full } \\
\text { array) to the daily load. Monthly average } \\
\text { daily values are used. This is a potential } \\
\text { solur fraction that would be realized with } \\
\text { infinite. loss-free storage }\end{array}$ & $\begin{array}{r}\text { dimensionless } \\
\text { decimal }\end{array}$ \\
\hline QS/A & $\begin{array}{l}\text { Monthly average daily array insoletion or } \\
\text { solar energy falling on the array }\end{array}$ & 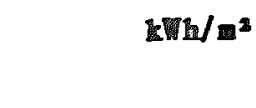 \\
\hline$(\mathrm{QS} / \mathrm{A})_{\mathbf{i}}$ & Instantancous insolation & 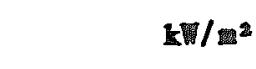 \\
\hline
\end{tabular}




\begin{tabular}{|c|c|c|}
\hline $\mathbf{P}$ & Power & various \\
\hline $\mathbf{s}$ & Array tilt up from horizontel & degrees \\
\hline $\mathbf{s}_{\mathbf{u}}$ & $\begin{array}{l}\text { Optimus for meximum monthly energy collec- } \\
\text { tion (see Table II pg. A-58) }\end{array}$ & degrees \\
\hline $\mathbf{T}_{\mathbf{a}}$ & Ambient temperature & $\mathbf{C}$ \\
\hline $\mathbf{T}_{\mathbf{c}}$ & $\begin{array}{l}\text { Month1y average cel1 temperature for calcu- } \\
\text { lating monthly everage conversion efficiency }\end{array}$ & $\mathbf{c}$ \\
\hline $\mathbf{T}_{\mathbf{c . 1}}$ & Instantaneous ce11 temperature & $\mathbf{c}$ \\
\hline TM & $\begin{array}{l}\text { Monthly average ambient temperature (averages } \\
\text { of all the daily high and low temperatures } \\
\text { for the month) as compiled by the National } \\
\text { Weather Service }\end{array}$ & $\mathbf{C}$ \\
\hline $\mathbf{T}_{\mathbf{r}}$ & $\begin{array}{l}\text { Some reference cel1 terperature for which } \\
\text { module efficiency (or maximum-power) is given } \\
\text { by a manfecturer }\end{array}$ & $\mathbf{c}$ \\
\hline $\mathbf{U}_{\mathbf{L}}$ & $\begin{array}{l}\text { Thermal loss coefficient for hoat rejection } \\
\text { between the cells in an array or modrie and } \\
\text { ambient (see eq. 2.1) }\end{array}$ & $\mathbf{L W} /\left(\mathrm{m}^{2} \cdot \mathrm{c}\right)$ \\
\hline $\mathbf{V}$ & Voltage & volts \\
\hline WS & Monthly average wind speed & $\mathrm{m} / \mathrm{s}$ \\
\hline
\end{tabular}


Greek

Strabo1s

a

$\boldsymbol{\beta}$

$\boldsymbol{\eta}$

$\eta_{\text {po }}$

$\eta_{\mathbf{I}}$

$\phi$
Significance

Solar absorptance of the photovoltaic array

Temperature coefficient for array officiency

Array or module efficiency for conversion of incident solar energy to electrical outpat

Power conditioning efficiency

A reference erray or module efficiency for converting solar energy to electrical output when the cells in the array or module are at a stated temperature $T_{r}$

Latitude
Most Comon Daits in this Geide

disensionless deciral

$c^{-1}$

\%

$\$$

甲

degrees

\begin{tabular}{|c|c|}
\hline Subscripts & Significance \\
\hline $\mathbf{a}$ & Ambient \\
\hline c & $\mathrm{Ce} 11$ \\
\hline high & $\begin{array}{l}\text { A typical high value of the subscripted varimble that ary } \\
\text { be expected over many years }\end{array}$ \\
\hline $\mathbf{i}$ & Instantaneous value \\
\hline Iat & $\begin{array}{l}\text { The value of the subscripted variable when the erray tilt } \\
\text { is equal to the local latitude angle }\end{array}$ \\
\hline $10 \mathrm{~W}$ & $\begin{array}{l}\text { A typical low value of the subscripted variable that may } \\
\text { be expected over many years }\end{array}$ \\
\hline mp & Maximun pover point \\
\hline pe & Power conditioning \\
\hline $\mathbf{r}$ & Reference \\
\hline
\end{tabular}


CHAPTER 1

\section{INTRODUCTION}

\subsection{PHOTOVOLTAICS}

Although the photovoltaic effect was first observed in 1839, it was the space program of the $1960^{\prime}$ 's that stimulated interest in and demand for solar cells. Solar photovoltaic systems on earth satellites and space probes offered the advantage of directly tapping a renewable resource, thus allowing extended issions in hostile environeents.

Interest in the terrestrial use of photovoltaic solar systems has blossomed over the past 6 to 8 years for exactly the same reason: the need to harness renewable resources for extending the mission of human habitation of the planet earth at the energy consuming level to which man has become accustomed.

Terrestrial photovoltaic solar systems are presently economical for many remote applications where costs of other alternatives, such as extending utility power lines or transporting fuel, are very high. Past examples have included remote repeater, phone and radar stations, navigational buoy lights, off-shore platforms, and pipeline corrosion protection. Figure 1.1, for example, shows a 3.5 kilowatt (peak) photovoltaic array that provides some electrical power for the remote town of Schuchuli, Arizona, U.S.A., which is not connected to a utility grid. Figure 1.2 shows a 60 kilowat, 1,110 square meter (12,000 square feet) array at Mount Laguna Air Force station in California that is backed up by a diesel powered grid.

In order to reduce costs and speed the introduction of photovoltaics into more energy intensive terrestrial markets, the national solar program is expending considerable effort in all areas of this discipline, including solar cell physics, array manufacturing techniques and stimulation, system studies and the removal of barriers to acceptance. There is evidence that the national program is on target for mecting its factory f.o.b. module price goals of $\$ 2.80$ per peak watt by 1982 and $\$ 0.70$ per peak watt by 1986 (1980 U.S. dollars assumed). Even though there can be no guarantees that these goals can be met, it is exciting to speculate about the possible wide-scale use of this technology.

As the arkets grow and prices drop further and further toward the program goals, many new applications will become feasible. For example, the widespread use of photovoltaics in residential and commercial buildings will hopefully become a reality in the near future. Figure 1.3 shows a prototype of a photovoltaic powered residence that was established in the summer of 1980 , to study 
component and system operation and problems. This systen is connected to atility for back-up and feeds ay excess solar generated electricity to the grid.

In addition to the hardware costs of photovoltaic systes, significant amounts of the total cost of installation are presenty due to the engineering design work involved. This is primarily a result of the lack of both design experience and easy to use design aids for dealing with this merging technology.

\subsection{INTRODUCTION TO THIS GUIDE}

This Guide is intended to help bridge the gap between high cost. sophisticated, one-of-a-kind design and low cost, wide-scale, rapidbut-reliable design. It is part of the overall national plan for speeding the widespread adoption of photovoltaic solar evergy systers.

The parpose is to provide informetion for sizing photovoltaic arrays and battery storage for meting particular electrical loads in various geographical locations. A desigher ay are use of the desigh procedures recomended in this Guide if he has chosen to use south facing. flat. unconcentrated, max-power tracked photovoltaic arrays and has sove basic inforwation on array behavior thet is gererally available from manfacturer's data. The array output calculations. along with the basic data sources and worst case insolation resits. are widely applicable to many types of photovoltaic systers. Howevex, the systems (array, power conditioning, and battery used to satisfy a given diurnal load shape) analysis is restricted to systems that have a back-up power source capable of meeting the load when the photovoltaic syster cannot.

This Guide is not necessarily intended to be an alternative to hourly computer simulation, bat it should be useful for preliminary design work and could oliminate sianlation studieg for sall and/or routine installions. Hourly simulation can answer some design questions that are not addressed by the simplified techniques described here (for example, frequency distribations of the power output). On the other hand, it is easy to overlook the assumptions that are necessury in hourly computer simulation and become overconfident in the results.

Any design method will be subject to uncertainties due to many factors. Chief ang these are: (a) the extent to which photovoltaic manucturer's sales data represent the modules that are sold and the extent that module data can be nsed to infer array behavior. (b) the extent to which the designer knows his load (size, shape and fluctuations). and (c) the extent to which long term insolation and weather data (including fluctuations frow the long term data) are known. 


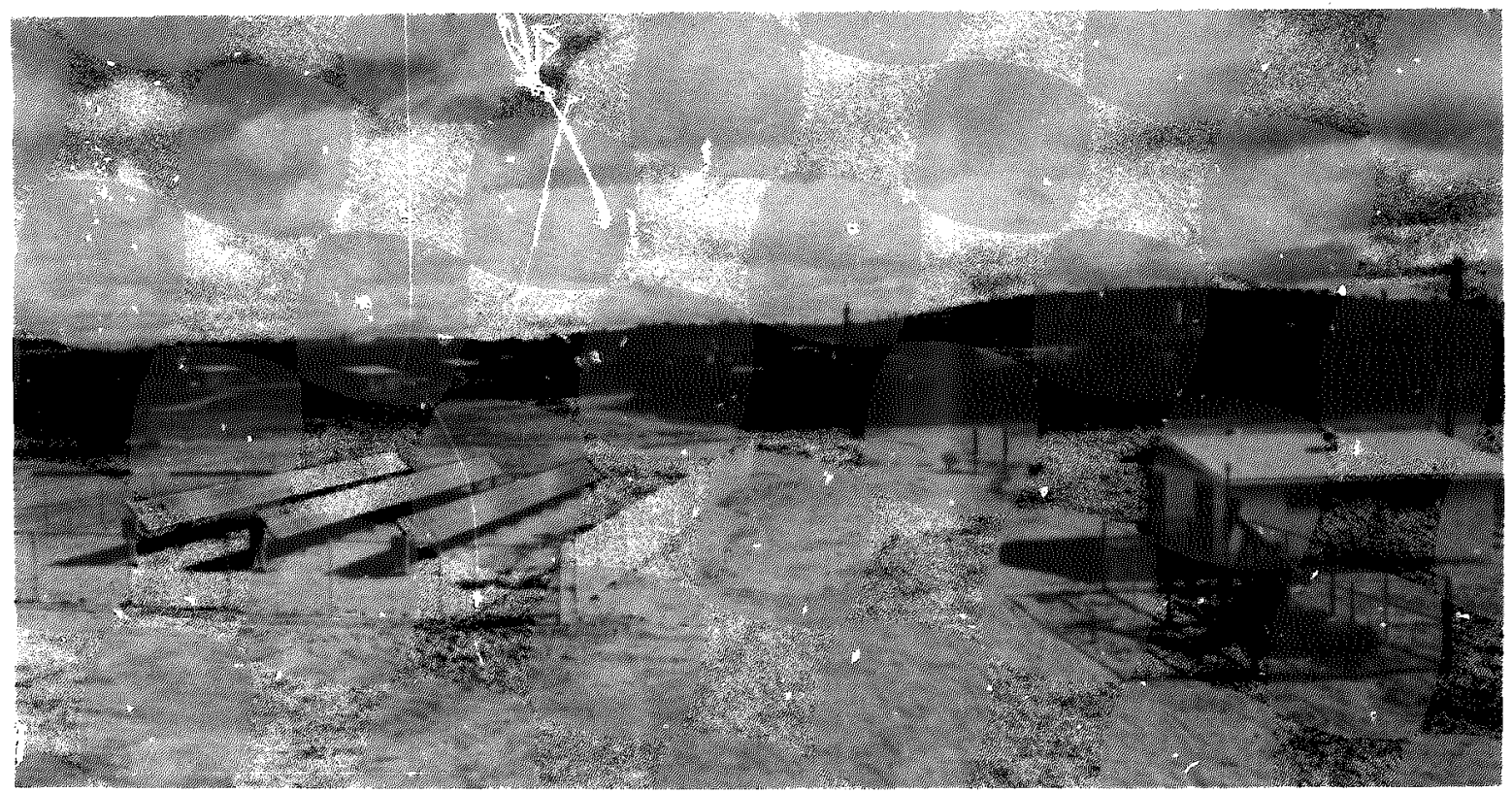

Fig. 1.1 Photovoltaic Village Porer Project - Schechm11. AZ, USA.

This 3.5 kllowatt (peak) solar photovoltale systo: is designed to meet the basic needs of the people of Sehrehu11. AZ. This standalome system has lead-acid storage batterio but no other back-up power systom. It provides power for 40,20 watt flourescent lights distributed among the homes and comanity buildings, a water panp (up to 5000 gallons per day). 15 refrigerator/freezer units, clothes washor, and sowing machine. (Photo courtesy of NASA, Lewis Reserrch Center.) 


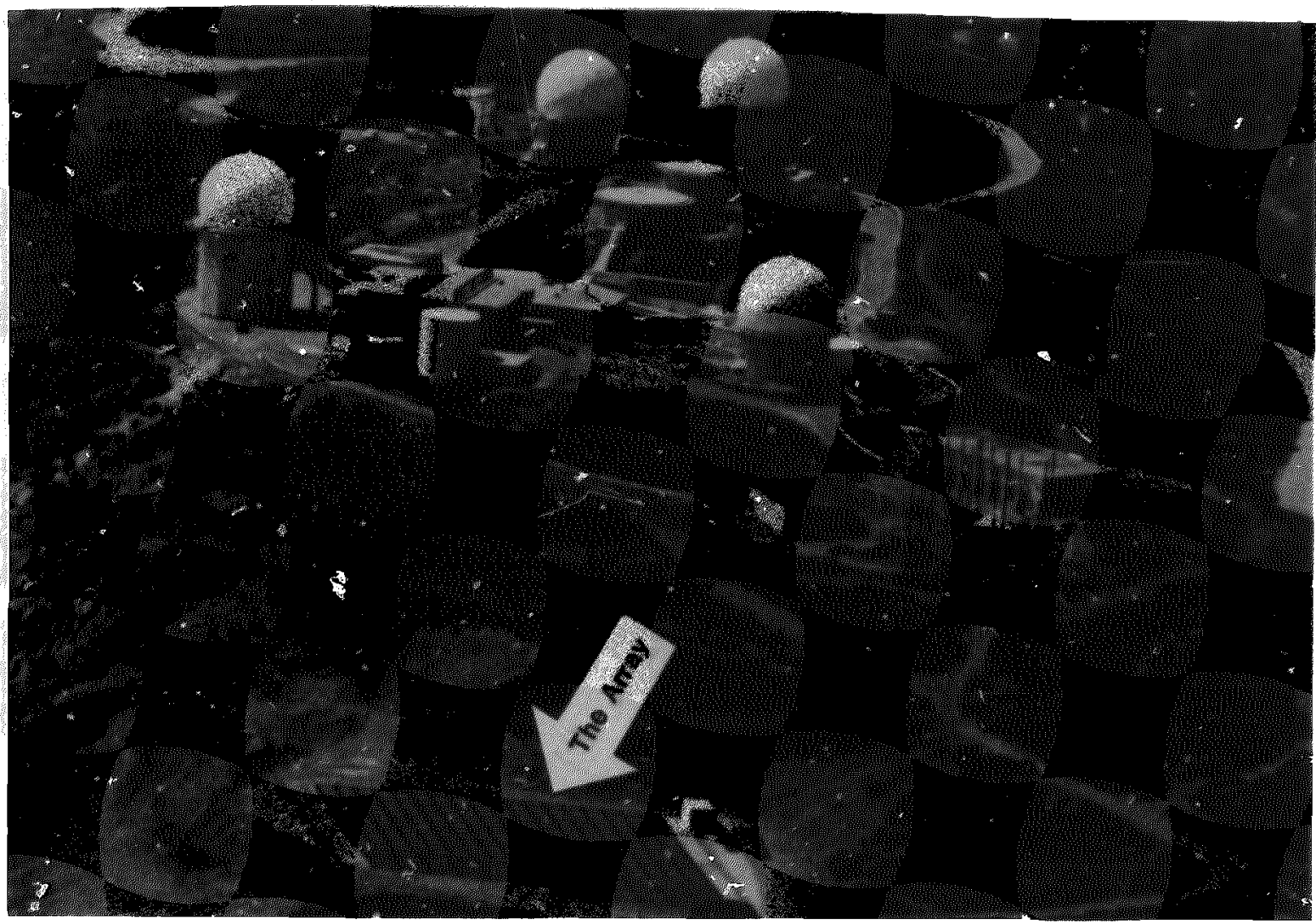

Fig. 1.2 Solar Photovoltair Power Augmontation - Mt. Lagum, CA, USA.

U.S. Atr Force personnel at Mt. Lagara Air Force Station, CA, roceivs an average of 10 percent of their electrical onergy from the sun. The 60 (perk) kilowatt photovoltaic flat array system has an array area of $1,110 \mathrm{sq}=(12,000 \mathrm{sq} f t)$, occupies $3,000 \mathrm{sq}=(32,000 \mathrm{sq} f t)$ of land area, and consists of nearly 98,000 individuel silicon soler cells. The arrays are tilted $25^{\circ} \mathrm{up}$ from horizontal. A power conditioner maximum power tracks the array and converts d-c to a-c to watch the stetion's 480 volt, 3-phase power from aiesel gererator plant. (Photo courtesy of J.S. Army Mobility Equipaent Research and Deve lopment Comand.) 


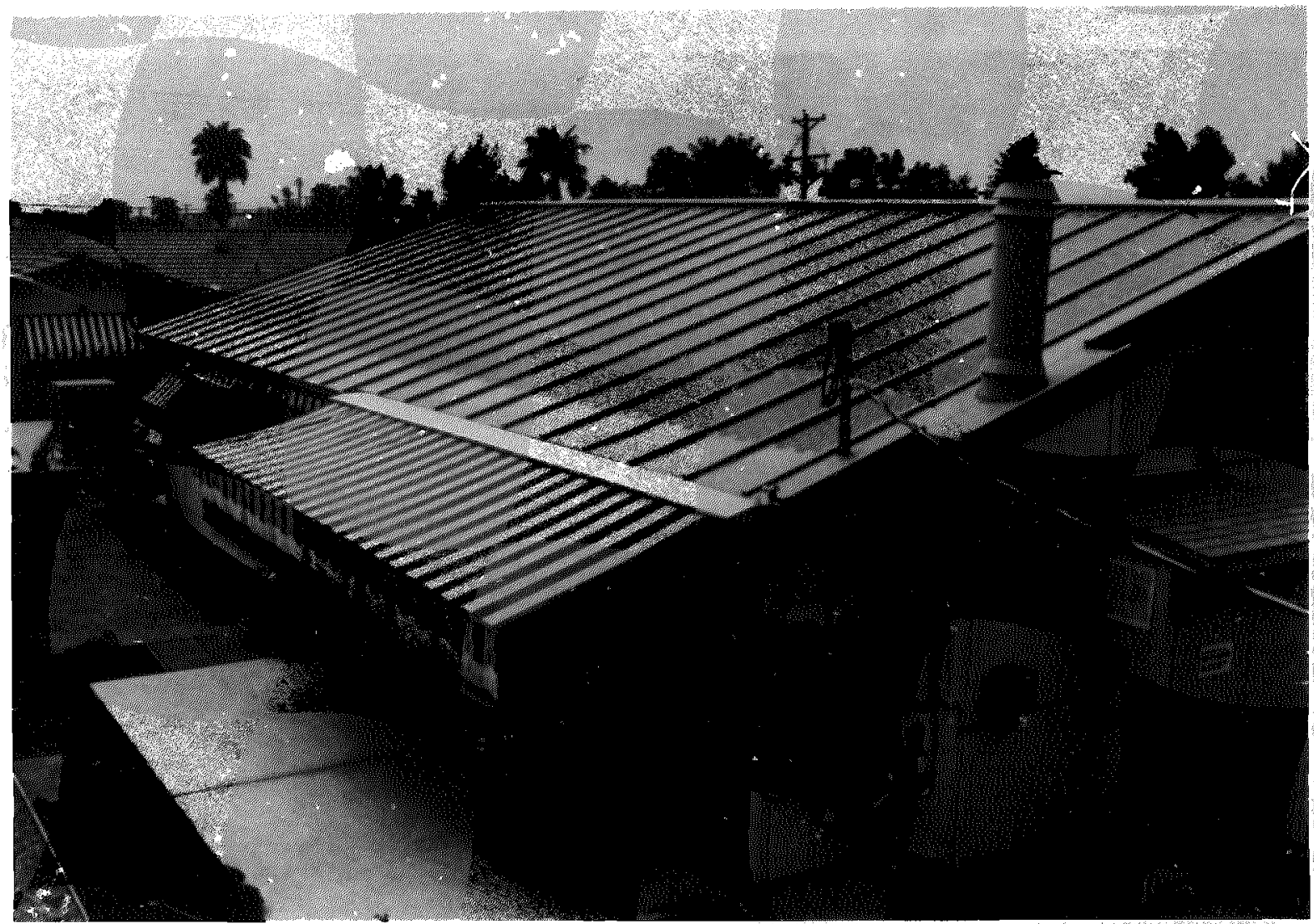

Fig 1.3 Residential Photovoltaic System-Phoenix, AZ, USA

This modal tract home in Phoenix, AZ, has its south sloping roof covered with solar cell modules. The array consists of 5 paralleled sub-arrays, each of which runs laterally across the roof. Interconnections are made in the batten seams that run vertically up the roof. The small shed like struoture on the near end of the residence houses the power conditioning equipment. No on-site electrical storago is jeovided, excess porer is fed back to the utility grid. Although the array produces roughly enough energy to meet the total requirements of the home, the solar system suppiles, directly, only 30 to $40 \%$ of the total need because of the dinrnal mismatch of array output and load. (Photo courtesy of ARCO Solar, Inc.) 


\section{CRAPTER 1}

What This Guide 111 Do:

Provided a designer lhas some information about the lood he intends to setisfy and the particnler arrays he intends to use, he ray use this Guide to:

A. Compute potential array performance for his location and season if ho has certain site specific solar/weather date available. Data for 97 representative U. S. or U. S. affilieted stations ar inoluded in this Guide in case site specific data are not available. Performance parameters addressed include:
a. month1y average array efficiency.
b. monthly average array insolation or solar irradiation
c. monthly average array and power conditioning outpat.

These parameters are imediately useful for systems in which 11 of the photovoltaic erray and power conditioner output can be used in meeting the load (i.e., if the load always exceeds the array and power conditioner output). In systems where the array and power conditioner output can exceed the load and action must be taken to tore, to dump. to avold collection, or to feed the excess power back to atility or grid, then these paraneters can still be useful by aiding in the determination of syster performance.

B. Comput monthly average systes: (array, storage, and power conditioning) performance $f(r) 41$ difi, ient monthly average diurnal load profiles. The system performance procedures are restricted to flat arrays operating with a back-up grid that is capable of supplying reserve power any time the photovoltaic syster is unable to meet the load. Various amounts of dedicated storage (i.e.. storage that is chargeable only from the photovoltaic array and not from the back-up grid) can bo accomodated including zero storage.

Mhat This Guide Will Not Do:

This Guide is not intended to be primer on solar energy, solar ce11s, photovoltaic arrays, or batteries. Although it will allow the determination of overall system performance in terms of the fraction of a given load supplied by solar, this Gaide will not give details on how to evaluate the economics of articular system choice. Designers are referred to Reference 1 for a detailed discussion of 1 ife cycle costing or cost-benefit analyses and to Reference 2 for a step-by-step economic evalustion for photovoltaics.

Also, this Guide will not provide information on detailed design either from mechanical (mounting structure, wind loading. etc.), civil (building codes, regulations, etc.), or electrical (electrical conrections, diodes, transient protection, module matching, etc.) 
standpoint. These are all outside the scope of this work. Designers are referred to, for example, Reference 3 for treatment of many of the electrical design features.

\subsection{ORDER OR THIS GUIDE}

Most simple procedures, when laid out in step-by-step format, look more complicated than they really are. Such is the case here. This may be confixmed by executing the process prosented in Chapters 2 and 3 a few times.

The procedure for determining system performance, as presented in this Guide, consists of two major steps. In the first part, user determines the array output that could potentially be obtained with either a load capabla of absorbing all of the available outpat or the presence of infinite, lossless storage. In the second part, the user calculates the potential or marimun solar fraction, frow the potential array output and the size of the load, and combines it with battery capacity parameter to gield the actual solar fraction. This last combination is dono with graphs prepared for various diurnal load shapes.

These two major steps are covered in Chapters 2 and 3 . Chapter 2 outlines the procedure for estimating potential array performance and output for various geographical locations. It refers to an extensive table of solar/meteorological dota for the U.S. and several of its affiliates which can be ased in the absence of data that may be more site specific.

Chapter 3 outlines the procedure for predicting system performance and discusses its use and limitations. The procedure makes use of an extensive table of graphs found in the appendix.

Chapter 4 is devoted to example problems which demonstrate and clarify the procedures outlined in Chapters 2 and 3 .

The development of much of the work underlying the procedures described herein is documented and discussed in Reference 4. Since the intent is to make this Guide as short and usable as possible no further documentation will be given. 
CHAPTER 1

(BIank) 


\title{
CHAPTER 2
}

\author{
PREDICTING POTENTTAL ARRAY \\ AND \\ POWER CONDITIONER PERFORMANCE
}

\subsection{BACKGROUND}

This chapter outlines a procedure for estimating monthly photovoltaic array performance using ainimum of information. It should be used only for south facing flat arrays having fixed tilt during any given month. (The tilt may vary from month to month.) The procedure assumes that the arrays always operate at the maximun power points of their current-voltage (I-V) curves.

The electrical energy produced by a photovoltaic array is considerably less than the energy absorbed from the incident solar rays. The balance of the solar energy must be efficiently rejected in order for the array to remain cool. The procedure described here assumes that an array rejects this extra energy to the surroundings by passive means, i.e. radiation and natural convection. This Guide should not be used if the energy rejection occurs by other means, e.g. by cooling with blown air or flowing liquid.

In order to use this procedure for a particular photovoltaic array, certain performance related parameters must be obtained from the array manufacturer. Unfortunately, there is not yet a uniform standard for reporting this array information. In many cases, the necessary parameters can be calculated from the information that is supplied on product specification sheets while in others the mannfacturer will have to be contacted. In somo cases, estimates will have to be made.

\subsection{ARRAY THERMAL PERFORMANCE}

One important array property that is product dependent is the efficiency for rejecting thermal energy to the surroundings. This property is important since, for any given manufacturer's array, the operating efficiency is primarily a function of array temperature:

Of course actual efficiency is strongly dependent on cell physics, density of packing of cells in a module, encapsulants, etc., but for a given manufacturer's product, these are essentially fixec. Of the local environmental variables that affect array performance, temperature is the most dominant. 
The poorer the heat rejection, the higher the array temperature and the lower the efficiency. A comonly cited parameter that contains information on this efficiency is the Nowal Operating Cell Temperature or NOCT. As mentioned above, the conditions ander which NOCT is determined have not been standerdized. However, the conditions under which a riticular manufacturer has determined the NOCT for his array is usually available in product literature.

Four items should be moted when using NoCT data. They are:

1. the total insolation (bean and diffuse) or solar irradiation f1ux, QS/A, on (normal to) the array when the NOCT measurement is made,

2. the temperature of the amient air suscounding the array, $T_{2}$,

3. the wind speed and direction (the wins should be near 1 meter per second and into the array).

4. the instantaneous ce11 temperature, $T_{c, i}$ (or NOCT), under the se conditions.

The term "'loss coefficient" (here given the symbol $\mathbb{U}_{L}$ ) is comonly aged to express the efficiency of heat rojection for the array. In photovoltaic arrays the ratio of $U_{L}$ to the solar absorptance $(\alpha)$ of the array is important, not just $\mathbb{U}_{L}$. This ratio of loss coefficient to absorptance can be computed from

$$
\nabla_{L} / \alpha=\frac{(Q S / A)_{i}}{T_{c, i}-T_{a}}
$$

where $(Q S / A)_{i}, T_{c}, i$, and $T_{a}$ are simultaneous measurents of the array insolation per unit array area, cell temperature, and abient temperature, respectively. $U_{L}$ is implicitly related to wind speed; therefore, the value used in the procedures outlined below should be representative of the wind conditions experienced by the arrays.

The procedure in this chapter requires knowledge of either NOCT or $U_{L} / a$. If neither an NOCT nor information from which $U_{L} / a$ can be calculated is available from the manufacturer, then the designer must resort to either estination or thermal analysis.

\subsection{ARRAY REFERENCE EFFICIENCY}

Another property that is highly product dependent is the efficiency for converting incident sunlight into electricity. Maxinum 
power operation is assumed in the procedures outlined in this Guide. Under this condition, the actual conversion efficiency, $\eta$, is, to good approximation, linearly related to cell temperature $T_{c}$ by

$$
\eta=\eta_{I}\left[1-\beta\left(T_{c}-T_{I}\right)\right]
$$

The procedure that follows predicts the monthly arerage cell temperature $\left(T_{c}\right)$ which can be used to estimete monthly average efficiency from eq. (2.2) if $\eta_{I}, T_{I}$ and $\beta$ are known to the designer. These latter quantities are discussed in the following paragraphs.

Usually, product information is complete enough to allow calculation of a reference efficiency, $\eta_{r}$, at a stated (reference) cell temperature, $T_{r}$. For example, if an array module max-power current,

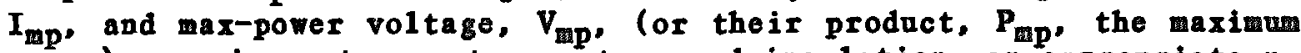
power) are given at some temperature and insolation, an appropriate $\eta_{r}$ can be calculated from

$$
\eta_{r}=\frac{I_{m p} \cdot V_{m p}}{A \cdot(Q S / A)_{i}} \cdot 100=\frac{P_{m p}}{A \cdot(Q S / A)_{i}} \cdot 100
$$

where $(Q S / A)_{i}$ is the instantaneous insolation on anit area of the array and $A$ is the area of the array module (the 160 's that appear in eq. 2.3 convert efficiencies to percent which is the way they are expressed in this guide). $T_{r}$ is taken to be the cell terperature at which these electrical properties are measured. Care should be taken in eq. (2.3) to make certain $\eta_{r}$ is dimensionless.

The array efficiency temperature coefficient, $\beta$, in eq. (2.2) is vsually not explicitly given in product specification sheeis. However, occasionally enough information is provided to allor the calculation of this parameter. Whenever two different efficiencies (or enough information to calculate two efficiencies) are given t two different cell temperatures but the same insolation, $\beta$ can be calcu1ated. Suppose these efficiencies are $\eta_{1}$ at $T_{c, i}=T_{1}$ and $\eta_{2}$ at $\mathbf{T}_{\mathrm{c}, \mathrm{i}}=\mathbf{T}_{2}$. Then

$$
\beta=\frac{1-\left(\eta_{2} / \eta_{1}\right)}{T_{2}-T_{1}} \text {. }
$$

\footnotetext{
In max-power operation the voltage on the array is continuously adjusted so that electrical power production is alvays maximized. The device that maintains the voltage at the max-power value is referred to as a max-power tracker, and is often an accessory iten that accompanies the power conditioner or inverter.
} 
If insufficient information is given, ther the designer has to resort to estimetion. Fortunately. $\beta$ is mily cell material dependent. For silicon arrays reasonable value to use is $0.0045 \mathrm{Cl}^{-1}$ and for cadmin sulfide arrays $0.006 \mathrm{C}^{-1}$ is recomended.

\subsection{PONER CONDITIONING}

In the procederes outlined in section 2.5, the designer must specify $\eta_{\text {pe }}$ the pover conditioning efficiency (in percent). Meny applications require alternating current (a-c) power, whereas photovoltaic arrays produce direct current (d-e) power. In these cases, the designer aust use an inverter between the array and the load to convert the d-c to a-c. Where the application requires regelated d-c power, some sort of power conditioning anit mest also be included in the design.

Although the conversion efficiencies of inverters and power conditionins equipment are typically functions of the amont of power boing processed, they are surprisingly independent of part-load-ratios over a large part of their operating range. (It nust be remembered that array output power will vary drastically over any particular day). This fact usually simplifies the selection of a monthly average power conditioning officiency, 䜣. Typisal values of $\eta_{p e}$ are in the range of 80 to 95 percent.

\subsection{MONTHLY AVERAGE POTENTIAL ARRAY AND POWER CONDITIONER OOTPUT}

For an appropriately determined monthly average potential array officiency, $\eta$. determined from eq. (2.2), the monthly average daily energy output per unit area of array (including pover conditioning 10sses) is givon by

$$
\mathrm{QE} / \mathrm{A}=\frac{\eta_{\mathrm{PC}}}{100} \cdot \frac{\eta}{100} \cdot \mathrm{QS} / \mathrm{A}
$$

where QS/A is the monthly average dally insolation on anit are of the array. The procedure outlined in the next section provides the that makes eq. (2.5) applicable for obtaining wonthly average results.

\subsection{THE PROCEDURE FOR CALCULATING POTzNTIAL ARRAY AND POWER CUNDITIONER OTTPUT}

Norksheet 1 , several copies of which can be found at the ond of the appendix, showld aid it the celculation of array monthly potential performance. The steps enumerated below are keyed to that forksheet: 
Step 1 Obtain $\eta_{r}$ and $T_{r}$ from mannfacturer's data. Bnte* these values at the top of Worksheet 1. Do not try to estimate or guess their values. If $\eta_{r}$ for some cell temperature, $T_{I}$. cannot be caloulated from data supplied in specification sheets (see section 2.2), contact the manacturer directly.

Step 2 Obtain $\beta$ from manufacturer's data and enter it at the top of Worksheet 1 . See Section 2.2 for the method of calculation. If sufficient information is not available, use $0.0045 \mathrm{C}^{-1}$ for silicon and $0.006 \mathrm{C}^{-1}$ for CdS arrays, or ask the manufacturer.

Step 3 Obtain NOCT and NOCT conditions from manufacturer's specifications. This NOCT will be needed to enter Fig. 2.1 in Step 9 below. If the conditions given by the manufacturer fall outside the limits of scales A1, A2, $A 3$ or A4 on that figure or cannot be used with these scales, calculate $\sigma_{L} / a$ from eq. (2.1) for entry on scale of Fig. 2.1. If insufficient data exist to determine either NOCT or $\mathrm{U}_{\mathrm{L}} / \alpha$, contact the manufacturer. Enter the appropriate values on the top of Worksheet 1 .

Step 4 If the array output power is to be processed through power conditioning equipment, estimate $\eta_{p c}$ from the equipment manufacturer's data and enter its value on Worksheet 1 .

Step 5 From Table $I$ in the appendix, determine which station for solar/meteorological data best represents your location. Use the rey maps on pages $A-1, A-2$, and $A-3$, to aid in finding this station in Table I. Table $I$ is arranged alphabetically by station, but 1 ists of the stations sorted by station, state, and latitude can be found on pages $A-4, A-5$, and $A-6$, respectively. Of course, if more site specific weather/insolation data are available they should be used, but they must be exactly the same quantities as listed in Table $I$. See Section 2.8, Table $I$ and the Use of Other Data Bases, for further discussion.

Step 6 Calculate the monthly optimum tilts using the site latitude and the equations found in Table II on page A-58 of the appendix. Bnter the computed values in column C3 of the worksheet. Decide npon the array tilt to be used. Arrays that are to be adjusted in tilt each month can be accomodated in this procedure. Enter the monthly tilts to be used in column $\mathrm{C} 4$ on Worksheet 1.

The choice of tilt, $s$, will depend on the application. If optinum energy is desired and monthly adjustment of the tilt can

The specific value of $T_{r}$ is not important, as long as it is a cell temperature (not an ambient temperature) and $\eta_{r}$ is the array efficiency at that $T_{\mathbf{r}}$. 
be made. s would be set equal to such month. A desigmer wonld want to acertain that the cost of monthly adjustment is moro than offeet by the value of the increased electrical outpat.

If a fixed yearly tilt is to be used and maxim yearly energy production is desired, s would essentially be set equal to the tilt giving the largest yearly total insolation. Differences in monthiy efficiency world alter this choice omly sightly. Table I lists yearly insolation (YRT) for various tilts.

If optimum energy collection is desired for particular month or seeson but fixed yearly s is required, s would be selected frova Table I to maximize insolation during that period. Energy production at other times of the year will suffer, however.

Step 7 Transfer VS, KT, TM and QS/A from the data for your station in Table I to coluans C1, C2, C6 and C9, respectively, of Worksheet 1. key for resding Table $I$ can bo found on page $A-7$.

The wind speeds, WS, that appear in Table $I$ are sOLWT data frog Reference 5. Something less than the W''s shown in Table I (but not less than 1 meter per second) should be entered on worksheot 1 due to the fact that arrays are typically mounted lower in the earth's boundary layer than are the National Feather Service wind mesuring instruments. A value that is 50 to 75 percent of the tabulated value is recomended. A sensitivity study of the influence of WS on $\eta$ can easily be performed by computing $\eta$ t several assumed wind speeds.

QS/A is the average daily array insolation per array area and must correspond to the monthly tilts given in column C4 of the worksheet. That is, enter Table I with the array tilt and month to locate the corresponding QS/A. Interpolation between tabulated tilts wil probably be necessary.

Step 8 Complete column $C 5$ of Worksheet 1. . absolute value of $s-s_{y}$. That is, if $\left(s-s_{y}\right)$ is negative, ignore the minus sign when entering the number in coluan C5.

Step 9 Determine $\mathbb{T}_{c}$, the average monthly cell temperature, by entering Fig. 2-1 each month with the values recorded on the worksheet. Enter on either axis $A$ or axis $B$, depending on whether NOCT or $\mathbb{U}_{L} / a$ is known. If entering on axis $A$, begin at axis

A1 if the NOCT is known for an insolation of $1 \mathrm{~km} / \mathrm{m}^{2}$ and an ambient temperature of $20 \mathrm{C}$,

A2 if the NOCT is known for an insolation of $1 \mathrm{z} / \mathrm{w}^{2}$ and the ambient temperature is different from $20 \mathrm{C}$. Subtract the 


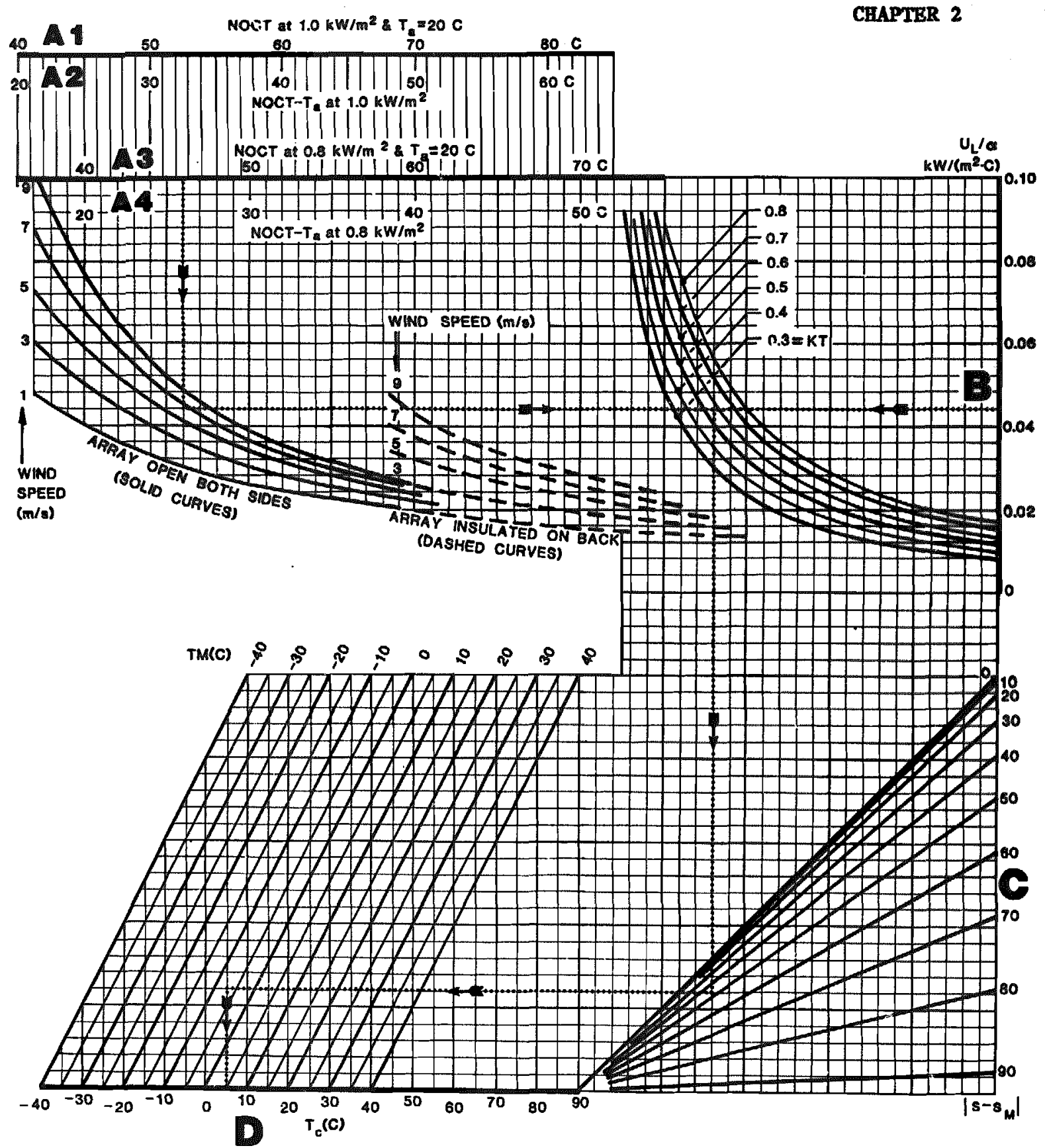

Graph for Estimating Monthly Average Cell Temperature

Figure 2.1 
CHAPTER 2

(B1ank) 
crown ambient temperature fros the NOCT before entering this ixis.

A3 if the NOCT is know for an insolation of $0.8 \mathrm{~kW} / \mathrm{m}^{2}$ and an ambient temperature of $20 \mathrm{C}$.

A4 if the NOCT is known for an isolation of $0.8 \mathrm{~kW} / \mathrm{m}^{2}$ and the ambient temperature is different from $20 \mathrm{C}$. Subtrect the know anbient temperature from the NOCT before entering this axis.

After entering axis A proceed downward until intersecting the wind speed curve appropriate for your location and month." After the intersection proceed to the right until reaching the clearness number, KT, curve for your location and month. If entry needs to be made into Fig. 2.1 with $\nabla_{L} / a$, begin at axis $B$ and proceed to the left until intersecting the appropriate IT curve. Frow the IT curve proceed downward until intersecting the appropriate sloping $\left|\mathrm{s}-\mathrm{s}_{M}\right|$ curves (labeled along axis C) for your installation and month. Then move to the left until reaching the appropriate mean monthly temperature, $M$, curve for the month and site. Proceed downward to the horizontal aris D to obtain the monthly average cell temperature, $T_{c}$, that can be used in eq. (2.2). Enter this $T_{c}$ in colum $C 7$ of Workshet 1.

Step 10 Calculate the monthly average array efficiency, $\eta$, from eq. (2.2) and enter the results in column C8.

Step 11 Calculate the monthly average daily energy potentialyy available from the power conditioning unit per unit area of array. $\mathrm{QE} / \mathrm{A}$, from eq. (2.5) and exter the resmit in columin C10. (Note that $\eta_{\text {. }} \eta_{r}$ and $\eta_{p c}$ are assumed to be in percent when entered in the worksheet. Thus the 100 's appear in the legend of colum C10.

\subsection{DEPARTURES FROM LONG TERM AVERAGE BEHAVIOR}

If the data of Table I have been nsed, the procedure out1ined above predicts long term monthly average array performance, since the values given in that table are averages over approximately 25 jears of

\footnotetext{
Wote there are two sets of wind speed curves in Fig 2.1; the solid curves represent arrays that are open on both sides (e.g., free standing arrays with no theral insulation) and the dashed curves represent arrays that are well insulated on their back sides (0.g., integral roof monnting). It is imperative that the mounting and testing of the arrays during NOCT tests be equivalent to the way ther will be moned and used in your application. Do not use the free standing NOCT's for arrays that will be insulated on the back and vice versa.
} 


\section{CHAPTER 2}

data. It is often desirable, however, to know the departures from the long term average that may be expected in array performace.

The most influential variable affecting array output is the array insolation or solar irradiation. Therefore. knowing the variation in insolation that can be expected over the years aliows one to prodict array outpat variations to be expected.

For any one locetion and month the monthly average array insolation varies nearly in proportion to the monthly clearmess number. IT, for that location and ponth. Monthly departures from the long term average KT for any location and month typically heve standerd deviation of 0.04 , although this increases somewhat in 10 W IT locations and decreases somewhat in high IT locations. Thes, muliples of this standard deviation can be added to (subtracted from) the long term monthly IT to obtain reasonable statistics on high (10w) array insolation levels. For oxample, since 95.4 percent of any norma1ly distributed set of nubers 1 ie within \pm 2 standard deviations of the average, anthly average erray insolation level of

$$
(Q S / A)_{h i g h}=(Q S / A) \frac{[E T+2(0.04)]}{K T}
$$

would be exceeded only 2.3 percent of the time. Likewise, anthy average insolation level of

$$
(Q S / A)_{1 O W}=(Q S / A) \frac{[E T-2(0.04)]}{K T}
$$

would be exceeded 97.7 percent of the time. Here the unsubscripted. parameters are the long term average valuos taken frow Table I of the appendix. Using such high and 1 ow values for QS/A in eq. (2.5) gives roasonable estimates of the high and low monthly average array output to expect over the years.

\subsection{CORRBCTIONS TO BE APPLIED}

The values of QS/A's listed in Table I do pot account for losses in available solnr energy that occur in the early morning and late afterioon when the angle between the normal to the array and the incoming solar rays is 1 arge. Also not considered are losses due to shading of the array surface by either other parts of the array or by nearby non-array elements, and losses due to scottering of the incident rays by dirt accuanlated on the array surface.

Although losses at high incidence angles have not been quantified here, they should be of the order of 5 percent or less. 
Shading losses are strongly dependent on the maner in which the colls and modules are wired together and the ratio of array area to the land area (this latter ratio is often referred to as the land packing factor). For near latitude tilts, self shading of the array (shading of one part of the array by other parts) is not significant at packing factors up to 0.3 to 0.4 and may be insignificant at values larger than 0.4. Due to differences in the sun's elevation in the sky, the self shading losses are always much greater in the winter than in the sumer. By using diodes or by wiring series strings of colls across the arrays (rather than up and down the errays) shading losses can be held to less than 1 or 2 porcent at packing factors as ligh as 0.6. Shading by non-array eleaents (buildings, trees, power poles, etc.) is highly site specific and should not be disregarded by the designer.

Losses due to dust and dirt accumulation are typically on the order of 3 to 5 percent although they have been observed to be as higa as 13 percent. In ost locations rain is frequent enough to keep such deposits at a sear negligible amount.

Designers should use some discretion in the removal of such losses as those discussed bove from the calculated monthly QE/A's. The losses are difficult, if not impossible to quantify in general way: the choice of magnitudes needs to be tompered with experience.

\subsection{TABLE I AND THE USE OF OTHER DATA BASES}

The data base included as Table $I$ is based on the monthly mean temperatures, wind speeds and daily total (globe1) radiation on the horizontal from Reference 5. The data represent averages for the period 1952 through 1976. The original source for Reference 5 was the SOLET tapes (Reference 6).

The SOLMET data base was originally established by rehabilitating measured data for 26 sites. Most of the systematic errors in the original data were removed in the correction process while other random and systematic errors were introduced. Insolation data for over 200 other sites were then constructed by applying regression analysis coefficients on month to month basis, from the closest SOLAET location, to synoptic data available for these additional sites. The largest errors in the original sOLET sites apparently occur in inter in northern latitudes and may be as large as $10 \%$. Probable errors in the "regressed" data base are difficult to quantify but are undoubtedly larger.

KT was computed from Reference 5 data by dividing the total radiation on the horizontal by the extraterrestrial radiation on the horizonta1. Total radiation on the tilt data in Table I were then 
compted using the method of Reference 7, assuming ground roflectance of 0.2 . (The accuracy of this computation is discussed below.)

Although the regionalization developed in Reference 5 (see pege A-2) is convenient, anomalies that can occur within any region, perticularly in mountainous or coastal regions, can lead to errors. Users of Table I are arged to apply discretion in this regard.

There are many data bases in use in the solar design comanity. Unfortunately, very seldow do any two or more of these bases give identical results. Indeed, one of the largest uncertainties in solar design ay result from uncertainties in the choice of data beses.

Because designers often have their favorite data bases and becanse Table I can and will oventually be replaced with more accurate data, some discussion of the use of other information may be in order.

Ustally if any data exist for a site they are total radiation on the horizontal. In order to use the procedure developed here, a designer must know IT. If a data base does not provid $\mathrm{ET}$, it can be computed by ratio? 3 the monthly (or monthly average daily) total radiation on the horizontal to the monthly (or monthly average daily) extraterrestrial radiation. This latter quantity can be obtained from Fig 2.2 for the wonth and 1atitude of interest.

A designer also needs the eonthly average temperature. TM. This is often available from meteorological data characteristic of the ste. Some data contain the monthly average temperatare daring daylight hours which is typically three degrees above the average temperature over all hours. Therefore, TM would be this daylight temperatrre mints three degrees.

In principle, the wind speed information required is the anthly average wind speed during daylight hours at the array height above the ground with the array in place. Such exteasive information is rarely available. Usually, at best, there may be some monthly average (all hours) data at another height. Fortunetely for mcuy situations, system performance is not strongly tied to wind speed.

The total radiation on the tilt, which is perhaps the most important variable, is usually the most difficult to obtains fen measurements exist. If the data base to be used does not inclade radiation on the tilt, a designer is usually faced with converting total radiation on the horizontal to total radiation on the tilt. Although vo1umes of papers have been written on such a conversion, no standard or "besi" method exists for doing this. Reference 8 does outline one step-by-step procedure for making this conversion. Various existing data bases that all start with the same total horizontal radiation data show discrepancies of 3 to $5 \%$ and occasionaly as ach as $10 \%$ in total radiation on the tilt. 

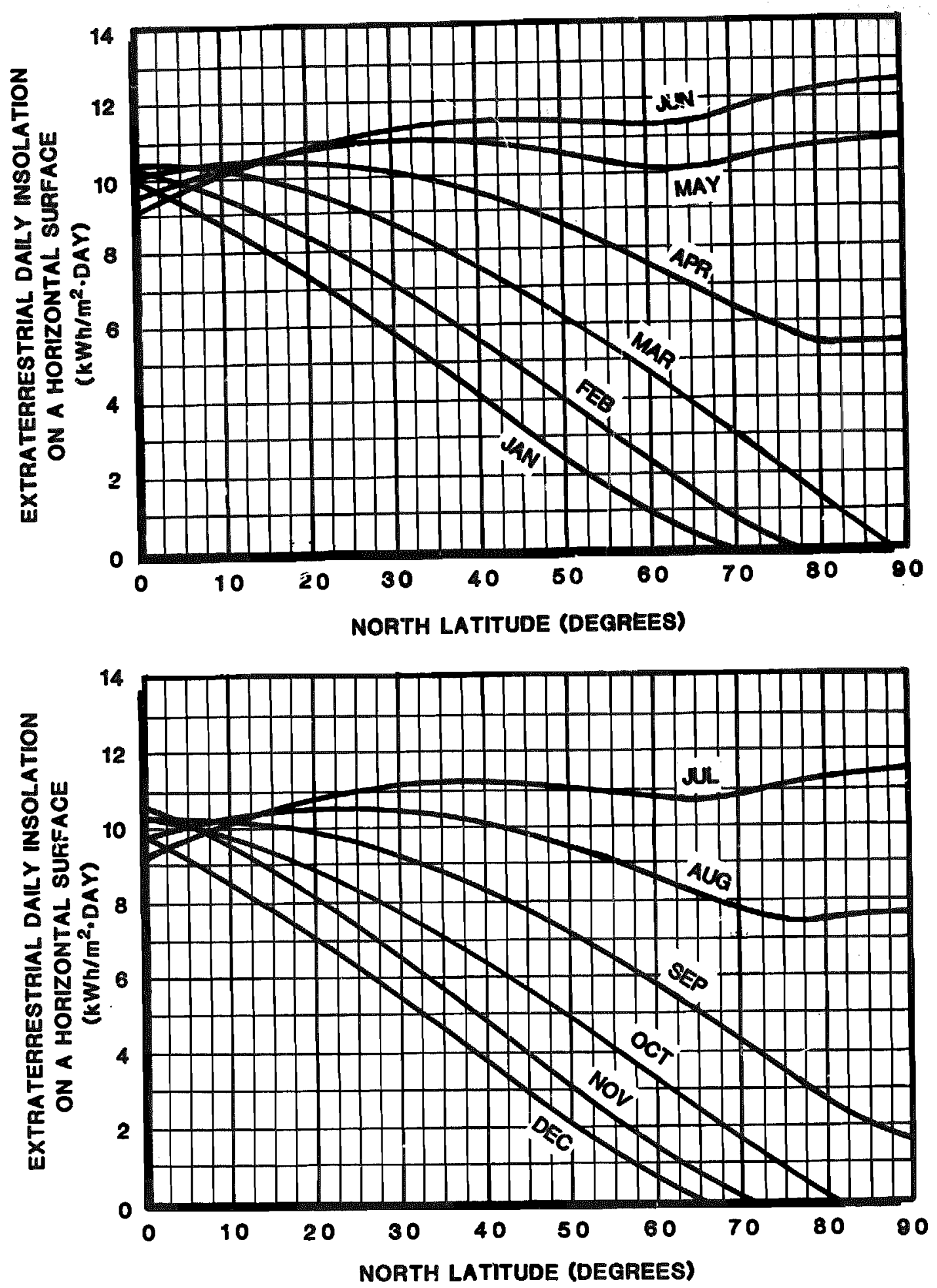

Figure 2.2 Extraterrestrial Daily Insolation Received on Horizontal Surface as a Function of Month and Latitude 
CHAPTER 2

(B1ank) 
CHAPTER 3

\section{PREDICTING SYSTEM PERFORMANCE}

\subsection{BACKGROUND}

The information contained in this chapter is used to estimate system performance, given an array performance prediction from Chapter 2. The results from Chapter 2 that are necessary here are the monthly effective array output per unit area, QE/A, and the monthly array efficiency, $\eta$.

This chapter introduces several additional quantities:

$$
\begin{aligned}
& \text { L - Monthly average daily electrical load (kWh) } \\
& \text { B - Electrical energy storage capacity (Wh) } \\
& \text { F - Solar fraction, or the portion of the electrical load } \\
& \text { supplied by the photovoltaic system. }
\end{aligned}
$$

\subsection{LOAD}

This number is determined by the application and must be supplied by the designer. The monthly average daily electrical load, $L$, is most accurately estimated by dividing the electrical load for an entire month in kWh by the number of days in that month if the magnitude is relatively constant from day to day. If significant variations occur from day to day, then the techniques of this chapter will overestimate the actual solar fraction, since the performance curves used assume repetitive daily loads over the month. If significant differences occur on certain days of the week (e.g., if weekend loads are different from weekday loads), then separate average daily loads should be computed for these days and separate performance estimates should be made. Monthly performance can be approximated by taking a weighted average of these separate daily estimates.

\subsection{ELECTRICAL STORAGE CAPACITY}

Lead-acid batteries having round trip efficiency of 80 percent are represented in these calculations. Electrical energy storage capacity, B (in Watt-hrs), is calculated from:

B [Wh] = Capacity per battery [Ah] x Average voltage per battery [V] $x$ Fraction of battery used $x$ Number of batteries

Battery manufacturers comonly size their products by amp-hour capacity at a moderate discharge rate, e.g., '30 amp-hours at the 10 hour rate." The amp-hour capacity entered in eq. (3.1) should be 
this value, 1.e., the capacity mesured at a rate wich cares complete discharge in $10 \pm_{2}$ hours.

In the present application, the average voltage per battery is the average voltage during both charge and discharge at approzimately the 10-hour rate. A voltage per cell of $2.17 \mathrm{has}$ been implicitly assumed in the performance curves that are used in the procedure presented in this Guide. Therefore, the voltage per battery to be used in eq. (3.1) 量st be 2.17 times the number of nominal 2 volt cells in series within the battery. This value differs only slightly fros the average voltage of 2.12 which can be competed from the information of Reference 9.

The "fraction of battery used"' depends upon how doep a discharge and how high a charge are permitted during battery operation. For example, if $60 \%$ of the total available battery capacity is utilized, this factor would be 0.6 . (The systen's power conditioner or regelator must monitor battery state of charge and/or voltage and regulate battery current accordingly.)

The number of batteries entered into eq. (3.1) is the total number of betteries in the storage system. For example, if the storage is arranged with. 3 batteries in series and 4 batteries in paralle1, ther the total mumber of batteries is $3 \times 4=12$.

\subsection{SOLAR FRACTIONS}

This chapter outlines how to calculate solar fractions, F, on a monthly and on an annual basis. Steps 1 to 7, 1isted in Section 3.4 below, detail how to estimate $F$ for single month. If these steps are carried out for al1 12 months, then an annul $\mathrm{F}$ can be computed by following steps 8 and 9 .

In Step 5, several of the quantities discussed in Chapter 2 and Section 3.2 are combined to give the variables which are recessury to eventually obtain solar fractions. These variables are:

$$
Q E / L=(Q E / A) \cdot(1 / L) \cdot A
$$

and

$$
B / A_{\eta}=\frac{1}{\eta} \cdot B \cdot \frac{1}{A} \cdot \frac{(Q S / A)_{12 t}}{Q S / A} \cdot \frac{90}{\eta_{p c}}
$$

$Q R / L$ is the potential solar fraction in that is represents the fraction of the load which conld potentially be satisfied by electrical energy from the array if infinite, loss free storage were available. In many cases part of the available array output cannot be used irmediately and most be stored, "dumped" (or not collected), or 
fed back to the grid (if that option is available). Other losses are due to battery inefficiencies. These carse the solar fraction, F, to always be less than $\mathrm{OE} / \mathrm{L}$.

QE/L is a dimensionless parameter and can be changed, for a given load and location, by increasing or decreasing array area (ohanging A), by changing the array tilt [which changes QS/A that is used in calculating $\mathrm{OE} / \mathrm{A}$ via oq. (2.5)], or by using different arrays [changing $\eta$ in eq. (2.5)].

For individual months, the parameter B/An has been empirically found to collapse solar fraction data for different geographic and climatological locations onto nearly a single family of curves in the (B/An. F) plane which have only $Q E / L$ as a parameter. However, such a collapse of data appears to be possible only if the arrays are tilted at the local 1atitude angle for each location and if the same power conditioning efficiency, $\eta_{\text {pe }}$ is used in all cases compared. This is an extremely important point since $B / A \eta$ is a dimensional parameter.

Since designers often desire to use various (non-latitude) tilts and other power conditioning efficiencies, it is necessary to be able to "correct" these latitude $t i 1 t$, fixed $\eta_{p c}$ data in order to improve

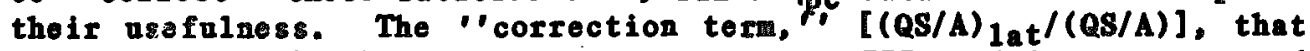
appears in eq. (3.3) allows the data of Table III, which were computed for latitude tilts, to be used for other array tilts. (QS/A) 1 at is the local array insolation (from Table I) corresponding to a tilt angle equal to the local latitude, while (QS/A) is the insolation for the array tilt actually used in the system. Likewise, since the data in Table III were computed with $\eta_{p c}=90$ percent, the "'correction'" $\left[90 / \eta_{p c}\right]$ allows that data to be used with other values of $\eta_{p c}$.

B/An can be changed by increasing or decreasing storage size (changing $B$ ), changing array area (A), controlling the array tilt (this latter option affects $B / A \eta$ through the "correction ter."' referred to above), using different arrays (i.e.. different $\eta^{\prime} s$ ), and/or using different power conditioning officiencies (i.e.) different $\left.\eta_{\mathrm{pc}} \mathrm{s}^{\mathrm{s}}\right)$. Notice that $A$ and $\eta$ affect both $Q R / L$ and $B / A \eta$ is the interplay of variables should not be ignored.

The next two sections outline a step-by-step procedure for calculating $\mathrm{OE} / \mathrm{L}$ and $\mathrm{B} / \mathrm{A} \eta$ and obtaining estimates of $\mathrm{F}$.

3.4 THE PROCEDURE FOR ESTIMATING

HONTHLY AND ANNUAL SOLAR FRACTIONS (F'S)

Worksheet 2, found on the back of Worksheet 1 at the end of the appendix, facilitates these calculations. The following steps refer to the worksheet. 
Sten 1 The designer must select A (array area) and $B$ (storage capacity). Enter these values at the top of Worksheet 2.

Once the location, array tilt, and array specifications are set, a designer might use $A$ to provide different $Q E / L ' s$ (Step 5 below); i.e., he wight investigate the effect of array area on the solar fraction. For most load shapes, the relationship between $A$ and solar fraction $F$ is not linear, especially above $F=0.4$, that is, there are diminishing returns for additional array area. Above $F=0.4$, each increment of area added supplies a smaller fraction of the load. At some point it becomes economical to nse the back-up source instead of increasing array size. For erample, n array chosen to provide potential solar fraction QE/L of 0.20 (or 20\%) would have an area of $0.2 \cdot \mathrm{L} /(\mathrm{OE} / \mathrm{A})$. For any load shapes (at least for those included in Table III) the actual solar fraction would be nearly 0.20 (or 20\%). For a potential solar fraction $\mathrm{QE} / \mathrm{L}$ of 0.8 (or $80 \%$ ), an array area of $0.8 \cdot \mathrm{L} /(\mathrm{OE} / \mathrm{A}$ ) wow1d be required. For most load shapes unless there is excellert diurnal 1 atching between the array output and the load, the actun solar fraction would be less than 0.8 by an amonnt that depends on the storage capacity and storage efficiency.

Once an erray area is chosen, "rile of thuab" on olectrical storage is that an upper 1 imit on capacity can be found by noting that storage capacities larger thas about $B=40 \cdot \eta \cdot A$ seldon result in incresing the solar fraction. In fact, the "olnoes" of the $F$ vs. storage capacity curves occur about $B=10 \cdot \eta \cdot A$ to $20 \cdot \eta \cdot A$. This should be more obvious to the designer after he has completed steps 6 and 7 below. Of course, if the back-up grid is to be used as the storage medium (e.g., if utility sellback is peritited), $\mathbf{B}=\mathbf{0}$.

Step 2 Enter the month1y $Q E / A$ and $L$ (colusens $C 10$ and C8, respectively, from Workgheet 1 ) in colums C12 and C13, respective1y.

Step 3 Enter into colum C14, the array insolation, (QS/A) 1at, frow Table I that corresponds to an array tilt equal to the local latitude angle. Usually this value will have to be interpolated in the table.

Step 4 Estimate the average daily electrical load for each month and enter in colum C15.

Step 5 Calculate $Q E / L$ and $B / A \eta$ from eqs. (3.2) and (3.3) and enter in columins C16 and C17. These values also vary monthly.

Step 6 From Table III of the appendix, select the system performance graphs which best reseable the application load profile. The key to and choice of graphs is discussed in Section 3.5 . 
Step 7 Enter the appropriate performance graphs of Tablo III with OR/L and $B / A n$ to obtain the monthly solar fractions. A reading key for Table III is given on page A-63.

For example, for ainter month with $Q E / L=0.6$ and $B / A_{\eta}=10$ $W h /\left(\mathrm{m}^{2} \cdot \mathrm{F}\right)$, the example graph in Figure 3.1 jields $F=0.43$.

For QE/L other than $0.2,0.4,0.6$, etc.. a simple interpolation is done, as illustrated in the examples in Chapter 4 of this Guide.

The final steps in this chapter's procedare give an estimete of the annual solar fraction:

Step 8 Multiply L I d for each month and enter in columin 19.

Stop 9 Perform the calculation presented at the botton of the worksheet. $"$ " derotes a summation of the indiceted quantities over al1 12 months.

\subsection{EEY TO GRAPHS OF TABLE III}

Selection of a particular page from anong the 41 pages of systen performance graphs in Table III of the appendix depends upon the shaps of the average daily electrica 1 load. The 41 pages are divided into four classtications:
1. Constant (1)
2. Simusoidal (20)
3. Unimoda1 (17)
4. Bimoda1 (3)

The numbers in parentheses indicate the number of load profiles in each category for which there are performance graphs in this Geide.

The constant load shape needs no further explanation. The profiles in category 2 are indexed on pages $A-59$ and $A-60$, while those for categories 3 and 4 are indered on pages $A-61$ and $A-62$. These curves are based upon the average daily load profiles for all the two-digit SIC (Standard Industrial Codes) applications 1isted In Reference 10. Several of the sinesoidal profiles ay also be representative of residential 1oads, but note the coments on residential loads in Section 3.7 .

Four comments pertain to the use of the profiles and indices:

(1) Note that in the Unimodal and Bimodal plots, the vertical scale ay vary for different profiles. 
CHAPIER 3

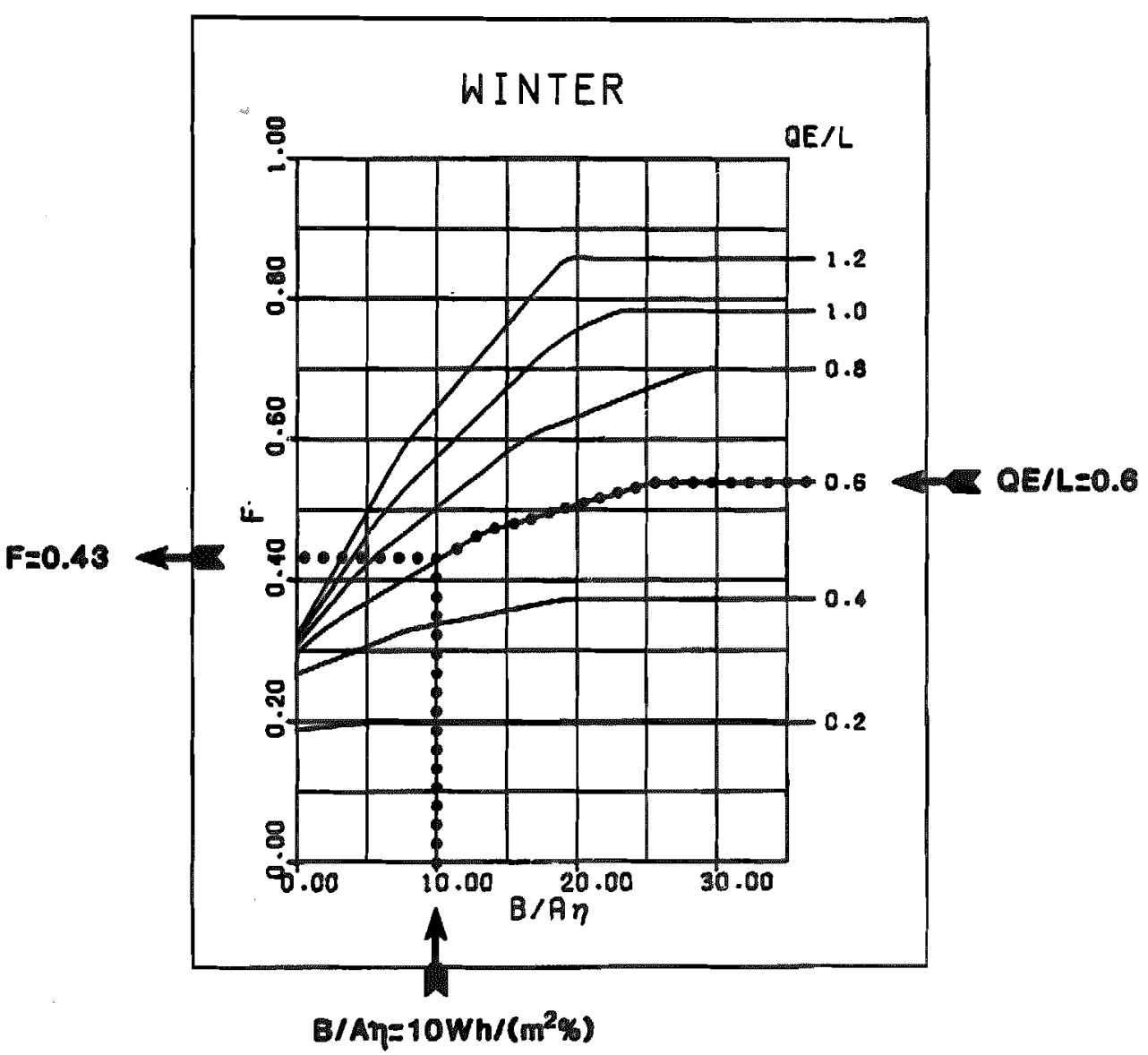

How to Use the Performance Curves of Table III to Find F

Figure 3.1 
(2) Select the profile which most closely resembles that of the application. In some cases, the use of graphs pertaining to several profiles and averaging of the results may be necessary.

(3) Only the shape of the curve is important in profile selection. The size of the loed or the area under the curve onter the procedure through the quantity $\mathrm{QE} / \mathrm{L}$.

(4) The "Spring-Fa11"' graphs are for the months of February. March, Apri1, Angust, September, and October. For Northern Hemisphere

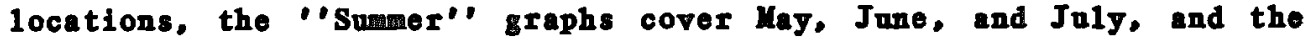
"Vinter" graphs are for November, December, and Jannary. The sumer and winter months are reversed for Southern Hemisphere sites.

\subsection{USE OF THE ELECTRICAL STORAGE}

Figure 3.2 illustrates how the eleotrical storage would be utilized during operation of a typical photovoltaic system. Although the calculations presented there aio for the spring and fall months for a sinusoidal load profile of amplitude to mean ratio of 0.3 and time of peak of 18:00 (profile 18.3 in Table III), they should be typical of other months and many other types of load shapes.

The small diagrams on the periphery of Figure 3.2 ere histograms of the battery state of charge which essentially tell how the battery would spend its time. For example, these show that small storage capacities [B/An 10 Wh/( $\left.\mathrm{w}^{*} \cdot \%\right)$ ] would cover the ontire permitted range of state of charge, since they typically would charge quickly during the day and then discharge quickly noar or after sundown. Most of the timo would be spent either fully charged or at the minimum permitted state of chargo. For $\mathrm{QE} / \mathrm{L}=0.6$, photovoltaic array untput would be

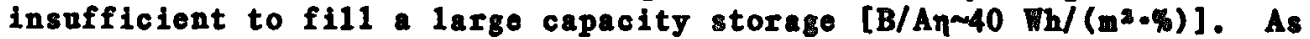
a result, the state of charge would be at or near the minimum permitted value most of the time. If this minimum happens to be near zero state of charge (i.e., if the storage were allowed to be fully discharged), such operation would not favor long battory lifotimes. This situation reverses for large arrays (0.g., $Q E / L=1.2)$ and large storage capacities. Here tho array output would maintain the betteries at full charge most of the time since there is more than enough energy to meet the average dally load. Such operation world favor long battery lifetimes.

Note that a fired $B / A \eta$ does not infer the same battery capecity at $Q E / L=0.6$ as it does at $Q E / L=1.2$. For the same load, it takes twice the array size for a $Q E / L=1.2$ as it does for a $Q E / L=0.6$. Equal $\mathrm{B} / \mathrm{An}$ thus requires twice the storage capacity for $Q E / L=1.2$ as for $Q E / L=0.6$. 


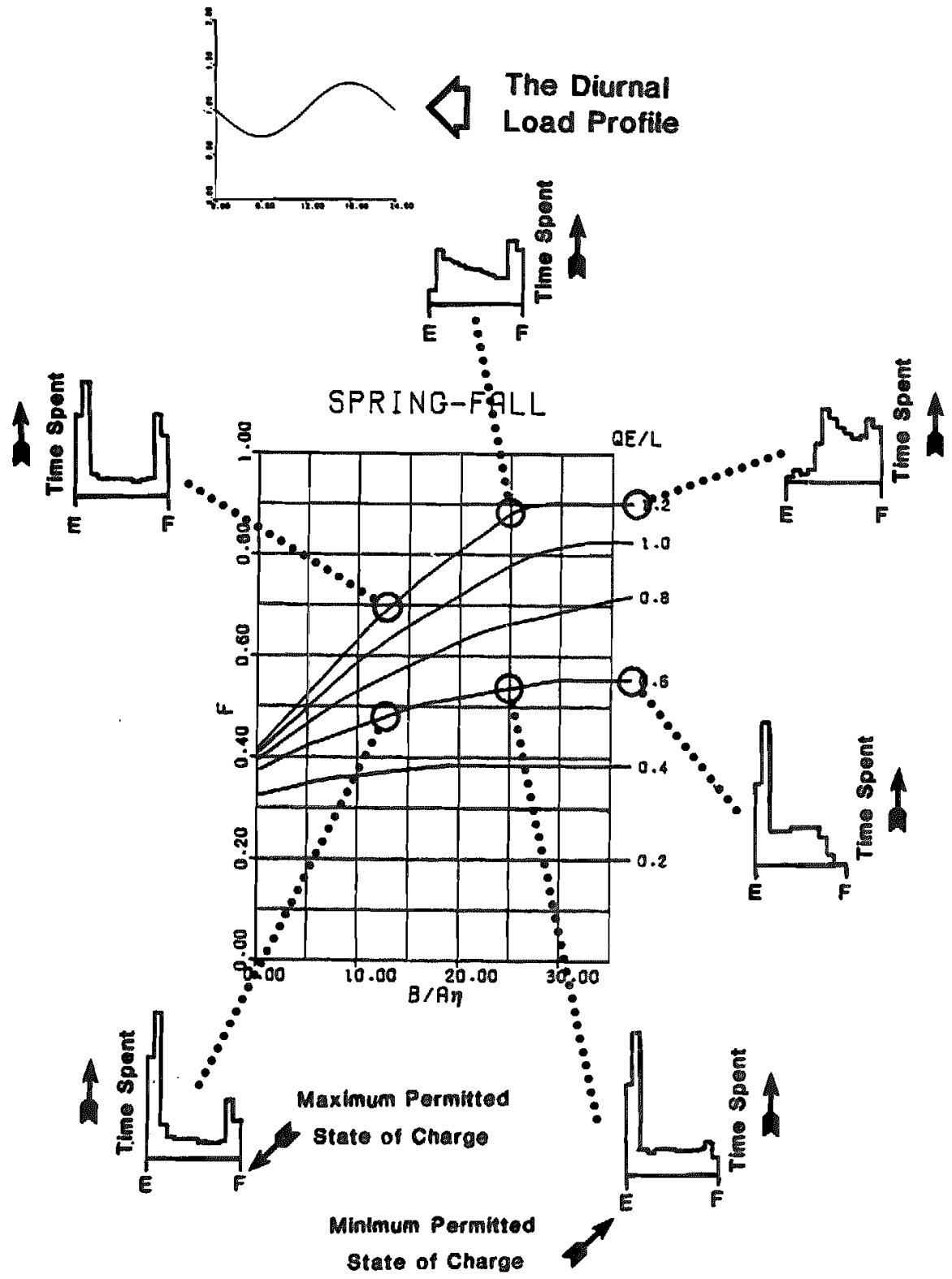

Histograas Showing How the Electrical Storage is Used

Figure 3.2 


\subsection{ERRORS IN STSTEM PERFORUANCE PREDICTIONS}

This section describes three sources of error in the predictions of $\mathrm{F}$. They are discussed in order of increasing importance.

Effect of "Noisy"' Loads

An actual load profile will seldom have the "smooth" appearance of those on pages A-59 to A-62. A1though the load shape way, on the average, approzimate one of those for which performance data is given in Table III, fluctuations or "'noise' will usually be superposed on the load curve for any given day.

Deviations from smooth profile will generally cause a negligiblo difference between actual system performance and this chapter's predictions. However, when the fluctuations become large enough, the solar frection will be less than what is estimated in the given procedure.

Specifically, when the amplitude of the noise is equal to or greater than the average load, then the solar fraction will be at least 5 w 108 s than the estimate.

Residential load applications, in which switching of appliances can lead to significant deviations from " "gacoth" load profile, way be subject to significant error. Caution is arged in the use of these performance curves for such applications. Probably just as important in residential applications are the day to day variations in daily 1oad. The performance curves of Table III vere constructed assuning repetitive daily loads over each month. If the loads vary significantiy from day to day the procedures using Table III will overestimate $F$.

Dependence of Performance Estimates upon ET and Latitude

The system performance graphs of Table III are constructed to take into account the two major factors which affect the interaction of array output and electrical load. The first consideration is load profile and the second is daylength, which varies appreciably from one season to another. Thus Table III contains three seasonei furformance curves for each of 41 load profiles.

Two minor effects are ignored in the generation of these grashs. The first of these is the variation of KT within a given season as the location of interest varies. A relativoly large value of ET implies that the weather is consistently good from one day to another. A sall KT, on the other hand, indicates either frequently clondy weather with a high degree of day-to-day variability or uniformly poor weather. 
The graphs of Table III are ctuelly predictions for 100 tion heving IT's approxinetely equel to the average values for ach semson of the 97 loentions 1isted in Table II. Figure 3.3 gives the monthly distributioss of IT for these 97 locations, while Table 3.1 gives the values used in constructing Table III.

The other effect ignored in Table III is the varietion of deylength during sumer or vinter dwe to latitude difierences ang 100ations. Table 3.2 shows how mach the dayleagth varies at the tro solstices over the latitude range covered in this Guide. (The daylength is 12.0 hours worldwide at the spring and fall equinoxes.)

Tab1e 3.1

Approrimate Values of IT Ised in Generating the System Performence Graphs of Tablo III

\begin{tabular}{lc} 
Sesson & Average IT \\
\hline Sprigg & .545 \\
Sunaer & .573 \\
Fal1 & .560 \\
Vinter & .442
\end{tabular}

Table 3.2

Varietion of Latitud and Daylength

\begin{tabular}{|c|c|c|c|}
\hline Date & Locetion & Latitude & Dayleath \\
\hline June 22 & $\begin{array}{l}\text { Barrow, AR } \\
\text { Caribon, MR } \\
\text { Lake Cherles, LA } \\
\text { Eoror Is. }\end{array}$ & $\begin{array}{r}71.3 \\
46.9 \\
30.1 \\
7.3\end{array}$ & $\begin{array}{l}24.0 \\
15.7 \\
13.9 \\
12.4\end{array}$ \\
\hline Docember 22 & $\begin{array}{l}\text { Barrow, } \mathbf{A R} \\
\text { Caribod, MP } \\
\text { Lake Charles LA } \\
\text { Toror Is. }\end{array}$ & $\begin{array}{r}71.3 \\
46.9 \\
30.1 \\
7.3\end{array}$ & $\begin{array}{r}0.0 \\
8.3 \\
10.1 \\
11.6\end{array}$ \\
\hline
\end{tabular}



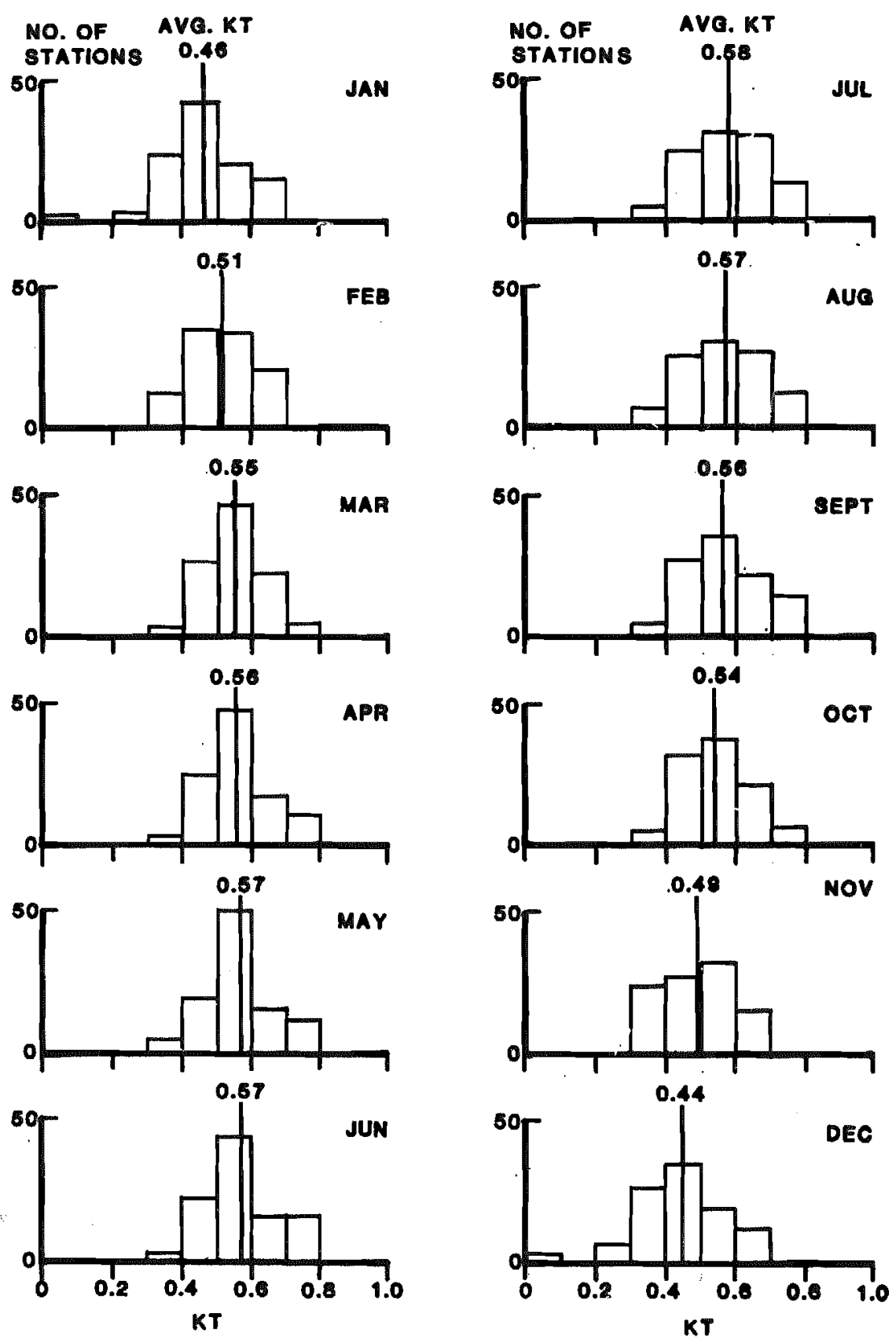

Month1y KT Distributions for the 97 Stations

for Which Data Are Included in Table $I$.

Figure 3.3. 
The significance of the fectors of IT and latitude/daylonth for locetions within the contigeous United States is displayed in Figs. 3.4 and 3.5. The date points in these plots are the resulte of computer sinelations using data for the four locetione indiceted and assuing a sinusoidel \#18.3 lasd profile.

The rationnle behind the selection of the locetions other than Albequarqu is described below. Resclts for Albuquerque are show bocaese these served as the starting point in the development of this entire systom perforance estimation procedere. Likerise; the sinusoidal 18.3 loed profil closely rosombles the "beseline load" used in the backgroand work. (Seo Reference 4.)

The infience of IT is illustrated by a comparison of the result: for Lake Charles and E1 Paso, which have approximately the same latitude ( $30.1 \mathrm{~N}$ and $33.7 \mathrm{~N}$, respective1y) but wol different $\mathrm{IT}^{\prime}$ for any given month. Notable differences in predicted soler fractios for these two locetions appor for two cases: (1) winter wonths, sall $B / A \eta$, (2) spring or fall wonths, large $Q R / L$ and large $B / A \eta$.

These variations in predicted $\mathrm{F}^{\circ} \mathrm{s}$ due to IT are 1058 sovere if the load profilo is a botter ateh to the average daily array output curve than the sinesoidal $\$ 18.3$ one, and are more serion if the lond shape differs from the array ontpet shapo to areater extent than the sinusoidal \#18.3 curvo.

The effect of latitude and heree daylength variation in suaner and winter months is depicted via the results in Figs. 3.4 and 3.5 for Caribou and Lake Charles. These two locatious have roughly the same I's during the months of interest, yot they differ considerably in latitude and solstice daylengths, as indicated in Table 3.2. The Figures show that this causes appreciable (J5\%) differences in $F$ only during vinter wonths and when $Q E / L$ is large.

Computer simnlations for locetions outside the contigmors V.S. heve not been done, but the solar fractions for those sites may differ considerably frow the results for sumer and winter presented in Figs. 3.4 and 3.5 , due to the 1atitude/daylength effect. It is therefore recomended that extreme cation be erercised in making use of system performence estimates for the Aleskan and island locations in sumer and winter. 


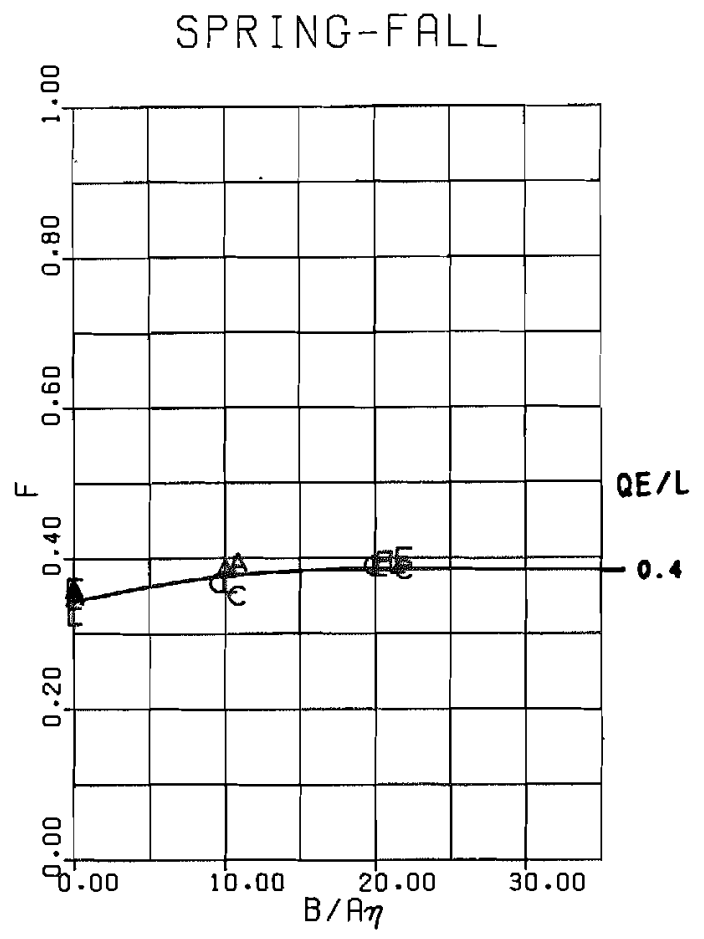

Bigrse 3.4

Comperison of the Simplified System Performance Curves with Hourly Simulation Results

Load Prof110 - Sinmsoida1\#18.3 (pg.A-81) QR/L...........................

Solid Lines - Performaneo Bsituates from this Onide

Data Points - Hiovily Simulation Results

A Albuquerque, N

C Ceribor, IT

E E1 Paso, TX

L Lake Charles, LA
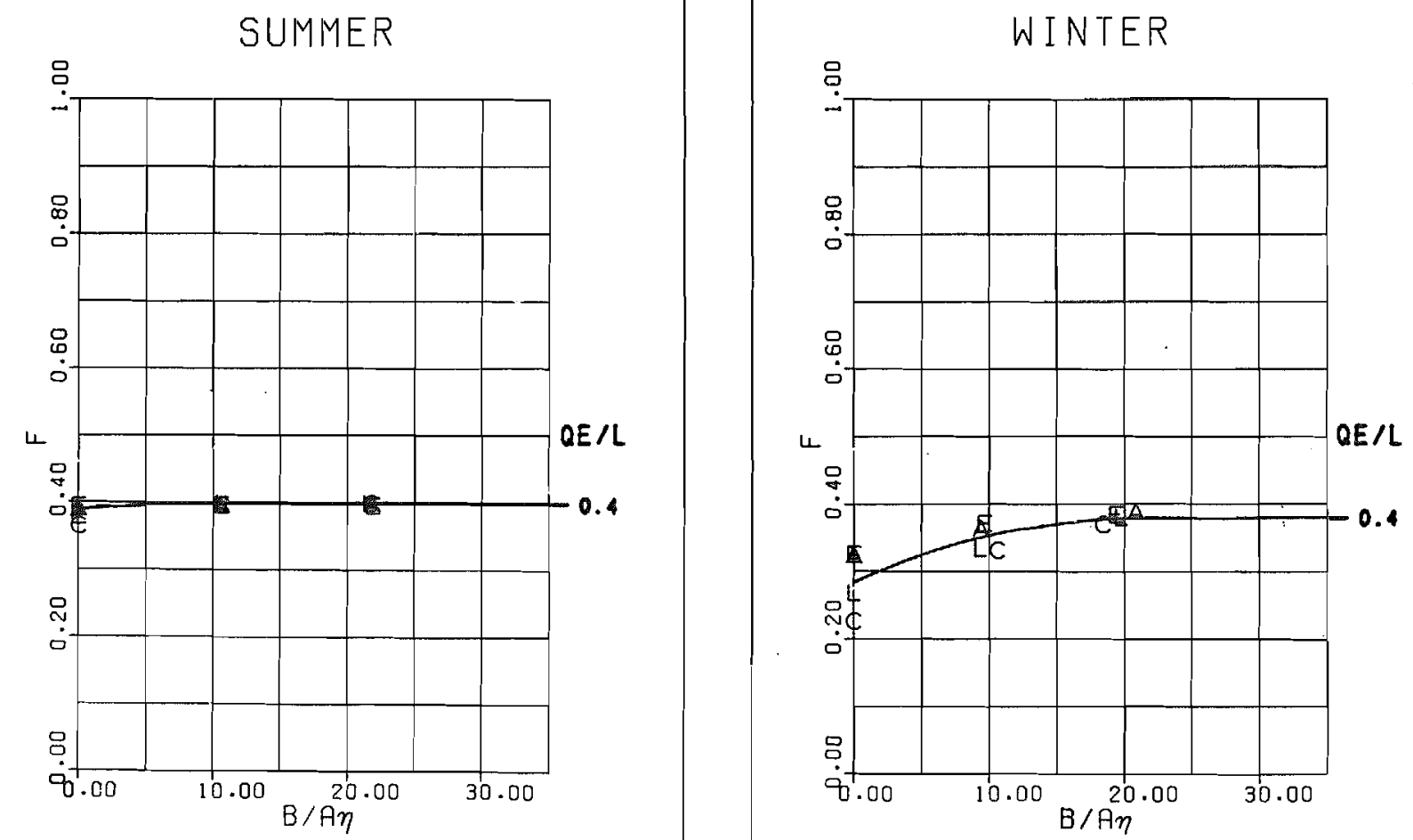
ChAPTER 3

Figare 3.5

Comparison of the Simplified Systom Performance Curves with Hourly Simuletion Result:

Losd Profi1e - Sinusoide1 $18.3(\mathrm{pg} \cdot \mathrm{A}-81$ ) $\mathrm{QR} / \mathrm{L} \cdot . . \cdot . \cdot . \cdot . \cdot . . . .1 .0$

Solid Lines - Performance Bsitmates from this Gaido

Dete Points - Hourly Sinu1ation Results

$\begin{array}{rr}\text { A } & \text { Albuquerque, NU } \\ \mathbf{C} & \text { Caribou, MR } \\ \mathrm{E} & \text { E1 Paso, TI } \\ \text { L } & \text { Lake Cherlos, LA }\end{array}$

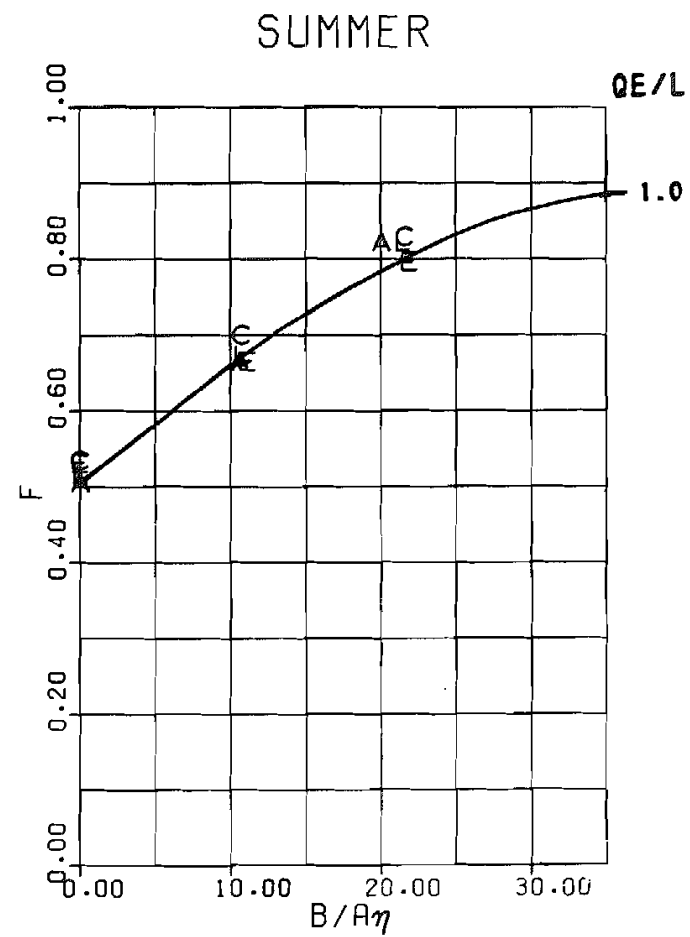

SPRING-FALL

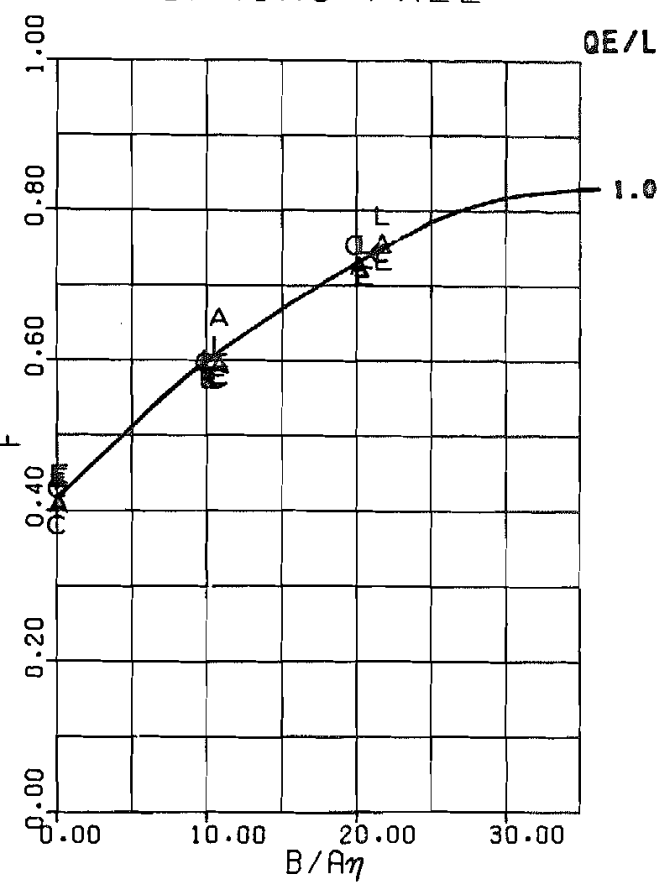

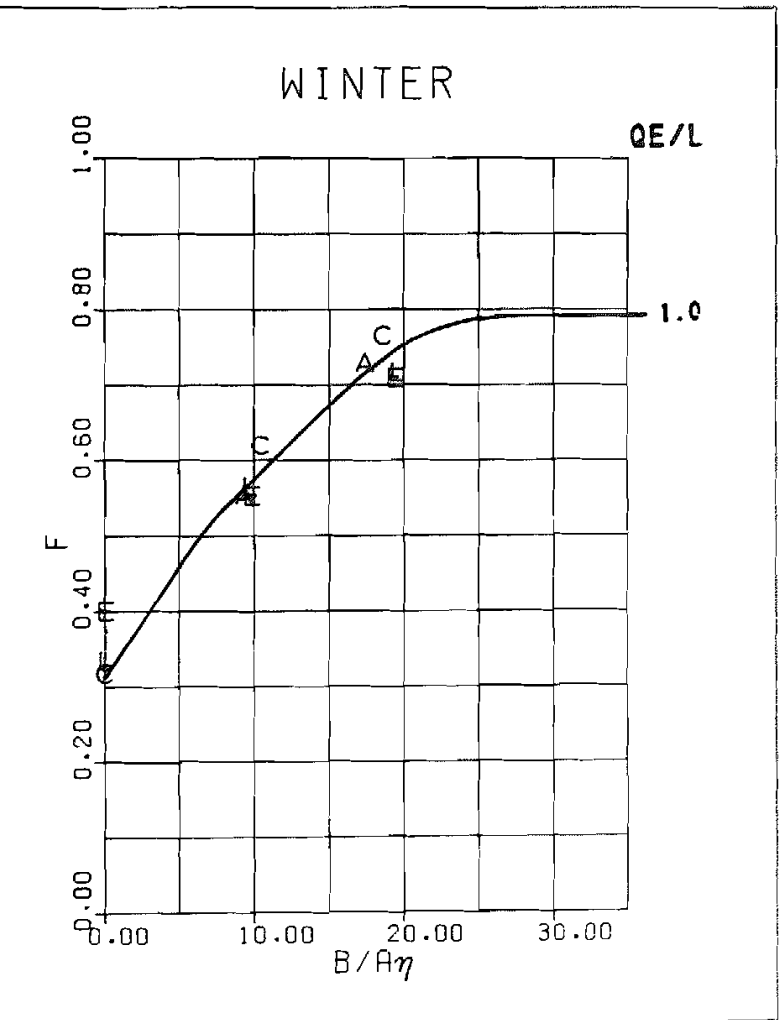




\section{CRAPTER 4}

\section{EMAMTES}

\subsection{INTRODUCTION}

This chapter cortains six examples of array and system performance cnlculations and demonstrates use of the information of Chapters 2 and 3 and the Appendix. Data on photovoltaic modules are from actuel manufecturers specification sheots. Fectors such as location, seeson, and load profile vary from one example to another to illustrate diverse (though fictitious) applicetions. Examples 1 to 5 are single month celculations. Bxample 6 shows how to obtein an anuel performence estimato and includes completed workhoets, whilo Eramplo 7 comperes a result using this Guido's method with that from another approech. Teble 4.1 sumerizes the Examples.

\section{Tab1e 4.1}

Sunaniry of Examples

\begin{tabular}{|c|c|c|c|c|c|c|c|c|}
\hline Exage le & Locetion & Moath & $\begin{array}{l}\text { Loed } \\
\text { Proflle }\end{array}$ & Application & $\mathrm{OE} / \mathrm{L}$ & $B / A T^{*}$ & $\mathbf{F}$ & Denonstration \\
\hline 1 & $\begin{array}{l}\text { Herrisburg, } \\
\text { PA }\end{array}$ & oCT & $\begin{array}{c}\text { Sinuisoidal } \\
\# 15.3\end{array}$ & $\begin{array}{l}\text { Rosidontial } \\
\text { Loed Contor }\end{array}$ & 0.77 & 20.1 & 0.63 & $\begin{array}{l}\text { Fuadanentala } \\
\text { of prceodure }\end{array}$ \\
\hline 2 & $\begin{array}{l}\text { Savazuah. } \\
\text { GA }\end{array}$ & $A P R$ & Unimode1 \#1 & Bank & 0.49 & 0 & 0.42 & $\begin{array}{l}\text { KT f rom ano- } \\
\text { thor source, } \\
\text { ntility } \\
\text { feedbeek }\end{array}$ \\
\hline 3 & $\begin{array}{l}\text { Honolula, } \\
\text { III }\end{array}$ & FEB & $\begin{array}{r}\text { Constent/ } \\
\text { sinnsoidal } \\
\$ 12.2\end{array}$ & $\begin{array}{l}\text { Printing } \\
\text { Shop }\end{array}$ & 0.65 & 11.2 & 0.50 & $\begin{array}{l}\text { Non-optimam } \\
\text { tilt, aot } \\
\text { tandard } \\
\text { lond }\end{array}$ \\
\hline 4 & St. Louis, & AUG & Bimode1 \#3 & $\begin{array}{l}\text { Service } \\
\text { Stetion }\end{array}$ & $\begin{array}{c}0.70 \\
\text { to } \\
0.75\end{array}$ & $\begin{array}{r}6.1 \\
\text { to } \\
7.0\end{array}$ & $\begin{array}{c}0.61 \\
t 0 \\
0.63\end{array}$ & $\begin{array}{l}\text { Variable } \\
\text { tilt }\end{array}$ \\
\hline 5 & $\begin{array}{l}\text { Flagstaff, } \\
\text { AZ }\end{array}$ & Nov & Unisoda1 \#6 & Lumber Mil1 & $\begin{array}{c}0.21 \\
\text { to } \\
0.83\end{array}$ & 10.0 & $\begin{array}{c}0.21 \\
\text { to } \\
0.60\end{array}$ & $\begin{array}{l}\text { Variable } \\
\text { A, B }\end{array}$ \\
\hline 6 & $\begin{array}{l}\text { Oakiand, } \\
\text { CA }\end{array}$ & $\begin{array}{l}\text { A11 } \\
\text { joar }\end{array}$ & Constant & Post Office & $\begin{array}{c}0.16 \\
\text { to } \\
0.72\end{array}$ & $\begin{array}{c}5.2 \\
t 0 \\
10.0\end{array}$ & $\begin{array}{c}0.16 \\
\text { to } \\
0.52\end{array}$ & $\begin{array}{l}12 \text { Donth } \\
\text { and sansel } \\
\text { calcuiatione }\end{array}$ \\
\hline 7 & $\begin{array}{l}\text { Madison, } \\
\text { MI }\end{array}$ & JAN & Constant & (Unknoma) & $\begin{array}{l}0.70 \\
0.77\end{array}$ & 17.4 & $\begin{array}{l}0.56 \\
0.59\end{array}$ & $\begin{array}{l}\text { Comperison } \\
\text { of Methods }\end{array}$ \\
\hline
\end{tabular}

$\left[\% h /\left(m^{2}+\infty\right)\right]$ 
CIAFTBR 4

4.1 ExMPLE 1: Merrisbarg, PA (1etitude $40.2 \mathrm{~N})$, October

Chepter 2 Colonlations:

Step 1: Manufacturer's deta for the photovoltaic nodules to be used include the max-power current output equel to 1.83 aps at 14.19 volts when the insoletion is $0.8 \mathrm{~kW} / \mathrm{m}^{2}$. The area of each modulo is $0.36 \mathrm{~m}^{2}$. Then froseq. (2.3)

$$
\eta_{I}=\frac{(1.83 \mathrm{~A})(14.19 \mathrm{~V})}{\left(0.36 \mathrm{w}^{8}\right)\left(0.81 \mathrm{k} / \mathrm{m}^{2}\right)} \cdot \frac{1 \mathrm{~K}}{1000 \mathrm{~V}} \cdot 100 \mathrm{~W}=9.02 \% \text {. }
$$

This is at a stated cell (reference) temperature, $T_{r}$ of $47 \mathrm{C}$.

Step 2: The module specification shects give insuficient inforation to oalenlate $\beta$. Because the cells are silicon, ase $\beta=0,0045 \mathrm{C}^{1}$.

Step 3: Tho nodule data ive $\mathrm{NOCT}=47 \mathrm{C}$ at $0.8 \mathrm{~kW} / \mathrm{m}^{2}$ and $\mathrm{T}_{\mathrm{a}}=20 \mathrm{C}$. with a rind speed of $1 \mathrm{w} / \mathrm{s}$.

Step 4: The two power conditioning components in this case are assuned to bo ax-power tracker and at inverter. The assened

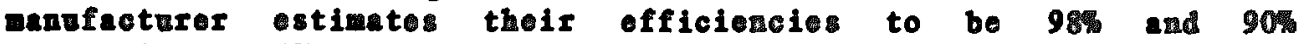
respectively. Then the overall power conditioning efficiency is

$$
\eta_{\text {pe }}=0.98 \cdot 0.90 \cdot 100 \%=88.2 \% \text {. }
$$

Step 5: The map on page A-2 indicates that calculations for Harrisberg should use tho Vilkes-Barre, PA solar/meteorological data or page A-54 of Table $I$.

Step 6: From Table II, $s y=40.2^{\circ}+10^{\circ}=50.2^{\circ}$. In order to aximize array output during October, we set $=50.2^{\circ}$.

Step 7: From the wilkes-Barre dat for 0ctober, WS $=3 \mathrm{~m} / \mathrm{s}$. The corrected WS $=2 / 3 \cdot 3=2 \mathrm{~m} / \mathrm{s}$. Table I also $11 \mathrm{st} \quad \mathrm{Er}=0.455$, $\mathrm{TH}=11 \mathrm{C}$, and for a tilt of approriante1y $50^{\circ}, \mathrm{QS} / \mathbb{A}=3.73 \mathrm{kWh} / \mathrm{m}^{2}$.

Step 8: $|s-s|=0$.

Step 9: For the given NOCT information, start at $47 \mathrm{C}$ on aris $\mathrm{A3}$ in Fig. 2.1. Continnation through the chart using the above WS, KT, $\left|s-s_{M}\right|$. and $T$ yields $T_{c}=29 \mathrm{C}$.

Step 10: Frow oq. (2.2),

$\eta=9.02 \%[1-0.0045(29-47)]=9.75 \%$.

Step 11: Pron oq. (2.5).

$$
\mathrm{OE} / \mathrm{A}=\frac{88.2}{100} \cdot \frac{9.75}{100} \cdot 3.73=0.32 \mathrm{kWh} / \mathrm{m}^{2} \text {. }
$$


CIAPTER 4

\section{Chapter 3 Celenlations:}

Step 1: Solect an rray area $A=720 \mathrm{~m}^{2}$ (thes requiring 200 of the $0.36 \mathrm{~m}^{2}$ modules) and storage cepacity $B=140,000 \mathrm{Wh}$.

Step 2: I and QR/A are given above in Steps 10 and 11, respectively.

Step 3: $(Q S / A)_{12 t}=3.69 \mathrm{kmh} / \mathrm{m}^{2}$.

Step 4: The monthly average daily electrical load, $L$, is estimated to be 300 kWh.

Step 5: From eq. (3.2),

$$
Q E / L=0.32 \cdot \frac{1}{300} \cdot 720=0.77 \text {. }
$$

and from eq. $(3.3)$,

$$
B / A \eta=\frac{1}{9.75} \cdot 140,000 \cdot \frac{1}{720} \cdot \frac{3.69}{3.73} \cdot \frac{90}{88.2}=20.1 \mathrm{Wh} /\left(\mathrm{m}^{2} \cdot 4\right) \text {. }
$$

Step 6: Suppose that the load is a residential load center (severai houses), with a sinesoidal shape, a peak at around 3 PM and an amplitude-to-mean ratio of about 0.3 . The key on page $A-59$ to $A-62$ clearly suggests using the sinusoidal \#15.3 performance graph on page A-76 in Table III.

Step 7: October is fall month. For $Q E / L=0.77$ and $B / A \eta=20.1$ $\mathrm{Wh} /\left(\mathrm{m}^{2} \cdot \%\right)$, the Spring-Fail graph on page A-76 shows $F$ to be 0.65 or $65 \%$.

$720 \mathrm{~m}^{2}$ of array area and 140,000 Wh of utilizable storage capacity will thus provide $65 \%$ of the given load in Harrisburg in October. "Dumping" of excess energy at certain times and storage inefficiencis cause $F$ to be $10 s$ than the potential solar fraction of $\mathrm{QE} / \mathrm{L}=0.77$.

\subsection{EXAMPLE 2: Savannah, GA (1atitude $32.1 \mathrm{~N}$ ), April}

\section{Chapter 2 Calculations:}

Step 1: In this example the module specifications 1 ist $I_{\text {㠿p }}=.551$ A and $V_{\operatorname{map}}=16.2 \mathrm{~V}$ at $(Q S / A)_{i}=100 \mathrm{miV} / \mathrm{cm}^{2}$. The dimensions of each module are 287 × 502 . Therefore,

$$
A=287 \operatorname{man} \cdot \frac{1 \mathrm{~cm}^{2}}{100 \mathrm{man}^{2}}=1440.7 \mathrm{~cm}^{2}
$$


and by eq. (2.3)

$$
\eta_{x}=\frac{(.551 \mathrm{~A})(16.2 V)}{\left(1440.7 \mathrm{~cm}^{2}\right)\left(100 \mathrm{~m} / \mathrm{cm}^{2}\right)} \cdot \frac{1000 \mathrm{~m}}{1 V} \cdot 100 \%=6.18 \% \text {. }
$$

The reference cell temperature, $T_{x}$, is $28 \mathrm{C}$.

Step 2: With insufficient manufacturer's information to caloulete $\beta$. and with the module comprised of silicon cells, nse $\beta=0.0045 \mathrm{C}^{-1}$.

Step 3: No NOCT data for this particular module are given in the spec sheots, but it is given that $T_{c e 11}=40 \mathrm{C}$ wher $Q S / \mathrm{A}=80 \mathrm{~m} / \mathrm{m} / \mathrm{cm}^{2}$ and $T_{a}=28$ C. Since cell temperature, anbient temperature and an insolation are given, eq. (2.1) jields

$$
\nabla_{L} / a=\frac{80 \mathrm{~mW} \cdot \mathrm{cm}^{2}}{40 \mathrm{C}-28 \mathrm{C}} \cdot \frac{1 \mathrm{~kW}}{10^{6} \mathrm{~mW}} \cdot \frac{10^{4} \mathrm{~cm}^{2}}{1 \mathrm{~m}^{2}}=0.067 \mathrm{~kW} /\left(\mathrm{m}^{2} \cdot \mathrm{C}\right)
$$

Sten 4: Assume that the same types of power conditioning conponents are used in this application as in Example 1. Then npc $=88.2 \%$.

Step 5: According to the locstion of Savannah and the map on page A-2. data from Tallahassee (page A-51) should bo osed. But suppose it is known from another source that the loag tera IT for Savannal in Apri1 1s 0.530. The corresponding value for Tallahasse in Tab10 I. 0.573, is considerably higher. Use of the Tallahasee data for QS/A could then lead to an overestimate of array output for this case.

From page A-2 and the 1ist of citios on page A-6, Meridian, MS has approximately the same latitude as Savannal and its proximity suggests that it may have similar $\mathrm{KT}$ values. In Table I, page A-35, the ET for Meridian in April is .527. Sigee this is close to the known Savanuh value of .530 , QS/A data from Meridian car bo used ia this examp1e.

The preceding discussion demosstrates how locally varying insolation or weather patterns can invalidate direct use of the locational maps on pages A-1 to A-3. Specifically, if the KT for a particular location is not within about 0.03 of the value in Table 1 for the suggested station, then QS/A data from station of mearly the same latitude and for the same month way be used, if its KT is a better match to the known valae.

Step 6: From Tab1e II, $s_{M}=32.1-10=22.1$ degrees. We select $s=30$ degrees.

Step 7: Although the Meridian QS/A data will be used, WS and TM should still be obtained from the Tallahasee listings in Table I. For April, wS is given as $3 \mathrm{~m} / \mathrm{s}$, and the corrected value is $2 \mathrm{~m} / \mathrm{s}$. TM 
is $19 \mathrm{C}$. $\mathrm{KT}$ is mown to be .530 , and $Q S / A=5.32 \mathrm{kWh} / \mathrm{m}^{2}$ (from Meridan tables, page $\mathrm{A}-35$ ).

Step 8: $|s-8 M|=|30-22.1|=7.9$ degrees

Step 9: To deterine $T_{c}$, begin at $U_{L} / a=0.067 \mathrm{~kW} /\left(\mathrm{m}^{2} \cdot \mathrm{C}\right)$ on axis $\mathrm{B}$ in Fig. 2.1. Proceeding through the chart using the above IT, Is-sMl, and $\mathrm{IM}$, gives $\mathrm{T}_{\mathrm{c}}=28 \mathrm{C}$.

Step 10: From eq. (2.2),

$$
\eta=6.18 \%[1-0.0045(28-28)]=6.18 \%
$$

Step 11: From eq. (2.5),

$$
Q R / A=\frac{88.2}{100} \cdot \frac{6.18}{100} \cdot 5.32=0.29 \mathrm{kWh} / \mathrm{m}^{2} \text {. }
$$

\section{Chapter 3 Calen1ations:}

Step 1: Suppose $A=432 \mathrm{~m}^{2}$ (i.e.. 3000 of the $0.144 \mathrm{~m}^{2}$ modules) and in this example let there be no on-site storage. Assume that array ortput which is in excess of the load at any given time is fed back into the electrical grid. (The utility can be thought of as furnishing the storage medium in this case.)

Step 2: I and QE/A have been deterinined above.

Step 3: $(Q S / A)_{1 a t}=5.28 \mathrm{kWh} / \mathrm{m}^{2}$ (interpolated from Heridan data) but will not be needed since $B=0$.

Step 4: L is estimated to be $256 \mathrm{kWh}$.

Step 5: From eq. (3.2),

$$
Q B / L=0.29 \cdot \frac{1}{256} \cdot 432=0.49 .
$$

and $B / A \eta=0$.

Step 6: Assume that the load profile resembles that of many businesses (e.g.. banks and ree,1 estate offices) and is approximated by the unimodal 1 profile on pages $A-61$ and $A-85$.

Step 7: April is apring month. $Q E / L=0.49$ and $B / A T=0$ in the Spring-Fal1 graph on page $A-85$ yield $F=0.42$.

In this example $42 \%$ of the electrical load is supplied directly by the array. The remaining array output, which is fed back to the utility on an average day, is equal to

$$
[(Q R / L)-F] \cdot L=(0.49-0.42) \cdot 256=17.9 \mathrm{kWh} \text {. }
$$


4.3 EXAPLE 3: Honolulu, II (1atitude $21.3 \mathrm{~N}$ ), Fobruary

\section{Chapter 2 Caloelations:}

Step 1: Specifictions for the selected modules state thet the max-power outpet is 40 watts when the insolation is $1.0 \mathrm{~m} / \mathrm{m}^{3}$. The area of each array module is $0.403 \mathrm{~m}^{2}$. Therefore, by eq. (2.3)

$$
\eta_{r}=\frac{40 \mathrm{~W}}{\left(1.0 \mathrm{~kW} / \mathrm{m}^{2}\right)\left(0.403 \mathrm{~m}^{2}\right)} \cdot \frac{1 \mathrm{k}}{1000 \mathrm{~W}} \cdot 100 \%=9.93 \% \mathrm{~F}
$$

The cell teaperature under these conditions (the reference temperature, $T_{r}$ ) is $28 \mathrm{C}$.

Step 2: The specifications also 1ist module ontput of 36.6 watts when the insoletion is once again $1.0 \mathrm{~kW} / \mathrm{m}^{2}$ but when the cell temperature is $50 \mathrm{C}$. The given information is sufficient to calculate the temperature coefficient $\beta$.

First, another efficiency, $\eta_{2}$, is determiand from the second sot of data and eq. (2.3):

$$
\eta_{2}=\frac{36.6 W}{\left(1.0 \mathrm{~kW} / \mathrm{m}^{2}\right)\left(0.403 \mathrm{~m}^{2}\right)} \cdot \frac{1 \mathrm{~kW}}{1000 \mathrm{~W}} \cdot 100 \mathrm{~W}=9.08 \%
$$

$T_{2}$ is $50 \mathrm{C}$, and frow step $1, \eta_{1}=9.93 \%$ and $T_{1}=28 \mathrm{C}$.

Now $\beta$ is deterwined by sebstitution in eq. (2.4):

$$
\beta=\frac{1-(9.08 / 9.93)}{50-28 \mathrm{C}}=0.0039 \mathrm{C}^{-1}
$$

Step 3: For this module, it is specified thet $N 0 C T=48 \mathrm{C}$ at $0.8 \mathrm{~kW} / \mathrm{m}^{2}$. The arironmental conditons of the NOCT tost aro unspecified, bat it may be assumed that they are the most comon ones, nawely $T_{\text {a }}=20 \mathrm{C}$ and a wind speed of $1 \mathrm{~m} / \mathrm{s}$.

Step 4: A max-power tracker with $96 \%$ efficiency and an $87 \%$ officient inverter are to be nsed. Then

$$
\eta_{\mathrm{pc}}=0.96 \cdot 0.87 \cdot 100 \%=83.5 \% \text {. }
$$

Step 5: Honolulin data, according to the map on page A-1, can be found on page $\mathrm{A}-30$ of Table $I$.

Step 6: Frow Table II, $=21.3^{\circ}+18^{\circ}=39.3^{\circ}$. Suppose that the array tilt is not adjusted to be the optimum every month, and in this case it is equal to the best value for the prior month, Janzary. Then from Table II,

$$
s=21.3^{\circ}+29^{\circ}=50.3^{\circ} \text {. }
$$


CIAPIER 4

Step 7: Rrom Table I,

WS $=2 / 3 \cdot 5=3.5 \mathrm{~m} / \mathrm{s}$,

$\mathbf{K T}=0.540, \quad T H=22 \mathrm{C}$, and by interpolation between the insolation values for tilts of $50^{\circ}$ and $60^{\circ}$,

$$
Q S / A=5.09-(5.09-4.86) \cdot \frac{(50.3-50)}{(60-50)}=5.08 \mathrm{kWh} / \mathrm{m}^{2}
$$

Step 8: $|s-8 \mathrm{M}|=\left|50.3^{\circ}-39.3^{\circ}\right|=11^{\circ}$.

Step 9: The NOCT deta for this array are almost identical to those of Examp1e 1. Again begin at axis A3 in Fig. 2.1, this time with NOCT $=48 \mathrm{C}$. Moving through the chart eventually yields $T_{c}=42 \mathrm{C}$. Note that wse of the optimum tilt 1ine, $\left|s-s_{1}\right| \equiv 0$, anes a difference of only about $0.5 \mathrm{C}$ in $T_{c}$. In general, $T_{c}$ charges only sightly when $|s-s|$ varies botwoen 00 and $20^{\circ}$. The small improvenent in cell temperature caused by using non-optimum tilt must be traded off against the siight decrease in insoletion (QS/A) when the tilt is other than the ideal value. This concept will be explored further in Examp10 4.

Step 10: From eq. (2.2),

$$
\eta=9.93 \%[1-0.0039(42-28)]=9.4 \% \text {. }
$$

Step 11: From eq. (2.5),

$$
Q \mathrm{EE} / \mathrm{A}=\frac{83.5}{100} \cdot \frac{9.4}{100} \cdot 5.08=0.40 \mathrm{kwh} / \mathrm{m}^{2} \text {. }
$$

\section{Chapter 3 Calculetions:}

Step 1: Use 700 of the $0.403 \mathrm{~m}^{2}$ modu1es, so that $A=282.1 \mathrm{~m}^{2}$. Also choose $B=27.9 \mathrm{kWh}$.

Step 2: $\eta$ and OE/A have been calculated above.

Step 3: $(Q S / A)_{12 t}=5.04 \mathrm{hWh} / \mathrm{m}^{2}$ by interpolation between the 20 and $30^{\circ}$ values.

Step 4: L is estimated to be $174 \mathrm{kmh}$.

Step 5: From eq. (3.2),

$$
\mathrm{QE} / \mathrm{L}=0.40 \cdot \frac{1}{174} \cdot 282.1=0.65
$$




\section{CHAPTER 4}

and from. $(3.3)$.

$$
\mathrm{B} / \mathrm{A \eta}=\frac{1}{9.41} \cdot 27.9 \cdot \frac{1}{282.1} \cdot \frac{1000 \mathrm{Wh}}{1 \mathrm{kWh}} \cdot \frac{5.04}{5.08} \cdot \frac{90}{83.5}=11.2 \mathrm{Wh} /\left(\mathrm{m}^{2} \cdot \%\right)
$$

Step 6: Consider the lond profile to be typical of a printing or publishing shop. The curve is nearly constant bat has a slight peak at moon and a small minimum at idnight. According to the convention of this Guide it can be characterized as sinesoidal $\$ 12.1$ profile.

This is not one of the curves ghown in the key on pages A-59 to A-62, bet a good system performance estinate can be obtained by averaging the results of using profiles which "Bracket"' the given one in appearance. In this case averaging of the solar fractions from the constant and sinusoidal $\$ 12.2$ graphs (on pages $A-64$ and A-70) is appropriate.

Step 7: February is a spring month. The above $Q R / L$ and $B / A \eta$ in the constant, spring-Fall graph yield $F=0.31$. The same quantitios entered in the sinusoidal 12.2 Spring-Fal1 graph give $F=0.52$. These two results are essentially identical, precluding the aeed to average thea.

\subsection{EXAMLE 4: St. Louis, MO (1atitude 38.8 N), Aagust}

\section{Chapter 2 Colonlations:}

Sten 1: In this example we design a system using modulo comprised of cadmiu sufide cel1s. The manufacturer specifications ive 65 wacts is the mas-pover output when the insolation is $100 \mathrm{~m} / \mathrm{cm}^{2}$. Each module is $262 \mathrm{~cm} \times 85$ in sizo, so that

$$
\Lambda=262 \mathrm{~cm} \cdot 85 \mathrm{~cm}=22270 \mathrm{~cm}^{2} \text {. }
$$

Then by eq. (2.3)

$$
\eta_{I}=\frac{65 W}{\left(22270 \mathrm{~cm}^{2}\right)\left(100 \mathrm{~mW} / \mathrm{cm}^{2}\right)} \cdot \frac{1000 \mathrm{~W}}{1 \%} \cdot 100 \%=2.92 \% \text {. }
$$

The reference temperature, $T_{I}$, is $28 \mathrm{C}$.

Step 2: Insufficient information is included in the specifications in order to calculate $\beta$. Contacting the manufacturer disulosed that $\beta=0.006 \mathrm{C}^{-1}$.

Step 3: The manufacturer also provided the NOCT of $43 \mathrm{C}$ at $0.8 \mathrm{~kW} / \mathrm{m}^{2}$ when $T_{a}=20 \mathrm{C}$ and the wind speed is $1 \mathrm{~m} / \mathrm{s}$. 
Step 4: If the same power conditioning equipment as in Example 3 is used, then $\eta_{p e}=83.5 \%$.

Step 5: The ley ap on page A-2 indicates that data for Kansas City should be used and that it can be found on page A-31.

Step 6: Fron Table II, $s_{M}=38.8-10=28.8$ degrees. In this example the effects of varying array tilt are investigated by letting $s=10$, 20, 30, 40, and 50\%. These values and the results which follow are displayed in Table 4.2 .

Tab1e 4.2

Effects of Tilt Variation, Erample 4

\begin{tabular}{|c|c|c|c|c|c|c|c|c|}
\hline $\mathbf{s}$ & $\begin{array}{l}\text { QS/A, } \\
\mathrm{kWh} / \mathbf{m}^{2}\end{array}$ & $\left|s-s_{M}\right|$ & $\mathrm{T}_{\mathrm{c}}, \mathrm{C}$ & $\eta, \%$ & $\begin{array}{l}\mathrm{QR} / \mathrm{A}, \\
\mathrm{KWh} / \mathrm{m}^{2}\end{array}$ & $\mathbf{Q E} / \mathrm{L}$ & $\begin{array}{c}B / A_{\eta} \\
W h /\left(\mathbf{m}^{2} \cdot{ }^{2}\right)\end{array}$ & $\mathbf{F}$ \\
\hline 10 & 6.05 & 18.8 & 43 & 2.60 & 0.13 & 0.75 & 6.2 & 0.63 \\
\hline 20 & 6.09 & 8.8 & 44 & 2.64 & 0.13 & 0.754 & 6.1 & 0.63 \\
\hline 30 & 5.99 & 1.2 & 44 & 2.64 & 0.13 & 0.75 & 6.2 & 0.63 \\
\hline 40 & 5.76 & 11.2 & 44 & 2.64 & 0.13 & 0.75 & 6.4 & 0.63 \\
\hline 50 & 5.41 & 21.2 & 43 & 2.60 & 0.12 & 0.70 & 7.0 & 0.61 \\
\hline
\end{tabular}

Step 7: From Table I, the corrected wind speed is WS $=2 / 3 \cdot 4=2.7$ a $/ \mathrm{s}, \mathrm{KT}=0.579$, and $\mathrm{TM}=26 \mathrm{C}$. The QS/A values corresponding to the selected tilts are listed in Table 4.2 .

Step 8: Table 4.2 gives the five values of $|\mathrm{s}-\mathrm{s} M|$.

Step 9: The NOCT specifications mean starting with axis A3 in Fig. 2.1. at NOCT $=43$ C. Variation of the array tilt does not affect use of the chart until the $\left|s-s_{M}\right|$ lines are reached. After that intersection, five slightly different paths (corresponding to the five values of $\left|s-s_{M}\right|$ in Table 4.2) eventually lead to five $T_{c}{ }^{\prime} s$. These are also given in Table 4.2 , note they are within about $1 \mathrm{C}$ if each other.

Step 10: Use of eq. (2.2) yields the five values of $\eta$ in Table 4.2. For example, for $T_{c}=43 \mathrm{C}$,

$$
\eta=2.92 \%[1-0.006(43-28)]=2.60 \% \text {. }
$$


Step 11: Similerly, five values of $Q$ R/A follow fromse of eq. (2.5). For the $s=10^{\circ}$ case,

$$
\mathrm{OE} / \mathrm{A}=\frac{83.5}{100} \cdot \frac{2.60}{100} \cdot 6.05=0.13 \mathrm{~km} / \mathrm{me}^{2} \text {. }
$$

\section{Chapter 3 Calonlations:}

Step 1: Select $A=446 \mathrm{~m}^{2}$, requiring 200 of the $2.23 \mathrm{~m}^{2}$ modules, and let $B=7000 \mathrm{Wh}$.

Step 2: I and OR/A ere 1isted in Trble 4.2 .

Step 3: $(Q S / A)_{1 a t}=5.79 \mathrm{kWh} / \mathrm{m}^{2}$ by interpolation.

Step 4: Let L be equal to $77 \mathrm{kWh}$.

Step 5: Results for QE/L and B/An, from of eqs. (3.2) and (3.3), are in Table 4.2 .

Step 6: The spplisetion in this example is an atomobil ropair shop. A typical average daily load curve resembles the bimodal ft3 profile. From the index on pages A-61, 62, the porformance graphs are on page A-104.

Step 7: August is a fall month. Entering the five sets of QR/L and B/Ay into the binodal $\$ 3$ Spring-Fall graph yields the solar fractions in Table 4.2 .

In this example, varying the tilt by $40^{\circ}$ leads to a 0.02 variation in F. In this case it would probably be wise to explore the effect of tilt on vinter performance before gelecting a final value.

\subsection{EXAMPLE 5: F1agstaff, AZ (1atitude $35.0 \mathrm{~N}$ ), Noverber}

Step 1: In this example the same kind of modele vill be used as in Examp1e 1. Thus $\eta_{x}=9.02 \%$ and $T_{I}=47 \mathrm{C}$.

Step 2: Assume $\beta=0.0045 C^{-1}$.

Step 3: $N O C T=47 \mathrm{C}$ at $0.8 \mathrm{~kW} / \mathrm{m}^{2}, T_{\mathrm{a}}=20 \mathrm{C}$ ars $\mathrm{i}$ w/s wind speed

Step 4: Also wse the same porer conditioner as in Example 1, so that $\eta_{p c}=88.25$.

Step 5: The page A-2 map shows that the data for Bryce Canyon on page A-14 are appropriate. 
Step 6: From Tab1e II, $s M=35.0^{\circ}+23^{\circ}=58.0^{\circ}$. Also, s is chosen to be $\mathbf{s} \cdot$

Stop 7: From Table $I$, the corrected wind speed is $W S=2 / 3 \cdot 3=2.0 \mathrm{~m} / \mathrm{s}$, $\overline{K T}=.658$, and $T=-1 \mathrm{C}$. Without forma1ly carrying out the mathemacal interpolating, it should be clear that $Q S / A=5.68 \mathrm{kWh} / \mathrm{m}^{2}$.

Step 8: $\left|s-s_{M}\right|=0$.

Step 9: With a start at NOCT $=47 \mathrm{C}$ on axis $\triangle 3$ in Fig. 2.1. progression through the chart yields $T_{c}=23 \mathrm{C}$.

Step 10: From eq. (2.2),

$$
\eta=9.02 \%[1-0.0045(23-47)]=9.99 \% \text {. }
$$

Step 11: From eq. (2.5).

$$
Q E / A=\frac{88.2}{100} \cdot \frac{9.75}{100} \cdot 5.98=0.51 \mathrm{kWh} / \mathrm{m}^{2} \text {. }
$$

\section{Chapter 3 Calculations:}

Step 1: In this example, the erray area and storage capacity aro varied. Specifically, suppose $400,800,1200$, and 1600 of the $0.36 \mathrm{~m}^{2}$ modules are used, resulting in $A=144,288,432$, and $576 \mathrm{~m}^{2}$. If $\mathrm{B}$ is varied such that $B / A \eta$ is to remain constint and equal to 10 , then $B=16.2,32.4,48.5$, and $64.7 \mathrm{kWh}$.

Step 2: QR/A and $\eta$ are given above.

Step 3: $(Q S / A)_{1 a t}=5.20 \mathrm{kWh} / \mathrm{m}^{2}$.

Step 4: L is estimated to be $354 \mathrm{kWh}$.

Step 5: Use of eq. (3.2), for the four array areas selected in Step 1, results in the four values of QE/L given in Table 4.3. The values of $B$ were chosen in Step 1 such that B/An equals 10.0 in a11 cases.

Step 6: In this example the application is a 1 umber mill, for which the unimodal \#6 load profile may be representative of the load curve. The relevant performance graphs are on page A-90.

Step 7: November is a winter month. The values of QE/L 1isted in Table 4.3 and $B / A \eta=10$, when entered into the unimoda1 \#6 Winter performance graph, give the solar fractions in Table 4.3. 


\section{CHAPTER 4}

Table 4.3

Effects of A and B Variation, Erample 5

\begin{tabular}{cccc}
\hline $\mathrm{A}\left[\mathrm{m}^{2}\right]$ & $\mathrm{B}[\mathrm{kWh}]$ & $\mathrm{QR} / \mathrm{L}$ & $\mathrm{F}$ \\
\hline 144 & 16.2 & 0.21 & 0.21 \\
288 & 32.4 & 0.41 & 0.38 \\
432 & 48.5 & 0.62 & 0.51 \\
576 & 64.7 & 0.83 & 0.60 \\
\hline
\end{tabular}

\subsection{EXAMPLE 6: Oakland, CA (1atitude $37.7 \mathrm{~N}$ ), A11 Year}

In this oxumple, performance estimates are ade for all 12 wonths and then for the entire year. The completed Vorksheets 1 and 2 of Table 4.4 accompany this axaple.

\section{Chepter 2 Celculations:}

Step 1: For this example, module specifications give 30 watts as the max-power output when the insolation is $100 \mathrm{mw} / \mathrm{cm}^{2}$. The dimensions of each module are $121.7 \mathrm{~cm} \times 30.2 \mathrm{~cm}$, giving an array area of

$$
A=121.7 \mathrm{~cm} \cdot 30.2 \mathrm{~cm}=3675.3 \mathrm{~cm}^{2} \text {. }
$$

Then by eq. (2.3)

$$
\eta_{r}=\frac{30 W}{\left(3675.3 \mathrm{~cm}^{2}\right)\left(100 \mathrm{~mW} / \mathrm{cm}^{2}\right)} \cdot \frac{1000 \mathrm{~m} W}{1 W} \cdot 100 \%=8.16 \% \text {. }
$$

The reference temperature, $T_{I}$, is $45 \mathrm{C}$.

Step 2: The specifications also include en-power output of 33 watts an insolation level of $100 \mathrm{~m}^{2} \mathrm{~cm}^{2}$ (same as above) and a cell temperature of $28 \mathrm{C}$.

This second set of data yield a second array efficiency, via eq. (2.3):

$$
\eta_{2}=\frac{33 W}{\left(3675.3 \mathrm{~cm}^{2}\right)\left(100 \mathrm{~mW} / \mathrm{cm}^{2}\right)} \cdot \frac{1000 \mathrm{~mW}}{1 W} \cdot 100 \%=8.98 \% .
$$


TABLE 4.4 Worksheets for Example 6

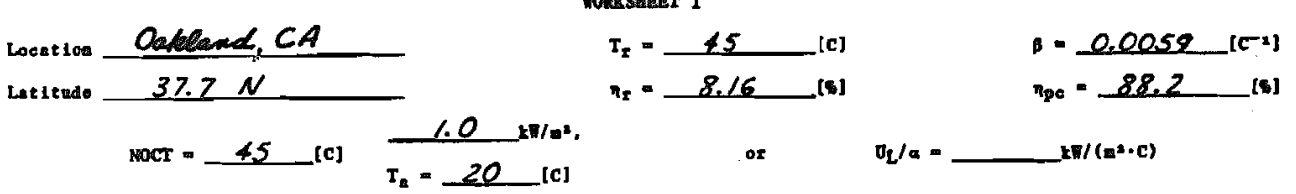

\begin{tabular}{|c|c|c|c|c|c|c|c|c|c|c|}
\hline \multirow[b]{3}{*}{ Month } & \multirow{3}{*}{ 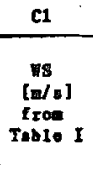 } & $c 2$ & c3 & c4 & cs & c6 & c7 & c8 & cs & c10 \\
\hline & & $\underset{\text { trom }}{\mathbf{T T}}$ & 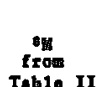 & dosignex's & 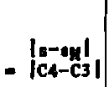 & $\underset{\substack{\text { If] } \\
\text { [roes }}}{\text { Th }}$ & $T_{0}$ & 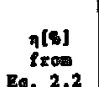 & {$\left[\mathbf{r m} / \mathbf{m}^{1}\right]$} & 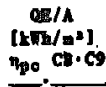 \\
\hline & & & & & & & & & & 100100 \\
\hline JNA & 2. & .497 & 66.7 & 37.7 & 29 & 9 & 23 & 9.22 & 3.56 & 0.29 \\
\hline FEB & 2. & .548 & 55.7 & $"$ & 18 & 11 & 26 & 9.07 & 4.55 & 0.36 \\
\hline MAR & 3. & .596 & 40.7 & " & 3 & 12 & 27 & 9.03 & 5.62 & 0.45 \\
\hline APR & 3. & .631 & 27.7 & $"$ & 10 & 13 & 28 & 8.98 & 6.31 & 0.50 \\
\hline $\operatorname{MAY}$ & 3. & .641 & 15.7 & " & 22 & 14 & 29 & 8.93 & 6.42 & 0.51 \\
\hline JUM & 3. & .648 & 12.7 & $"$ & 25 & 16 & 31 & 8.83 & 6.45 & 0.50 \\
\hline JUL & 3. & .653 & 13.7 & $"$ & 24 & 17 & 31 & 8.83 & 6.52 & 0.51 \\
\hline$A 0 G$ & 3. & .634 & 27.7 & $"$ & 10 & 17 & 32 & 8.79 & 6.36 & 0.49 \\
\hline SEP & 3. & .632 & 35.7 & $"$ & 2 & 17 & 32 & 8.79 & 6.16 & 0.88 \\
\hline oCT & 2. & .584 & 47.7 & $"$ & 10 & 16 & 32 & 8.79 & 5.16 & 0.40 \\
\hline Nov & 2. & .534 & 60.7 & “ & 23 & 13 & 25 & 9.12 & 4.04 & 0.32 \\
\hline$D B C$ & 2. & .496 & 67.7 & “ & 30 & 9 & 22 & 9.27 & 3.40 & 0.28 \\
\hline
\end{tabular}

WORKSEETI

woarsaket 2

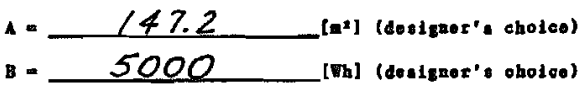

\begin{tabular}{|c|c|c|c|c|c|c|c|c|c|}
\hline & C11 & c12 & C13 & C14 & c1s & c16 & C17 & C18 & C19 \\
\hline Month & d & 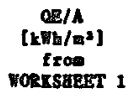 & $\begin{array}{c}\eta[\$] \\
\text { from } \\
\text { TORKSEEET } 1\end{array}$ & $\begin{array}{l}(08 / A)_{1 a t} \\
\text { [kTh/gej } \\
\text { frow } \\
\text { Table } 1\end{array}$ & $\stackrel{\text { L }}{\text { [km] }}$ & $=\frac{\frac{08 / L}{C 12 \cdot A}}{C 15}$ & 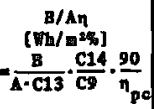 & $\begin{array}{c}\text { F } \\
\text { from } \\
\text { C16.C17 in } \\
\text { TABLE III. }\end{array}$ & $\begin{array}{c}L \cdot d \\
{[k W h]} \\
= \\
\text { c11. C1s }\end{array}$ \\
\hline JAN & 31 & 0.29 & 9.22 & 3.56 & 260 & 0.16 & 3.76 & 0.16 & 8060 \\
\hline FEB & 28 & 0.36 & 9.07 & 4.55 & 243 & 0.22 & 3.82 & 0.21 & 6804 \\
\hline Wh & 31 & 0.45 & 9.03 & 5.62 & 230 & 0.29 & 3.84 & 0.26 & $7 / 30$ \\
\hline APQ & 30 & 0.50 & 8.98 & 6.31 & 187 & 0.39 & 3.86 & 0.33 & 5610 \\
\hline nAY & 31 & 0.51 & 8.93 & 6.42 & 155 & 0.48 & 3.88 & 0.42 & 4805 \\
\hline IJN & 30 & 0.50 & 8.83 & 6.45 & 102 & 0.72 & 3.93 & 0.51 & 3060 \\
\hline JाL & 31 & 0.51 & 8.83 & 6.52 & $/ / 8$ & 0.64 & 3.93 & 0.49 & 3658 \\
\hline$A D G$ & 31 & 0.49 & 8.79 & 6.36 & 135 & 0.53 & 3.94 & 0.39 & $4 / 85$ \\
\hline SEP & 30 & 0.48 & 8.79 & 6.16 & 129 & 0.55 & 3.94 & 0.36 & 3870 \\
\hline oct & 31 & 0.40 & 8.79 & 5.16 & 141 & 0.42 & 3.94 & 0.35 & 4371 \\
\hline Nov & 30 & 0.32 & 9.12 & 4.04 & 181 & 0.26 & 380 & 0.23 & 5430 \\
\hline DEC & 31 & 0.28 & 9.27 & 3.40 & 202 & 0.20 & 3.74 & 0.19 & 6262 \\
\hline
\end{tabular}

Ansan1 F $=\frac{\sum(\text { P.L.d })}{\sum(L \cdot d)}=\frac{\sum(\text { C18.C19) }}{\sum \text { C19 }}=0.30$ 
It is al:o known that $T_{2}=28 \mathrm{C}$, and from Step $1, \eta_{1}=8.16 \mathrm{w}$ and $T_{1}=45 \mathrm{C}$. Therefore, by eq. ${ }^{2}(2.4)$

$$
\beta=\frac{1-(8.98 / 8.16)}{28-45 \mathrm{C}}=0.0059 \mathrm{C}^{-1}
$$

Step 3: It is given that NOCT $=45 \mathrm{C}$ at $100 \mathrm{mIl} / \mathrm{cm}^{2}\left(i .0 ., 1 \mathrm{kw} / \mathrm{m}^{2}\right)$. As in Example 3, the ambient conditions are unspecified, so they are assumed to be $T_{a}=20 \mathrm{C}$ and $1 \mathrm{~s} / \mathrm{s}$ wind speed.

Step 4: The power conditioner is the same as in Eramples 1 and 2, and $\eta_{\text {pe }}=88.2 \%$.

Step 5: The key wap on page A-2 shows that the date in this example are on page A-38.

Step 6: The optimua array tilts, based upon Table II and $=37.7^{\circ}$, are 1 isted in Table 4.4. Assume that the tilt is always $37.7^{\circ}$.

Step 7: The wonthiy WS (corrected to 0.6 of the tabulated value), IT, $T$, and QS/A (on the appropriate $t i 1 t$ for each month) are given in Table 4.4.

Step 8: With s always equal to $0,|s-8 M|$ is simply the ragnitude of the number added to or subtracted from in Table II.

Step 9: Calculation of $T_{c}$ for each month always bogins at axis $A 1$ in Fig. 2.1, at NOCT $=45 \mathrm{C}$. The values of WS, KT, $\left|s-s_{M}\right|$, and TM ther vary from month to month. The resulting $T_{c}$ 's are 1 isted in Table 4.4.

Step 10: The corresponding monthly values of $\eta$ are given in c8 of Table 4.4 .

Step 11: $\eta_{p c}=88.2 \%$ and the calculated values of $\eta$ and QS/A yield the QE/A's in Table 4.4.

\section{Chapter 3 Calculations:}

Step 1: Select $A=147.2 \mathrm{~m}^{2}$, requiring 400 of the $0.368 \mathrm{~m}^{2}$ modules, and 1et $B=5000 \mathrm{Fh}$.

Step 2: QE/A and $\eta$ are carried over to Worisheet 2 from Worksheet 1.

Step 3: Because the array tilt angle is always equal to the latitude angle, the $(Q S / A)_{1 a t}$ values of C14 are identical to the QS/A values of C9.

Step 4: Assume that the average daily loads for the 12 months are as given in Worksheet 2 of Table 4.4 . 
Step 5: The resulting values of $Q E / L$ and $B / A \eta$ are 1isted in Table 4.4. Note that the tilt correction factor, (QS/A) 1 at $/(Q S / A)$, is equal to 1 for every month, since the array is always tilted at the latitude angle.

Step 6: The application in this examp1e is a Post office for which the load is approximately constant throughout the day. The performance graphs are on page A-64 of Table III.

Step 7: The resulting enth1y solar fractions are given in Table 4.4 .

Step 8: The products of the average daily load and number of days each wonth are 1 isted in C19 of Table 4.4 .

Step 9: When the results in C18 and C19 of Tab10 4.4 are combined and summed, it is found that

$$
\begin{aligned}
& \Sigma(F \cdot L \cdot d)=\Sigma(\text { C18 } \cdot C 19)=19658 \\
& \Sigma(L \cdot d)=\Sigma \text { C19 }=63245 .
\end{aligned}
$$

and therefore the annual solar fraction is

$$
F=\frac{19658}{63245}=0.31
$$

\subsection{EXAMLE 7}

This example compares the simplified procedure developed in Reference 11 with the procedure out1ined in this Guide. Reference 9 makes use of the "utilizability" concept which is quite general, but the system analysis is restricted to a constant load profile. The data given in the example problew in Reference 11 are:

Location
Month
Tilt
Array Area
Array Loss Coefficient
Solar Absorptance
Reference Efficiency
Reference Temperature
Terperature Coefficient
Power Conditioner Efficiency
Average Daily Load
Storage Capacity

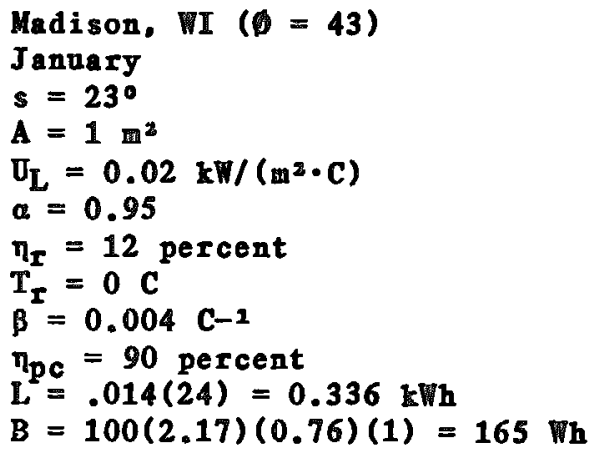


CHAPTER 4

The battery capacity in Wh is slightly larger than that shown in Reference 11 due to the required use of 2.17 volts per cell (see Section 3.2).

According to the key on page A-2, the data for La Crosse, WI on page A-33 should be representative of Madison, WI. From that data:

$$
\begin{aligned}
(Q S / A)_{2,0} & =2.30 \mathrm{kWh} / \mathrm{m}^{2} \\
(Q S / A)_{1 \mathrm{t}} & =2.76 \mathrm{kWh} / \mathrm{m}^{2} \\
K T & =0.44 \\
T M & =-9 \mathrm{C}
\end{aligned}
$$

Table II on page A-58 gives

$$
s_{K}=0+29=43+29=72
$$

Th.28

$$
\left|s-s_{M}\right|=\left|s_{M}-s\right|=72-23=490
$$

Figure 2.1 entered at axis $B$ with $U_{L} / a=0.21$ and the above |sMr yields

$$
T_{c}=11 \mathrm{C}
$$

Equation (2.2) then yields

$$
\begin{aligned}
\eta & =12[1-0.004(11-0)] \\
& =11.5 \%
\end{aligned}
$$

This is less than 1\% different than the value obtained in the example of Reference 11

QE/L and $B / A n$ now need to be computed in orde= to obtain the solar fraction $F$. Equation 3.3 yields

$$
\begin{aligned}
\mathrm{B} / \mathrm{A \eta} & =(1 / 11.5) \cdot(165) \cdot(1 / 1) \cdot[2.76 / 2.30] \cdot[90 / 90] \\
& =17.2 \mathrm{Wh} /\left(\mathrm{m}^{2} \cdot \mathrm{F}\right)
\end{aligned}
$$

The array insolation in Table $I\left(2.3 \mathrm{kWh} / \mathrm{m}^{2}\right)$ is somewhat less than the array insolation used in Reference $11\left(2.52 \mathrm{kWh} / \mathrm{m}^{2}\right)$. Therefore, two sets of calculations will be carried out (denoted by the subscripts 1 and 2 ), to determine the uncertainty in $F$ introduced by those differences. Then eq $(3.2)$ yields: 


$$
\begin{aligned}
(\mathrm{QE} / \mathrm{L})_{1} & =\left[\frac{90}{100} \cdot \frac{11.5}{100} \cdot(2.30)\right] \cdot(1 / 0.336) \cdot(1) \\
& =0.71 \\
(\mathrm{QE} / \mathrm{L})_{2} & =\left[\frac{90}{100} \cdot \frac{11.5}{100} \cdot(2.52)\right] \cdot(1 / 0.336) \cdot(1) \\
& =0.78
\end{aligned}
$$

For $B / \eta A$ and $(Q E / L)_{1}$, the winter data on page A-64 of Table III gives:

$$
F_{1}=0.55 \text { or } 55 \% \text {. }
$$
For $B / \eta A$ and $(Q E / L)_{2}$, the graph for winter on page A-64 of Table III
gives:

$$
F_{2}=0.60 \text { or } 60 \% \text {. }
$$

Reference 11 gives $F=59$ percent. Therefore, for the same month1y average daily array insolation (QS/A $=2.52 \mathrm{kWh} / \mathrm{m}^{2}$, the 2 subsoripted variables), both Reference 11 and this Guide give nearly identical results. The 9 percont relative uncertainty in array insolation gives on1y a 3 percent incremental ( 5 percent relative) uncertainty in $F$.

If a comparison is made at $B=0$ (no battery) then

$$
F_{1}=0.30 \text { or } 30 \%
$$

and

$$
F_{2}=0.31 \text { or } 31 \% \text {. }
$$

Reference 11 would gield $F=31$ percent for no storage. Again, for the same array insolation, both Reference 11 and this Guide give nearly identical results. 


\section{REFERENCZS}

1. R.T. Ruegg, Solar Hesting and Cooling of Buildings: Methods of Economic Evaleation, US, Dept, of Cowerce, NBS Report NBSIR-78-712 (Springfie1d: NTIS, 1975).

2. S. Young, et. 21., Photovoltaic Power Sustems Design Fardbook, SAND 80-7147 (Albuquerque: Sandia Laboratories, 1980).

3. R.H. Turfler, T.J. Lambarski, R.T. Grant, Desien Guidelines for Large Photovoltaic Arrays, SAND 79-7001 (Albuquerque: Sandia Laboratories, 1979).

4. D.L. Evans, T.A. Facine11i, L, P. Koeh1er, Simulation and Simplified Design Studies of Photovoltaic Srstems, SAND 80-7013 (A1buquerque: Sandia Laboratories, 1980).

5. W.H. Hoecker, G.F. Cotton, W.A. Hess, Solar Radiation and Climatic Date for Quasi-Homorencons Climatic Regions of the United States, ERL ARL77 (Silver Springs: NOAA Environmental Researc! Laboratories).

6. NOAA, SOLET, Volnge 1, User's Manen 1, TD-9724 (Ashvi110, NC: Nationa1 C1imatic Center, 1978) and NOAA, SOLES II, Voluve 2 Final Report, TD-9724 (Ashvi11e, NC: National Climatic Center, 1979).

7. T. Eusude and R. Ishii, Hourly Solar Badiation Date for Vertical and Horizontal Surfaces on Average Days in the Dnited States and Canade, US, Dept, of Cowerce, NBS Building Science Series 96 (Washington: Goverment Printing Office, 1977).

8. W.A. Becknen, S.A. K10in and J.A. Duffie, Soler Heating Design (New York: John Wiley and Sons, 1977).

9. G.W. Vina1, Storage Batteries (New York: John Wiley and Sons, 1955).

10. R.A. Whisnant, C.B. Morrison, N.G. Staff, R.D. Alberts, Application Anelysis and Photoroltaic Srstem Conceptual Design for Service/Comercial/Institutional and Indestrial Sectors. SAND 79-7020 (Albrquerque: Sandia Laboratories, 1979).

11. M.D. Siegel and W.A. Beckman, "Simplified Design Methods for Photovoltaic Systems," Proceedings of the 1980 Annual Meeting American Section of the International Solar Energy Society. Phoenix (1980). 
TABLE I KEY Pages A-1 to A-7 $-2-$

TABLE I Peges A-8 to A-56

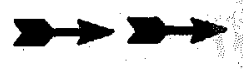

APPENDIX

TABLE II Page A-58

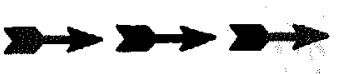

TABLE III KEY Pages A-59 to A-63

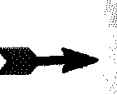

TABLE III Pagos A-64 to A-104Z

WORESHEETS 1 and 2
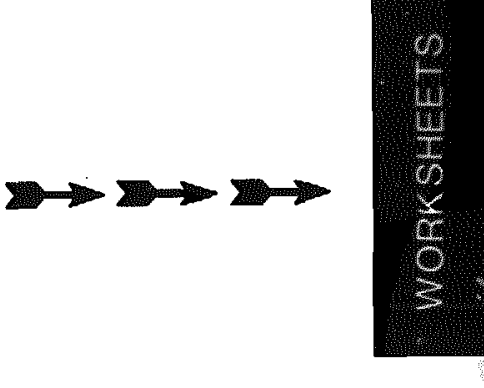


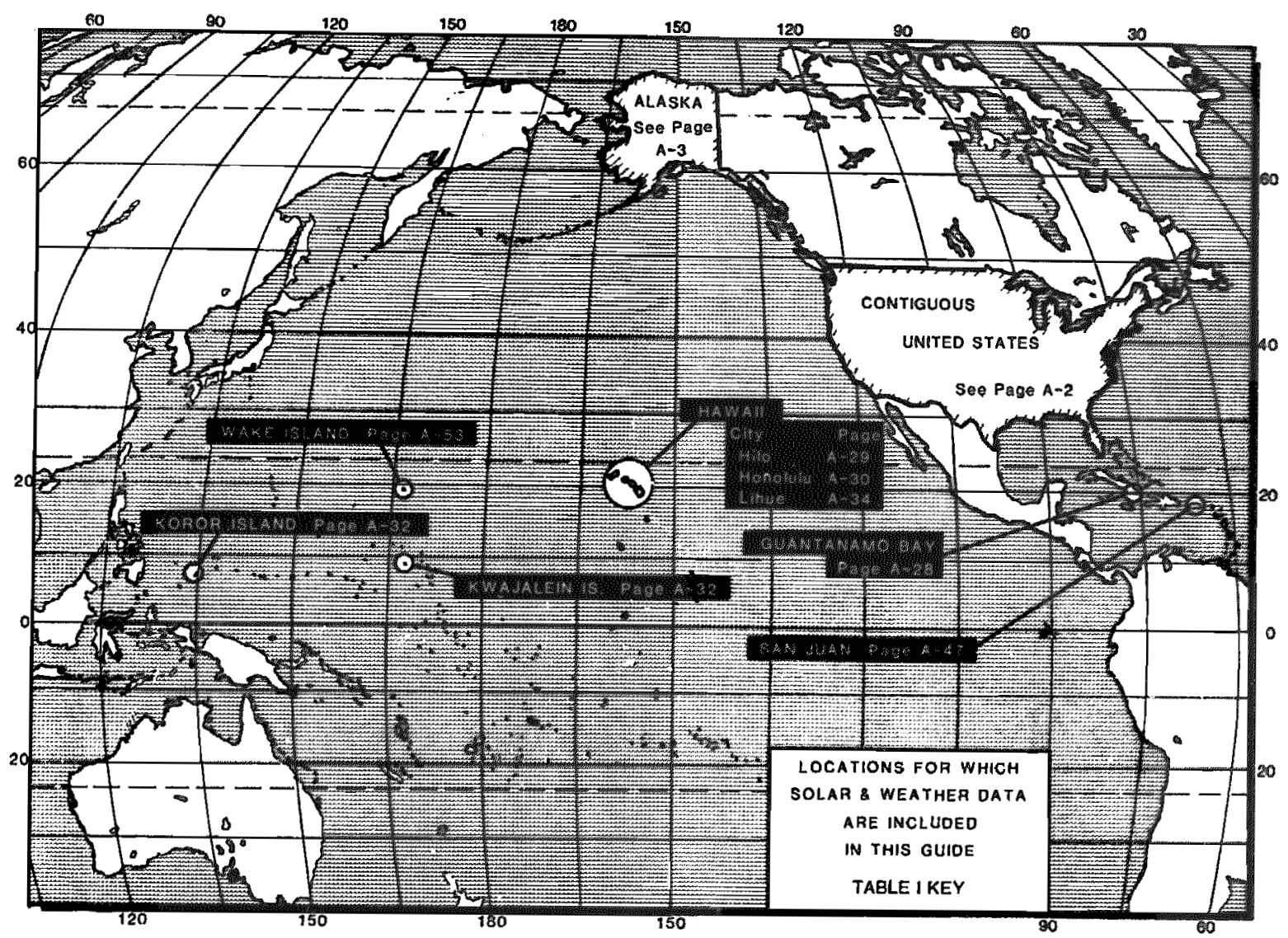

Map Showing United States and Affiliated Regions for Which Solar/weather Data Are Included in Table I.

(The number A-xx shown for each locetion

is the page number in this appendix on which

more inforation can be fornd)

TABLE I REY 


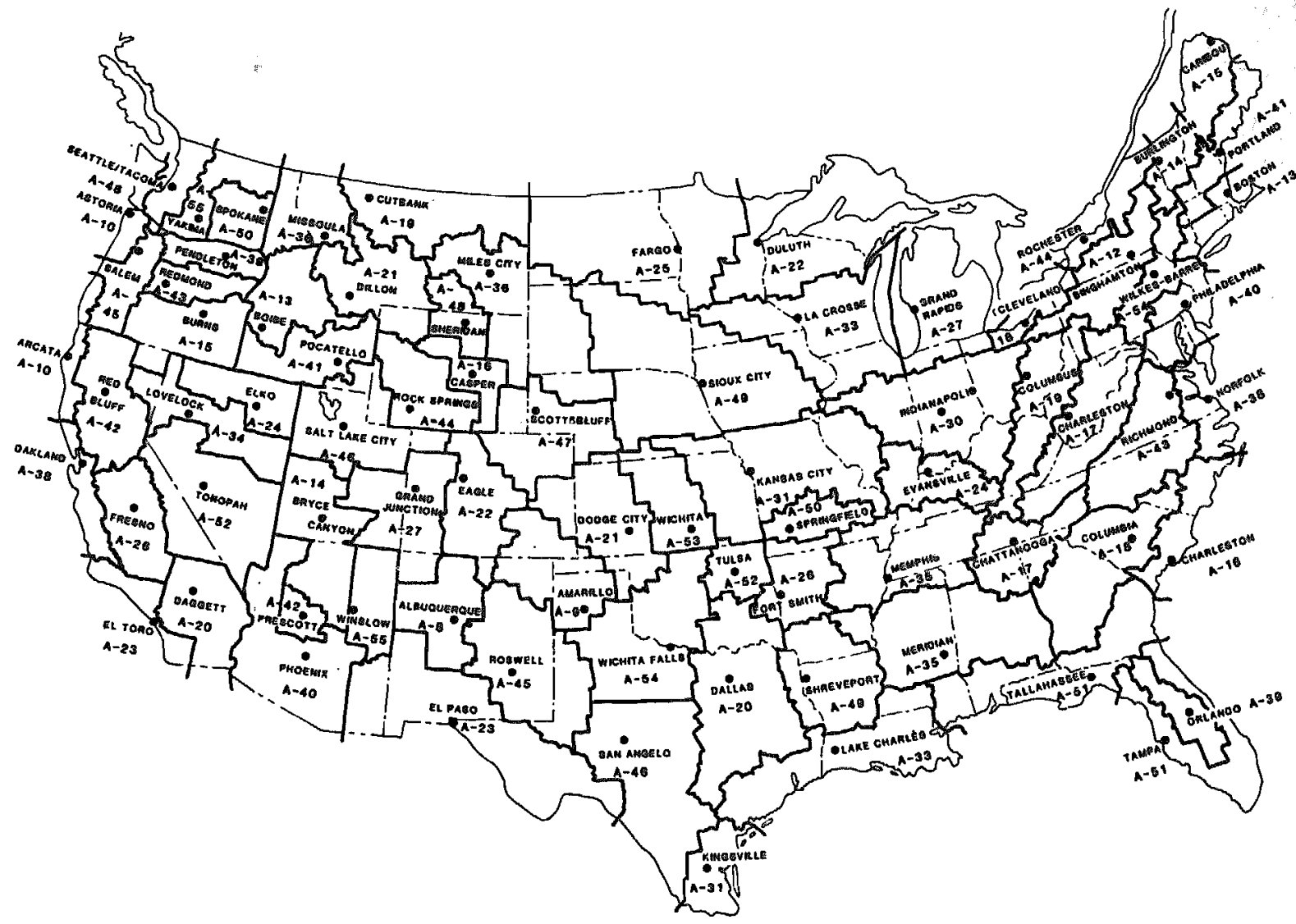

Map of Contignons United States Stations and Regions for Which Solar/Weather Data Are Included in Tab1e I. The region boundaries follow county borders. (From Ref. 5)

(The number A-rI shown for each location

is the page number in this appendix on which more information can be found)

TABLE I KEY 


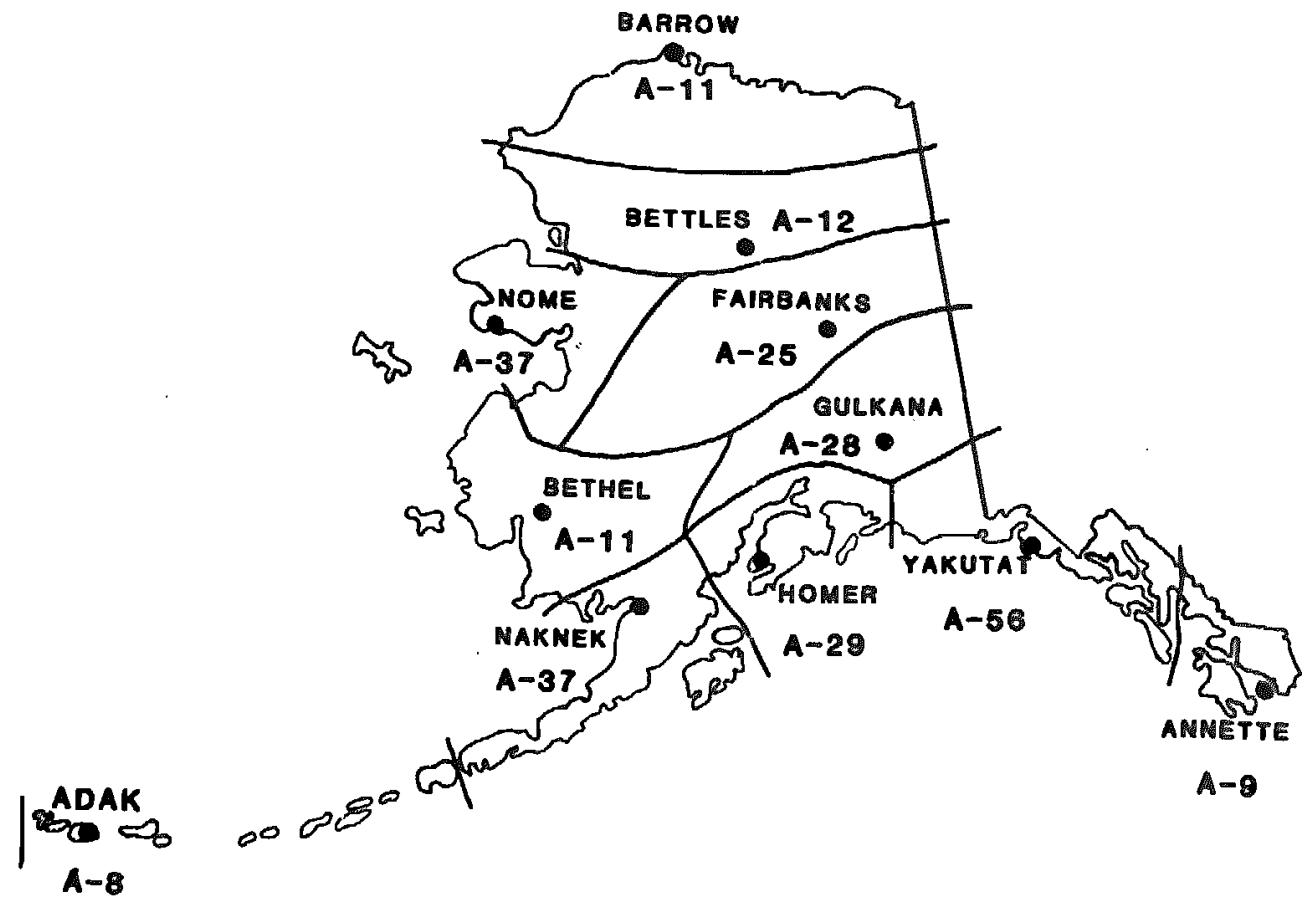

Map of Alaskn Stations of Representative Regions for Which Solar/Radiation Deta are Included in Table I. (Fron Ref. 5)

(The number A-rx shown for each station is the page

in this appendix on which the data can be foumd)

TABLE I KEY 
Koy to TABLE I.

List of Stations for Which Solar Radiation and C1imatic Data aro Presented in Table I

Listed Alphabetically by Station

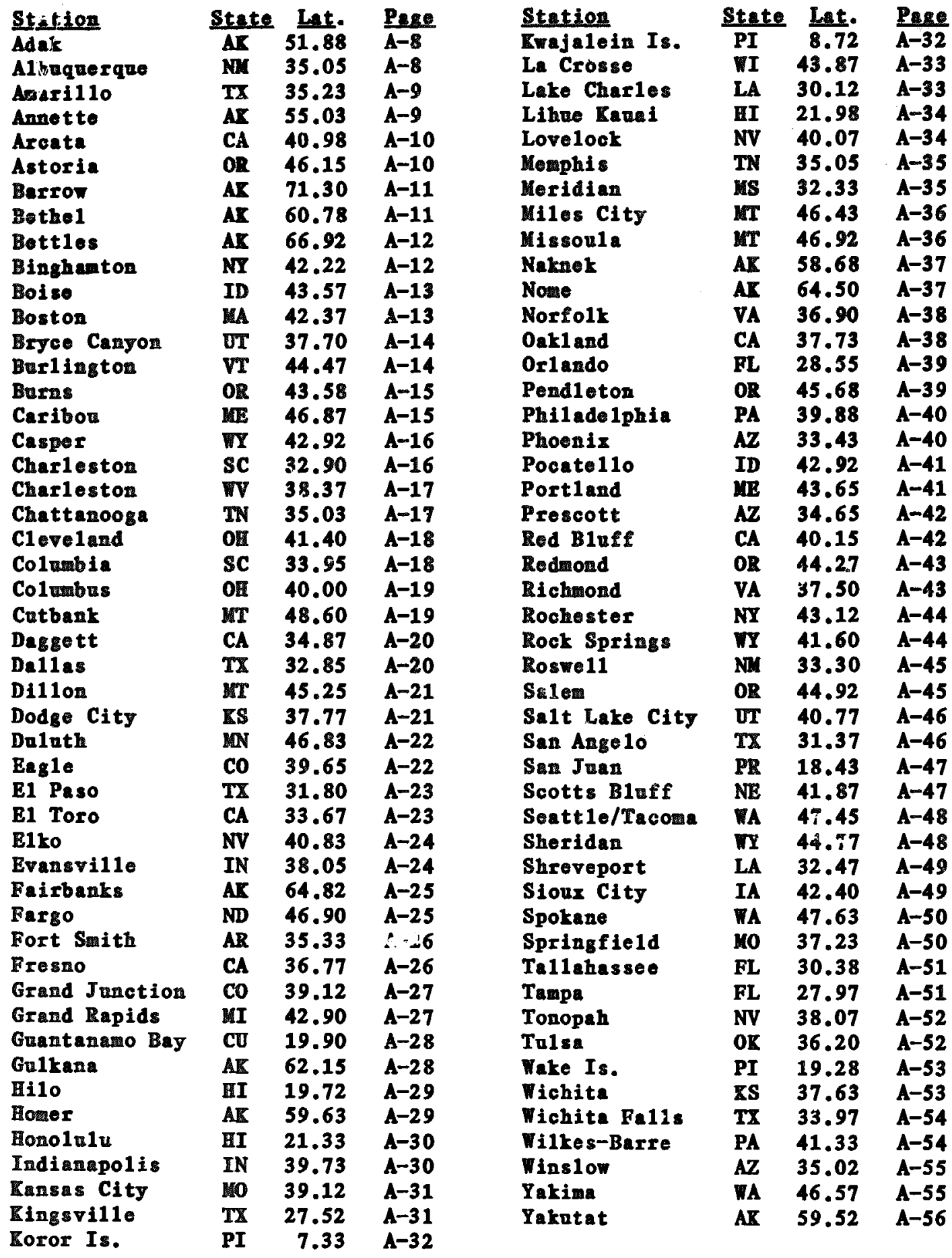


Key to TABLE I.

List of Stations for Which Solar Radiation and C1imatic Data are Presented in Table I

\section{Listed Alphabetical1y by Stat}

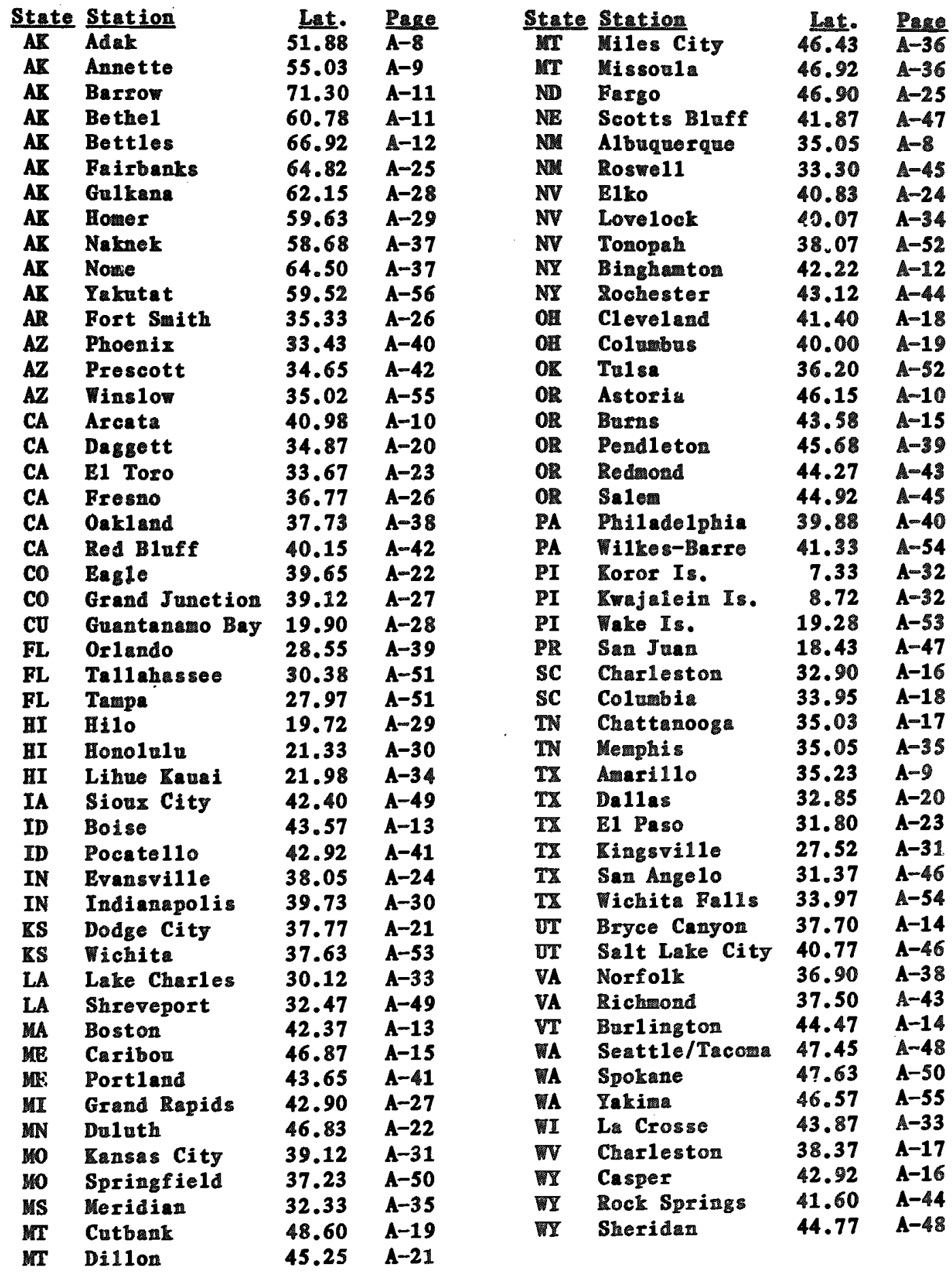


Tey to TABLE I.

List of Stations for Which Solar Radiation and Climatic Data are Presented in Table I

Listed Numeriea11y by Latitude

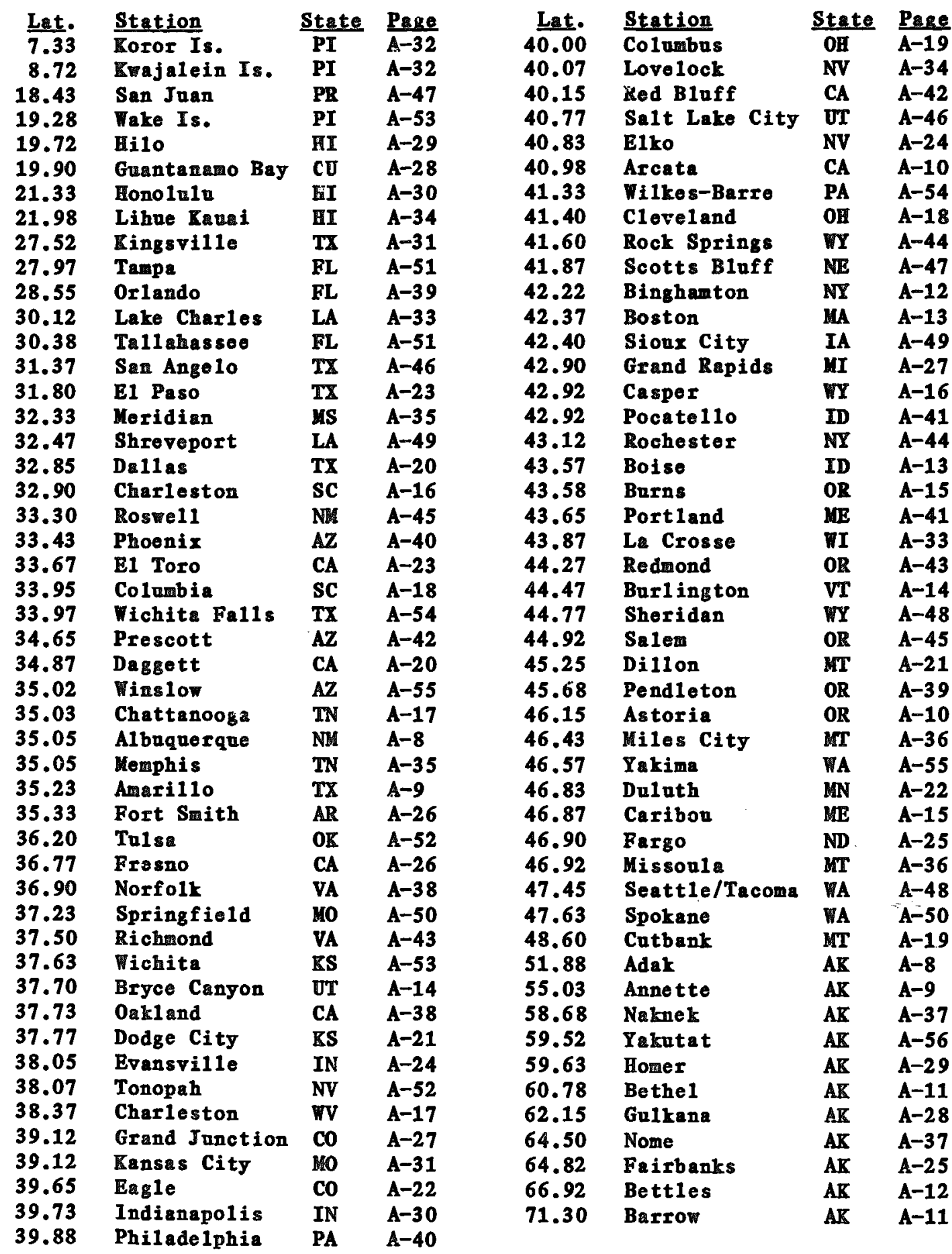




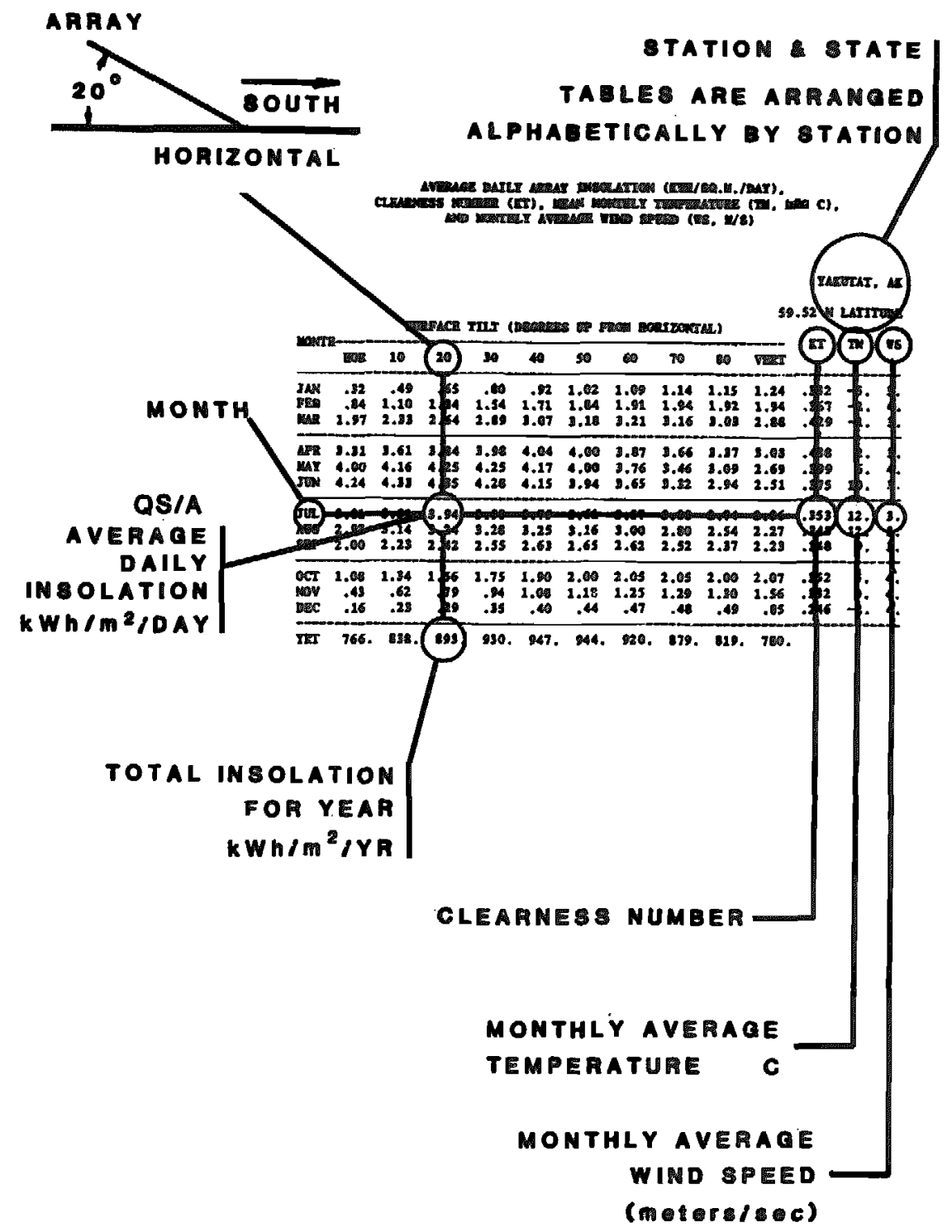

TM, WS and Total Radiation on the Horizontal Data for Table I were Taken from Ref. 5. KT and Total Radiation Data on the Tilt wer: Computed Using the Method of Ref. 7 .

A ground reflectance of 0.2 was assumed.

KEY for reading TABLE I 
AVERAGE DAILY ARRAY INSOLATION (KWH/SQ.M./DAY), CLEARNESS NUWBER (ITT), MEAN MONTHLY TEMPERATURE (TM, DEG C), AND MONTHLY AVERAGE WIND SPEED (WS, M/S)

ADAR, AR

51.88 N LATITUDE

SURFACE TILT (DEGREES UP FROM HORIZONTAL)

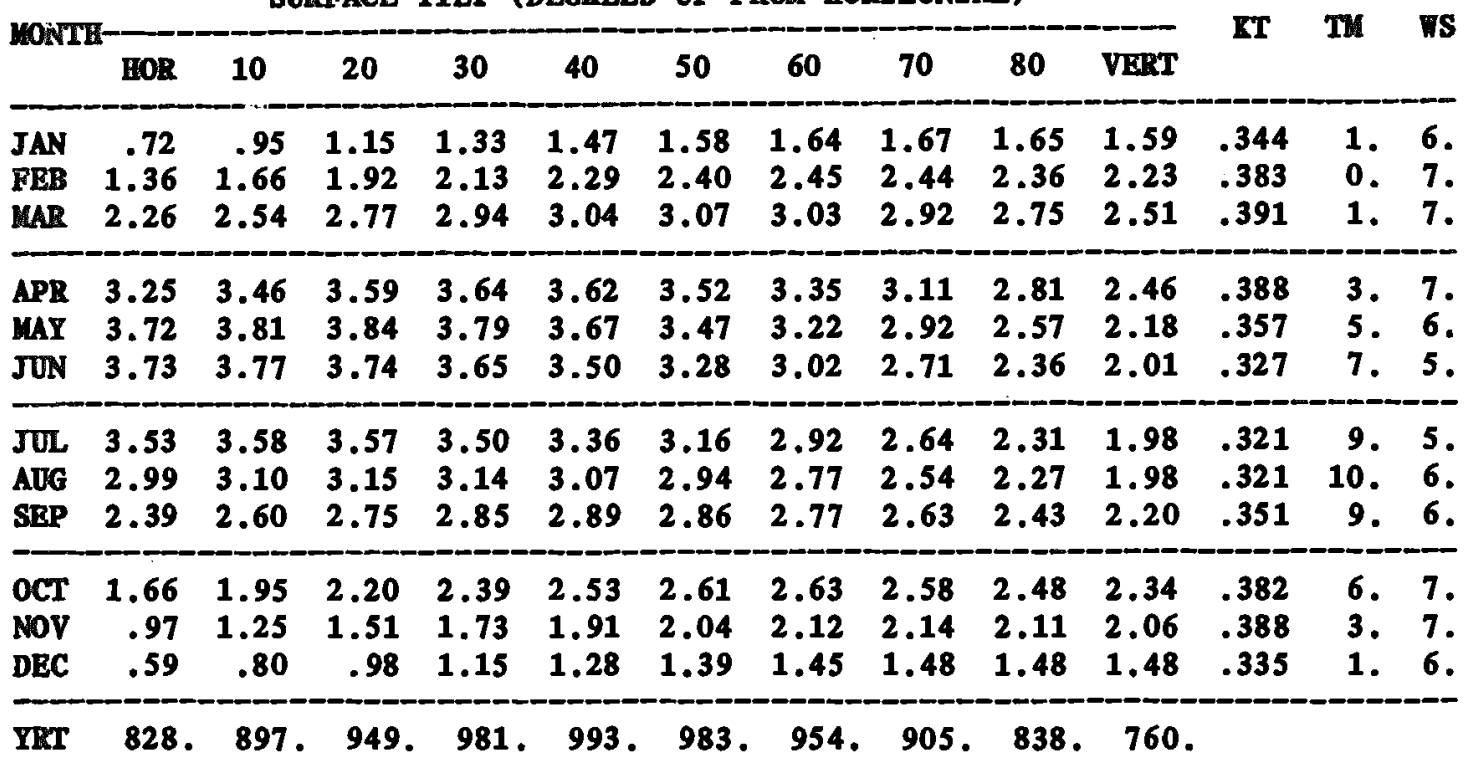

ALBUQUERQUE, NM

35.05 N LATITUDE

SURFACE TILT (DEGREES UP FROM HORIZONTAL)

\begin{tabular}{|c|c|c|c|c|c|c|c|c|c|c|c|c|}
\hline & HOR & 10 & 20 & 30 & 40 & 50 & 60 & 70 & 80 & ERT & & \\
\hline & $\begin{array}{l}4.22 \\
5.58\end{array}$ & & & & & & & & & & & 0 \\
\hline II & $\begin{array}{l}8.00 \\
8.44\end{array}$ & & & & & & & & & & & $\begin{array}{l}18 . \\
24 .\end{array}$ \\
\hline $\begin{array}{l}\pi \\
\mathbf{B G} \\
\mathrm{BP}\end{array}$ & $\begin{array}{l}7.84 \\
7.22 \\
6.21\end{array}$ & $\begin{array}{l}7 \\
6\end{array}$ & & & & & & & & & & $\begin{array}{l}24 . \\
20 .\end{array}$ \\
\hline BC & $\begin{array}{l}3.57 \\
2.93\end{array}$ & $\begin{array}{l}4.29 \\
3.62\end{array}$ & & & 5.10 & 5.34 & 5.44 & 5.40 & 5.20 & $\begin{array}{l}5.20 \\
4.90\end{array}$ & $\begin{array}{l}.674 \\
.640\end{array}$ & 2 . \\
\hline
\end{tabular}

YRT 2105. 2254. 2348. 2384. 2363. 2285. 2152. 1968. 1743. 1491. 
TABLE I (Continued)

AVERAGE DAILY ARRAY INSOLATION (KWER/SQ.M./DAT),

CleARNESS NUBBER (KT), MEAN MONTILI TEMPERATURE (TM, DEC C), AND MONIILI AVERAGE VIND SPEED (WS, M/S)

AMARILLO, TX

35.23 N LATITUDE

SURFACE TILT (DEGREES UP FROM HORIZONTAL)

\begin{tabular}{llllllllllllll}
\multicolumn{1}{l}{ MONTH- } & HOR & 10 & 20 & 30 & 40 & 50 & 60 & 70 & 80 & VERT & & & \\
\hline JAN & 3.03 & 3.67 & 4.22 & 4.67 & 5.00 & 5.19 & 5.26 & 5.18 & 4.97 & 4.64 & .618 & 2. & 6. \\
FEB & 3.91 & 4.52 & 5.01 & 5.37 & 5.61 & 5.69 & 5.64 & 5.44 & 5.10 & 4.65 & .629 & 4. & 6. \\
MAR & 5.14 & 5.62 & 5.97 & 6.17 & 6.21 & 6.11 & 5.85 & 5.45 & 4.92 & 4.29 & .642 & 8. & 7. \\
\hline APR & 6.36 & 6.62 & 6.72 & 6.66 & 6.45 & 6.08 & 5.58 & 4.94 & 4.20 & 3.39 & .652 & 14. & 7. \\
MAY & 6.97 & 7.02 & 6.89 & 6.61 & 6.19 & 5.65 & 4.99 & 4.22 & 3.43 & 2.60 & .639 & 19. & 7. \\
JUN & 7.54 & 7.48 & 7.25 & 6.84 & 6.30 & 5.64 & 4.87 & 4.03 & 3.17 & 2.35 & .662 & 24. & 6. \\
\hline JUL & 7.19 & 7.17 & 6.99 & 6.64 & 6.16 & 5.56 & 4.85 & 4.05 & 3.24 & 2.43 & .641 & 26. & 6. \\
AUG & 6.63 & 6.79 & 6.79 & 6.63 & 6.32 & 5.87 & 5.29 & 4.60 & 3.81 & 3.01 & .644 & 25. & 5. \\
SEP & 5.55 & 5.93 & 6.17 & 6.27 & 6.21 & 6.00 & 5.65 & 5.17 & 4.56 & 3.87 & .636 & 20. & 6. \\
\hline OCT & 4.43 & 5.00 & 5.46 & 5.77 & 5.95 & 5.97 & 5.85 & 5.57 & 5.16 & 4.64 & .642 & 14. & 6. \\
NOV & 3.25 & 3.88 & 4.41 & 4.83 & 5.12 & 5.29 & 5.32 & 5.21 & 4.36 & 4.61 & .618 & 7. & 6. \\
DEC & 2.75 & 3.38 & 3.93 & 4.39 & 4.72 & 4.94 & 5.02 & 4.98 & 4.80 & 4.51 & .605 & 3. & 6. \\
\hline
\end{tabular}

YRT 1911. 2042, 2125. 2156. 2137. 2068. 1951. 1788. 1590. 1367.

ANNETTE IS, AK

55.03 N LATITUDE

SURFACE TILT (DEGREES UP FROM HORIZONTAL)

\begin{tabular}{lccccccccccccc}
\multicolumn{1}{l}{ MONTH- } & \multicolumn{1}{c}{ HOR } & 10 & 20 & 30 & 40 & 50 & 60 & 70 & 80 & VERT & & & WS \\
\hline JAN & .56 & .77 & .97 & 1.15 & 1.29 & 1.41 & 1.48 & 1.52 & 1.52 & 1.94 & .345 & 1. & 5. \\
FEB & 1.18 & 1.48 & 1.75 & 1.98 & 2.16 & 2.29 & 2.36 & 2.37 & 2.32 & 2.23 & .390 & 2. & 5. \\
MAR & 2.26 & 2.61 & 2.89 & 3.11 & 3.26 & 3.33 & 3.32 & 3.23 & 3.07 & 2.85 & .427 & 3. & 5. \\
\hline APR & 3.62 & 3.91 & 4.11 & 4.22 & 4.23 & 4.15 & 3.99 & 3.73 & 3.40 & 3.01 & .449 & 6. & 5. \\
MAY & 4.64 & 4.82 & 4.89 & 4.88 & 4.75 & 4.53 & 4.22 & 3.84 & 3.39 & 2.89 & .453 & 9. & 4. \\
JUN & 4.62 & 4.71 & 4.71 & 4.62 & 4.45 & 4.18 & 3.85 & 3.47 & 3.02 & 2.55 & .407 & 12. & 4. \\
\hline JUL & 4.54 & 4.66 & 4.68 & 4.62 & 4.47 & 4.22 & 3.91 & 3.53 & 3.10 & 2.61 & .416 & 14. & 4. \\
AUG & 3.67 & 3.87 & 3.99 & 4.02 & 3.97 & 3.84 & 3.63 & 3.36 & 3.01 & 2.63 & .405 & 14. & 4. \\
SEP & 2.56 & 2.84 & 3.07 & 3.22 & 3.30 & 3.31 & 3.24 & 3.10 & 2.89 & 2.65 & .401 & 12. & 4. \\
\hline OCT & 1.33 & 1.57 & 1.78 & 1.95 & 2.07 & 2.15 & 2.18 & 2.15 & 2.07 & 1.98 & .347 & 8. & 5. \\
NOV & .68 & .91 & 1.12 & 1.29 & 1.44 & 1.55 & 1.62 & 1.65 & 1.64 & 1.62 & .347 & 4. & 5. \\
DEC & .39 & .53 & .67 & .79 & .89 & .97 & 1.02 & 1.05 & 1.05 & 1.06 & .301 & 2. & 6. \\
\hline
\end{tabular}

YRT 916. 996. 1055. 1092. 1105. 1094. 1060.1004. 927. 852. 
TABLE I (Continued)

AVERAGE DAILY ARRAY INSOLATION (KWH/SQ.M./DAY), CLEARNESS NUMBER (KT), MEAN MONTHLY TEMPERATURE (TM, DEG C), AND MONTHLY AVERAGE WIND SPEED (TS, M/S)

ARCATA, CA

SURFACE TILT (DEGREES UP FROM HORIZONTAL)

40.98 N LATITUDE

\begin{tabular}{lcccccccccccc}
\multicolumn{1}{l}{ MONTH } \\
\hline
\end{tabular}

YRT 1399. 1491. 1549. 1573. 1561. 1517. 1439. 1329. 1195. 1053.

ASTORIA, OR

SURFACE TILT (DEGREES UP FROM HORIZONTAL)

46.15 N LATITUDE

\begin{tabular}{lrllllllllllll}
\multicolumn{1}{l}{ MONTH- } & \multicolumn{1}{c}{ HOR } & 10 & 20 & 30 & 40 & 50 & 60 & 70 & 80 & VERT & & & WS \\
\hline JAN & .99 & 1.19 & 1.37 & 1.52 & 1.63 & 1.71 & 1.74 & 1.74 & 1.69 & 1.71 & .323 & 5.4 \\
FEB & 1.71 & 1.99 & 2.23 & 2.42 & 2.56 & 2.63 & 2.64 & 2.59 & 2.48 & 2.34 & .381 & 6. & 4. \\
MAR & 2.73 & 3.01 & 3.23 & 3.38 & 3.45 & 3.45 & 3.36 & 3.20 & 2.97 & 2.71 & .413 & 7. & 4. \\
\hline APR & 3.95 & 4.17 & 4.29 & 4.32 & 4.26 & 4.10 & 3.87 & 3.55 & 3.16 & 2.74 & .442 & 9. & 4. \\
MAY & 5.07 & 5.19 & 5.20 & 5.10 & 4.89 & 4.59 & 4.20 & 3.74 & 3.21 & 2.66 & .476 & 11. & 4. \\
JUN & 5.12 & 5.17 & 5.11 & 4.95 & 4.68 & 4.34 & 3.93 & 3.45 & 2.93 & 2.41 & .447 & 14. & 4. \\
\hline JUL & 5.51 & 5.59 & 5.56 & 5.41 & 5.15 & 4.79 & 4.35 & 3.83 & 3.25 & 2.67 & .494 & 15. & 4. \\
AUG & 4.72 & 4.91 & 5.00 & 4.98 & 4.85 & 4.61 & 4.29 & 3.88 & 3.40 & 2.89 & .485 & 16. & 3. \\
SEP & 3.73 & 4.06 & 4.31 & 4.46 & 4.50 & 4.44 & 4.28 & 4.02 & 3.67 & 3.29 & .494 & 15. & 3. \\
\hline OCT & 2.25 & 2.58 & 2.85 & 3.06 & 3.20 & 3.26 & 3.25 & 3.16 & 2.99 & 2.80 & .426 & 12. & 3. \\
NOV & 1.19 & 1.43 & 1.64 & 1.81 & 1.94 & 2.02 & 2.05 & 2.04 & 1.97 & 1.95 & .345 & 8. & 4. \\
DEC & .82 & .99 & 1.15 & 1.28 & 1.38 & 1.44 & 1.48 & 1.48 & 1.44 & 1.45 & .305 & 6. & 4. \\
\hline
\end{tabular}

YRT 1152. 1228. 1278. 1300. 1294. 1260. 1201. 1116. 1009. 901. 
TABLE I (Continned)

AVERAGE DAILY ARRAY INSOLATION (KWR/SQ.M./DAY),

CLEARNESS NUABER (KT), JBAN MONTHLY TEMPRRATURE (TM, DEG C), AND MONTHLY AVERAGE IND SPEED (WS, M/S)

BARROW, AR

71.30 N LATITUDE

SURFACE TILT (DEGREES UP FROA HORIZONTAL)

\begin{tabular}{|c|c|c|c|c|c|c|c|c|c|c|c|c|c|}
\hline & HOR & 10 & 20 & 30 & 40 & 50 & 60 & 70 & 80 & VERT & & M & W \\
\hline $\begin{array}{l}\text { JAN } \\
\text { FBB } \\
\text { MAR }\end{array}$ & $\begin{array}{r}.00 \\
.23 \\
1.55\end{array}$ & $\begin{array}{r}.00 \\
.53 \\
2.22\end{array}$ & $\begin{array}{r}.00 \\
.82 \\
2.84\end{array}$ & $\begin{array}{r}.00 \\
1.09 \\
3.38\end{array}$ & $\begin{array}{r}.00 \\
1.33 \\
3.84\end{array}$ & $\begin{array}{r}.00 \\
1.53 \\
4.18\end{array}$ & $\begin{array}{r}.00 \\
1.68 \\
4.42\end{array}$ & $\begin{array}{r}.00 \\
1.78 \\
4.53\end{array}$ & $\begin{array}{r}.00 \\
1.84 \\
4.51\end{array}$ & $\begin{array}{r}.00 \\
1.84 \\
4.37\end{array}$ & $\begin{array}{r}.000 \\
.484 \\
.595\end{array}$ & $\begin{array}{l}-26 \\
-29 \\
-27\end{array}$ & $\begin{array}{l}5 . \\
5 . \\
5\end{array}$ \\
\hline $\begin{array}{l}\text { APR } \\
\text { MAY } \\
\text { JUN }\end{array}$ & $\begin{array}{l}3.31 \\
3.59 \\
4.81\end{array}$ & $\begin{array}{l}3.86 \\
3.78 \\
4.93\end{array}$ & $\begin{array}{l}4.32 \\
3.91 \\
5.00\end{array}$ & $\begin{array}{l}4.68 \\
3.97 \\
5.01\end{array}$ & $\begin{array}{l}4.92 \\
3.96 \\
4.92\end{array}$ & 5. & $\begin{array}{l}5.04 \\
3.72 \\
4.52\end{array}$ & $\begin{array}{l}4.91 \\
3.49 \\
4.18\end{array}$ & $\begin{array}{l}4.67 \\
3.20 \\
3.79\end{array}$ & $\begin{array}{l}4.32 \\
2.86 \\
3.34\end{array}$ & $\begin{array}{r}.544 \\
.374 \\
.410\end{array}$ & $\begin{array}{r}-18 \\
-7 \\
1\end{array}$ & $\begin{array}{l}5 . \\
5 . \\
5 .\end{array}$ \\
\hline $\begin{array}{l}\text { JUL } \\
\text { AUG } \\
\text { SEP }\end{array}$ & $\begin{array}{l}4.60 \\
2.69 \\
1.31\end{array}$ & $\begin{array}{l}4.77 \\
2.92 \\
1.56\end{array}$ & $\begin{array}{l}4.89 \\
3.10 \\
1.78\end{array}$ & $\begin{array}{l}4.94 \\
3.21 \\
1.96\end{array}$ & $\begin{array}{l}4.89 \\
3.26 \\
2.09\end{array}$ & $\begin{array}{l}4.76 \\
3.24 \\
2.18\end{array}$ & $\begin{array}{l}4.54 \\
3.15 \\
2.21\end{array}$ & $\begin{array}{l}4.22 \\
3.00 \\
2.19\end{array}$ & $\begin{array}{l}3.85 \\
2.79 \\
2.12\end{array}$ & $\begin{array}{l}3.41 \\
2.55 \\
2.09\end{array}$ & $\begin{array}{r}.422 \\
.355 \\
.335\end{array}$ & $\begin{array}{r}3 \\
-1\end{array}$ & $\begin{array}{l}5 \\
5 \\
6\end{array}$ \\
\hline $\begin{array}{l}\text { OCT } \\
\text { NOV } \\
\text { DEC }\end{array}$ & $\begin{array}{l}.39 \\
.00 \\
.00\end{array}$ & $\begin{array}{l}.61 \\
.00 \\
.00\end{array}$ & $\begin{array}{l}.82 \\
.00 \\
.00\end{array}$ & $\begin{array}{r}1.01 \\
.00 \\
.00\end{array}$ & $\begin{array}{r}1.17 \\
.00 \\
.00\end{array}$ & $\begin{array}{r}1.30 \\
.00 \\
.00\end{array}$ & $\begin{array}{r}1.40 \\
.00 \\
.00\end{array}$ & $\begin{array}{r}1.45 \\
.00 \\
.00\end{array}$ & $\begin{array}{r}1.47 \\
.00 \\
.00\end{array}$ & $\begin{array}{r}1.84 \\
.00 \\
.00\end{array}$ & $\begin{array}{l}.348 \\
.000 \\
.000\end{array}$ & $\begin{array}{l}-10 \\
-19 \\
-25\end{array}$ & $\begin{array}{l}6 . \\
6 . \\
5 .\end{array}$ \\
\hline & 87. & & 8. & 92. & 3 & 241 & 93 & 90 & 859. & 810 & & & \\
\hline
\end{tabular}

BETHEL, $\mathbf{A R}$

60.78 N LATITUDE

SURFACE TILT (DEGREES UP FROM HORIZONTAL)

\begin{tabular}{lccccccccccccc}
\multicolumn{1}{l}{ MONTH- } & \multicolumn{1}{c}{ HOR } & 10 & 20 & 30 & 40 & 50 & 60 & 70 & 80 & VERT & & & WS \\
\hline JAN & .30 & .53 & .74 & .94 & 1.11 & 1.25 & 1.35 & 1.42 & 1.44 & 1.43 & .390 & -16. & 6. \\
FEB & 1.00 & 1.41 & 1.79 & 2.12 & 2.40 & 2.62 & 2.76 & 2.83 & 2.82 & 2.74 & .481 & -15. & 6. \\
MAR & 2.33 & 2.85 & 3.31 & 3.69 & 3.97 & 4.16 & 4.23 & 4.20 & 4.06 & 3.81 & .532 & -12. & 6. \\
\hline APR & 3.78 & 4.19 & 4.50 & 4.70 & 4.80 & 4.78 & 4.65 & 4.42 & 4.09 & 3.67 & .511 & -5. & 6. \\
MAY & 4.58 & 4.81 & 4.93 & 4.96 & 4.89 & 4.71 & 4.43 & 4.09 & 3.66 & 3.17 & .460 & 4. & 5. \\
JUN & 4.79 & 4.91 & 4.95 & 4.89 & 4.76 & 4.52 & 4.20 & 3.83 & 3.38 & 2.89 & .424 & 10. & 5. \\
\hline JUL & 4.06 & 4.19 & 4.24 & 4.20 & 4.10 & 3.92 & 3.65 & 3.35 & 2.98 & 2.57 & .378 & 13. & 5. \\
AUG & 2.90 & 3.07 & 3.18 & 3.22 & 3.20 & 3.11 & 2.97 & 2.77 & 2.52 & 2.27 & .339 & 11. & 5. \\
SEP & 2.21 & 2.51 & 2.77 & 2.96 & 3.08 & 3.13 & 3.11 & 3.01 & 2.85 & 2.68 & .397 & 7. & 5. \\
\hline OCT & 1.17 & 1.50 & 1.80 & 2.05 & 2.25 & 2.40 & 2.49 & 2.51 & 2.46 & 2.54 & .406 & -1. & 5. \\
NOV & .43 & .67 & .90 & 1.11 & 1.28 & 1.43 & 1.53 & 1.59 & 1.61 & 1.91 & .388 & -8. & 6. \\
DEC & .15 & .27 & .38 & .48 & .57 & .64 & .69 & .73 & .74 & 1.11 & .304 & -15. & 6. \\
\hline IRT & 844 & 942. & 1019 & 1075. & 1108 & 1115. & 1096 & 1055 & 991. & 935. & &
\end{tabular}


TABLE I (Continned)

AVERAGE DAILY ARRAY INSOLATION (KWH/SQ.M./DAY), CLEARNESS NUMBER (KT), MEAN WONTHLY TEMPERATURE (TM, DEG C), AND MONTHLY AVERAGE WIND SPEED (WS, M/S)

BETTLES, AR

SURFACE TILT (DEGRERS UP FROM HORIZONTAL)

66.92 N LATITODE MONTH-

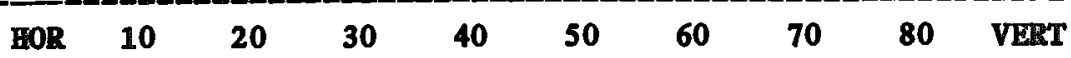

KT TM Vs

\begin{tabular}{|c|c|c|c|c|c|c|c|c|c|c|c|c|c|}
\hline $\begin{array}{l}\text { JAN } \\
\text { FEB } \\
\text { MAR }\end{array}$ & $\begin{array}{r}.03 \\
.54 \\
1.94\end{array}$ & $\begin{array}{r}.11 \\
.93 \\
2.57\end{array}$ & $\begin{array}{r}.19 \\
1.30 \\
3.14\end{array}$ & $\begin{array}{r}.27 \\
1.63 \\
3.63\end{array}$ & $\begin{array}{r}.33 \\
1.91 \\
4.03\end{array}$ & $\begin{array}{r}.39 \\
2.14 \\
4.32\end{array}$ & $\begin{array}{r}.43 \\
2.32 \\
4.49\end{array}$ & $\begin{array}{r}.46 \\
2.42 \\
4.54\end{array}$ & $\begin{array}{l}.48 \\
2.46 \\
4.46\end{array}$ & $\begin{array}{r}.93 \\
2.76 \\
4.34\end{array}$ & $\begin{array}{r}.338 \\
.495 \\
.579\end{array}$ & $\begin{array}{l}-26 \\
-23 \\
-17\end{array}$ & $\begin{array}{l}3 . \\
3 . \\
3 .\end{array}$ \\
\hline $\begin{array}{l}\text { APR } \\
\text { UAY } \\
\text { JUN }\end{array}$ & $\begin{array}{l}3.87 \\
5.35 \\
5.85\end{array}$ & $\begin{array}{l}4.45 \\
5.71 \\
6.06\end{array}$ & $\begin{array}{l}4.92 \\
5.96 \\
6.16\end{array}$ & $\begin{array}{l}5.27 \\
6.07 \\
6.16\end{array}$ & $\begin{array}{l}5.49 \\
6.09 \\
6.05\end{array}$ & $\begin{array}{l}5.57 \\
5.95 \\
5.83\end{array}$ & $\begin{array}{l}5.51 \\
5.69 \\
5.48\end{array}$ & $\begin{array}{l}5.32 \\
5.30 \\
5.04\end{array}$ & $\begin{array}{l}5.01 \\
4.83 \\
4.52\end{array}$ & $\begin{array}{l}4.61 \\
4.25 \\
3.92\end{array}$ & $\begin{array}{r}.583 \\
.554 \\
.514\end{array}$ & $\begin{array}{r}-6 \\
14 \\
6\end{array}$ & 3 \\
\hline $\begin{array}{l}\text { JUL } \\
\text { AUG } \\
\text { SEP }\end{array}$ & $\begin{array}{l}4.93 \\
3.39 \\
2.12\end{array}$ & $\begin{array}{l}5.14 \\
3.69 \\
2.55\end{array}$ & $\begin{array}{l}5.26 \\
3.90 \\
2.91\end{array}$ & $\begin{array}{l}5.28 \\
4.05 \\
3.21\end{array}$ & $\begin{array}{l}5.21 \\
4.10 \\
3.44\end{array}$ & $\begin{array}{l}5.04 \\
4.06 \\
3.57\end{array}$ & $\begin{array}{l}4.77 \\
3.93 \\
3.62\end{array}$ & $\begin{array}{l}4.40 \\
3.72 \\
3.58\end{array}$ & $\begin{array}{l}3.98 \\
3.44 \\
3.44\end{array}$ & $\begin{array}{l}3.48 \\
3.12 \\
3.31\end{array}$ & $\begin{array}{r}.462 \\
.425 \\
.460\end{array}$ & $\begin{array}{r}15 \\
12 \\
4\end{array}$ & 2 \\
\hline $\begin{array}{l}\text { OCT } \\
\text { NOV } \\
\text { DEC }\end{array}$ & $\begin{array}{l}.80 \\
.13 \\
.00\end{array}$ & $\begin{array}{r}1.15 \\
.33 \\
.00\end{array}$ & $\begin{array}{r}1.47 \\
.51 \\
.00\end{array}$ & $\begin{array}{r}1.76 \\
.69 \\
.00\end{array}$ & $\begin{array}{r}2.00 \\
.84 \\
.00\end{array}$ & $\begin{array}{r}2.19 \\
.98 \\
.00\end{array}$ & $\begin{array}{r}2.32 \\
1.08 \\
.00\end{array}$ & $\begin{array}{r}2.39 \\
1.15 \\
.00\end{array}$ & $\begin{array}{r}2.39 \\
1.19 \\
.00\end{array}$ & $\begin{array}{r}2.55 \\
1.78 \\
.00\end{array}$ & $\begin{array}{l}.431 \\
.42 \\
.00\end{array}$ & $\begin{array}{r}-7 \\
-19 \\
-24\end{array}$ & $\begin{array}{l}3 . \\
3 . \\
3 .\end{array}$ \\
\hline
\end{tabular}

IRT 884. 997. 1089. 1159. 1203, 1219, 1206. 1165. 1101. 1064 .

BINGHAMTON, NY

SURFACE TILT (DEGREES UP FROM HORIZONTAL)

\begin{tabular}{|c|c|c|c|c|c|c|c|c|c|c|c|c|c|}
\hline WN & HOR & 10 & 20 & 30 & 40 & 50 & 60 & 70 & 80 & VERT & 雨 & $\mathbf{T M}$ & WIS \\
\hline $\begin{array}{l}\text { JAN } \\
\text { FEB } \\
\text { MAR }\end{array}$ & $\begin{array}{l}1.22 \\
1.81 \\
2.72\end{array}$ & $\begin{array}{l}1.43 \\
2.05 \\
2.94\end{array}$ & $\begin{array}{l}1.61 \\
2.24 \\
3.11\end{array}$ & $\begin{array}{l}1.76 \\
2.38 \\
3.21\end{array}$ & $\begin{array}{l}1.86 \\
2.47 \\
3.24\end{array}$ & $\begin{array}{l}1.93 \\
2.51 \\
3.20\end{array}$ & $\begin{array}{l}1.95 \\
2.49 \\
3.09\end{array}$ & $\begin{array}{l}1.92 \\
2.41 \\
2.91\end{array}$ & $\begin{array}{l}1.85 \\
2.28 \\
2.68\end{array}$ & $\begin{array}{l}1.74 \\
2.10 \\
2.39\end{array}$ & $\begin{array}{r}.326 \\
.353 \\
.380\end{array}$ & $\begin{array}{l}-6 \\
-5 \\
-1\end{array}$ & $\begin{array}{l}5 . \\
5 . \\
5 .\end{array}$ \\
\hline $\begin{array}{l}\text { APR } \\
\text { MAY } \\
\text { JUN }\end{array}$ & $\begin{array}{l}3.92 \\
4.71 \\
5.30\end{array}$ & $\begin{array}{l}4.08 \\
4.79 \\
5.32\end{array}$ & $\begin{array}{l}4.17 \\
4.76 \\
5.23\end{array}$ & $\begin{array}{l}4.16 \\
4.63 \\
5.03\end{array}$ & $\begin{array}{l}4.07 \\
4.41 \\
4.72\end{array}$ & $\begin{array}{l}3.89 \\
4.11 \\
4.35\end{array}$ & $\begin{array}{l}3.63 \\
3.74 \\
3.90\end{array}$ & $\begin{array}{l}3.31 \\
3.30 \\
\mathbf{3 . 3 8}\end{array}$ & $\begin{array}{l}2.92 \\
2.80 \\
2.84\end{array}$ & $\begin{array}{l}2.47 \\
2.30 \\
2.27\end{array}$ & $\begin{array}{r}.422 \\
.437 \\
.462\end{array}$ & $\begin{array}{r}7 . \\
13 . \\
18 .\end{array}$ & $\begin{array}{l}5 . \\
5 . \\
4 .\end{array}$ \\
\hline $\begin{array}{l}\text { JUL } \\
\text { AUG } \\
\text { SEP }\end{array}$ & $\begin{array}{l}5.23 \\
4.49 \\
3.56\end{array}$ & $\begin{array}{l}5.28 \\
4.63 \\
3.82\end{array}$ & $\begin{array}{l}5.21 \\
4.67 \\
4.00\end{array}$ & $\begin{array}{l}5.04 \\
4.61 \\
4.08\end{array}$ & $\begin{array}{l}4.76 \\
4.45 \\
4.08\end{array}$ & $\begin{array}{l}4.40 \\
4.21 \\
3.98\end{array}$ & $\begin{array}{l}3.96 \\
3.88 \\
3.80\end{array}$ & $\begin{array}{l}3.46 \\
3.48 \\
3.54\end{array}$ & $\begin{array}{l}2.91 \\
3.01 \\
3.20\end{array}$ & $\begin{array}{l}2.35 \\
2.52 \\
2.82\end{array}$ & $\begin{array}{r}.467 \\
.450 \\
.445\end{array}$ & $\begin{array}{l}20 . \\
19 . \\
15 .\end{array}$ & $\begin{array}{l}4 . \\
4 . \\
4 .\end{array}$ \\
\hline $\begin{array}{l}\text { OCT } \\
\text { NOV } \\
\text { DEC }\end{array}$ & $\begin{array}{r}2.46 \\
1.30 \\
.94\end{array}$ & $\begin{array}{l}2.76 \\
1.50 \\
1.08\end{array}$ & $\begin{array}{l}3.01 \\
1.67 \\
1.20\end{array}$ & $\begin{array}{l}3.19 \\
1.80 \\
1.30\end{array}$ & $\begin{array}{l}3.30 \\
1.89 \\
1.37\end{array}$ & $\begin{array}{l}3.33 \\
1.94 \\
1.41\end{array}$ & $\begin{array}{l}3.28 \\
1.94 \\
1.42\end{array}$ & $\begin{array}{l}3.16 \\
1.90 \\
1.40\end{array}$ & $\begin{array}{l}2.96 \\
1.82 \\
1.35\end{array}$ & $\begin{array}{l}2.73 \\
1.79 \\
1.35\end{array}$ & $\begin{array}{r}.418 \\
.317 \\
.280\end{array}$ & $\begin{array}{r}10 . \\
3 . \\
-3 .\end{array}$ & $\begin{array}{l}4 . \\
5 . \\
5 .\end{array}$ \\
\hline
\end{tabular}


TABLE I (Continaed)

AVERAGR DATLY ARRAY INSOLATION (ITH/SO.M./DAY), CLEARNESS NUBBER (KT), MEAN MONTHLY TEUPERATTRE (TM, WRG C), AND MONTHLY AVBRAGE VIND SPEED (TS, M/S)

BOISE, ID

43.57 N LATITUDE

SURFACE TILT (DEGREES UP FROM HORIZONTAL)

MONTH

\begin{tabular}{|c|c|c|c|c|c|c|c|}
\hline BOR & 20 & 30 & 40 & 50 & 60 & 70 & VERT \\
\hline
\end{tabular}

\begin{tabular}{llllllllllllll}
\hline JAN & 1.53 & 1.90 & 2.22 & 2.49 & 2.70 & 2.84 & 2.91 & 2.91 & 2.83 & 2.77 & .437 & -1. & 4. \\
FEB & 2.64 & 3.14 & 3.56 & 3.90 & 4.14 & 4.28 & 4.31 & 4.22 & 4.04 & 3.78 & .537 & 2. & 4. \\
MAR & 4.11 & 4.61 & 5.00 & 5.27 & 5.41 & 5.42 & 5.29 & 5.03 & 4.65 & 4.19 & .591 & 5. & 4. \\
\hline ArR & 5.76 & 6.12 & 6.33 & 6.39 & 6.29 & 6.06 & 5.68 & 5.17 & 4.55 & 3.84 & .628 & 9. & 5. \\
MAY & 7.18 & 7.36 & 7.37 & 7.20 & 6.86 & 6.39 & 5.79 & 5.06 & 4.22 & 3.37 & .668 & 14. & 4. \\
JUN & 7.77 & 7.83 & 7.72 & 7.43 & 6.96 & 6.38 & 5.67 & 4.84 & 3.97 & 3.07 & .677 & 19. & 4. \\
\hline JUL & 8.23 & 8.37 & 8.31 & 8.05 & 7.59 & 6.99 & 6.24 & 5.35 & 4.38 & 3.39 & .736 & 24. & 4. \\
AUG & 6.92 & 7.25 & 7.40 & 7.37 & 7.16 & 6.79 & 6.27 & 5.60 & 4.80 & 3.92 & .700 & 23. & 4. \\
SEP & 5.48 & 6.05 & 6.47 & 6.73 & 6.83 & 6.74 & 6.49 & 6.08 & 5.51 & 4.83 & .697 & 17. & 4. \\
\hline OCT & 3.58 & 4.21 & 4.73 & 5.14 & 5.42 & 5.55 & 5.54 & 5.39 & 5.10 & 4.71 & .632 & 11. & 4. \\
NOV & 1.98 & 2.45 & 2.87 & 3.21 & 3.47 & 3.64 & 3.72 & 3.71 & 3.60 & 3.49 & .510 & 4.4 & 4. \\
DEC & 1.38 & 1.74 & 2.07 & 2.35 & 2.57 & 2.72 & 2.80 & 2.81 & 2.75 & 2.72 & .441 & 0. & 4. \\
\hline
\end{tabular}

IRT 1725. 1860. 1952. 1996. 1992. 1942. 1848. 1709. 1533. 1340.

BOSTON, MA

42.37 N LATITUDE

SURFACE TILT (DEGREES UP FROM HORIZONTAL)

MONTH$\begin{array}{llllllllll}\text { HOR } & 10 & 20 & 30 & 40 & 50 & 60 & 70 & 80 & \text { VERT }\end{array}$

\begin{tabular}{llllllllllllll}
\hline JAN & 1.50 & 1.82 & 2.10 & 2.34 & 2.51 & 2.63 & 2.68 & 2.66 & 2.58 & 2.54 & .405 & -2. & 7. \\
FEB & 2.23 & 2.58 & 2.87 & 3.10 & 3.25 & 3.32 & 3.32 & 3.23 & 3.07 & 2.86 & .437 & -1. & 7. \\
MAR & 3.20 & 3.51 & 3.74 & 3.89 & 3.95 & 3.91 & 3.79 & 3.58 & 3.30 & 2.97 & .450 & 3. & 7. \\
\hline APR & 4.18 & 4.37 & 4.47 & 4.47 & 4.37 & 4.18 & 3.91 & 3.56 & 3.13 & 2.67 & .451 & 8. & 6. \\
MAAY & 5.26 & 5.35 & 5.33 & 5.19 & 4.94 & 4.60 & 4.18 & 3.67 & 3.11 & 2.54 & .488 & 14. & 6. \\
JUN & 5.73 & 5.75 & 5.65 & 5.44 & 5.11 & 4.70 & 4.20 & 3.63 & 3.04 & 2.42 & .499 & 20. & 5. \\
\hline JUL & 5.52 & 5.57 & 5.50 & 5.32 & 5.02 & 4.64 & 4.18 & 3.64 & 3.06 & 2.46 & .493 & 23. & 5. \\
AUG & 4.68 & 4.84 & 4.88 & 4.82 & 4.66 & 4.41 & 4.07 & 3.64 & 3.15 & 2.63 & .470 & 21. & 5. \\
SEP & 3.97 & 4.28 & 4.49 & 4.60 & 4.61 & 4.51 & 4.31 & 4.01 & 3.63 & 3.19 & .497 & 18. & 5. \\
\hline OCT & 2.80 & 3.19 & 3.50 & 3.73 & 3.88 & 3.93 & 3.88 & 3.75 & 3.52 & 3.25 & .479 & 13. & 6. \\
NOV & 1.58 & 1.88 & 2.14 & 2.34 & 2.49 & 2.59 & 2.61 & 2.58 & 2.48 & 2.42 & .387 & 7. & 6 \\
DEC & 1.27 & 1.56 & 1.81 & 2.02 & 2.19 & 2.30 & 2.35 & 2.35 & 2.28 & 2.26 & .382 & 1. & 6. \\
\hline IRT & 1278 & 1361 & 1416 & 1439 & 1430 & 1391 & 1323 & 1226 & 1106 & 979. & &
\end{tabular}

YRT 1278. 1361. 1416. 1439. 1430. 1391. 1323. 1226. 1106. 979. 
TABLE I (Continued)

AVERAEZ DAILY ARRAY INSOLATION (KWH/SQ.M:/DAY), CLEARNESS NUMBER (ET), MEAN MONTHLY TEMPERATURE (TM, DEG C), AND MONTHLY AVERAGE WIND SPEED (WS, M/S)

BRYCE CANYON, UT 37.70 N LATITUDE SURFACE TILT (DEGREES UP FROM HORIZONTAL)

\begin{tabular}{|c|c|c|c|c|c|c|c|c|c|c|c|c|}
\hline & HOR & 10 & 20 & 30 & 40 & 50 & 60 & 70 & 80 & VERT & & $\mathbf{M}$ \\
\hline $\begin{array}{l}\text { JAN } \\
\text { FEB } \\
\text { MAR }\end{array}$ & $\begin{array}{l}2.88 \\
3.89 \\
5.31\end{array}$ & $\begin{array}{l}3.58 \\
4.57 \\
5.89\end{array}$ & $\begin{array}{l}4.19 \\
5.13 \\
6.32\end{array}$ & $\begin{array}{l}4.69 \\
5.57 \\
6.59\end{array}$ & $\begin{array}{l}5.06 \\
5.86 \\
6.69\end{array}$ & $\begin{array}{l}5.31 \\
6.00 \\
6.62\end{array}$ & $\begin{array}{l}5.41 \\
5.98 \\
6.39\end{array}$ & $\begin{array}{l}5.37 \\
5.81 \\
6.00\end{array}$ & 5. & $\begin{array}{l}4.96 \\
5.05 \\
4.81\end{array}$ & $\begin{array}{l}.642 \\
.655 \\
.689\end{array}$ & $\begin{array}{l}-7 \\
-5 \\
-2\end{array}$ \\
\hline $\begin{array}{l}\text { APR } \\
\text { MAY } \\
\text { JUN }\end{array}$ & $\begin{array}{l}6.72 \\
7.73 \\
8.37\end{array}$ & $\begin{array}{l}7.06 \\
7.83 \\
8.34\end{array}$ & $\begin{array}{l}7.22 \\
7.74 \\
8.12\end{array}$ & $\begin{array}{l}7.20 \\
7.47 \\
7.70\end{array}$ & $\begin{array}{l}7.01 \\
7.02 \\
7.10\end{array}$ & $\begin{array}{l}6.66 \\
6.44 \\
6.39\end{array}$ & $\begin{array}{l}6.14 \\
5.71 \\
5.53\end{array}$ & $\begin{array}{l}5.48 \\
4.85 \\
4.57\end{array}$ & $\begin{array}{l}4.70 \\
3.94 \\
3.61\end{array}$ & $\begin{array}{l}3.84 \\
2.99 \\
2.63\end{array}$ & $\begin{array}{r}.700 \\
.711 \\
.732\end{array}$ & $\begin{array}{r}3 . \\
9 . \\
14 .\end{array}$ \\
\hline $\begin{array}{l}\text { JUL } \\
\text { AUG } \\
\text { SEP }\end{array}$ & $\begin{array}{l}7.64 \\
6.80 \\
6.05\end{array}$ & $\begin{array}{l}7.67 \\
7.01 \\
6.56\end{array}$ & $\begin{array}{l}7.51 \\
7.05 \\
6.90\end{array}$ & $\begin{array}{l}7.17 \\
6.92 \\
7.07\end{array}$ & $\begin{array}{l}6.68 \\
6.63 \\
7.07\end{array}$ & $\begin{array}{l}6.07 \\
6.20 \\
6.88\end{array}$ & $\begin{array}{l}5.32 \\
5.63 \\
6.53\end{array}$ & $\begin{array}{l}4.47 \\
4.93 \\
6.01\end{array}$ & $\begin{array}{l}3.60 \\
4.13 \\
5.35\end{array}$ & $\begin{array}{l}2.69 \\
3.28 \\
4.57\end{array}$ & $\begin{array}{l}.681 \\
.666 \\
.713\end{array}$ & $\begin{array}{l}17 . \\
16 \\
12 .\end{array}$ \\
\hline $\begin{array}{l}\text { OCT } \\
\text { NOV } \\
\text { DEC }\end{array}$ & $\begin{array}{l}4.62 \\
3.20 \\
2.58\end{array}$ & $\begin{array}{l}5.32 \\
3.91 \\
3.26\end{array}$ & $\begin{array}{l}5.88 \\
4.53 \\
3.85\end{array}$ & $\begin{array}{l}6.30 \\
5.02 \\
4.35\end{array}$ & $\begin{array}{l}6.56 \\
5.39 \\
4.73\end{array}$ & $\begin{array}{l}6.64 \\
5.61 \\
4.99\end{array}$ & $\begin{array}{l}6.55 \\
5.69 \\
5.11\end{array}$ & $\begin{array}{l}6.29 \\
5.61 \\
5.10\end{array}$ & $\begin{array}{l}5.87 \\
5.39 \\
4.95\end{array}$ & $\begin{array}{l}5.31 \\
5.19 \\
4.83\end{array}$ & $\begin{array}{r}.705 \\
.658 \\
.626\end{array}$ & $\begin{array}{r}6 \\
-1 \\
-6\end{array}$ \\
\hline
\end{tabular}

YET 2004. 2161. 2266. 2314. 2306. 2245. 2128. 1960. 1752. 1523.

BURLINGTON, VT

SURFACE TILT (DEGREES UP FROM HORIZONTAL)

\begin{tabular}{llllllllllllll}
\multicolumn{1}{l}{ HONTH- } & \multicolumn{1}{c}{ HOR } & 10 & 20 & 30 & 40 & 50 & 60 & 70 & 80 & VERT & & & WS \\
\hline JAN & 1.34 & 1.66 & 1.93 & 2.16 & 2.34 & 2.47 & 2.53 & 2.52 & 2.46 & 2.49 & .401 & -8. & 4. \\
FEB & 2.13 & 2.50 & 2.82 & 3.06 & 3.24 & 3.33 & 3.35 & 3.28 & 3.13 & 2.93 & .447 & -7. & 4 \\
MAR & 3.33 & 3.69 & 3.97 & 4.16 & 4.25 & 4.24 & 4.14 & 3.93 & 3.64 & 3.28 & .487 & -2. & 4. \\
\hline APR & 4.57 & 4.82 & 4.96 & 4.99 & 4.91 & 4.72 & 4.44 & 4.05 & 3.59 & 3.06 & .502 & 6. & 4. \\
MAY & 5.57 & 5.69 & 5.69 & 5.57 & 5.32 & 4.97 & 4.53 & 4.01 & 3.40 & 2.79 & .520 & 13. & 4. \\
JUN & 6.15 & 6.19 & 6.11 & 5.90 & 5.56 & 5.12 & 4.60 & 3.99 & 3.34 & 2.67 & .536 & 18. & 4. \\
\hline JUL & 6.15 & 6.24 & 6.19 & 6.01 & 5.69 & 5.27 & 4.76 & 4.15 & 3.48 & 2.80 & .550 & 21. & 3. \\
AUG & 5.27 & 5.49 & 5.58 & 5.54 & 5.38 & 5.11 & 4.74 & 4.26 & 3.70 & 3.09 & .536 & 19. & 3. \\
SEP & 3.98 & 4.33 & 4.58 & 4.72 & 4.76 & 4.68 & 4.50 & 4.21 & 3.83 & 3.39 & .514 & 15. & 3. \\
\hline OCT & 2.63 & 3.02 & 3.34 & 3.58 & 3.74 & 3.81 & 3.79 & 3.67 & 3.47 & 3.22 & .475 & 9. & 4. \\
NOV & 1.37 & 1.63 & 1.86 & 2.05 & 2.19 & 2.28 & 2.32 & 2.30 & 2.22 & 2.17 & .366 & 3. & 4. \\
DEC & 1.01 & 1.23 & 1.43 & 1.60 & 1.73 & 1.81 & 1.86 & 1.86 & 1.81 & 1.80 & .340 & -5. & 4. \\
\hline ITT & 1326 & 1417 & 1477 & 1503 & 1495 & 1456 & 1386 & 1285 & 1157 & 1024 & &
\end{tabular}

YRT 1326, 1417, 1477, 1503, 1495, 1456, 1386, 1285, 1157, 1024. 
TABLE I (Contiraed)

AVERAGE DAILY ARRAT INSOLATION (KTH/SQ.M./DAY),

CLRARNESS NUMBER (IT), MRAN HONTHLY TEMPERTURE (M, DRG C), AND MONTHLY AVERAGE WDP SPEED (WS, M/S)

BURNS, OR

43.58 N LATITUDE

SURFACE TILT (DEGRES OP FROM HORIZONTAL)

\begin{tabular}{lccccccccccccc} 
UONTH & HOR & 10 & 20 & 30 & 40 & 50 & 60 & 70 & 80 & VERT & & & \\
\hline JAN & 1.55 & 1.92 & 2.25 & 2.52 & 2.74 & 2.88 & 2.95 & 2.95 & 2.87 & 2.80 & .442 & -3. & 2. \\
FEB & 2.49 & 2.94 & 3.32 & 3.62 & 3.83 & 3.95 & 3.97 & 3.89 & 3.71 & 3.48 & .507 & 0. & 3. \\
MAR & 3.75 & 4.17 & 4.50 & 4.72 & 4.83 & 4.83 & 4.70 & 4.47 & 4.13 & 3.73 & .538 & 2. & 3. \\
\hline APR & 5.20 & 5.50 & 5.67 & 5.71 & 5.62 & 5.40 & 5.06 & 4.61 & 4.06 & 3.46 & .567 & 6. & 4. \\
MAY & 6.47 & 6.62 & 6.62 & 6.47 & 6.17 & 5.75 & 5.22 & 4.57 & 3.84 & 3.10 & .603 & 12. & 4. \\
JUN & 7.19 & 7.24 & 7.14 & 6.87 & 6.45 & 5.92 & 5.27 & 4.52 & 3.73 & 2.91 & .626 & 16. & 4. \\
\hline JUL & 7.75 & 7.87 & 7.81 & 7.57 & 7.14 & 6.58 & 5.89 & 5.07 & 4.17 & 3.26 & .693 & 21. & 3. \\
AUG & 6.56 & 6.86 & 7.00 & 6.96 & 6.76 & 6.41 & 5.92 & 5.29 & 4.55 & 3.72 & .664 & 20. & 3. \\
SEF & 5.11 & 5.62 & 5.99 & 6.22 & 6.29 & 6.21 & 5.97 & 5.59 & 5.07 & 4.45 & .650 & 15. & 3. \\
\hline OCT & 3.28 & 3.82 & 4.27 & 4.62 & 4.85 & 4.96 & 4.94 & 4.80 & 4.53 & 4.19 & .579 & 8.3. & 3. \\
NOV & 1.87 & 2.30 & 2.68 & 2.99 & 3.22 & 3.38 & 3.45 & 3.43 & 3.32 & 3.23 & .482 & 2. & 3. \\
DEC & 1.36 & 1.71 & 2.03 & 2.30 & 2.51 & 2.66 & 2.74 & 2.75 & 2.69 & 2.66 & .435 & -2. & 2. \\
\hline IRT & 1603 & 1724 & 1806 & 1845 & 1840 & 1794 & 1707 & 1580 & 1420 & 1246 & &
\end{tabular}

IRT 1603, 1724, 1806, 1845, 1840, 1794, 1707, 1580, 1420, 1246.

CARIBOU, UE

46.87 N LATITUDE

SURFACE TILT (DRGREES UP FROM HORIZONTAL)

MONTH$\begin{array}{llllllllllll}\text { HOR } & 10 & 20 & 30 & 40 & 50 & 60 & 70 & 80 & \text { VERT } & \text { KT } & \text { TI }\end{array}$

\begin{tabular}{llllllllllllll}
\hline JAN & 1.32 & 1.70 & 2.03 & 2.32 & 2.54 & 2.71 & 2.80 & 2.82 & 2.77 & 2.74 & .449 & -11. & 5. \\
FEB & 2.28 & 2.76 & 3.18 & 3.52 & 3.77 & 3.93 & 3.99 & 3.94 & 3.80 & 3.65 & .520 & -10. & 5. \\
UAR & 3.57 & 4.04 & 4.41 & 4.68 & 4.84 & 4.87 & 4.79 & 4.59 & 4.28 & 3.89 & .549 & -4. & 6. \\
\hline APR & 4.46 & 4.73 & 4.89 & 4.95 & 4.89 & 4.73 & 4.47 & 4.10 & 3.66 & 3.16 & .502 & 3. & 5. \\
MAY & 4.97 & 5.10 & 5.11 & 5.02 & 4.82 & 4.52 & 4.15 & 3.70 & 3.19 & 2.64 & .468 & 10. & 5. \\
JUN & 5.54 & 5.60 & 5.54 & 5.37 & 5.09 & 4.72 & 4.27 & 3.75 & 3.17 & 2.59 & .484 & 16. & 5. \\
\hline JUL & 5.56 & 5.65 & 5.62 & 5.48 & 5.22 & 4.86 & 4.43 & 3.91 & 3.31 & 2.72 & .499 & 19. & 4. \\
AUG & 4.72 & 4.93 & 5.02 & 5.01 & 4.88 & 4.65 & 4.34 & 3.93 & 3.45 & 2.93 & .488 & 17. & 4. \\
SEP & 3.47 & 3.78 & 4.01 & 4.15 & 4.19 & 4.14 & 3.99 & 3.76 & 3.44 & 3.08 & .465 & 13. & 5. \\
\hline OCT & 2.17 & 2.49 & 2.77 & 2.97 & 3.11 & 3.18 & 3.17 & 3.08 & 2.92 & 2.74 & .420 & 6. & 5. \\
NOV & 1.16 & 1.39 & 1.60 & 1.77 & 1.91 & 1.99 & 2.03 & 2.02 & 1.96 & 1.92 & .346 & 0. & 5. \\
DEC & .98 & 1.25 & 1.50 & 1.71 & 1.88 & 2.00 & 2.08 & 2.09 & 2.06 & 2.04 & .380 & -9. & 5. \\
\hline
\end{tabular}

YRT 1225. 1322. 1391. 1429. 1434. 1408. 1353. 1267. 1154. 1036. 
AVERAGR DAILY ARRAY INSOLATION (KWH/SQ.M./DAY), CLRARNESS NUMBER (KT), WRAN MONTMLY TEMPERATURE (TM, DEG C), AND MONTILY AVERAGE WIND SPEED (WS, M/S)

CASPRR, WY

SURPACE TILT (DEGREES UP FROU HORIZONTAL)

42.92 N LATITUDE

\begin{tabular}{|c|c|c|c|c|c|c|c|c|c|c|c|c|c|}
\hline \multicolumn{2}{|c|}{ MONTH- } & & & & & & & & & & \multirow[t]{2}{*}{$\mathrm{TT}$} & \multirow{2}{*}{$\mathbf{T M}$} & \multirow[t]{2}{*}{$7 \mathrm{~s}$} \\
\hline & HOR & 10 & 20 & 30 & 40 & 50 & 60 & 70 & 80 & VERT & & & \\
\hline $\begin{array}{l}\mathbf{A N} \\
\mathbf{R B} \\
\mathbf{A R}\end{array}$ & $\begin{array}{l}3.19 \\
4.55\end{array}$ & $\begin{array}{l}3.85 \\
5.12\end{array}$ & $\begin{array}{l}3.32 \\
4.41 \\
5.57\end{array}$ & $\begin{array}{l}4.86 \\
5.88\end{array}$ & $\begin{array}{l}9 \\
4\end{array}$ & $\begin{array}{l}4 \\
5 \\
6\end{array}$ & 3 & & & & $\begin{array}{l}.5 \\
.6 \\
.6\end{array}$ & $\begin{array}{l}-4 \\
-3 \\
0\end{array}$ & 6 \\
\hline $\begin{array}{l}\mathbf{P R} \\
\mathbf{A Y} \\
\mathrm{UN}\end{array}$ & $\begin{array}{l}5.82 \\
6.95 \\
7.88\end{array}$ & 7 & $\begin{array}{l}6.38 \\
7.11 \\
7.82\end{array}$ & $\begin{array}{l}43 \\
93 \\
51\end{array}$ & $\begin{array}{l}3 \\
0 \\
3\end{array}$ & $\begin{array}{l}6.14 \\
6.43\end{array}$ & $\begin{array}{l}9 \\
5 \\
0\end{array}$ & & & & $\begin{array}{r}.631 \\
.646 \\
.688\end{array}$ & $\begin{array}{l}5 . \\
11 . \\
17 .\end{array}$ & $\begin{array}{l}5 \\
5\end{array}$ \\
\hline $\begin{array}{l}\text { UL } \\
\text { UG } \\
B P\end{array}$ & $\begin{array}{l}7.99 \\
7.02 \\
5.51\end{array}$ & 7.34 & 7. & $\begin{array}{l}7.44 \\
6.74\end{array}$ & $\begin{array}{l}2 \\
2 \\
2\end{array}$ & 6. & $\begin{array}{l}0 \\
9 \\
6\end{array}$ & $\begin{array}{l}4 \\
1 \\
4\end{array}$ & & & $\begin{array}{r}.714 \\
.706 \\
.695\end{array}$ & $\begin{array}{l}22 \\
21 \\
14\end{array}$ & 5 \\
\hline $\begin{array}{l}\mathrm{CT} \\
\mathrm{DV} \\
\mathrm{BC}\end{array}$ & $\begin{array}{l}3.84 \\
2.42 \\
1.87\end{array}$ & 3.04 & $\begin{array}{l}3.60 \\
2.97\end{array}$ & $\begin{array}{l}4.06 \\
3.42\end{array}$ & $\begin{array}{l}4.42 \\
3.77\end{array}$ & $\begin{array}{l}5.96 \\
4.66 \\
4.03\end{array}$ & 4.77 & $\begin{array}{l}4.76 \\
4.21\end{array}$ & $\begin{array}{l}5.47 \\
4.63 \\
4.13\end{array}$ & 4 & $\begin{array}{l}.665 \\
.604 \\
.580\end{array}$ & $\begin{array}{r}8 \\
1 \\
-3\end{array}$ & 6 \\
\hline
\end{tabular}

YRT 1804. 1965. 2079. 2142. 2152, 2112. 2023. 1883. 1702. 1500.

CHARLESTON, SC

32.90 N LATITUDE

SURFACE TILT (DEGREES UP FROM HORIZONTAL)

\begin{tabular}{|c|c|c|c|c|c|c|c|c|c|c|c|c|}
\hline & HOR & 10 & 20 & 30 & 40 & 50 & 60 & 70 & 0 & TERT & & \\
\hline $\begin{array}{l}\mathrm{AN} \\
\mathrm{EB} \\
\mathrm{AR}\end{array}$ & $\begin{array}{l}3.14 \\
4.22\end{array}$ & $\begin{array}{l}2.70 \\
3.50 \\
4.52\end{array}$ & $\begin{array}{l}3.00 \\
3.79 \\
4.72\end{array}$ & $\begin{array}{l}3.24 \\
3.98 \\
4.81\end{array}$ & $\begin{array}{l}9 \\
9 \\
0\end{array}$ & $\begin{array}{l}7 \\
0 \\
7\end{array}$ & $\begin{array}{l}6 \\
1 \\
4\end{array}$ & 3. & $\begin{array}{l}9 \\
6 \\
9\end{array}$ & $\begin{array}{l}7 \\
24 \\
1\end{array}$ & $\begin{array}{r}.444 \\
.477 \\
.511\end{array}$ & $\begin{array}{r}9 . \\
10 \\
13\end{array}$ \\
\hline $\begin{array}{l}\mathbf{A Y} \\
\mathrm{UN}\end{array}$ & $\begin{array}{l}5.46 \\
5.87 \\
5.81\end{array}$ & $\begin{array}{l}5.63 \\
5.87 \\
5.74\end{array}$ & $\begin{array}{l}5.66 \\
5.74 \\
5.55\end{array}$ & $\begin{array}{l}5.57 \\
5.49 \\
5.23\end{array}$ & $\begin{array}{l}5.13 \\
4.83\end{array}$ & $\begin{array}{l}3 \\
7 \\
5\end{array}$ & $\begin{array}{l}4.59 \\
4.12 \\
3.77\end{array}$ & $\begin{array}{l}4.06 \\
3.50 \\
3.17\end{array}$ & $\begin{array}{l}5 \\
6 \\
5\end{array}$ & $\begin{array}{l}9 \\
2 \\
6\end{array}$ & $\begin{array}{l}2 \\
7 \\
2\end{array}$ & $\begin{array}{l}18 \\
22 \\
26\end{array}$ \\
\hline $\begin{array}{l}\text { UG } \\
\text { EP }\end{array}$ & $\begin{array}{l}5.66 \\
5.00 \\
4.39\end{array}$ & $\begin{array}{l}5.62 \\
5.07 \\
4.62\end{array}$ & $\begin{array}{l}5.46 \\
5.03 \\
4.74\end{array}$ & $\begin{array}{l}5.18 \\
4.89 \\
4.75\end{array}$ & $\begin{array}{l}4.64 \\
4.67\end{array}$ & $\begin{array}{l}4.36 \\
4.31 \\
4.47\end{array}$ & $\begin{array}{l}81 \\
88 \\
19\end{array}$ & $\begin{array}{l}3.22 \\
3.39 \\
3.81\end{array}$ & $\begin{array}{l}2.62 \\
2.83 \\
3.35\end{array}$ & & $\begin{array}{r}.507 \\
.481 \\
.491\end{array}$ & $\begin{array}{l}26 . \\
26 . \\
23 .\end{array}$ \\
\hline $\begin{array}{l}\mathrm{T} \\
\mathrm{V} \\
\mathrm{C}\end{array}$ & $\begin{array}{l}5.10 \\
2.94 \\
2.27\end{array}$ & $\begin{array}{l}4.10 \\
3.40 \\
2.66\end{array}$ & $\begin{array}{l}3.78 \\
3.00\end{array}$ & $\begin{array}{l}4.03 \\
4.07 \\
3.26\end{array}$ & $\begin{array}{l}4.11 \\
4.26 \\
3.45\end{array}$ & $\begin{array}{l}4.34 \\
3.55\end{array}$ & $\begin{array}{l}4.53 \\
4.32 \\
3.56\end{array}$ & $\begin{array}{l}4.19 \\
3.49\end{array}$ & $\begin{array}{l}3.96 \\
3.33\end{array}$ & $\begin{array}{l}3.64 \\
3.11\end{array}$ & $\begin{array}{r}.521 \\
.522 \\
.460\end{array}$ & 13 \\
\hline
\end{tabular}

YRT 1549. 1628. 1671. 1677. 1647. 1581. 1481. 1350. 1195. 1027. 
TABLE I (Continged)

AVERAGE DAILY ARRAY INSOLATION (ITH/SQ.M./DAT), ClEARNESS NUBBE (KT), MRAN MONTHLY TEMPERATURE (TM, DEG C), AND MONTHLY AVERAGE WIND SPEED (WS, M/S)

CHARLESTON, WV

38.37 N LATITUDE

SURFACE TILT (DEGRERS UP FROM HORIZONTAL)

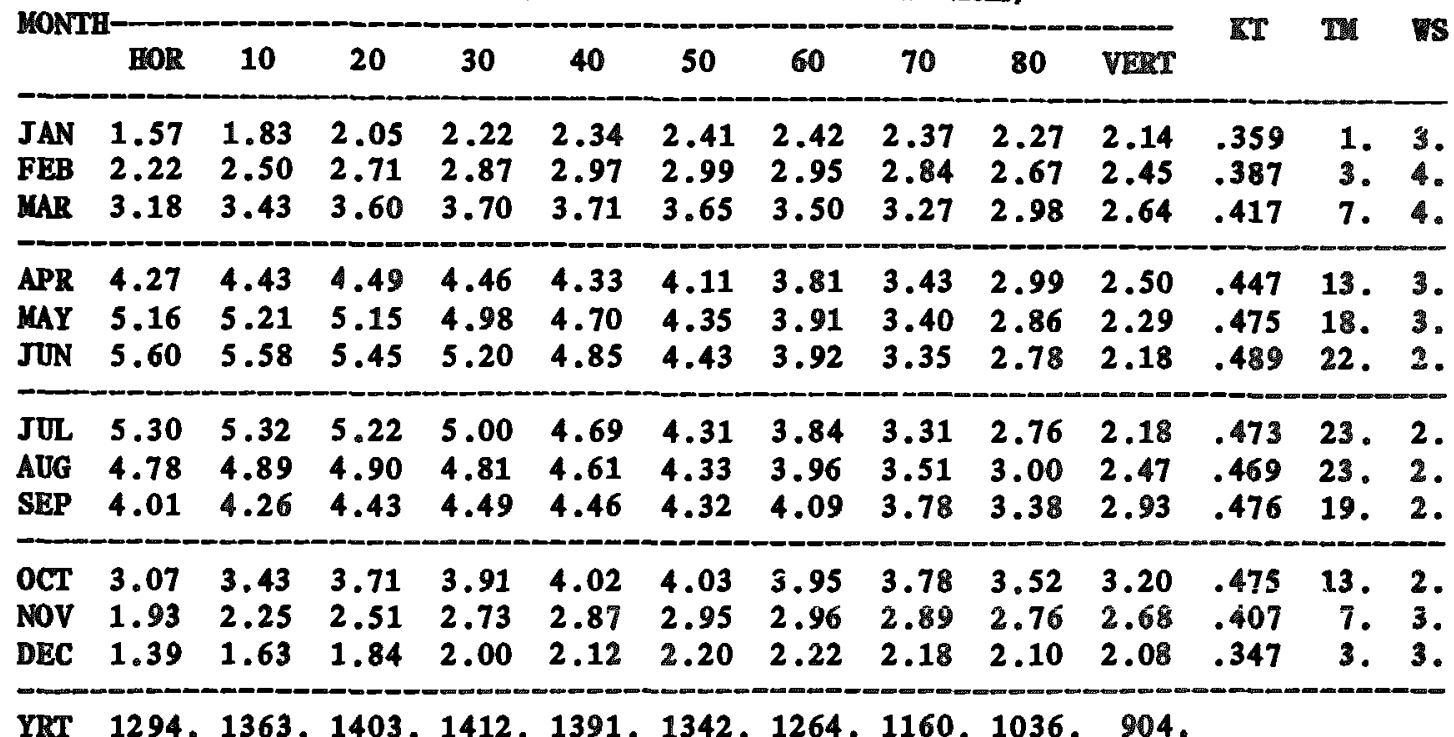

CHATTANOOGA, TN

35.03 N LATITUDE

SURFACE TILT (DEGRRES UP FROM HORIZONTAL)

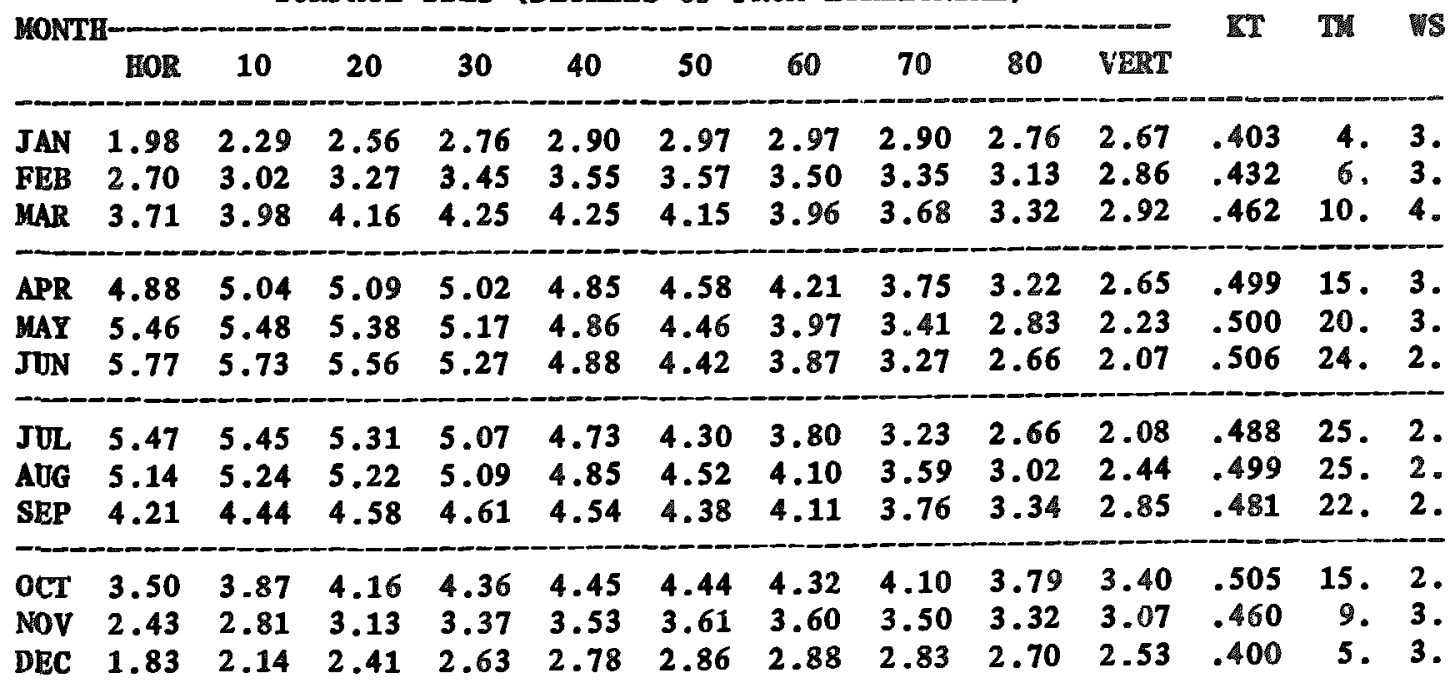

YRT 1434. 1507, 1548. 1554. 1527. 1468, 1377. 1259. 1118. 966. 
TABLE I (Continued)

AVERAGE DAILY ARRAY INSOLATION (KTH/SQ.M./DAY), CLEARNESS NUMBER (KT), MRAN MONTHLY TEMPERATURE (TM, DEG C), AND YONTHLY AVERAGE WIND SPEED (WS, M/S)

CLEVELAND, OH

SURFACE TILT (DEGREES UP FROM HORIZONTAL)

41.40 N LATITUDE

\begin{tabular}{llllllllllllll} 
MONTH- & HOR & 10 & 20 & 30 & 40 & 50 & 60 & 70 & 80 & VERT & & & WS \\
\hline JAN & 1.23 & 1.42 & 1.59 & 1.73 & 1.82 & 1.88 & 1.89 & 1.86 & 1.79 & 1.69 & .317 & -3. & 6. \\
FEB & 1.89 & 2.13 & 2.33 & 2.47 & 2.57 & 2.60 & 2.57 & 2.49 & 2.35 & 2.17 & .359 & -2. & 5. \\
UAR & 2.91 & 3.15 & 3.33 & 3.44 & 3.47 & 3.43 & 3.31 & 3.12 & 2.86 & 2.56 & .401 & 2. & 6. \\
\hline APR & 4.26 & 4.44 & 4.53 & 4.53 & 4.42 & 4.22 & 3.94 & 3.57 & 3.14 & 2.65 & .455 & 9. & 5. \\
UAY & 5.87 & 5.97 & 5.94 & 5.77 & 5.48 & 5.09 & 4.60 & 4.02 & 3.37 & 2.72 & .543 & 15. & 5. \\
JUN & 5.81 & 5.82 & 5.72 & 5.49 & 5.14 & 4.72 & 4.21 & 3.62 & 3.02 & 2.39 & .507 & 20. & 4. \\
\hline JUL & 5.76 & 5.81 & 5.73 & 5.53 & 5.21 & 4.80 & 4.31 & 3.73 & 3.12 & 2.49 & .514 & 22. & 4. \\
AUG & 4.99 & 5.15 & 5.19 & 5.12 & 4.94 & 4.66 & 4.29 & 3.83 & 3.30 & 2.74 & .498 & 21. & 4. \\
SEP & 3.90 & 4.19 & 4.39 & 4.48 & 4.48 & 4.37 & 4.17 & 3.87 & 3.49 & 3.06 & .482 & 18. & 4. \\
\hline OCT & 2.73 & 3.09 & 3.37 & 3.57 & 3.70 & 3.73 & 3.68 & 3.54 & 3.32 & 3.05 & .455 & 12. & 5. \\
NOV & 1.47 & 1.71 & 1.91 & 2.07 & 2.18 & 2.24 & 2.25 & 2.21 & 2.12 & 2.07 & .346 & 6. & 5. \\
DEC & 1.01 & 1.16 & 1.29 & 1.40 & 1.47 & 1.52 & 1.53 & 1.51 & 1.45 & 1.46 & .287 & 0. & 5. \\
\hline
\end{tabular}

YKT 1275 . 1343. 1381, 1390, 1367, 1318, 1241, 1138, 1014. 884.

COLUMBIA, SC

33.95 N LATITUDE

SURFACE TILT (DEGREES UP FROM HORIZONTAL)

\begin{tabular}{|c|c|c|c|c|c|c|c|c|c|c|c|c|c|}
\hline & & & & & & & & & & & & & \\
\hline & HOR & 10 & 20 & 30 & 40 & 50 & 0 & 0 & 80 & ERT & & & \\
\hline $\begin{array}{l}\text { JAN } \\
\text { FEB } \\
\text { MAR }\end{array}$ & $\begin{array}{l}2.39 \\
3.22 \\
4.27\end{array}$ & $\begin{array}{l}2.79 \\
3.61 \\
4.60\end{array}$ & $\begin{array}{l}3.13 \\
3.93 \\
4.82\end{array}$ & $\begin{array}{l}9 \\
5 \\
3\end{array}$ & $\begin{array}{l}7 \\
8 \\
3\end{array}$ & & $\begin{array}{l}7 \\
3 \\
9\end{array}$ & & $\begin{array}{l}.42 \\
.78 \\
.83\end{array}$ & $\begin{array}{l}3.26 \\
3.44 \\
3.35\end{array}$ & $\begin{array}{r}.469 \\
.501 \\
.524\end{array}$ & $\begin{array}{r}7 . \\
9 .\end{array}$ & $\begin{array}{l}3 . \\
3 . \\
4 .\end{array}$ \\
\hline $\begin{array}{l}\text { APK } \\
\text { MAY } \\
\text { JUN }\end{array}$ & $\begin{array}{l}5.50 \\
5.97 \\
6.13\end{array}$ & $\begin{array}{l}5.69 \\
5.99 \\
6.07\end{array}$ & $\begin{array}{l}.74 \\
.87 \\
.88\end{array}$ & & & & & & & & $\begin{array}{r}.559 \\
.547 \\
.539\end{array}$ & $\begin{array}{l}18 . \\
22 . \\
25\end{array}$ & $\begin{array}{l}4 . \\
3 . \\
3 .\end{array}$ \\
\hline $\begin{array}{l}\text { JUL } \\
\text { AUG } \\
\text { SEP }\end{array}$ & $\begin{array}{l}5.80 \\
5.37 \\
4.53\end{array}$ & $\begin{array}{l}5.77 \\
5.46 \\
4.78\end{array}$ & 5 & $\begin{array}{l}4 \\
9 \\
6\end{array}$ & $\begin{array}{l}4.96 \\
5.03 \\
4.88\end{array}$ & $\begin{array}{l}4 . \\
4\end{array}$ & $\begin{array}{l}4 . \\
4\end{array}$ & $\begin{array}{l}4 \\
8 \\
2\end{array}$ & & $\begin{array}{l}2.10 \\
2.46 \\
3.01\end{array}$ & $\begin{array}{r}.518 \\
.519 \\
.513\end{array}$ & $\begin{array}{l}26 \\
26 \\
23\end{array}$ & $\begin{array}{l}3 . \\
3 . \\
3 .\end{array}$ \\
\hline $\begin{array}{l}\mathrm{CT} \\
\mathrm{KOV} \\
\mathrm{EC}\end{array}$ & $\begin{array}{l}3.82 \\
2.90 \\
2.28\end{array}$ & $\begin{array}{l}4.24 \\
3.38 \\
2.70\end{array}$ & $\begin{array}{l}3.77 \\
3.06\end{array}$ & $\begin{array}{l}4.78 \\
4.08 \\
3.35\end{array}$ & $\begin{array}{l}4.88 \\
4.29 \\
3.56\end{array}$ & $\begin{array}{l}4.39 \\
3.68\end{array}$ & $\begin{array}{l}4.73 \\
4.38\end{array}$ & 4.26 & $\begin{array}{l}4.13 \\
4.04\end{array}$ & $\begin{array}{l}3.69 \\
3.72\end{array}$ & $\begin{array}{r}.540 \\
.530\end{array}$ & $\begin{array}{l}17 . \\
12 .\end{array}$ & 3. \\
\hline EC & 2.28 & 70 & 3.06 & 3.35 & 3.56 & 3.68 & 3.70 & 3. & 3.48 & 3.26 & .479 & 8. & 3 \\
\hline
\end{tabular}

YRT 1589. 1677, 1727. 1738. 1711. 1646. 1545. 1412. 1253. 1080. 


\section{TABLB I (Contined)}

AVERAGE DAILI ARRAT INSOLATION (KWH/SQ.M./DAY), CLEARNESS NUMBER (KT), MAN MONTILY TEMPERATURE (T, DEC C), AND MONTHLY AVERAGE WIND SPEED (WS, H/\$)

COLUMBOS, OH

$40.00 \mathrm{~N}$ LATITUDE

SURFACE TILT (DEGREES UP FROM FORIZONTAL)

\begin{tabular}{llllllllllllll} 
HONTH & HOR & 10 & 20 & 30 & 40 & 50 & 60 & 70 & 80 & VERT & & & ET \\
\hline JAN & 1.45 & 1.70 & 1.91 & 2.08 & 2.21 & 2.28 & 2.30 & 2.26 & 2.17 & 2.05 & .353 & -2. & 5. \\
FEB & 2.13 & 2.41 & 2.63 & 2.80 & 2.90 & 2.94 & 2.91 & 2.81 & 2.65 & 2.44 & .388 & 0. & 5. \\
MAR & 3.09 & 3.34 & 3.53 & 3.63 & 3.66 & 3.60 & 3.47 & 3.26 & 2.98 & 2.65 & .416 & 4. & 5. \\
\hline APR & 4.27 & 4.44 & 4.51 & 4.49 & 4.38 & 4.17 & 3.88 & 3.51 & 3.07 & 2.58 & .451 & 11. & 5. \\
MAY & 5.19 & 5.25 & 5.21 & 5.05 & 4.78 & 4.44 & 4.01 & 3.50 & 2.95 & 2.39 & .479 & 16. & 4. \\
JUN & 5.71 & 5.71 & 5.60 & 5.36 & 5.01 & 4.59 & 4.08 & 3.50 & 2.91 & 2.29 & .499 & 21. & 3. \\
\hline JUL & 5.53 & 5.56 & 5.47 & 5.26 & 4.95 & 4.56 & 4.08 & 3.52 & 2.94 & 2.34 & .493 & 23. & 3. \\
AUG & 4.99 & 5.13 & 5.16 & 5.08 & 4.89 & 4.60 & 4.22 & 3.76 & 3.22 & 2.66 & .495 & 22. & 3. \\
SEP & 4.04 & 4.32 & 4.51 & 4.59 & .4 .57 & 4.45 & 4.23 & 3.92 & 3.52 & 3.07 & .489 & 19. & 3. \\
\hline OCT & 2.98 & 3.36 & 3.66 & 3.87 & 3.99 & 4.02 & 3.96 & 3.80 & 3.55 & 3.25 & .480 & 12. & 3. \\
NOV & 1.69 & 1.97 & 2.21 & 2.40 & 2.53 & 2.60 & 2.61 & 2.56 & 2.45 & 2.39 & .378 & 6. & 4. \\
DEC & 1.22 & 1.44 & 1.62 & 1.77 & 1.88 & 1.94 & 1.96 & 1.94 & 1.87 & 1.86 & .328 & 0. & 4. \\
\hline
\end{tabular}

YRT 1289. 1360, 1402, 1413. 1393.1346. 1270, 1167. 1043.911.

CUTBANK, MT

48.60 N LATITUDE

SURFACE TILT (DEGREES DP FROM HORIZONTAL)

MONTH-

\begin{tabular}{lllllllllllllll}
\hline JAN & 1.27 & 1.67 & 2.04 & 2.36 & 2.62 & 2.80 & 2.92 & 2.96 & 2.92 & 2.90 & .478 & -9. & 6. \\
FEB & 2.16 & 2.67 & 3.10 & 3.47 & 3.74 & 3.92 & 4.00 & 3.97 & 3.84 & 3.72 & .528 & -5. & 6. \\
MAR & 3.56 & 4.07 & 4.48 & 4.79 & 4.97 & 5.04 & 4.98 & 4.79 & 4.49 & 4.10 & .568 & -3. & 6. \\
\hline APR & 4.68 & 5.00 & 5.21 & 5.30 & 5.27 & 5.11 & 4.85 & 4.48 & 4.01 & 3.47 & .537 & 4. & 6. \\
MAY & 5.93 & 6.12 & 6.18 & 6.10 & 5.88 & 5.53 & 5.09 & 4.54 & 3.91 & 3.22 & .562 & 10. & 6. \\
JUN & 6.45 & 6.54 & 6.50 & 6.32 & 6.01 & 5.57 & 5.05 & 4.43 & 3.73 & 3.04 & .564 & 14. & 5. \\
\hline JUL & 7.21 & 7.38 & 7.40 & 7.24 & 6.92 & 6.44 & 5.87 & 5.16 & 4.35 & 3.52 & .650 & 18. & 5. \\
AUG & 5.98 & 6.32 & 6.51 & 6.54 & 6.42 & 6.15 & 5.76 & 5.23 & 4.59 & 3.84 & .625 & 17. & 5. \\
SEP & 4.26 & 4.74 & 5.11 & 5.35 & 5.47 & 5.45 & 5.30 & 5.02 & 4.62 & 4.11 & .588 & 12. & 5. \\
\hline OCT & 2.74 & 3.28 & 3.75 & 4.11 & 4.38 & 4.53 & 4.57 & 4.49 & 4.30 & 4.01 & .562 & 7. & 6. \\
NOV & 1.51 & 1.96 & 2.35 & 2.69 & 2.96 & 3.16 & 3.27 & 3.30 & 3.23 & 3.12 & .498 & -1. & 6. \\
DEC & 1.05 & 1.43 & 1.78 & 2.08 & 2.33 & 2.51 & 2.63 & 2.68 & 2.66 & 2.60 & .461 & -5. & 7. \\
\hline
\end{tabular}

YRT 1427. 1561. 1658. 1717. 1735. 1712. 1652. 1554. 1419. 1267. 


\section{TABLE I (Continaed)}

AVERAGE DAILY ARRAY INSOLATION (KWH/SQ.M./DAY), CLEARNESS NUMBER (ET), MEAN MONTHLY TEMPERATURE (TM, DEG C), AND MONTHLY AVERAGE WIND SPEED (WS, M/S)

DAGGETT, CA

34.87 N LATITUDE

SURFACE TILT (DEGREES UP FROM HORIZONTAL)

\begin{tabular}{|c|c|c|c|c|c|c|c|c|c|c|c|c|}
\hline 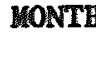 & HOR & 10 & 20 & 30 & 40 & 50 & 60 & 70 & 80 & VERT & & \\
\hline $\begin{array}{l}\mathrm{AN} \\
\mathrm{BB} \\
\mathrm{AB}\end{array}$ & $\begin{array}{l}3.02 \\
4.03 \\
5.59\end{array}$ & $\begin{array}{l}3.65 \\
4.65 \\
6.13\end{array}$ & $\begin{array}{l}4 . \\
5 . \\
6 .\end{array}$ & 4 & & 5. & & & $\begin{array}{l}7 \\
4 \\
9\end{array}$ & & $\begin{array}{l}9 \\
2 \\
5\end{array}$ & $\begin{array}{r}8 . \\
11 . \\
14 .\end{array}$ \\
\hline $\begin{array}{l}A Y \\
\text { UN }\end{array}$ & $\begin{array}{l}7.17 \\
8.17 \\
8.72\end{array}$ & $\begin{array}{l}7.48 \\
8.23 \\
8.64\end{array}$ & $\begin{array}{l}7.61 \\
8.08 \\
8.35\end{array}$ & $\begin{array}{l}3 \\
5\end{array}$ & $\begin{array}{l}0 \\
2 \\
9\end{array}$ & $\begin{array}{l}8 \\
5 \\
0\end{array}$ & & & & & $\begin{array}{r}.732 \\
.749 \\
.765\end{array}$ & $\begin{array}{l}23 \\
27\end{array}$ \\
\hline $\begin{array}{l}\text { UL } \\
\text { UG } \\
\text { EPP }\end{array}$ & $\begin{array}{l}8.21 \\
7.51 \\
6.33\end{array}$ & $\begin{array}{l}8.18 \\
7.71 \\
6.80\end{array}$ & 7. & 7. & $\begin{array}{l}6.97 \\
7.17 \\
7.18\end{array}$ & $\begin{array}{l}6.26 \\
6.64 \\
6.94\end{array}$ & $\begin{array}{l}0 \\
6 \\
3\end{array}$ & & & & $\begin{array}{r}.732 \\
.728 \\
.722\end{array}$ & 30 . \\
\hline $\begin{array}{l}\mathrm{OV} \\
\mathrm{EC}\end{array}$ & $\begin{array}{l}4.78 \\
3.35 \\
2.77\end{array}$ & $\begin{array}{l}4.00 \\
3.39\end{array}$ & $\begin{array}{l}4.55 \\
3.93\end{array}$ & 4.37 & $\begin{array}{l}6.49 \\
5.29 \\
4.70\end{array}$ & $\begin{array}{l}6.52 \\
5.46 \\
4.91\end{array}$ & $\begin{array}{l}6.38 \\
5.48 \\
4.99\end{array}$ & $\begin{array}{l}6.09 \\
5.36 \\
4.94\end{array}$ & $\begin{array}{l}5.63 \\
5.11 \\
4.76\end{array}$ & $\begin{array}{l}5.05 \\
4.73 \\
4.46\end{array}$ & $\begin{array}{l}.688 \\
.630 \\
.601\end{array}$ & 20. \\
\hline
\end{tabular}

IRT 2121. 2262. 2347, 2373. 2343. 2258. 2117, 1926. 1697. 1439.

DALLAS, TX

32.65 N LATITUDE

SURFACE TILT (DEGREES UP FROM HORIZONTAL)

\begin{tabular}{|c|c|c|c|c|c|c|c|c|c|c|c|c|}
\hline & HOR & 10 & 20 & 30 & 40 & 50 & 60 & 70 & 80 & VERT & $\mathbf{T}$ & $\mathbf{T M}$ \\
\hline $\begin{array}{l}\text { JAN } \\
\text { FEB } \\
\text { MAR }\end{array}$ & $\begin{array}{l}2.59 \\
3.38 \\
4.48\end{array}$ & $\begin{array}{l}3.01 \\
3.78 \\
4.81\end{array}$ & $\begin{array}{l}3.36 \\
4.10 \\
5.04\end{array}$ & $\begin{array}{l}3.64 \\
4.33 \\
5.14\end{array}$ & $\begin{array}{l}3.82 \\
4.45 \\
5.13\end{array}$ & $\begin{array}{l}3.91 \\
4.46 \\
4.99\end{array}$ & $\begin{array}{l}3.91 \\
4.37 \\
4.75\end{array}$ & $\begin{array}{l}3.81 \\
4.18 \\
4.39\end{array}$ & $\begin{array}{l}3.61 \\
3.88 \\
3.94\end{array}$ & $\begin{array}{l}3.34 \\
3.51 \\
3.41\end{array}$ & $\begin{array}{r}.488 \\
.510 \\
.540\end{array}$ & $\begin{array}{r}7 . \\
9 . \\
13 .\end{array}$ \\
\hline $\begin{array}{l}\text { APR } \\
\text { MAY } \\
\text { JUN }\end{array}$ & $\begin{array}{l}5.13 \\
5.95 \\
6.73\end{array}$ & $\begin{array}{l}5.27 \\
5.95 \\
6.64\end{array}$ & $\begin{array}{l}5.30 \\
5.82 \\
6.40\end{array}$ & $\begin{array}{l}5.21 \\
5.56 \\
6.02\end{array}$ & $\begin{array}{l}5.01 \\
5.20 \\
5.53\end{array}$ & $\begin{array}{l}4.70 \\
4.73 \\
4.94\end{array}$ & $\begin{array}{l}4.29 \\
4.17 \\
4.25\end{array}$ & $\begin{array}{l}3.80 \\
3.52 \\
3.52\end{array}$ & $\begin{array}{l}3.23 \\
2.88 \\
2.76\end{array}$ & $\begin{array}{l}2.61 \\
2.21 \\
2.07\end{array}$ & $\begin{array}{r}.517 \\
.545 \\
.593\end{array}$ & $\begin{array}{l}19 . \\
23 \\
28 .\end{array}$ \\
\hline $\begin{array}{l}\text { JUL } \\
\text { AUG } \\
\text { SEP }\end{array}$ & $\begin{array}{l}6.69 \\
6.15 \\
5.00\end{array}$ & $\begin{array}{l}6.64 \\
6.25 \\
5.28\end{array}$ & $\begin{array}{l}6.43 \\
6.21 \\
5.44\end{array}$ & $\begin{array}{l}6.09 \\
6.03 \\
5.47\end{array}$ & $\begin{array}{l}5.63 \\
5.72 \\
5.38\end{array}$ & $\begin{array}{l}5.06 \\
5.29 \\
5.16\end{array}$ & $\begin{array}{l}4.38 \\
4.74 \\
4.82\end{array}$ & $\begin{array}{l}3.65 \\
4.09 \\
4.38\end{array}$ & $\begin{array}{l}2.90 \\
3.37 \\
3.85\end{array}$ & $\begin{array}{l}2.18 \\
2.64 \\
3.24\end{array}$ & $\begin{array}{r}.598 \\
.592 \\
.558\end{array}$ & $\begin{array}{l}30 . \\
29 . \\
26 .\end{array}$ \\
\hline $\begin{array}{l}\text { OCT } \\
\text { NOV } \\
\text { DEC }\end{array}$ & $\begin{array}{l}4.03 \\
2.95 \\
2.46\end{array}$ & $\begin{array}{l}4.46 \\
3.40 \\
2.90\end{array}$ & $\begin{array}{l}4.78 \\
3.77 \\
3.27\end{array}$ & $\begin{array}{l}5.00 \\
4.06 \\
3.57\end{array}$ & $\begin{array}{l}5.09 \\
4.24 \\
3.78\end{array}$ & $\begin{array}{l}5.06 \\
4.32 \\
3.90\end{array}$ & $\begin{array}{l}4.91 \\
4.30 \\
3.91\end{array}$ & $\begin{array}{l}4.64 \\
4.17 \\
3.84\end{array}$ & $\begin{array}{l}4.26 \\
3.94 \\
3.66\end{array}$ & $\begin{array}{l}3.80 \\
3.62 \\
3.42\end{array}$ & $\begin{array}{r}.555 \\
.519 \\
.495\end{array}$ & $\begin{array}{r}20 \\
13 . \\
9\end{array}$ \\
\hline
\end{tabular}


TABLE I (Continat)

AVERAGE DAILY ARRAY INSOLATION (KWI/SQ.M./DAY),

CLEARNESS NUMBER (KT), MEAN MONTHLY TEMPERATURE (TM, DEG C), AND MONTHLY AVERAGE WIND SPEED (WS, M/S)

DILLON, MT

45.25 N LATITUDE

SURFACE TILT (DEGREES UP FROM HORIZONTAL)

\begin{tabular}{|c|c|c|c|c|c|c|c|c|c|c|c|c|c|}
\hline & HOR & 10 & 20 & 30 & 40 & 50 & 60 & 70 & 80 & VERT & $\mathbf{I}$ & $\mathrm{TH}$ & \\
\hline $\begin{array}{l}\text { JAN } \\
\text { EEB } \\
\text { MAR }\end{array}$ & $\begin{array}{l}1.64 \\
2.66 \\
4.04\end{array}$ & $\begin{array}{l}2.11 \\
3.23 \\
4.56\end{array}$ & $\begin{array}{l}2.52 \\
3.72 \\
4.98\end{array}$ & $\begin{array}{l}2.88 \\
4.11 \\
5.28\end{array}$ & $\begin{array}{l}3.16 \\
4.40 \\
5.44\end{array}$ & $\begin{array}{l}3 . \\
4 . \\
5 .\end{array}$ & $\begin{array}{l}3.47 \\
4.64 \\
5.37\end{array}$ & $\begin{array}{l}3.49 \\
4.58 \\
5.13\end{array}$ & $\begin{array}{l}3.42 \\
4.40 \\
4.76\end{array}$ & $\begin{array}{l}3.28 \\
4.11 \\
4.29\end{array}$ & $\begin{array}{r}.510 \\
.573 \\
.599\end{array}$ & $\begin{array}{l}-6 \\
-3 \\
-1\end{array}$ & $\begin{array}{l}5 . \\
5 . \\
5 .\end{array}$ \\
\hline $\begin{array}{l}\text { IAY } \\
\text { UN }\end{array}$ & $\begin{array}{l}6.27 \\
6.76\end{array}$ & $\begin{array}{l}6.44 \\
6.82\end{array}$ & $\begin{array}{l}5.69 \\
6.46 \\
6.74\end{array}$ & $\begin{array}{l}6 . \\
6 .\end{array}$ & $\begin{array}{l}5.68 \\
6.06 \\
6.15\end{array}$ & $\begin{array}{l}5.66 \\
5.66\end{array}$ & $\begin{array}{l}5.16 \\
5.17 \\
5.08\end{array}$ & $\begin{array}{l}4.72 \\
4.55 \\
4.40\end{array}$ & $\begin{array}{l}8 \\
6 \\
6\end{array}$ & & $\begin{array}{r}.572 \\
.587 \\
.589\end{array}$ & $\begin{array}{l}4 . \\
10 \\
15\end{array}$ & $\begin{array}{l}5 . \\
4 .\end{array}$ \\
\hline $\begin{array}{l}\text { JUL } \\
\text { ADG } \\
\text { SEP }\end{array}$ & $\begin{array}{l}7.54 \\
6.38 \\
4.79\end{array}$ & $\begin{array}{l}7.68 \\
6.69 \\
5.29\end{array}$ & $\begin{array}{l}7.65 \\
6.85 \\
5.66\end{array}$ & $\begin{array}{l}7.44 \\
6.84 \\
5.90\end{array}$ & $\begin{array}{l}5 \\
6 \\
8\end{array}$ & $\begin{array}{l}6.52 \\
6.34 \\
5.93\end{array}$ & $\begin{array}{l}37 \\
8 \\
2\end{array}$ & $\begin{array}{l}5.09 \\
5.29 \\
5.37\end{array}$ & $\begin{array}{l}2 \\
7 \\
0\end{array}$ & & $\begin{array}{r}.676 \\
.652 \\
.626\end{array}$ & $\begin{array}{l}19 . \\
18 . \\
12 .\end{array}$ & 4. \\
\hline $\begin{array}{l}\text { OCT } \\
\text { NOV } \\
\text { DEC }\end{array}$ & $\begin{array}{l}3.22 \\
1.90 \\
1.42\end{array}$ & $\begin{array}{l}3.80 \\
2.40 \\
1.86\end{array}$ & $\begin{array}{l}4.28 \\
2.84 \\
2.25\end{array}$ & $\begin{array}{l}3.21 \\
2.59\end{array}$ & $\begin{array}{l}3.50 \\
2.86\end{array}$ & $\begin{array}{l}3.70 \\
3.06\end{array}$ & $\begin{array}{l}3.80 \\
3.18\end{array}$ & $\begin{array}{l}4.94 \\
3.81 \\
3.22\end{array}$ & $\begin{array}{l}4.69 \\
3.71 \\
3.16\end{array}$ & 1 & $\begin{array}{l}.596 \\
.527 \\
.500\end{array}$ & $\begin{array}{r}7 . \\
0 \\
-5\end{array}$ & $\because$ \\
\hline
\end{tabular}

YRT 1579, 1718, 1817, 1873, 1883, 1851, 1777, 1660, 1506, 1332.

DODGE CITY, RA

37.77 N LATITUDE

SURFACE TILT (DEGREES UP FRON HORIZONTAL)

MONTH

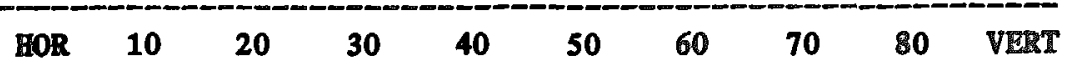

\begin{tabular}{llllllllllllll}
\hline JAN & 2.61 & 3.20 & 3.71 & 4.13 & 4.44 & 4.64 & 4.72 & 4.68 & 4.51 & 4.31 & .582 & -2. & 6. \\
FEB & 3.53 & 4.11 & 4.59 & 4.95 & 5.19 & 5.30 & 5.28 & 5.12 & 4.83 & 4.45 & .605 & 1. & 6. \\
MAR & 4.66 & 5.12 & 5.45 & 5.66 & 5.73 & 5.66 & 5.45 & 5.11 & 4.65 & 4.11 & .604 & 5. & 7. \\
\hline APR & 5.94 & 6.21 & 6.34 & 6.31 & 6.14 & 5.83 & 5.38 & 4.82 & 4.15 & 3.42 & .619 & 12. & 7. \\
MAY & 6.58 & 6.66 & 6.58 & 6.35 & 5.98 & 5.50 & 4.90 & 4.21 & 3.46 & 2.70 & .606 & 18. & 7 \\
JUN & 7.43 & 7.41 & 7.22 & 6.86 & 6.35 & 5.74 & 5.00 & 4.18 & 3.35 & 2.52 & .650 & 23. & 6. \\
\hline JUL & 7.24 & 7.26 & 7.11 & 6.80 & 6.34 & 5.77 & 5.07 & 4.27 & 3.46 & 2.61 & .645 & 26. & 6. \\
AUG & 6.48 & 6.67 & 6.71 & 6.59 & 6.31 & 5.91 & 5.37 & 4.71 & 3.95 & 3.16 & .635 & 25. & 6. \\
SEP & 5.31 & 5.72 & 5.99 & 6.12 & 6.10 & 5.93 & 5.62 & 5.17 & 4.61 & 3.95 & .627 & 20. & 6. \\
\hline OCT & 4.10 & 4.68 & 5.14 & 5.47 & 5.67 & 5.73 & 5.64 & 5.41 & 5.04 & 4.56 & .627 & 14. & 6. \\
NOV & 2.81 & 3.39 & 3.88 & 4.28 & 4.57 & 4.74 & 4.79 & 4.71 & 4.51 & 4.35 & .580 & 5. & 6. \\
DEC & 2.31 & 2.87 & 3.36 & 3.77 & 4.08 & 4.29 & 4.38 & 4.36 & 4.23 & 4.13 & .561 & 0. & 6. \\
\hline
\end{tabular}

YR' 1797. 1927. 2011. 2047. 2035. 1978. 1873. 1725. 1542. 1345. 
AVERAGE DAILY ARRAY INSOLATYON (KWH/SQ.M./DAY), CLEARNESS NUMBR (TT), MRAN MONIHLY TEMPERATURE (TM, DEG C), AND MONTHLY AVERAGE WIND SPEED (WS, M/S)

DULUTH, MN

SURFACE TILT (DEGREES UP FROM HORIZONTAL)

\begin{tabular}{|c|c|c|c|c|c|c|c|c|c|c|c|c|c|}
\hline & & & $\mathrm{AC}$ & 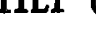 & . & & & & & & RT & 8 & 9 \\
\hline & HOR & 10 & 20 & 30 & 40 & 50 & 60 & 70 & 80 & VERT & & & \\
\hline $\begin{array}{l}\text { JAN } \\
\text { FEB } \\
\text { MAR }\end{array}$ & $\begin{array}{l}1.22 \\
2.11 \\
3.26\end{array}$ & $\begin{array}{l}1.55 \\
2.54 \\
3.66\end{array}$ & $\begin{array}{l}1.84 \\
2.90 \\
3.97\end{array}$ & $\begin{array}{l}2.09 \\
3.20 \\
4.19\end{array}$ & $\begin{array}{l}2.29 \\
3.42 \\
4.31\end{array}$ & $\begin{array}{l}2.43 \\
3.55 \\
4.33\end{array}$ & $\begin{array}{l}2.51 \\
3.60 \\
4.25\end{array}$ & $\begin{array}{l}2.52 \\
3.55 \\
4.06\end{array}$ & $\begin{array}{l}2.47 \\
3.82 \\
3.78\end{array}$ & $\begin{array}{l}2.50 \\
3.34 \\
3.43\end{array}$ & $\begin{array}{r}.415 \\
.482 \\
.501\end{array}$ & $\begin{array}{r}-14 \\
-11 \\
-5\end{array}$ & $\begin{array}{l}5 . \\
5 . \\
5 .\end{array}$ \\
\hline $\begin{array}{l}\text { APR } \\
\text { MAY } \\
\text { JUN }\end{array}$ & $\begin{array}{l}4.33 \\
5.18 \\
5.57\end{array}$ & $\begin{array}{l}4.58 \\
5.31 \\
5.63\end{array}$ & $\begin{array}{l}4.74 \\
5.33 \\
5.57\end{array}$ & $\begin{array}{l}4.79 \\
5.23 \\
5.40\end{array}$ & $\begin{array}{l}4.73 \\
5.02 \\
5.12\end{array}$ & $\begin{array}{l}4.57 \\
4.71 \\
4.74\end{array}$ & $\begin{array}{l}4.32 \\
4.33 \\
4.30\end{array}$ & $\begin{array}{l}3.97 \\
3.86 \\
3.77\end{array}$ & $\begin{array}{l}3.54 \\
3.31 \\
3.19\end{array}$ & $\begin{array}{l}3.04 \\
2.74 \\
2.60\end{array}$ & $\begin{array}{r}.487 \\
.487 \\
.486\end{array}$ & $\begin{array}{r}3 \\
10 \\
15\end{array}$ & $\begin{array}{l}6 . \\
5 . \\
5 .\end{array}$ \\
\hline $\begin{array}{l}\text { JUL } \\
\text { AUG } \\
\text { SEP }\end{array}$ & $\begin{array}{l}5.85 \\
4.87 \\
3.45\end{array}$ & $\begin{array}{l}5.95 \\
5.08 \\
3.76\end{array}$ & $\begin{array}{l}5.92 \\
5.18 \\
3.98\end{array}$ & $\begin{array}{l}5.78 \\
5.17 \\
4.12\end{array}$ & $\begin{array}{l}5.50 \\
5.04 \\
4.16\end{array}$ & $\begin{array}{l}5.12 \\
4.81 \\
4.11\end{array}$ & $\begin{array}{l}4.65 \\
4.48 \\
3.96\end{array}$ & $\begin{array}{l}4.10 \\
4.06 \\
3.72\end{array}$ & $\begin{array}{l}3.47 \\
3.55 \\
3.41\end{array}$ & $\begin{array}{l}2.84 \\
3.02 \\
3.05\end{array}$ & $\begin{array}{r}.525 \\
.503 \\
.462\end{array}$ & $\begin{array}{l}18 . \\
17 . \\
12 .\end{array}$ & $\begin{array}{l}4 . \\
4 . \\
5 .\end{array}$ \\
\hline $\begin{array}{l}\text { OCT } \\
\text { NOV } \\
\text { DEC }\end{array}$ & $\begin{array}{r}2.28 \\
1.20 \\
.92\end{array}$ & $\begin{array}{l}2.64 \\
1.46 \\
1.16\end{array}$ & $\begin{array}{l}2.93 \\
1.68 \\
1.38\end{array}$ & $\begin{array}{l}3.16 \\
1.87 \\
1.56\end{array}$ & $\begin{array}{l}3.31 \\
2.01 \\
1.71\end{array}$ & $\begin{array}{l}3.39 \\
2.10 \\
1.82\end{array}$ & $\begin{array}{l}3.38 \\
2.15 \\
1.88\end{array}$ & $\begin{array}{l}3.29 \\
2.14 \\
1.89\end{array}$ & $\begin{array}{l}3.12 \\
2.07 \\
1.85\end{array}$ & $\begin{array}{l}2.92 \\
2.03 \\
1.85\end{array}$ & $\begin{array}{r}.442 \\
.359 \\
.356\end{array}$ & $\begin{array}{r}7 \\
-2 \\
-10\end{array}$ & $\begin{array}{l}5 . \\
5 . \\
5 .\end{array}$ \\
\hline
\end{tabular}

YRT 1227. 1319. 1384, 1418, 1419. 1390. 1332. 1244. 1130. 1014.

EAGLE, CO

SURFACE TILT (DEGREES UP FROM HORIZONTAL)

\begin{tabular}{|c|c|c|c|c|c|c|c|c|c|c|c|c|c|}
\hline & HOR & 10 & 20 & 30 & 40 & 50 & 60 & 70 & 0 & VERT & & $M$ & \\
\hline $\mathbb{R}$ & 9 & $\begin{array}{l}6 \\
9 \\
6\end{array}$ & $\begin{array}{l}6 \\
0 \\
5\end{array}$ & 8 & & & & & & & & $\begin{array}{r}-8 \\
-5 \\
0\end{array}$ & 2 \\
\hline $\begin{array}{l}\mathrm{AY} \\
\mathrm{UN}\end{array}$ & $\begin{array}{l}6.09 \\
7.11 \\
7.91\end{array}$ & .23 & 74 & 5 & & & & & & & & $\begin{array}{l}5 . \\
11 \\
16\end{array}$ & 3 \\
\hline $\begin{array}{l}\text { JUL } \\
\text { AUG } \\
\text { SEP }\end{array}$ & $\begin{array}{l}7.52 \\
6.57 \\
5.57\end{array}$ & $\begin{array}{l}7.57 \\
6.80 \\
6.05\end{array}$ & $\begin{array}{l}7.45 \\
6.87 \\
6.39\end{array}$ & $\begin{array}{l}7.15 \\
6.77 \\
6.57\end{array}$ & $\begin{array}{l}6.68 \\
6.51 \\
6.59\end{array}$ & $\begin{array}{l}1 \\
2 \\
4\end{array}$ & $\begin{array}{l}0 \\
9 \\
4\end{array}$ & $\begin{array}{l}4.58 \\
4.93 \\
5.68\end{array}$ & $\begin{array}{l}3.73 \\
4.17 \\
5.09\end{array}$ & & $\begin{array}{r}.670 \\
.650 \\
.672\end{array}$ & $\begin{array}{l}19 . \\
17 . \\
13 .\end{array}$ & \\
\hline $\begin{array}{l}\text { WOV } \\
\text { OEC }\end{array}$ & $\begin{array}{l}4.12 \\
2.74 \\
2.18\end{array}$ & $\begin{array}{l}3.36 \\
2.76\end{array}$ & $\begin{array}{l}3.90 \\
3.28\end{array}$ & $\begin{array}{l}5.68 \\
4.34 \\
3.71\end{array}$ & $\begin{array}{l}4.66 \\
4.05\end{array}$ & $\begin{array}{l}4.87 \\
4.28\end{array}$ & $\begin{array}{l}5.96 \\
4.95 \\
4.40\end{array}$ & $\begin{array}{l}5.74 \\
4.90 \\
4.40\end{array}$ & $\begin{array}{l}5.38 \\
4.72 \\
4.28\end{array}$ & $\begin{array}{l}4.55 \\
4.19\end{array}$ & $\begin{array}{r}.658 \\
.603 \\
.575\end{array}$ & $\begin{array}{r}6 \\
-2 \\
-8\end{array}$ & \\
\hline
\end{tabular}

YRT 1837. 1981. 2078. 2124. 2118. 2066 1963 . 1814. 1627. 1422 . 
TABLE I (Continged)

AVERAGE DAILY ARRAY INSOLATION (医H/SQ.M./DAY),

CLEARNESS NUMBER (KT), MEAN WONTHLY TEMPERATURE (Th, DEG C). AND WONTHLY AVERAGE VIND SPEED (WS, M/S)

EL PASO, TI

31.80 N LATITUDE

SURFACE TILT (DEGREES UP FROM BORIZONTAL)

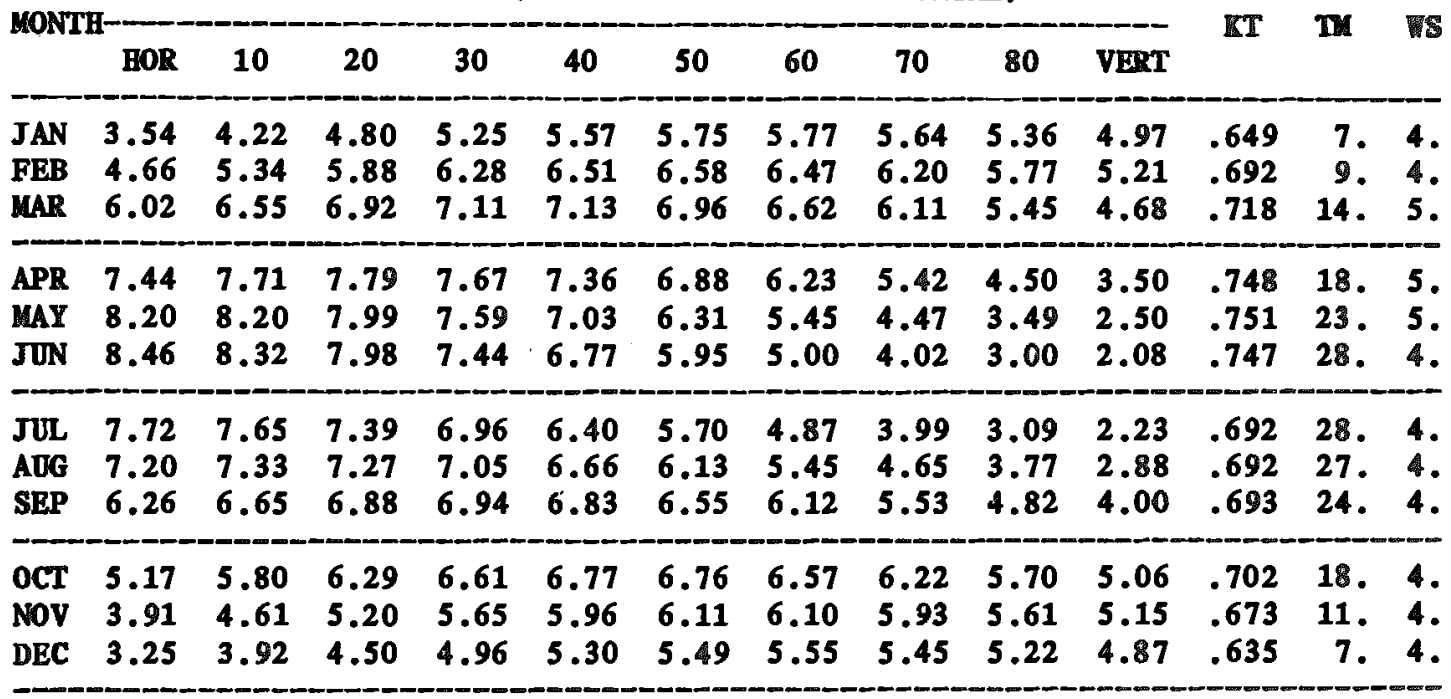

YRT 2187. 2322. 2400. 2419. 2381. 2285. 2133 1934. 1694. 1430 .

EL TORO, CA

33.67 N LATITUDE

SURFACE TILT (DEGREES UP FROM HORIZONTAL)

MONTH $\begin{array}{llllllllll}\text { HOR } & 10 & 20 & 30 & 40 & 50 & 60 & 70 & 80 & \text { VERT }\end{array}$

\begin{tabular}{lllllllllllllll} 
JAN & 2.98 & 3.55 & 4.03 & 4.41 & 4.69 & 4.84 & 4.87 & 4.77 & 4.55 & 4.24 & .578 & 12. & 2. \\
FEB & 3.89 & 4.44 & 4.88 & 5.21 & 5.40 & 5.46 & 5.38 & 5.16 & 4.82 & 4.37 & .603 & 13. & 3. \\
MAR & 5.08 & 5.51 & 5.82 & 5.98 & 6.00 & 5.87 & 5.60 & 5.19 & 4.67 & 4.04 & .621 & 13. & 2. \\
\hline APR & 6.08 & 6.29 & 6.36 & 6.27 & 6.05 & 5.68 & 5.19 & 4.58 & 3.88 & 3.11 & .617 & 12. & 3. \\
MAY & 6.53 & 6.54 & 6.41 & 6.13 & 5.73 & 5.22 & 4.59 & 3.88 & 3.15 & 2.39 & .598 & 16. & 3. \\
JUN & 6.92 & 6.84 & 6.61 & 6.22 & 5.73 & 5.12 & 4.42 & 3.66 & 2.89 & 2.15 & .608 & 18. & 2. \\
\hline JUL & 7.45 & 7.41 & 7.19 & 6.80 & 6.29 & 5.64 & 4.88 & 4.04 & 3.18 & 2.34 & .665 & 21. & 2. \\
AUG & 6.80 & 6.94 & 6.91 & 6.73 & 6.39 & 5.91 & 5.30 & 4.57 & 3.75 & 2.92 & .656 & 21. & 2. \\
SEP & 5.47 & 5.82 & 6.03 & 6.09 & 6.01 & 5.78 & 5.42 & 4.94 & 4.34 & 3.65 & .617 & 20. & 2. \\
\hline OCT & 4.28 & 4.78 & 5.17 & 5.43 & 5.56 & 5.55 & 5.40 & 5.13 & 4.73 & 4.22 & .601 & 18. & 2. \\
NOV & 3.23 & 3.79 & 4.27 & 4.63 & 4.88 & 5.01 & 5.01 & 4.88 & 4.63 & 4.27 & .586 & 15. & 2. \\
DEC & 2.74 & 3.31 & 3.80 & 4.20 & 4.49 & 4.66 & 4.72 & 4.65 & 4.46 & 4.17 & .571 & 13. & 2. \\
\hline
\end{tabular}

YRT 1871. 1986. 2054. 2072. 2044. 1969. 1848. 1686. 1490. 1272. 
TABLE I (Continged)

AVERAGE DAILY ARRAY INSOLATION (KWH/SQ.M./DAY), CLEARNESS NUMBER (ET), MRAN MONTHLY TEMPERATURE (TM, DEG C), AND MONTHLY AVERAGE WIND SPEED (TS, M/S)

ELTO, NV

SURFACE TILT (DEGREES UP FROM HORIZONTAL)

40.83 N LATITUDE

\begin{tabular}{|c|c|c|c|c|c|c|c|c|c|c|c|c|}
\hline & HOR & 10 & 20 & 30 & 40 & 50 & 60 & 70 & 80 & ERT & & \\
\hline $\begin{array}{l}A N \\
\text { EB } \\
\text { AR }\end{array}$ & $\begin{array}{l}2.17 \\
3.26 \\
4.62\end{array}$ & & .55 & & & & & & & & $\begin{array}{l}.548 \\
.608 \\
.630\end{array}$ & $\begin{aligned}-4 . & 2 . \\
-1 . & 3 . \\
2 . & 3 .\end{aligned}$ \\
\hline $\begin{array}{l}\text { PR } \\
\text { AY } \\
\text { UN }\end{array}$ & 7.9 & & & & & & & & & & $\begin{array}{l}.638 \\
.672 \\
.697\end{array}$ & 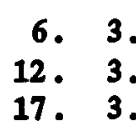 \\
\hline & 500 & & & & & & & & & & $\begin{array}{l}.737 \\
.726 \\
.731\end{array}$ & $\begin{array}{l}22 . \\
20 . \\
15 .\end{array}$ \\
\hline $\mathbf{E C}$ & $\begin{array}{l}2.56 \\
1.95\end{array}$ & 2.78 & $\begin{array}{l}3.6 \\
2.9\end{array}$ & נ.0נ & $\begin{array}{l}4.44 \\
3.64\end{array}$ & & & & & & $\begin{array}{l}.685 \\
.590 \\
.543\end{array}$ & $\begin{array}{r}8 \\
2 . \\
-4\end{array}$ \\
\hline
\end{tabular}

YRT 1874, 2024, 2126, 2175, 2170, 2117, 2012, 1859, 1666, 1449.

EVANSVILLE, IN

SURFACE TILT (DEGREES UP FROM HORIZONTAL)

38.05 N LATITUDE

\begin{tabular}{|c|c|c|c|c|c|c|c|c|c|c|c|c|}
\hline \multirow{2}{*}{ NT } & \multirow[b]{2}{*}{ HOR } & \multirow[b]{2}{*}{10} & \multirow[b]{2}{*}{20} & \multirow[b]{2}{*}{30} & \multirow[b]{2}{*}{40} & & & & \multirow[b]{2}{*}{30} & & & \\
\hline & & & & & & 50 & 60 & 70 & & VERT & & \\
\hline $\mathbf{N}$ & 1.81 & 14 & 2.42 & & 2.80 & 39 & 92 & 87 & 75 & 70 & 09 & 0 . \\
\hline $\mathbf{R}$ & 3.6 & & & & & & & & & & 73 & 7. \\
\hline $\mathbf{R}$ & 4.73 & 4.91 & 99 & 4. & 4.81 & 7 & & .80 & .30 & 5 & .493 & 14. \\
\hline & & & & & & & & & & & & \\
\hline $\mathbf{U N}$ & 6.25 & 6.23 & 6.08 & 5.7 & 5.38 & 4. & & .65 & 2 & 2. & .546 & 4. \\
\hline UL & 6.0 & 6. & 5 & 5. & 5 & 4. & & 9 & & 1 & 0 & 25. \\
\hline IG & & & & & & & & & & & & \\
\hline EP & 4.42 & 4.72 & 4.91 & 4.99 & 4.96 & 4.81 & 4 & 4.20 & 3.75 & 3.24 & .523 & 20 . \\
\hline $\mathrm{CT}$ & 3. & 3. & 4 & 4. & 4 & 4 & & 4 & & & .528 & \\
\hline V & 2 & & & & & & & & & & & \\
\hline C & 1.57 & 1.87 & 2.13 & 2.34 & 2.49 & 2.59 & 2.62 & 2.59 & 2.49 & 2.46 & .387 & 2. \\
\hline
\end{tabular}

YRT 1454. 1538. 1587. 1601, 1579, 1525, 1437, 1318. 2175. 1027. 
TABLE I (Continned)

AVERAGE DAILY ARRAY INSOLATION (KVT/SQ.M./DAY),

CLEARNESS NULBER (KT), MRAN MONTHLY TEMPERATURE (TM, DEG C),

AND MONTHLY AVERAGE WDN SPEED (WS, M/S)

FAIRBANKS, AR

64.82 N LATTTUDE

SURFACE TILT (DEGREES UP FROM HORIZONTAL)

\begin{tabular}{lccccccccccccc}
\multicolumn{1}{l}{ MONTH- } & HOR & 10 & 20 & 30 & 40 & 50 & 60 & 70 & 80 & VERT & & & \\
\hline JAN & .10 & .22 & .33 & .44 & .53 & .61 & .68 & .72 & .74 & 1.51 & .331 & -26. & 1. \\
FEB & .70 & 1.10 & 1.48 & 1.82 & 2.11 & 2.35 & 2.51 & 2.61 & 2.64 & 2.90 & .491 & -15. & 2. \\
MAR & 2.13 & 2.74 & 3.29 & 3.76 & 4.13 & 4.39 & 4.53 & 4.55 & 4.45 & 4.25 & .574 & -13. & 2. \\
\hline APR & 3.76 & 4.26 & 4.65 & 4.93 & 5.10 & 5.14 & 5.05 & 4.85 & 4.54 & 4.12 & .545 & -1. & 3. \\
MAY & 5.05 & 5.36 & 5.55 & 5.63 & 5.61 & 5.46 & 5.18 & 4.81 & 4.36 & 3.81 & .519 & 9. & 3. \\
JUN & 5.52 & 5.70 & 5.79 & 5.76 & 5.64 & 5.41 & 5.06 & 4.64 & 4.14 & 3.57 & .488 & 16. & 3. \\
\hline JUL & 4.86 & 5.06 & 5.17 & 5.17 & 5.09 & 4.90 & 4.61 & 4.25 & 3.82 & 3.32 & .456 & 17. & 3. \\
AUG & 3.52 & 3.81 & 4.02 & 4.15 & 4.19 & 4.13 & 3.98 & 3.75 & 3.45 & 3.10 & .432 & 13. & 3. \\
SEP & 2.24 & 2.64 & 2.99 & 3.26 & 3.46 & 3.57 & 3.60 & 3.53 & 3.38 & 3.21 & .453 & 7. & 3. \\
\hline OCT & .92 & 1.27 & 1.58 & 1.86 & 2.08 & 2.26 & 2.37 & 2.42 & 2.41 & 2.53 & .420 & -4. & 2. \\
NOV & .23 & .48 & .71 & .92 & 1.11 & 1.26 & 1.38 & 1.46 & 1.50 & 2.14 & .429 & -16. & 2. \\
DEC & .02 & .02 & .02 & .02 & .02 & .01 & .01 & .01 & .01 & .86 & .068 & -23. & 1. \\
\hline IRT & 887 & 996 & 1084 & 1149 & 1189 & 1202 & 1186 & 1144 & 1077 & 1073 & &
\end{tabular}

FARGO, ND

46.90 N LATITUDE

SURFACE TILT (DEGREES UP FROM HORIZONTAL)

\begin{tabular}{|c|c|c|c|c|c|c|c|c|c|c|c|c|c|}
\hline 01 & HOR & 10 & 20 & 30 & 40 & 50 & 60 & 70 & 80 & VERT & & $\mathrm{I}$ & \\
\hline $\begin{array}{l}\text { JAN } \\
\text { FEB } \\
\text { MAR }\end{array}$ & $\begin{array}{l}1.31 \\
2.22 \\
3.43\end{array}$ & $\begin{array}{l}1.67 \\
2.68 \\
3.86\end{array}$ & $\begin{array}{l}2.00 \\
3.08 \\
4.21\end{array}$ & $\begin{array}{l}2.28 \\
3.40 \\
4.46\end{array}$ & $\begin{array}{l}2.51 \\
3.64 \\
4.60\end{array}$ & $\begin{array}{l}2.67 \\
3.79 \\
4.63\end{array}$ & $\begin{array}{l}2.76 \\
3.85 \\
4.54\end{array}$ & $\begin{array}{l}8 \\
0 \\
5\end{array}$ & $\begin{array}{l}2.73 \\
3.66 \\
4.05\end{array}$ & $\begin{array}{l}2.80 \\
3.62 \\
3.73\end{array}$ & $\begin{array}{r}.444 \\
.507 \\
.527\end{array}$ & $\begin{array}{r}-15 \\
-11 \\
-4\end{array}$ & $\begin{array}{l}6 . \\
6 . \\
6 .\end{array}$ \\
\hline $\begin{array}{l}\text { APR } \\
\text { MAY } \\
\text { JUN }\end{array}$ & $\begin{array}{l}4.65 \\
5.78 \\
6.29\end{array}$ & $\begin{array}{l}4.94 \\
5.94 \\
6.36\end{array}$ & $\begin{array}{l}5.13 \\
5.98 \\
6.30\end{array}$ & $\begin{array}{l}5.19 \\
5.88 \\
6.11\end{array}$ & $\begin{array}{l}5.14 \\
5.64 \\
5.79\end{array}$ & $\begin{array}{l}.97 \\
.29 \\
.35\end{array}$ & & & $\begin{array}{l}3.84 \\
3.69 \\
3.55\end{array}$ & $\begin{array}{l}3.35 \\
3.06 \\
2.89\end{array}$ & $\begin{array}{r}.524 \\
.544 \\
.549\end{array}$ & $\begin{array}{r}6 . \\
13 \\
19\end{array}$ & $\begin{array}{l}6 . \\
6 . \\
5 .\end{array}$ \\
\hline $\begin{array}{l}\text { JUL } \\
\text { AUG } \\
\text { SEP }\end{array}$ & $\begin{array}{l}6.68 \\
5.75 \\
4.11\end{array}$ & $\begin{array}{l}6.82 \\
6.04 \\
4.52\end{array}$ & $\begin{array}{l}6.80 \\
6.19 \\
4.83\end{array}$ & $\begin{array}{l}6.63 \\
6.19 \\
5.03\end{array}$ & $\begin{array}{l}6.31 \\
6.05 \\
5.11\end{array}$ & $\begin{array}{l}5.87 \\
5.77 \\
5.06\end{array}$ & $\begin{array}{l}5.32 \\
5.38 \\
4.89\end{array}$ & & & $\begin{array}{l}3.20 \\
3.59 \\
3.79\end{array}$ & $\begin{array}{l}.601 \\
.594 \\
.551\end{array}$ & $\begin{array}{l}22 . \\
21 . \\
14 .\end{array}$ & $\begin{array}{l}5 . \\
5 . \\
6 .\end{array}$ \\
\hline $\begin{array}{l}\text { OCT } \\
\text { NOV } \\
\text { DEC }\end{array}$ & $\begin{array}{l}2.75 \\
1.44 \\
1.06\end{array}$ & $\begin{array}{l}3.24 \\
1.80 \\
1.38\end{array}$ & $\begin{array}{l}3.65 \\
2.12 \\
1.67\end{array}$ & $\begin{array}{l}2.39 \\
1.92\end{array}$ & $\begin{array}{l}4.19 \\
2.59 \\
2.12\end{array}$ & $\begin{array}{l}4.31 \\
2.74 \\
2.27\end{array}$ & $\begin{array}{l}2.81 \\
2.36\end{array}$ & $\begin{array}{l}4.23 \\
2.81 \\
2.38\end{array}$ & $\begin{array}{l}4.03 \\
2.74 \\
2.35\end{array}$ & $\begin{array}{l}3.79 \\
2.70 \\
2.35\end{array}$ & $\begin{array}{r}.534 \\
.433 \\
.414\end{array}$ & $\begin{array}{r}8 \\
-2 \\
-10\end{array}$ & 6. \\
\hline
\end{tabular}

YRT 1396. 1502. 1583. 1628. 1635. 1605. 1540.1440. 1308. 1182. 
TABLE I (Continued)

AVERAGE DAILY ARRAY INSOLATION (KWH/SQ.M./DAY)

CLEARNESS NUMBER (ET), MEAN MONIHLY TEMPERATURE (TM, DRG C), AND MONTMLY AVERAGE WIND SPEED (WS, M/S)

FORT SMITH, AR

SURFACE TILT (DEGREES UP FROM HORIZONTAL)

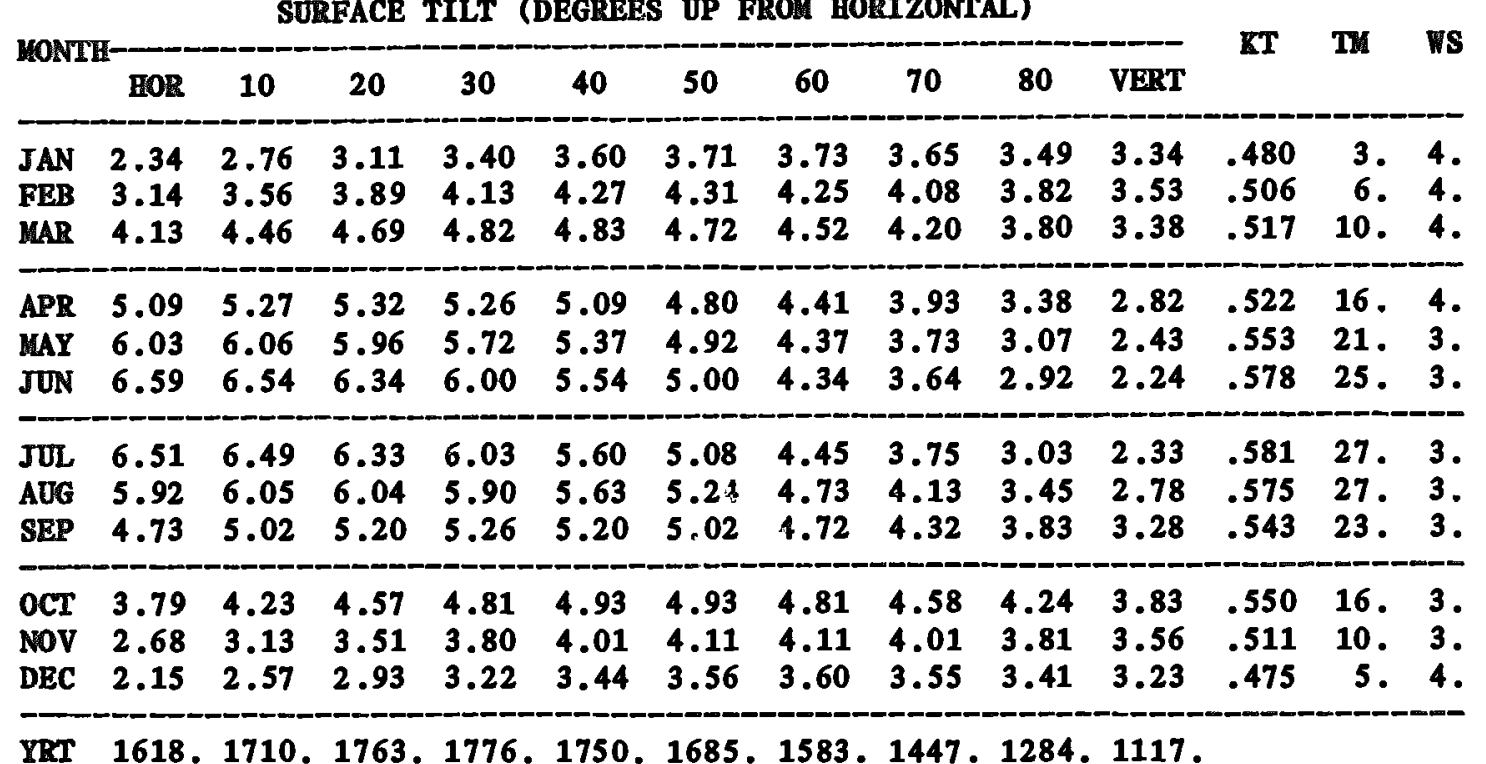

35.33 N LATITUDE

YRT 1618, 1710, 1763, 1776, 1750, 1685, 1583, 1447, 1284, 1117.

FRESNO, CA

36.77 N LATITUDE

SURFACE TILT (DEGREES UP FROM HORIZONTAL)

\begin{tabular}{|c|c|c|c|c|c|c|c|c|c|c|c|c|c|}
\hline \multirow{2}{*}{ MONTH } & \multirow{2}{*}{ HOR } & & & & \multirow[b]{2}{*}{40} & \multirow[b]{2}{*}{50} & & \multirow[b]{2}{*}{70} & \multirow[b]{2}{*}{80} & \multirow[b]{2}{*}{ VERT } & \multirow{2}{*}{$\mathbf{K T}$} & \multirow{2}{*}{$T M$} & \multirow{2}{*}{ WS } \\
\hline & & 10 & 20 & 30 & & & 60 & & & & & & \\
\hline $\mathbf{N}$ & 2 & 2.44 & 2.76 & 3.02 & 3.20 & 31 & 3.33 & 3.27 & 3.13 & 2.96 & .446 & & \\
\hline 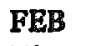 & 3.18 & 3.64 & 4.02 & 4.29 & 4.47 & 4.53 & 4.49 & 4.33 & 4.07 & 3.74 & .532 & 10. & \\
\hline MAR & 4.94 & 5.42 & 5.77 & 5.99 & 6.05 & 5.97 & 5.74 & 5.37 & 4.87 & 4.29 & .631 & 12. & \\
\hline APR & 6.59 & 6.90 & 7.04 & 7.00 & 6.80 & 6.44 & 5.93 & 5.28 & 4.51 & 3.68 & .682 & 15 & \\
\hline AY & 7. & 7.91 & 7.81 & 7.5 & 7. & 6.4 & & & 3.88 & & .7 & & \\
\hline JUN & 8.61 & 8.57 & 8.32 & 7.86 & 7.24 & .48 & 5.58 & 4.58 & 3.57 & 2.60 & .754 & 24. & \\
\hline JUL & 8.47 & 8.48 & 8.29 & 7.89 & 7 & 6.60 & 5.74 & 4 & 3.76 & 2 & .755 & & \\
\hline ADG & 7.64 & 7. & 7.93 & 7. & & & & & & & & & \\
\hline SEP & 6.26 & 6.77 & 7.12 & 7.28 & 7.27 & 7.06 & 6.68 & 6.13 & 5.44 & 4.64 & .729 & 23. & \\
\hline CT & 4.51 & 5.15 & 5.66 & 6. & 6. & 6.31 & 6. & 5 & 3 & 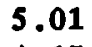 & .6 & & \\
\hline Nov & 2.8 & 3. & 3.78 & 4. & 4. & & 4. & & 4.29 & & .558 & & \\
\hline DEC & 1.81 & 2.16 & 2.46 & 2.71 & 2.89 & 2.99 & 3.03 & 2.99 & 2.88 & 2.88 & .423 & 7. & \\
\hline
\end{tabular}

IRT 1972, 2092, 2161, 2178, 2142, 2058, 1924. 1745. 1533. 1313. 
TABLE I (Continued)

AVERAGE DAILY ARRAY INSOLATION (KWH/SQ.M./DAY),

CLEARNESS NUIBER (ET), MEAN MONTHLY TEMPERATURE (TM, DRG C), AND MONTHLY AVERAGE WIND SPEED (TS, M/S)

GRAND JUNCTION, CO

39.12 N LATITUDE

SURFACE TILT (DEGREES UP FROM HORIZONTAL)

\begin{tabular}{|c|c|c|c|c|c|c|c|c|c|c|c|c|c|}
\hline $\mathrm{ON}$ & mOR & 10 & 20 & 30 & 40 & 50 & 60 & 70 & 80 & VERT & $\mathrm{W}$ & $\mathrm{II}$ & 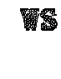 \\
\hline $\begin{array}{l}\text { JAN } \\
\text { FEB } \\
\text { MAR }\end{array}$ & $\begin{array}{l}2.50 \\
3.52 \\
4.90\end{array}$ & $\begin{array}{l}3.10 \\
4.14 \\
5.44\end{array}$ & $\begin{array}{l}3.63 \\
4.66 \\
5.84\end{array}$ & $\begin{array}{l}4.06 \\
5.07 \\
6.10\end{array}$ & $\begin{array}{l}4.39 \\
5.34 \\
6.21\end{array}$ & $\begin{array}{l}4.61 \\
5.48 \\
6.17\end{array}$ & $\begin{array}{l}4.70 \\
5.47 \\
5.97\end{array}$ & $\begin{array}{l}4.67 \\
5.33 \\
5.62\end{array}$ & $\begin{array}{l}4.52 \\
5.05 \\
5.13\end{array}$ & $\begin{array}{l}4.44 \\
4.67 \\
4.56\end{array}$ & $\begin{array}{l}.587 \\
.626 \\
.650\end{array}$ & $\begin{array}{r}-4 \\
0 \\
5\end{array}$ & $\begin{array}{l}3 . \\
3 . \\
4 .\end{array}$ \\
\hline $\begin{array}{l}\text { APR } \\
\text { MAY } \\
\text { JUN }\end{array}$ & $\begin{array}{l}6.26 \\
7.50 \\
8.19\end{array}$ & $\begin{array}{l}6.58 \\
7.62 \\
8.19\end{array}$ & $\begin{array}{l}6.75 \\
7.56 \\
8.00\end{array}$ & $\begin{array}{l}6.75 \\
7.31 \\
7.61\end{array}$ & $\begin{array}{l}6.59 \\
6.89 \\
7.05\end{array}$ & $\begin{array}{l}6.28 \\
6.35 \\
6.38\end{array}$ & $\begin{array}{l}5.82 \\
5.67 \\
5.56\end{array}$ & $\begin{array}{l}5.22 \\
4.85 \\
4.63\end{array}$ & $\begin{array}{l}4.51 \\
3.97 \\
3.71\end{array}$ & $\begin{array}{l}3.73 \\
3.09 \\
2.77\end{array}$ & $\begin{array}{l}.658 \\
.691 \\
.715\end{array}$ & $\begin{array}{l}11 . \\
17 . \\
22 .\end{array}$ & $\begin{array}{l}4 . \\
4 . \\
4 .\end{array}$ \\
\hline $\begin{array}{l}\text { JUL } \\
\text { AUG } \\
\text { SEY }\end{array}$ & $\begin{array}{l}7.77 \\
6.88 \\
5.78\end{array}$ & $\begin{array}{l}7.82 \\
7.12 \\
6.28\end{array}$ & $\begin{array}{l}7.69 \\
7.19 \\
6.63\end{array}$ & $\begin{array}{l}7.37 \\
7.08 \\
6.82\end{array}$ & $\begin{array}{l}6.87 \\
6.81 \\
6.83\end{array}$ & $\begin{array}{l}6.27 \\
6.39 \\
6.67\end{array}$ & $\begin{array}{l}5.53 \\
5.82 \\
6.35\end{array}$ & $\begin{array}{l}4.66 \\
5.12 \\
5.87\end{array}$ & $\begin{array}{l}3.78 \\
4.31 \\
5.25\end{array}$ & $\begin{array}{l}2.87 \\
3.48 \\
4.54\end{array}$ & $\begin{array}{l}.693 \\
.679 \\
.693\end{array}$ & $\begin{array}{l}26 . \\
24 . \\
19 .\end{array}$ & $\begin{array}{l}4 . \\
4 .\end{array}$ \\
\hline $\begin{array}{l}\text { OCT } \\
\text { NOV } \\
\text { DEC }\end{array}$ & $\begin{array}{l}4.24 \\
2.90 \\
2.31\end{array}$ & $\begin{array}{l}4.89 \\
3.55 \\
2.93\end{array}$ & $\begin{array}{l}5.42 \\
4.13 \\
3.47\end{array}$ & $\begin{array}{l}5.82 \\
4.59 \\
3.93\end{array}$ & $\begin{array}{l}6.07 \\
4.94 \\
4.28\end{array}$ & $\begin{array}{l}0.16 \\
5.16 \\
4.53\end{array}$ & $\begin{array}{l}6.09 \\
5.24 \\
4.65\end{array}$ & $\begin{array}{l}5.87 \\
5.18 \\
4.65\end{array}$ & $\begin{array}{l}5.49 \\
4.99 \\
4.52\end{array}$ & $\begin{array}{l}5.02 \\
4.83 \\
4.45\end{array}$ & $\begin{array}{l}.668 \\
.625 \\
.595\end{array}$ & $\begin{array}{r}12 \\
4 \\
-2\end{array}$ & $\begin{array}{l}4 . \\
3 . \\
3 .\end{array}$ \\
\hline
\end{tabular}

GRAND RAPIDS, MI

42.90 N LATITUDE

SURFACE TILT (DEGREES OP FROM HORIZONTAL)

\begin{tabular}{|c|c|c|c|c|c|c|c|c|c|c|c|c|c|}
\hline$\pi v_{2}$ & BOR & 10 & 20 & 30 & 40 & 50 & 60 & 70 & 80 & VERT & & IT & \\
\hline $\begin{array}{l}\text { JAN } \\
\text { FEB } \\
\text { MAR }\end{array}$ & $\begin{array}{l}1.17 \\
2.04 \\
3.20\end{array}$ & $\begin{array}{l}1.37 \\
2.35 \\
3.51\end{array}$ & $\begin{array}{l}1.55 \\
2.61 \\
3.75\end{array}$ & $\begin{array}{l}1.69 \\
2.81 \\
3.90\end{array}$ & $\begin{array}{l}1.80 \\
2.94 \\
3.97\end{array}$ & $\begin{array}{l}1 \\
3 \\
3\end{array}$ & & & & $\begin{array}{l}.86 \\
.60 \\
.02\end{array}$ & $\begin{array}{r}.322 \\
.406 \\
.454\end{array}$ & $\begin{array}{l}-4 \\
-4 \\
0\end{array}$ & $\begin{array}{l}5 . \\
5 . \\
5 .\end{array}$ \\
\hline $\begin{array}{l}\text { APR } \\
\text { MAY } \\
\text { JUN }\end{array}$ & $\begin{array}{l}4.45 \\
5.53 \\
6.17\end{array}$ & $\begin{array}{l}4.67 \\
5.64 \\
6.20\end{array}$ & $\begin{array}{l}4.79 \\
5.62 \\
6.10\end{array}$ & $\begin{array}{l}5.48 \\
5.87\end{array}$ & $\begin{array}{l}4.70 \\
5.22 \\
5.51\end{array}$ & $\begin{array}{l}4.51 \\
4.87 \\
5.07\end{array}$ & $\begin{array}{l}4.22 \\
4.42 \\
4.53\end{array}$ & $\begin{array}{l}3.84 \\
3.89 \\
3.91\end{array}$ & & & $\begin{array}{r}.483 \\
.514 \\
.538\end{array}$ & $\begin{array}{l}8 . \\
14 \\
20\end{array}$ & $\begin{array}{l}5 . \\
5 . \\
4 .\end{array}$ \\
\hline $\begin{array}{l}\text { JUL } \\
\text { AUG } \\
\text { SEP }\end{array}$ & $\begin{array}{l}6.04 \\
5.28 \\
3.98\end{array}$ & $\begin{array}{l}6.10 \\
5.48 \\
4.29\end{array}$ & $\begin{array}{l}6.04 \\
5.55 \\
4.52\end{array}$ & $\begin{array}{l}5.84 \\
5.50 \\
4.64\end{array}$ & $\begin{array}{l}5 . \\
5 . \\
4 .\end{array}$ & $\begin{array}{l}5 . \\
4 .\end{array}$ & $\begin{array}{l}4 . \\
4 .\end{array}$ & $\begin{array}{l}4 . \\
4 .\end{array}$ & $\begin{array}{l}3.33 \\
3.59 \\
3.68\end{array}$ & $\begin{array}{l}2.69 \\
3.01 \\
3.27\end{array}$ & $\begin{array}{r}.539 \\
.532 \\
.502\end{array}$ & $\begin{array}{l}22 \\
21 \\
17\end{array}$ & $\begin{array}{l}4 . \\
4 . \\
4 .\end{array}$ \\
\hline $\begin{array}{l}\mathrm{DCT} \\
\mathrm{NOV} \\
\mathrm{DEC}\end{array}$ & $\begin{array}{r}2.70 \\
1.41 \\
.98\end{array}$ & $\begin{array}{l}3.08 \\
1.65 \\
1.15\end{array}$ & $\begin{array}{l}1.86 \\
1.31\end{array}$ & $\begin{array}{l}3.61 \\
2.03 \\
1.43\end{array}$ & $\begin{array}{l}3.75 \\
2.15 \\
1.52\end{array}$ & $\begin{array}{l}3.80 \\
2.22 \\
1.58\end{array}$ & $\begin{array}{l}2.25 \\
1.60\end{array}$ & $\begin{array}{l}3.63 \\
2.21 \\
1.59\end{array}$ & $\begin{array}{l}3.42 \\
2.13 \\
1.54\end{array}$ & $\begin{array}{l}3.18 \\
2.11 \\
1.56\end{array}$ & $\begin{array}{r}.468 \\
.351 \\
.302\end{array}$ & $\begin{array}{r}11 \\
4 \\
-2\end{array}$ & 5 \\
\hline
\end{tabular}

YRT 1309. 1387. 1434. 1450. 1433. 1387. 1311. 1207. 1080.958. 
TABLE I (Continmed)

AVERAGE DAILY ARRAY INSOLATION (KWH/SQ.M./DAY), CLEARNESS NUABER (KT), MEAN MONTHLY TEMPERATURE (TM, DEG C), AND MONTHLY AVERAGE WIND SPEED (WS, K/S)

GUANTANAMO BAY, CU

SURFACE TILT (DEGREES UP FROW HORIZONTAL)

19.90 N LATITUDE

\begin{tabular}{|c|c|c|c|c|c|c|c|c|c|c|c|c|}
\hline \multicolumn{11}{|l|}{ YONTV } & \multirow{2}{*}{ ET } & \multirow{2}{*}{$\mathbf{T M}$} \\
\hline & HOR & 10 & 20 & 30 & 40 & 50 & 60 & 70 & 80 & VERT & & \\
\hline $\begin{array}{l}\text { JAN } \\
\text { FEB } \\
\text { MAR }\end{array}$ & $\begin{array}{l}4.42 \\
5.20 \\
6.07\end{array}$ & $\begin{array}{l}4.96 \\
5.66 \\
6.35\end{array}$ & $\begin{array}{l}5.37 \\
5.98 \\
6.47\end{array}$ & $\begin{array}{l}5.66 \\
6.15 \\
6.44\end{array}$ & $\begin{array}{l}5.80 \\
6.18 \\
6.26\end{array}$ & $\begin{array}{l}5.80 \\
6.05 \\
5.92\end{array}$ & $\begin{array}{l}5.66 \\
5.78 \\
5.45\end{array}$ & $\begin{array}{l}5.38 \\
5.37 \\
4.86\end{array}$ & $\begin{array}{l}4.97 \\
4.83 \\
4.16\end{array}$ & $\begin{array}{l}4.49 \\
4.24 \\
3.43\end{array}$ & $\begin{array}{l}.603 \\
.624 \\
.642\end{array}$ & $\begin{array}{l}23 \\
24 \\
25\end{array}$ \\
\hline $\begin{array}{l}\text { APR } \\
\text { MAY } \\
\text { JUN }\end{array}$ & $\begin{array}{l}6.68 \\
6.42 \\
6.18\end{array}$ & $\begin{array}{l}6.70 \\
6.26 \\
5.95\end{array}$ & $\begin{array}{l}6.57 \\
5.96 \\
5.59\end{array}$ & $\begin{array}{l}6.29 \\
5.54 \\
5.12\end{array}$ & $\begin{array}{l}5.86 \\
5.00 \\
4.55\end{array}$ & $\begin{array}{l}5.30 \\
4.35 \\
3.89\end{array}$ & $\begin{array}{l}4.62 \\
3.64 \\
3.21\end{array}$ & $\begin{array}{l}3.85 \\
2.90 \\
2.50\end{array}$ & $\begin{array}{l}3.03 \\
2.17 \\
1.88\end{array}$ & $\begin{array}{l}2.23 \\
1.65 \\
1.63\end{array}$ & $\begin{array}{l}.646 \\
.599 \\
.571\end{array}$ & $\begin{array}{l}26 \\
27 \\
28\end{array}$ \\
\hline $\begin{array}{l}\text { JUL } \\
\text { AUG } \\
\text { SEP }\end{array}$ & $\begin{array}{l}6.57 \\
6.31 \\
5.75\end{array}$ & $\begin{array}{l}6.35 \\
6.25 \\
5.89\end{array}$ & $\begin{array}{l}5.99 \\
6.05 \\
5.90\end{array}$ & $\begin{array}{l}5.51 \\
5.71 \\
5.78\end{array}$ & $\begin{array}{l}4.91 \\
5.25 \\
5.52\end{array}$ & $\begin{array}{l}4.21 \\
4.68 \\
5.14\end{array}$ & $\begin{array}{l}3.48 \\
4.01 \\
4.65\end{array}$ & $\begin{array}{l}2.71 \\
3.28 \\
4.06\end{array}$ & $\begin{array}{l}2.00 \\
2.53 \\
3.39\end{array}$ & $\begin{array}{l}1.63 \\
1.86 \\
2.70\end{array}$ & $\begin{array}{l}.608 \\
.599 \\
.584\end{array}$ & $\begin{array}{l}28 \\
28 \\
28\end{array}$ \\
\hline $\begin{array}{l}\text { OCT } \\
\text { NOV } \\
\text { DEC }\end{array}$ & $\begin{array}{l}5.00 \\
4.52 \\
4.14\end{array}$ & $\begin{array}{l}5.33 \\
5.00 \\
4.67\end{array}$ & $\begin{array}{l}5.53 \\
5.38 \\
5.09\end{array}$ & $\begin{array}{l}5.61 \\
5.62 \\
5.39\end{array}$ & $\begin{array}{l}5.55 \\
5.72 \\
5.56\end{array}$ & $\begin{array}{l}5.36 \\
5.69 \\
5.59\end{array}$ & $\begin{array}{l}5.05 \\
5.51 \\
5.48\end{array}$ & $\begin{array}{l}4.63 \\
5.21 \\
5.23\end{array}$ & $\begin{array}{l}4.10 \\
4.78 \\
4.86\end{array}$ & $\begin{array}{l}3.54 \\
4.28 \\
4.42\end{array}$ & $\begin{array}{l}.569 \\
.592 \\
.587\end{array}$ & $\begin{array}{l}27 \\
26 \\
25 .\end{array}$ \\
\hline
\end{tabular}

IRT 2046. 2110. 2125. 2092. 2011. 1883 . 1718. 1518. 1296. 1095.

GULKANA, AK

62.15 N LATITUDE

SURFACE TILT (DEGREES UP FROM HORIZONTAL)

\begin{tabular}{lccccccccccccc}
\multicolumn{1}{l}{ HONTH- } & HOR & 10 & 20 & 30 & 40 & 50 & 60 & 70 & 80 & VERT & & & WS \\
\hline JAN & .23 & .43 & .62 & .79 & .94 & 1.07 & 1.17 & 1.23 & 1.26 & 2.94 & .380 & -23. & 2. \\
FEB & .90 & 1.32 & 1.71 & 2.05 & 2.34 & 2.56 & 2.72 & 2.80 & 2.80 & 2.94 & .488 & -16. & 2. \\
MAR & 2.39 & 3.00 & 3.53 & 3.98 & 4.32 & 4.55 & 4.66 & 4.65 & 4.52 & 4.31 & .575 & -10. & 3. \\
\hline APR & 4.11 & 4.61 & 5.01 & 5.28 & 5.43 & 5.44 & 5.32 & 5.08 & 4.72 & 4.28 & .568 & 0. & 4. \\
MAT & 5.09 & 5.37 & 5.54 & 5.60 & 5.54 & 5.36 & 5.06 & 4.68 & 4.21 & 3.67 & .515 & 7. & 4. \\
JUN & 5.54 & 5.71 & 5.78 & 5.73 & 5.59 & 5.33 & 4.96 & 4.53 & 4.01 & 3.43 & .491 & 13. & 4. \\
\hline JUL & 5.08 & 5.28 & 5.38 & 5.37 & 5.26 & 5.05 & 4.72 & 4.33 & 3.86 & 3.32 & .475 & 14. & 4. \\
AUG & 3.94 & 4.26 & 4.48 & 4.61 & 4.63 & 4.55 & 4.36 & 4.10 & 3.74 & 3.36 & .469 & 12. & 4. \\
SEP & 2.51 & 2.92 & 3.27 & 3.54 & 3.72 & 3.82 & 3.82 & 3.73 & 3.55 & 3.35 & .468 & 6. & 3. \\
\hline OCT & 1.23 & 1.64 & 2.02 & 2.35 & 2.61 & 2.81 & 2.93 & 2.98 & 2.94 & 3.05 & .466 & -3. & 3. \\
NOV & .37 & .62 & .86 & 1.08 & 1.26 & 1.42 & 1.53 & 1.60 & 1.63 & 1.96 & .406 & -14. & 2. \\
DEC & .09 & .16 & .22 & .27 & .32 & .36 & .40 & .42 & .43 & .79 & .259 & -20. & 2. \\
\hline
\end{tabular}

YRT 961. 1077. 1171. 1238. 1278. 1288, 1268. 1220. 1145. 1138. 
TABLE I (Continged)

AVERAGE DAILY ARRAY INSOLATTON (FWT/SQ.M./DAY), CLEARNESS NUMBER (KT), MEAN MONTHLY TEMPERATURE (T, DEG C), AND MONTHLI AVERAGE WIND SPEED (WS, M/S)

HILO, HI

19.72 N LATITUDE

SURFACE TILT (DEGREES UP FROM HORIZONTAL)

\begin{tabular}{llllllllllllll}
\multicolumn{1}{l}{ MONTH } & HOR & 10 & 20 & 30 & 40 & 50 & 60 & 70 & 80 & VERT & & & \\
\hline JAN & 3.53 & 3.89 & 4.16 & 4.34 & 4.41 & 4.39 & 4.26 & 4.04 & 3.72 & 3.41 & .479 & 21. & 3. \\
FEB & 3.94 & 4.21 & 4.40 & 4.48 & 4.47 & 4.36 & 4.15 & 3.85 & 3.46 & 3.09 & .470 & 21. & 4. \\
UAR & 4.25 & 4.39 & 4.44 & 4.40 & 4.26 & 4.03 & 3.72 & 3.33 & 2.88 & 2.47 & .448 & 21. & 3. \\
\hline APR & 4.52 & 4.52 & 4.44 & 4.26 & 3.99 & 3.65 & 3.23 & 2.77 & 2.26 & 1.83 & .437 & 22. & 3. \\
MAY & 4.90 & 4.79 & 4.58 & 4.29 & 3.91 & 3.46 & 2.96 & 2.44 & 1.92 & 1.57 & .457 & 23. & 3. \\
JUN & 5.23 & 5.05 & 4.77 & 4.40 & 3.94 & 3.41 & 2.87 & 2.30 & 1.79 & 1.61 & .483 & 23. & 3. \\
\hline JUL & 5.12 & 4.97 & 4.72 & 4.38 & 3.95 & 3.45 & 2.92 & 2.36 & 1.84 & 1.59 & .475 & 24. & 3. \\
AUG & 5.02 & 4.97 & 4.82 & 4.57 & 4.22 & 3.80 & 3.30 & 2.76 & 2.20 & 1.73 & .477 & 24. & 3. \\
SEP & 4.87 & 4.97 & 4.97 & 4.86 & 4.64 & 4.33 & 3.92 & 3.44 & 2.90 & 2.39 & .495 & 24. & 3. \\
\hline OCT & 4.33 & 4.58 & 4.73 & 4.78 & 4.71 & 4.54 & 4.28 & 3.92 & 3.48 & 3.05 & .492 & 24. & 3. \\
NOV & 3.49 & 3.80 & 4.03 & 4.16 & 4.21 & 4.16 & 4.01 & 3.78 & 3.46 & 3.14 & .455 & 23. & 3. \\
DEC & 3.21 & 3.56 & 3.82 & 4.00 & 4.09 & 4.08 & 3.98 & 3.79 & 3.51 & 3.23 & .454 & 22. & 3. \\
\hline
\end{tabular}

YRT 1594. 1634. 1639. 1609. 1545. 1448. 1325. 1178. 1015. 884.

HOMER, AK

59.63 N LATITUDE

SURFACE TILT (DEGREES UP FROM HORIZONTAL)

\begin{tabular}{|c|c|c|c|c|c|c|c|c|c|c|c|c|c|}
\hline & HOR & 10 & 20 & 30 & 40 & 50 & 60 & 70 & 80 & VERT & & $x$ & Wis \\
\hline $\begin{array}{l}\text { JAN } \\
\text { FEB } \\
\text { MAR }\end{array}$ & $\begin{array}{r}.38 \\
1.05 \\
2.39\end{array}$ & $\begin{array}{r}.64 \\
1.45 \\
2.90\end{array}$ & $\begin{array}{r}.88 \\
1.81 \\
3.34\end{array}$ & $\begin{array}{l}1.10 \\
2.12 \\
3.70\end{array}$ & $\begin{array}{l}1.28 \\
2.38 \\
3.97\end{array}$ & $\begin{array}{l}1.44 \\
2.58 \\
4.13\end{array}$ & $\begin{array}{l}1.55 \\
2.71 \\
4.19\end{array}$ & $\begin{array}{l}1.62 \\
2.77 \\
4.14\end{array}$ & $\begin{array}{l}1.64 \\
2.75 \\
3.99\end{array}$ & $\begin{array}{l}2.25 \\
2.86 \\
3.81\end{array}$ & $\begin{array}{l}.409 \\
.464 \\
.524\end{array}$ & $\begin{array}{l}-7 \\
-4 \\
-3\end{array}$ & $\begin{array}{l}3 . \\
3 . \\
3 .\end{array}$ \\
\hline $\begin{array}{l}\text { APR } \\
\text { MAY } \\
\text { JUN }\end{array}$ & $\begin{array}{l}3.93 \\
4.99 \\
5.52\end{array}$ & $\begin{array}{l}4.34 \\
5.24 \\
5.67\end{array}$ & $\begin{array}{l}4.66 \\
5.37 \\
5.72\end{array}$ & $\begin{array}{l}4.86 \\
5.40 \\
5.65\end{array}$ & $\begin{array}{l}4.95 \\
5.31 \\
5.49\end{array}$ & $\begin{array}{l}4.92 \\
5.11 \\
5.21\end{array}$ & $\begin{array}{l}4.77 \\
4.80 \\
4.83\end{array}$ & $\begin{array}{l}4.53 \\
4.42 \\
4.38\end{array}$ & $\begin{array}{l}4.18 \\
3.94 \\
3.86\end{array}$ & $\begin{array}{l}3.78 \\
3.41 \\
3.27\end{array}$ & $\begin{array}{l}.522 \\
.498 \\
.489\end{array}$ & $\begin{array}{r}2 . \\
6 \\
10\end{array}$ & $\begin{array}{l}4 . \\
3 .\end{array}$ \\
\hline $\begin{array}{l}\text { JUL } \\
\text { AUG } \\
\text { SEP }\end{array}$ & $\begin{array}{l}5.04 \\
3.75 \\
2.49\end{array}$ & $\begin{array}{l}5.22 \\
4.00 \\
2.85\end{array}$ & $\begin{array}{l}5.29 \\
4.18 \\
3.14\end{array}$ & $\begin{array}{l}5.26 \\
4.26 \\
3.36\end{array}$ & $\begin{array}{l}5.14 \\
4.26 \\
3.50\end{array}$ & $\begin{array}{l}4.90 \\
4.15 \\
3.55\end{array}$ & $\begin{array}{l}4.56 \\
3.96 \\
3.53\end{array}$ & $\begin{array}{l}4.16 \\
3.70 \\
3.42\end{array}$ & $\begin{array}{l}3.69 \\
3.36 \\
3.23\end{array}$ & $\begin{array}{l}3.15 \\
2.99 \\
3.02\end{array}$ & $\begin{array}{l}.467 \\
.433 \\
.435\end{array}$ & $\begin{array}{c}12 \\
12 \\
9\end{array}$ & $\begin{array}{l}3 . \\
3 \\
3\end{array}$ \\
\hline $\begin{array}{l}\text { OCT } \\
\text { NOV } \\
\text { DEC }\end{array}$ & $\begin{array}{r}1.38 \\
.55 \\
.20\end{array}$ & $\begin{array}{r}1.77 \\
.86 \\
.34\end{array}$ & $\begin{array}{r}2.12 \\
1.15 \\
.47\end{array}$ & $\begin{array}{r}2.42 \\
1.42 \\
.59\end{array}$ & $\begin{array}{r}2.66 \\
1.64 \\
.69\end{array}$ & $\begin{array}{r}2.84 \\
1.82 \\
.78\end{array}$ & $\begin{array}{r}2.93 \\
1.94 \\
.84\end{array}$ & $\begin{array}{r}2.96 \\
2.02 \\
.88\end{array}$ & $\begin{array}{r}2.90 \\
2.04 \\
.90\end{array}$ & $\begin{array}{l}2.97 \\
2.38 \\
1.38\end{array}$ & $\begin{array}{l}.450 \\
.436 \\
.316\end{array}$ & $\begin{array}{l}3 \\
-2 \\
-5\end{array}$ & $\begin{array}{l}3 . \\
3 \\
3\end{array}$ \\
\hline
\end{tabular}

YRT 966. 1076. 1162. 1223. 1257. 1261. 1236. 1186. 1109. 1072. 
AVERAGE DAILY ARRAY INSOLATION (EWH/SQ.M./DAY), CLEARNESS NUMBER (KT), MEAN MONTHLY TEMPERATURE (TM, DEG C), AND MONTILY AVERAGE WIND SPEED (WS, M/S)

HONOLULU, HI

SURFACE TILT (DEGREES UP FROM HORIZONTAL)

21.33 N LATITUDE

\begin{tabular}{llllllllllllll} 
MONTH- & HOR & 10 & 20 & 30 & 40 & 50 & 60 & 70 & 80 & VERT & & & TS \\
\hline JAN & 3.72 & 4.14 & 4.47 & 4.69 & 4.81 & 4.80 & 4.69 & 4.46 & 4.13 & 3.77 & .522 & 22. & 4. \\
FEB & 4.41 & 4.77 & 5.03 & 5.17 & 5.19 & 5.09 & 4.86 & 4.53 & 4.10 & 3.64 & .540 & 22. & 5. \\
MAR & 5.11 & 5.33 & 5.43 & 5.41 & 5.26 & 5.00 & 4.62 & 4.15 & 3.59 & 3.03 & .546 & 23. & 5. \\
\hline APR & 5.66 & 5.69 & 5.59 & 5.38 & 5.04 & 4.60 & 4.06 & 3.45 & 2.78 & 2.16 & .548 & 24. & 5. \\
MAY & 6.15 & 6.01 & 5.75 & 5.36 & 4.87 & 4.27 & 3.61 & 2.92 & 2.22 & 1.69 & .571 & 25. & 5. \\
JUN & 6.32 & 6.10 & 5.74 & 5.28 & 4.71 & 4.04 & 3.35 & 2.62 & 1.96 & 1.66 & .580 & 25. & 6. \\
\hline JUL & 6.31 & 6.13 & 5.80 & 5.37 & 4.82 & 4.17 & 3.48 & 2.76 & 2.08 & 1.65 & .581 & 26. & 6. \\
AUG & 6.20 & 6.15 & 5.97 & 5.66 & 5.23 & 4.68 & 4.04 & 3.33 & 2.61 & 1.95 & .588 & 26. & 6. \\
SEP & 5.70 & 5.87 & 5.89 & 5.79 & 5.55 & 5.18 & 4.71 & 4.13 & 3.47 & 2.80 & .584 & 26. & 5. \\
\hline OCT & 4.86 & 5.20 & 5.41 & 5.50 & 5.46 & 5.30 & 5.01 & 4.60 & 4.10 & 3.57 & .563 & 26. & 5. \\
NOV & 3.99 & 4.42 & 4.74 & 4.95 & 5.05 & 5.02 & 4.88 & 4.62 & 4.25 & 3.84 & .538 & 24. & 5. \\
DEC & 3.57 & 4.01 & 4.36 & 4.61 & 4.74 & 4.77 & 4.68 & 4.47 & 4.16 & 3.82 & .523 & 23 & 5. \\
\hline
\end{tabular}

YRT 1887. 1942. 1953. 1922. 1847. 1731. 1580.1399. 1198. 1020.

INDIANAPOLIS, IN

SURFACE TILT (DEGREES UP FROM HORIZONTAL)

39.73 N LATITUDE

\begin{tabular}{lrllllllllllll}
\multicolumn{1}{l}{ HONTK- } & \multicolumn{1}{c}{ HOR } & 10 & 20 & 30 & 40 & 50 & 60 & 70 & 80 & VERT & & & WS \\
\hline JAN & 1.56 & 1.85 & 2.09 & 2.28 & 2.43 & 2.51 & 2.53 & 2.50 & 2.40 & 2.43 & .377 & -3. & 5. \\
FEB & 2.35 & 2.67 & 2.94 & 3.14 & 3.26 & 3.31 & 3.28 & 3.18 & 3.00 & 2.81 & .425 & -1. & 5. \\
MAR & 3.27 & 3.55 & 3.75 & 3.87 & 3.90 & 3.84 & 3.70 & 3.48 & 3.18 & 2.88 & .438 & 4. & 5. \\
\hline APR & 4.40 & 4.58 & 4.66 & 4.64 & 4.52 & 4.31 & 4.00 & 3.61 & 3.16 & 2.71 & .465 & 11. & 5. \\
MAY & 5.32 & 5.39 & 5.34 & 5.17 & 4.90 & 4.54 & 4.10 & 3.57 & 3.00 & 2.46 & .491 & 17. & 4. \\
JUN & 5.89 & 5.89 & 5.76 & 5.51 & 5.15 & 4.71 & 4.18 & 3.57 & 2.96 & 2.36 & .514 & 22. & 4. \\
\hline JUL & 5.69 & 5.72 & 5.63 & 5.41 & 5.08 & 4.68 & 4.18 & 3.60 & 3.00 & 2.41 & .508 & 24. & 3. \\
AUG & 5.18 & 5.33 & 5.36 & 5.28 & 5.07 & 4.77 & 4.37 & 3.89 & 3.32 & 2.77 & .513 & 23. & 3. \\
SEP & 4.17 & 4.47 & 4.66 & 4.75 & 4.73 & 4.61 & 4.38 & 4.05 & 3.64 & 3.20 & .504 & 19. & 4. \\
\hline OCT & 3.08 & 3.47 & 3.78 & 4.01 & 4.14 & 4.17 & 4.10 & 3.93 & 3.67 & 3.39 & .493 & 13. & 4. \\
NOV & 1.83 & 2.14 & 2.41 & 2.62 & 2.77 & 2.86 & 2.87 & 2.82 & 2.70 & 2.66 & .403 & 5. & 5. \\
DEC & 1.31 & 1.56 & 1.77 & 1.94 & 2.06 & 2.14 & 2.17 & 2.14 & 2.07 & 2.09 & .348 & 0. & 5.
\end{tabular}

YRT 1343. 1420.1466.1480, 1461, 1413. 1334.1227. 1098. 977. 
TABLE I (Continued)

AVBRAGE DAILY ARRAY INSOLATION (XWH/SQ.M./DAY),

CLBARNESS NUMBER (IKT), JEAN MONTHLY TEMPERATURE (TM, DEG C),

AND HONTHLY AVERAGE WIND SPEED (WS, W/S)

KANSAS CIT, yo

39.12 N LATITUDE

SURFACE TILT (DEGREES UP FROM HORIZONTAL)

\begin{tabular}{llllllllllllll} 
MONTH- & HOR & 10 & 20 & 30 & 40 & 50 & 60 & 70 & 80 & VERT & & & \\
\hline JAN & 2.04 & 2.47 & 2.84 & 3.14 & 3.37 & 3.51 & 3.56 & 3.52 & 3.40 & 3.33 & .480 & -2. & 4. \\
FBB & 2.82 & 3.24 & 3.58 & 3.84 & 4.01 & 4.09 & 4.06 & 3.93 & 3.71 & 3.46 & .500 & 1. & 5. \\
MAR & 3.79 & 4.13 & 4.38 & 4.54 & 4.58 & 4.52 & 4.35 & 4.09 & 3.73 & 3.35 & .503 & 6. & 5. \\
\hline APR & 4.97 & 5.18 & 5.28 & 5.26 & 5.12 & 4.87 & 4.52 & 4.07 & 3.54 & 2.99 & .522 & 14. & 5. \\
WAY & 5.90 & 5.97 & 5.92 & 5.73 & 5.41 & 5.01 & 4.50 & 3.90 & 3.25 & 2.62 & .544 & 19. & 5. \\
JUN & 6.55 & 6.55 & 6.40 & 6.11 & 5.68 & 5.18 & 4.56 & 3.86 & 3.17 & 2.47 & .572 & 24. & 4. \\
\hline JUL & 6.63 & 6.66 & 6.55 & 6.28 & 5.88 & 5.38 & 4.77 & 4.07 & 3.34 & 2.62 & .591 & 27. & 4. \\
AUG & 5.87 & 6.05 & 6.09 & 5.99 & 5.76 & 5.41 & 4.94 & 4.37 & 3.70 & 3.04 & .579 & 26. & 4. \\
SEP & 4.58 & 4.91 & 5.14 & 5.24 & 5.23 & 5.09 & 4.83 & 4.46 & 4.00 & 3.49 & .549 & 21. & 4. \\
\hline OCT & 3.44 & 3.90 & 4.27 & 4.54 & 4.69 & 4.74 & 4.66 & 4.47 & 4.18 & 3.84 & .543 & 15. & 4. \\
NOV & 2.32 & 2.77 & 3.16 & 3.47 & 3.70 & 3.83 & 3.87 & 3.81 & 3.65 & 3.56 & .502 & 7. & 4. \\
DRC & 1.77 & 2.17 & 2.51 & 2.80 & 3.02 & 3.16 & 3.22 & 3.20 & 3.10 & 3.08 & .456 & 1. & 4. \\
\hline
\end{tabular}

YRT 1544. 1645. 1709. 1733. 1718. 1667. 1577. 1453. 1301. 1151.

KINGSVILLE, TX

27.52 N LATITUDE

SURFACE TILT (DEGREES UP FROM HORIZONTAL)

\begin{tabular}{|c|c|c|c|c|c|c|c|c|c|c|c|c|}
\hline $\mathbf{N}$ & BOR & 10 & 20 & 30 & 40 & 50 & 60 & 70 & 80 & VERT & $\mathbf{E T}$ & $\mathrm{I}$ \\
\hline $\begin{array}{l}\text { JAN } \\
\text { FEB } \\
\text { MAR }\end{array}$ & $\begin{array}{l}2.87 \\
3.66 \\
4.52\end{array}$ & $\begin{array}{l}3.24 \\
4.02 \\
4.78\end{array}$ & $\begin{array}{l}3.54 \\
4.29 \\
4.93\end{array}$ & $\begin{array}{l}3.76 \\
4.46 \\
4.96\end{array}$ & $\begin{array}{l}3.89 \\
4.52 \\
4.89\end{array}$ & $\begin{array}{l}3.93 \\
4.49 \\
4.71\end{array}$ & $\begin{array}{l}3.88 \\
4.34 \\
4.42\end{array}$ & $\begin{array}{l}3.73 \\
4.10 \\
4.03\end{array}$ & $\begin{array}{l}3.50 \\
3.77 \\
3.57\end{array}$ & $\begin{array}{l}3.24 \\
3.40 \\
3.08\end{array}$ & $\begin{array}{r}.467 \\
.498 \\
.513\end{array}$ & $\begin{array}{l}14 . \\
15 . \\
19 .\end{array}$ \\
\hline $\begin{array}{l}\text { APR } \\
\text { MAY } \\
\text { JUN }\end{array}$ & $\begin{array}{l}5.24 \\
5.88 \\
6.42\end{array}$ & $\begin{array}{l}5.33 \\
5.82 \\
6.27\end{array}$ & $\begin{array}{l}5.30 \\
5.64 \\
5.98\end{array}$ & $\begin{array}{l}5.16 \\
5.34 \\
5.57\end{array}$ & $\begin{array}{l}4.91 \\
4.93 \\
5.07\end{array}$ & $\begin{array}{l}4.55 \\
4.43 \\
4.45\end{array}$ & $\begin{array}{l}4.10 \\
3.83 \\
3.77\end{array}$ & $\begin{array}{l}3.57 \\
3.20 \\
3.07\end{array}$ & $\begin{array}{l}2.98 \\
2.54 \\
2.36\end{array}$ & $\begin{array}{l}2.40 \\
1.96 \\
1.81\end{array}$ & $\begin{array}{r}.516 \\
.539 \\
.573\end{array}$ & $\begin{array}{l}23 . \\
25 \\
28\end{array}$ \\
\hline $\begin{array}{l}\text { JUL } \\
\text { AUG } \\
\text { SEP }\end{array}$ & $\begin{array}{l}6.66 \\
6.06 \\
5.12\end{array}$ & $\begin{array}{l}6.54 \\
6.09 \\
5.33\end{array}$ & $\begin{array}{l}6.27 \\
5.99 \\
5.42\end{array}$ & $\begin{array}{l}5.87 \\
5.75 \\
5.39\end{array}$ & $\begin{array}{l}5.36 \\
5.40 \\
5.24\end{array}$ & $\begin{array}{l}4.74 \\
4.92 \\
4.97\end{array}$ & $\begin{array}{l}4.02 \\
4.34 \\
4.59\end{array}$ & $\begin{array}{l}3.29 \\
3.68 \\
4.11\end{array}$ & $\begin{array}{l}2.53 \\
2.98 \\
3.55\end{array}$ & $\begin{array}{l}1.90 \\
2.30 \\
2.96\end{array}$ & $\begin{array}{r}.601 \\
.577 \\
.546\end{array}$ & $\begin{array}{l}29 . \\
27 .\end{array}$ \\
\hline $\begin{array}{l}\text { OCT } \\
\text { NOV } \\
\text { DEC }\end{array}$ & $\begin{array}{l}4.39 \\
3.26 \\
2.67\end{array}$ & $\begin{array}{l}4.77 \\
3.66 \\
3.05\end{array}$ & $\begin{array}{l}5.04 \\
3.98 \\
3.35\end{array}$ & $\begin{array}{l}5.20 \\
4.21 \\
3.58\end{array}$ & $\begin{array}{l}5.23 \\
4.34 \\
3.73\end{array}$ & $\begin{array}{l}5.14 \\
4.37 \\
3.78\end{array}$ & $\begin{array}{l}4.93 \\
4.29 \\
3.75\end{array}$ & $\begin{array}{l}4.60 \\
4.11 \\
3.62\end{array}$ & $\begin{array}{l}4.17 \\
3.83 \\
3.42\end{array}$ & $\begin{array}{l}3.70 \\
3.52 \\
3.18\end{array}$ & $\begin{array}{r}.554 \\
.502 \\
.459\end{array}$ & $\begin{array}{l}18 . \\
14\end{array}$ \\
\hline
\end{tabular}

YRT 1728. 1793. 1819. 1804. 1750. 1657. 1528. 1372. 1191. 1017. 


\section{TABLE I (Continned)}

AVERAGE DAILY ARRAY INSOLATION (KWH/SQ.M./DAY), CLEARNESS NUMBER (KT), MRAN MONTHLY TEMPERATURE (TM, DEG C), AND MONTHLY AVERAGE WIND SPEED (WS, M/S)

SURFACE TILT (DEGREES UP FROM HORIZONTAL)

\begin{tabular}{llllllllllllll} 
MONTH- & \multicolumn{1}{c}{ HOR } & 10 & 20 & 30 & 40 & 50 & 60 & 70 & 80 & VERT & & & WS \\
\hline JAN & 4.41 & 4.69 & 4.87 & 4.95 & 4.91 & 4.76 & 4.51 & 4.15 & 3.72 & 3.25 & .486 & 27. & 3. \\
FEB & 4.92 & 5.12 & 5.22 & 5.19 & 5.06 & 4.81 & 4.45 & 4.01 & 3.48 & 2.94 & .509 & 27. & 4. \\
MAR & 5.13 & 5.19 & 5.13 & 4.96 & 4.69 & 4.31 & 3.85 & 3.32 & 2.73 & 2.15 & .505 & 27. & 3. \\
\hline APR & 5.33 & 5.21 & 4.98 & 4.65 & 4.22 & 3.70 & 3.12 & 2.51 & 1.88 & 1.53 & .518 & 27. & 3. \\
MAY & 4.94 & 4.71 & 4.39 & 3.98 & 3.49 & 2.96 & 2.40 & 1.86 & 1.52 & 1.48 & .491 & 27. & 3. \\
JUN & 4.59 & 4.33 & 3.99 & 3.57 & 3.09 & 2.58 & 2.07 & 1.62 & 1.46 & 1.43 & .464 & 27. & 2. \\
\hline JUL & 4.54 & 4.32 & 4.00 & 3.60 & 3.14 & 2.66 & 2.14 & 1.68 & 1.46 & 1.43 & .456 & 27. & 3. \\
AUG & 4.67 & 4.52 & 4.28 & 3.96 & 3.55 & 3.08 & 2.58 & 2.06 & 1.58 & 1.46 & .458 & 27. & 3. \\
SEP & 4.80 & 4.79 & 4.67 & 4.46 & 4.15 & 3.77 & 3.31 & 2.79 & 2.23 & 1.70 & .470 & 27. & 3. \\
\hline OCT & 4.75 & 4.88 & 4.91 & 4.84 & 4.66 & 4.37 & 4.00 & 3.55 & 3.04 & 2.52 & .481 & 27. & 3. \\
NOV & 4.57 & 4.83 & 4.99 & 5.04 & 4.98 & 4.80 & 4.52 & 4.14 & 3.67 & 3.19 & .495 & 27. & 3. \\
DEC & 4.22 & 4.52 & 4.72 & 4.82 & 4.80 & 4.68 & 4.45 & 4.13 & 3.72 & 3.28 & .476 & 27. & 3. \\
\hline IRT & 1729 & 1736 & 1707 & 1641 & 1541 & 1412 & 1257 & 1087 & 925 & 801. & &
\end{tabular}

IWWJALEIN IS, PI

8.72 N LATITUDE

SURFACE TILT (DEGREES UP FROM HORIZONTAL)

\begin{tabular}{|c|c|c|c|c|c|c|c|c|c|c|c|c|c|}
\hline & HOR & 10 & 20 & 30 & 40 & 50 & 60 & 70 & 0 & $\mathbf{T}$ & & & \\
\hline $\begin{array}{l}\mathrm{AN} \\
\mathrm{EB} \\
\mathrm{AR}\end{array}$ & $\begin{array}{l}5.53 \\
5.66\end{array}$ & $\begin{array}{l}5.34 \\
5.81 \\
5.74\end{array}$ & $\begin{array}{l}.60 \\
.95 \\
.70\end{array}$ & $\begin{array}{l}5.72 \\
5.96 \\
5.53\end{array}$ & $\begin{array}{l}1 \\
2 \\
3\end{array}$ & $\begin{array}{l}7 \\
6 \\
2\end{array}$ & & $\begin{array}{l}4.90 \\
4.65 \\
3.71\end{array}$ & $\begin{array}{l}9 \\
15 \\
4\end{array}$ & $\begin{array}{l}34 \\
41 \\
38\end{array}$ & $\begin{array}{l}.558 \\
.580 \\
.560\end{array}$ & $\begin{array}{l}27 . \\
27 .\end{array}$ & 7. \\
\hline $\begin{array}{l}\text { IAY } \\
\text { UN }\end{array}$ & $\begin{array}{l}5.48 \\
5.12 \\
5.07\end{array}$ & $\begin{array}{l}5.38 \\
4.90 \\
4.79\end{array}$ & $\begin{array}{l}5.15 \\
4.58 \\
4.41\end{array}$ & $\frac{2}{6}$ & & & & & & & $\begin{array}{l}.531 \\
.504 \\
.507\end{array}$ & 28 . & \\
\hline $\begin{array}{l}\text { UG } \\
\text { EPP }\end{array}$ & $\begin{array}{l}5.31 \\
5.08\end{array}$ & $\begin{array}{l}4.82 \\
5.15 \\
5.08\end{array}$ & $\begin{array}{l}4.88 \\
4.97\end{array}$ & $\begin{array}{l}2 \\
1 \\
6\end{array}$ & $\begin{array}{l}4.04 \\
4.44\end{array}$ & $\begin{array}{l}2.94 \\
3.49 \\
4.03\end{array}$ & $\begin{array}{l}2.35 \\
2.90 \\
3.55\end{array}$ & & & & $\begin{array}{r}.503 \\
.518 \\
.498\end{array}$ & $\begin{array}{l}28 \\
28\end{array}$ & $\begin{array}{l}4 \\
4\end{array}$ \\
\hline $\begin{array}{l}\text { OOV } \\
\text { EC }\end{array}$ & $\begin{array}{l}4.60 \\
4.58\end{array}$ & $\begin{array}{l}4.89 \\
4.95\end{array}$ & $\begin{array}{l}5.07 \\
5.20\end{array}$ & $\begin{array}{l}5.14 \\
5.34\end{array}$ & $\begin{array}{l}5.09 \\
5.35\end{array}$ & $\begin{array}{l}4.92 \\
5.24\end{array}$ & $\begin{array}{l}4.13 \\
4.65 \\
5.01\end{array}$ & $\begin{array}{l}4.27 \\
4.66\end{array}$ & $\begin{array}{l}3.16 \\
3.81 \\
4.21\end{array}$ & $\begin{array}{l}3.31 \\
3.72\end{array}$ & $\begin{array}{r}.492 \\
.507 \\
.527\end{array}$ & $\begin{array}{l}28 . \\
27 .\end{array}$ & 5 \\
\hline
\end{tabular}

IRT 1863. 1879. 1853. 1787. 1682. 1545. 1378. 1193. 1011.871. 
TABLE I (Continaed)

AVERAGE DAILY ARRAY INSOLATION (KNT/SQ.M./DAT).

CLEARNESS NUMBER (IT), NRAN MOMTHI TELPERATURE (TM, DEG C), AND MONTHLY AVERAGE WIND SPEED (WS, M/\$)

LA CROSSE, WI

43.87 N LATITODE

SURFACE TILT (DEGREES UP FROM HORIZONTAL)

\begin{tabular}{llllllllllllll} 
MONTH- & HOR & 10 & 20 & 30 & 40 & 50 & 60 & 70 & 80 & VERT & & & \\
\hline JAN & 1.52 & 1.89 & 2.22 & 2.49 & 2.70 & 2.85 & 2.92 & 2.92 & 2.84 & 3.04 & .440 & -9. & 4. \\
FEB & 2.41 & 2.84 & 3.20 & 3.49 & 3.70 & 3.81 & 3.83 & 3.75 & 3.58 & 3.37 & .494 & -6. & 3. \\
UAR & 3.47 & 3.85 & 4.14 & 4.33 & 4.42 & 4.41 & 4.30 & 4.08 & 3.77 & 3.43 & .501 & -1. & 4. \\
\hline APR & 4.50 & 4.73 & 4.86 & 4.88 & 4.80 & 4.61 & 4.32 & 3.94 & 3.49 & 3.01 & .492 & 8. & 5. \\
MAY & 5.40 & 5.51 & 5.50 & 5.37 & 5.13 & 4.79 & 4.36 & 3.85 & 3.27 & 2.71 & .503 & 15. & 4. \\
JUN & 6.01 & 6.04 & 5.96 & 5.75 & 5.41 & 4.98 & 4.47 & 3.87 & 3.24 & 2.62 & .524 & 20. & 4. \\
\hline JUL & 5.99 & 6.07 & 6.02 & 5.83 & 5.52 & 5.11 & 4.61 & 4.02 & 3.37 & 2.75 & .536 & 22. & 3. \\
AUG & 5.25 & 5.46 & 5.54 & 5.50 & 5.33 & 5.06 & 4.68 & 4.20 & 3.64 & 3.07 & .532 & 21. & 3. \\
SEP & 3.91 & 4.24 & 4.47 & 4.59 & 4.62 & 4.53 & 4.35 & 4.06 & 3.69 & 3.30 & .500 & 16. & 4. \\
\hline OCT & 2.72 & 3.12 & 3.45 & 3.69 & 3.85 & 3.92 & 3.89 & 3.77 & 3.55 & 3.32 & .484 & 10. & 4. \\
NOV & 1.56 & 1.88 & 2.16 & 2.39 & 2.56 & 2.67 & 2.72 & 2.70 & 2.61 & 2.58 & .405 & 2. & 4. \\
DEC & 1.16 & 1.44 & 1.69 & 1.90 & 2.06 & 2.17 & 2.23 & 2.24 & 2.18 & 2.20 & .379 & -6. & 4. \\
\hline
\end{tabular}

YRT 1338. 1433. 1498. 1529. 1524, 1488. 1419.1319. 1192. 1075 .

LAKE CHARLES, LA

30.12 N LATITUDE

SURFACE TILT (DEGREES UP FROM HORIZONTAL)

\begin{tabular}{llllllllllllll}
\multicolumn{1}{l}{ MONTH- } & HOR & 10 & 20 & 30 & 40 & 50 & 60 & 70 & 80 & VERT & & & WS \\
\hline JAN & 2.29 & 2.59 & 2.82 & 3.00 & 3.11 & 3.14 & 3.10 & 3.00 & 2.82 & 2.65 & .400 & 11. & 4. \\
FEB & 3.18 & 3.51 & 3.76 & 3.92 & 3.99 & 3.97 & 3.86 & 3.66 & 3.38 & 3.10 & .456 & 12. & 5. \\
MAR & 4.14 & 4.39 & 4.55 & 4.60 & 4.55 & 4.40 & 4.16 & 3.82 & 3.41 & 2.99 & .484 & 16. & 5. \\
\hline APR & 4.95 & 5.06 & 5.06 & 4.94 & 4.73 & 4.41 & 4.01 & 3.53 & 2.98 & 2.45 & .493 & 20. & 5. \\
MAY & 5.83 & 5.81 & 5.65 & 5.37 & 5.00 & 4.52 & 3.95 & 3.33 & 2.69 & 2.11 & .534 & 24. & 4. \\
JUN & 6.21 & 6.10 & 5.86 & 5.48 & 5.03 & 4.47 & 3.82 & 3.16 & 2.48 & 1.93 & .551 & 26. & 3. \\
\hline JUL & 5.63 & 5.57 & 5.38 & 5.08 & 4.69 & 4.21 & 3.66 & 3.07 & 2.46 & 1.94 & .506 & 27. & 3. \\
AUG & 5.23 & 5.28 & 5.21 & 5.03 & 4.76 & 4.38 & 3.92 & 3.38 & 2.80 & 2.27 & .500 & 27. & 3. \\
SEP & 4.68 & 4.89 & 5.00 & 4.99 & 4.87 & 4.64 & 4.32 & 3.90 & 3.40 & 2.90 & .510 & 25. & 3. \\
\hline OCT & 4.12 & 4.51 & 4.80 & 4.97 & 5.03 & 4.97 & 4.80 & 4.51 & 4.11 & 3.69 & .542 & 20. & 3. \\
NOV & 2.88 & 3.26 & 3.57 & 3.79 & 3.93 & 3.97 & 3.92 & 3.77 & 3.53 & 3.28 & .474 & 15. & 4. \\
DEC & 2.22 & 2.54 & 2.80 & 3.00 & 3.13 & 3.19 & 3.17 & 3.08 & 2.92 & 2.75 & .412 & 12. & 4. \\
\hline YRT & 1564 & 1628. & 1657. & 1649 & 1607. & 1530 & 1419 & 1283 & 1124. & 974. & &
\end{tabular}


TABLE I (Continued)

AVERAGE DAILY ARRAY INSOLATION (KWH/SQ.M./DAY), CLEARNESS NUBBER (KT), MEAN MONTHLY TEMPERATURE (TM, DEG C), AND HONTHLY AVERAGE WIND SPEED (WS, M/S)

LIHUE KAUAI, HI

21.98 N LAFITUDE

SURFACE TILT (DEGREES UP FROM HORIZONTAL)

\begin{tabular}{llllllllllllll} 
MONTH- & HOR & 10 & 20 & 30 & 40 & 50 & 60 & 70 & 80 & VERT & & & WS \\
\hline JAN & 3.48 & 3.87 & 4.17 & 4.37 & 4.48 & 4.47 & 4.37 & 4.16 & 3.85 & 3.52 & .495 & 22. & 5. \\
FEB & 4.10 & 4.43 & 4.67 & 4.79 & 4.81 & 4.71 & 4.51 & 4.21 & 3.81 & 3.40 & .507 & 22. & 5. \\
MAR & 4.65 & 4.84 & 4.93 & 4.91 & 4.78 & 4.54 & 4.21 & 3.79 & 3.30 & 2.81 & .500 & 22. & 5. \\
\hline APR & 5.17 & 5.20 & 5.12 & 4.93 & 4.64 & 4.25 & 3.77 & 3.23 & 2.64 & 2.09 & .501 & 23. & 6. \\
MAY & 5.75 & 5.64 & 5.40 & 5.06 & 4.61 & 4.07 & 3.46 & 2.84 & 2.20 & 1.70 & .533 & 24. & 5. \\
JUN & 5.89 & 5.70 & 5.39 & 4.97 & 4.46 & 3.86 & 3.24 & 2.57 & 1.97 & 1.65 & .538 & 25. & 6. \\
\hline JUL & 5.87 & 5.71 & 5.43 & 5.04 & 4.55 & 3.97 & 3.34 & 2.69 & 2.06 & 1.64 & .539 & 25. & 6. \\
AUG & 5.73 & 5.70 & 5.54 & 5.27 & 4.88 & 4.39 & 3.82 & 3.18 & 2.52 & 1.93 & .544 & 26. & 6. \\
SEP & 5.49 & 5.65 & 5.68 & 5.59 & 5.36 & 5.02 & 4.57 & 4.02 & 3.39 & 2.76 & .564 & 26. & 5. \\
\hline OCT & 4.57 & 4.89 & 5.09 & 5.17 & 5.14 & 4.98 & 4.72 & 4.34 & 3.88 & 3.39 & .534 & 25. & 5. \\
NOV & 3.64 & 4.01 & 4.29 & 4.48 & 4.56 & 4.53 & 4.40 & 4.16 & 3.83 & 3.48 & .497 & 24. & 5. \\
DEC & 3.32 & 3.72 & 4.04 & 4.26 & 4.39 & 4.41 & 4.32 & 4.14 & 3.85 & 3.54 & .494 & 22. & 5. \\
\hline YRT & 1755. & 1806. & 1818 & 1790. & 1723. & 1618 & 1481 & 1317. & 1133. & 970. & &
\end{tabular}

LOVELOCK, NV 40.07 N LATITUDE SURFACE TILT (DEGREES UP FROM HORIZONTAL)

\begin{tabular}{|c|c|c|c|c|c|c|c|c|c|c|c|c|}
\hline & HOR & 10 & 20 & 30 & 40 & 50 & 60 & 70 & 80 & VERT & & 10, \\
\hline $\begin{array}{l}\mathbf{A N} \\
\mathbf{E B} \\
\mathbf{A R}\end{array}$ & $\begin{array}{l}2.54 \\
3.67 \\
5.23\end{array}$ & $\begin{array}{l}3.20 \\
4.37 \\
5.85\end{array}$ & $\begin{array}{l}3.78 \\
4.96 \\
6.33\end{array}$ & $\begin{array}{l}7 \\
3 \\
6\end{array}$ & $\begin{array}{l}4.64 \\
5.75 \\
6.81\end{array}$ & $\begin{array}{l}39 \\
79 \\
79\end{array}$ & $\begin{array}{l}5 . \\
5 . \\
6 .\end{array}$ & $\begin{array}{l}0 \\
1 \\
2\end{array}$ & & $\begin{array}{l}4.74 \\
5.15 \\
5.10\end{array}$ & $\begin{array}{r}.620 \\
.670 \\
.704\end{array}$ & $\begin{array}{r}-1 \\
2 \\
5\end{array}$ \\
\hline $\begin{array}{l}\text { IPR } \\
\text { IAY } \\
\text { IUN }\end{array}$ & $\begin{array}{l}6.83 \\
8.05 \\
8.66\end{array}$ & $\begin{array}{l}7.22 \\
8.21 \\
8.68\end{array}$ & $\begin{array}{l}7.44 \\
8.17 \\
8.50\end{array}$ & $\begin{array}{l}.47 \\
.92 \\
.10\end{array}$ & $\begin{array}{l}7.32 \\
7.47 \\
7.51\end{array}$ & & & & & & $\begin{array}{r}.723 \\
.744 \\
.756\end{array}$ & $\begin{array}{r}9 . \\
15 . \\
16 .\end{array}$ \\
\hline $\begin{array}{l}\text { UL } \\
\text { UG } \\
\text { EP }\end{array}$ & $\begin{array}{l}8.77 \\
7.83 \\
6.39\end{array}$ & $\begin{array}{l}8.86 \\
8.16 \\
7.01\end{array}$ & $\begin{array}{l}8.72 \\
8.27 \\
7.46\end{array}$ & $\begin{array}{l}8.37 \\
8.18 \\
7.71\end{array}$ & $\begin{array}{l}7.82 \\
7.88 \\
7.77\end{array}$ & $\begin{array}{l}7.13 \\
7.41 \\
7.62\end{array}$ & $\begin{array}{l}6.28 \\
6.76 \\
7.28\end{array}$ & $\begin{array}{l}.28 \\
.95 \\
.75\end{array}$ & & $\begin{array}{l}3.20 \\
4.01 \\
5.25\end{array}$ & $\begin{array}{l}.782 \\
.776 \\
.775\end{array}$ & $\begin{array}{l}25 \\
23 . \\
18 .\end{array}$ \\
\hline $\begin{array}{l}C T \\
\text { OV } \\
\text { EC }\end{array}$ & $\begin{array}{l}4.57 \\
2.93 \\
2.25\end{array}$ & $\begin{array}{l}5.36 \\
3.65 \\
2.89\end{array}$ & $\begin{array}{l}4.27 \\
3.45\end{array}$ & $\begin{array}{l}0.50 \\
4.79 \\
3.93\end{array}$ & $\begin{array}{l}6.83 \\
5.18 \\
4.31\end{array}$ & $\begin{array}{l}5.43 \\
4.56\end{array}$ & $\begin{array}{l}6.93 \\
5.54 \\
4.70\end{array}$ & $\begin{array}{l}6.70 \\
5.50 \\
4.71\end{array}$ & $\begin{array}{l}6.29 \\
5.31 \\
4.60\end{array}$ & $\begin{array}{l}5.16 \\
4.54\end{array}$ & $\begin{array}{r}.738 \\
.655 \\
.606\end{array}$ & $\begin{array}{r}11 \\
3 \\
-1\end{array}$ \\
\hline
\end{tabular}

YRT 2064. 2238 2356. 2415. 2413. 2356. 2239. 2067. 1850. 1623. 
TARLE I (Continmed)

AVERAGE DAILY ARRAY INSOLATION (ITVIISQ. CLEARNESS NUMBER (TT), MEAN MONTILY TEUPERATIRE (TM, DRG C), AND MONTHLI AVERAGE WIND SPERD (TS, M/S)

MEMPHIS, TN

35.05 N LATITUDE

SURFACE TILT (DEGEEES UP FROM FORIZONTAL) MONTH

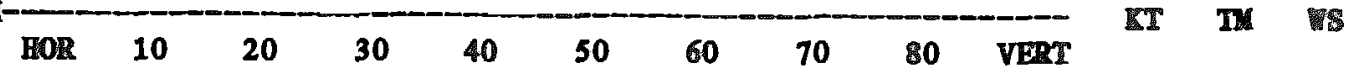

\begin{tabular}{llllllllllllll}
\hline JAN & 2.15 & 2.51 & 2.81 & 3.04 & 3.21 & 3.30 & 3.30 & 3.23 & 3.08 & 3.04 & .436 & 5. & 5 \\
FEB & 2.98 & 3.35 & 3.64 & 3.86 & 3.98 & 4.01 & 3.94 & 3.78 & 3.53 & 3.26 & .476 & 7. & 5. \\
MAR & 4.03 & 4.34 & 4.55 & 4.66 & 4.67 & 4.56 & 4.36 & 4.05 & 3.66 & 3.24 & .502 & 11. & 5. \\
\hline APr. & 5.16 & 5.34 & 5.40 & 5.33 & 5.15 & 4.86 & 4.46 & 3.97 & 3.41 & 2.82 & .528 & 17. & 5. \\
MAY & 5.94 & 5.97 & 5.86 & 5.63 & 5.28 & 4.84 & 4.29 & 3.66 & 3.02 & 2.38 & .545 & 22. & 4. \\
JUN & 6.44 & 6.39 & 6.20 & 5.86 & 5.42 & 4.88 & 4.25 & 3.56 & 2.86 & 2.21 & .565 & 26. & 4. \\
\hline JUL & 6.22 & 6.20 & 6.04 & 5.75 & 5.35 & 4.85 & 4.26 & 3.59 & 2.92 & 2.27 & .555 & 27. & 3. \\
AUG & 5.75 & 5.87 & 5.86 & 5.72 & 5.45 & 5.07 & 4.58 & 4.00 & 3.34 & 2.71 & .558 & 26. & 3. \\
SEP & 4.63 & 4.91 & 5.08 & 5.13 & 5.06 & 4.88 & 4.59 & 4.20 & 3.71 & 3.20 & .530 & 23. & 3. \\
\hline OCT & 3.80 & 4.24 & 4.58 & 4.81 & 4.93 & 4.93 & 4.80 & 4.57 & 4.22 & 3.82 & .549 & 17. & 3. \\
NOV & 2.57 & 2.98 & 3.33 & 3.59 & 3.78 & 3.86 & 3.86 & 3.76 & 3.57 & 3.33 & .486 & 11. & 4. \\
DEC & 1.98 & 2.34 & 2.65 & 2.90 & 3.08 & 3.18 & 3.21 & 3.15 & 3.02 & 2.87 & .434 & 6. & 4. \\
\hline YKT & 1573 & 1658. & 1705. & 1713. & 1684. & 1619 & 1518 & 1385 & 1226. & 1068. & &
\end{tabular}

MERIDTAN, US

32.33 N LATITUDE

SURFACE TILT (DEGREES UP FROM HORIZONTAL)

MONTH-

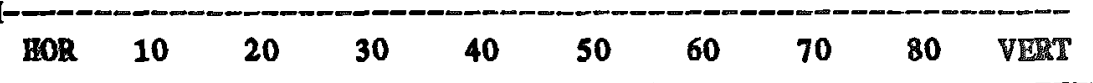

\begin{tabular}{llllllllllllll}
\hline JAN & 2.34 & 2.69 & 2.98 & 3.20 & 3.35 & 3.41 & 3.40 & 3.30 & 3.13 & 2.92 & .436 & 8. & 3. \\
FEB & 3.19 & 3.55 & 3.84 & 4.03 & 4.14 & 4.14 & 4.05 & 3.86 & 3.59 & 3.28 & .479 & 10. & 3. \\
MAR & 4.18 & 4.47 & 4.66 & 4.74 & 4.72 & 4.59 & 4.35 & 4.02 & 3.61 & 3.16 & .503 & 14. & 4. \\
\hline APR & 5.24 & 5.36 & 5.41 & 5.32 & 5.11 & 4.79 & 4.37 & 3.86 & 3.27 & 2.67 & .527 & 19. & 3. \\
MAY & 5.86 & 5.86 & 5.73 & 5.47 & 5.11 & 4.65 & 4.09 & 3.46 & 2.83 & 2.21 & .537 & 22. & 3. \\
JUN & 6.18 & 6.10 & 5.88 & 5.54 & 5.10 & 4.56 & 3.94 & 3.29 & 2.61 & 2.01 & .546 & 26. & 2. \\
\hline JUL & 5.74 & 5.70 & 5.53 & 5.24 & 4.86 & 4.39 & 3.83 & 3.23 & 2.61 & 2.04 & .514 & 27. & 2. \\
AUG & 5.49 & 5.56 & 5.52 & 5.35 & 5.08 & 4.70 & 4.22 & 3.66 & 3.04 & 2.44 & .527 & 26. & 2. \\
SEP & 4.58 & 4.81 & 4.94 & 4.96 & 4.86 & 4.66 & 4.35 & 3.95 & 3.47 & 2.96 & .510 & 24. & 2. \\
\hline OCT & 3.97 & 4.38 & 4.69 & 4.89 & 4.97 & 4.94 & 4.79 & 4.52 & 4.15 & 3.73 & .544 & 18. & 2. \\
NOV & 2.82 & 3.23 & 3.57 & 3.82 & 3.99 & 4.05 & 4.02 & 3.89 & 3.67 & 3.40 & .492 & 12. & 3. \\
DEC & 2.20 & 2.56 & 2.87 & 3.11 & 3.27 & 3.36 & 3.36 & 3.29 & 3.13 & 2.96 & .438 & 9. & 3. \\
\hline IRT & 1577 & 1653. & 1693. & 1694 & 1659 & 1589 & 1483 & 1348. & 1188. & 1027. & &
\end{tabular}


TABLE I (Continued)

AVERAGE DAILI ARRAY INSOLATION (KWH/SQ.K./DAY), CLEARNESS NUMBER (KT), MEAN MONIHLY TEMPRRATURE (TM, DEG C), AND MONTELY AVERAGE WIND SPEED (WS, M/S)

MILES CITY, MT

SURFACE TILT (DEGREES UP FROM HORIZONTAL)

\begin{tabular}{llllllllllllll} 
MONTH- & \multicolumn{1}{c}{ HOR } & 10 & 20 & 30 & 40 & 50 & 60 & 70 & 80 & VERT & & \\
\hline JAN & 1.44 & 1.86 & 2.23 & 2.54 & 2.80 & 2.98 & 3.08 & 3.10 & 3.04 & 2.96 & .478 & -10. & 4. \\
FEB & 2.34 & 2.84 & 3.26 & 3.61 & 3.87 & 4.02 & 4.08 & 4.03 & 3.88 & 3.67 & .527 & -5. & 4. \\
MAR & 3.74 & 4.23 & 4.62 & 4.91 & 5.07 & 5.11 & 5.02 & 4.80 & 4.48 & 4.08 & .569 & 0. & 5. \\
\hline APR & 4.86 & 5.17 & 5.36 & 5.43 & 5.37 & 5.19 & 4.90 & 4.50 & 4.00 & 3.46 & .545 & 7. & 5. \\
MAY & 5.97 & 6.14 & 6.17 & 6.06 & 5.82 & 5.45 & 4.99 & 4.43 & 3.77 & 3.13 & .561 & 14. & 5. \\
JUN & 6.76 & 6.84 & 6.77 & 6.57 & 6.21 & 5.73 & 5.16 & 4.49 & 3.75 & 3.04 & .590 & 19. & 5. \\
\hline JUL & 7.23 & 7.37 & 7.36 & 7.17 & 6.82 & 6.32 & 5.72 & 4.99 & 4.16 & 3.38 & .649 & 24. & 4. \\
AUG & 6.23 & 6.55 & 6.72 & 6.73 & 6.58 & 6.27 & 5.84 & 5.27 & 4.58 & 3.86 & .642 & 23. & 4. \\
SEP & 4.55 & 5.03 & 5.39 & 5.63 & 5.72 & 5.67 & 5.49 & 5.17 & 4.73 & 4.24 & .605 & 15.4. \\
\hline OCT & 3.02 & 3.58 & 4.05 & 4.42 & 4.68 & 4.82 & 4.84 & 4.73 & 4.50 & 4.23 & .579 & 9. & 4. \\
NOV & 1.74 & 2.21 & 2.63 & 2.98 & 3.25 & 3.45 & 3.55 & 3.56 & 3.48 & 3.42 & .510 & 0. & 4. \\
DEC & 1.26 & 1.66 & 2.03 & 2.34 & 2.60 & 2.78 & 2.90 & 2.93 & 2.89 & 2.89 & .476 & -5. & 4. \\
\hline
\end{tabular}

YRT 1499. 1630. 1725. 1778. 1790. 1760. 1691. 1582. 1438. 1288.

MISSOULA, MT

SURFACE TILT (DEGREES DP FROM HORIZONTAL)

46.92 N LATITUDE

\begin{tabular}{|c|c|c|c|c|c|c|c|c|c|c|c|c|c|}
\hline & HOR & 10 & 20 & 30 & 40 & 50 & 60 & 70 & 80 & VERT & & $\mathbf{T M}$ & \\
\hline $\begin{array}{l}\text { JAN } \\
\text { FEB } \\
\text { MAR }\end{array}$ & $\begin{array}{r}.98 \\
1.80 \\
3.10\end{array}$ & $\begin{array}{l}1.20 \\
2.13 \\
3.46\end{array}$ & $\begin{array}{l}1.39 \\
2.41 \\
3.75\end{array}$ & $\begin{array}{l}1.55 \\
2.64 \\
3.95\end{array}$ & $\begin{array}{l}1.68 \\
2.80 \\
4.06\end{array}$ & $\begin{array}{l}1.76 \\
2.90 \\
4.08\end{array}$ & $\begin{array}{l}1.80 \\
2.92 \\
3.99\end{array}$ & $\begin{array}{l}1.80 \\
2.88 \\
3.82\end{array}$ & $\begin{array}{l}1.76 \\
2.76 \\
3.56\end{array}$ & $\begin{array}{l}1.78 \\
2.69 \\
3.28\end{array}$ & $\begin{array}{r}.334 \\
.413 \\
.476\end{array}$ & $\begin{array}{l}-5 \\
-2 \\
1\end{array}$ & $\begin{array}{l}2 . \\
3 . \\
3 .\end{array}$ \\
\hline $\begin{array}{l}\text { APR } \\
\text { MAY } \\
\text { JUN }\end{array}$ & $\begin{array}{l}4.36 \\
5.62 \\
6.09\end{array}$ & $\begin{array}{l}4.62 \\
5.77 \\
6.16\end{array}$ & $\begin{array}{l}4.78 \\
5.80 \\
6.10\end{array}$ & $\begin{array}{l}4.83 \\
5.70 \\
5.92\end{array}$ & $\begin{array}{l}4.77 \\
5.47 \\
5.61\end{array}$ & $\begin{array}{l}4.61 \\
5.14 \\
5.19\end{array}$ & $\begin{array}{l}4.36 \\
4.71 \\
4.69\end{array}$ & $\begin{array}{l}4.00 \\
4.19 \\
4.10\end{array}$ & $\begin{array}{l}3.57 \\
3.59 \\
3.45\end{array}$ & $\begin{array}{l}3.13 \\
2.99 \\
2.83\end{array}$ & $\begin{array}{l}.491 \\
.529 \\
.532\end{array}$ & $\begin{array}{l}6 . \\
11 . \\
15\end{array}$ & $\begin{array}{l}3 . \\
3 . \\
3 .\end{array}$ \\
\hline $\begin{array}{l}\text { JUL } \\
\text { AUG } \\
\text { SEP }\end{array}$ & $\begin{array}{l}7.34 \\
5.92 \\
4.28\end{array}$ & $\begin{array}{l}7.49 \\
6.23 \\
4.72\end{array}$ & $\begin{array}{l}7.48 \\
6.39 \\
5.06\end{array}$ & $\begin{array}{l}7.30 \\
6.39 \\
5.27\end{array}$ & $\begin{array}{l}6.95 \\
6.25 \\
5.36\end{array}$ & $\begin{array}{l}6.45 \\
5.97 \\
5.32\end{array}$ & $\begin{array}{l}5.84 \\
5.56 \\
5.15\end{array}$ & $\begin{array}{l}5.11 \\
5.03 \\
4.85\end{array}$ & $\begin{array}{l}4.26 \\
4.38 \\
4.44\end{array}$ & $\begin{array}{l}3.46 \\
3.71 \\
4.00\end{array}$ & $\begin{array}{r}.659 \\
.612 \\
.574\end{array}$ & $\begin{array}{l}20 \\
19 \\
13\end{array}$ & 3. \\
\hline $\begin{array}{l}\text { OCT } \\
\text { NOV } \\
\text { DEC }\end{array}$ & $\begin{array}{r}2.56 \\
1.29 \\
.84\end{array}$ & $\begin{array}{l}2.99 \\
1.59 \\
1.05\end{array}$ & $\begin{array}{l}3.35 \\
1.85 \\
1.23\end{array}$ & $\begin{array}{l}3.63 \\
2.07 \\
1.39\end{array}$ & $\begin{array}{l}3.82 \\
2.24 \\
1.51\end{array}$ & $\begin{array}{l}3.92 \\
2.36 \\
1.60\end{array}$ & $\begin{array}{l}3.92 \\
2.41 \\
1.64\end{array}$ & $\begin{array}{l}3.83 \\
2.41 \\
1.65\end{array}$ & $\begin{array}{l}3.64 \\
2.34 \\
1.62\end{array}$ & $\begin{array}{l}3.43 \\
2.33 \\
1.65\end{array}$ & $\begin{array}{r}.497 \\
.389 \\
.329\end{array}$ & $\begin{array}{r}6 \\
0 \\
-4\end{array}$ & 2 \\
\hline
\end{tabular}

IRT 1348. 1446. 1512, 1544, 1540, 1501. 1432, 1330. 1199. 1074. 
TABLE I (Contimed)

AVERAGB DAILY ARTAY INSOLATION (KW/SQ.M./DAT),

CLEARNESS NUMBER (KT), MRAN MONTULY TEPPRATURE (TA, DEG C), AND MONTLL AVERAGE VIND SPEDD (VS, H/S)

NAFNEX, AR

$58.68 \mathrm{~N}$ LATITUDE

SURFACE TILT (DEGREES UP FRON HORIZONTAL)

\begin{tabular}{|c|c|c|c|c|c|c|c|c|c|c|c|c|c|}
\hline & HOR & 10 & 20 & 30 & 40 & 50 & 60 & 70 & 80 & VERT & $\mathbf{r}$ & 1 & \\
\hline $\begin{array}{l}\text { JAN } \\
\text { FEB } \\
\text { MAR }\end{array}$ & $\begin{array}{r}.46 \\
1.19 \\
2.52\end{array}$ & $\begin{array}{r}.75 \\
1.63 \\
3.04\end{array}$ & $\begin{array}{l}1.02 \\
2.02 \\
3.49\end{array}$ & $\begin{array}{l}1.26 \\
2.37 \\
3.85\end{array}$ & $\begin{array}{l}1.47 \\
2.65 \\
4.12\end{array}$ & $\begin{array}{l}1.64 \\
2.87 \\
4.28\end{array}$ & $\begin{array}{l}1.76 \\
3.01 \\
4.33\end{array}$ & $\begin{array}{l}1.84 \\
3.06 \\
4.28\end{array}$ & $\begin{array}{l}1.86 \\
3.04 \\
4.11\end{array}$ & $\begin{array}{l}1.95 \\
3.04 \\
3.91\end{array}$ & $\begin{array}{r}.431 \\
.492 \\
.534\end{array}$ & $\begin{array}{r}-12 \\
-10 \\
-7\end{array}$ & $\begin{array}{l}5 . \\
5 . \\
5 .\end{array}$ \\
\hline $\begin{array}{l}\text { APR } \\
\text { MAY } \\
\text { JUN }\end{array}$ & $\begin{array}{l}3.80 \\
4.67 \\
4.85\end{array}$ & $\begin{array}{l}4.16 \\
4.89 \\
4.97\end{array}$ & $\begin{array}{l}4.44 \\
4.99 \\
5.00\end{array}$ & $\begin{array}{l}4.61 \\
5.01 \\
4.93\end{array}$ & $\begin{array}{l}4.68 \\
4.92 \\
4.77\end{array}$ & $\begin{array}{l}4.63 \\
4.72 \\
4.52\end{array}$ & $\begin{array}{l}4.48 \\
4.42 \\
4.18\end{array}$ & $\begin{array}{l}4.24 \\
4.06 \\
3.79\end{array}$ & $\begin{array}{l}3.90 \\
3.62 \\
3.34\end{array}$ & $\begin{array}{l}3.51 \\
3.12 \\
2.84\end{array}$ & $\begin{array}{r}.497 \\
.464 \\
.429\end{array}$ & $\begin{array}{r}-1 \\
6 \\
10\end{array}$ & $\begin{array}{l}5 . \\
5 . \\
5 .\end{array}$ \\
\hline $\begin{array}{l}\text { JUL } \\
\text { AUG } \\
\text { SEP }\end{array}$ & $\begin{array}{l}4.36 \\
3.30 \\
2.45\end{array}$ & $\begin{array}{l}4.50 \\
3.49 \\
2.77\end{array}$ & $\begin{array}{l}4.54 \\
3.62 \\
3.04\end{array}$ & $\begin{array}{l}4.50 \\
3.67 \\
3.23\end{array}$ & $\begin{array}{l}4.38 \\
3.64 \\
3.35\end{array}$ & $\begin{array}{l}4.17 \\
3.54 \\
3.39\end{array}$ & $\begin{array}{l}3.87 \\
3.37 \\
3.36\end{array}$ & $\begin{array}{l}3.53 \\
3.13 \\
3.24\end{array}$ & $\begin{array}{l}3.13 \\
2.84 \\
3.05\end{array}$ & $\begin{array}{l}2.68 \\
2.52 \\
2.85\end{array}$ & $\begin{array}{r}.404 \\
.377 \\
.417\end{array}$ & $\begin{array}{c}12 . \\
12 . \\
8 .\end{array}$ & $\begin{array}{l}4 . \\
5 . \\
5 .\end{array}$ \\
\hline $\begin{array}{l}\text { OCT } \\
\text { NOV } \\
\text { DEC }\end{array}$ & $\begin{array}{r}1.49 \\
.64 \\
.28\end{array}$ & $\begin{array}{r}1.91 \\
.98 \\
.49\end{array}$ & $\begin{array}{r}2.27 \\
1.30 \\
.69\end{array}$ & $\begin{array}{r}2.59 \\
1.59 \\
.87\end{array}$ & $\begin{array}{l}2.84 \\
1.83 \\
1.03\end{array}$ & $\begin{array}{l}3.01 \\
2.02 \\
1.15\end{array}$ & $\begin{array}{l}3.11 \\
2.16 \\
1.25\end{array}$ & $\begin{array}{l}3.13 \\
2.24 \\
1.31\end{array}$ & $\begin{array}{l}3.06 \\
2.26 \\
1.33\end{array}$ & $\begin{array}{l}3.10 \\
2.60 \\
1.89\end{array}$ & $\begin{array}{r}.463 \\
.454 \\
.376\end{array}$ & $\begin{array}{r}1 \\
-5 \\
-11\end{array}$ & $\begin{array}{l}5 . \\
5 . \\
5 .\end{array}$ \\
\hline
\end{tabular}

NOME, AK.

64.50 N LATITUDE

SURFACE TILT (DEGREES UP FROM HORIZONTAL)

\begin{tabular}{lccccccccccccc} 
HONTH- & HOR & 10 & 20 & 30 & 40 & 50 & 60 & 70 & 80 & VERT & & & WS \\
\hline JAN & .09 & .18 & .26 & .34 & .41 & .47 & .51 & .54 & .55 & 1.12 & .286 & -15. & 5. \\
FEB & .70 & 1.09 & 1.46 & 1.79 & 2.07 & 2.29 & 2.45 & 2.54 & 2.56 & 2.91 & .478 & -16. & 5. \\
UAR & 1.99 & 2.53 & 3.00 & 3.40 & 3.72 & 3.94 & 4.05 & 4.06 & 3.96 & 3.82 & .529 & -14 & 5. \\
\hline APR & 3.74 & 4.22 & 4.60 & 4.87 & 5.03 & 5.06 & 4.97 & 4.77 & 4.46 & 4.07 & .538 & -8. & 5. \\
UAY & 4.96 & 5.25 & 5.43 & 5.51 & 5.48 & 5.32 & 5.05 & 4.69 & 4.24 & 3.71 & .508 & 2. & 5. \\
JUN & 5.53 & 5.71 & 5.79 & 5.76 & 5.64 & 5.40 & 5.05 & 4.63 & 4.13 & 3.55 & .489 & 8. & 4. \\
\hline JUL & 4.46 & 4.63 & 4.72 & 4.71 & 4.63 & 4.45 & 4.18 & 3.85 & 3.46 & 3.01 & .418 & 10. & 5. \\
AUG & 3.13 & 3.36 & 3.52 & 3.62 & 3.63 & 3.57 & 3.43 & 3.23 & 2.97 & 2.66 & .382 & 10. & 5. \\
SEP & 2.41 & 2.85 & 3.23 & 3.54 & 3.76 & 3.88 & 3.91 & 3.84 & 3.68 & 3.48 & .482 & 6. & 5. \\
\hline OCT & .96 & 1.32 & 1.64 & 1.93 & 2.17 & 2.34 & 2.46 & 2.51 & 2.50 & 2.61 & .428 & -2. & 5. \\
NOV & .20 & .37 & .53 & .67 & .80 & .91 & .99 & 1.04 & 1.06 & 1.73 & .346 & -9. & 5. \\
DEC & .02 & .02 & .02 & .02 & .02 & .02 & .02 & .02 & .01 & .86 & .054 & -15. & 4. \\
\hline
\end{tabular}

YRT 860.961. 1042. 1101. 1136. 1145. 1127. 1085. 1020. 1018. 
TABLE I (Continned)

AVERAGE DAILY ARRAY INSOLATION (KWI/SQ.K./DAY), CLEARNESS NUBBR :ITT), MRAN MONTHLY TEMPERATURE (TM; DEG C), AND MONTHLY AVERAGE WIND SPEED (WS, M/S)

NORFOLK, VA

SURFACE TILT (DEGREES OP FROM BORIZONTAL)

36.90 N LATITUDE

\begin{tabular}{|c|c|c|c|c|c|c|c|c|c|c|c|c|}
\hline & HOR & 10 & 20 & 30 & 40 & 50 & 60 & 70 & 80 & VERT & & \\
\hline $\begin{array}{l}\text { JAN } \\
\text { FEB } \\
\text { MAR }\end{array}$ & $\begin{array}{l}2.14 \\
2.93 \\
4.04\end{array}$ & $\begin{array}{l}2.54 \\
3.33 \\
4.38\end{array}$ & $\begin{array}{l}2.88 \\
3.66 \\
4.63\end{array}$ & $\begin{array}{l}3.15 \\
3.89 \\
4.77\end{array}$ & $\begin{array}{l}3.35 \\
4.04 \\
4.79\end{array}$ & $\begin{array}{l}3.46 \\
4.09 \\
4.71\end{array}$ & $\begin{array}{l}3.49 \\
4.04 \\
4.52\end{array}$ & $\begin{array}{l}3.44 \\
3.90 \\
4.22\end{array}$ & $\begin{array}{l}3.29 \\
3.66 \\
3.83\end{array}$ & $\begin{array}{l}3.27 \\
3.40 \\
3.42\end{array}$ & $\begin{array}{r}.463 \\
.491 \\
.517\end{array}$ & 5 \\
\hline $\begin{array}{l}\text { APR } \\
\text { MAY } \\
\text { JUN }\end{array}$ & $\begin{array}{l}5.29 \\
5.95 \\
6.31\end{array}$ & $\begin{array}{l}5.49 \\
6.00 \\
6.28\end{array}$ & $\begin{array}{l}5.58 \\
5.91 \\
6.11\end{array}$ & $\begin{array}{l}5.53 \\
5.69 \\
5.80\end{array}$ & $\begin{array}{l}37 \\
36 \\
39\end{array}$ & $\begin{array}{l}5.08 \\
4.93 \\
4.88\end{array}$ & $\begin{array}{l}4.69 \\
4.40 \\
4.28\end{array}$ & $\begin{array}{l}4.19 \\
3.78 \\
3.61\end{array}$ & $\begin{array}{l}3.61 \\
3.13 \\
2.94\end{array}$ & $\begin{array}{l}3.02 \\
2.51 \\
2.28\end{array}$ & $\begin{array}{r}.547 \\
.546 \\
.552\end{array}$ & $\begin{array}{l}19 \\
23\end{array}$ \\
\hline $\begin{array}{l}\text { UL } \\
\text { DG } \\
\text { EP }\end{array}$ & $\begin{array}{l}5.84 \\
5.30 \\
4.40\end{array}$ & $\begin{array}{l}5.84 \\
5.42 \\
4.67\end{array}$ & $\begin{array}{l}5.72 \\
5.43 \\
4.85\end{array}$ & $\begin{array}{l}5.47 \\
5.31 \\
4.91\end{array}$ & $\begin{array}{l}5.11 \\
5.08 \\
4.87\end{array}$ & $\begin{array}{l}4.66 \\
4.75 \\
4.71\end{array}$ & $\begin{array}{l}4.13 \\
4.32 \\
4.45\end{array}$ & $\begin{array}{l}3.52 \\
3.80 \\
4.08\end{array}$ & $\begin{array}{l}2.90 \\
3.22 \\
3.64\end{array}$ & $\begin{array}{l}2.28 \\
2.63 \\
3.15\end{array}$ & $\begin{array}{r}.521 \\
.518 \\
.513\end{array}$ & $\begin{array}{l}25 \\
22\end{array}$ \\
\hline $\begin{array}{l}\mathrm{CT} \\
\mathrm{OV} \\
\mathrm{BC}\end{array}$ & $\begin{array}{l}3.42 \\
2.55 \\
1.97\end{array}$ & $\begin{array}{l}3.82 \\
3.01 \\
2.37\end{array}$ & $\begin{array}{l}4.13 \\
3.40 \\
2.72\end{array}$ & $\begin{array}{l}4.35 \\
3.71 \\
3.01\end{array}$ & $\begin{array}{l}4.46 \\
3.93 \\
3.22\end{array}$ & $\begin{array}{l}4.47 \\
4.05 \\
3.35\end{array}$ & $\begin{array}{l}4.37 \\
4.06 \\
3.40\end{array}$ & $\begin{array}{l}4.17 \\
3.98 \\
3.36\end{array}$ & $\begin{array}{l}3.87 \\
3.80 \\
3.24\end{array}$ & $\begin{array}{l}3.52 \\
3.67 \\
3.18\end{array}$ & $\begin{array}{r}.513 \\
.512 \\
.462\end{array}$ & $\begin{array}{r}16 . \\
11 . \\
6 .\end{array}$ \\
\hline
\end{tabular}

IET 1526. 1618, 1674, 1692. 1672, 1617. 1525. 1400, 1250. 1104.

OAKLAND, CA

37.73 N LATITUDE

SURFACE TILT (DEGREES OP FROM HORIZONTAL)

\begin{tabular}{|c|c|c|c|c|c|c|c|c|c|c|c|c|c|}
\hline & HOR & 10 & 20 & 30 & 40 & 50 & 60 & 70 & 80 & RRT & & MI & \\
\hline $\begin{array}{l}\mathbf{A N} \\
\mathbf{B B} \\
\mathbf{A R}\end{array}$ & $\begin{array}{l}2.23 \\
3.20 \\
4.59\end{array}$ & $\begin{array}{l}8 \\
9 \\
4\end{array}$ & $\begin{array}{l}3.07 \\
4.09 \\
5.37\end{array}$ & $\begin{array}{l}3.38 \\
4.40 \\
5.57\end{array}$ & $\begin{array}{l}3.61 \\
4.59 \\
5.63\end{array}$ & $\begin{array}{l}3.75 \\
4.67 \\
5.56\end{array}$ & $\begin{array}{l}.80 \\
.64 \\
.35\end{array}$ & $\begin{array}{l}3.75 \\
4.49 \\
5.02\end{array}$ & $\begin{array}{l}3.60 \\
4.23 \\
4.57\end{array}$ & $\begin{array}{l}3.51 \\
3.9 \\
4.04\end{array}$ & $\begin{array}{r}.497 \\
.548 \\
.596\end{array}$ & $\begin{array}{l}9 . \\
11 . \\
12 .\end{array}$ & $\begin{array}{l}3 . \\
3 . \\
4 .\end{array}$ \\
\hline $\begin{array}{l}\mathbf{P R} \\
\mathbf{A Y} \\
\mathrm{UN}\end{array}$ & $\begin{array}{l}6.06 \\
6.97 \\
7.41\end{array}$ & $\begin{array}{l}4 \\
5 \\
9\end{array}$ & $\begin{array}{l}6.47 \\
6.97 \\
7.19\end{array}$ & $\begin{array}{l}6.44 \\
6.72 \\
6.83\end{array}$ & $\begin{array}{l}7 \\
3 \\
3\end{array}$ & $\begin{array}{l}5 \\
1 \\
2\end{array}$ & & & & & $\begin{array}{l}631 \\
641 \\
648\end{array}$ & $\begin{array}{l}13 . \\
14 . \\
16 .\end{array}$ & $\begin{array}{l}4 . \\
5 . \\
4 .\end{array}$ \\
\hline $\begin{array}{l}\text { UL } \\
\text { UG } \\
\text { EP }\end{array}$ & $\begin{array}{l}7.32 \\
6.47 \\
5.36\end{array}$ & $\begin{array}{l}6.66 \\
5.77\end{array}$ & 6. & $\begin{array}{l}6.87 \\
6.58 \\
6.18\end{array}$ & $\begin{array}{l}1 \\
6 \\
6\end{array}$ & 5. & & & $\begin{array}{l}4 \\
5\end{array}$ & & $\begin{array}{l}.653 \\
.634 \\
.632\end{array}$ & $\begin{array}{l}17 . \\
17 . \\
17 .\end{array}$ & $\begin{array}{l}4 . \\
4 . \\
4 .\end{array}$ \\
\hline $\begin{array}{l}C T \\
\mathrm{EV} \\
\mathrm{EC}\end{array}$ & $\begin{array}{l}3.82 \\
2.59 \\
2.04\end{array}$ & $\begin{array}{l}3.09 \\
2.50\end{array}$ & $\begin{array}{l}4.74 \\
3.51 \\
2.89\end{array}$ & $\begin{array}{l}5.03 \\
3.85 \\
3.21\end{array}$ & $\begin{array}{l}5.20 \\
4.10 \\
3.46\end{array}$ & $\begin{array}{l}5.24 \\
4.24 \\
3.62\end{array}$ & $\begin{array}{l}5.15 \\
4.27 \\
3.68\end{array}$ & $\begin{array}{l}4.93 \\
4.20 \\
3.65\end{array}$ & $\begin{array}{l}4.59 \\
4.01 \\
3.53\end{array}$ & $\begin{array}{l}3.89 \\
3.48\end{array}$ & $\begin{array}{r}.584 \\
.534 \\
.496\end{array}$ & $\begin{array}{c}16 . \\
13 . \\
9\end{array}$ & 3. \\
\hline
\end{tabular}

YET 1769. 1885. 1956. 1981, 1959. 1894, 1785. 1635, 1453. 1266. 
AVERAGE DAILY ARRAY INSOLATION (EVEI/SQ.M./DAY), CLEARNESS NUMER (ITT), HEAN MONWLY TEMPERATURE (TM, DIE $c$ ). AND 16ONTILY AVERAGE FIND SPERD (VS, M/S)

ORLANDO, FL

28.55 N LATITUDE

SURFACE TILT (DEGREES UP FROM HORIZONTAL)

MONTH-

$\begin{array}{lllllllllll}\text { HOR } & 10 & 20 & 30 & 40 & 50 & 60 & 70 & 80 & \text { VERT } & \text { FT }\end{array}$

\begin{tabular}{llllllllllllll}
\hline JAN & 3.14 & 3.59 & 3.97 & 4.24 & 4.42 & 4.49 & 4.45 & 4.30 & 4.04 & 3.73 & .524 & 15. & 4. \\
FEB & 3.92 & 4.35 & 4.68 & 4.89 & 4.99 & 4.98 & 4.84 & 4.58 & 4.22 & 3.80 & .544 & 16. & 5. \\
HAR & 4.99 & 5.31 & 5.51 & 5.58 & 5.52 & 5.33 & 5.02 & 4.59 & 4.07 & 3.49 & .572 & 18. & 5. \\
\hline APR & 5.98 & 6.11 & 6.11 & 5.96 & 5.68 & 5.27 & 4.75 & 4.12 & 3.42 & 2.71 & .592 & 22. & 4. \\
MAY & 6.27 & 6.23 & 6.04 & 5.72 & 5.29 & 4.75 & 4.11 & 3.43 & 2.72 & 2.06 & .575 & 25. & 4. \\
JUN & 5.77 & 5.66 & 5.42 & 5.07 & 4.64 & 4.12 & 3.53 & 2.93 & 2.31 & 1.79 & .514 & 26. & 4. \\
\hline JUL & 5.68 & 5.60 & 5.39 & 5.07 & 4.67 & 4.17 & 3.60 & 3.01 & 2.38 & 1.84 & .511 & 27. & 3. \\
AUG & 5.28 & 5.31 & 5.23 & 5.04 & 4.74 & 4.35 & 3.88 & 3.33 & 2.74 & 2.17 & .503 & 27. & 3. \\
SEP & 4.71 & 4.91 & 5.00 & 4.97 & 4.84 & 4.60 & 4.26 & 3.83 & 3.32 & 2.79 & .507 & 26. & 4. \\
\hline OCT & 4.12 & 4.48 & 4.74 & 4.89 & 4.93 & 4.85 & 4.66 & 4.36 & 3.96 & 3.51 & .529 & 23. & $4:$ \\
NOV & 3.45 & 3.93 & 4.31 & 4.59 & 4.76 & 4.81 & 4.75 & 4.56 & 4.27 & 3.91 & .546 & 19. & 4. \\
DEC & 2.91 & 3.37 & 3.75 & 4.05 & 4.24 & 4.33 & 4.31 & 4.19 & 3.96 & 3.67 & .516 & 16. & 4. \\
\hline
\end{tabular}

YRT 1711, 1791. 1829. 1827. 1786. 1704, 1584. 1435. 1258, 1077.

PENDLETON, OR

45.68 N LATITUDE

SURFACE TILT (DEGREES OP FROM HORIZONTAL)

\begin{tabular}{|c|c|c|c|c|c|c|c|c|c|c|c|c|c|}
\hline \multicolumn{11}{|c|}{ 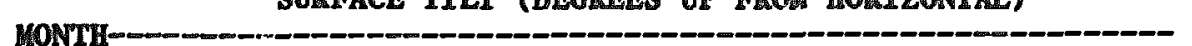 } & \multirow{2}{*}{$\mathbf{E T}$} & \multirow{2}{*}{$\mathbb{T}$} & \multirow{2}{*}{ WS } \\
\hline & HOR & 10 & 20 & 30 & 40 & $\mathbf{5 0}$ & 60 & 70 & 80 & VERT & & & \\
\hline $\begin{array}{l}\text { JAN } \\
\text { FEB } \\
\text { MAR }\end{array}$ & $\begin{array}{l}1.09 \\
1.93 \\
3.29\end{array}$ & $\begin{array}{l}1.33 \\
2.27 \\
3.67\end{array}$ & $\begin{array}{l}1.53 \\
2.55 \\
3.96\end{array}$ & $\begin{array}{l}1.71 \\
2.78 \\
4.17\end{array}$ & $\begin{array}{l}1.84 \\
2.95 \\
4.28\end{array}$ & $\begin{array}{l}1.93 \\
3.04 \\
4.28\end{array}$ & $\begin{array}{l}1.97 \\
3.06 \\
4.19\end{array}$ & $\begin{array}{l}1.97 \\
3.00 \\
3.99\end{array}$ & $\begin{array}{l}1.91 \\
2.87 \\
3.71\end{array}$ & $\begin{array}{l}1.85 \\
2.71 \\
3.37\end{array}$ & $\begin{array}{r}.346 \\
.422 \\
.493\end{array}$ & $\begin{array}{l}1 . \\
4 . \\
6\end{array}$ & $\begin{array}{l}4 . \\
4 . \\
5 .\end{array}$ \\
\hline $\begin{array}{l}\text { APR } \\
\text { MAY } \\
\text { JUN }\end{array}$ & $\begin{array}{l}4.74 \\
6.07 \\
6.76\end{array}$ & $\begin{array}{l}5.02 \\
6.23 \\
6.83\end{array}$ & $\begin{array}{l}5.19 \\
6.25 \\
6.76\end{array}$ & $\begin{array}{l}5.24 \\
6.13 \\
6.54\end{array}$ & $\begin{array}{l}5.18 \\
5.88 \\
6.17\end{array}$ & $\begin{array}{l}4.99 \\
5.50 \\
5.69\end{array}$ & $\begin{array}{l}4.70 \\
5.02 \\
5.11\end{array}$ & $\begin{array}{l}4.31 \\
4.44 \\
4.43\end{array}$ & $\begin{array}{l}3.83 \\
3.78 \\
3.70\end{array}$ & $\begin{array}{l}3.29 \\
3.10 \\
2.97\end{array}$ & $\begin{array}{r}.527 \\
.569 \\
.590\end{array}$ & $\begin{array}{l}10 . \\
15 . \\
19 .\end{array}$ & $\begin{array}{l}5 . \\
5 . \\
5 .\end{array}$ \\
\hline $\begin{array}{l}\text { JUL } \\
\text { AUG } \\
\text { SEP }\end{array}$ & $\begin{array}{l}7.55 \\
6.29 \\
4.73\end{array}$ & $\begin{array}{l}7.70 \\
6.60 \\
5.23\end{array}$ & $\begin{array}{l}7.67 \\
6.76 \\
5.60\end{array}$ & $\begin{array}{l}7.47 \\
6.75 \\
5.84\end{array}$ & $\begin{array}{l}7.08 \\
6.59 \\
5.93\end{array}$ & $\begin{array}{l}6.56 \\
6.27 \\
5.88\end{array}$ & $\begin{array}{l}5.91 \\
5.83 \\
5.68\end{array}$ & $\begin{array}{l}5.14 \\
5.25 \\
5.34\end{array}$ & $\begin{array}{l}4.27 \\
4.55 \\
4.88\end{array}$ & $\begin{array}{l}3.41 \\
3.80 \\
4.34\end{array}$ & $\begin{array}{r}.677 \\
.644 \\
.622\end{array}$ & $\begin{array}{l}24 . \\
22 . \\
18 .\end{array}$ & $\begin{array}{l}4 . \\
4 . \\
4 .\end{array}$ \\
\hline $\begin{array}{l}\text { OCT } \\
\text { NOV } \\
\text { DEC }\end{array}$ & $\begin{array}{r}2.86 \\
1.38 \\
.92\end{array}$ & $\begin{array}{l}3.34 \\
1.69 \\
1.14\end{array}$ & $\begin{array}{l}3.75 \\
1.95 \\
1.33\end{array}$ & $\begin{array}{l}4.06 \\
2.17 \\
1.49\end{array}$ & $\begin{array}{l}4.28 \\
2.34 \\
1.61\end{array}$ & $\begin{array}{l}4.39 \\
2.45 \\
1.70\end{array}$ & $\begin{array}{l}4.39 \\
2.50 \\
1.74\end{array}$ & $\begin{array}{l}4.27 \\
2.49 \\
1.75\end{array}$ & $\begin{array}{l}4.06 \\
2.41 \\
1.71\end{array}$ & $\begin{array}{l}3.79 \\
2.38 \\
1.72\end{array}$ & $\begin{array}{r}.535 \\
.391 \\
.334\end{array}$ & $\begin{array}{r}11 . \\
5 . \\
2 .\end{array}$ & 4 \\
\hline
\end{tabular}

YRT 1453, 1557, 1626, 1657, 1649, 1605, 1526, 1412, 1268. 1118. 
TABLE I (Continued)

AVERAGE DAILY ARRAY INSOLATION (KWH/SQ.M./DAY), CLEARNESS NUMBER (KT), MEAN MONIHLY TBMPERATURE (TM, DEG C), AND WONTHLY AVERAGE WIND SPEED (WS, M/S)

PHILADELPHIA, PA

39.88 N LATITUDE

SURFACE TILT (DEGREES UP FROM HORIZONTAL)

\begin{tabular}{|c|c|c|c|c|c|c|c|c|c|c|c|c|c|}
\hline & HOR & 10 & 20 & 30 & 40 & 50 & 60 & 70 & 80 & VERT & & & \\
\hline $\begin{array}{l}\text { JAN } \\
\text { FEB } \\
\text { MAR }\end{array}$ & $\begin{array}{l}1.75 \\
2.50 \\
3.49\end{array}$ & $\begin{array}{l}2.10 \\
2.86 \\
\mathbf{3 . 8 1}\end{array}$ & $\begin{array}{l}2.41 \\
3.16 \\
4.04\end{array}$ & $\begin{array}{l}2.65 \\
3.39 \\
4.17\end{array}$ & $\begin{array}{l}2.84 \\
3.53 \\
4.22\end{array}$ & $\begin{array}{l}2.95 \\
3.60 \\
4.16\end{array}$ & $\begin{array}{l}2.99 \\
3.57 \\
4.01\end{array}$ & $\begin{array}{l}2.96 \\
3.46 \\
3.77\end{array}$ & $\begin{array}{l}2.85 \\
3.27 \\
3.45\end{array}$ & $\begin{array}{l}2.78 \\
3.05 \\
3.11\end{array}$ & $\begin{array}{l}.425 \\
.454 \\
.470\end{array}$ & $\begin{array}{l}0 . \\
1 . \\
5 .\end{array}$ & $\begin{array}{l}5 . \\
5 . \\
5 .\end{array}$ \\
\hline $\begin{array}{l}\text { APR } \\
\text { MAY } \\
\text { JUN }\end{array}$ & $\begin{array}{l}4.52 \\
5.23 \\
5.71\end{array}$ & $\begin{array}{l}4.71 \\
5.29 \\
5.71\end{array}$ & $\begin{array}{l}4.80 \\
5.25 \\
5.59\end{array}$ & $\begin{array}{l}4.78 \\
5.09 \\
5.35\end{array}$ & $\begin{array}{l}4.65 \\
4.82 \\
5.00\end{array}$ & $\begin{array}{l}4.43 \\
4.47 \\
4.58\end{array}$ & $\begin{array}{l}4.12 \\
4.04 \\
4.07\end{array}$ & $\begin{array}{l}3.72 \\
3.52 \\
3.49\end{array}$ & $\begin{array}{l}3.25 \\
2.97 \\
2.90\end{array}$ & $\begin{array}{l}2.77 \\
2.42 \\
2.31\end{array}$ & $\begin{array}{l}.478 \\
.483 \\
.498\end{array}$ & $\begin{array}{l}12 . \\
17 . \\
22 .\end{array}$ & $\begin{array}{l}5 . \\
4 . \\
4 .\end{array}$ \\
\hline $\begin{array}{l}\text { JUL } \\
\text { ADG } \\
\text { SEP }\end{array}$ & $\begin{array}{l}5.54 \\
4.96 \\
4.04\end{array}$ & $\begin{array}{l}5.57 \\
5.10 \\
4.32\end{array}$ & $\begin{array}{l}5.48 \\
5.13 \\
4.50\end{array}$ & $\begin{array}{l}5.27 \\
5.05 \\
4.59\end{array}$ & $\begin{array}{l}4.95 \\
4.86 \\
4.57\end{array}$ & $\begin{array}{l}4.56 \\
4.57 \\
4.44\end{array}$ & $\begin{array}{l}4.08 \\
4.19 \\
4.22\end{array}$ & $\begin{array}{l}3.52 \\
3.73 \\
3.91\end{array}$ & $\begin{array}{l}2.94 \\
3.20 \\
3.51\end{array}$ & $\begin{array}{l}2.36 \\
2.66 \\
3.08\end{array}$ & $\begin{array}{r}.494 \\
.492 \\
.489\end{array}$ & $\begin{array}{l}25 . \\
24 . \\
20 .\end{array}$ & $\begin{array}{l}4 . \\
4 . \\
4 .\end{array}$ \\
\hline $\begin{array}{l}\text { OCT } \\
\text { NOV } \\
\text { DEC }\end{array}$ & $\begin{array}{l}3.02 \\
1.95 \\
1.48\end{array}$ & $\begin{array}{l}3.40 \\
2.31 \\
1.79\end{array}$ & $\begin{array}{l}3.71 \\
2.61 \\
2.07\end{array}$ & $\begin{array}{l}3.93 \\
2.86 \\
2.29\end{array}$ & $\begin{array}{l}4.05 \\
3.03 \\
2.46\end{array}$ & $\begin{array}{l}4.08 \\
3.14 \\
2.56\end{array}$ & $\begin{array}{l}4.01 \\
3.16 \\
2.61\end{array}$ & $\begin{array}{l}3.85 \\
3.11 \\
2.59\end{array}$ & $\begin{array}{l}3.60 \\
2.98 \\
2.51\end{array}$ & $\begin{array}{l}3.31 \\
2.91 \\
2.49\end{array}$ & $\begin{array}{r}.485 \\
.434 \\
.396\end{array}$ & $\begin{array}{r}14 . \\
8 . \\
2 .\end{array}$ & $\begin{array}{l}4 . \\
4 .\end{array}$ \\
\hline
\end{tabular}

YRT 1347. 1431. 1484, 1504, 1490, 1447. 1371. 1266. 1138. 1010.

PHOENIX, AZ

33.43 N LATITUDE

SURFACE TILT (DEGREES OP FROM HORIZONTAL)

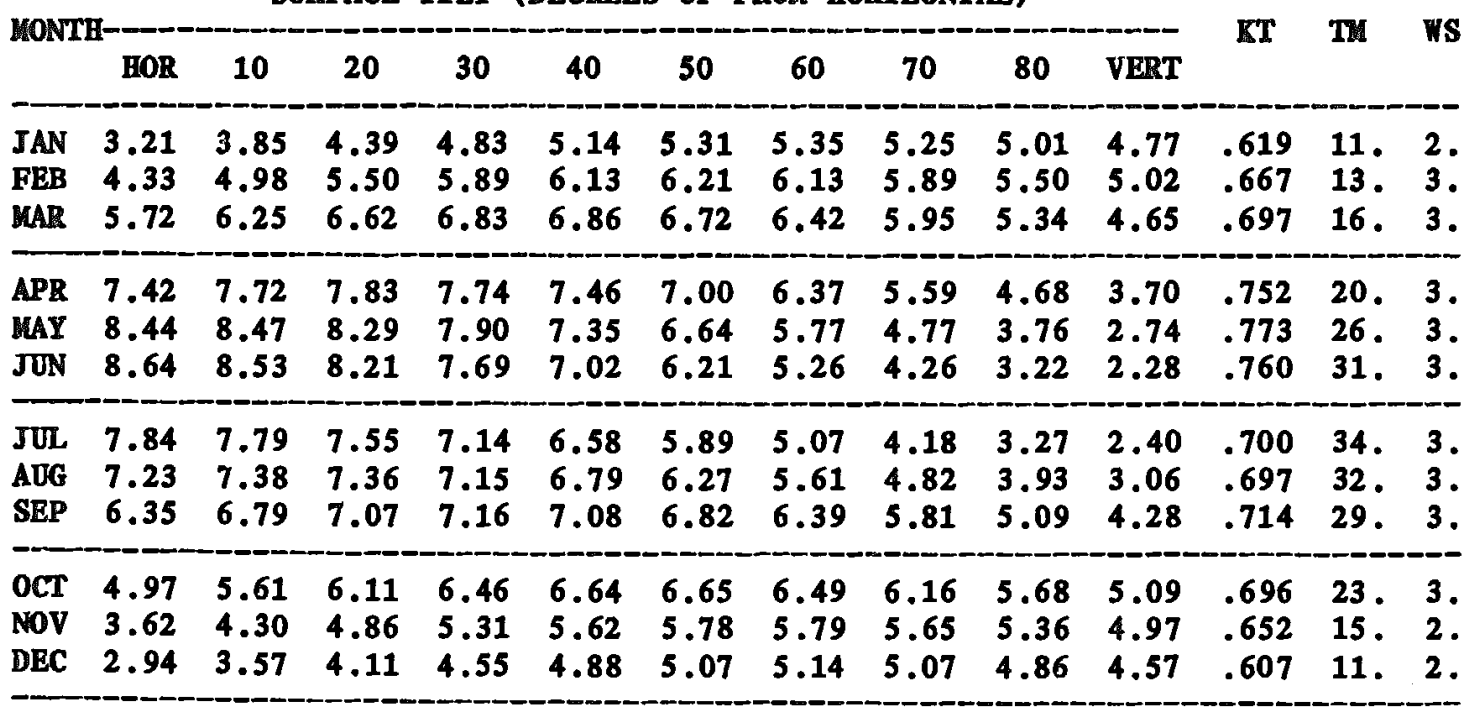

YRT 2153. 2290. 2371. 2393. 2358. 2268. 2121. 1926. 1692, 1443. 


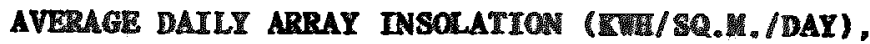
CLEARNESS NUMBER (KT), MEAN MONTULY TEWPERATURE (TM, DEG $\mathrm{C}$ ) AND WONTLLY AVERAGE WIND SPECD (W, H

POCATELLO, ID

42.92 N LATITUDE

SURFACE TILT (DEGREES UP FROM HORIZONTAL)

\begin{tabular}{|c|c|c|c|c|c|c|c|c|c|c|c|c|}
\hline ONI & HOR & 10 & 20 & 30 & 40 & 50 & 60 & 70 & 80 & VERT & $T$ & 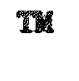 \\
\hline $\begin{array}{l}\text { JAN } \\
\text { FBB } \\
\text { MAR }\end{array}$ & $\begin{array}{l}1.70 \\
2.77 \\
4.33\end{array}$ & $\begin{array}{l}2.12 \\
3.29 \\
4.85\end{array}$ & $\begin{array}{l}2.48 \\
3.74 \\
5.26\end{array}$ & $\begin{array}{l}2.79 \\
4.09 \\
5.54\end{array}$ & $\begin{array}{l}3.02 \\
4.33 \\
5.69\end{array}$ & $\begin{array}{l}3.18 \\
4.47 \\
5.69\end{array}$ & $\begin{array}{l}3.26 \\
4.50 \\
5.55\end{array}$ & $\begin{array}{l}3.26 \\
4.41 \\
5.27\end{array}$ & $\begin{array}{l}3.17 \\
4.21 \\
4.87\end{array}$ & $\begin{array}{l}3.04 \\
3.93 \\
4.38\end{array}$ & $\begin{array}{r}.471 \\
.552 \\
.614\end{array}$ & $\begin{array}{r}-4 \\
-2 \\
2\end{array}$ \\
\hline $\begin{array}{l}\mathbf{M P R} \\
\mathbf{M A Y} \\
\mathbf{W N}\end{array}$ & $\begin{array}{l}5.74 \\
7.19 \\
.7 .82\end{array}$ & $\begin{array}{l}6.08 \\
7.36 \\
7.87\end{array}$ & $\begin{array}{l}6.28 \\
7.36 \\
7.75\end{array}$ & $\begin{array}{l}6.33 \\
7.18 \\
7.45\end{array}$ & $\begin{array}{l}6.23 \\
6.84 \\
6.97\end{array}$ & $\begin{array}{l}5.98 \\
6.36 \\
6.37\end{array}$ & $\begin{array}{l}5.60 \\
5.75 \\
5.65\end{array}$ & $\begin{array}{l}5.09 \\
5.01 \\
4.81\end{array}$ & $\begin{array}{l}4.47 \\
4.16 \\
3.93\end{array}$ & $\begin{array}{l}3.77 \\
3.34 \\
3.04\end{array}$ & $\begin{array}{l}.622 \\
.668 \\
.681\end{array}$ & $\begin{array}{r}7 . \\
13 \\
17 .\end{array}$ \\
\hline $\begin{array}{l}\text { JUL } \\
\text { AUG } \\
\text { SEP }\end{array}$ & $\begin{array}{l}8.19 \\
7.06 \\
5.58\end{array}$ & $\begin{array}{l}8.32 \\
7.39 \\
6.15\end{array}$ & $\begin{array}{l}8.25 \\
7.53 \\
6.57\end{array}$ & $\begin{array}{l}7.97 \\
7.49 \\
6.83\end{array}$ & $\begin{array}{l}7.51 \\
7.27 \\
6.91\end{array}$ & $\begin{array}{l}6.90 \\
6.88 \\
6.82\end{array}$ & $\begin{array}{l}6.15 \\
6.34 \\
6.55\end{array}$ & $\begin{array}{l}5.26 \\
5.64 \\
6.12\end{array}$ & $\begin{array}{r}4.30 \\
4.82 \\
5.54\end{array}$ & $\begin{array}{l}3.33 \\
3.94 \\
4.86\end{array}$ & $\begin{array}{r}.732 \\
.711 \\
.703\end{array}$ & $\begin{array}{l}22 . \\
21 \\
15\end{array}$ \\
\hline $\begin{array}{l}\text { DCT } \\
\text { WOV } \\
\text { OEC }\end{array}$ & $\begin{array}{l}3.79 \\
2.17 \\
1.50\end{array}$ & $\begin{array}{l}4.46 \\
2.70 \\
1.91\end{array}$ & $\begin{array}{l}5.01 \\
3.16 \\
2.26\end{array}$ & $\begin{array}{l}5.44 \\
3.54 \\
2.57\end{array}$ & $\begin{array}{l}5.73 \\
3.84 \\
2.80\end{array}$ & $\begin{array}{l}5.87 \\
4.03 \\
2.97\end{array}$ & $\begin{array}{l}5.86 \\
4.12 \\
3.06\end{array}$ & $\begin{array}{l}5.69 \\
4.10 \\
3.07\end{array}$ & $\begin{array}{l}5.38 \\
3.98 \\
3.00\end{array}$ & $\begin{array}{l}4.97 \\
3.88 \\
2.99\end{array}$ & $\begin{array}{r}.657 \\
.543 \\
.465\end{array}$ & $\begin{array}{r}2 . \\
-3\end{array}$ \\
\hline
\end{tabular}

YKT 1763. 1905. 2000, 2047, 2044, 1995. 1899. 1757, 1576. 1382.

PORTLAND; ME

43.65 N LATITUDE

SURFACE TILT (DEGREES UP FROM HORIZONTAL)

MONTH-

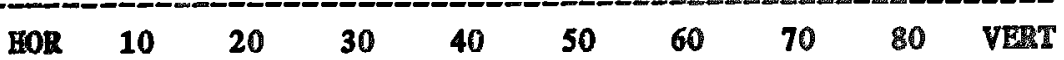

\begin{tabular}{llllllllllllll}
\hline JAN & 1.42 & 1.75 & 2.03 & 2.27 & 2.45 & 2.57 & 2.63 & 2.63 & 2.55 & 2.54 & .407 & -5. & 4. \\
FEB & 2.14 & 2.50 & 2.79 & 3.03 & 3.19 & 3.27 & 3.28 & 3.20 & 3.05 & 2.87 & .437 & -4. & 4. \\
MAR & 3.06 & 3.36 & 3.59 & 3.74 & 3.80 & 3.78 & 3.67 & 3.48 & 3.21 & 2.92 & .440 & 0. & 5. \\
\hline APR & 4.11 & 4.31 & 4.42 & 4.43 & 4.35 & 4.17 & 3.91 & 3.57 & 3.15 & 2.72 & .449 & 6. & 5. \\
MAY & 4.94 & 5.03 & 5.02 & 4.90 & 4.67 & 4.37 & 3.98 & 3.52 & 3.00 & 2.49 & .460 & 12. & 4. \\
JUN & 5.40 & 5.42 & 5.34 & 5.15 & 4.85 & 4.48 & 4.03 & 3.50 & 2.95 & 2.40 & .470 & 17. & 4. \\
\hline JUL & 5.23 & 5.29 & 5.24 & 5.07 & 4.80 & 4.45 & 4.03 & 3.53 & 2.98 & 2.44 & .468 & 20. & 3. \\
AUG & 4.60 & 4.76 & 4.82 & 4.77 & 4.62 & 4.38 & 4.05 & 3.64 & 3.17 & 2.68 & .465 & 19. & 3. \\
SEP & 3.65 & 3.93 & 4.13 & 4.24 & 4.26 & 4.17 & 4.00 & 3.73 & 3.39 & 3.01 & .465 & 15. & 4. \\
\hline OCT & 2.59 & 2.96 & 3.25 & 3.48 & 3.62 & 3.67 & 3.64 & 3.52 & 3.32 & 3.09 & .458 & 9. & 4. \\
NOV & 1.45 & 1.73 & 1.97 & 2.16 & 2.31 & 2.40 & 2.43 & 2.40 & 2.32 & 2.29 & .374 & 4. & 4. \\
DEC & 1.14 & 1.41 & 1.64 & 1.84 & 1.99 & 2.09 & 2.14 & 2.14 & 2.09 & 2.09 & .367 & -3. & 4. \\
\hline IRT & 1211. & 1293 & 1347. & 1372 & 1367. & 1333. & 1271 & 1182 & 1069 & 959. & &
\end{tabular}


AVERAGE DAILY ARRAY INSOLATION (EWH/SQ.M./DAY), CLEARNESS NUMBER (ET), MRAN MONTHLY TEMPERATURE (TM, DEG C), AND UONTMLY AVERAGE WIND SPEED (WS, M/S)

PRESCOTT, AZ

SURFACE TILT (DEGREES UP FROM HORIZONTAL)

34.65 N LATITUDE

\begin{tabular}{|c|c|c|c|c|c|c|c|c|c|c|c|c|}
\hline & HOR & 10 & 20 & 30 & 40 & 50 & 60 & 70 & 80 & VERT & & \\
\hline $\begin{array}{l}\text { JAN } \\
\text { FEB } \\
\text { MAR }\end{array}$ & $\begin{array}{l}3.20 \\
4.20 \\
5.61\end{array}$ & $\begin{array}{l}3.89 \\
4.86 \\
6.15\end{array}$ & $\begin{array}{l}4.47 \\
5.40 \\
6.53\end{array}$ & $\begin{array}{l}4.95 \\
5.80 \\
6.76\end{array}$ & $\begin{array}{l}5.29 \\
6.05 \\
6.81\end{array}$ & $\begin{array}{l}5.50 \\
6.15 \\
6.70\end{array}$ & $\begin{array}{l}5.56 \\
6.09 \\
6.41\end{array}$ & $\begin{array}{l}5.47 \\
5.87 \\
5.97\end{array}$ & $\begin{array}{l}5.24 \\
5.50 \\
5.38\end{array}$ & $\begin{array}{l}4.98 \\
5.04 \\
4.71\end{array}$ & $\begin{array}{l}.641 \\
.666 \\
.694\end{array}$ & $\begin{array}{l}3 . \\
4 . \\
7 .\end{array}$ \\
\hline $\begin{array}{l}\text { APR } \\
\text { MAY } \\
\text { JUN }\end{array}$ & $\begin{array}{l}7.17 \\
8.29 \\
8.71\end{array}$ & $\begin{array}{l}7.48 \\
8.35 \\
8.62\end{array}$ & $\begin{array}{l}7.60 \\
8.19 \\
8.33\end{array}$ & $\begin{array}{l}7.53 \\
7.83 \\
7.82\end{array}$ & $\begin{array}{l}7.29 \\
7.31 \\
7.17\end{array}$ & $\begin{array}{l}6.86 \\
6.63 \\
6.37\end{array}$ & $\begin{array}{l}6.27 \\
5.79 \\
5.42\end{array}$ & $\begin{array}{l}5.53 \\
4.82 \\
4.41\end{array}$ & $\begin{array}{l}4.66 \\
3.83 \\
3.38\end{array}$ & $\begin{array}{l}3.74 \\
2.83 \\
2.41\end{array}$ & $\begin{array}{l}.732 \\
.760 \\
.764\end{array}$ & $\begin{array}{l}11 \\
16 \\
22\end{array}$ \\
\hline $\begin{array}{l}\text { JUL } \\
\text { AUG } \\
\text { SRP }\end{array}$ & $\begin{array}{l}7.28 \\
6.60 \\
6.16\end{array}$ & $\begin{array}{l}7.25 \\
6.74 \\
6.60\end{array}$ & $\begin{array}{l}7.06 \\
6.73 \\
6.89\end{array}$ & $\begin{array}{l}6.70 \\
6.57 \\
7.00\end{array}$ & $\begin{array}{l}6.20 \\
6.25 \\
6.94\end{array}$ & $\begin{array}{l}5.59 \\
5.80 \\
6.70\end{array}$ & $\begin{array}{l}4.86 \\
5.22 \\
6.30\end{array}$ & $\begin{array}{l}4.04 \\
4.53 \\
5.75\end{array}$ & $\begin{array}{l}3.22 \\
3.74 \\
5.06\end{array}$ & $\begin{array}{l}2.41 \\
2.96 \\
4.28\end{array}$ & $\begin{array}{l}.650 \\
.639 \\
.701\end{array}$ & $\begin{array}{l}24 \\
22 \\
20\end{array}$ \\
\hline $\begin{array}{l}\text { OCT } \\
\text { NOV } \\
\text { DEC }\end{array}$ & $\begin{array}{l}4.87 \\
3.59 \\
2.92\end{array}$ & $\begin{array}{l}5.52 \\
4.31 \\
3.60\end{array}$ & $\begin{array}{l}6.04 \\
4.91 \\
4.19\end{array}$ & $\begin{array}{r}6.41 \\
.5 .40 \\
4.67\end{array}$ & $\begin{array}{l}6.61 \\
5.74 \\
5.03\end{array}$ & $\begin{array}{l}6.64 \\
5.93 \\
5.26\end{array}$ & $\begin{array}{l}6.50 \\
5.96 \\
5.35\end{array}$ & $\begin{array}{l}6.19 \\
5.84 \\
5.29\end{array}$ & $\begin{array}{l}5.73 \\
5.56 \\
5.10\end{array}$ & $\begin{array}{l}5.15 \\
5.17 \\
4.80\end{array}$ & $\begin{array}{l}.697 \\
.670 \\
.630\end{array}$ & $\begin{array}{c}14 . \\
7 . \\
3 .\end{array}$ \\
\hline
\end{tabular}

YKT 2088. 2233. 2323. 2355. 2332. 2253. 2119. 1936. 1713. 1472.

RED BLUFF, CA

SURFACE TILT (DEGREES UP FROM HORIZONTAL)

40.15 N LATITUDE MONTH

$\begin{array}{llllllllll}\text { HOR } & 10 & 20 & 30 & 40 & 50 & 60 & 70 & 80 & \text { VERT }\end{array}$

KT TM VS

\begin{tabular}{llllllllllllll}
\hline JAN & 1.80 & 2.17 & 2.50 & 2.76 & 2.96 & 3.09 & 3.13 & 3.10 & 3.00 & 2.85 & .441 & 7. & 4. \\
FEB & 2.81 & 3.25 & 3.63 & 3.91 & 4.10 & 4.19 & 4.18 & 4.06 & 3.84 & 3.56 & .514 & 10. & 4. \\
WAR & 4.27 & 4.72 & 5.06 & 5.27 & 5.36 & 5.32 & 5.15 & 4.85 & 4.45 & 3.96 & .576 & 11. & 5. \\
\hline APR & 6.02 & 6.34 & 6.51 & 6.52 & 6.38 & 6.09 & 5.66 & 5.10 & 4.43 & 3.69 & .638 & 15. & 4. \\
MAY & 7.48 & 7.62 & 7.58 & 7.35 & 6.94 & 6.42 & 5.74 & 4.94 & 4.06 & 3.18 & .691 & 20. & 4. \\
JUN & 8.19 & 8.21 & 8.04 & 7.67 & 7.12 & 6.46 & 5.66 & 4.73 & 3.81 & 2.85 & .715 & 25. & 4. \\
\hline JUL & 8.42 & 8.50 & 8.37 & 8.04 & 7.51 & 6.85 & 6.04 & 5.09 & 4.10 & 3.09 & .751 & 28. & 4. \\
AUG & 7.29 & 7.57 & 7.67 & 7.58 & 7.31 & 6.87 & 6.28 & 5.53 & 4.66 & 3.75 & .722 & 27. & 4. \\
SEP & 5.82 & 6.35 & 6.73 & 6.94 & 6.98 & 6.84 & 6.52 & 6.05 & 5.43 & 4.71 & .706 & 23. & 4. \\
\hline OCT & 3.87 & 4.46 & 4.94 & 5.30 & 5.53 & 5.62 & 5.56 & 5.36 & 5.03 & 4.61 & .625 & 18. & 4. \\
NOV & 2.23 & 2.68 & 3.06 & 3.38 & 3.61 & 3.75 & 3.79 & 3.74 & 3.60 & 3.51 & .500 & 11. & 4. \\
DEC & 1.61 & 1.98 & 2.30 & 2.56 & 2.76 & 2.90 & 2.96 & 2.95 & 2.86 & 2.85 & .435 & 7. & 4.
\end{tabular}

YRT 1823. 1946. 2023. 2050. 2027. 1960. 1847. 1689. 1498. 1295. 
TABLE I (Continged)

AVERAGE DAILY ARRAY INSOLATION (KWT/SQ.M./DAY),

CLEARNESS NUABER (IT), MEAN MONITLI TEMPERMTURE (TI, DEG C), AND MOATHLY AVERAGE VIIND SPEED (WS, M/S)

REDMOND, OR

44.27 N LATITUDE

SURFACE TILT (DEGREES UP FROM HORIZONTAL)

\begin{tabular}{llllllllllllll} 
MONTH- & HOR & 10 & 20 & 30 & 40 & 50 & 60 & 70 & 80 & VERT & & & \\
\hline JAN & 1.55 & 1.94 & 2.29 & 2.59 & 2.82 & 2.98 & 3.06 & 3.06 & 2.99 & 2.98 & .458 & 0. & 3. \\
FEB & 2.44 & 2.89 & 3.27 & 3.58 & 3.80 & 3.92 & 3.95 & 3.88 & 3.71 & 3.48 & .507 & 2. & 3. \\
MAR & 3.75 & 4.20 & 4.54 & 4.78 & 4.90 & 4.91 & 4.79 & 4.56 & 4.22 & 3.82 & .547 & 3. & 3. \\
\hline APR & 5.31 & 5.63 & 5.82 & 5.87 & 5.79 & 5.57 & 5.23 & 4.78 & 4.22 & 3.60 & .582 & 6. & 3. \\
MAY & 6.55 & 6.72 & 6.73 & 6.59 & 6.29 & 5.87 & 5.34 & 4.69 & 3.94 & 3.21 & .612 & 11. & 3. \\
JUN & 7.21 & 7.27 & 7.18 & 6.92 & 6.51 & 5.98 & 5.34 & 4.59 & 3.79 & 3.00 & .629 & 15. & 3. \\
\hline JUL & 7.71 & 7.84 & 7.79 & 7.56 & 7.15 & 6.60 & 5.92 & 5.11 & 4.22 & 3.34 & .690 & 20. & 3. \\
AUG & 6.52 & 6.83 & 6.97 & 6.95 & 6.76 & 6.42 & 5.94 & 5.32 & 4.58 & 3.79 & .662 & 18. & 3. \\
SEP & 4.99 & 5.50 & 5.88 & 6.11 & 6.19 & 6.12 & 5.89 & 5.52 & 5.02 & 4.44 & .642 & 14. & 3. \\
\hline OCT & 3.15 & 3.67 & 4.11 & 4.45 & 4.67 & 4.78 & 4.77 & 4.64 & 4.39 & 4.08 & .566 & 9.3. & 3. \\
NOV & 1.81 & 2.23 & 2.60 & 2.91 & 3.15 & 3.31 & 3.38 & 3.37 & 3.27 & 3.20 & .479 & 4. & 3. \\
DEC & 1.34 & 1.71 & 2.04 & 2.32 & 2.54 & 2.70 & 2.78 & 2.80 & 2.75 & 2.73 & .445 & 1. & 3. \\
\hline
\end{tabular}

$\operatorname{IRT} 1596.1720,1805.1847 .1844 .1801 .1717 .1592 .1433 .1267$.

RICHOND, VA

$37.50 \mathrm{~N}$ LATITUDE

SURFACE TILT (DEGREES UP FROM HORIZONTAL)

MONTH-

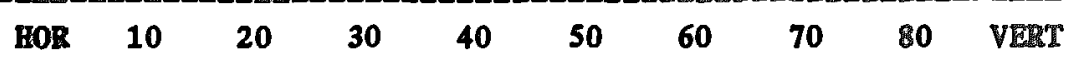

\begin{tabular}{llllllllllllll}
\hline JAN & 1.99 & 2.36 & 2.68 & 2.93 & 3.11 & 3.22 & 3.25 & 3.19 & 3.06 & 2.97 & .440 & 3. & 4. \\
FEB & 2.76 & 3.13 & 3.44 & 3.66 & 3.80 & 3.85 & 3.80 & 3.67 & 3.45 & 3.20 & .469 & 4. & 4. \\
MAR & 3.82 & 4.14 & 4.36 & 4.49 & 4.52 & 4.44 & 4.26 & 3.99 & 3.62 & 3.23 & .493 & 8. & 4. \\
\hline APR & 4.94 & 5.13 & 5.21 & 5.17 & 5.01 & 4.75 & 4.39 & 3.94 & 3.41 & 2.86 & .513 & 14. & 4. \\
MAY & 5.55 & 5.60 & 5.52 & 5.33 & 5.03 & 4.64 & 4.15 & 3.59 & 2.99 & 2.42 & .511 & 19. & 4. \\
JUN & 5.90 & 5.88 & 5.73 & 5.46 & 5.08 & 4.62 & 4.07 & 3.46 & 2.84 & 2.23 & .516 & 23. & 3. \\
\hline JUL & 5.59 & 5.60 & 5.48 & 5.25 & 4.92 & 4.50 & 4.00 & 3.42 & 2.84 & 2.25 & .499 & 25. & 3. \\
AUG & 5.05 & 5.17 & 5.17 & 5.06 & 4.85 & 4.54 & 4.14 & 3.66 & 3.11 & 2.56 & .494 & 24. & 3. \\
SEP & 4.24 & 4.51 & 4.68 & 4.75 & 4.71 & 4.56 & 4.31 & 3.96 & 3.54 & 3.07 & .499 & 21. & 3. \\
\hline OCT & 3.26 & 3.64 & 3.93 & 4.14 & 4.25 & 4.26 & 4.17 & 3.98 & 3.70 & 3.37 & .495 & 14. & 3. \\
NOV & 2.31 & 2.71 & 3.05 & 3.32 & 3.51 & 3.62 & 3.63 & 3.56 & 3.40 & 3.29 & .472 & 9. & 3. \\
DEC & 1.79 & 2.15 & 2.46 & 2.71 & 2.90 & 3.02 & 3.06 & 3.02 & 2.92 & 2.88 & .430 & 4. & 3. \\
\hline
\end{tabular}

YRT 1437. 1523. 1574. 1591. 1573. 1521. 1437, 1321, 1182, 1043. 
AVERAGE DAILY ARRAY INSOLATION (ITH/SQ.M./DAY), CLEARNESS NUMBER (KT), MEAN MONTHLY TZMPERATURE (TM, DEG C), AND MONTHLY AVERAGE WIND SPEED (TS, M/S)

ROCHESTER, NY

SURFACE TILT (DEGREES UP FROM HORIZONTAL)

43.12 N LATITUDE

\begin{tabular}{|c|c|c|c|c|c|c|c|c|c|c|c|c|}
\hline \multicolumn{2}{|c|}{ MONTH- } & & & & & & & & & & \multirow{2}{*}{$\mathbf{K T}$} & \multirow{2}{*}{$\mathbf{T M}$} \\
\hline & HOR & 10 & 20 & 30 & 40 & 50 & 60 & 70 & 80 & VERT & & \\
\hline $\begin{array}{l}\text { JAN } \\
\text { FEB } \\
\text { MAR }\end{array}$ & $\begin{array}{l}1.15 \\
1.76 \\
2.85\end{array}$ & $\begin{array}{l}1.35 \\
2.00 \\
3.11\end{array}$ & $\begin{array}{l}1.53 \\
2.19 \\
3.30\end{array}$ & $\begin{array}{l}1.67 \\
2.34 \\
3.43\end{array}$ & $\begin{array}{l}1.78 \\
2.44 \\
3.47\end{array}$ & $\begin{array}{l}1.84 \\
2.48 \\
3.44\end{array}$ & $\begin{array}{l}1.87 \\
2.46 \\
3.33\end{array}$ & $\begin{array}{l}1.84 \\
2.39 \\
3.15\end{array}$ & $\begin{array}{l}1.78 \\
2.27 \\
2.91\end{array}$ & $\begin{array}{l}1.81 \\
2.13 \\
2.63\end{array}$ & $\begin{array}{l}.321 \\
.353 \\
.406\end{array}$ & $\begin{array}{l}-4 \\
-4\end{array}$ \\
\hline $\begin{array}{l}\text { APR } \\
\text { MAY } \\
\text { JUN }\end{array}$ & $\begin{array}{l}4.22 \\
5.06 \\
5.73\end{array}$ & $\begin{array}{l}4.43 \\
5.16 \\
5.75\end{array}$ & $\begin{array}{l}4.53 \\
5.14 \\
5.66\end{array}$ & $\begin{array}{l}4.54 \\
5.01 \\
5.46\end{array}$ & $\begin{array}{l}4.45 \\
4.77 \\
5.13\end{array}$ & $\begin{array}{l}4.27 \\
4.46 \\
4.72\end{array}$ & $\begin{array}{l}4.00 \\
4.06 \\
4.24\end{array}$ & $\begin{array}{l}3.64 \\
3.58 \\
3.67\end{array}$ & $\begin{array}{l}3.21 \\
3.04 \\
3.08\end{array}$ & $\begin{array}{l}2.76 \\
2.52 \\
2.48\end{array}$ & $\begin{array}{r}459 \\
.471 \\
.499\end{array}$ & $\begin{array}{r}8 . \\
14 . \\
19\end{array}$ \\
\hline $\begin{array}{l}\text { JUL } \\
\text { AUG } \\
\text { SEP }\end{array}$ & $\begin{array}{l}5.61 \\
4.79 \\
3.65\end{array}$ & $\begin{array}{l}5.67 \\
4.95 \\
3.93\end{array}$ & $\begin{array}{l}5.61 \\
5.01 \\
4.13\end{array}$ & $\begin{array}{l}5.43 \\
4.96 \\
4.23\end{array}$ & $\begin{array}{l}5.14 \\
4.80 \\
4.24\end{array}$ & $\begin{array}{l}4.76 \\
4.54 \\
4.15\end{array}$ & $\begin{array}{l}4.29 \\
4.20 \\
3.97\end{array}$ & $\begin{array}{l}3.74 \\
3.77 \\
3.70\end{array}$ & $\begin{array}{l}3.15 \\
3.27 \\
3.35\end{array}$ & $\begin{array}{l}2.56 \\
2.75 \\
2.98\end{array}$ & $\begin{array}{r}.502 \\
.483 \\
.462\end{array}$ & $\begin{array}{l}22 \\
21 \\
17\end{array}$ \\
\hline $\begin{array}{l}\text { OCI } \\
\text { NOV } \\
\text { DEC }\end{array}$ & $\begin{array}{r}2.46 \\
1.27 \\
.88\end{array}$ & $\begin{array}{l}2.79 \\
1.48 \\
1.02\end{array}$ & $\begin{array}{l}3.05 \\
1.65 \\
1.14\end{array}$ & $\begin{array}{l}3.24 \\
1.79 \\
1.23\end{array}$ & $\begin{array}{l}3.36 \\
1.88 \\
1.30\end{array}$ & $\begin{array}{l}3.40 \\
1.94 \\
1.34\end{array}$ & $\begin{array}{l}3.36 \\
1.95 \\
1.35\end{array}$ & $\begin{array}{l}3.25 \\
1.92 \\
1.33\end{array}$ & $\begin{array}{l}3.05 \\
1.84 \\
1.29\end{array}$ & $\begin{array}{l}2.84 \\
1.83 \\
1.32\end{array}$ & $\begin{array}{r}.429 \\
.321 \\
.276\end{array}$ & $\begin{array}{r}11 . \\
5 . \\
-2 .\end{array}$ \\
\hline
\end{tabular}

YRT 1203. 1269. 1309. 1320. 1303. 1259. 1190. 1095.981. 870.

ROCK SPRINGS, WY

SURFACE TILT (DEGREES UP FROM HORIZONTAL)

$41.60 \mathrm{~N}$ LATITUDE

\begin{tabular}{llllllllllllll} 
MONTH- & HOR & 10 & 20 & 30 & 40 & 50 & 60 & 70 & 80 & VERT & & & WS \\
\hline JAN & 2.32 & 2.95 & 3.51 & 3.98 & 4.35 & 4.60 & 4.73 & 4.73 & 4.61 & 4.46 & .604 & -6. & 6. \\
FEB & 3.43 & 4.11 & 4.70 & 5.16 & 5.49 & 5.68 & 5.72 & 5.60 & 5.34 & 4.99 & .655 & -5. & 6. \\
MAR & 4.83 & 5.42 & 5.88 & 6.19 & 6.35 & 6.35 & 6.18 & 5.86 & 5.39 & 4.84 & .668 & -2. & 6. \\
\hline APR & 6.13 & 6.48 & 6.69 & 6.72 & 6.60 & 6.33 & 5.90 & 5.34 & 4.66 & 3.92 & .657 & 4. & 6. \\
MAY & 7.39 & 7.55 & 7.53 & 7.33 & 6.95 & 6.44 & 5.79 & 5.02 & 4.15 & 3.29 & .685 & 10. & 5. \\
JUN & 8.11 & 8.15 & 8.01 & 7.67 & 7.15 & 6.51 & 5.74 & 4.84 & 3.92 & 2.98 & .708 & 16. & 5. \\
\hline JUL & 8.03 & 8.13 & 8.03 & 7.74 & 7.26 & 6.66 & 5.91 & 5.04 & 4.10 & 3.16 & .717 & 20. & 4. \\
AUG & 7.06 & 7.36 & 7.48 & 7.42 & 7.17 & 6.77 & 6.21 & 5.51 & 4.68 & 3.80 & .706 & 19. & 4. \\
SEP & 5.77 & 6.35 & 6.76 & 7.00 & 7.07 & 6.95 & 6.66 & 6.20 & 5.59 & 4.88 & .715 & 13. & 5. \\
\hline OCT & 4.11 & 4.82 & 5.41 & 5.86 & 6.16 & 6.30 & 6.27 & 6.08 & 5.73 & 5.27 & .689 & 7. & 5. \\
NOV & 2.61 & 3.26 & 3.83 & 4.31 & 4.67 & 4.91 & 5.02 & 4.99 & 4.83 & 4.69 & .618 & -1. & 5. \\
DEC & 2.05 & 2.66 & 3.20 & 3.66 & 4.03 & 4.29 & 4.43 & 4.46 & 4.36 & 4.30 & .593 & -5. & 5. \\
\hline
\end{tabular}

YRT 1884. 2048. 2162. 2223. 2229. 2184. 2085. 1936. 1743. 1537. 
TABLE I (Continued)

AVERAGE DAILY ARRAY INSOLATION (EWVISO.M./DAY),

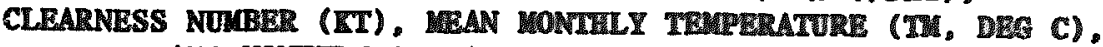
AND MONTILY AVERACE WIND SEEED (WS, M/S)

ROSWELL, NH

33.30 N LATITUDE

SURFACE TILT (DEGREES UP FROM HORTZONTAL)

\begin{tabular}{|c|c|c|c|c|c|c|c|c|c|c|c|c|c|}
\hline 2 & HOR & 10 & 20 & 30 & 40 & 50 & 60 & 70 & 80 & VERT & $\mathbf{r}$ & TIIII & \\
\hline $\begin{array}{l}\text { JAN } \\
\text { FEB } \\
\text { MAR }\end{array}$ & $\begin{array}{l}3.30 \\
4.33 \\
5.70\end{array}$ & $\begin{array}{l}3.96 \\
4.97 \\
6.22\end{array}$ & $\begin{array}{l}4.52 \\
5.49 \\
6.59\end{array}$ & $\begin{array}{l}4.97 \\
5.87 \\
6.79\end{array}$ & $\begin{array}{l}5.29 \\
6.11 \\
6.82\end{array}$ & $\begin{array}{l}5.47 \\
6.19 \\
6.68\end{array}$ & $\begin{array}{l}5.51 \\
6.10 \\
6.37\end{array}$ & $\begin{array}{l}5.41 \\
5.87 \\
5.91\end{array}$ & $\begin{array}{l}5.16 \\
5.48 \\
5.30\end{array}$ & $\begin{array}{l}4.82 \\
4.99 \\
4.61\end{array}$ & $\begin{array}{l}.632 \\
.664 \\
.693\end{array}$ & $\begin{array}{r}4 . \\
11 \\
11\end{array}$ & $\begin{array}{l}4 . \\
5 . \\
5 .\end{array}$ \\
\hline $\begin{array}{l}\text { APR } \\
\text { UAY } \\
\text { JUN }\end{array}$ & $\begin{array}{l}6.99 \\
7.76 \\
8.23\end{array}$ & $\begin{array}{l}7.25 \\
7.78 \\
8.13\end{array}$ & $\begin{array}{l}7.34 \\
7.61 \\
7.82\end{array}$ & $\begin{array}{l}7.25 \\
7.26 \\
7.33\end{array}$ & $\begin{array}{l}6.99 \\
6.76 \\
6.71\end{array}$ & $\begin{array}{l}6.56 \\
6.12 \\
5.94\end{array}$ & $\begin{array}{l}5.97 \\
5.33 \\
5.05\end{array}$ & $\begin{array}{l}5.24 \\
4.43 \\
4.10\end{array}$ & $\begin{array}{l}4.40 \\
3.53 \\
3.13\end{array}$ & $\begin{array}{l}3.51 \\
2.61 \\
2.24\end{array}$ & $\begin{array}{r}.708 \\
.710 \\
.724\end{array}$ & $\begin{array}{l}17 . \\
22 . \\
27\end{array}$ & 6 \\
\hline $\begin{array}{l}\text { JUL } \\
\text { AUG } \\
\text { SEP }\end{array}$ & $\begin{array}{l}7.69 \\
7.07 \\
6.03\end{array}$ & $\begin{array}{l}7.64 \\
7.21 \\
6.43\end{array}$ & $\begin{array}{l}7.41 \\
7.18 \\
6.67\end{array}$ & $\begin{array}{l}7.00 \\
6.98 \\
6.75\end{array}$ & $\begin{array}{l}6.46 \\
6.63 \\
6.67\end{array}$ & $\begin{array}{l}5.78 \\
6.12 \\
6.42\end{array}$ & $\begin{array}{l}4.98 \\
5.48 \\
6.01\end{array}$ & $\begin{array}{l}4.11 \\
4.71 \\
5.46\end{array}$ & $\begin{array}{l}3.22 \\
3.85 \\
4.79\end{array}$ & $\begin{array}{l}2.37 \\
3.00 \\
4.03\end{array}$ & $\begin{array}{l}.687 \\
.682 \\
.677\end{array}$ & $\begin{array}{l}28 . \\
27 . \\
23 .\end{array}$ & 4 \\
\hline $\begin{array}{l}C T \\
O V \\
E C\end{array}$ & $\begin{array}{l}4.82 \\
3.56 \\
3.00\end{array}$ & $\begin{array}{l}5.42 \\
4.21 \\
3.65\end{array}$ & $\begin{array}{l}5.89 \\
4.76 \\
4.21\end{array}$ & $\begin{array}{l}6.21 \\
5.19 \\
4.66\end{array}$ & $\begin{array}{l}6.38 \\
5.48 \\
4.99\end{array}$ & $\begin{array}{l}6.38 \\
5.63 \\
5.19\end{array}$ & $\begin{array}{l}6.22 \\
5.64 \\
5.26\end{array}$ & $\begin{array}{l}5.91 \\
5.50 \\
5.19\end{array}$ & $\begin{array}{l}5.44 \\
5.22 \\
4.98\end{array}$ & $\begin{array}{l}4.87 \\
4.83 \\
4.68\end{array}$ & $\begin{array}{r}.672 \\
.639 \\
.617\end{array}$ & $\begin{array}{r}17 . \\
9 .\end{array}$ & 4. \\
\hline
\end{tabular}

YEX 2085. 2218. 2297. 2320. 2289. 2204. 2065. 1879. 1655. 1414.

SALEM, OR .

44.92 N LATITUDE

SURFACE TILT (DEGREES UP FROM HORIZONTAL)

\begin{tabular}{lccccccccccccc} 
MONTH- & \multicolumn{1}{c}{ HOR } & 10 & 20 & 30 & 40 & 50 & 60 & 70 & 80 & VERT & & & WS \\
\hline JAN & 1.05 & 1.25 & 1.42 & 1.57 & 1.68 & 1.75 & 1.78 & 1.76 & 1.71 & 1.65 & .320 & 4. & 4. \\
FEB & 1.85 & 2.15 & 2.40 & 2.60 & 2.73 & 2.81 & 2.81 & 2.75 & 2.63 & 2.47 & .394 & 6. & 3. \\
MAR & 2.99 & 3.30 & 3.54 & 3.70 & 3.77 & 3.76 & 3.66 & 3.48 & 3.23 & 2.93 & .441 & 7. & 4. \\
\hline APR & 4.32 & 4.55 & 4.69 & 4.71 & 4.64 & 4.46 & 4.20 & 3.84 & 3.40 & 2.93 & .477 & 9. & 3. \\
MAY & 5.48 & 5.60 & 5.61 & 5.49 & 5.25 & 4.91 & 4.48 & 3.97 & 3.38 & 2.79 & .512 & 13. & 3. \\
JUN & 5.83 & 5.87 & 5.80 & 5.60 & 5.29 & 4.88 & 4.59 & 3.83 & 3.22 & 2.61 & .508 & 16. & 3. \\
\hline JUL & 6.75 & 6.86 & 6.82 & 6.63 & 6.28 & 5.82 & 5.25 & 4.57 & 3.81 & 3.07 & .605 & 19. & 3. \\
JG & 5.59 & 5.84 & 5.95 & 5.92 & 5.76 & 5.47 & 5.08 & 4.57 & 3.96 & 3.33 & .570 & 19. & 3. \\
SEP & 4.19 & 4.57 & 4.86 & 5.03 & 5.08 & 5.01 & 4.82 & 4.52 & 4.11 & 3.66 & .544 & 16. & 3. \\
\hline OCT & 2.42 & 2.77 & 3.06 & 3.28 & 3.42 & 3.48 & 3.46 & 3.35 & 3.17 & 2.96 & .444 & 11. & 3. \\
NOV & 1.30 & 1.54 & 1.76 & 1.94 & 2.07 & 2.15 & 2.18 & 2.16 & 2.09 & 2.06 & .353 & 7. & 3. \\
DEC & .87 & 1.05 & 1.20 & 1.32 & 1.42 & 1.48 & 1.51 & 1.50 & 1.46 & 1.48 & .302 & 5. & 4.
\end{tabular}

YET 1301. 1383. 1436. 1456. 1443. 1400. 1328. 1227. 1100. 972. 
AVERAGE DATLY ARRAY INSOLATION (KWH/SQ.K./DAY), CLEARNESS NUMBER (IT), MEAN MONIHLY TEMPERATURE (TM, DEG C), AND MONTRII AVERAGE WIND SPEED (WS, M/S)

SALT LAKE CITY, UT

SURFACE TILT (DEGREES UP FROM HORIZONTAL)

\begin{tabular}{|c|c|c|c|c|c|c|c|c|c|c|c|c|}
\hline & BOR & 10 & 20 & 30 & 40 & 50 & 60 & 70 & 80 & VERT & & $\boldsymbol{U}$ \\
\hline $\begin{array}{l}\text { JAN } \\
\text { FRB } \\
\text { MAR }\end{array}$ & $\begin{array}{l}2.02 \\
3.11 \\
4.59\end{array}$ & $\begin{array}{l}2.49 \\
3.66 \\
5.11\end{array}$ & $\begin{array}{l}2.90 \\
4.13 \\
5.51\end{array}$ & $\begin{array}{l}3.24 \\
4.49 \\
5.77\end{array}$ & $\begin{array}{l}3.50 \\
4.74 \\
5.89\end{array}$ & $\begin{array}{l}3.67 \\
4.87 \\
5.87\end{array}$ & $\begin{array}{l}3.74 \\
4.88 \\
5.70\end{array}$ & $\begin{array}{l}3.72 \\
4.76 \\
5.38\end{array}$ & $\begin{array}{l}3 . \\
4 . \\
4 .\end{array}$ & $\begin{array}{l}0 \\
2 \\
3\end{array}$ & $\begin{array}{l}.508 \\
.580 \\
.626\end{array}$ & $\begin{array}{r}-2 \\
1 \\
5\end{array}$ \\
\hline $\begin{array}{l}\text { MAY } \\
\text { JUY }\end{array}$ & $\begin{array}{l}5.97 \\
7.45 \\
8.07\end{array}$ & $\begin{array}{l}6.30 \\
7.59 \\
8.09\end{array}$ & $\begin{array}{l}6.47 \\
7.56 \\
7.94\end{array}$ & $\begin{array}{l}6.50 \\
7.34 \\
7.58\end{array}$ & $\begin{array}{l}6.36 \\
6.95 \\
7.05\end{array}$ & $\begin{array}{l}6.08 \\
6.43 \\
6.42\end{array}$ & $\begin{array}{l}5.66 \\
5.77 \\
5.64\end{array}$ & $\begin{array}{l}5.11 \\
4.98 \\
4.74\end{array}$ & & & & $\begin{array}{l}9 . \\
15 \\
20\end{array}$ \\
\hline $\begin{array}{l}\text { JUL } \\
\text { ADG } \\
\text { SEP }\end{array}$ & $\begin{array}{l}8.16 \\
7.11 \\
5.81\end{array}$ & $\begin{array}{l}8.25 \\
7.39 \\
6.36\end{array}$ & $\begin{array}{l}8.14 \\
7.50 \\
6.76\end{array}$ & $\begin{array}{l}7.83 \\
7.42 \\
6.98\end{array}$ & $\begin{array}{l}7.33 \\
7.16 \\
7.03\end{array}$ & $\begin{array}{l}6.70 \\
6.74 \\
6.90\end{array}$ & $\begin{array}{l}5.93 \\
6.17 \\
6.60\end{array}$ & $\begin{array}{l}5.02 \\
5.46 \\
6.13\end{array}$ & & & $\begin{array}{l}.728 \\
.707 \\
.711\end{array}$ & $\begin{array}{l}25 . \\
24 . \\
18 .\end{array}$ \\
\hline $\begin{array}{l}\text { OCT } \\
\text { NOV } \\
\text { DEC }\end{array}$ & $\begin{array}{l}4.07 \\
2.48 \\
1.80\end{array}$ & $\begin{array}{l}4.74 \\
3.05 \\
2.25\end{array}$ & $\begin{array}{l}5.29 \\
3.55 \\
2.65\end{array}$ & $\begin{array}{l}5.71 \\
3.95 \\
2.99\end{array}$ & $\begin{array}{l}5.98 \\
4.26 \\
3.25\end{array}$ & $\begin{array}{l}6.10 \\
4.45 \\
3.43\end{array}$ & $\begin{array}{l}6.05 \\
4.53 \\
3.52\end{array}$ & $\begin{array}{l}5.86 \\
4.49 \\
3.52\end{array}$ & $\begin{array}{l}5.50 \\
4.33 \\
3.42\end{array}$ & $\begin{array}{l}5.05 \\
4.22 \\
3.39\end{array}$ & $\begin{array}{r}.669 \\
.570 \\
.499\end{array}$ & $\begin{array}{r}11 \\
4 \\
-1\end{array}$ \\
\hline
\end{tabular}

YRT 1848. 1989. 2083. 2125. 2115. 2059. 1953. 1799. 1609. 1407.

SAN ANGELO, TX

SURFACE TILT (DEGREES UP FROM HORIZONTAL)

\begin{tabular}{llllllllllllll}
\multicolumn{1}{l}{ HONTH- } & HOR & 10 & 20 & 30 & 40 & 50 & 60 & 70 & 80 & VERT & & & WS \\
\hline JAN & 3.03 & 3.53 & 3.96 & 4.28 & 4.51 & 4.61 & 4.61 & 4.49 & 4.25 & 3.95 & .547 & 8. & 5. \\
FEB & 3.81 & 4.28 & 4.65 & 4.91 & 5.05 & 5.06 & 4.96 & 4.73 & 4.39 & 3.98 & .560 & 10. & 5. \\
UAR & 5.07 & 5.45 & 5.70 & 5.82 & 5.80 & 5.65 & 5.35 & 4.94 & 4.41 & 3.82 & .601 & 14. & 6. \\
\hline APR & 5.83 & 6.00 & 6.02 & 5.91 & 5.67 & 5.30 & 4.81 & 4.23 & 3.55 & 2.86 & .584 & 19. & 5. \\
UAY & 6.40 & 6.39 & 6.23 & 5.93 & 5.52 & 4.99 & 4.37 & 3.66 & 2.95 & 2.25 & .586 & 23. & 5. \\
JUN & 6.89 & 6.78 & 6.52 & 6.11 & 5.59 & 4.97 & 4.24 & 3.49 & 2.70 & 2.01 & .609 & 27. & 5. \\
\hline JUL & 6.69 & 1.62 & 6.40 & 6.04 & 5.57 & 4.98 & 4.30 & 3.57 & 2.81 & 2.11 & .599 & 28. & 4. \\
AUG & 6.20 & 6.28 & 6.23 & 6.03 & 5.70 & 5.25 & 4.69 & 4.03 & 3.30 & 2.58 & .594 & 28. & 4. \\
SEP & 5.06 & 5.33 & 5.47 & 5.49 & 5.38 & 5.15 & 4.80 & 4.34 & 3.79 & 3.19 & .558 & 24. & 4. \\
\hline OCT & 4.22 & 4.65 & 4.98 & 5.19 & 5.27 & 5.23 & 5.06 & 4.77 & 4.37 & 3.90 & .563 & 19. & 4. \\
NOV & 3.28 & 3.79 & 4.21 & 4.53 & 4.73 & 4.82 & 4.78 & 4.63 & 4.37 & 4.02 & .558 & 12. & 4. \\
DEC & 2.81 & 3.33 & 3.77 & 4.11 & 4.36 & 4.49 & 4.51 & 4.42 & 4.21 & 3.95 & .543 & 8. & 5. \\
\hline
\end{tabular}

YRT 1805. 1901. 1952, 1958. 1921. 1840. 1717. 1559. 1370. 1173. 
TABLE I (Continad)

AVRRAGE DAILY ARRAY INSOLATION (IN⿴囗十)/SQ.M./DAT). CLEARNESS NUMBER (IT), HRAN MONTHLY TEMPERATURE (TH, DRE C). AND MONTHLY AVERAGE WIND SPEED (WS, /S)

SAN JUAN, PR

18.43 N LATITUDE

SURFACE TILT (DEGREES UP FROM HORIZONTAL)

\begin{tabular}{|c|c|c|c|c|c|c|c|c|c|c|c|c|}
\hline & BOR & 10 & 20 & 30 & 40 & 50 & 60 & 70 & 80 & VERT & & III \\
\hline $\begin{array}{l}\text { JAN } \\
\text { FEB } \\
\text { MAR }\end{array}$ & $\begin{array}{l}4.18 \\
4.85 \\
5.63\end{array}$ & $\begin{array}{l}4.63 \\
5.22 \\
5.85\end{array}$ & $\begin{array}{l}4.98 \\
5.47 \\
5.93\end{array}$ & $\begin{array}{l}5.20 \\
5.60 \\
5.88\end{array}$ & $\begin{array}{l}5.30 \\
5.59 \\
5.69\end{array}$ & $\begin{array}{l}5.28 \\
5.45 \\
5.36\end{array}$ & $\begin{array}{l}5.12 \\
5.18 \\
4.92\end{array}$ & $\begin{array}{l}4.85 \\
4.79 \\
4.37\end{array}$ & $\begin{array}{l}4.46 \\
4.30 \\
3.73\end{array}$ & $\begin{array}{l}3.99 \\
3.73 \\
3.05\end{array}$ & $\begin{array}{r}.553 \\
.569 \\
.589\end{array}$ & $\begin{array}{l}24 \\
24 \\
25\end{array}$ \\
\hline $\begin{array}{l}\text { APR } \\
\text { MAY } \\
\text { JUN }\end{array}$ & $\begin{array}{l}5.96 \\
5.72 \\
5.73\end{array}$ & $\begin{array}{l}5.96 \\
5.57 \\
5.51\end{array}$ & $\begin{array}{l}5.82 \\
5.30 \\
5.17\end{array}$ & $\begin{array}{l}5.56 \\
4.92 \\
4.74\end{array}$ & $\begin{array}{l}5.17 \\
4.44 \\
4.21\end{array}$ & $\begin{array}{l}4.68 \\
3.88 \\
3.60\end{array}$ & $\begin{array}{l}4.08 \\
3.26 \\
2.98\end{array}$ & $\begin{array}{l}3.41 \\
2.62 \\
2.34\end{array}$ & $\begin{array}{l}2.70 \\
2.00 \\
1.78\end{array}$ & $\begin{array}{l}1.99 \\
1.57 \\
1.58\end{array}$ & $\begin{array}{l}.575 \\
.536 \\
.534\end{array}$ & $\begin{array}{l}26 . \\
26 . \\
27 .\end{array}$ \\
\hline $\begin{array}{l}\text { JUL } \\
\text { AUG } \\
\text { SEP }\end{array}$ & $\begin{array}{l}5.91 \\
5.79 \\
5.27\end{array}$ & $\begin{array}{l}5.70 \\
5.72 \\
5.38\end{array}$ & $\begin{array}{l}5.38 \\
5.52 \\
5.37\end{array}$ & $\begin{array}{l}4.95 \\
5.21 \\
5.23\end{array}$ & $\begin{array}{l}4.42 \\
4.78 \\
4.99\end{array}$ & $\begin{array}{l}3.80 \\
4.25 \\
4.63\end{array}$ & $\begin{array}{l}3.16 \\
3.65 \\
4.18\end{array}$ & $\begin{array}{l}2.47 \\
2.99 \\
3.64\end{array}$ & $\begin{array}{l}1.87 \\
2.32 \\
3.04\end{array}$ & $\begin{array}{l}1.58 \\
1.71 \\
2.41\end{array}$ & $\begin{array}{l}.551 \\
.551 \\
.532\end{array}$ & $\begin{array}{l}27 . \\
27 . \\
27 .\end{array}$ \\
\hline $\begin{array}{l}\text { OCT } \\
\text { NOV } \\
\text { DEC }\end{array}$ & $\begin{array}{l}4.78 \\
4.31 \\
3.90\end{array}$ & $\begin{array}{l}5.06 \\
4.74 \\
4.34\end{array}$ & $\begin{array}{l}5.23 \\
5.05 \\
4.69\end{array}$ & $\begin{array}{l}5.27 \\
5.24 \\
4.93\end{array}$ & $\begin{array}{l}5.20 \\
5.31 \\
5.04\end{array}$ & $\begin{array}{l}5.00 \\
5.25 \\
5.04\end{array}$ & $\begin{array}{l}4.70 \\
5.07 \\
4.92\end{array}$ & $\begin{array}{l}4.29 \\
4.77 \\
4.68\end{array}$ & $\begin{array}{l}3.79 \\
4.36 \\
4.33\end{array}$ & $\begin{array}{l}3.23 \\
3.87 \\
3.20\end{array}$ & $\begin{array}{l}.535 \\
.551 \\
.535\end{array}$ & $\begin{array}{l}27 . \\
26 . \\
25 .\end{array}$ \\
\hline
\end{tabular}

YRT 1887. 1937, 1943. 1907, 1828, 1708, 1556. 1373.1173.990.

SCOTTSBLUFF, NE

41.87 N LATTTUDE

SURFACE TILT (DEGRERS UP FROM HORIZONTAL)

\begin{tabular}{llllllllllllll} 
MONTH- & HOR & 10 & 20 & 30 & 40 & 50 & 60 & 70 & 80 & VERT & & & WS \\
\hline JAN & 2.13 & 2.69 & 3.19 & 3.60 & 3.93 & 4.15 & 4.26 & 4.26 & 4.15 & 4.12 & .563 & -4. & 5. \\
FEB & 2.99 & 3.54 & 4.01 & 4.38 & 4.64 & 4.78 & 4.80 & 4.70 & 4.47 & 4.16 & .576 & -1. & 5. \\
MAR & 4.12 & 4.58 & 4.93 & 5.17 & 5.28 & 5.26 & 5.11 & 4.84 & 4.45 & 3.99 & .574 & 2. & 6. \\
\hline APR & 5.26 & 5.54 & 5.69 & 5.71 & 5.59 & 5.36 & 5.00 & 4.54 & 3.97 & 3.35 & .565 & 8. & 6. \\
MAY & 6.09 & 6.21 & 6.18 & 6.02 & 5.72 & 5.32 & 4.81 & 4.20 & 3.52 & 2.85 & .565 & 14. & 5. \\
JUN & 7.05 & 7.08 & 6.96 & 6.67 & 6.24 & 5.71 & 5.06 & 4.32 & 3.55 & 2.76 & .615 & 19. & 5. \\
\hline JUL & 7.20 & 7.28 & 7.20 & 6.94 & 6.53 & 6.00 & 5.35 & 4.59 & 3.78 & 2.97 & .643 & 23. & 4. \\
AUG & 6.30 & 6.55 & 6.65 & 6.59 & 6.37 & 6.01 & 5.53 & 4.92 & 4.20 & 3.45 & .631 & 22. & 4. \\
SEP & 5.04 & 5.49 & 5.82 & 6.01 & 6.04 & 5.94 & 5.68 & 5.29 & 4.77 & 4.19 & .626 & 16. & 4. \\
\hline OCT & 3.61 & 4.19 & 4.66 & 5.02 & 5.26 & 5.36 & 5.32 & 5.15 & 4.85 & 4.47 & .609 & 9. & 4. \\
NOV & 2.28 & 2.81 & 3.28 & 3.66 & 3.95 & 4.14 & 4.22 & 4.19 & 4.05 & 3.94 & .547 & 2. & 5. \\
DEC & 1.81 & 2.32 & 2.77 & 3.15 & 3.45 & 3.66 & 3.78 & 3.79 & 3.71 & 3.66 & .532 & -3. & 5.
\end{tabular}

YRT 1642. 1775. 1868. 1915. 1917. 1877. 1792. 1666. 1504. 1335. 
AVERAGE DAILY ARRAY INSOLATION (KWW/SQ.M./DAY), CLEARNESS NUMBER (ET), MEAN MONIHLY TEMPERATURE (TM, DEG C), AND MONTELI AVERAGE WIND SPEED (IS, M/S)

SEATTLE/TACOMA, WA

47.45 N LATITUDE

SURFACE TILT (DEGREES UP FROM HORIZONTAL)

\begin{tabular}{|c|c|c|c|c|c|c|c|c|c|c|c|c|c|}
\hline & & & & & & & & & & & & 4 & \\
\hline & HOR & 10 & 20 & 30 & 40 & 50 & 60 & 70 & 80 & VERT & & & \\
\hline $\begin{array}{l}\text { JAN } \\
\text { FEB } \\
\text { MAR }\end{array}$ & $\begin{array}{r}.83 \\
1.55 \\
2.69\end{array}$ & $\begin{array}{r}.98 \\
1.81 \\
2.99\end{array}$ & $\begin{array}{l}1.12 \\
2.04 \\
3.23\end{array}$ & $\begin{array}{l}1.23 \\
2.21 \\
3.39\end{array}$ & $\begin{array}{l}1.32 \\
2.34 \\
3.47\end{array}$ & $\begin{array}{l}1.37 \\
2.41 \\
3.48\end{array}$ & $\begin{array}{l}1.40 \\
2.42 \\
3.41\end{array}$ & $\begin{array}{l}1.39 \\
2.38 \\
3.25\end{array}$ & $\begin{array}{l}1.35 \\
2.28 \\
3.03\end{array}$ & $\begin{array}{l}1.41 \\
2.26 \\
2.79\end{array}$ & $\begin{array}{r}.290 \\
.363 \\
.419\end{array}$ & $\begin{array}{l}4 . \\
6 . \\
6 .\end{array}$ & $\begin{array}{l}5 . \\
4 . \\
5 .\end{array}$ \\
\hline $\begin{array}{l}\text { APR } \\
\text { MAY } \\
\text { JUN }\end{array}$ & $\begin{array}{l}4.09 \\
5.42 \\
5.66\end{array}$ & $\begin{array}{l}4.33 \\
5.57 \\
5.73\end{array}$ & $\begin{array}{l}4.47 \\
5.60 \\
5.67\end{array}$ & $\begin{array}{l}4.52 \\
5.51 \\
5.51\end{array}$ & $\begin{array}{l}4.47 \\
5.30 \\
5.23\end{array}$ & $\begin{array}{l}4.32 \\
4.98 \\
4.85\end{array}$ & $\begin{array}{l}4.08 \\
4.57 \\
4.39\end{array}$ & $\begin{array}{l}3.76 \\
4.08 \\
3.86\end{array}$ & $\begin{array}{l}3.36 \\
3.50 \\
3.27\end{array}$ & $\begin{array}{l}2.93 \\
2.92 \\
2.69\end{array}$ & $\begin{array}{r}.462 \\
.511 \\
.495\end{array}$ & $\begin{array}{r}9 . \\
12 . \\
15 .\end{array}$ & $\begin{array}{l}4 . \\
4 . \\
4 .\end{array}$ \\
\hline $\begin{array}{l}\text { JUL } \\
\text { AUG } \\
\text { SEP }\end{array}$ & $\begin{array}{l}6.24 \\
5.06 \\
3.64\end{array}$ & $\begin{array}{l}6.37 \\
5.30 \\
3.98\end{array}$ & $\begin{array}{l}6.35 \\
5.42 \\
4.24\end{array}$ & $\begin{array}{l}6.20 \\
5.42 \\
4.40\end{array}$ & $\begin{array}{l}5.91 \\
5.29 \\
4.45\end{array}$ & $\begin{array}{l}5.50 \\
5.05 \\
4.41\end{array}$ & $\begin{array}{l}5.01 \\
4.71 \\
4.26\end{array}$ & $\begin{array}{l}4.41 \\
4.28 \\
4.01\end{array}$ & $\begin{array}{l}3.72 \\
3.75 \\
3.68\end{array}$ & $\begin{array}{l}3.06 \\
3.17 \\
3.29\end{array}$ & $\begin{array}{r}.562 \\
.525 \\
.492\end{array}$ & $\begin{array}{l}18 \\
17 \\
15\end{array}$ & $\begin{array}{l}4 . \\
4 . \\
4 .\end{array}$ \\
\hline $\begin{array}{l}\text { OCT } \\
\text { NOV } \\
\text { DEC }\end{array}$ & $\begin{array}{r}2.05 \\
1.07 \\
.67\end{array}$ & $\begin{array}{r}2.36 \\
1.28 \\
.79\end{array}$ & $\begin{array}{r}2.61 \\
1.47 \\
.90\end{array}$ & $\begin{array}{r}2.81 \\
1.62 \\
.99\end{array}$ & $\begin{array}{l}2.94 \\
1.74 \\
1.06\end{array}$ & $\begin{array}{l}3.00 \\
1.82 \\
1.11\end{array}$ & $\begin{array}{l}2.99 \\
1.85 \\
1.13\end{array}$ & $\begin{array}{l}2.91 \\
1.84 \\
1.12\end{array}$ & $\begin{array}{l}2.76 \\
1.79 \\
1.09\end{array}$ & $\begin{array}{l}2.58 \\
1.74 \\
1.10\end{array}$ & $\begin{array}{r}.404 \\
.330 \\
.270\end{array}$ & $\begin{array}{r}11 . \\
7 . \\
5 .\end{array}$ & 4. \\
\hline
\end{tabular}

YRT 1189. 1265. 1315. 1335. 1326. 1288. 1225. 1135. 1022. 911.

SHERIDAN, WY

44.77 N LATITUDE

SURFACE TILT (DEGREES UP FROM HORIZONTAL)

\begin{tabular}{|c|c|c|c|c|c|c|c|c|c|c|c|c|c|}
\hline YONT & & & & & & & & & & & BT & $\mathbf{T}$ & WS \\
\hline & HOR & 10 & 20 & 30 & 40 & 50 & 60 & 70 & 80 & VERT & & & \\
\hline $\begin{array}{l}\text { JAN } \\
\text { FEB } \\
\text { MAR }\end{array}$ & $\begin{array}{l}1.63 \\
2.48 \\
3.80\end{array}$ & $\begin{array}{l}2.07 \\
2.96 \\
4.26\end{array}$ & $\begin{array}{l}2.47 \\
3.38 \\
4.63\end{array}$ & $\begin{array}{l}2.80 \\
3.71 \\
4.88\end{array}$ & $\begin{array}{l}3.07 \\
3.95 \\
5.02\end{array}$ & $\begin{array}{l}3.25 \\
4.09 \\
5.03\end{array}$ & $\begin{array}{l}3.35 \\
4.13 \\
4.92\end{array}$ & $\begin{array}{l}3.37 \\
4.06 \\
4.69\end{array}$ & $\begin{array}{l}3.29 \\
3.89 \\
4.35\end{array}$ & $\begin{array}{l}3.19 \\
3.65 \\
3.94\end{array}$ & $\begin{array}{r}.495 \\
.525 \\
.559\end{array}$ & $\begin{array}{l}-6 \\
-3 \\
0\end{array}$ & $\begin{array}{l}3 . \\
4 . \\
4 .\end{array}$ \\
\hline $\begin{array}{l}\text { APR } \\
\text { MAY } \\
\text { JUN }\end{array}$ & $\begin{array}{l}4.85 \\
5.93 \\
6.80\end{array}$ & $\begin{array}{l}5.13 \\
6.08 \\
6.86\end{array}$ & $\begin{array}{l}5.29 \\
6.09 \\
6.77\end{array}$ & $\begin{array}{l}5.34 \\
5.96 \\
6.54\end{array}$ & $\begin{array}{l}5.26 \\
5.70 \\
6.16\end{array}$ & $\begin{array}{l}5.07 \\
5.33 \\
5.67\end{array}$ & $\begin{array}{l}4.76 \\
4.85 \\
5.08\end{array}$ & $\begin{array}{l}4.36 \\
4.28 \\
4.39\end{array}$ & $\begin{array}{l}3.85 \\
3.63 \\
3.65\end{array}$ & $\begin{array}{l}3.30 \\
2.98 \\
2.91\end{array}$ & $\begin{array}{r}.534 \\
.555 \\
.593\end{array}$ & $\begin{array}{r}6 . \\
12 . \\
17 .\end{array}$ & $\begin{array}{l}4 . \\
4 . \\
4 .\end{array}$ \\
\hline $\begin{array}{l}\text { JUL } \\
\text { AUG } \\
\text { SEP }\end{array}$ & $\begin{array}{l}7.34 \\
6.32 \\
4.73\end{array}$ & $\begin{array}{l}7.47 \\
6.63 \\
5.21\end{array}$ & $\begin{array}{l}7.43 \\
6.77 \\
5.56\end{array}$ & $\begin{array}{l}7.21 \\
6.75 \\
5.77\end{array}$ & $\begin{array}{l}6.83 \\
6.57 \\
5.85\end{array}$ & $\begin{array}{l}6.31 \\
6.25 \\
5.78\end{array}$ & $\begin{array}{l}5.68 \\
5.79 \\
5.57\end{array}$ & $\begin{array}{l}4.93 \\
5.20 \\
5.23\end{array}$ & $\begin{array}{l}4.09 \\
4.49 \\
4.76\end{array}$ & $\begin{array}{l}3.26 \\
3.73 \\
4.22\end{array}$ & $\begin{array}{r}.658 \\
.644 \\
.613\end{array}$ & $\begin{array}{l}22 . \\
21 . \\
14 .\end{array}$ & $\begin{array}{l}3 . \\
3 . \\
3 .\end{array}$ \\
\hline $\begin{array}{l}\text { OCT } \\
\text { NOV } \\
\text { DEC }\end{array}$ & $\begin{array}{l}3.17 \\
1.86 \\
1.39\end{array}$ & $\begin{array}{l}3.71 \\
2.33 \\
1.80\end{array}$ & $\begin{array}{l}4.17 \\
2.73 \\
2.17\end{array}$ & $\begin{array}{l}4.52 \\
3.07 \\
2.48\end{array}$ & $\begin{array}{l}4.76 \\
3.34 \\
2.73\end{array}$ & $\begin{array}{l}4.88 \\
3.52 \\
2.91\end{array}$ & $\begin{array}{l}4.88 \\
3.60 \\
3.02\end{array}$ & $\begin{array}{l}4.75 \\
3.60 \\
3.04\end{array}$ & $\begin{array}{l}4.51 \\
3.50 \\
2.99\end{array}$ & $\begin{array}{l}4.20 \\
3.42 \\
2.97\end{array}$ & $\begin{array}{r}.577 \\
.505 \\
.476\end{array}$ & $\begin{array}{r}8 \\
0 \\
-4\end{array}$ & $\begin{array}{l}3 . \\
3 . \\
3 .\end{array}$ \\
\hline
\end{tabular}


AVERAGE DAILY ARRAY INSOLATION (KWE/SQ.M./DAY), CleARNESS NOUBER (IT), MRAN MONIHLY TEMPEATUER (TM, DRG C), AND HONTRLY AVERAGE VI'D SPEED (WE, M/\$)

SHREVEPORT, LA

32.47 N LATITUDE

SURFACE TILT (DEGREES UP FROM HORIZONTAL)

\begin{tabular}{|c|c|c|c|c|c|c|c|c|c|c|c|c|c|}
\hline ON. & HOR & 10 & 20 & 30 & 40 & 50 & 60 & 70 & 80 & VERT & $\mathbf{E T}$ & $\mathrm{TH}$ & 78 \\
\hline $\begin{array}{l}\text { JAN } \\
\text { FEB } \\
\text { MAR }\end{array}$ & $\begin{array}{l}2.40 \\
3.27 \\
4.23\end{array}$ & $\begin{array}{l}2.76 \\
3.65 \\
4.52\end{array}$ & $\begin{array}{l}3.07 \\
3.95 \\
4.72\end{array}$ & $\begin{array}{l}3.30 \\
4.16 \\
4.81\end{array}$ & $\begin{array}{l}3.46 \\
4.27 \\
4.78\end{array}$ & $\begin{array}{l}3.53 \\
4.28 \\
4.65\end{array}$ & $\begin{array}{l}3.52 \\
4.19 \\
4.42\end{array}$ & $\begin{array}{l}3.42 \\
4.00 \\
4.08\end{array}$ & $\begin{array}{l}3.24 \\
3.71 \\
3.66\end{array}$ & $\begin{array}{l}3.04 \\
3.40 \\
3.22\end{array}$ & $\begin{array}{r}.448 \\
.493 \\
.509\end{array}$ & $\begin{array}{r}8 . \\
10 . \\
14 .\end{array}$ & $\begin{array}{l}4 . \\
5 . \\
5 .\end{array}$ \\
\hline $\begin{array}{l}\text { APR } \\
\text { MAY } \\
\text { JUN }\end{array}$ & $\begin{array}{l}5.08 \\
5.95 \\
6.51\end{array}$ & $\begin{array}{l}5.22 \\
5.95 \\
6.42\end{array}$ & $\begin{array}{l}5.25 \\
5.81 \\
6.19\end{array}$ & $\begin{array}{l}5.16 \\
5.55 \\
5.82\end{array}$ & $\begin{array}{l}4.95 \\
5.18 \\
5.35\end{array}$ & $\begin{array}{l}4.65 \\
4.72 \\
4.78\end{array}$ & $\begin{array}{l}4.24 \\
4.15 \\
4.12\end{array}$ & $\begin{array}{l}3.75 \\
3.51 \\
3.42\end{array}$ & $\begin{array}{l}3.19 \\
2.86 \\
2.70\end{array}$ & $\begin{array}{l}2.62 \\
2.24 \\
2.05\end{array}$ & $\begin{array}{r}.512 \\
.544 \\
.574\end{array}$ & $\begin{array}{l}19 . \\
22 . \\
26 .\end{array}$ & $\begin{array}{l}5 . \\
4 .\end{array}$ \\
\hline $\begin{array}{l}\text { JUL } \\
\text { AUG } \\
\text { SEP }\end{array}$ & $\begin{array}{l}6.34 \\
5.92 \\
4.89\end{array}$ & $\begin{array}{l}6.29 \\
6.01 \\
5.16\end{array}$ & $\begin{array}{l}6.10 \\
5.97 \\
5.31\end{array}$ & $\begin{array}{l}5.77 \\
5.79 \\
5.33\end{array}$ & $\begin{array}{l}5.34 \\
5.49 \\
5.24\end{array}$ & $\begin{array}{l}4.81 \\
5.08 \\
5.02\end{array}$ & $\begin{array}{l}4.17 \\
4.55 \\
4.69\end{array}$ & $\begin{array}{l}3.49 \\
3.94 \\
4.26\end{array}$ & $\begin{array}{l}2.79 \\
3.25 \\
3.74\end{array}$ & $\begin{array}{l}2.13 \\
2.58 \\
3.17\end{array}$ & $\begin{array}{r}.568 \\
.569 \\
.545\end{array}$ & $\begin{array}{l}28 \\
27 . \\
24 .\end{array}$ & $\begin{array}{l}3 . \\
3 . \\
3 .\end{array}$ \\
\hline $\begin{array}{l}\text { OCT } \\
\text { NOV } \\
\text { DEC }\end{array}$ & $\begin{array}{l}4.11 \\
2.92 \\
2.30\end{array}$ & $\begin{array}{l}4.55 \\
3.36 \\
2.69\end{array}$ & $\begin{array}{l}4.89 \\
3.73 \\
3.02\end{array}$ & $\begin{array}{l}5.11 \\
4.00 \\
3.28\end{array}$ & $\begin{array}{l}5.20 \\
4.18 \\
3.47\end{array}$ & $\begin{array}{l}5.17 \\
4.25 \\
3.57\end{array}$ & $\begin{array}{l}5.02 \\
4.23 \\
3.58\end{array}$ & $\begin{array}{l}4.74 \\
4.10 \\
3.50\end{array}$ & $\begin{array}{l}4.36 \\
3.87 \\
3.34\end{array}$ & $\begin{array}{l}3.50 \\
3.57 \\
3.14\end{array}$ & $\begin{array}{r}.565 \\
.512 \\
.460\end{array}$ & $\begin{array}{r}19 . \\
13 . \\
9 .\end{array}$ & 3 \\
\hline
\end{tabular}

IXT 1642, 1724, 1766, 1768, 1732, 1658, 1547, 1405, 1237, 1065.

SIOUX CITY. IA

42.40 N LATITUDE

SURFACE TILT (DEGREES UP FROM HORIZONTAL)

\begin{tabular}{|c|c|c|c|c|c|c|c|c|c|c|c|c|c|}
\hline & $\mathrm{BOR}$ & 10 & 20 & 30 & 40 & 50 & 60 & 70 & 0 & VERT & $\mathbf{T}$ & IM & \\
\hline $\begin{array}{l}\mathbf{A N} \\
\mathbf{E B} \\
\mathbf{A R}\end{array}$ & $\begin{array}{l}1.79 \\
2.65 \\
3.69\end{array}$ & $\begin{array}{l}2.23 \\
3.11 \\
4.08\end{array}$ & $\begin{array}{l}2.61 \\
3.50 \\
4.38\end{array}$ & $\begin{array}{l}2.93 \\
3.81 \\
4.57\end{array}$ & $\begin{array}{l}8 \\
2 \\
6\end{array}$ & & $\begin{array}{l}3.42 \\
4.14 \\
4.50\end{array}$ & $\begin{array}{l}1 \\
5 \\
6\end{array}$ & $\begin{array}{l}2 \\
6 \\
3\end{array}$ & & $\begin{array}{l}.485 \\
.519 \\
.519\end{array}$ & $\begin{array}{r}-8 \\
-4 \\
i\end{array}$ & $\begin{array}{l}5 . \\
5 . \\
6 .\end{array}$ \\
\hline $\begin{array}{l}\text { PR } \\
\text { AYY } \\
\text { UN }\end{array}$ & $\begin{array}{l}4.97 \\
5.99 \\
6.69\end{array}$ & $\begin{array}{l}5.23 \\
6.11 \\
6.73\end{array}$ & $\begin{array}{l}5.37 \\
6.09 \\
6.61\end{array}$ & $\begin{array}{l}5.39 \\
5.93 \\
6.36\end{array}$ & $\begin{array}{l}5.29 \\
5.64 \\
5.95\end{array}$ & $\begin{array}{l}5.07 \\
5.25 \\
5.46\end{array}$ & $\begin{array}{l}4.74 \\
4.76 \\
4.86\end{array}$ & $\begin{array}{l}4.30 \\
4.17 \\
4.16\end{array}$ & $\begin{array}{l}8 \\
0 \\
4\end{array}$ & $\begin{array}{l}1 \\
5 \\
1\end{array}$ & $\begin{array}{r}.537 \\
.556 \\
.584\end{array}$ & $\begin{array}{l}10 . \\
16 . \\
22\end{array}$ & $\begin{array}{l}6 . \\
5 . \\
5 .\end{array}$ \\
\hline $\begin{array}{l}\text { JUL } \\
\text { SUG } \\
\text { SEP }\end{array}$ & $\begin{array}{l}6.69 \\
5.82 \\
4.48\end{array}$ & $\begin{array}{l}6.77 \\
6.04 \\
4.86\end{array}$ & $\begin{array}{l}6.69 \\
6.13 \\
5.13\end{array}$ & $\begin{array}{l}6.47 \\
6.07 \\
5.28\end{array}$ & $\begin{array}{l}6.09 \\
5.87 \\
5.31\end{array}$ & $\begin{array}{l}5.62 \\
5.55 \\
5.21\end{array}$ & $\begin{array}{l}5.03 \\
5.12 \\
4.99\end{array}$ & 4. & $\begin{array}{l}3.60 \\
3.92 \\
4.20\end{array}$ & $\begin{array}{l}2.86 \\
3.25 \\
3.70\end{array}$ & $\begin{array}{l}.598 \\
.584 \\
.561\end{array}$ & $\begin{array}{l}24 . \\
23 . \\
17 .\end{array}$ & \\
\hline $\begin{array}{l}\mathrm{CI} \\
\text { OV } \\
\mathrm{EC}\end{array}$ & $\begin{array}{l}3.27 \\
2.03 \\
1.48\end{array}$ & $\begin{array}{l}3.77 \\
2.47 \\
1.86\end{array}$ & $\begin{array}{l}4.19 \\
2.86 \\
2.19\end{array}$ & $\begin{array}{l}4.50 \\
3.19 \\
2.47\end{array}$ & $\begin{array}{l}3.43 \\
2.69\end{array}$ & $\begin{array}{l}4.79 \\
3.58 \\
2.84\end{array}$ & $\begin{array}{l}4.75 \\
3.65 \\
2.92\end{array}$ & $\begin{array}{l}4.60 \\
3.62 \\
2.92\end{array}$ & $\begin{array}{l}4.33 \\
3.50 \\
2.85\end{array}$ & $\begin{array}{l}4.01 \\
3.41 \\
2.83\end{array}$ & $\begin{array}{l}.559 \\
.496 \\
.446\end{array}$ & $\begin{array}{r}11 \\
2 \\
-5\end{array}$ & 5. \\
\hline
\end{tabular}

YRT 1510. 1623. 1698, 1734. 1730. 1688. 1609. 1492. 1345. 1190. 


\section{TABLE I (Continned)}

AVERAGE DAILY ARRAY INSOLATION (KWH/SQ.M./DAY), CLEARNESS NUMBER (KT), MRAN MONTHLY TEMPRRATURE (TM, DEG C), AND MONTHLY AVERAGE WIND SPEED (WS, M/S)

SPOKANE, WA

SURFACE TILT (DEGREES UP FROM HORIZONTAL)

47.63 N LA:TTUDE

\begin{tabular}{|c|c|c|c|c|c|c|c|c|c|c|c|c|}
\hline & HOR & 10 & 20 & 30 & 40 & 50 & 60 & 70 & 80 & VERT & & \\
\hline $\begin{array}{l}\mathbf{A N} \\
\mathbf{B B} \\
\mathbf{A R}\end{array}$ & $\begin{array}{r}.99 \\
1.90 \\
3.28\end{array}$ & $\begin{array}{l}1.23 \\
2.28 \\
3.70\end{array}$ & $\begin{array}{l}1.45 \\
2.61 \\
4.03\end{array}$ & $\begin{array}{l}1.63 \\
2.88 \\
4.27\end{array}$ & $\begin{array}{l}1 . \\
3 . \\
4 .\end{array}$ & $\begin{array}{l}1.87 \\
3.19 \\
4.44\end{array}$ & 7 & $\begin{array}{l}3 \\
9 \\
9\end{array}$ & $\begin{array}{l}1.89 \\
3.07 \\
3.91\end{array}$ & $\begin{array}{l}1.92 \\
3.00 \\
3.59\end{array}$ & $\begin{array}{r}.353 \\
.448 \\
.513\end{array}$ & $\begin{array}{r}-3 \\
0 \\
3\end{array}$ \\
\hline $\begin{array}{l}\mathbf{P R} \\
\mathbf{A Y} \\
\mathrm{UN}\end{array}$ & $\begin{array}{l}4.72 \\
6.04 \\
6.56\end{array}$ & $\begin{array}{l}5.03 \\
6.23 \\
6.65\end{array}$ & $\begin{array}{l}5.22 \\
6.28 \\
6.60\end{array}$ & $\begin{array}{l}5.30 \\
6.18 \\
6.41\end{array}$ & $\begin{array}{l}5.26 \\
5.95 \\
6.08\end{array}$ & $\begin{array}{l}.09 \\
.58 \\
.62\end{array}$ & $\begin{array}{l}.82 \\
.13 \\
.09\end{array}$ & $\begin{array}{l}4.44 \\
4.56 \\
4.44\end{array}$ & $\begin{array}{l}3.96 \\
3.90 \\
3.73\end{array}$ & & $\begin{array}{r}.535 \\
.570 \\
.573\end{array}$ & $\begin{array}{r}7 . \\
13 \\
17 .\end{array}$ \\
\hline $\begin{array}{l}\text { IUL } \\
\text { IDP }\end{array}$ & $\begin{array}{l}7.43 \\
6.12 \\
4.52\end{array}$ & $\begin{array}{l}7.60 \\
6.46 \\
5.03\end{array}$ & $\begin{array}{l}7.60 \\
6.64 \\
5.42\end{array}$ & $\begin{array}{l}7.43 \\
6.66 \\
5.67\end{array}$ & $\begin{array}{l}7.09 \\
6.53 \\
5.79\end{array}$ & $\begin{array}{l}6.58 \\
6.24 \\
5.76\end{array}$ & $\begin{array}{l}8 \\
3 \\
9\end{array}$ & $\begin{array}{l}5.23 \\
5.28 \\
5.29\end{array}$ & $\begin{array}{l}4.38 \\
4.61 \\
4.85\end{array}$ & $\begin{array}{l}55 \\
6 \\
33\end{array}$ & $\begin{array}{r}.669 \\
.636 \\
.614\end{array}$ & $\begin{array}{l}21 . \\
20 \\
15 .\end{array}$ \\
\hline $\begin{array}{l}\text { OCT } \\
\text { NOV } \\
\text { DEC }\end{array}$ & $\begin{array}{r}2.65 \\
1.25 \\
.80\end{array}$ & $\begin{array}{l}3.12 \\
1.55 \\
1.01\end{array}$ & $\begin{array}{l}3.53 \\
1.82 \\
1.19\end{array}$ & $\begin{array}{l}3.84 \\
2.04 \\
1.35\end{array}$ & $\begin{array}{l}4.01 \\
2.21 \\
1.47\end{array}$ & $\begin{array}{l}4.19 \\
2.33 \\
1.56\end{array}$ & $\begin{array}{l}4 . \\
2 . \\
1 .\end{array}$ & $\begin{array}{l}4.12 \\
2.39 \\
1.62\end{array}$ & $\begin{array}{l}3.93 \\
2.33 \\
1.60\end{array}$ & $\begin{array}{l}3.67 \\
2.27 \\
1.59\end{array}$ & $\begin{array}{r}.526 \\
.391 \\
.329\end{array}$ & $\begin{array}{r}8 \\
2 \\
-1\end{array}$ \\
\hline
\end{tabular}

IRT 1412. 1522. 1597. 1636, 1636. 1598. 1527. 1421. 1283. 1140.

SPRINOFIELD, MO

SURFACE TILT (DEGREES UP FROM HORIZONTAL)

\begin{tabular}{|c|c|c|c|c|c|c|c|c|c|c|c|c|}
\hline & HOR & 10 & 20 & 30 & 40 & 50 & 60 & 70 & 80 & VERT & & $M$ \\
\hline $\begin{array}{l}\mathrm{AN} \\
\mathrm{EB} \\
\mathrm{AR}\end{array}$ & $\begin{array}{l}2.91 \\
3.90\end{array}$ & $\begin{array}{l}2.57 \\
3.32 \\
4.22\end{array}$ & $\begin{array}{l}2.92 \\
3.64 \\
4.45\end{array}$ & 3. & $\begin{array}{l}3.41 \\
4.03 \\
4.61\end{array}$ & $\begin{array}{l}3 \\
9 \\
3\end{array}$ & $\begin{array}{l}7 \\
4 \\
4\end{array}$ & $\begin{array}{l}3.51 \\
3.90 \\
4.06\end{array}$ & & 3. & $\begin{array}{r}.472 \\
.492 \\
.501\end{array}$ & $\begin{array}{l}2 . \\
7 .\end{array}$ \\
\hline $\begin{array}{l}\mathbf{P R} \\
\mathrm{AY} \\
\mathrm{DN}\end{array}$ & $\begin{array}{l}5.06 \\
5.93 \\
6.54\end{array}$ & $\begin{array}{l}5.25 \\
5.98 \\
6.52\end{array}$ & $\begin{array}{l}5.33 \\
5.90 \\
6.34\end{array}$ & $\begin{array}{l}5.29 \\
5.69 \\
6.03\end{array}$ & $\begin{array}{l}5.13 \\
5.36 \\
5.59\end{array}$ & $\begin{array}{l}4.87 \\
4.93 \\
5.07\end{array}$ & $\begin{array}{l}4.49 \\
4.41 \\
4.44\end{array}$ & & & & $\begin{array}{l}.525 \\
.545 \\
.572\end{array}$ & $\begin{array}{l}13 \\
18 \\
23\end{array}$ \\
\hline JEG & $\begin{array}{l}6.50 \\
5.91 \\
4.66\end{array}$ & $\begin{array}{l}6.06 \\
4.98\end{array}$ & $\begin{array}{l}6.37 \\
6.08 \\
5.18\end{array}$ & $\begin{array}{l}6.09 \\
5.96 \\
5.26\end{array}$ & $\begin{array}{l}5.69 \\
5.70 \\
5.22\end{array}$ & $\begin{array}{l}5.18 \\
5.33 \\
5.06\end{array}$ & $\begin{array}{l}4.57 \\
4.85 \\
4.79\end{array}$ & $\begin{array}{l}3.87 \\
4.26 \\
4.40\end{array}$ & $\begin{array}{l}3.16 \\
3.58 \\
3.92\end{array}$ & $\begin{array}{l}2.45 \\
2.90 \\
3.39\end{array}$ & $\begin{array}{l}.580 \\
.578 \\
.547\end{array}$ & $\begin{array}{l}25 \\
24 \\
20\end{array}$ \\
\hline EV & $\begin{array}{l}3.01 \\
2.44 \\
1.90\end{array}$ & $\begin{array}{l}4.05 \\
2.87 \\
2.29\end{array}$ & $\begin{array}{l}4.41 \\
3.24 \\
2.63\end{array}$ & $\begin{array}{l}4.66 \\
3.53 \\
2.91\end{array}$ & $\begin{array}{l}3.74 \\
3.11\end{array}$ & $\begin{array}{l}3.85 \\
3.24\end{array}$ & $\begin{array}{l}4.72 \\
3.87 \\
3.29\end{array}$ & $\begin{array}{l}4.51 \\
3.79 \\
3.25\end{array}$ & $\begin{array}{l}4.20 \\
3.61 \\
3.14\end{array}$ & $\begin{array}{l}3.50 \\
3.09\end{array}$ & $\begin{array}{l}.54 ; \\
.495 \\
.452\end{array}$ & $\begin{array}{r}14 \\
7 \\
2\end{array}$ \\
\hline
\end{tabular}

YRT 1569. 1664. 1721. 1738. 1716. 1658. 1563. 1433. 1277, 1116. 
TABLE I (Contimaed)

AVERAGE DAILY ARRAY INSOLATION (ETR; SQ.M./DAY), CleARNESS NUDBRR (KT), MEAN MONTHLY TEMPERATURE (TM, DEG C), AND WONTILY AVERAGE VIND SPEWD (VS, M/S)

TALLAHASSEE, FL

30.38 N LATITUDE

SURFACE TILT (DEGRRES OP FROM HORIZONTAL)

\begin{tabular}{llllllllllllll} 
MONTH- & HOR & 10 & 20 & 3 r & 40 & 50 & 60 & 70 & 80 & VERT & & & IS \\
\hline JAN & 2.76 & 3.16 & 3.50 & 3.75 & 3.91 & 3.98 & 3.96 & 3.83 & 3.62 & 3.35 & .485 & 11. & 3. \\
FEB & 3.59 & 3.99 & 4.30 & 4.51 & 4.61 & 4.61 & 4.49 & 4.27 & 3.95 & 3.57 & .516 & 12. & 3. \\
MAR & 4.66 & 4.98 & 5.18 & 5.27 & 5.23 & 5.06 & 4.79 & 4.40 & 3.92 & 3.39 & .547 & 15. & 4. \\
\hline APR & 5.75 & 5.89 & 5.91 & 5.78 & 5.53 & 5.16 & 4.68 & 4.09 & 3.43 & 2.75 & .573 & 19. & 3. \\
MAY & 6.10 & 6.08 & 5.92 & 5.62 & 5.23 & 4.73 & 4.13 & 3.46 & 2.79 & 2.14 & .559 & 23. & 3. \\
JUN & 5.93 & 5.83 & 5.61 & 5.26 & 4.83 & 4.31 & 3.70 & 3.08 & 2.43 & 1.88 & .526 & 26. & 3. \\
\hline JUL & 5.51 & 5.45 & 5.27 & 4.98 & 4.60 & 4.14 & 3.60 & 3.03 & 2.43 & 1.90 & .494 & 26. & 2. \\
AUG & 5.28 & 5.34 & 5.27 & 5.10 & 4.82 & 4.44 & 3.97 & 3.43 & 2.84 & 2.27 & .505 & 26. & 2. \\
SEP & 4.70 & 4.92 & 5.03 & 5.03 & 4.91 & 4.69 & 4.36 & 3.94 & 3.44 & 2.90 & .514 & 25. & 3. \\
\hline OCT & 4.16 & 4.56 & 4.86 & 5.05 & 5.11 & 5.06 & 4.88 & 4.59 & 4.19 & 3.73 & .550 & 20. & 3. \\
NOV & 3.17 & 3.63 & 3.99 & 4.27 & 4.44 & 4.50 & 4.45 & 4.30 & 4.04 & 3.71 & .526 & 14. & 3. \\
DEC & 2.55 & 2.97 & 3.31 & 3.57 & 3.75 & 3.84 & 3.84 & 3.74 & 3.55 & 3.31 & .478 & 11. & 3. \\
\hline
\end{tabular}

YRT 1649. 1728.1769.1770. 1733. 1657. 1545. 1403. 1234. 1060.

TAMA, FL

27.97 N LATITUDE

SURFACE TILT (DEGREES UP FROM HORIZONTAL)

\begin{tabular}{|c|c|c|c|c|c|c|c|c|c|c|c|c|}
\hline & HOR & 10 & 20 & 30 & 40 & 50 & 60 & 70 & 80 & VERT & & \\
\hline $\begin{array}{l}\text { JAN } \\
\text { FEB } \\
\text { UAR }\end{array}$ & $\begin{array}{l}3.18 \\
3.97 \\
5.02\end{array}$ & $\begin{array}{l}3.63 \\
4.40 \\
5.34\end{array}$ & $\begin{array}{l}4.00 \\
4.72 \\
5.53\end{array}$ & $\begin{array}{l}4.28 \\
4.93 \\
5.60\end{array}$ & $\begin{array}{l}4.45 \\
5.03 \\
5.53\end{array}$ & $\begin{array}{l}4.51 \\
5.00 \\
5.33\end{array}$ & $\begin{array}{l}4.46 \\
4.86 \\
5.01\end{array}$ & $\begin{array}{l}4.31 \\
4.60 \\
4.58\end{array}$ & $\begin{array}{l}4.05 \\
4.23 \\
4.05\end{array}$ & $\begin{array}{l}3.72 \\
3.80 \\
3.46\end{array}$ & $\begin{array}{l}.523 \\
.545 \\
.573\end{array}$ & $\begin{array}{l}15 . \\
16 . \\
19 .\end{array}$ \\
\hline $\begin{array}{l}\text { APR } \\
\text { MAY } \\
\text { JUN }\end{array}$ & $\begin{array}{l}6.01 \\
6.30 \\
5.82\end{array}$ & $\begin{array}{l}6.14 \\
6.25 \\
5.70\end{array}$ & $\begin{array}{l}6.12 \\
6.05 \\
5.46\end{array}$ & $\begin{array}{l}5.97 \\
5.72 \\
5.10\end{array}$ & $\begin{array}{l}5.68 \\
5.29 \\
4.66\end{array}$ & $\begin{array}{l}5.26 \\
4.74 \\
4.13\end{array}$ & $\begin{array}{l}4.73 \\
4.09 \\
3.52\end{array}$ & $\begin{array}{r}4.10 \\
3.40 \\
2.91\end{array}$ & $\begin{array}{l}3.39 \\
2.68 \\
2.29\end{array}$ & $\begin{array}{l}2.68 \\
2.03 \\
1.77\end{array}$ & $\begin{array}{l}.594 \\
.578 \\
.520\end{array}$ & $\begin{array}{l}22 . \\
25 . \\
26 .\end{array}$ \\
\hline $\begin{array}{l}\text { JUL } \\
\text { AUG } \\
\text { SEP }\end{array}$ & $\begin{array}{l}5.53 \\
5.21 \\
4.70\end{array}$ & $\begin{array}{l}5.44 \\
5.24 \\
4.89\end{array}$ & $\begin{array}{l}5.24 \\
5.16 \\
4.97\end{array}$ & $\begin{array}{l}4.93 \\
4.96 \\
4.94\end{array}$ & $\begin{array}{l}4.53 \\
4.67 \\
4.80\end{array}$ & $\begin{array}{l}4.05 \\
4.28 \\
4.55\end{array}$ & $\begin{array}{l}3.49 \\
3.80 \\
4.21\end{array}$ & $\begin{array}{l}2.92 \\
3.26 \\
3.78\end{array}$ & $\begin{array}{l}2.31 \\
2.68 \\
3.28\end{array}$ & $\begin{array}{l}1.81 \\
2.12 \\
2.74\end{array}$ & $\begin{array}{r}.498 \\
.497 \\
.504\end{array}$ & $\begin{array}{l}27 . \\
27 . \\
26 .\end{array}$ \\
\hline $\begin{array}{l}\text { OCT } \\
\text { NOV } \\
\text { DEC }\end{array}$ & $\begin{array}{l}4.25 \\
3.49 \\
2.94\end{array}$ & $\begin{array}{l}4.62 \\
3.96 \\
3.39\end{array}$ & $\begin{array}{l}4.89 \\
4.33 \\
3.76\end{array}$ & $\begin{array}{l}5.04 \\
4.61 \\
4.05\end{array}$ & $\begin{array}{l}5.07 \\
4.77 \\
4.23\end{array}$ & $\begin{array}{l}4.99 \\
4.81 \\
4.31\end{array}$ & $\begin{array}{l}4.79 \\
4.74 \\
4.29\end{array}$ & $\begin{array}{l}4.47 \\
4.55 \\
4.16\end{array}$ & $\begin{array}{l}4.06 \\
4.26 \\
3.93\end{array}$ & $\begin{array}{l}3.59 \\
3.89 \\
3.64\end{array}$ & $\begin{array}{l}.541 \\
.543 \\
.512\end{array}$ & $\begin{array}{l}23 \\
19 . \\
16 .\end{array}$ \\
\hline
\end{tabular}


AVERAGE DAILY ARRAY INSOLATION (KWH/SQ.M./DAY), CLEARNESS NUMBRR (KT), IEAN MONTHLY TEMPERATURE (T, DEG C), AND MONTILY AVERAGE WIND SPEED (WS, H/S)

TONOPAH, NV

38.07 N LATITUDE

SURFACE TILT (DEGREES UP FRON HORIZONTAL)

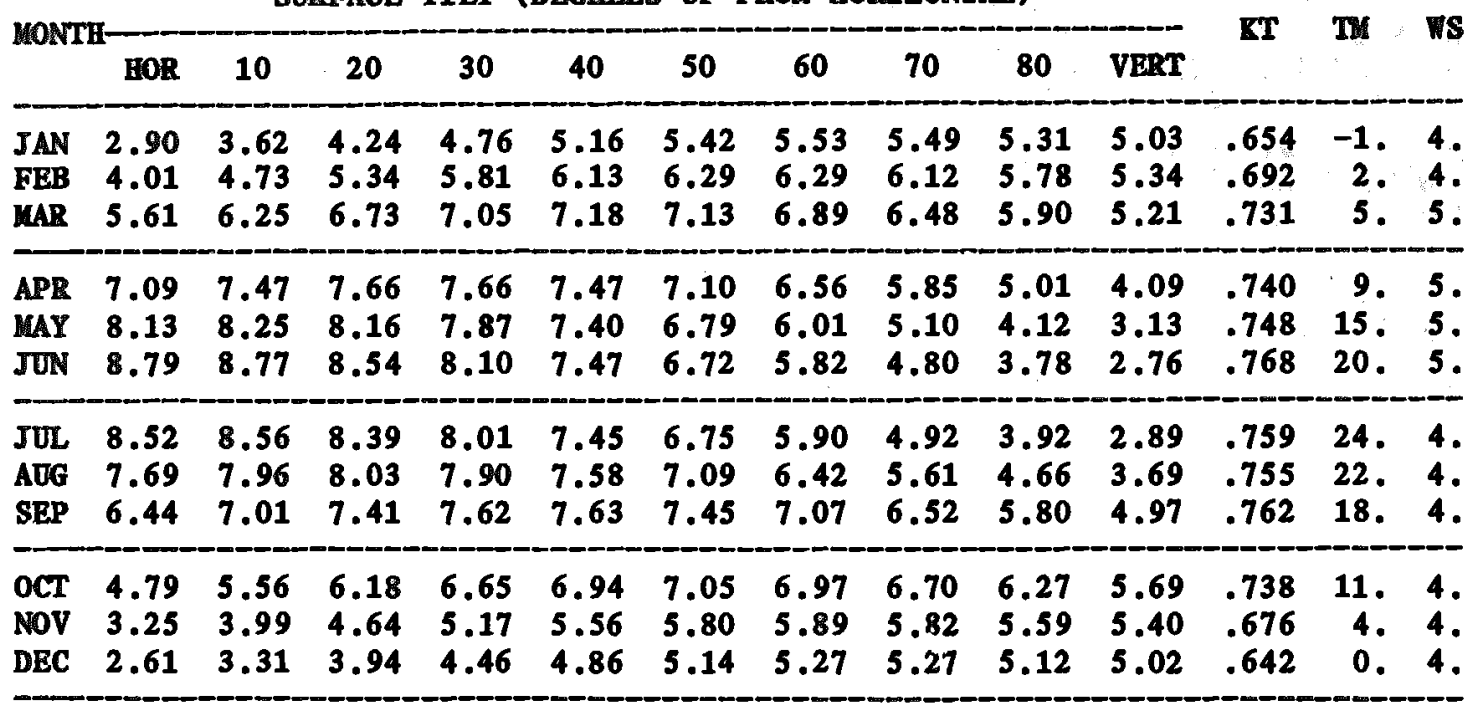

YRT 2126. 2299. 2413. 2467. 2459. 2394. 2269. 2087. 1862. 1617.

TULSA, OK

$36.20 \mathrm{~N}$. LATITUDE

SURFACE TILT (DEGREES UP FROM HORIZONTAL)

\begin{tabular}{llclllllllllll}
\multicolumn{1}{l}{ MONTH- } & HOR & 10 & 20 & 30 & 40 & 50 & 60 & 70 & 80 & VERT & & & \\
\hline JAN & 2.30 & 2.73 & 3.10 & 3.40 & 3.61 & 3.73 & 3.76 & 3.69 & 3.54 & 3.48 & .486 & 2. & 5. \\
FEB & 3.08 & 3.50 & 3.84 & 4.08 & 4.24 & 4.28 & 4.23 & 4.07 & 3.82 & 3.51 & .507 & 5. & 5. \\
MAR & 4.12 & 4.46 & 4.70 & 4.83 & 4.85 & 4.76 & 4.56 & 4.26 & 3.85 & 3.40 & .522 & 9. & 6. \\
\hline APR & 5.05 & 5.23 & 5.30 & 5.25 & 5.08 & 4.80 & 4.43 & 3.95 & 3.41 & 2.82 & .520 & 16. & 6. \\
MAY & 5.74 & 5.78 & 5.69 & 5.48 & 5.15 & 4.73 & 4.22 & 3.63 & 3.00 & 2.38 & .527 & 20. & 5. \\
JUN & 6.37 & 6.34 & 6.16 & 5.84 & 5.41 & 4.89 & 4.28 & 3.60 & 2.91 & 2.25 & .558 & 25. & 5. \\
\hline JUL & 6.40 & 6.40 & 6.25 & 5.96 & 5.55 & 5.05 & 4.44 & 3.75 & 3.06 & 2.36 & .571 & 28. & 4. \\
AUG & 5.88 & 6.02 & 6.03 & 5.89 & 5.63 & 5.25 & 4.76 & 4.17 & 3.49 & 2.82 & .573 & 27. & 4. \\
SEP & 4.64 & 4.93 & 5.12 & 5.19 & 5.13 & 4.96 & 4.68 & 4.29 & 3.81 & 3.28 & .537 & 23. & 4. \\
\hline OCT & 3.67 & 4.11 & 4.45 & 4.69 & 4.82 & 4.82 & 4.72 & 4.50 & 4.17 & 3.78 & .542 & 17. & 4. \\
NOV & 2.60 & 3.06 & 3.44 & 3.74 & 3.95 & 4.06 & 4.07 & 3.98 & 3.79 & 3.54 & .510 & 9. & 5. \\
DEC & 2.08 & 2.50 & 2.87 & 3.16 & 3.38 & 3.52 & 3.56 & 3.52 & 3.39 & 3.21 & .475 & 4. & 5. \\
\hline
\end{tabular}

YRT 1582 . 1677. 1733. 1750. 1729. 1669. 1572. 1441, 1284. 1120. 
TARB I (Continned)

AVERAGE DAILY ARRAY INSOLATION (KW:R/SQ.M./DAY),

CLRARNESS NUABR (IT), MAN HONTILY TEMPERATURE (TM, DER C). AND MONTHLY AVERAGR TIND SPEED (WS, M/S)

WAKE ISLAND, PI

19.28 N LATITUDE

SURFACE TILT (DEGRES UP FROM HORIZONTAL)

\begin{tabular}{llllllllllllll} 
HONTH- & HOR & 10 & 20 & 30 & 40 & 50 & 60 & 70 & 80 & VERT & & & \\
\hline JAN & 4.26 & 4.74 & 5.11 & 5.36 & 5.48 & 5.47 & 5.33 & 5.05 & 4.66 & 4.19 & .573 & 25. & 6. \\
FEB & 4.96 & 5.37 & 5.64 & 5.79 & 5.80 & 5.66 & 5.40 & 5.00 & 4.50 & 3.92 & .589 & 25. & 6. \\
MAR & 5.71 & 5.95 & 6.04 & 6.00 & 5.82 & 5.50 & 5.05 & 4.50 & 3.85 & 3.16 & .600 & 25. & 7. \\
\hline APR & 6.16 & 6.17 & 6.04 & 5.78 & 5.38 & 4.87 & 4.26 & 3.56 & 2.82 & 2.09 & .595 & 25. & 7. \\
UAT & 6.48 & 6.31 & 5.99 & 5.56 & 5.00 & 4.34 & 3.62 & 2.87 & 2.14 & 1.60 & .605 & 26. & 7. \\
JUN & 6.45 & 6.20 & 5.80 & 5.30 & 4.69 & 3.98 & 3.26 & 2.51 & 1.86 & 1.61 & .598 & 27. & 6. \\
\hline JUL & 6.07 & 5.87 & 5.54 & 5.10 & 4.56 & 3.93 & 3.26 & 2.56 & 1.92 & 1.60 & .564 & 28. & 6. \\
AUG & 5.90 & 5.83 & 5.64 & 5.33 & 4.90 & 4.37 & 3.75 & 3.08 & 2.39 & 1.77 & .560 & 28. & 5. \\
SEP & 5.47 & 5.60 & 5.60 & 5.47 & 5.22 & 4.86 & 4.39 & 3.83 & 3.20 & 2.54 & .555 & 28. & 6. \\
\hline OCT & 4.96 & 5.27 & 5.46 & 5.52 & 5.46 & 5.27 & 4.96 & 4.53 & 4.01 & 3.43 & .560 & 28. & 6. \\
NOV & 4.53 & 5.01 & 5.37 & 5.60 & 5.70 & 5.65 & 5.47 & 5.16 & 4.72 & 4.21 & .587 & 27. & 7. \\
DEC & 4.13 & 4.64 & 5.05 & 5.33 & 5.49 & 5.51 & 5.39 & 5.14 & 4.77 & 4.31 & .578 & 25. & 7. \\
\hline
\end{tabular}

IRT 1980. 2036. 2046.2011. 1930. 1805.1645. 1452. 1240. 1045.

WICHITA, KA

$37.63 N$ LATITUDE

SURFACE TILT (DEGRERS OP FROM HORIZOATAL)

\begin{tabular}{|c|c|c|c|c|c|c|c|c|c|c|c|c|c|}
\hline \multicolumn{2}{|c|}{ MONTH-- } & \multicolumn{3}{|c|}{ SUEFACE IILL } & \multicolumn{6}{|c|}{3} & \multirow{2}{*}{$\mathbf{R T}$} & \multirow{2}{*}{$\mathbf{m}$} & \multirow{2}{*}{ Ws } \\
\hline & HOR & 10 & 20 & 30 & 40 & 50 & 60 & 70 & 80 & VERT & & & \\
\hline $\begin{array}{l}\text { JAN } \\
\text { FEB } \\
\text { MAR }\end{array}$ & $\begin{array}{l}2.47 \\
3.33 \\
4.43\end{array}$ & $\begin{array}{l}3.01 \\
3.85 \\
4.85\end{array}$ & $\begin{array}{l}3.47 \\
4.27 \\
5.16\end{array}$ & $\begin{array}{l}3.85 \\
4.60 \\
5.34\end{array}$ & $\begin{array}{l}4.13 \\
4.81 \\
5.40\end{array}$ & $\begin{array}{l}4.30 \\
4.90 \\
5.32\end{array}$ & $\begin{array}{l}4.36 \\
4.87 \\
5.12\end{array}$ & $\begin{array}{l}4.31 \\
4.71 \\
4.80\end{array}$ & $\begin{array}{l}4.15 \\
4.44 \\
4.36\end{array}$ & $\begin{array}{l}4.09 \\
4.09 \\
3.86\end{array}$ & $\begin{array}{r}.549 \\
.568 \\
.574\end{array}$ & $\begin{array}{r}-1 . \\
2 \\
6\end{array}$ & $\begin{array}{l}6 . \\
6 . \\
7 .\end{array}$ \\
\hline $\begin{array}{l}\text { APR } \\
\text { MAY } \\
\text { JUN }\end{array}$ & $\begin{array}{l}5.62 \\
6.41 \\
7.14\end{array}$ & $\begin{array}{l}5.86 \\
6.48 \\
7.11\end{array}$ & $\begin{array}{l}5.97 \\
6.40 \\
6.93\end{array}$ & $\begin{array}{l}5.94 \\
6.17 \\
6.58\end{array}$ & $\begin{array}{l}5.77 \\
5.82 \\
6.10\end{array}$ & $\begin{array}{l}5.47 \\
5.35 \\
5.52\end{array}$ & $\begin{array}{l}5.06 \\
4.77 \\
4.82\end{array}$ & $\begin{array}{l}4.53 \\
4.10 \\
4.04\end{array}$ & $\begin{array}{l}3.90 \\
3.38 \\
3.25\end{array}$ & $\begin{array}{l}3.23 \\
2.66 \\
2.48\end{array}$ & $\begin{array}{r}.584 \\
.590 \\
.624\end{array}$ & $\begin{array}{l}14 . \\
19 . \\
24 .\end{array}$ & $\begin{array}{l}7 . \\
6 . \\
6 .\end{array}$ \\
\hline $\begin{array}{l}\text { JUL } \\
\text { AUG } \\
\text { SEP }\end{array}$ & $\begin{array}{l}7.06 \\
6.41 \\
5.09\end{array}$ & $\begin{array}{l}7.07 \\
6.59 \\
5.47\end{array}$ & $\begin{array}{l}6.93 \\
6.62 \\
5.71\end{array}$ & $\begin{array}{l}6.62 \\
6.50 \\
5.83\end{array}$ & $\begin{array}{l}6.18 \\
6.23 \\
5.80\end{array}$ & $\begin{array}{l}5.62 \\
5.83 \\
5.63\end{array}$ & $\begin{array}{l}4.95 \\
5.29 \\
5.33\end{array}$ & $\begin{array}{l}4.17 \\
4.64 \\
4.91\end{array}$ & $\begin{array}{l}3.39 \\
3.90 \\
4.37\end{array}$ & $\begin{array}{l}2.59 \\
3.14 \\
3.77\end{array}$ & $\begin{array}{l}.629 \\
.628 \\
.600\end{array}$ & $\begin{array}{l}27 . \\
26 \\
21 .\end{array}$ & $\begin{array}{l}5 . \\
5 \\
5\end{array}$ \\
\hline $\begin{array}{l}\text { OCT } \\
\text { NOV } \\
\text { DEC }\end{array}$ & $\begin{array}{l}3.94 \\
2.74 \\
2.18\end{array}$ & $\begin{array}{l}4.47 \\
3.29 \\
2.68\end{array}$ & $\begin{array}{l}4.90 \\
3.75 \\
3.12\end{array}$ & $\begin{array}{l}5.20 \\
4.13 \\
3.48\end{array}$ & $\begin{array}{l}5.38 \\
4.40 \\
3.75\end{array}$ & $\begin{array}{l}5.42 \\
4.56 \\
3.93\end{array}$ & $\begin{array}{l}5.33 \\
4.60 \\
4.01\end{array}$ & $\begin{array}{l}5.11 \\
4.52 \\
3.98\end{array}$ & $\begin{array}{l}4.76 \\
4.33 \\
3.85\end{array}$ & $\begin{array}{l}4.33 \\
4.19 \\
3.79\end{array}$ & $\begin{array}{r}.601 \\
.563 \\
.526\end{array}$ & $\begin{array}{c}15 \\
7 . \\
1 .\end{array}$ & 6. \\
\hline
\end{tabular}


TABLE I (Continned)

AVERAGE DAILI ARRAY INSOLATION (KTH/SQ.M./DAY), CLEARNESS NURBER (ET), MEAN MONTHLY TEMPERATURE (TM, DEG C), AND MONTILY AVERAGE WIND SPEED (WS, M/S)

WICHITA FALLS, TX

33.97 N LATITUDE

SURFACE TILT (DEGREES UP FROM HORIZONTAL)

\begin{tabular}{|c|c|c|c|c|c|c|c|c|c|c|c|c|c|}
\hline & FOR & 10 & 20 & 30 & 40 & 50 & 60 & 70 & 80 & VERI & $\boldsymbol{S T}$ & TH & WS \\
\hline $\begin{array}{l}\text { JAN } \\
\text { FEB } \\
\text { MAR }\end{array}$ & $\begin{array}{l}2.71 \\
3.54 \\
4.64\end{array}$ & $\begin{array}{l}3.21 \\
4.01 \\
5.02\end{array}$ & $\begin{array}{l}3.63 \\
4.39 \\
5.28\end{array}$ & $\begin{array}{l}3.96 \\
4.66 \\
5.41\end{array}$ & $\begin{array}{l}4.19 \\
4.82 \\
5.42\end{array}$ & $\begin{array}{r}4.32 \\
4.87 \\
5.30\end{array}$ & $\begin{array}{l}4.34 \\
4.79 \\
5.06\end{array}$ & $\begin{array}{l}4.25 \\
4.60 \\
4.69\end{array}$ & $\begin{array}{l}4.05 \\
4.29 \\
4.22\end{array}$ & $\begin{array}{l}3.92 \\
3.92 \\
3.70\end{array}$ & $\begin{array}{l}.532 \\
.551 \\
.569\end{array}$ & $\begin{array}{l}5 \\
7 \\
12\end{array}$ & $\begin{array}{l}5 . \\
5 . \\
6 .\end{array}$ \\
\hline $\begin{array}{l}\text { APR } \\
\text { KAY } \\
\text { JUN }\end{array}$ & $\begin{array}{l}5.55 \\
6.36 \\
7.00\end{array}$ & $\begin{array}{l}5.74 \\
6.38 \\
6.93\end{array}$ & $\begin{array}{l}5.79 \\
6.25 \\
6.70\end{array}$ & $\begin{array}{l}5.72 \\
5.99 \\
6.31\end{array}$ & $\begin{array}{l}5.51 \\
5.60 \\
5.81\end{array}$ & $\begin{array}{l}5.19 \\
5.11 \\
5.20\end{array}$ & $\begin{array}{l}4.75 \\
4.50 \\
4.48\end{array}$ & $\begin{array}{l}4.21 \\
3.81 \\
3.72\end{array}$ & $\begin{array}{l}3.58 \\
3.11 \\
2.93\end{array}$ & $\begin{array}{l}2.92 \\
2.40 \\
2.20\end{array}$ & $\begin{array}{l}.564 \\
.583 \\
.615\end{array}$ & $\begin{array}{l}18 . \\
22 . \\
27\end{array}$ & $\begin{array}{l}6 . \\
5 . \\
5 .\end{array}$ \\
\hline $\begin{array}{l}\text { JUL } \\
\text { AUG } \\
\text { SEP }\end{array}$ & $\begin{array}{l}6.83 \\
6.21 \\
5.04\end{array}$ & $\begin{array}{l}6.79 \\
6.33 \\
5.35\end{array}$ & $\begin{array}{l}6.60 \\
6.31 \\
5.53\end{array}$ & $\begin{array}{l}6.26 \\
6.14 \\
5.58\end{array}$ & $\begin{array}{l}5.80 \\
5.84 \\
5.50\end{array}$ & $\begin{array}{l}5.23 \\
5.42 \\
5.30\end{array}$ & $\begin{array}{l}4.55 \\
4.87 \\
4.97\end{array}$ & $\begin{array}{l}3.80 \\
4.22 \\
4.53\end{array}$ & $\begin{array}{l}3.04 \\
3.50 \\
3.99\end{array}$ & $\begin{array}{l}2.30 \\
2.78 \\
3.39\end{array}$ & $\begin{array}{l}.610 \\
.600 \\
.571\end{array}$ & $\begin{array}{l}29 . \\
29 . \\
24 .\end{array}$ & $\begin{array}{l}5 . \\
5 . \\
5 .\end{array}$ \\
\hline $\begin{array}{l}\text { OCT } \\
\text { NOV } \\
\text { DEC }\end{array}$ & $\begin{array}{l}4.07 \\
3.01 \\
2.52\end{array}$ & $\begin{array}{l}4.54 \\
3.52 \\
3.02\end{array}$ & $\begin{array}{l}4.90 \\
3.95 \\
3.45\end{array}$ & $\begin{array}{l}5.15 \\
4.28 \\
3.80\end{array}$ & $\begin{array}{l}5.27 \\
4.51 \\
4.05\end{array}$ & $\begin{array}{l}5.26 \\
4.62 \\
4.20\end{array}$ & $\begin{array}{l}5.12 \\
4.61 \\
4.24\end{array}$ & $\begin{array}{l}4.86 \\
4.49 \\
4.18\end{array}$ & $\begin{array}{l}4.48 \\
4.26 \\
4.01\end{array}$ & $\begin{array}{l}4.03 \\
3.95 \\
3.77\end{array}$ & $\begin{array}{l}.576 \\
.551 \\
.530\end{array}$ & $\begin{array}{r}18 \\
11 \\
6\end{array}$ & $\begin{array}{l}5 \\
5 \\
5\end{array}$ \\
\hline
\end{tabular}

VILKES-BARRE, PA

41.33 N LATITUDE

SURFACE TILT (DEGREES UP FROM HORIZONTAL)

MONTH $\begin{array}{llllllllll}\text { HOR } & 10 & 20 & 30 & 40 & 50 & 60 & 70 & 80 & \text { VERT }\end{array}$

\begin{tabular}{|c|c|c|c|c|c|c|c|c|c|c|c|c|}
\hline $\begin{array}{l}\text { JAN } \\
\text { FEB } \\
\text { MAR }\end{array}$ & $\begin{array}{l}1.44 \\
2.17 \\
3.13\end{array}$ & $\begin{array}{l}1.71 \\
2.48 \\
3.40\end{array}$ & $\begin{array}{l}1.95 \\
2.73 \\
3.61\end{array}$ & $\begin{array}{l}2.14 \\
2.93 \\
3.74\end{array}$ & $\begin{array}{l}2.28 \\
3.05 \\
3.78\end{array}$ & $\begin{array}{l}2.37 \\
3.11 \\
3.73\end{array}$ & $\begin{array}{l}2.40 \\
3.09 \\
3.61\end{array}$ & $\begin{array}{l}2.38 \\
3.00 \\
3.40\end{array}$ & $\begin{array}{l}2.29 \\
2.84 \\
3.12\end{array}$ & $\begin{array}{l}2.19 \\
2.64 \\
2.80\end{array}$ & $\begin{array}{r}.370 \\
.411 \\
.431\end{array}$ & $\begin{array}{l}-4 \\
-2\end{array}$ \\
\hline $\begin{array}{l}\text { APR } \\
\text { MAY } \\
\text { JUN }\end{array}$ & $\begin{array}{l}4.22 \\
5.01 \\
5.55\end{array}$ & $\begin{array}{l}4.41 \\
5.09 \\
5.56\end{array}$ & $\begin{array}{l}4.50 \\
5.05 \\
5.46\end{array}$ & $\begin{array}{l}4.49 \\
4.91 \\
5.24\end{array}$ & $\begin{array}{l}4.38 \\
4.66 \\
4.91\end{array}$ & $\begin{array}{l}4.19 \\
4.34 \\
4.51\end{array}$ & $\begin{array}{l}0 \\
4 \\
3\end{array}$ & $\begin{array}{l}3.54 \\
3.46 \\
3.48\end{array}$ & & & $\begin{array}{r}.452 \\
.464 \\
.484\end{array}$ & $\begin{array}{r}9 . \\
15 \\
20\end{array}$ \\
\hline $\begin{array}{l}\text { JUL } \\
\text { AUG } \\
\text { SEP }\end{array}$ & $\begin{array}{l}5.50 \\
4.77 \\
3.77\end{array}$ & $\begin{array}{l}5.54 \\
4.92 \\
4.05\end{array}$ & $\begin{array}{l}5.47 \\
4.96 \\
4.23\end{array}$ & $\begin{array}{l}5.28 \\
4.89 \\
4.32\end{array}$ & $\begin{array}{l}7 \\
1 \\
1\end{array}$ & $\begin{array}{l}4.59 \\
4.45 \\
4.20\end{array}$ & $\begin{array}{l}4.12 \\
4.09 \\
4.00\end{array}$ & $\begin{array}{l}3.58 \\
3.66 \\
3.72\end{array}$ & $\begin{array}{l}3.00 \\
3.15 \\
3.35\end{array}$ & & $\begin{array}{r}.491 \\
.476 \\
.466\end{array}$ & $\begin{array}{l}22 . \\
21 . \\
17 .\end{array}$ \\
\hline $\begin{array}{l}\text { OCT } \\
\text { NOV } \\
\text { DEC }\end{array}$ & $\begin{array}{l}.73 \\
.54 \\
.16\end{array}$ & $\begin{array}{l}3.08 \\
1.80 \\
1.38\end{array}$ & $\begin{array}{l}3.37 \\
2.02 \\
1.56\end{array}$ & $\begin{array}{l}3.57 \\
2.20 \\
1.72\end{array}$ & $\begin{array}{l}3.69 \\
2.32 \\
1.83\end{array}$ & $\begin{array}{l}3.73 \\
2.40 \\
1.91\end{array}$ & $\begin{array}{l}3.67 \\
2.41 \\
1.93\end{array}$ & $\begin{array}{l}3.53 \\
2.37 \\
1.91\end{array}$ & $\begin{array}{l}3.31 \\
2.27 \\
1.85\end{array}$ & $\begin{array}{l}3.06 \\
2.24 \\
1.86\end{array}$ & $\begin{array}{l}.455 \\
.362 \\
.331\end{array}$ & 11 \\
\hline
\end{tabular}

IRT 1249. 1323. 1368. 1383. 1367. 1325. 1254. 1157. 1038. 918. 
TABLE I (Contimed)

AVERAGE DAILY ARRAY INSOLATION (KTR/SQ.M./DAY).

CLEARNESS NOMBER (KT), URAN MONTILY TEMPRRATUTE (TM, DEG C),

AND MONTELY AVERAGE WIND SPEED (WS, 路'S)

WINSLOW, AZ

35.02 N LATITUDE

SURFACE TILT (DEGREES UP FROM HORIZONTAL)

\begin{tabular}{|c|c|c|c|c|c|c|c|c|c|c|c|c|c|}
\hline ND & HOR & 10 & 20 & 30 & 40 & 50 & 60 & 70 & 80 & VExT & & 渭 & \\
\hline $\begin{array}{l}\mathbf{A N} \\
\mathbf{E B} \\
\mathrm{AR}\end{array}$ & $\begin{array}{l}3.10 \\
4.18 \\
5.62\end{array}$ & $\begin{array}{l}3.76 \\
4.84 \\
6.17\end{array}$ & $\begin{array}{l}4.33 \\
5.38 \\
6.57\end{array}$ & $\begin{array}{l}.79 \\
.79 \\
.80\end{array}$ & $\begin{array}{l}5 . \\
6 .\end{array}$ & $\begin{array}{l}3 \\
5 \\
5\end{array}$ & $\begin{array}{l}9 \\
0 \\
7\end{array}$ & $\begin{array}{l}1 \\
8 \\
3\end{array}$ & & & $\begin{array}{l}.629 \\
.668 \\
.699\end{array}$ & $\begin{array}{l}0 . \\
3 . \\
7 .\end{array}$ & $\begin{array}{l}3 . \\
4 . \\
4 .\end{array}$ \\
\hline $\begin{array}{l}\mathbf{P R} \\
\mathbf{U Y} \\
\mathbf{U N}\end{array}$ & $\begin{array}{l}7.19 \\
8.18 \\
8.55\end{array}$ & $\begin{array}{l}7.51 \\
8.24 \\
8.47\end{array}$ & $\begin{array}{l}7.64 \\
8.10 \\
8.19\end{array}$ & $\begin{array}{l}7.59 \\
7.75 \\
7.70\end{array}$ & $\begin{array}{l}7.34 \\
7.24 \\
7.06\end{array}$ & $\begin{array}{l}6.92 \\
6.57 \\
6.29\end{array}$ & $\begin{array}{l}6.33 \\
5.75 \\
5.37\end{array}$ & $\begin{array}{l}9 \\
30 \\
37\end{array}$ & & & $\begin{array}{l}.736 \\
.750 \\
.750\end{array}$ & $\begin{array}{l}12 . \\
17 . \\
23 .\end{array}$ & $\begin{array}{l}5 . \\
5 . \\
5 .\end{array}$ \\
\hline $\begin{array}{l}\text { TUL } \\
\text { UEG } \\
\text { GEP }\end{array}$ & $\begin{array}{l}7.40 \\
6.75 \\
6.07\end{array}$ & $\begin{array}{l}7.38 \\
6.91 \\
6.52\end{array}$ & $\begin{array}{l}7.18 \\
6.91 \\
6.80\end{array}$ & $\begin{array}{l}6.82 \\
6.74 \\
6.92\end{array}$ & $\begin{array}{l}6.32 \\
6.42 \\
6.86\end{array}$ & $\begin{array}{l}5.70 \\
5.96 \\
6.63\end{array}$ & $\begin{array}{l}4.96 \\
5.37 \\
6.24\end{array}$ & $\begin{array}{l}4.12 \\
4.66 \\
5.70\end{array}$ & $\begin{array}{l}8 \\
5 \\
3\end{array}$ & $\begin{array}{l}2.46 \\
3.05 \\
4.26\end{array}$ & $\begin{array}{l}.660 \\
.655 \\
.694\end{array}$ & $\begin{array}{l}25 . \\
24 . \\
20 .\end{array}$ & 4. \\
\hline $\begin{array}{l}\text { OCT } \\
\text { NOV } \\
\text { DEC }\end{array}$ & $\begin{array}{l}3.53 \\
2.82\end{array}$ & $\begin{array}{l}5.41 \\
4.23 \\
3.48\end{array}$ & $\begin{array}{l}5.93 \\
4.84 \\
4.04\end{array}$ & $\begin{array}{l}6.29 \\
5.32 \\
4.51\end{array}$ & $\begin{array}{l}6.49 \\
5.66 \\
4.86\end{array}$ & $\begin{array}{l}5.85 \\
5.08\end{array}$ & $\begin{array}{l}6.39 \\
5.89 \\
5.17\end{array}$ & $\begin{array}{l}6.09 \\
5.77 \\
5.12\end{array}$ & $\begin{array}{l}4 \\
0 \\
3\end{array}$ & $\begin{array}{l}5.08 \\
5.12 \\
4.65\end{array}$ & $\begin{array}{l}.689 \\
.665 \\
.617\end{array}$ & $\begin{array}{r}13 . \\
6 . \\
0 .\end{array}$ & 3. \\
\hline
\end{tabular}

YKI 2075. 2219. 2310. 2343 . 2320. 2243. 2110. 1928. 1707. 1467.

YAKIMA, WA

46.57 N LATITUDE

SURFACE TILT (DRGREES UP FROM HORIZONTAL)

\begin{tabular}{|c|c|c|c|c|c|c|c|c|c|c|c|c|c|}
\hline ON & HOR & 10 & 20 & 30 & 40 & 50 & 60 & 70 & 80 & VERT & & of & \\
\hline $\begin{array}{l}\text { TAN } \\
\mathrm{PEB} \\
\mathrm{MAR}\end{array}$ & $\begin{array}{l}1.15 \\
2.09 \\
3.54\end{array}$ & $\begin{array}{l}1.44 \\
2.50 \\
3.99\end{array}$ & $\begin{array}{l}1.69 \\
2.86 \\
4.35\end{array}$ & $\begin{array}{l}1.91 \\
3.14 \\
4.61\end{array}$ & $\begin{array}{l}2.08 \\
3.35 \\
4.75\end{array}$ & $\begin{array}{l}2.20 \\
3.48 \\
4.78\end{array}$ & $\begin{array}{l}2.26 \\
3.52 \\
4.69\end{array}$ & $\begin{array}{l}2.27 \\
3.47 \\
4.49\end{array}$ & $\begin{array}{l}2.22 \\
3.33 \\
4.19\end{array}$ & & $\begin{array}{r}.385 \\
.473 \\
.540\end{array}$ & $\begin{array}{r}-2 \\
2 \\
5\end{array}$ & $\begin{array}{l}3 . \\
3 . \\
4 .\end{array}$ \\
\hline $\begin{array}{l}\text { APR } \\
\text { MAY } \\
\text { JUN }\end{array}$ & $\begin{array}{l}5.04 \\
6.33 \\
6.84\end{array}$ & $\begin{array}{l}5.37 \\
6.52 \\
6.92\end{array}$ & $\begin{array}{l}5.58 \\
6.56 \\
6.85\end{array}$ & $\begin{array}{l}5.65 \\
6.45 \\
6.64\end{array}$ & $\begin{array}{l}5.60 \\
6.19 \\
6.28\end{array}$ & $\begin{array}{l}5.42 \\
5.80 \\
5.80\end{array}$ & $\begin{array}{l}5.11 \\
5.31 \\
5.22\end{array}$ & $\begin{array}{l}4.70 \\
4.70 \\
4.54\end{array}$ & $\begin{array}{l}4.18 \\
4.00 \\
3.79\end{array}$ & & $\begin{array}{l}.565 \\
.595 \\
.597\end{array}$ & $\begin{array}{l}10 . \\
15 \\
19\end{array}$ & $\begin{array}{l}4 . \\
4 . \\
4 .\end{array}$ \\
\hline $\begin{array}{l}\text { JUL } \\
\text { AUG } \\
\text { SEP }\end{array}$ & $\begin{array}{l}7.43 \\
6.22 \\
4.67\end{array}$ & $\begin{array}{l}7.59 \\
6.55 \\
5.18\end{array}$ & $\begin{array}{l}7.58 \\
6.72 \\
5.57\end{array}$ & $\begin{array}{l}7.39 \\
6.73 \\
5.82\end{array}$ & $\begin{array}{l}7.02 \\
6.57 \\
5.92\end{array}$ & $\begin{array}{l}6.52 \\
6.27 \\
5.88\end{array}$ & $\begin{array}{l}5.89 \\
5.84 \\
5.70\end{array}$ & $\begin{array}{l}5.14 \\
5.27 \\
5.37\end{array}$ & $\begin{array}{l}4.28 \\
4.59 \\
4.92\end{array}$ & $\begin{array}{l}3.45 \\
3.85 \\
4.39\end{array}$ & $\begin{array}{l}.668 \\
.641 \\
.623\end{array}$ & $\begin{array}{l}22 . \\
21 . \\
16 .\end{array}$ & $\begin{array}{l}3 . \\
3 .\end{array}$ \\
\hline $\begin{array}{l}\text { OCI } \\
\text { NOV } \\
\text { DEC }\end{array}$ & $\begin{array}{r}2.80 \\
1.40 \\
.93\end{array}$ & $\begin{array}{l}3.30 \\
1.73 \\
1.17\end{array}$ & $\begin{array}{l}3.71 \\
2.03 \\
1.38\end{array}$ & $\begin{array}{l}4.04 \\
2.27 \\
1.56\end{array}$ & $\begin{array}{l}4.26 \\
2.46 \\
1.71\end{array}$ & $\begin{array}{l}4.38 \\
2.59 \\
1.81\end{array}$ & $\begin{array}{l}4.39 \\
2.66 \\
1.87\end{array}$ & $\begin{array}{l}4.29 \\
2.66 \\
1.88\end{array}$ & $\begin{array}{l}4.08 \\
2.59 \\
1.85\end{array}$ & $\begin{array}{l}3.83 \\
2.55 \\
1.86\end{array}$ & $\begin{array}{r}.539 \\
.414 \\
.354\end{array}$ & $\begin{array}{l}9 . \\
3 . \\
0 .\end{array}$ & $\begin{array}{l}3 . \\
3 . \\
2 .\end{array}$ \\
\hline
\end{tabular}

YRT 1478. 1593.1672. 1713. 1712. 1673. 1597. 1485. 1339. 1185. 
AVERAGE DAILY ARRAY INSOLATION (KWH/SQ.M./DAY), CLEARNZSS NUMBER (ET), MEAN MONTHLY TEMPERATURE (TM, DEG C), AND MONTLLII AVERAGE WIND SPERD (WS, M/S)

YAKUTAT, AK

SURFACE TILT (DEGREES UP FROM HORIZONTAL)

\begin{tabular}{|c|c|c|c|c|c|c|c|c|c|c|c|c|c|}
\hline on & HOR & 10 & 20 & 30 & 40 & 50 & 60 & 70 & 80 & VERT & $\mathbf{S T}$ & $\mathbf{T M}$ & \\
\hline $\begin{array}{l}\text { JAN } \\
\text { FEB } \\
\text { MAR }\end{array}$ & $\begin{array}{r}.32 \\
.84 \\
1.97\end{array}$ & $\begin{array}{r}.49 \\
1.10 \\
2.33\end{array}$ & $\begin{array}{r}.65 \\
1.34 \\
2.64\end{array}$ & $\begin{array}{r}.80 \\
1.54 \\
2.89\end{array}$ & $\begin{array}{r}.92 \\
1.71 \\
3.07\end{array}$ & $\begin{array}{l}1.02 \\
1.84 \\
3.18\end{array}$ & $\begin{array}{l}1.09 \\
1.91 \\
3.21\end{array}$ & $\begin{array}{l}1.14 \\
1.94 \\
3.16\end{array}$ & $\begin{array}{l}1.15 \\
1.92 \\
3.03\end{array}$ & $\begin{array}{l}1.24 \\
1.94 \\
2.88\end{array}$ & $\begin{array}{r}.332 \\
.367 \\
.429\end{array}$ & $\begin{array}{l}-5 \\
-2 \\
-1\end{array}$ & 3. \\
\hline $\begin{array}{l}\text { APR } \\
\text { MAY } \\
\text { JUN }\end{array}$ & $\begin{array}{l}3.31 \\
4.00 \\
4.24\end{array}$ & $\begin{array}{l}3.61 \\
4.16 \\
4.33\end{array}$ & $\begin{array}{l}3.84 \\
4.25 \\
4.35\end{array}$ & $\begin{array}{l}3.98 \\
4.25 \\
4.28\end{array}$ & $\begin{array}{l}4.04 \\
4.17 \\
4.15\end{array}$ & $\begin{array}{l}4.00 \\
4.00 \\
3.94\end{array}$ & $\begin{array}{l}3.87 \\
3.76 \\
3.65\end{array}$ & $\begin{array}{l}3.66 \\
3.46 \\
3.32\end{array}$ & $\begin{array}{l}3.37 \\
3.09 \\
2.94\end{array}$ & $\begin{array}{l}3.03 \\
2.69 \\
2.51\end{array}$ & $\begin{array}{r}.438 \\
.399 \\
.375\end{array}$ & $\begin{array}{r}2 . \\
6 \\
10\end{array}$ & 4 \\
\hline $\begin{array}{l}\text { JUL } \\
\text { AUG } \\
\text { SEP }\end{array}$ & $\begin{array}{l}3.81 \\
2.97 \\
2.00\end{array}$ & $\begin{array}{l}3.91 \\
3.14 \\
2.23\end{array}$ & $\begin{array}{l}3.94 \\
3.24 \\
2.42\end{array}$ & $\begin{array}{l}3.90 \\
3.28 \\
2.55\end{array}$ & $\begin{array}{l}3.79 \\
3.25 \\
2.63\end{array}$ & $\begin{array}{l}3.61 \\
3.16 \\
2.65\end{array}$ & $\begin{array}{l}3.37 \\
3.00 \\
2.62\end{array}$ & $\begin{array}{l}3.08 \\
2.80 \\
2.52\end{array}$ & $\begin{array}{l}2.74 \\
2.54 \\
2.37\end{array}$ & $\begin{array}{l}2.36 \\
2.27 \\
2.23\end{array}$ & $\begin{array}{r}.353 \\
.343 \\
.348\end{array}$ & $\begin{array}{l}12 . \\
12 . \\
9\end{array}$ & $\begin{array}{l}3 . \\
3 . \\
3 .\end{array}$ \\
\hline $\begin{array}{l}\text { OCI } \\
\text { NOV } \\
\text { DEC }\end{array}$ & $\begin{array}{r}1.08 \\
.43 \\
.16\end{array}$ & $\begin{array}{r}1.34 \\
.62 \\
.23\end{array}$ & $\begin{array}{r}1.56 \\
.75 \\
.29\end{array}$ & $\begin{array}{r}1.75 \\
.94 \\
.35\end{array}$ & $\begin{array}{r}1.90 \\
1.08 \\
.40\end{array}$ & $\begin{array}{r}2.00 \\
1.18 \\
.44\end{array}$ & $\begin{array}{r}2.05 \\
1.25 \\
.47\end{array}$ & $\begin{array}{r}2.05 \\
1.29 \\
.48\end{array}$ & $\begin{array}{r}2.00 \\
1.30 \\
.49\end{array}$ & $\begin{array}{r}2.07 \\
1.56 \\
.85\end{array}$ & $\begin{array}{r}.352 \\
.332 \\
.246\end{array}$ & $\begin{array}{r}5 \\
0 \\
-2\end{array}$ & $\begin{array}{l}4 . \\
4 . \\
4 .\end{array}$ \\
\hline & & & & & & & & & & & & & \\
\hline
\end{tabular}


BLANT

A-57 


\section{TABLF II}

\section{- Monthly Optimun Tilts-}

Tilt Angle (su) between the Plane of the F1at Array and Horizontal for Optimun Incident Enorgy*

Month

January .......................... $\phi+29$

February ........................ $\phi+18$

Varch .......................... $\phi+3$

Apri1 .......................... $\phi-10$

May ........................... $\phi-22$

June $\ldots \ldots \ldots \ldots \ldots \ldots \ldots \ldots \ldots \ldots \ldots \ldots \ldots \ldots \ldots \ldots . . \ldots-25$

$J_{\text {ely }} \ldots \ldots \ldots \ldots \ldots \ldots \ldots \ldots \ldots \ldots \ldots \ldots \ldots \ldots \ldots . . \ldots \phi-24$

August $\ldots \ldots \ldots \ldots \ldots \ldots \ldots \ldots \ldots \ldots \ldots \ldots \ldots \ldots . \phi-10$

September ......................... $\phi-2$

October .......................... $\phi+10$

Noverber .......................... $\phi+23$

December ......................... $\phi+30$

-Array is assumed to be south facing * $\phi$ is latitude in degrees 


\section{Sinusoidal Loads}

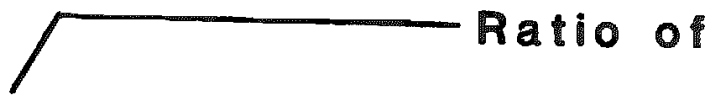

.2

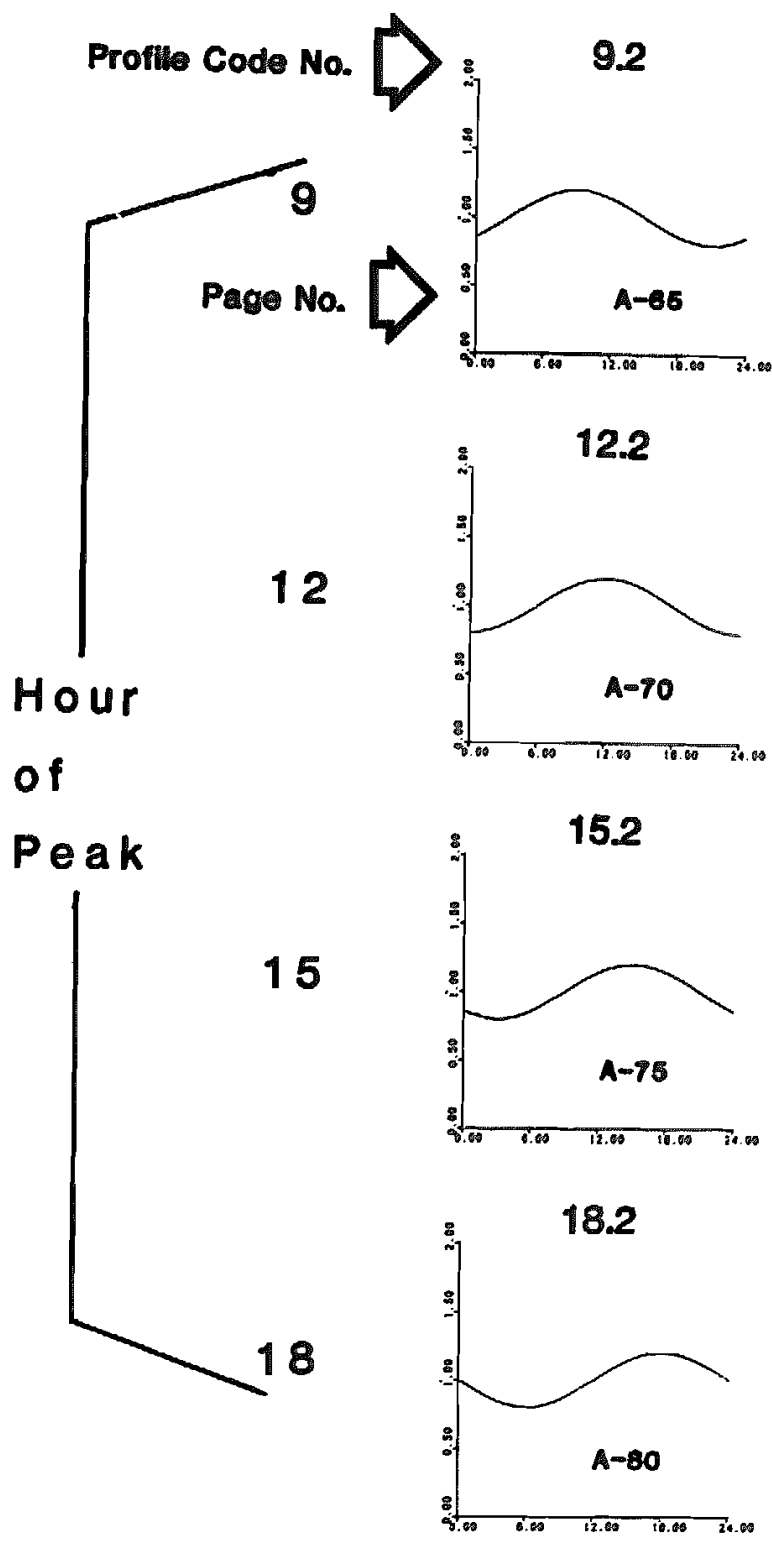

.3

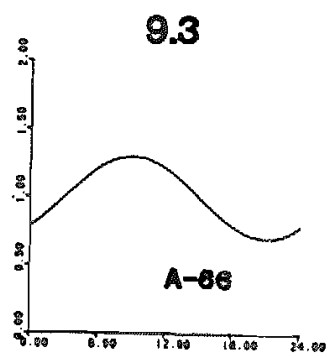

12.3
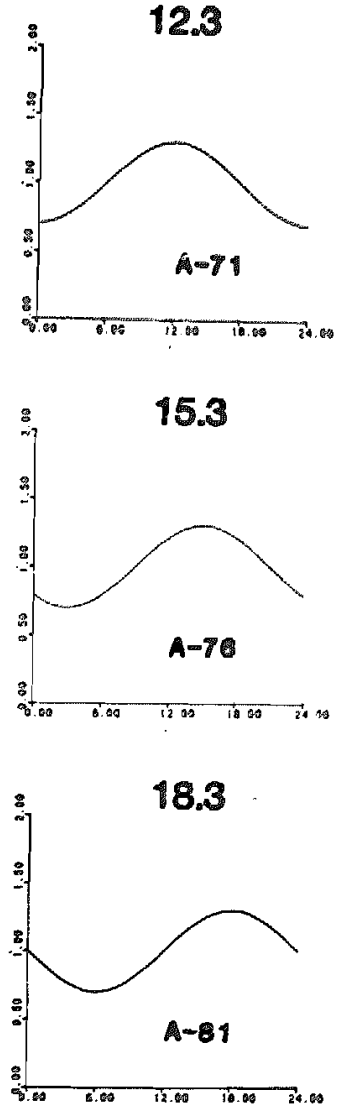

Monthly Average Daily Lond Shapes for Which Data Are Given in Table III. (The number A-xx shown for each shape is the page numer in this apperdix on which the corresponding system performance graphs can be found) 


\section{Amplitude to Mean}

.4
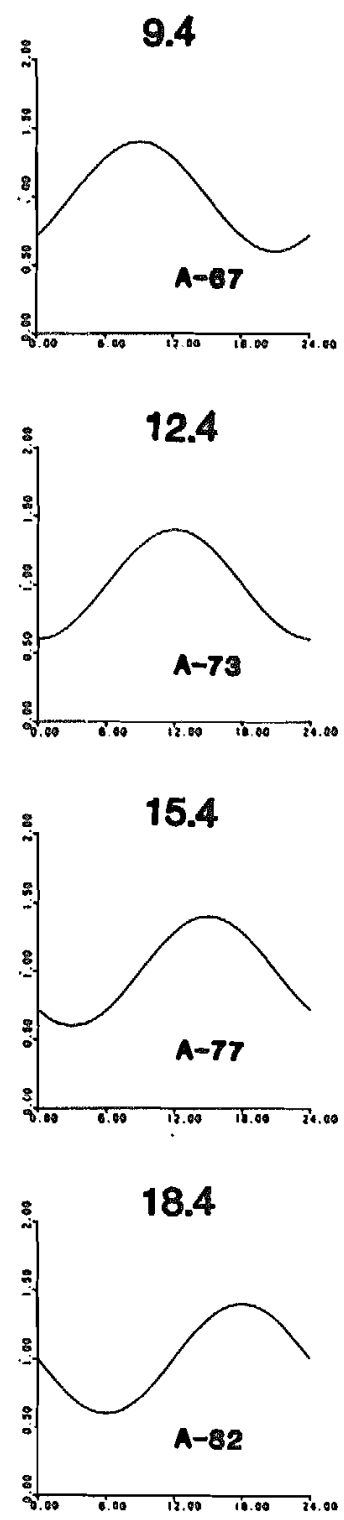

.5
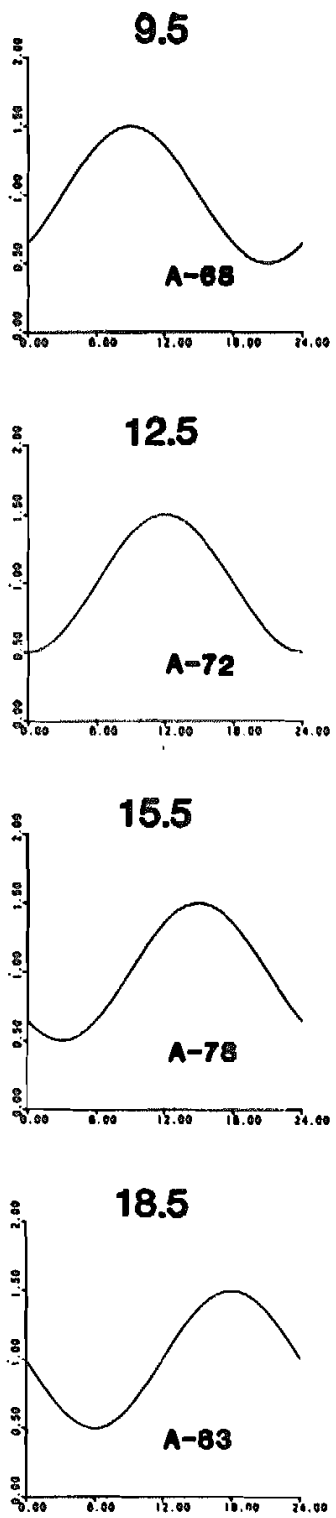

.7

9.7

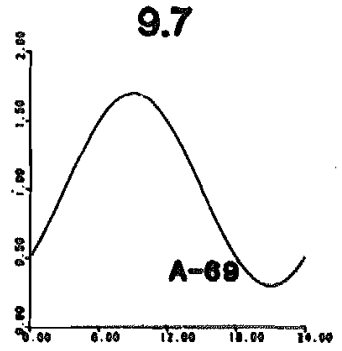

12.7

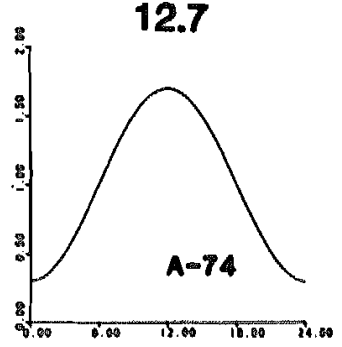

15.7

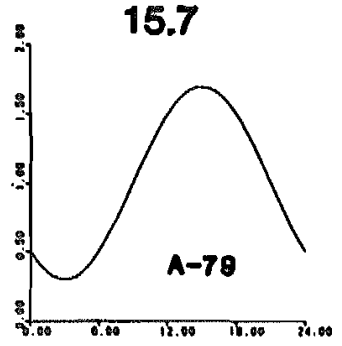

18.7

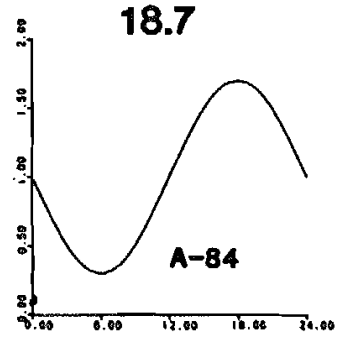

Only the load shape is important in selecting the proper graph. The magnitude of the load enters through the parameter QE/L. These shapes encompass all the two-digit SIC applications listed in Ref. $i$. 


\section{Unimodal}

Loads
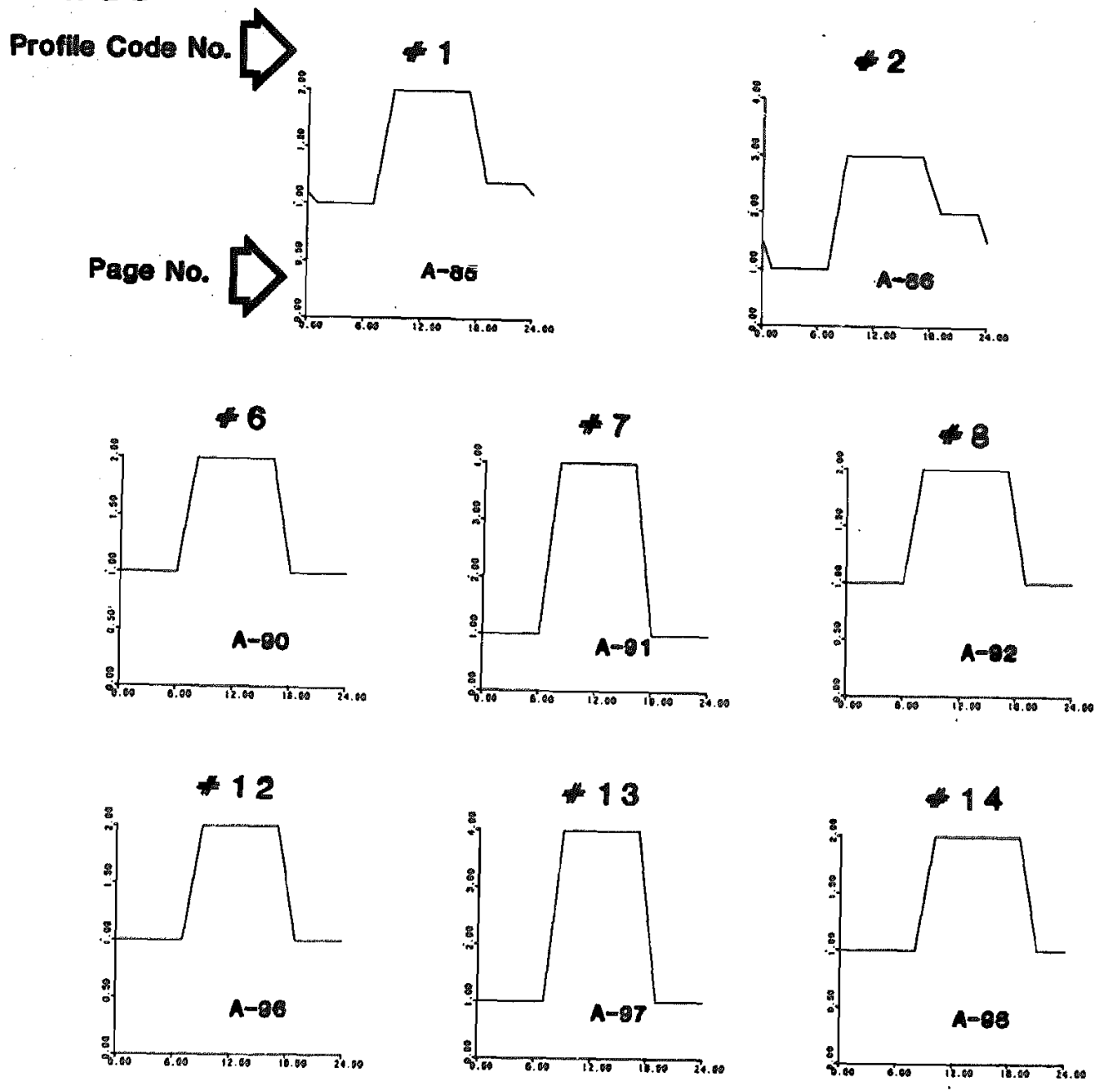

\section{Bimodal}

Loads
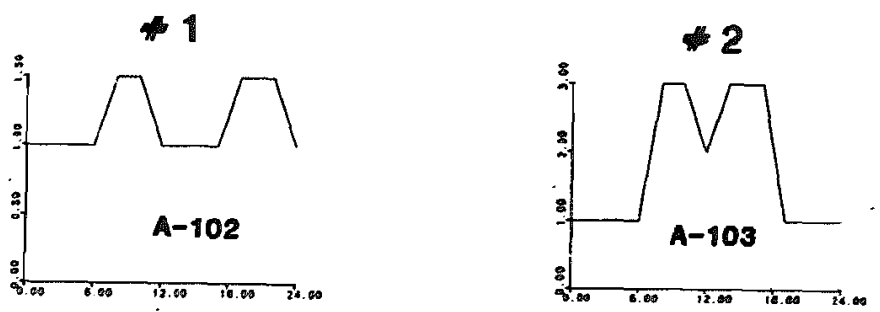

Monthly Average Daily Load Shapes for Which Data Are Given in Table III. (The number A-xr shown for each shape is the page nuaber in this appendix on which the corresponding system performance graphs can be found) 

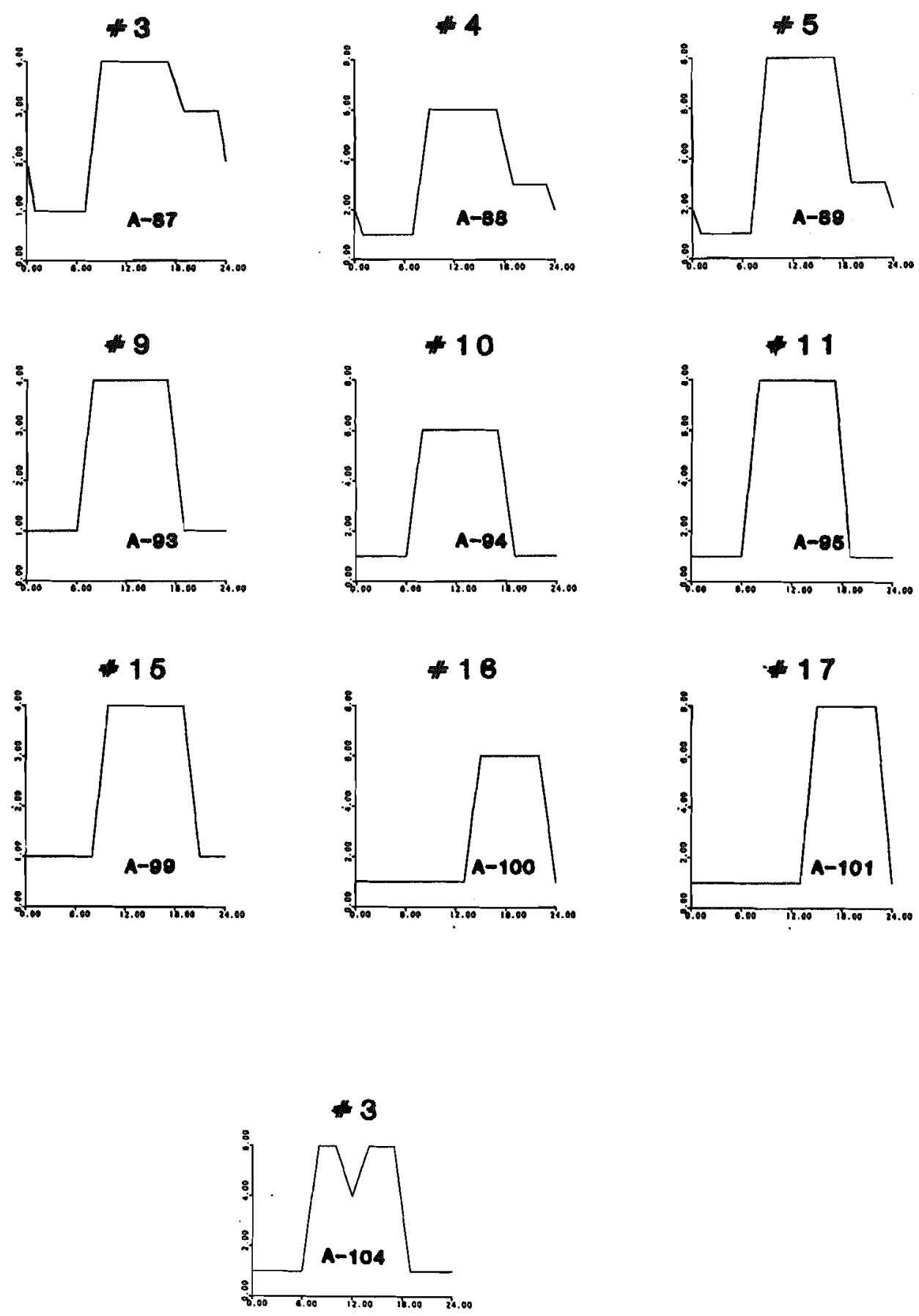

Only the load shape is important in selocting the proper graph. The magnitude of the load enters through the parameter OR/L. These shapes oncompass 11 the two-digit SIC applications listod in Ref. 7. 

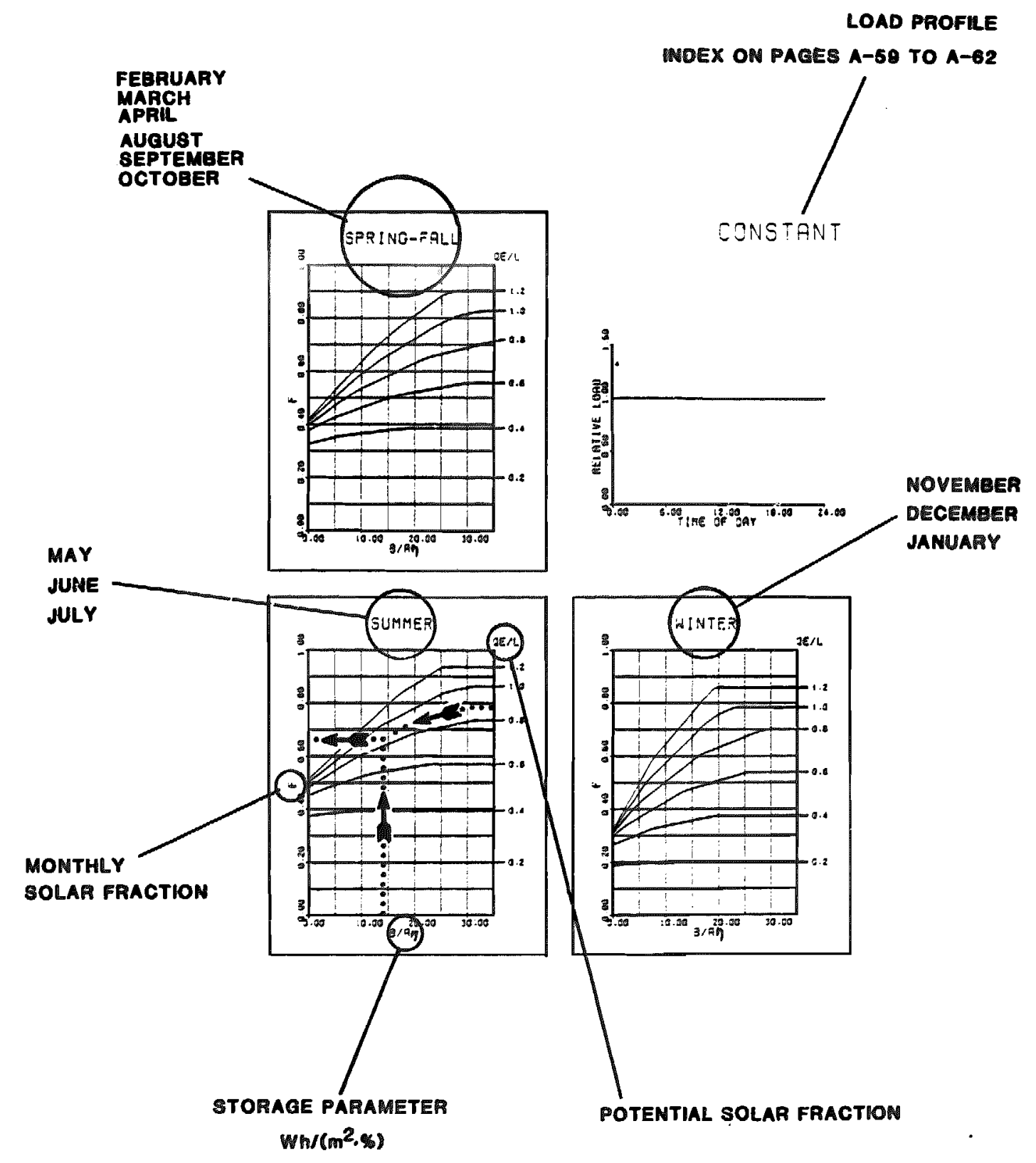

KEY for reading TABLE III 

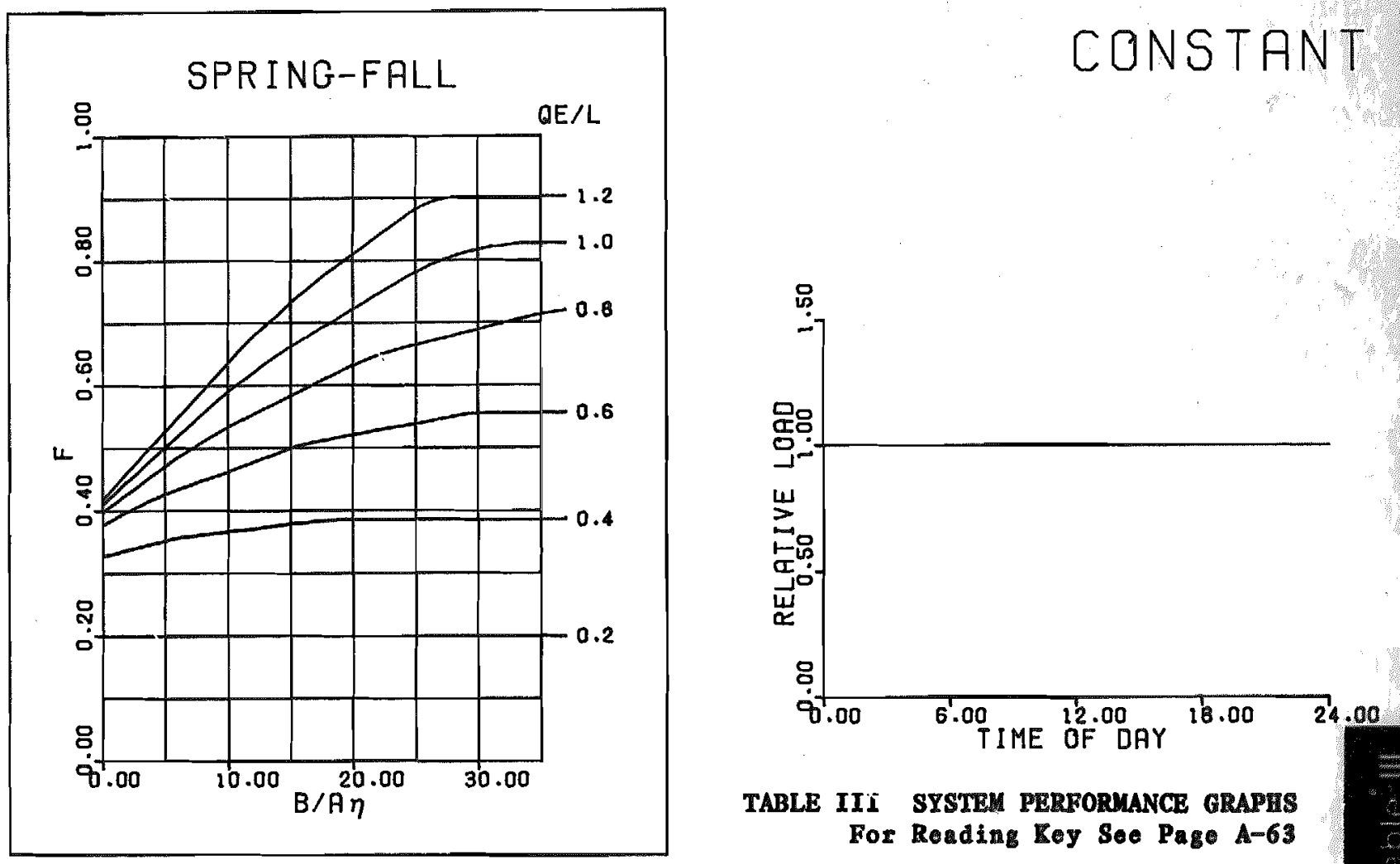

TABLE III SYSTEM PERFORMANCE GRAPHS For Reading Key Soe Page A-63

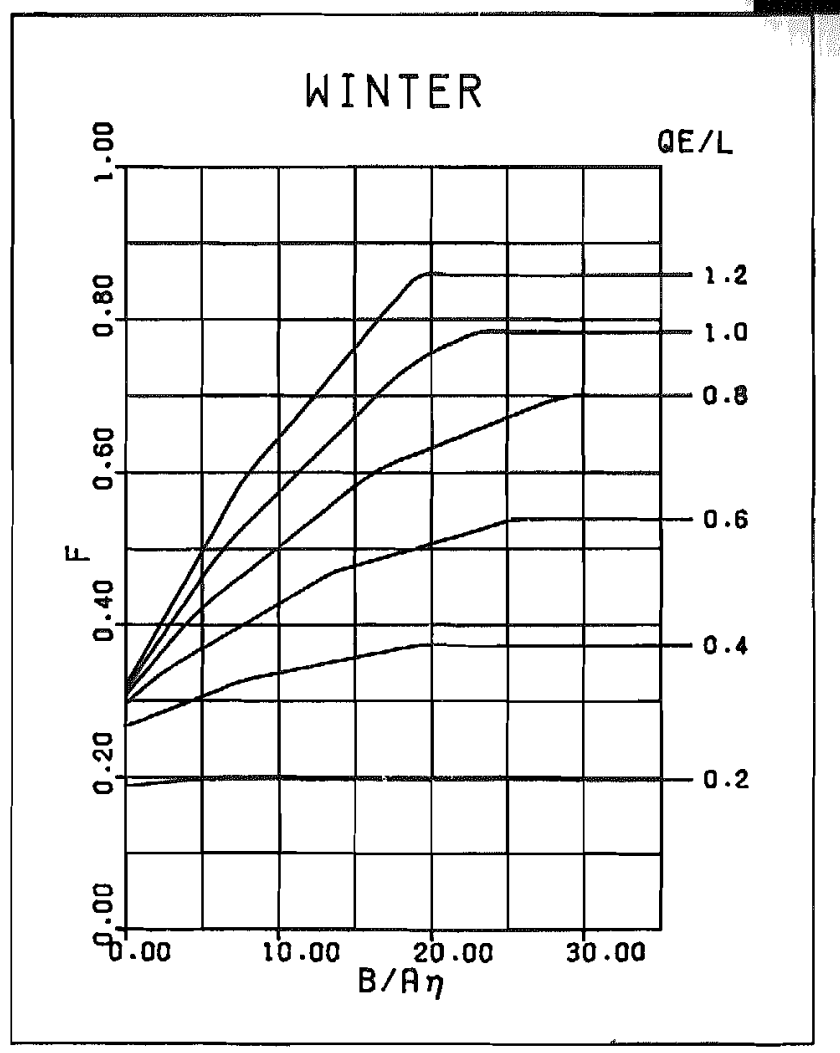


S INUSO IDAL\#9.2

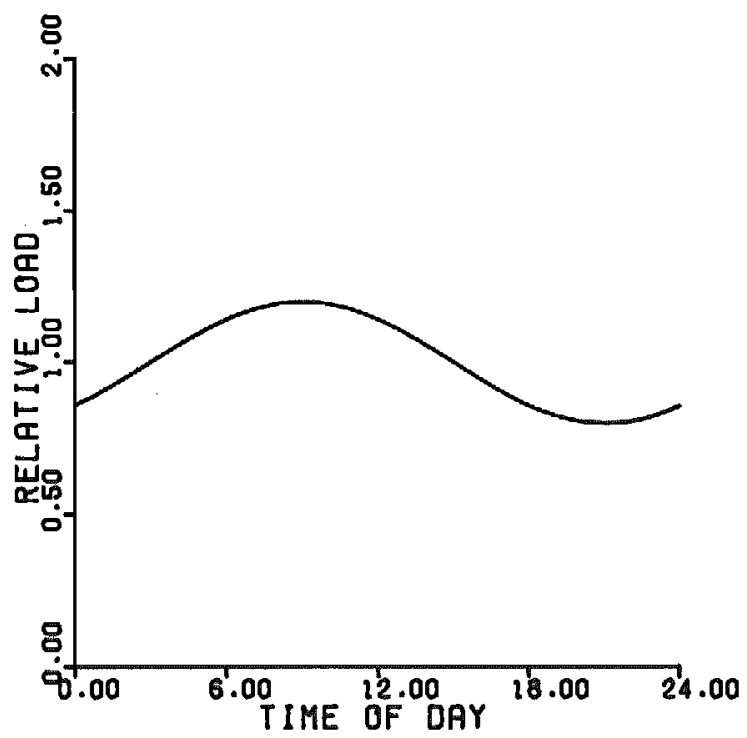

TABLE III SYSTEM PERFORANCE GRAPIS For Rouding Rey see Page A-63

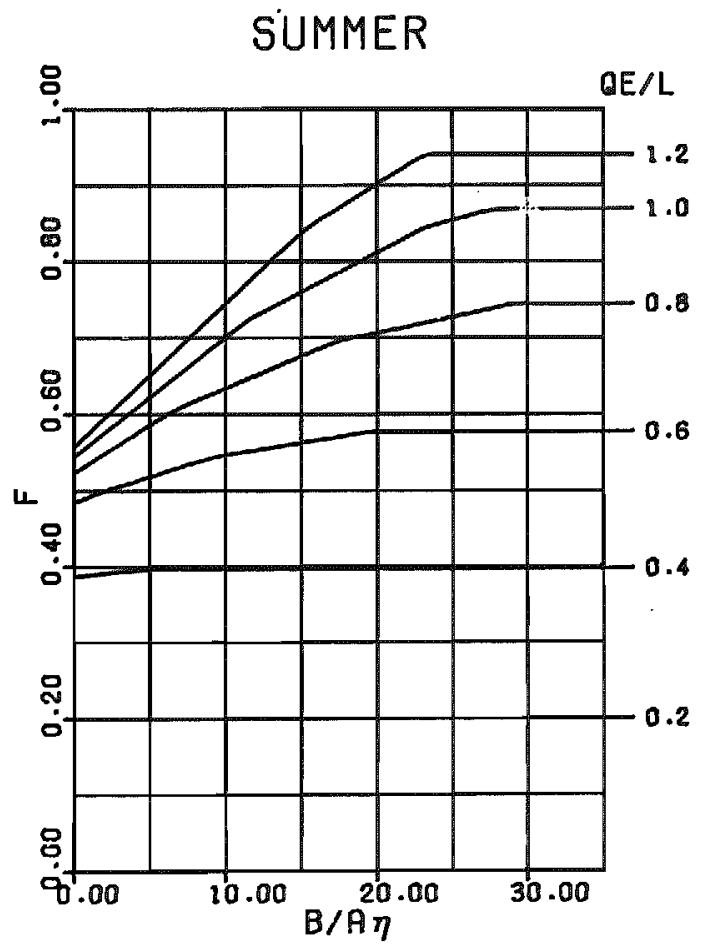

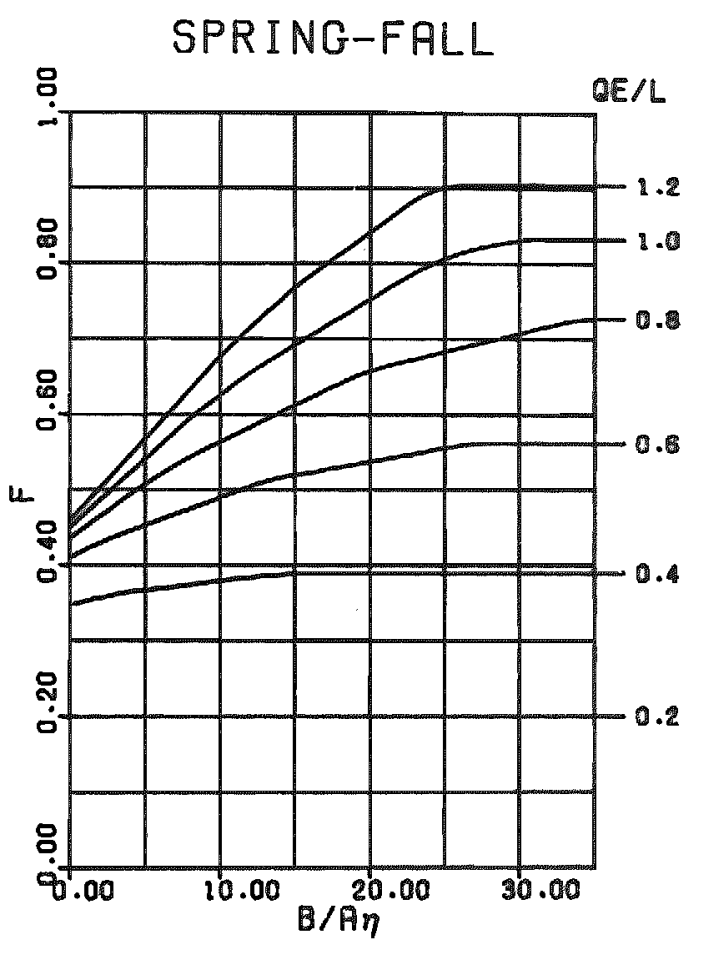

W INTER

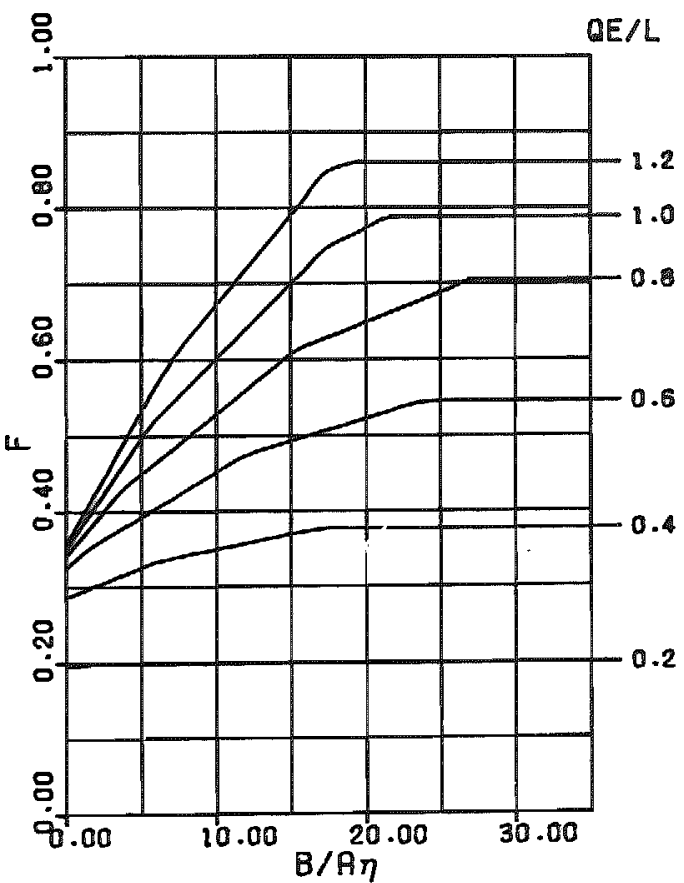


SPRING-FALL

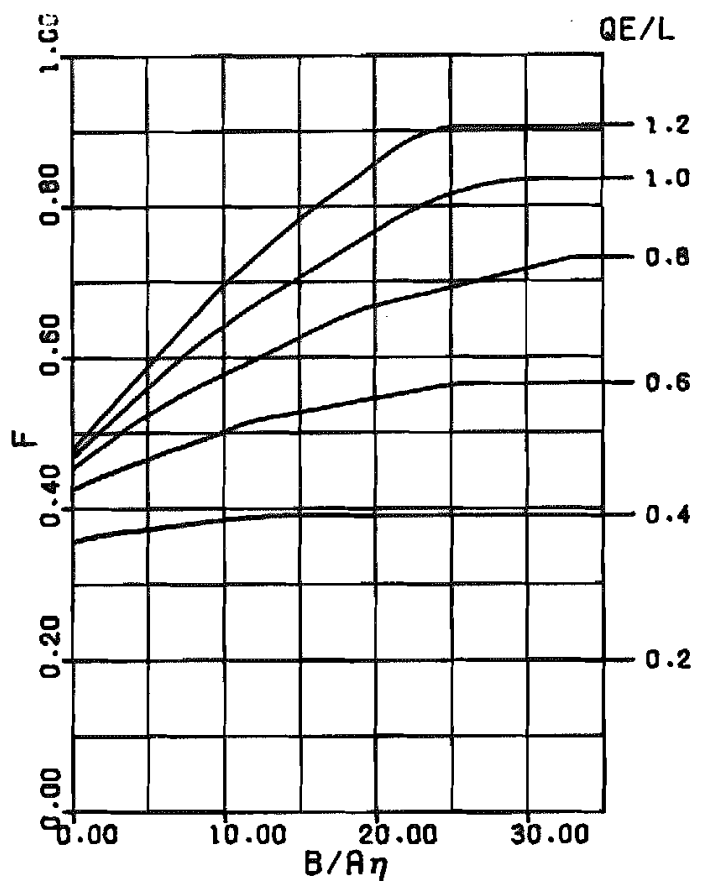

QE/L

2.2

0.8

0.6

0.4

0.2

SUMMER

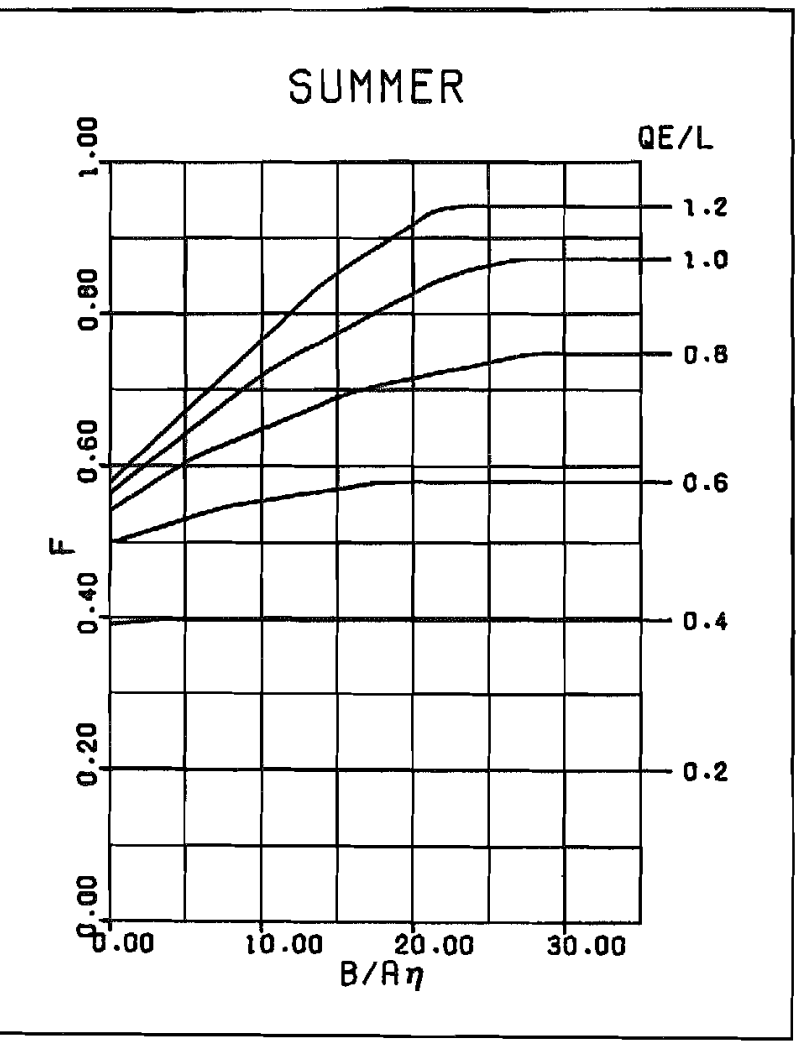

S I NUSO I DAL \# 9.3

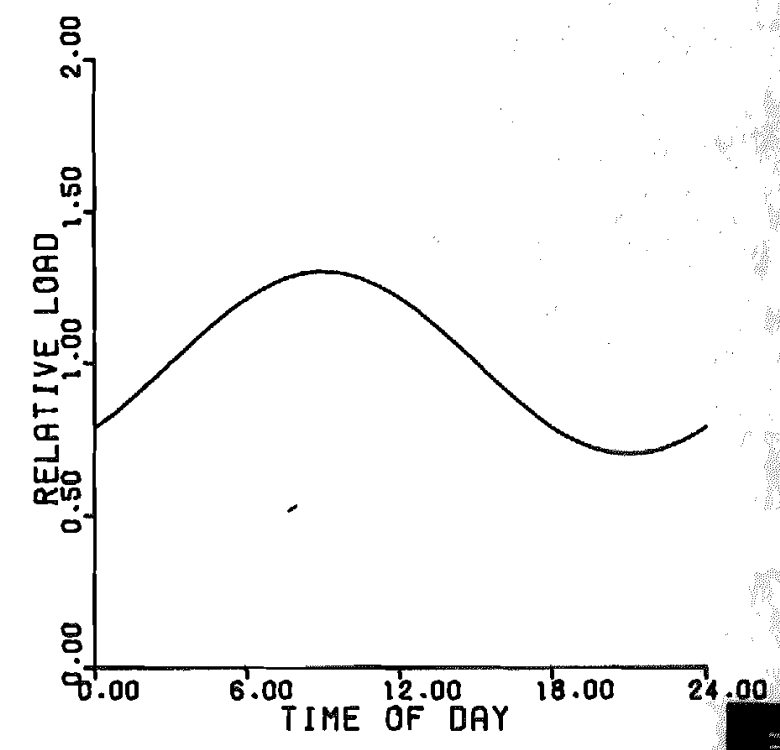

TABLE III SYSTEM PERFORMANCE ORAPES For Reading Koy See Page A-63

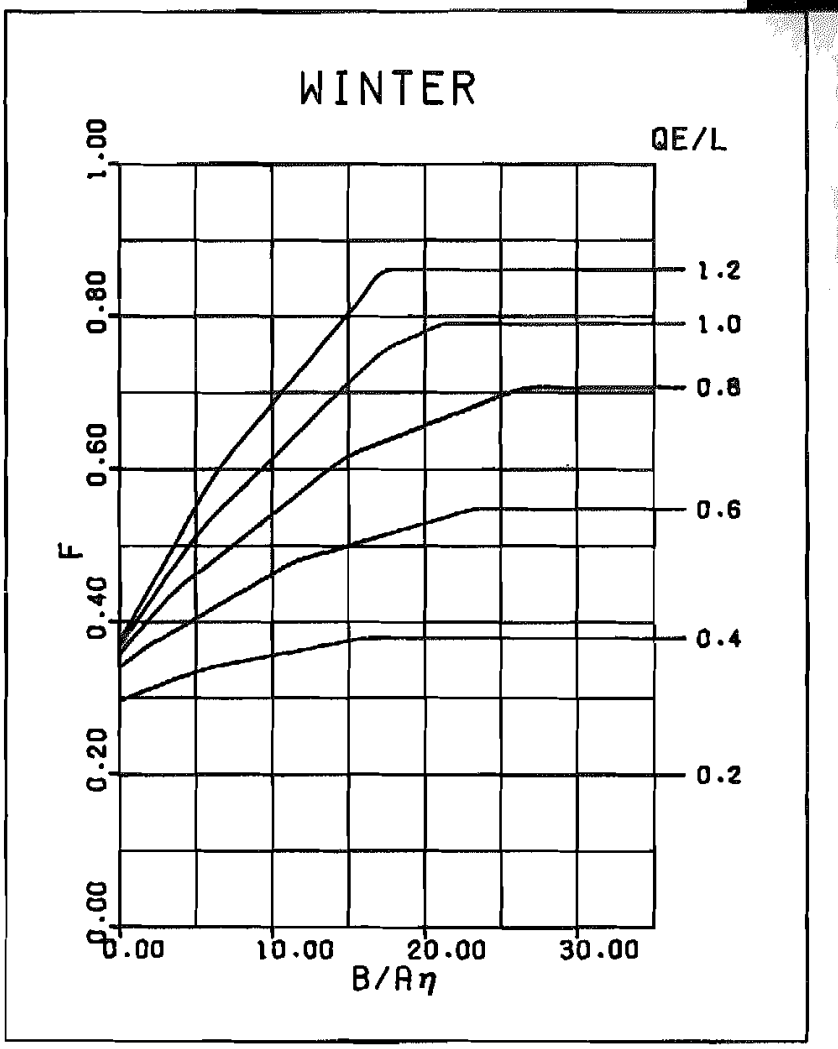


S INUSOIDAL\# 9.4

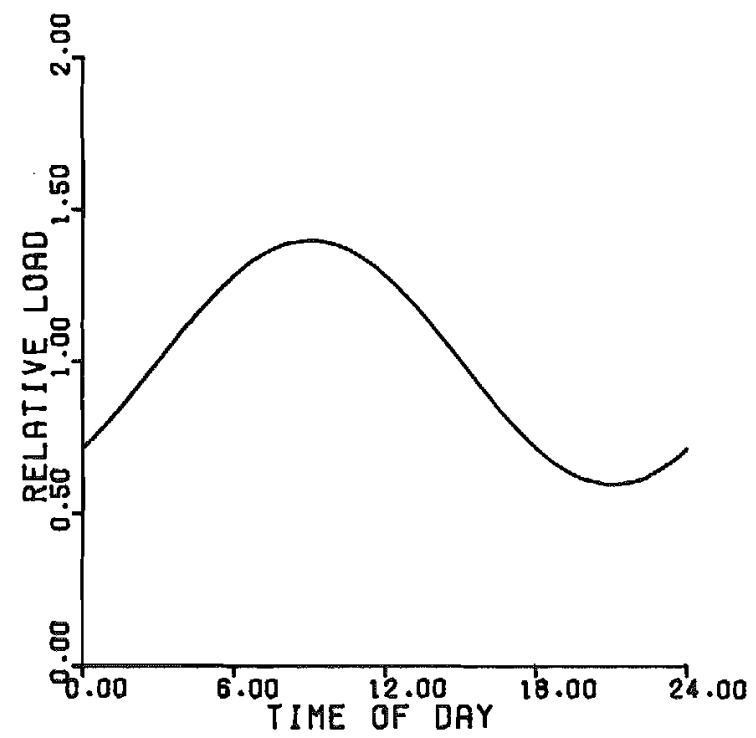

TABLE III SYSTEM PERFORMANCE GRAPHS

For Reading Key See Page A-63

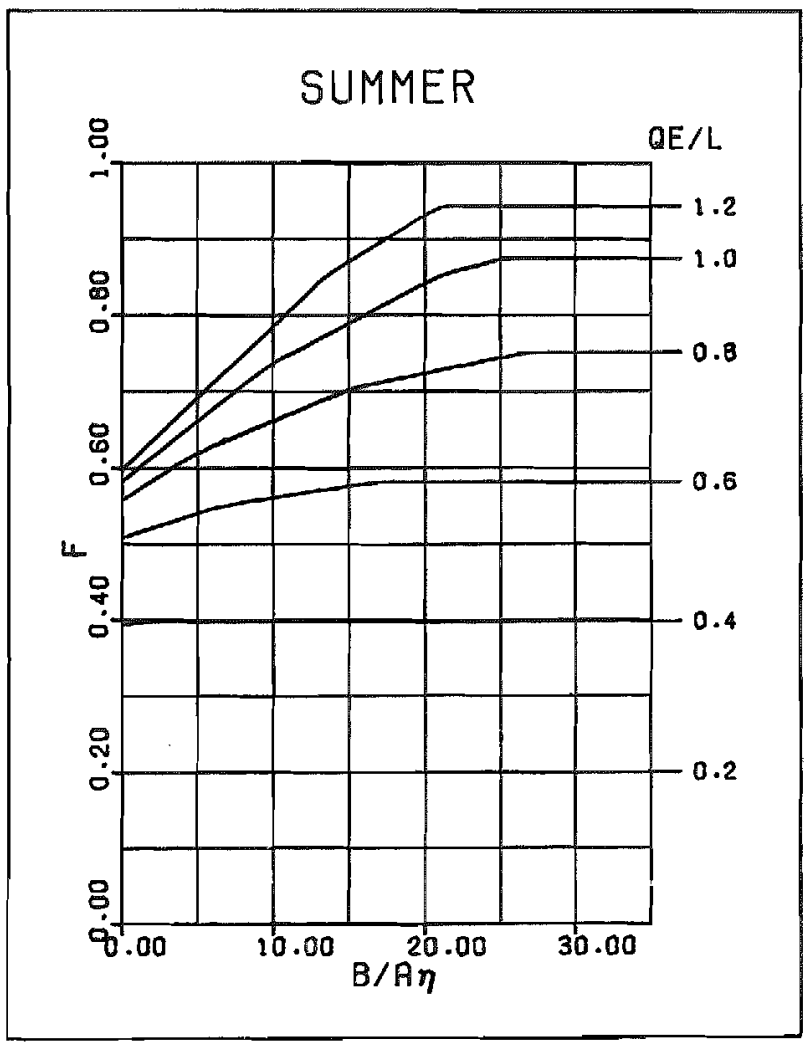

SPRING-FALL

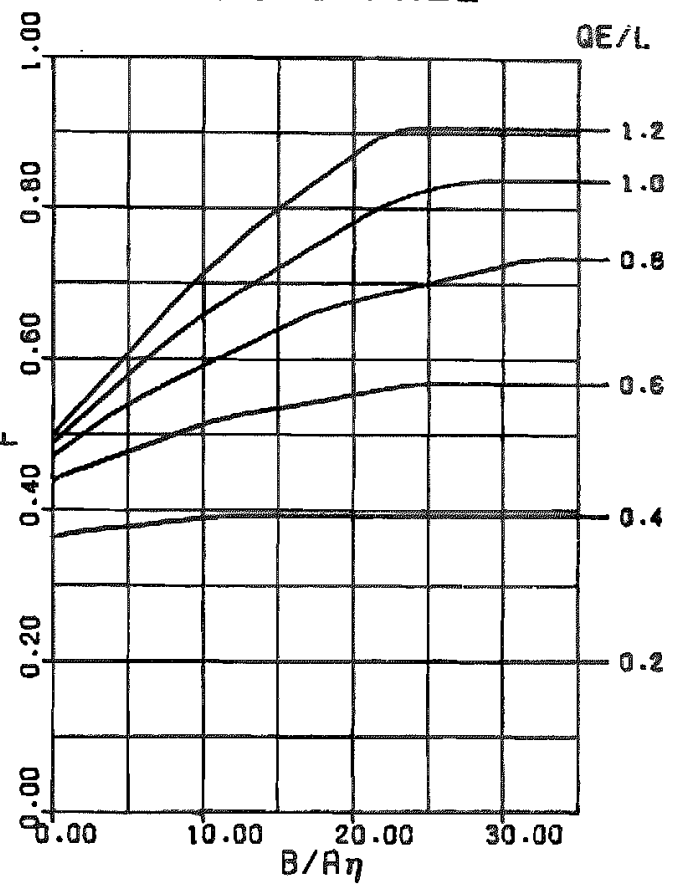

W INTER

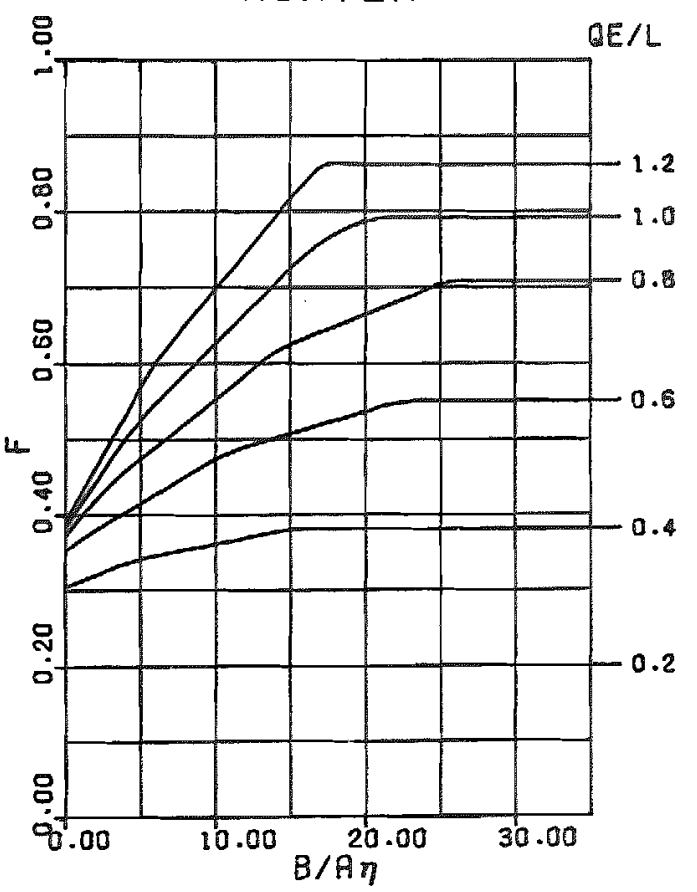



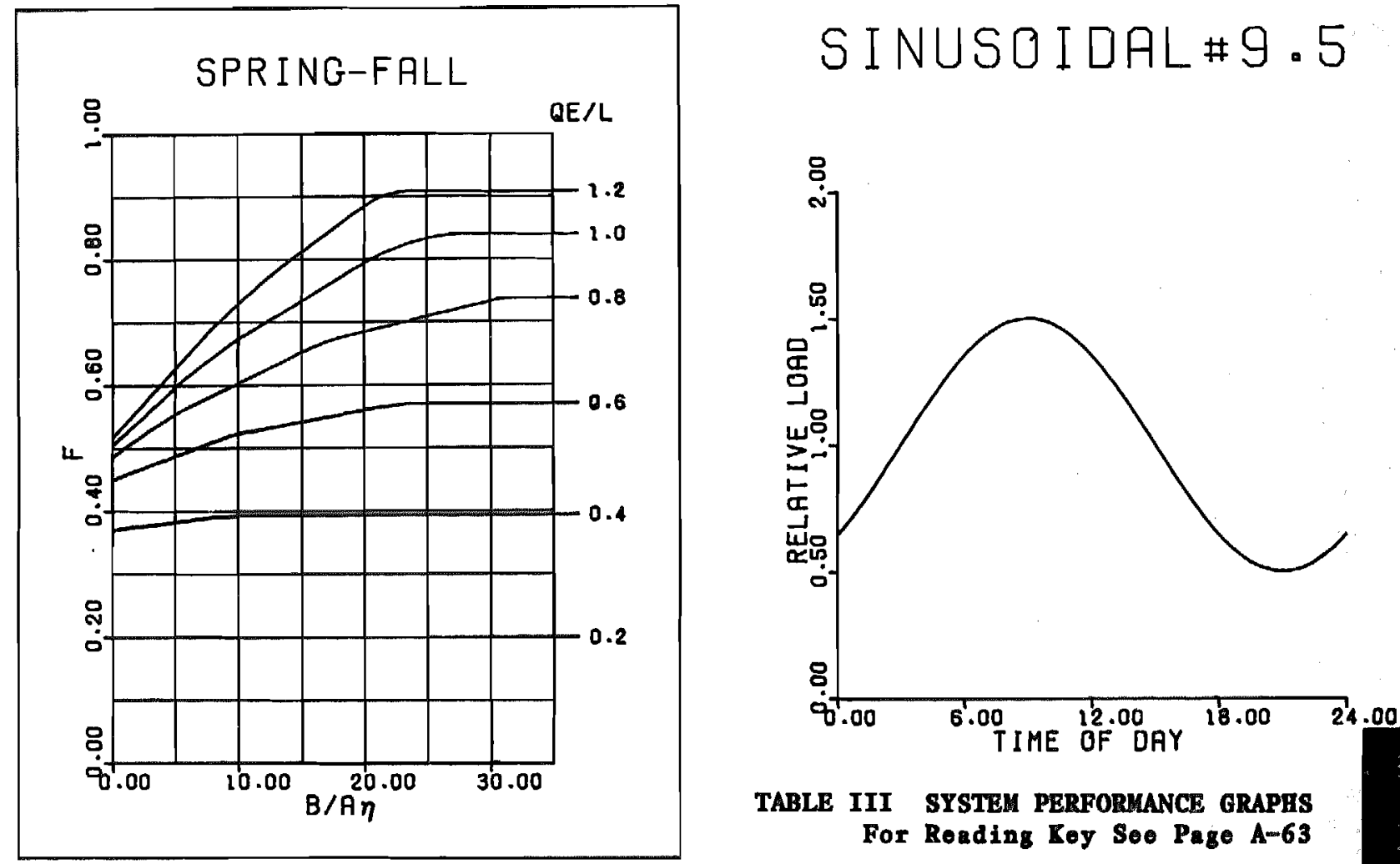

TABLE III SYSTEM PERFORMANCE GRAPHS For Roading Koy Soo Page A-63

WINTER

QE/L
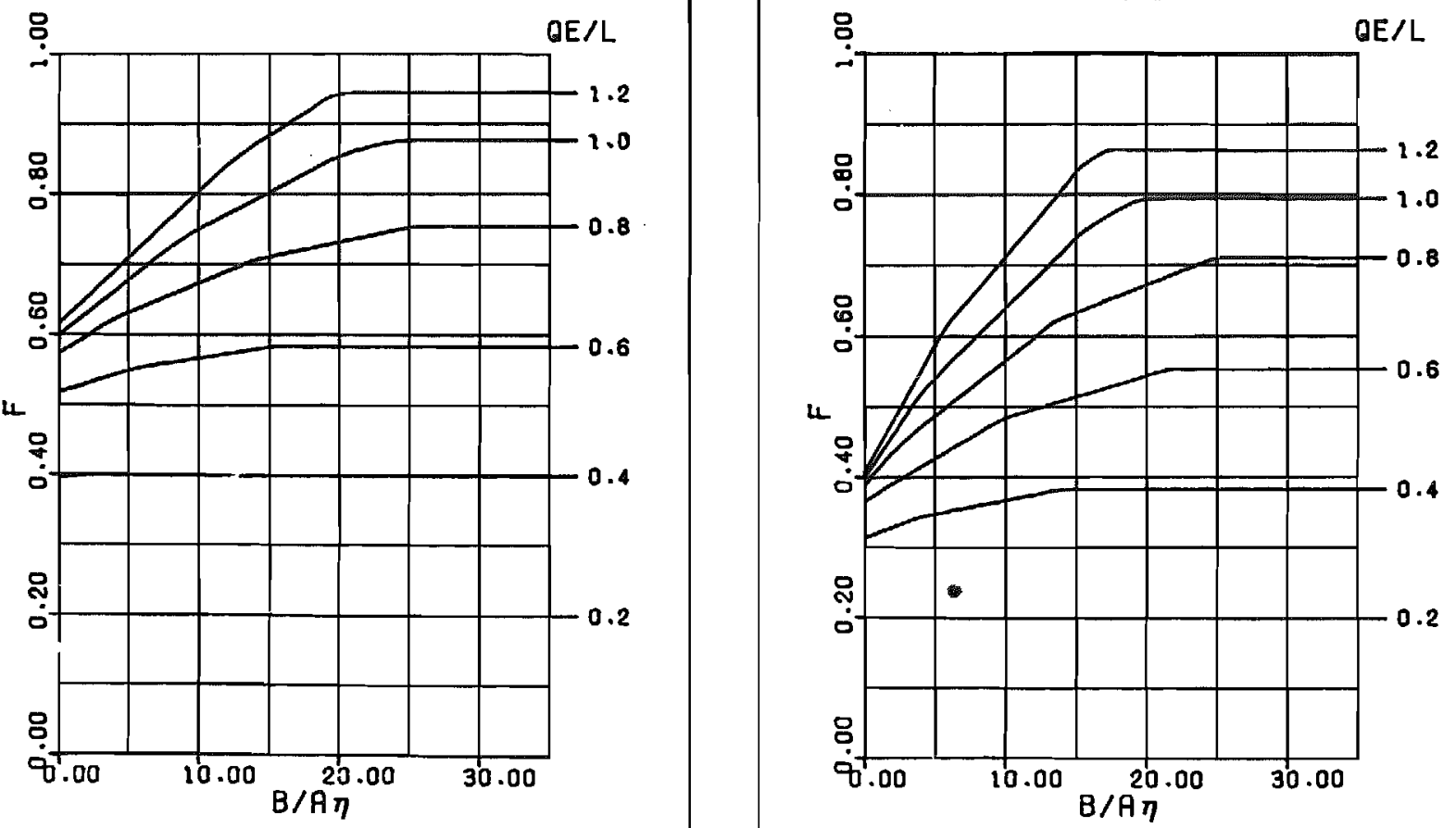
SINUSOIDAL\#9.7

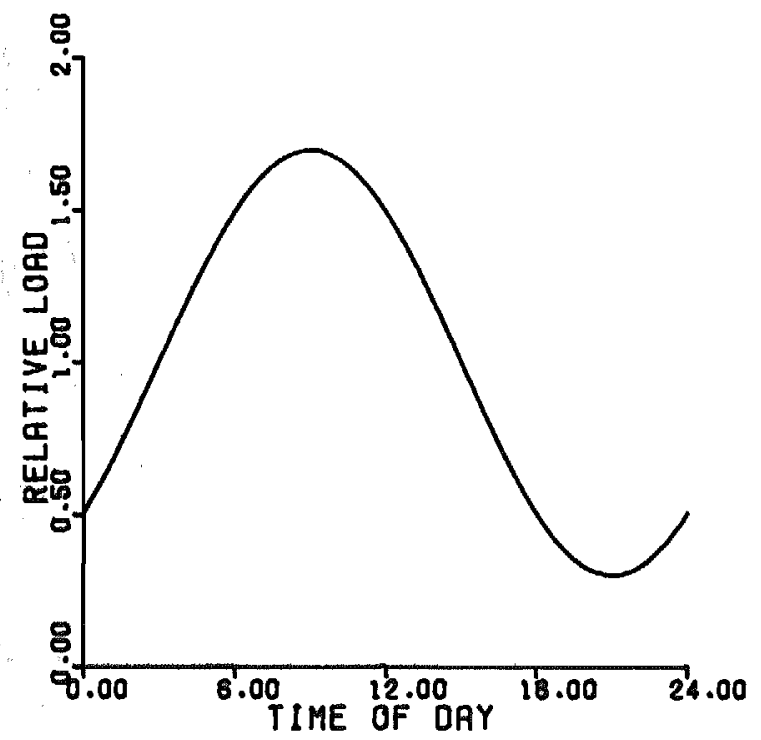

TABLE III SYSTEM PERFORMANCE GRAPHS

For Reading Koy See Page A-63

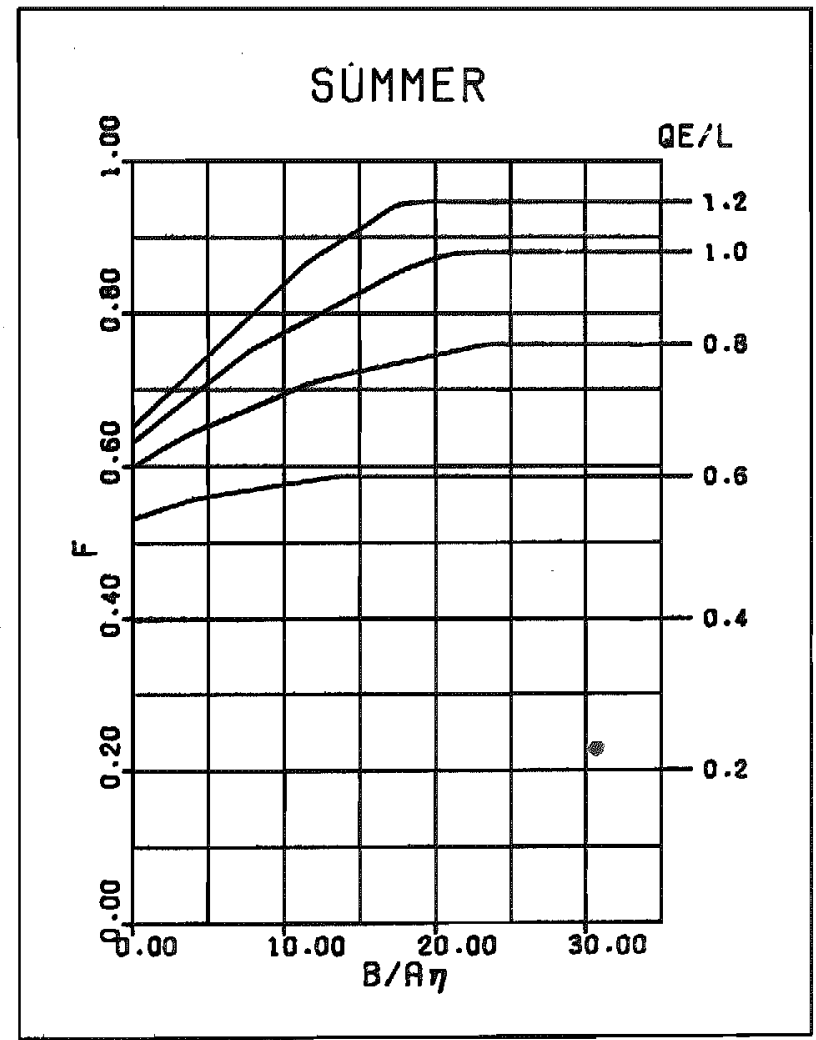

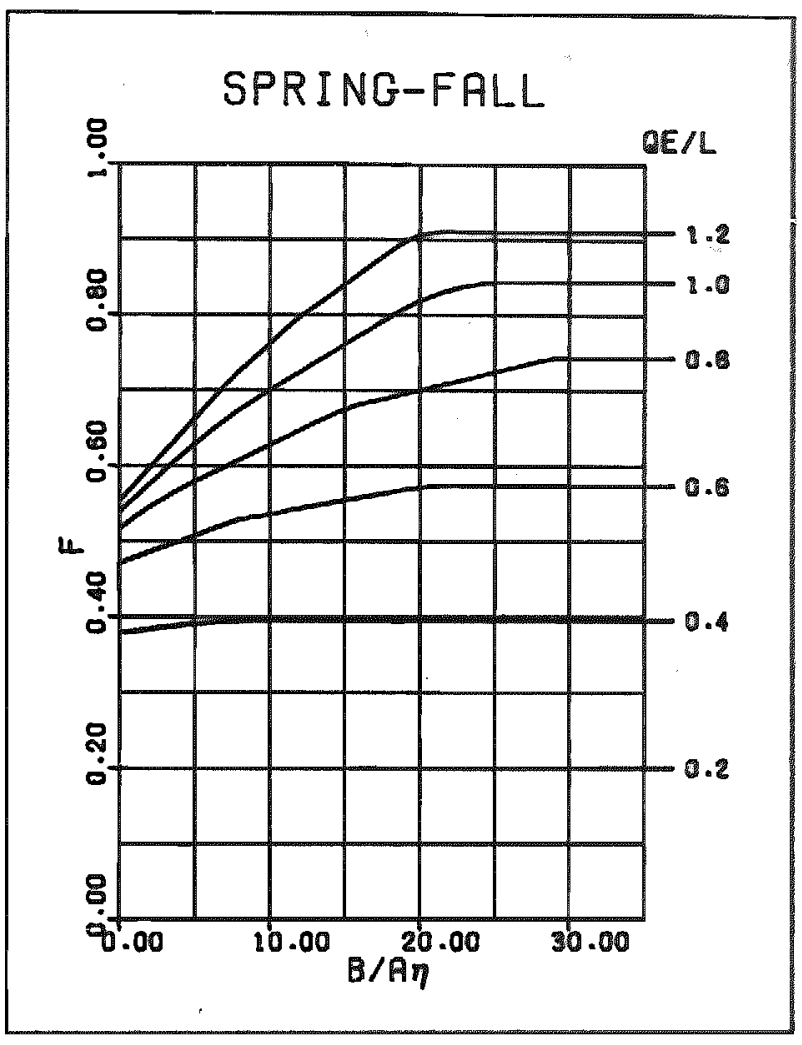

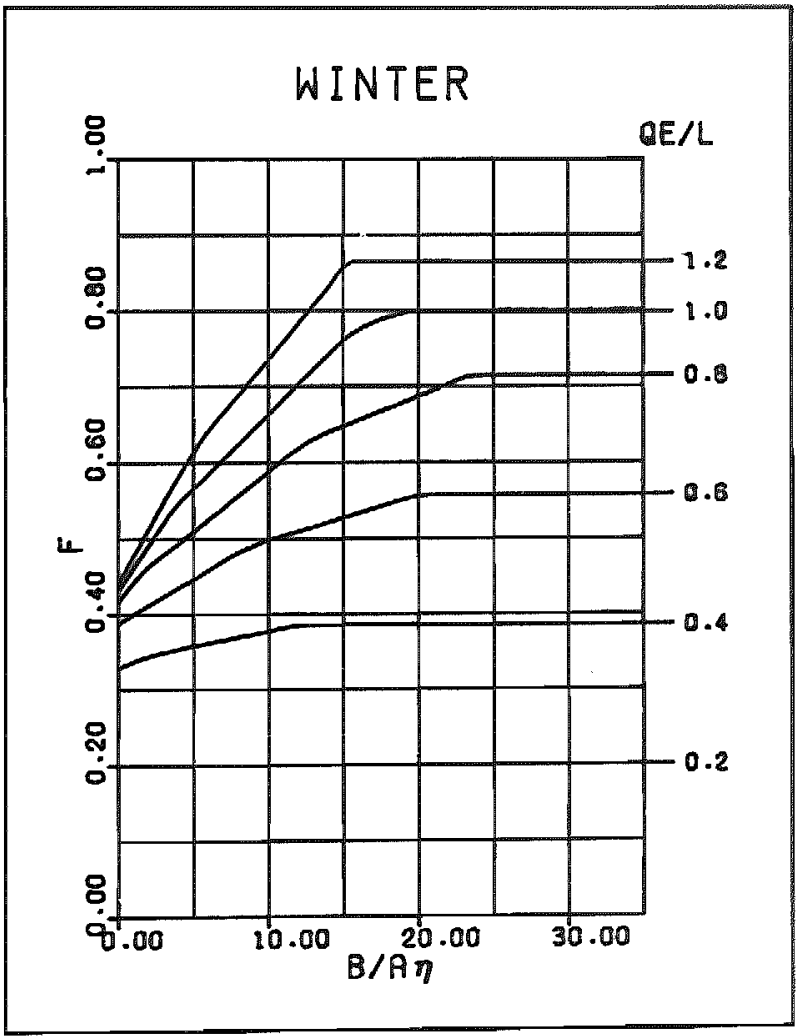




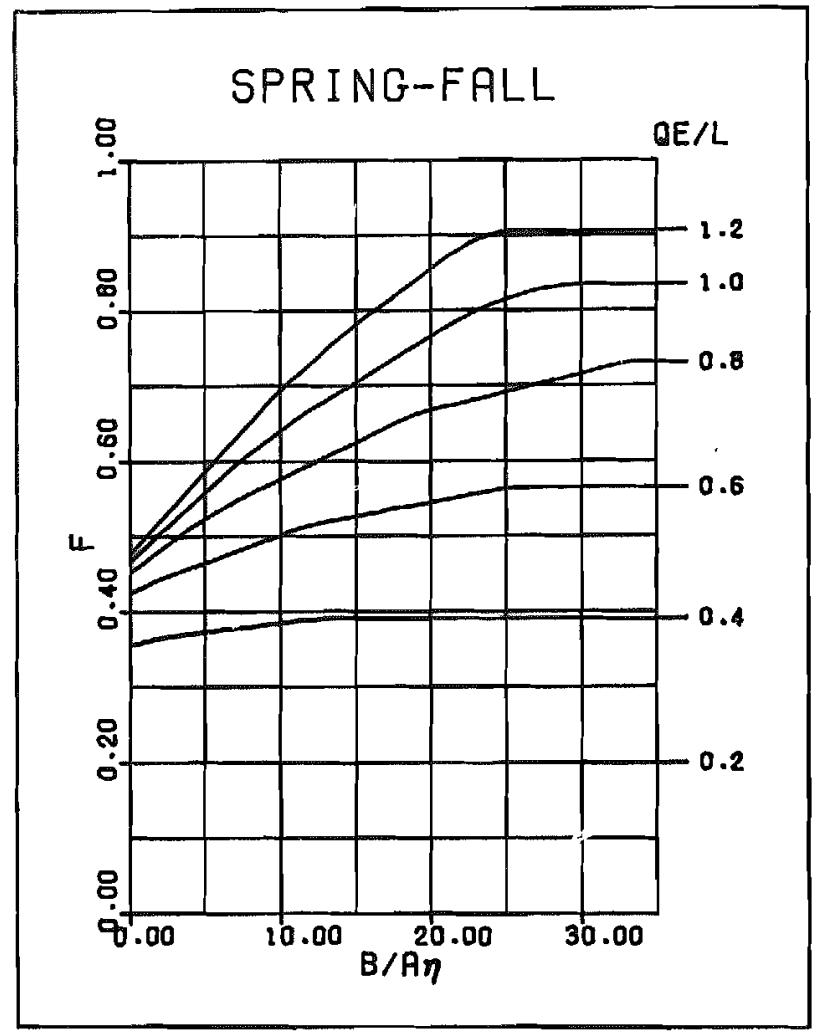

S INUSO IDAL\# $12 \cdot 2$

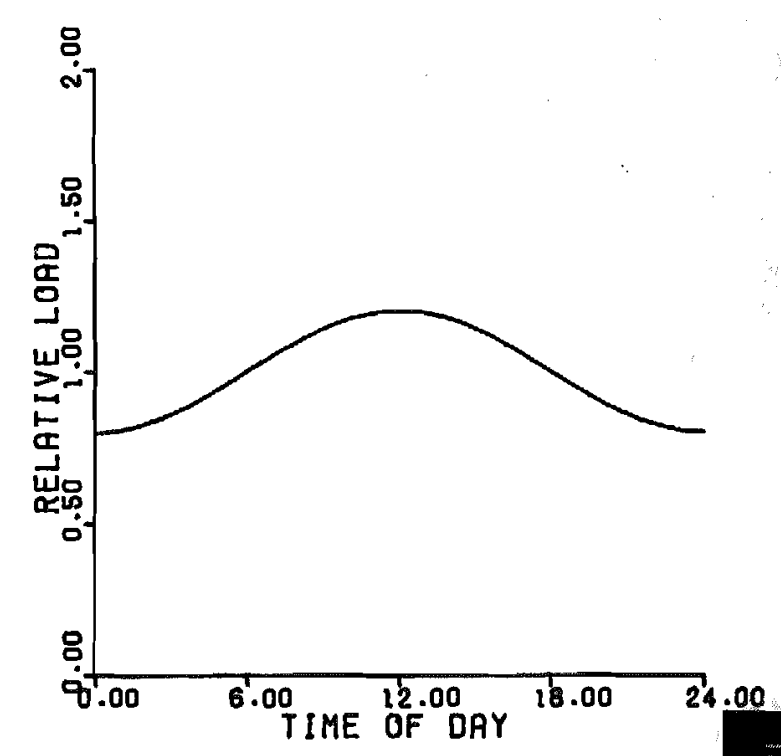

TABLE III SYSTEM PERPORMANCE GRAPHS

For Rerding Koy See Page A-63
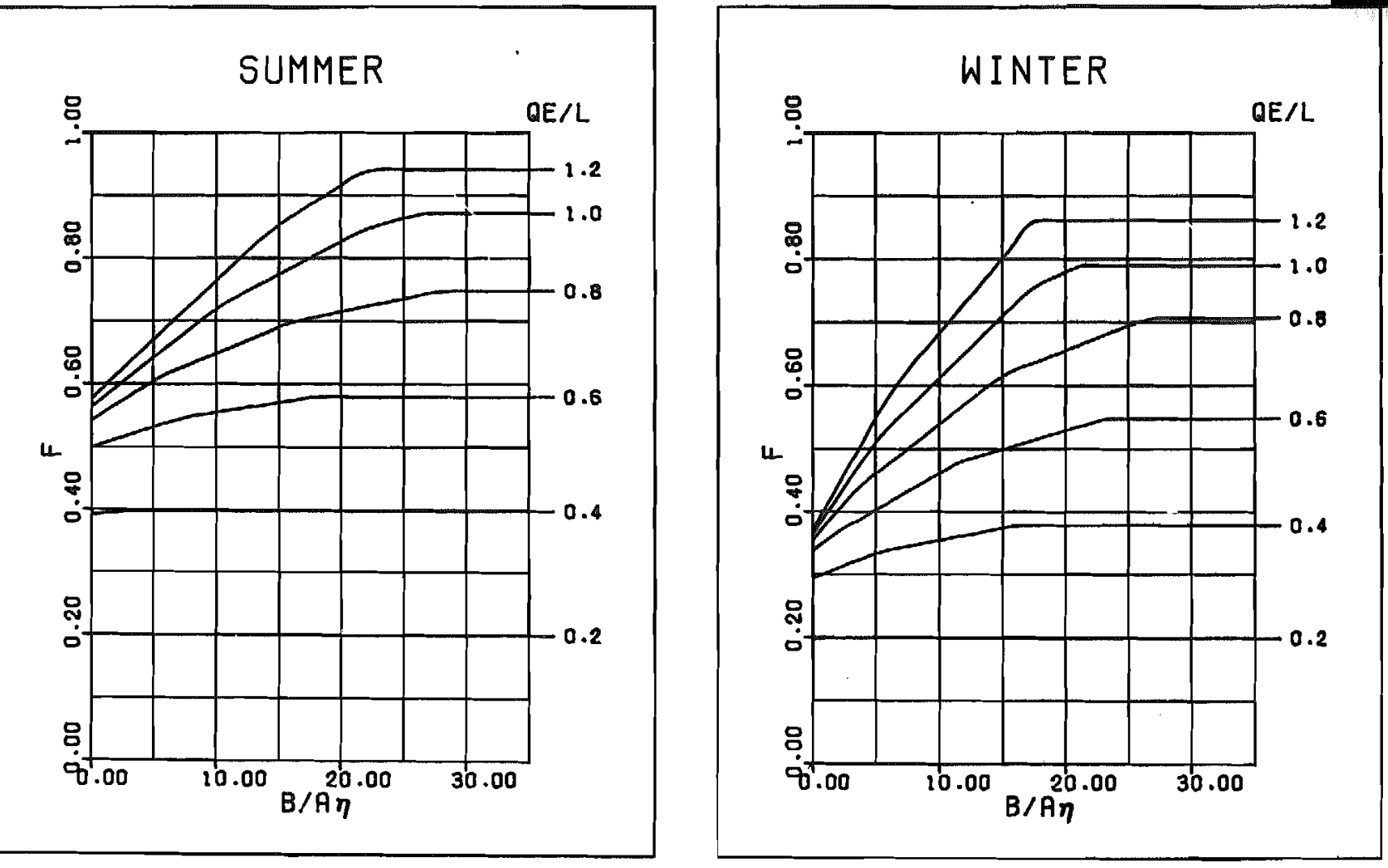
SINUSO IDAL\# $12 \cdot 3$

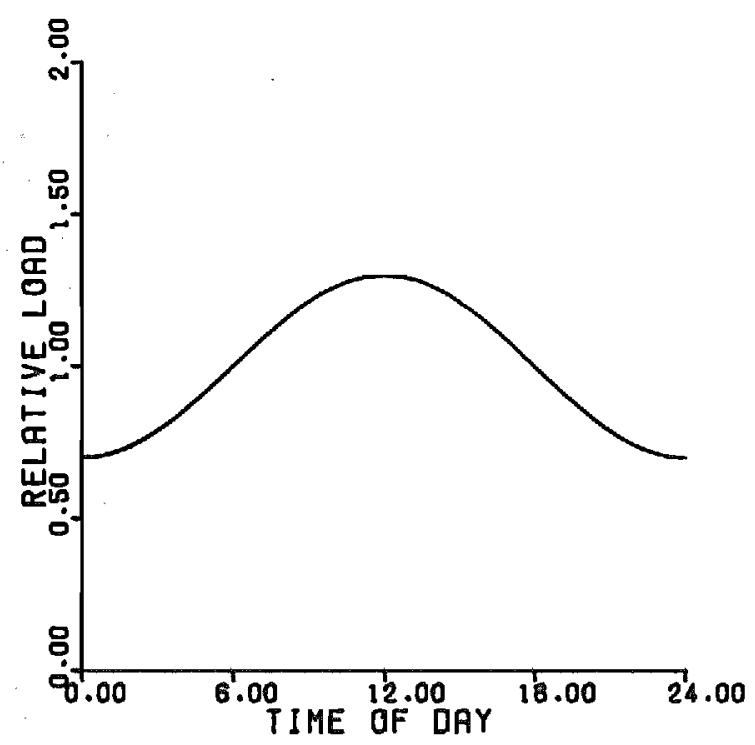

TABLE III SYSTEM PERFORMANCE GRAPHS For Reading Key See Page A-63

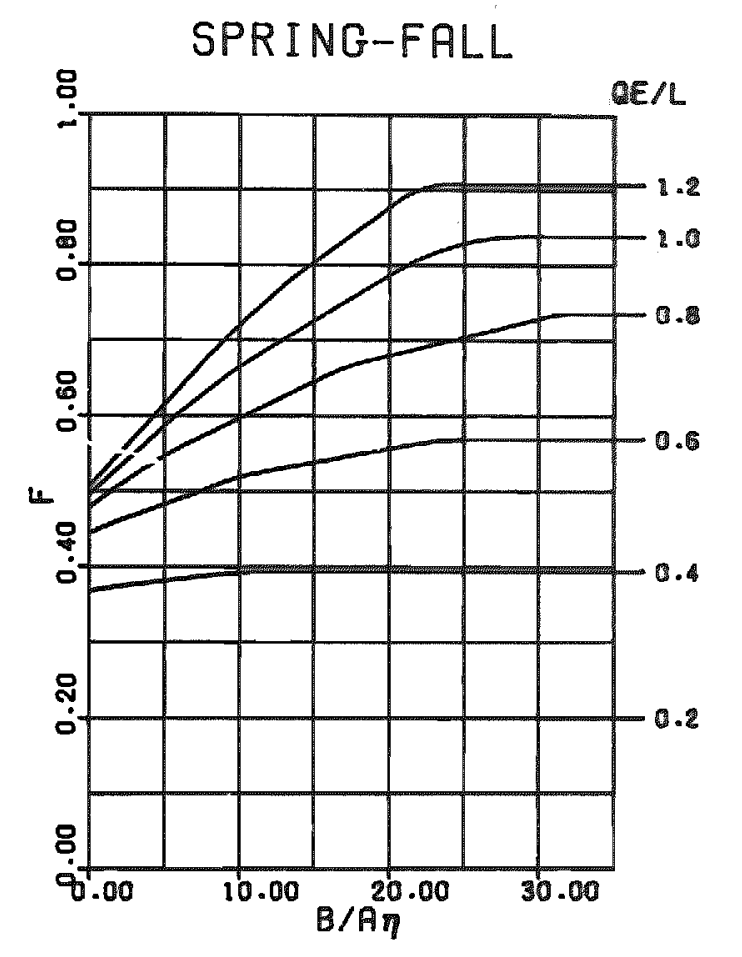

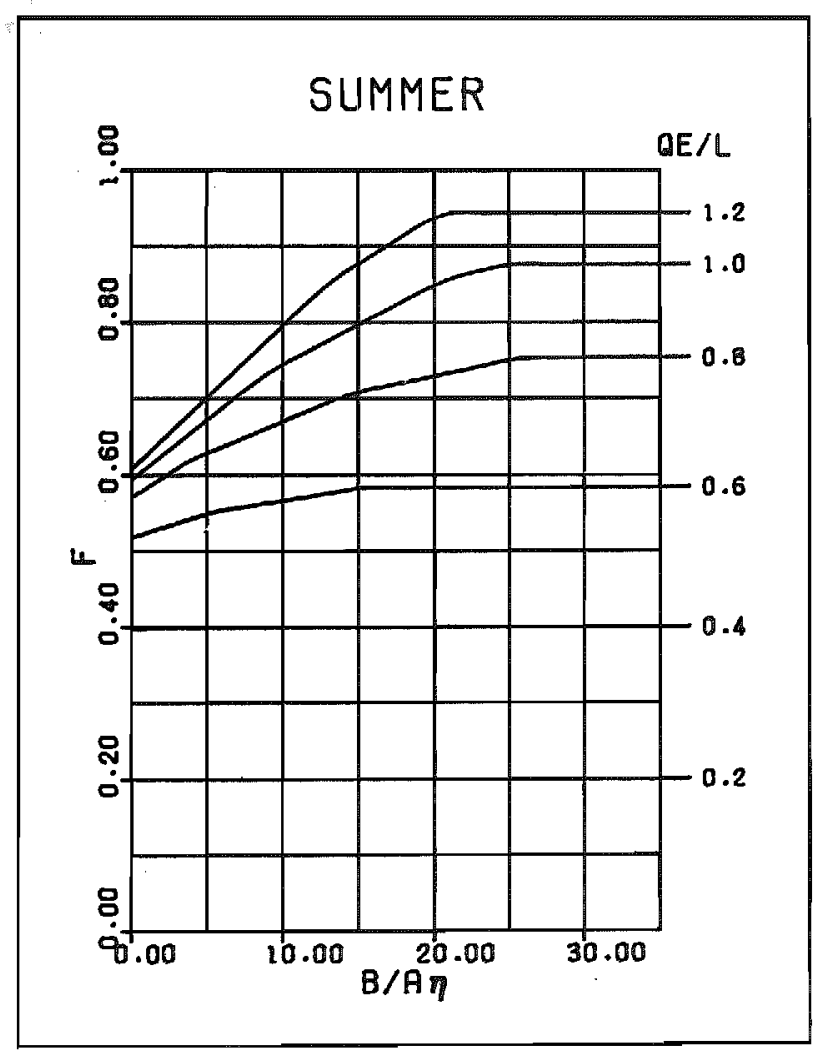

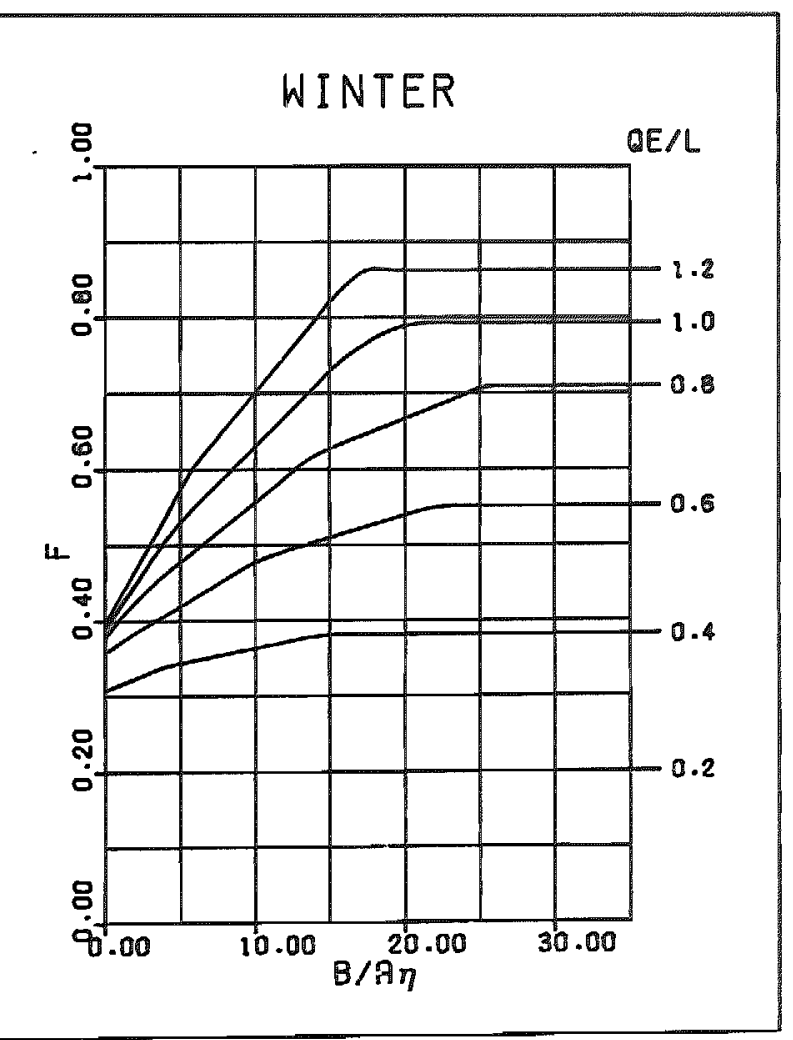




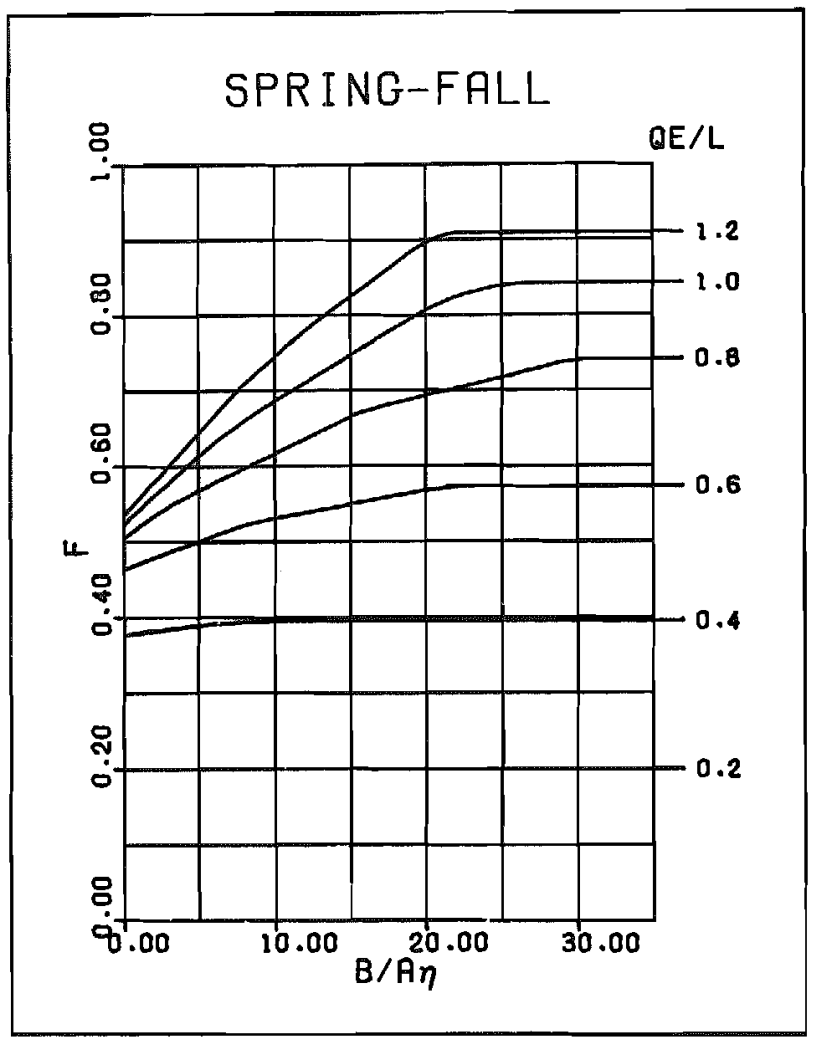

S I NUSO I DAL \# 12.4

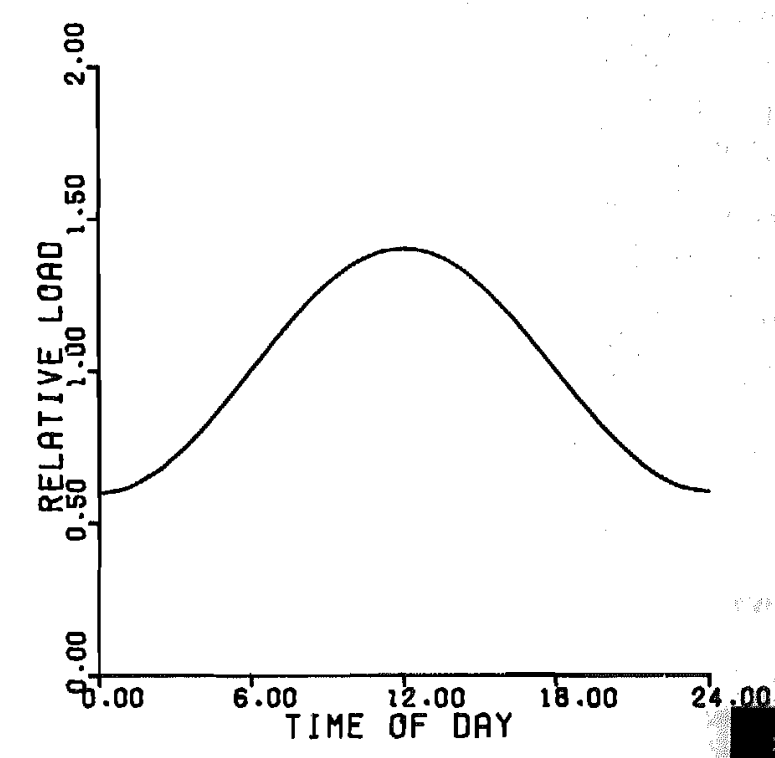

TABLE III SYSTEM PERFORMANCE GRAPHS

For Reading Key See Page A-63

WINTER

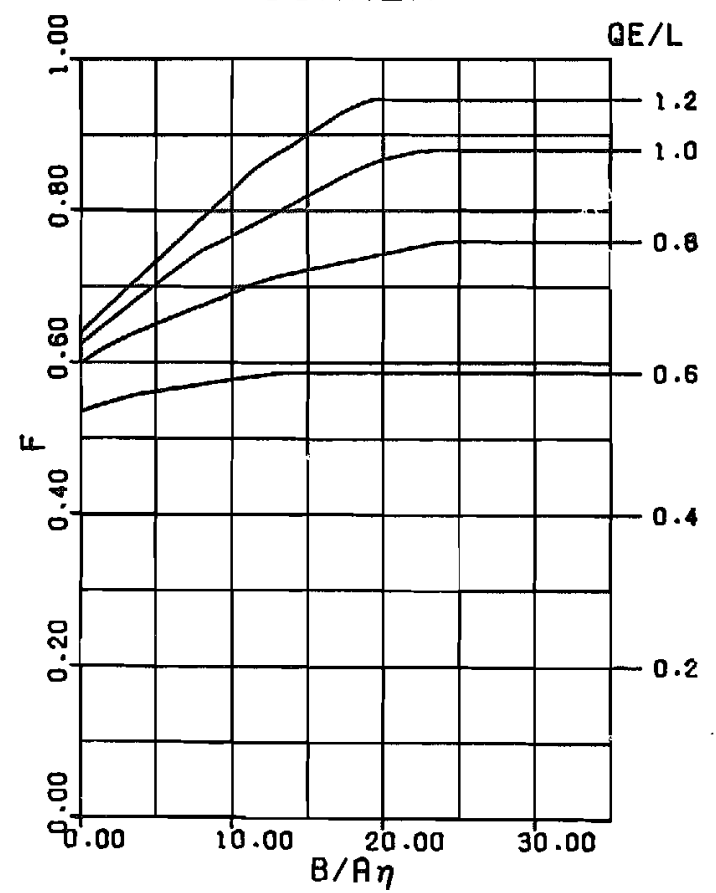

\section{SUMMER}

$\mathrm{QE} / \mathrm{L}$

1.2

.8

0.6

요.

QE/L

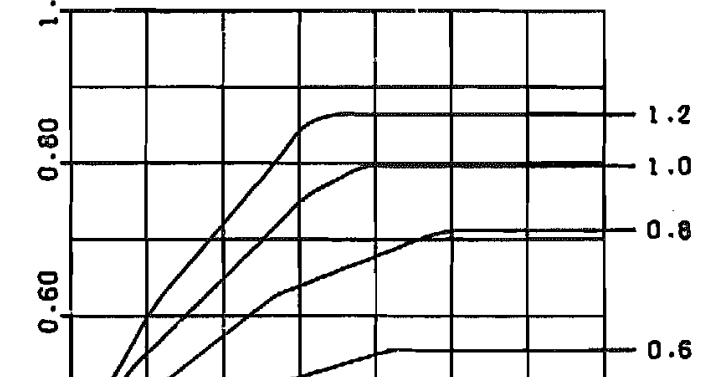

u.

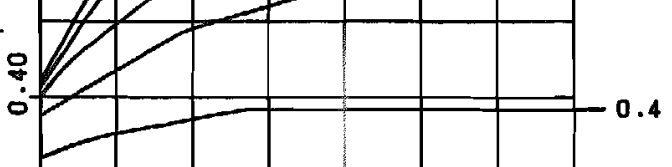

จุ.

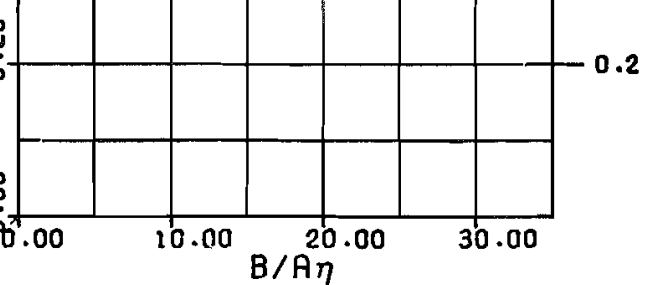


SINUSOIDAL\# 12.5

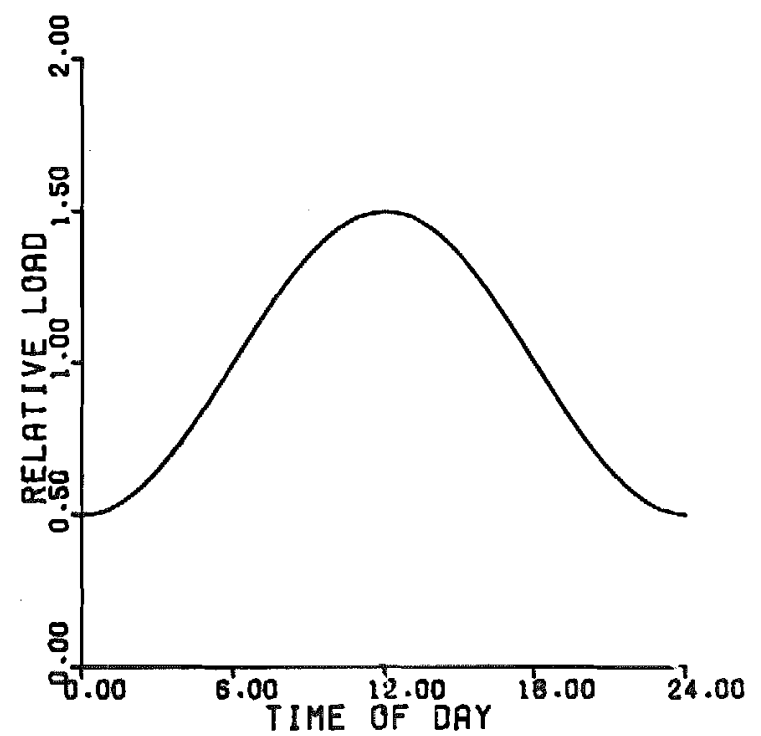

TABLE III SYSTEM PERFORMANCE GRAPHS

For Reading Key See Page A-63

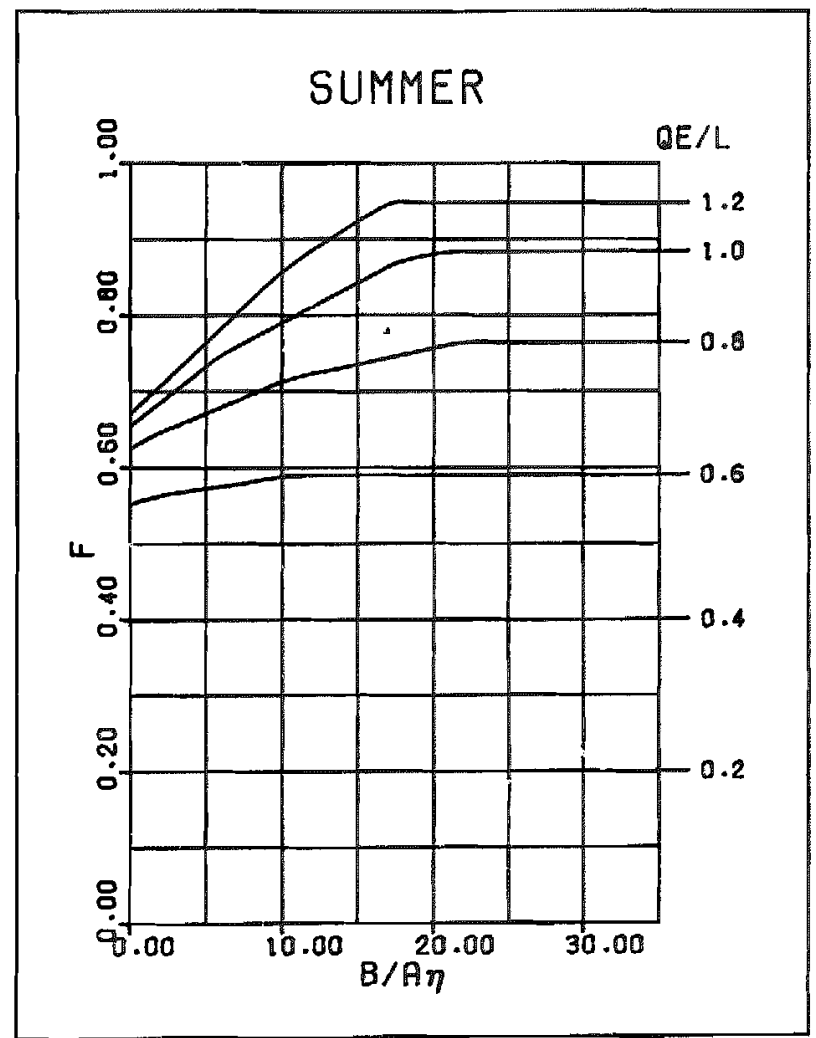

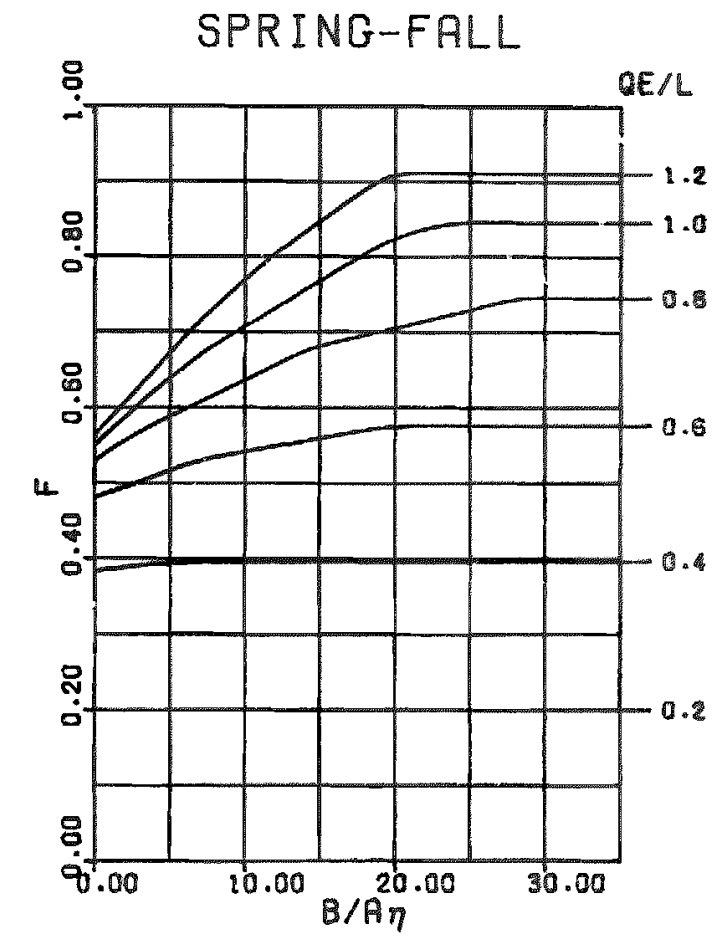

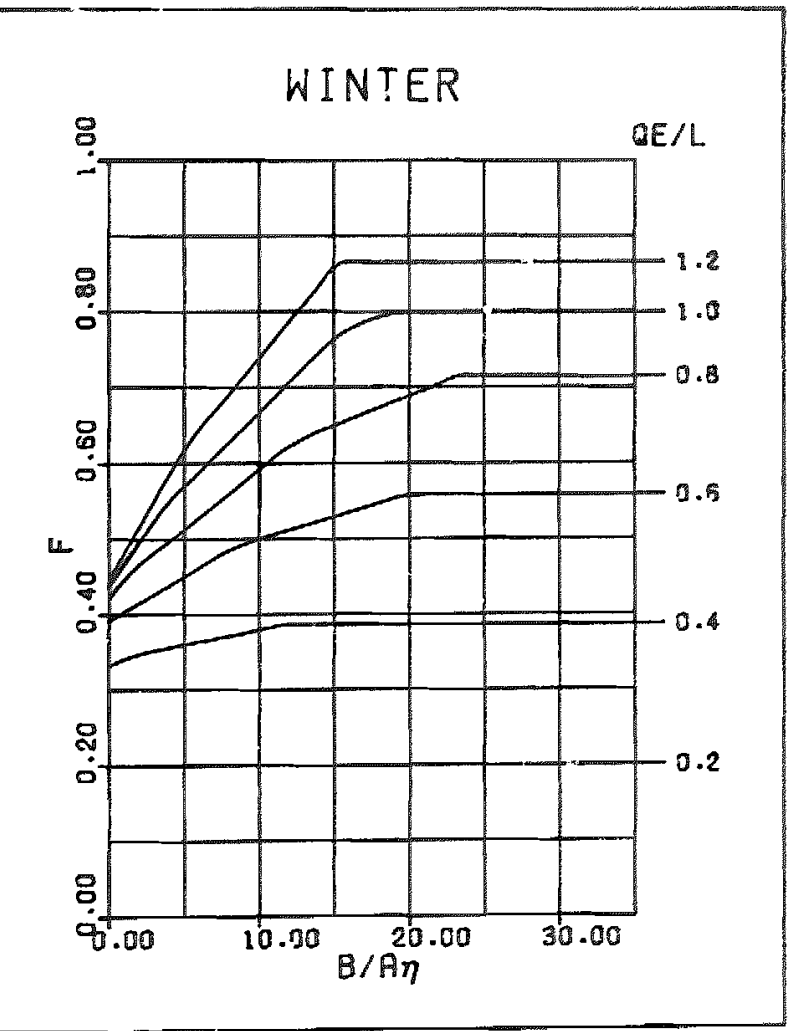




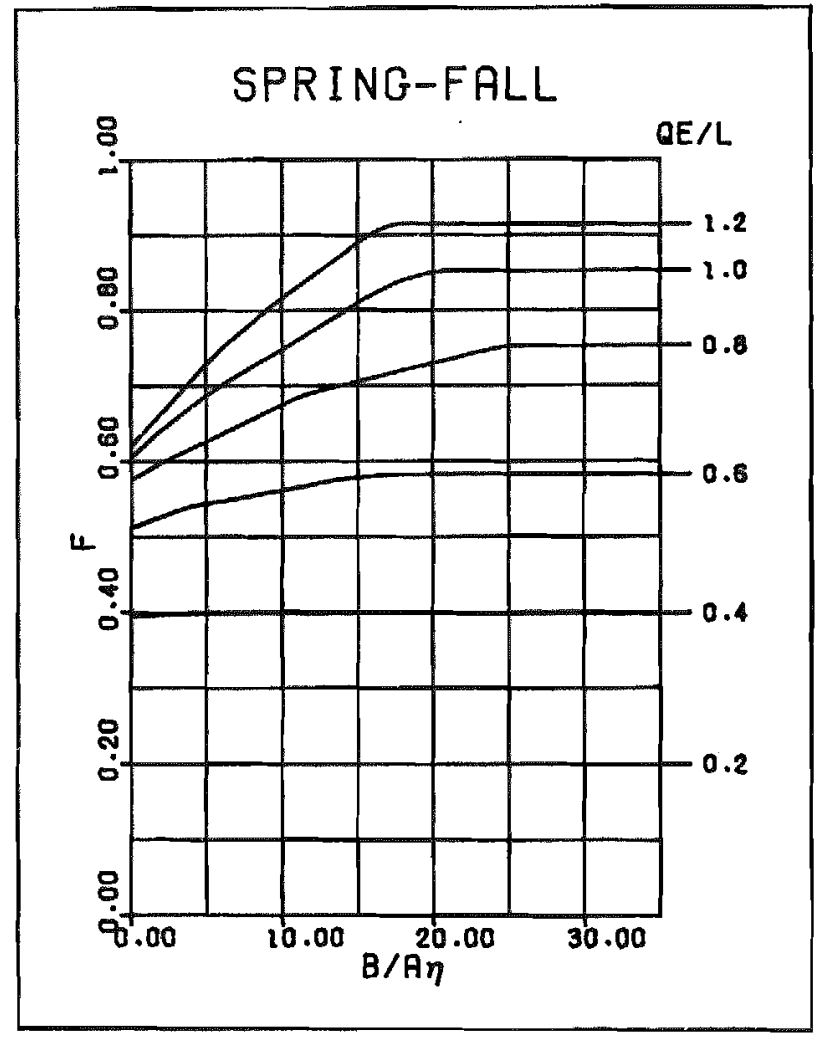

S INUSO IDAL \#12.7

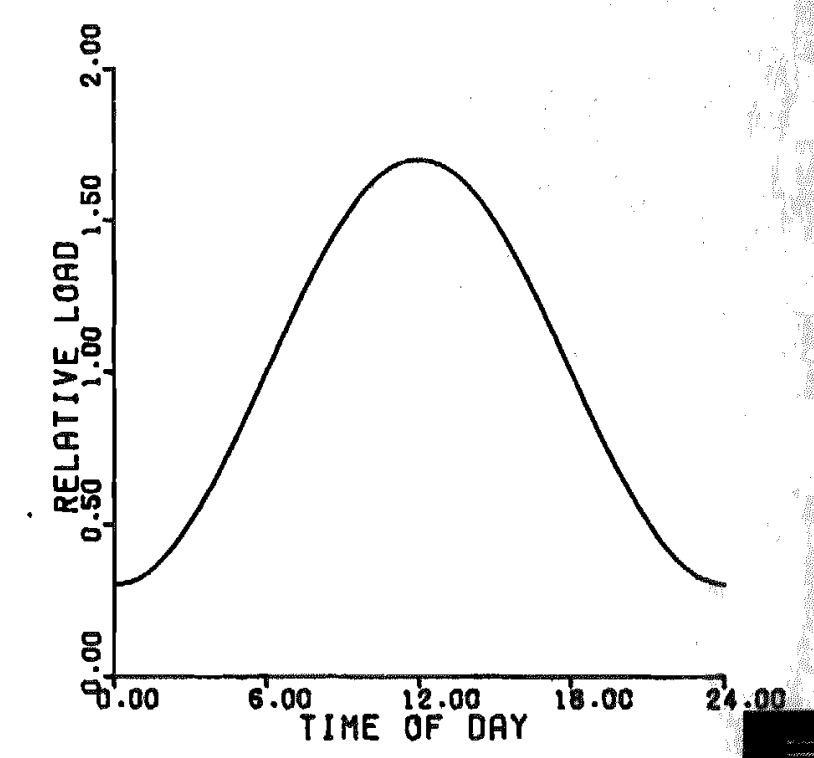

TABLE III SYSTEM PERPORWANCE GRAPHS For Reading Koy 800 Pago $1-63$
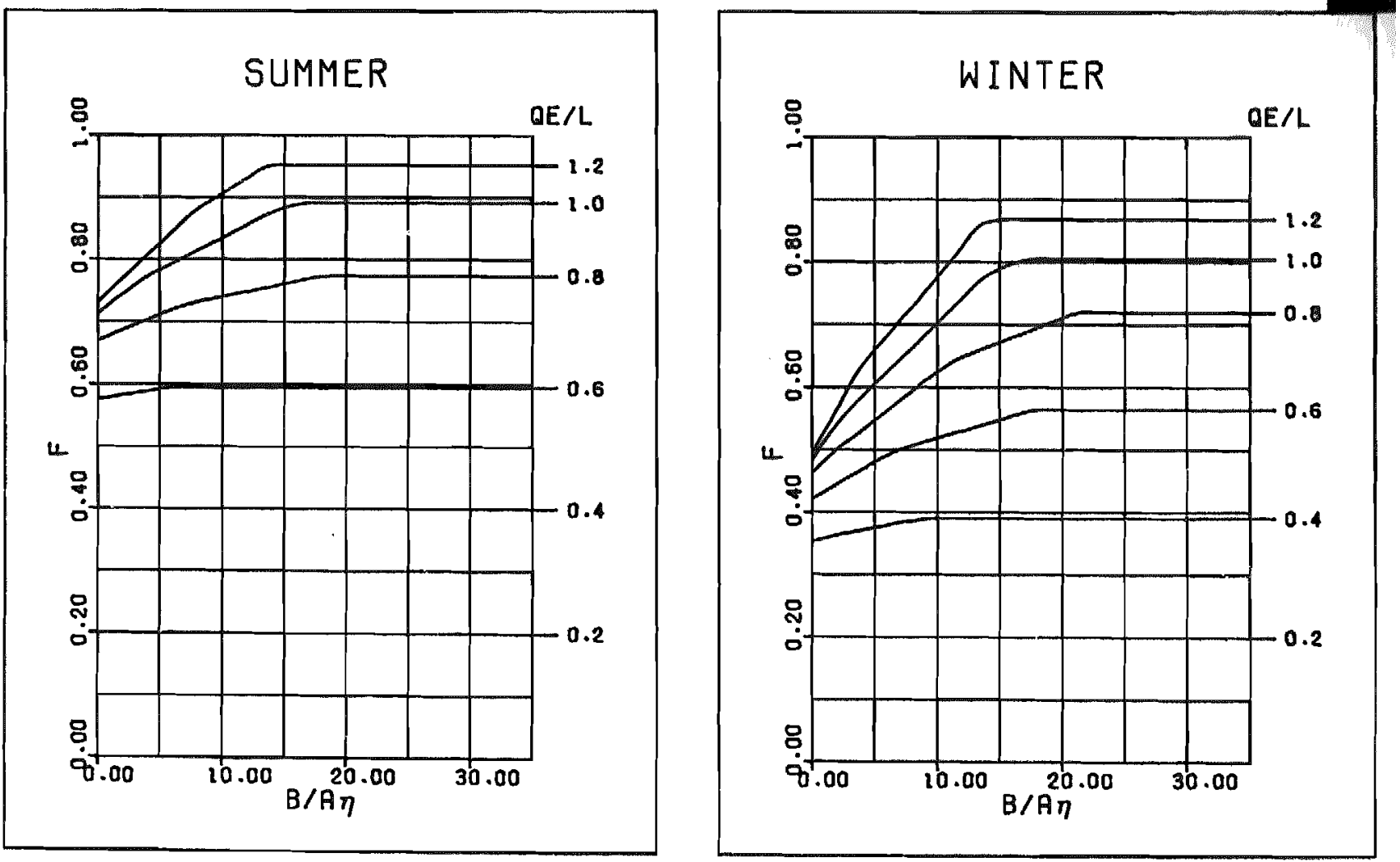
SINUSOIDAL\# 15.2

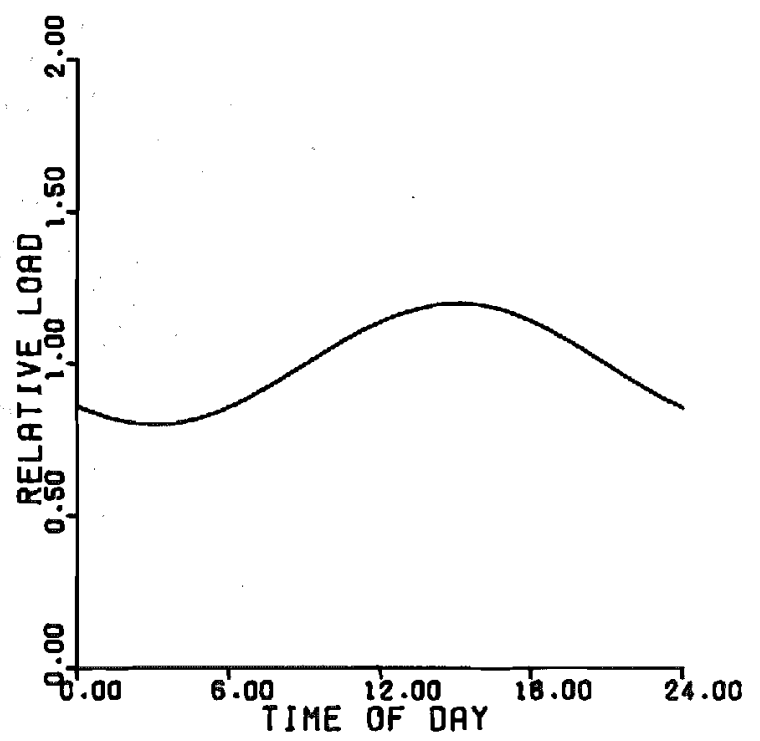

TABLE III SYSTEU PERFORUANCE GRAPHS

For Reading Key See Page $A-63$

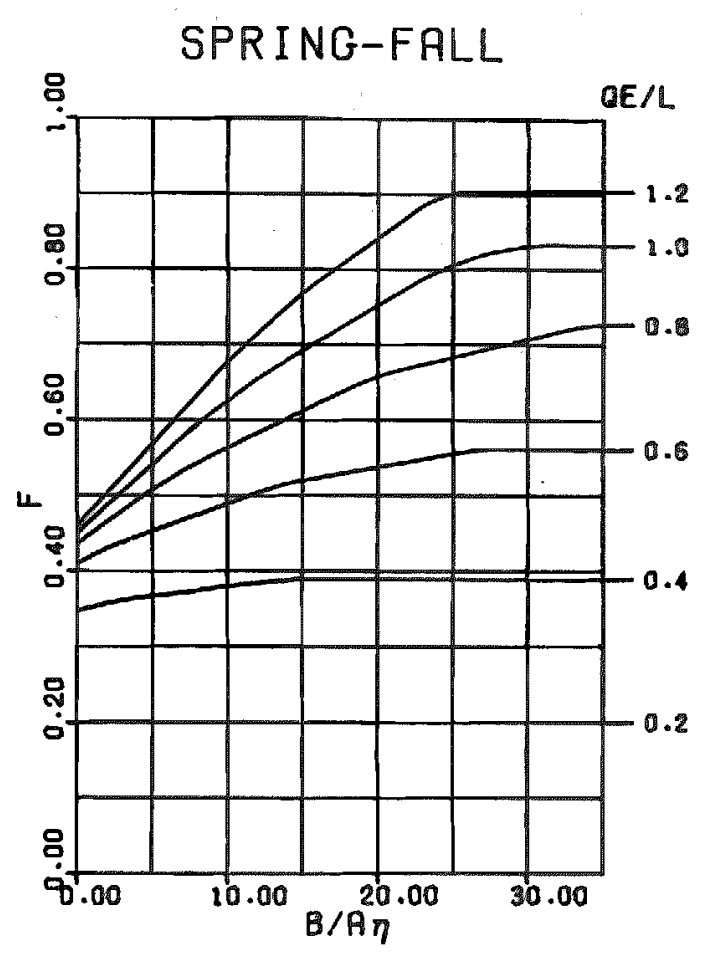

$\mathrm{QE} / \mathrm{L}$

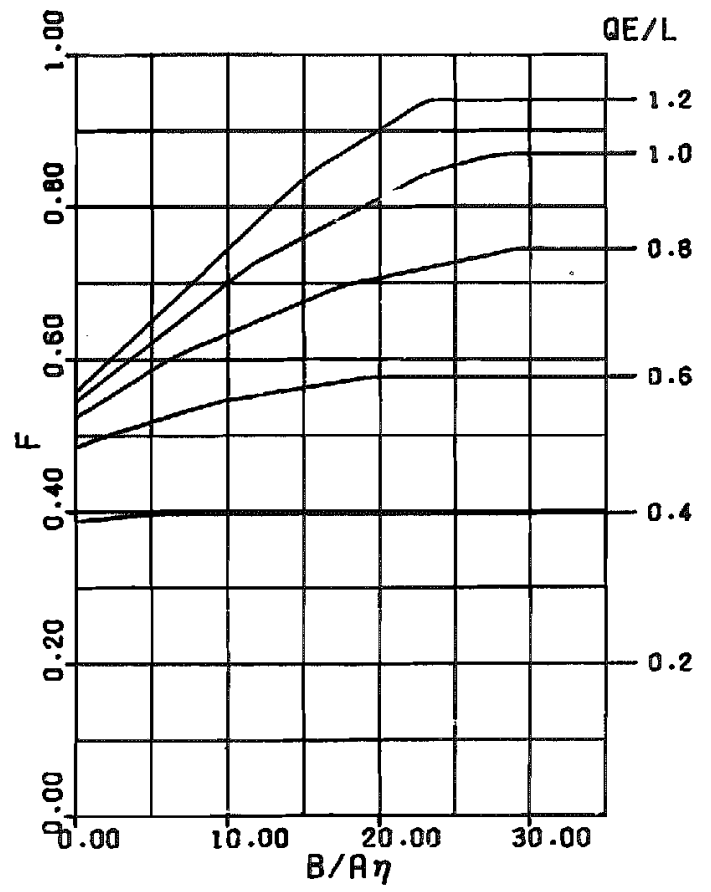

WINTER

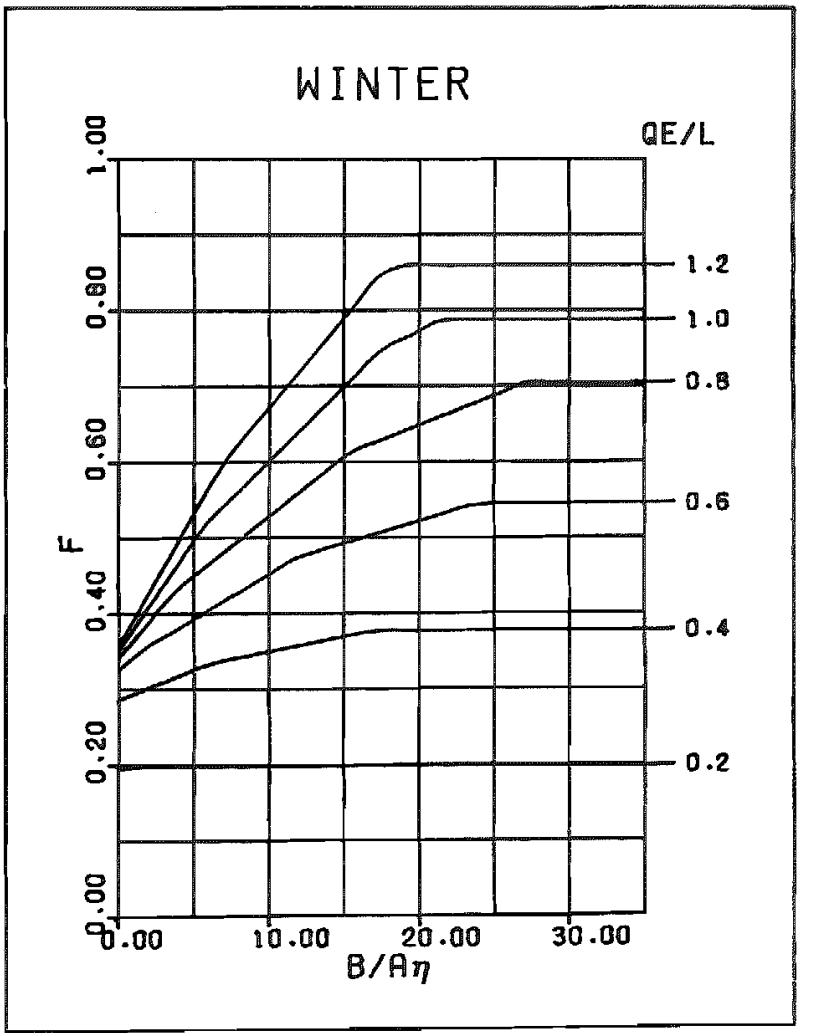




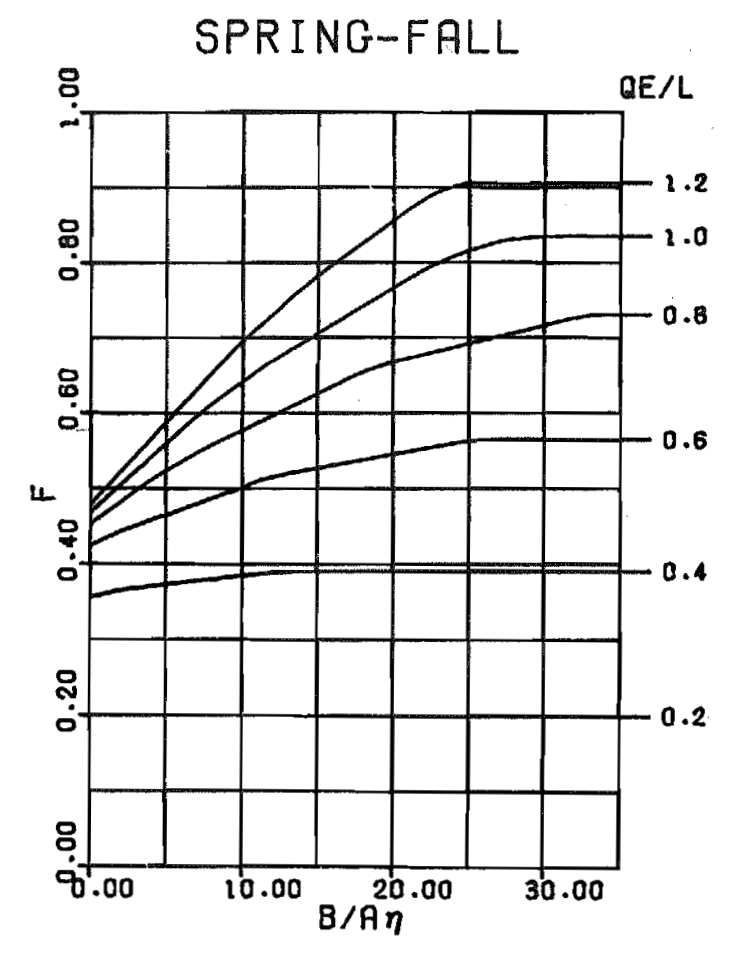

S INUSO IDAL \#15.3

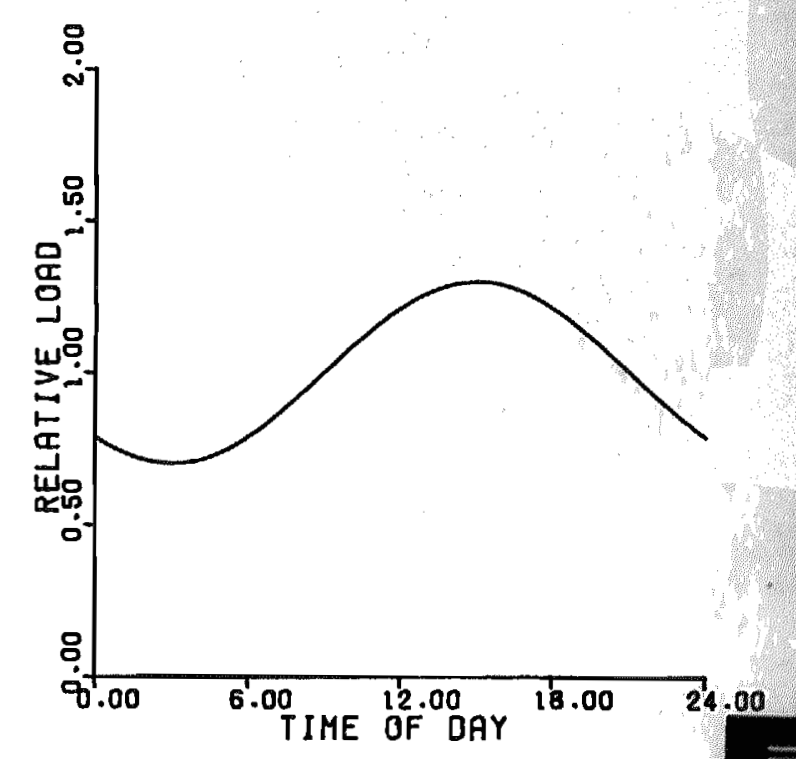

TABLE III SYSTEM PERFORMANCE GRAPAS

For Reading Key See Page A-63

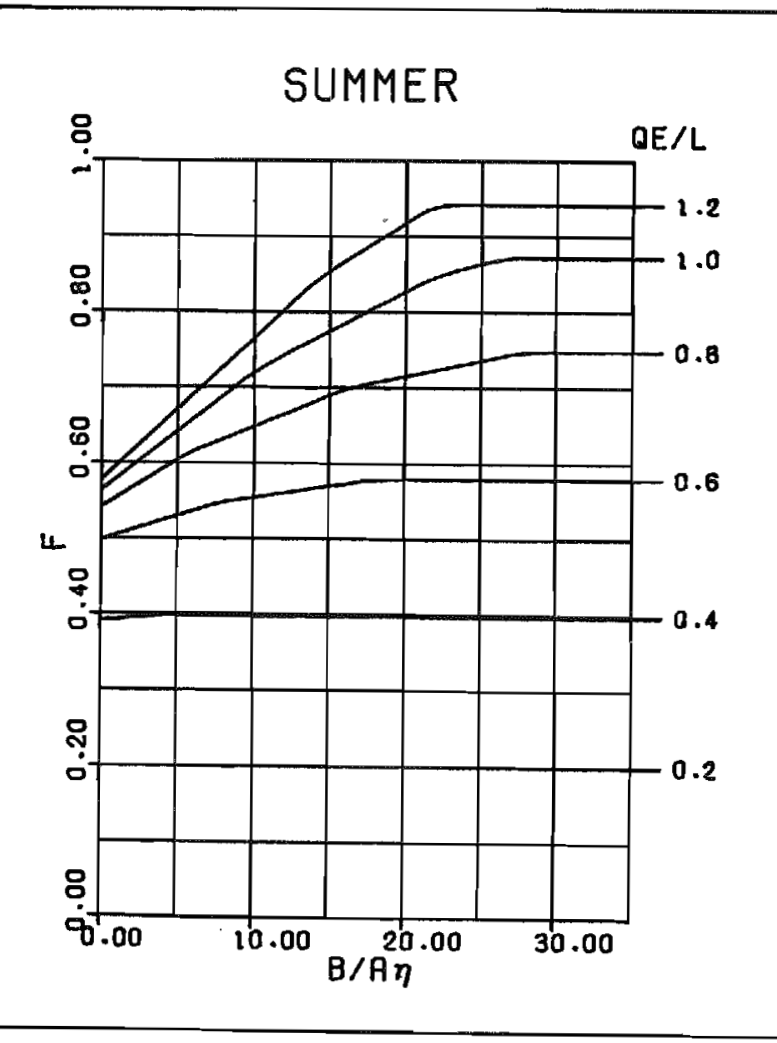

WINTER

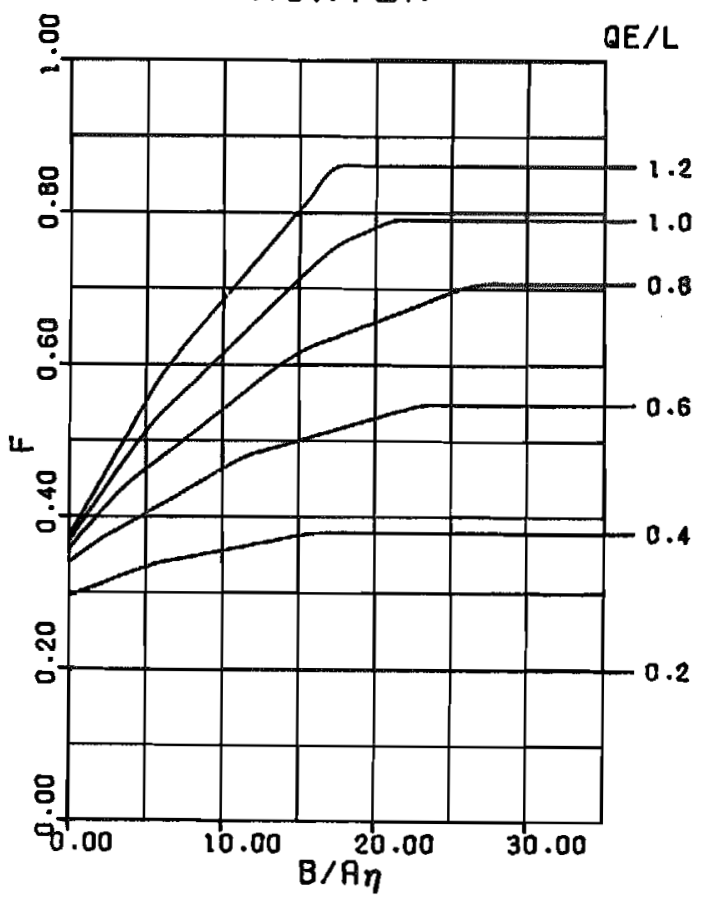


S INUSO IDAL\#15.4

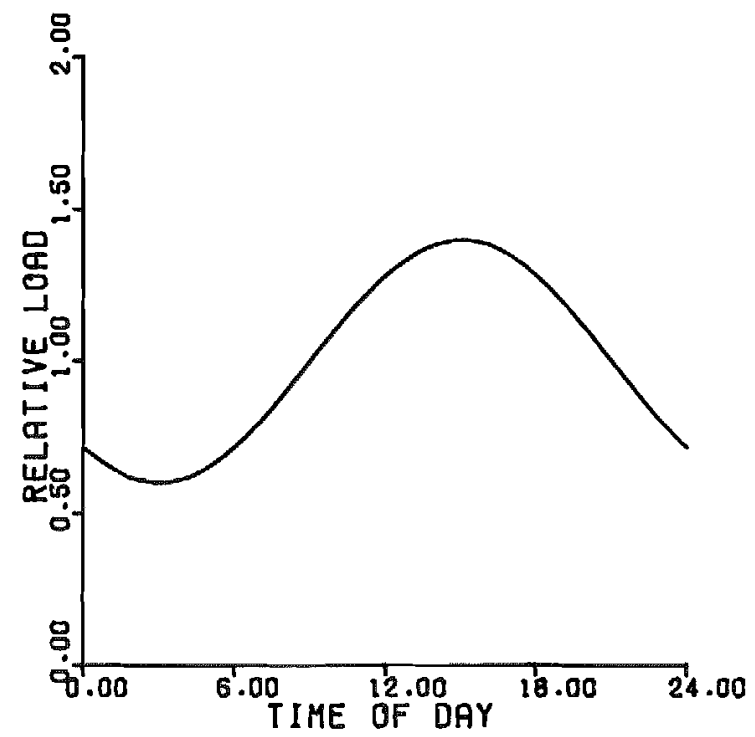

TABLE III SYSTEM PERFORMANCE GRAPHS

For Reading Koy Ste Page A-63

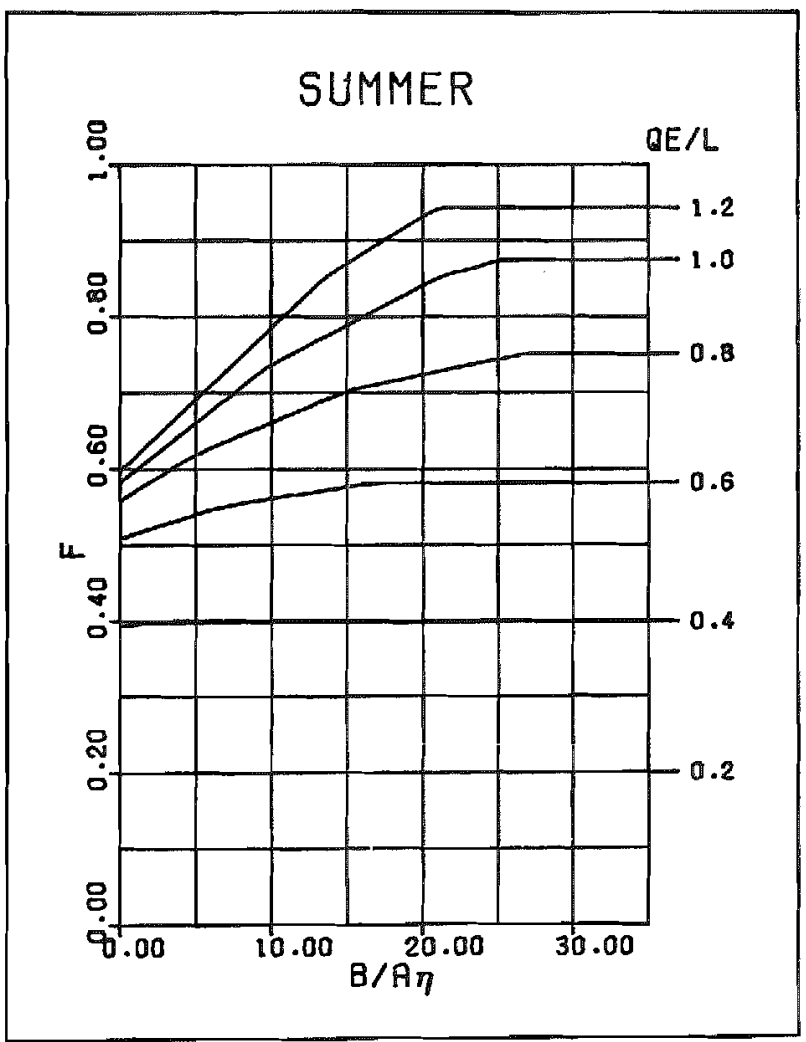

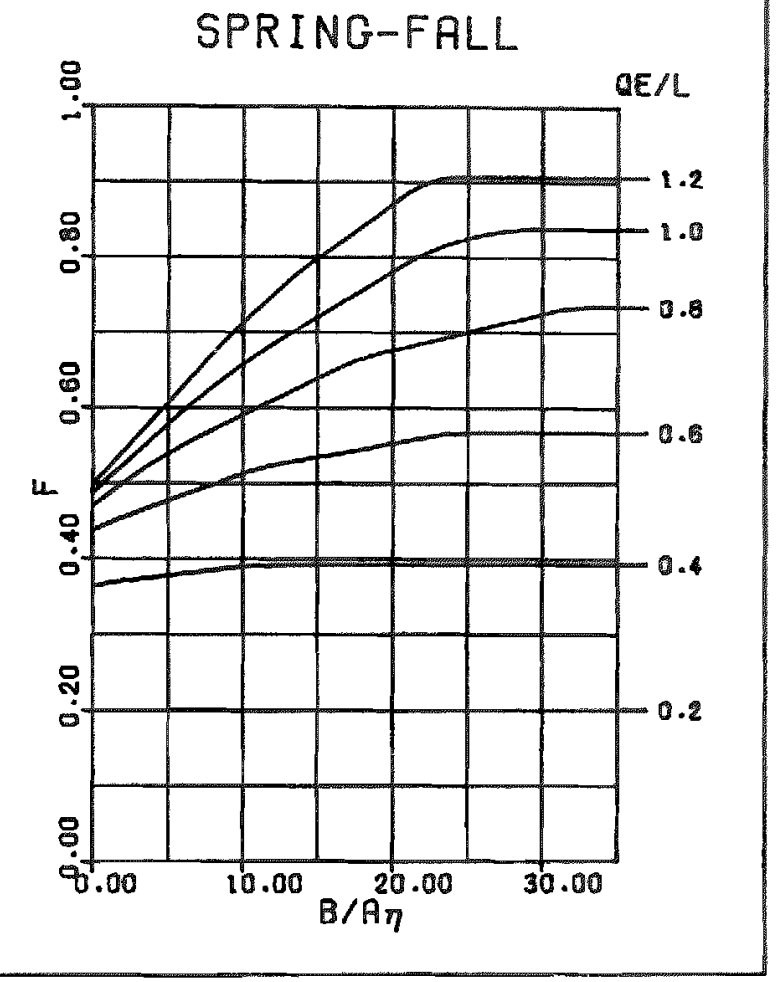

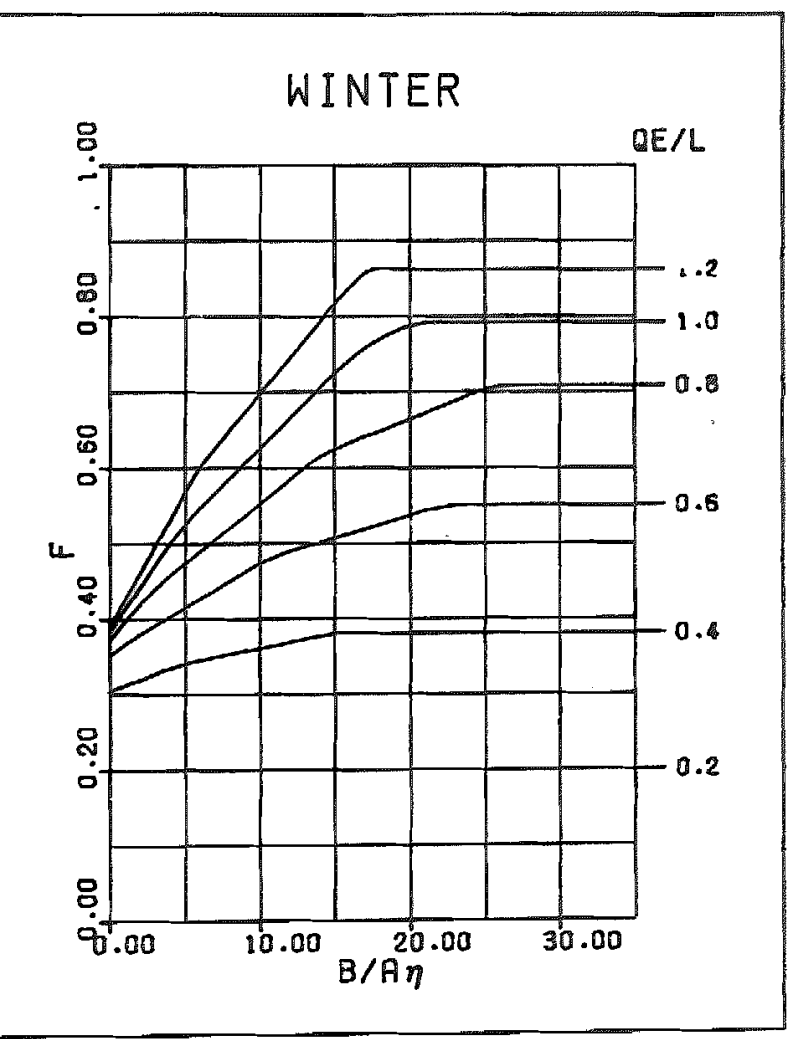




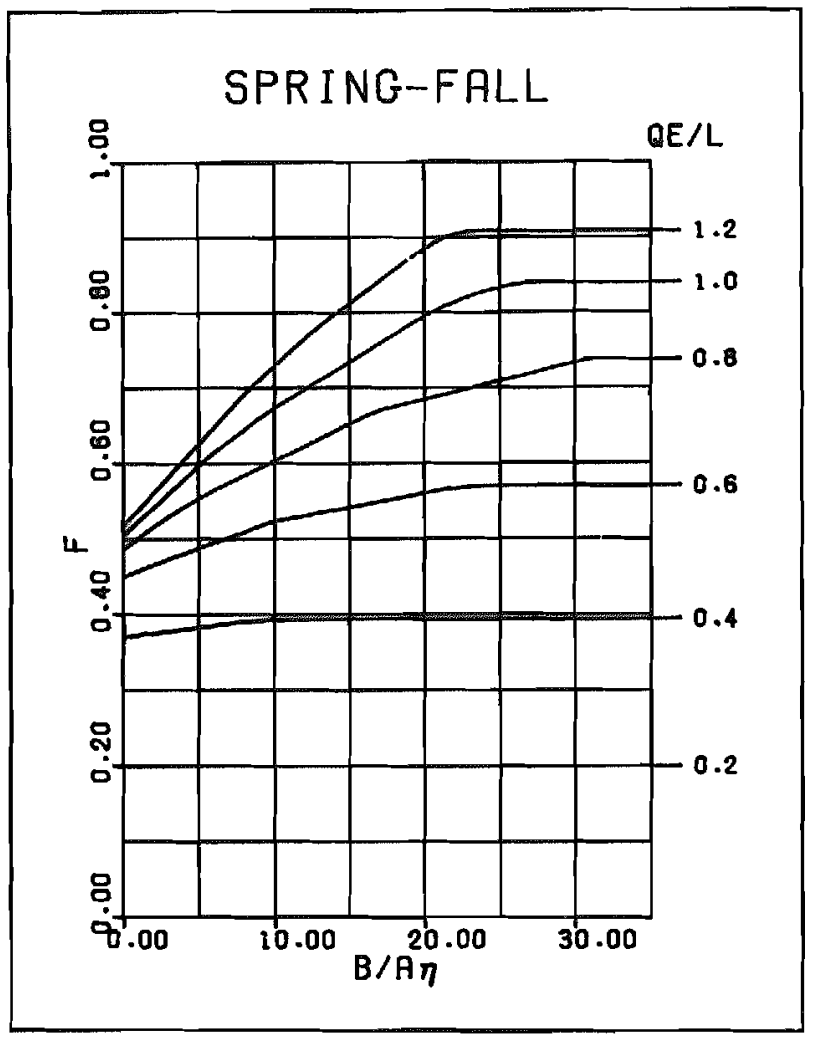

S I NUSO I DAL $\# 15.5$

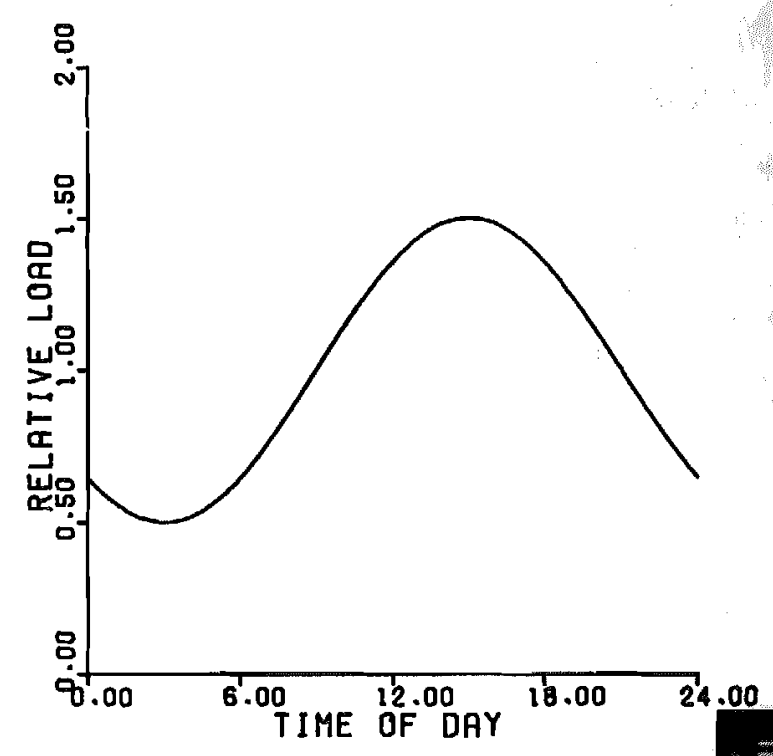

TABLE III SYSTEM PERFORUANCE GRAPHS

For Reading Key See Page A-63

$\equiv$

SUMMER

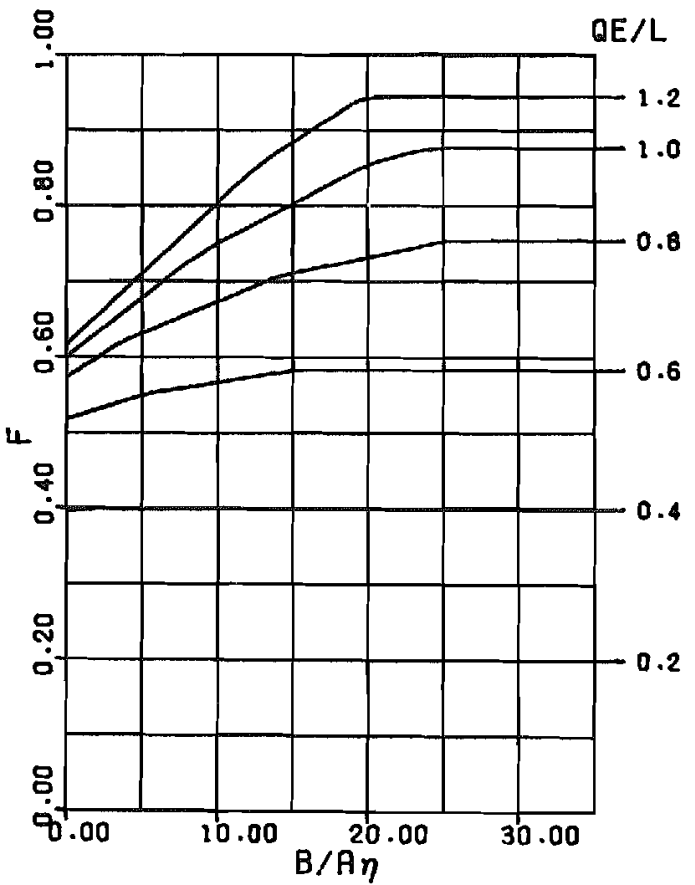

WINTER

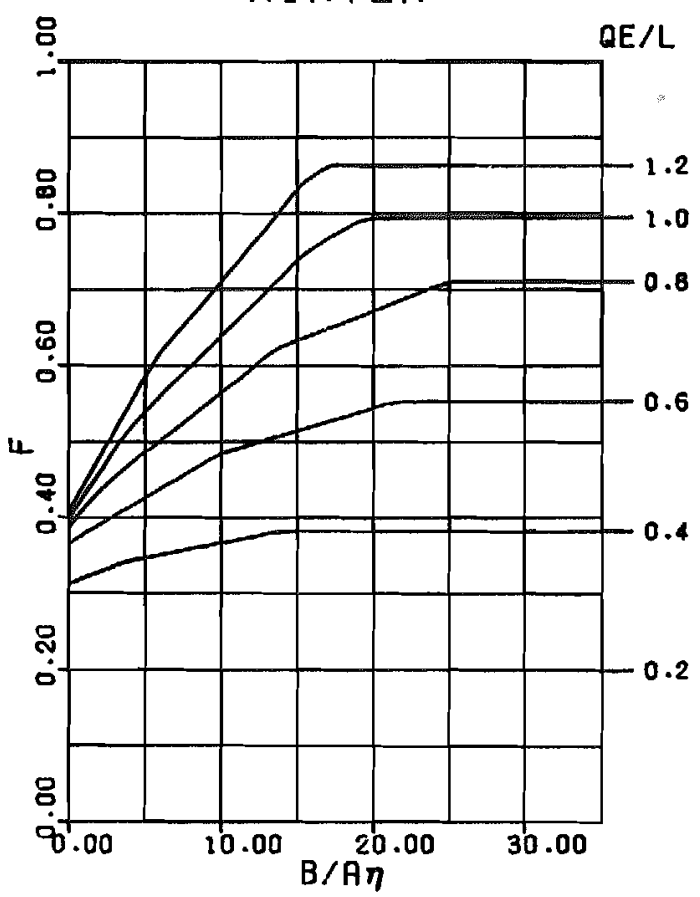


S INUSOIDAL\# 15.7

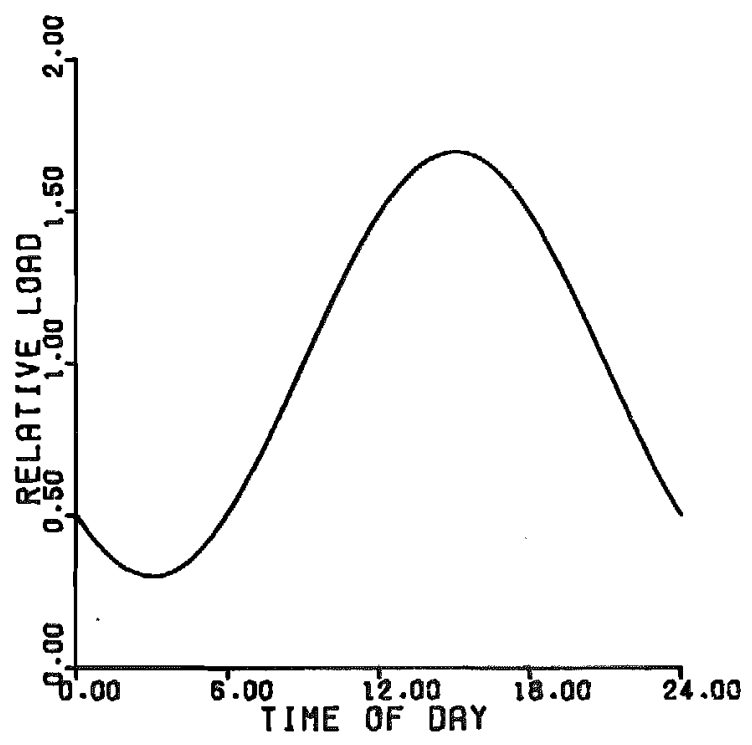

TABLE III SYSTEM PERFONANCE GRAPHS

For Reading Key See Page A-63

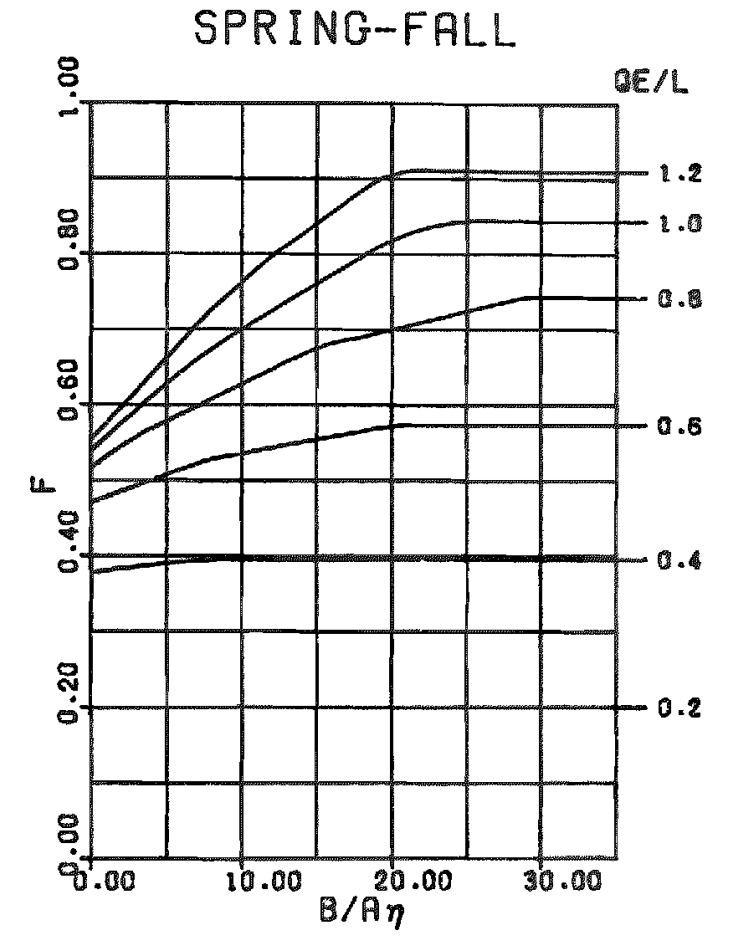

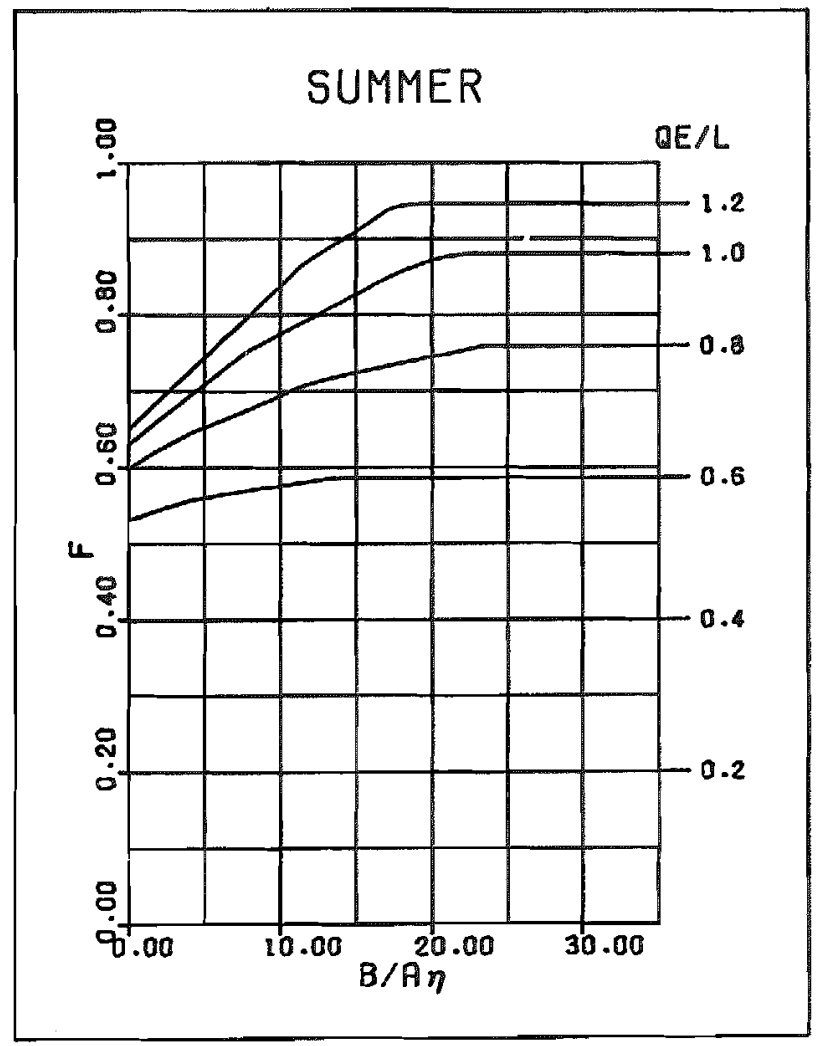

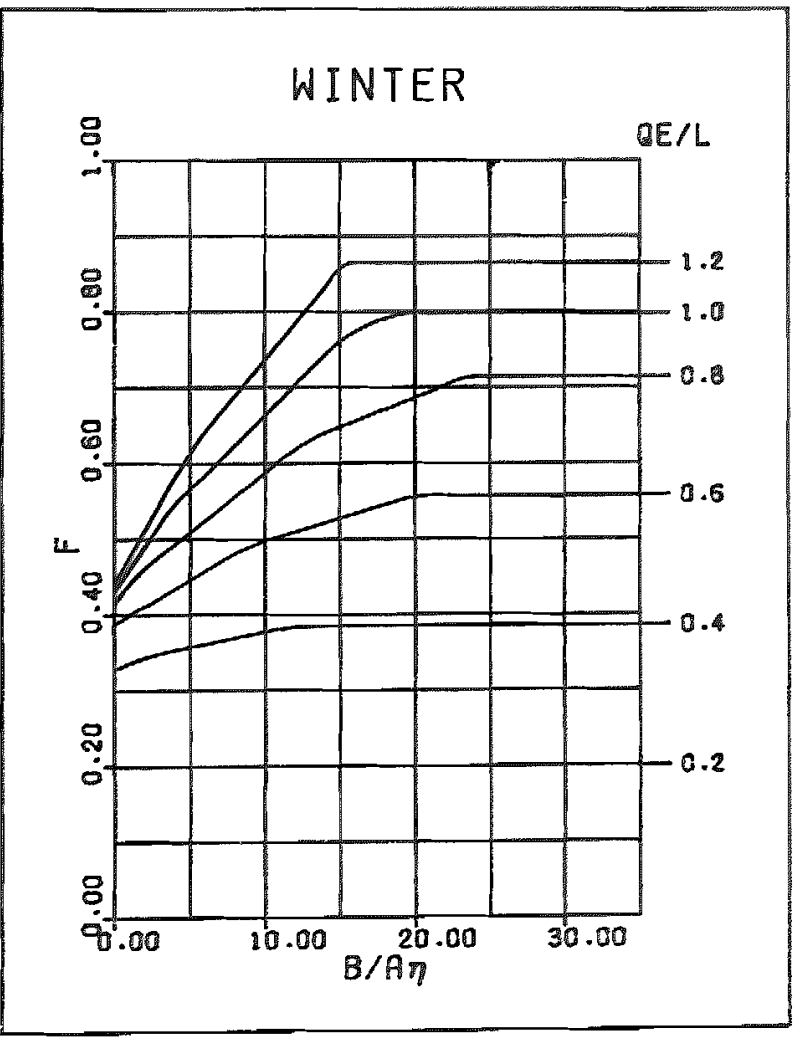




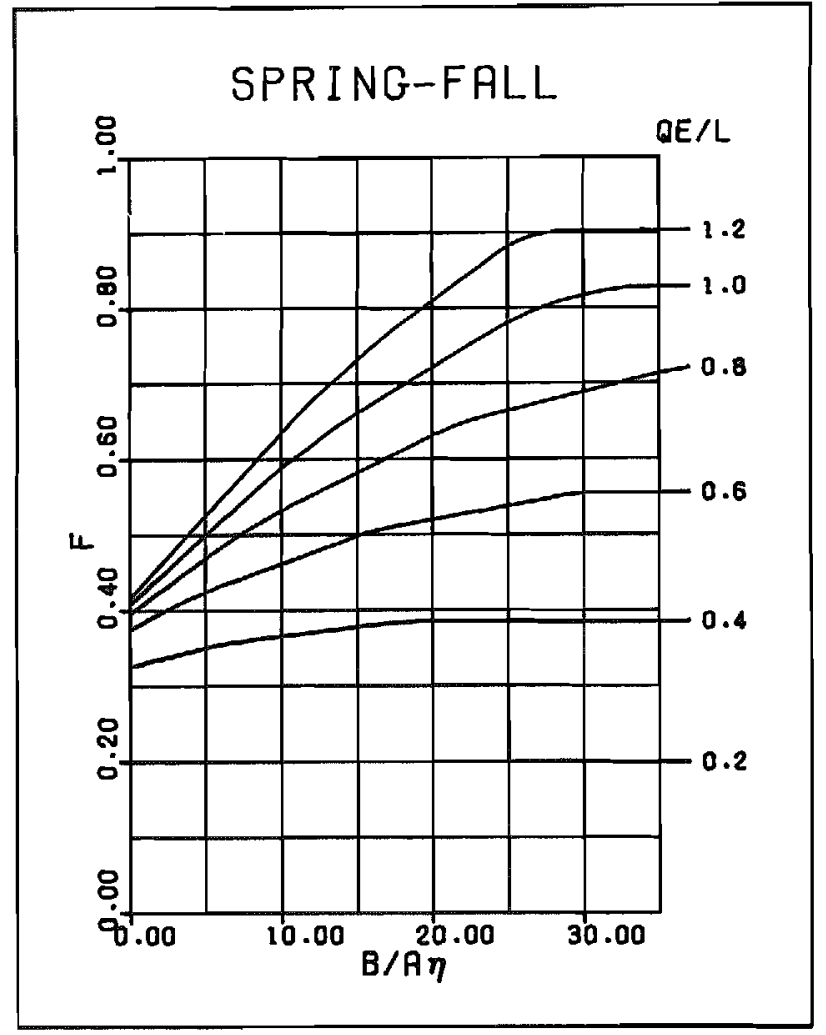

S INUSOIIDAL\#18.2

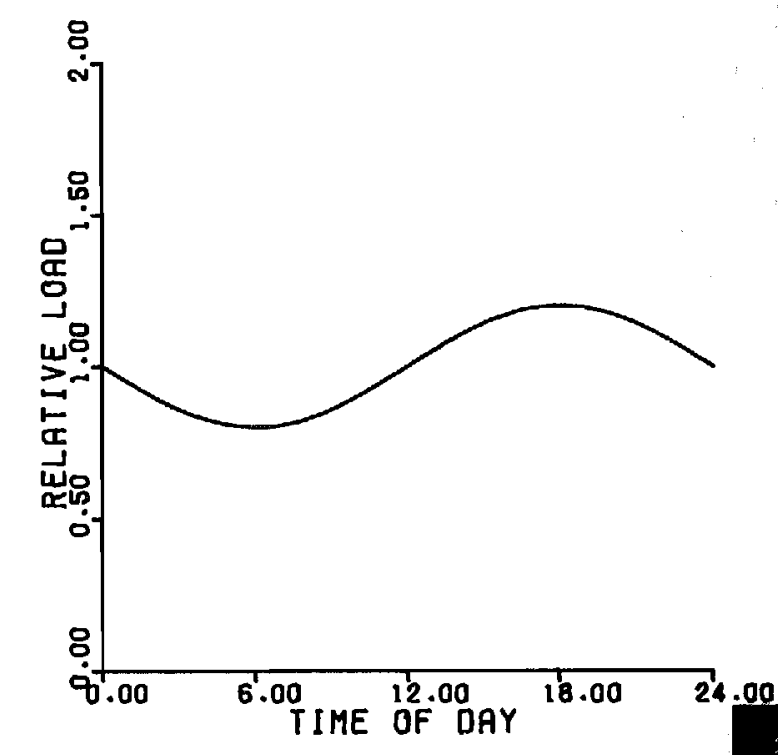

TABLE III SYSTEM PERFORMANCE GRAPHS

For Reading Key See Page A-63

SUMMER

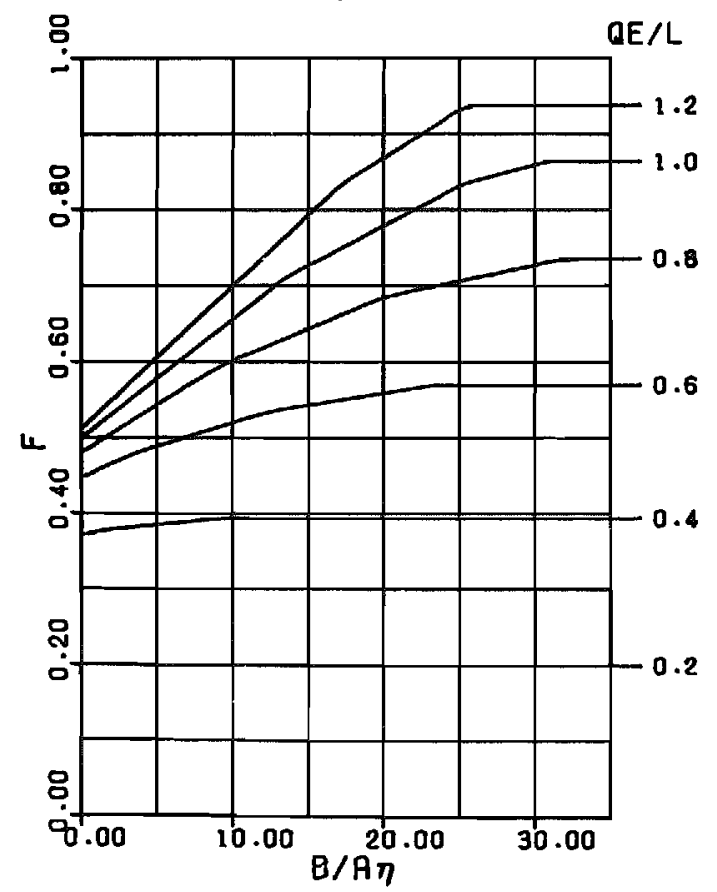

W INTER

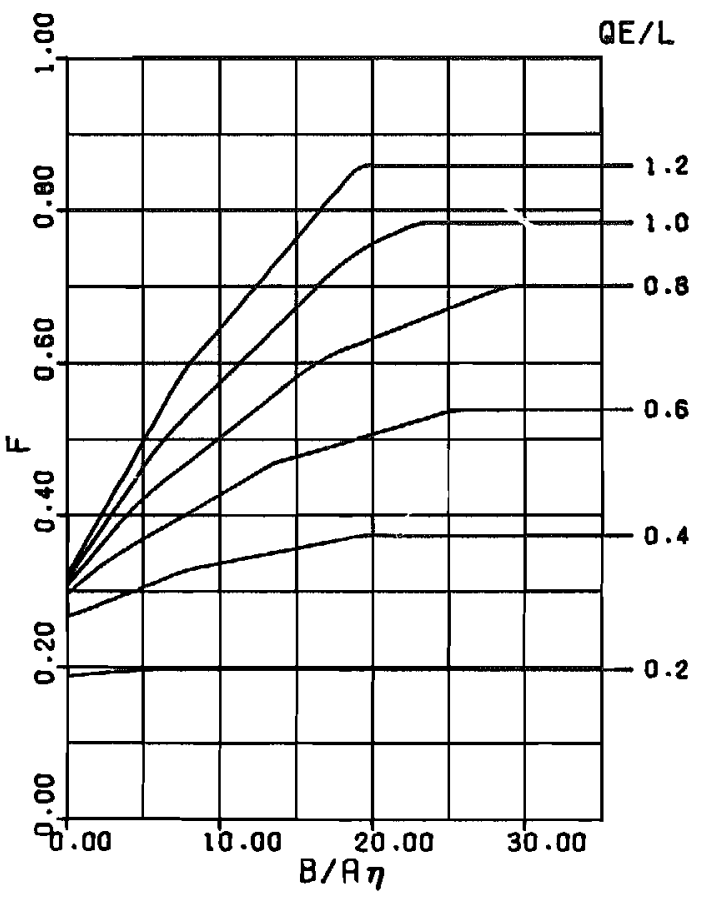


S INUSOIDAL \#18.3

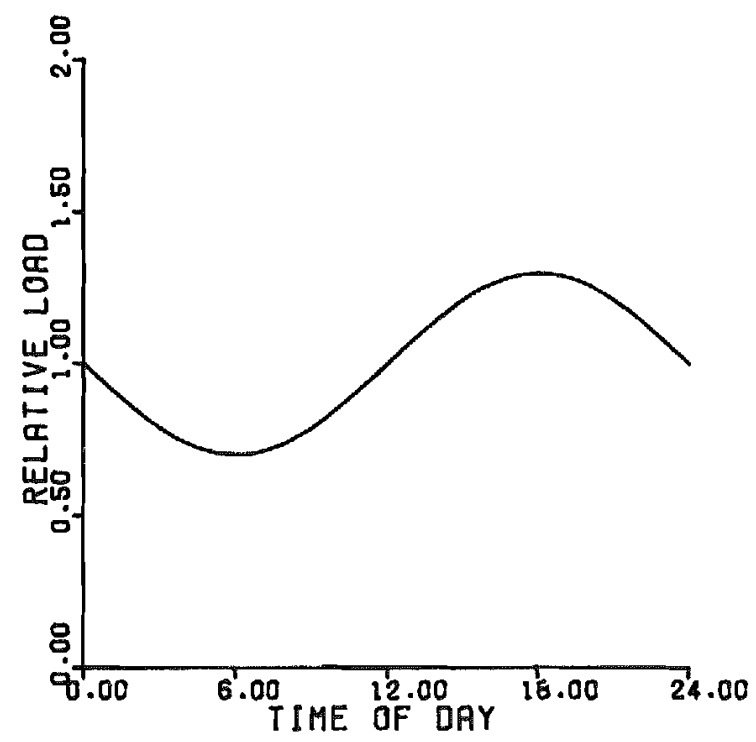

TABLE III SYSTEM PERFORMANCE GRAPHS

For Roading Koy See Page A-63
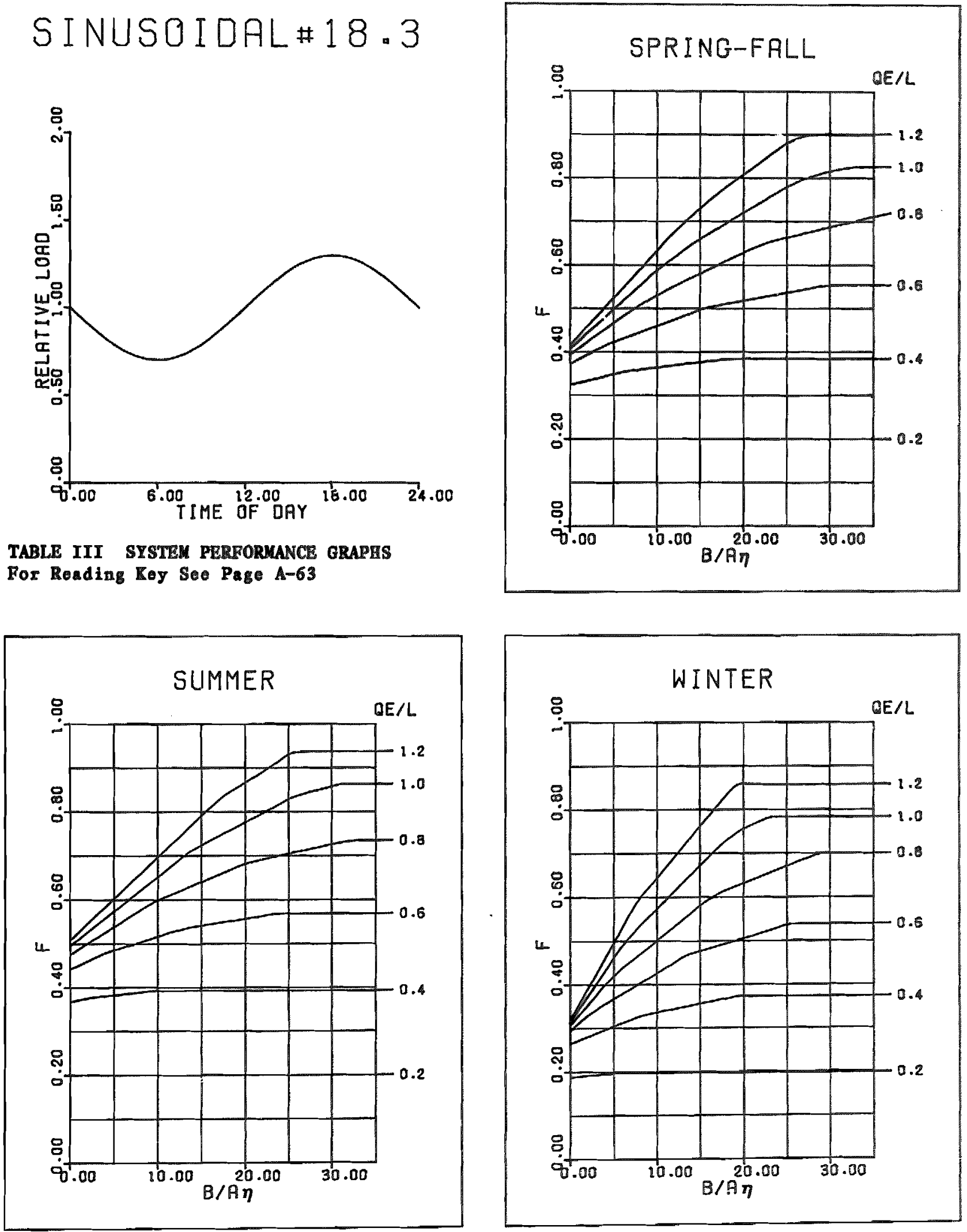


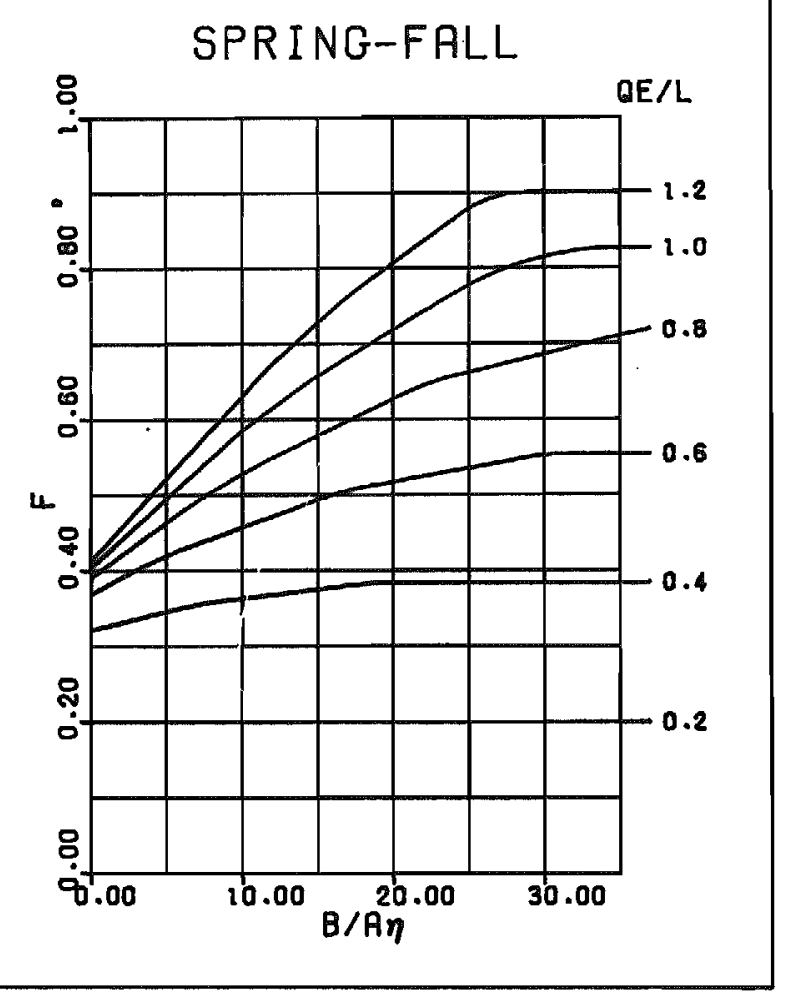

S INUSO IDAL\# 18.4

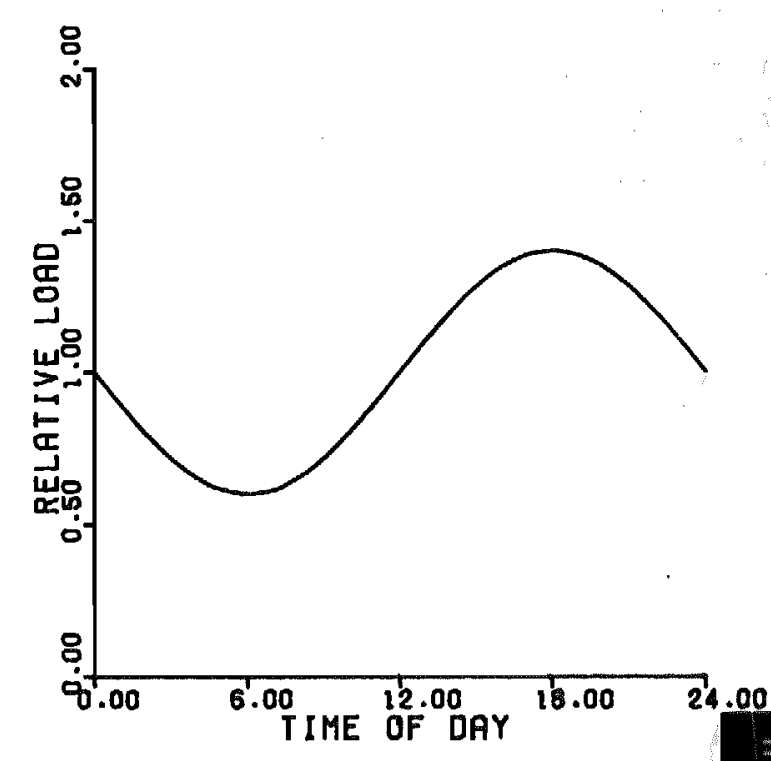

TABLE III SYSTEM PERFORMANCE GRAPHS

For Reading Key See Page A-63
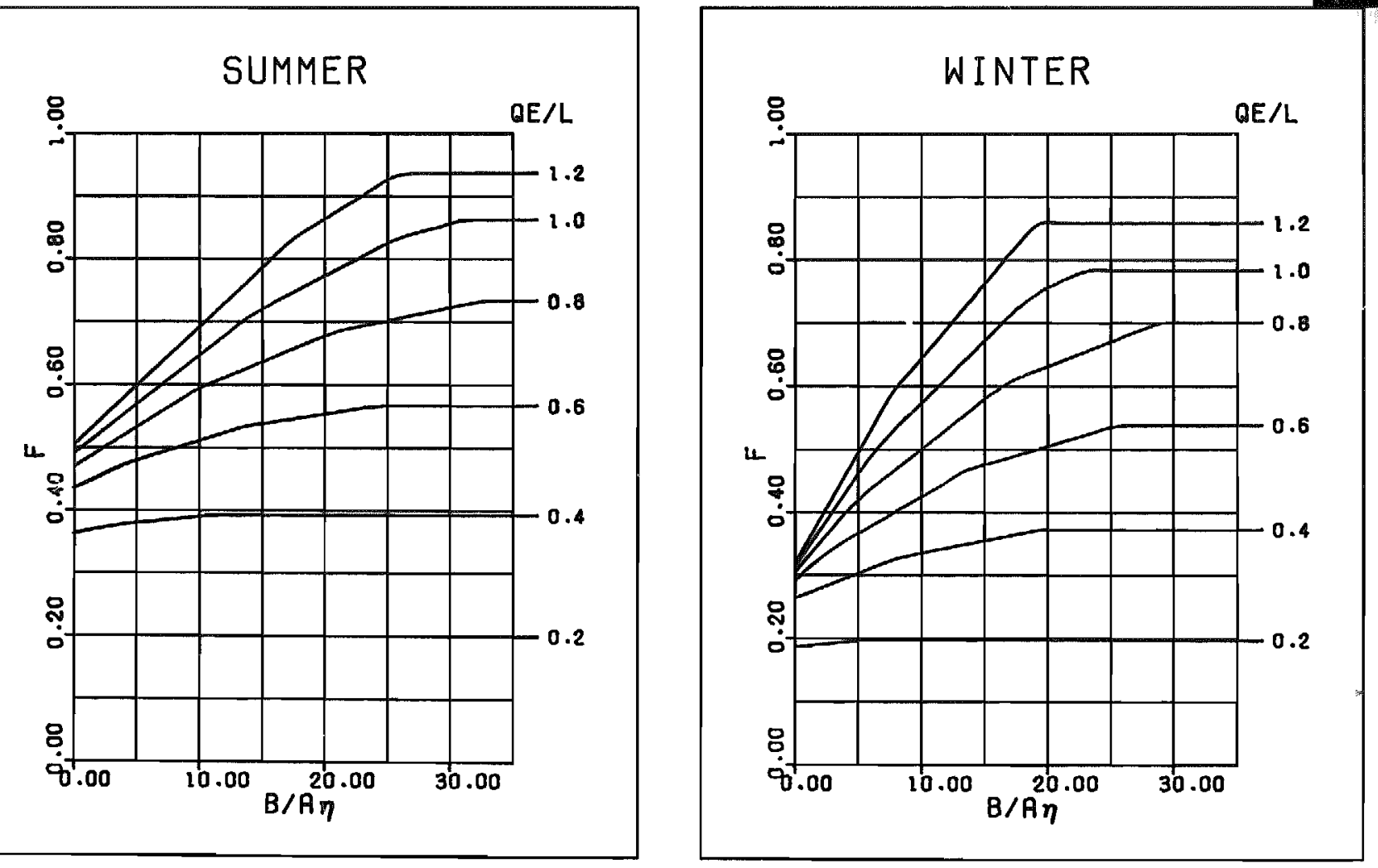
SINUSO IDAL\# 18.5

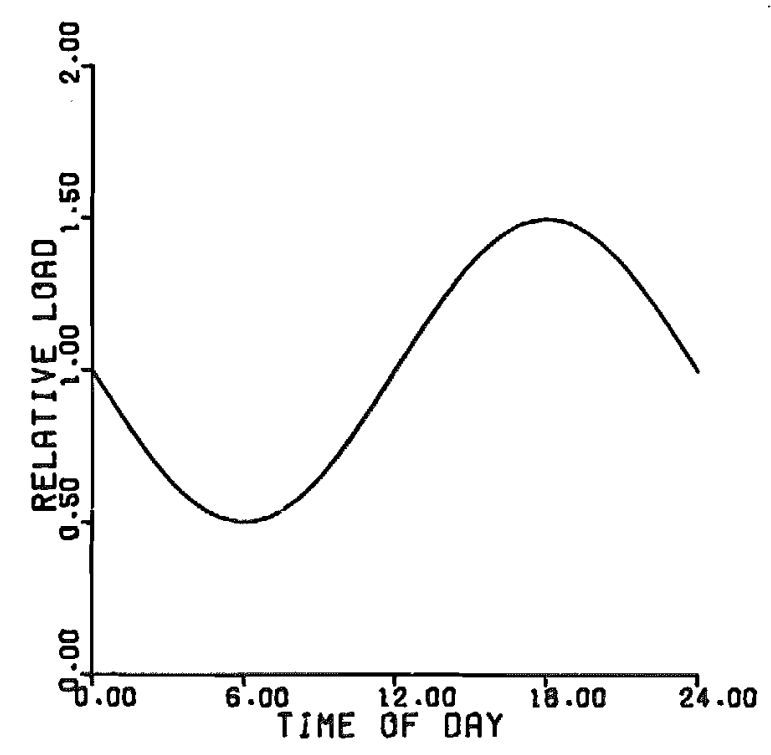

TABLE III SYSTEM PERFOWMANCE GRAPHS

Fox Rading Key See Page A-63

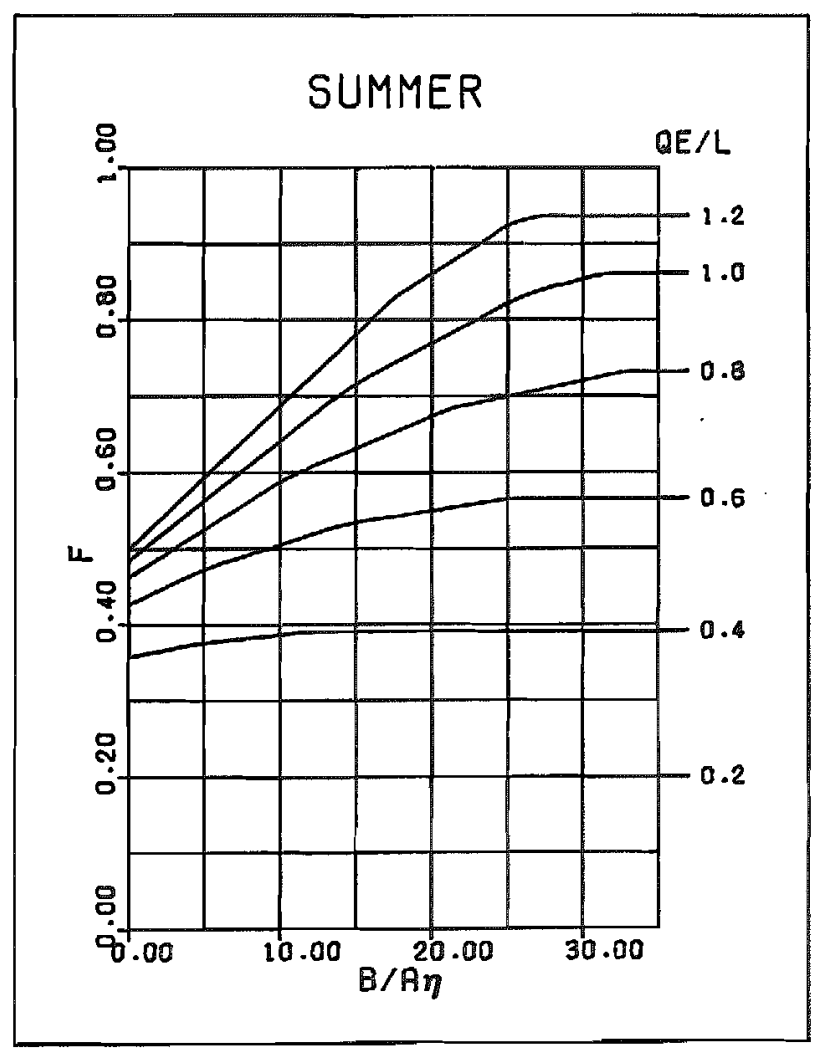

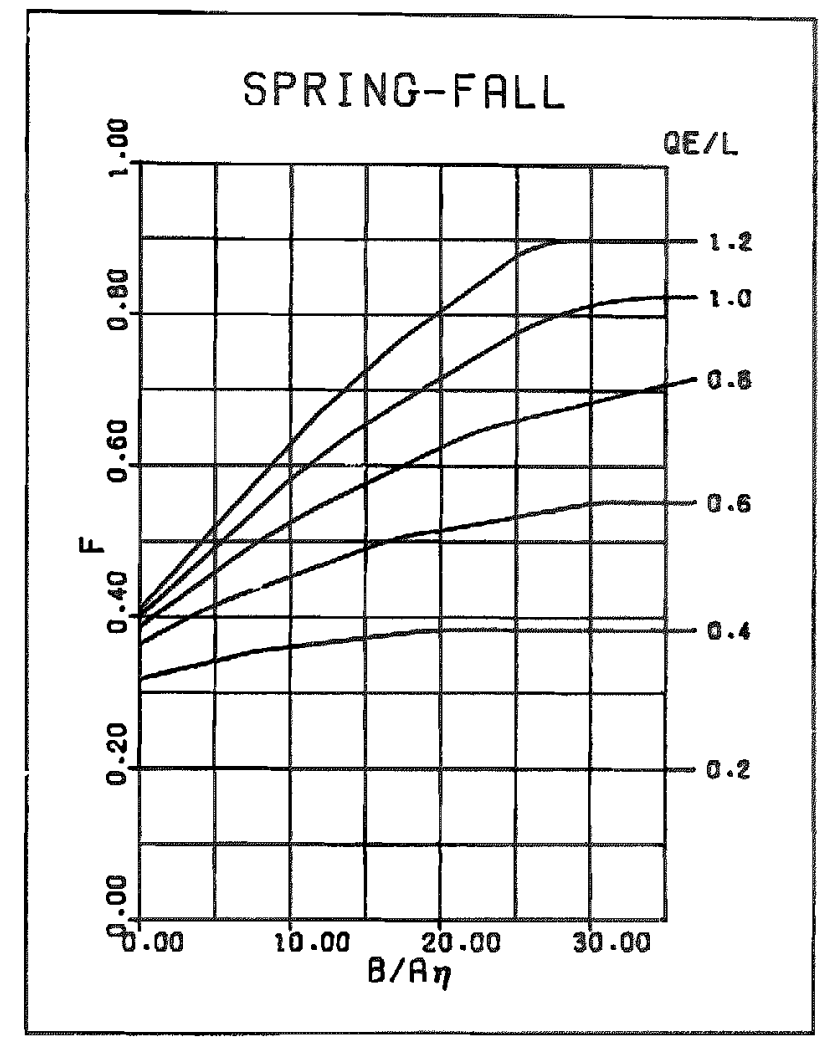

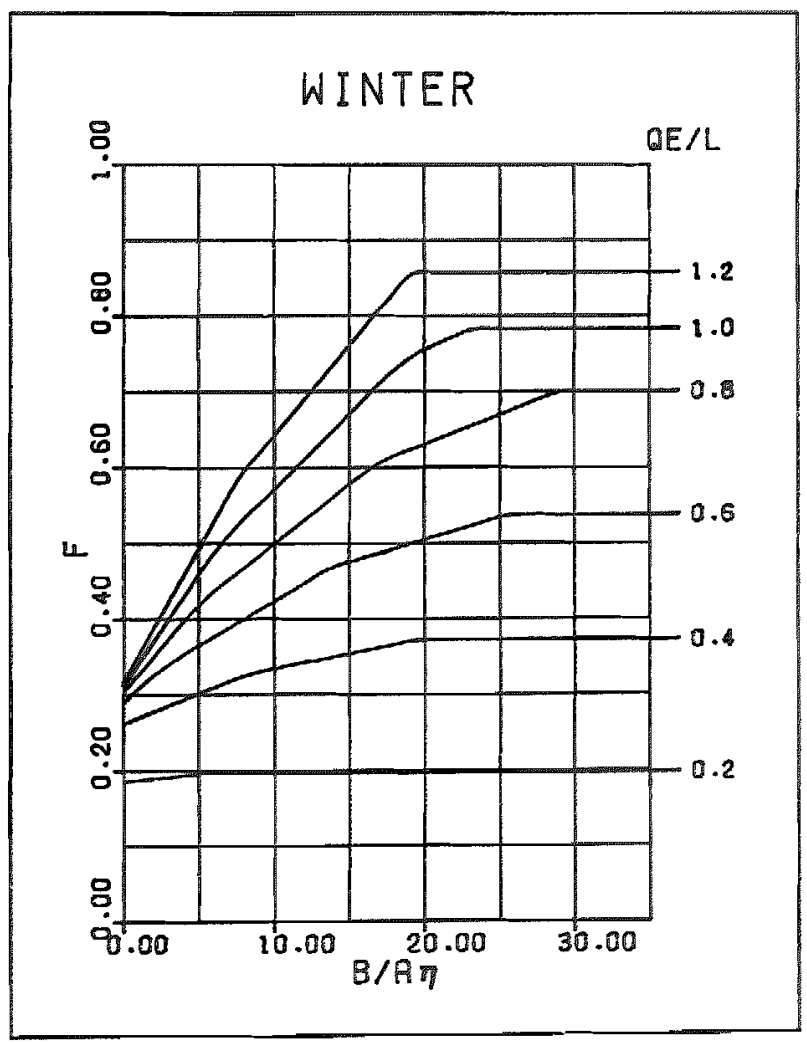




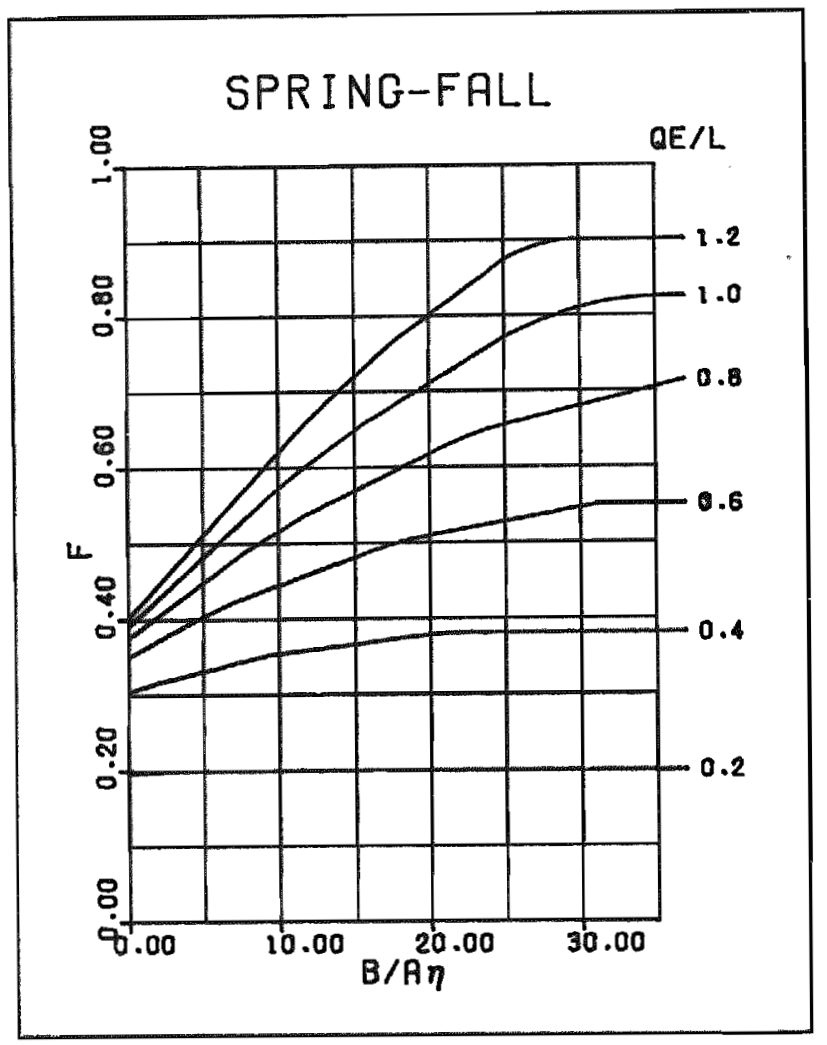

\section{SINUSOIDAL\#18.7}

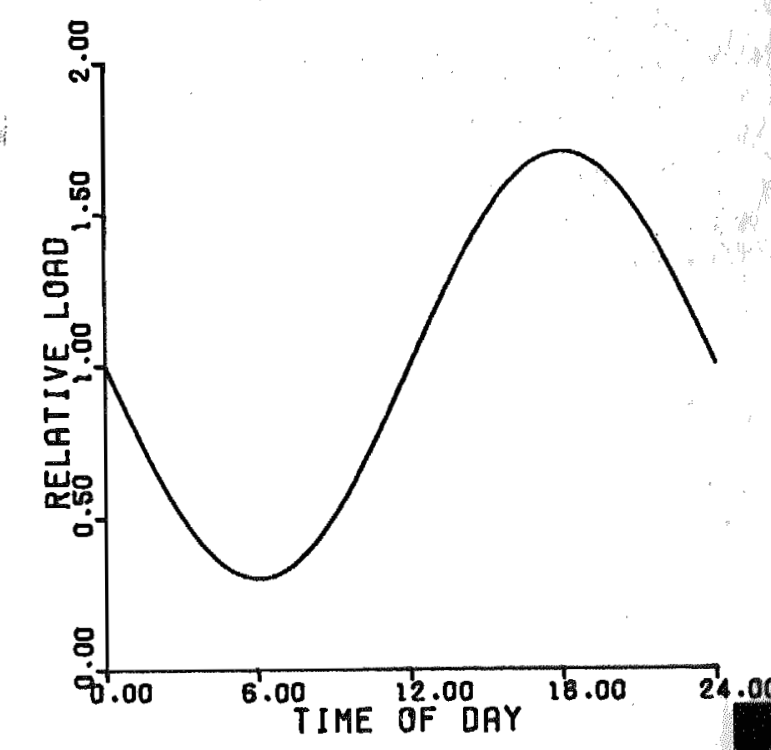

TABLE III SYSTEM PERFORMANCE GRAPHS For Reading Key See Page A-63

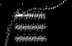

SUMMER

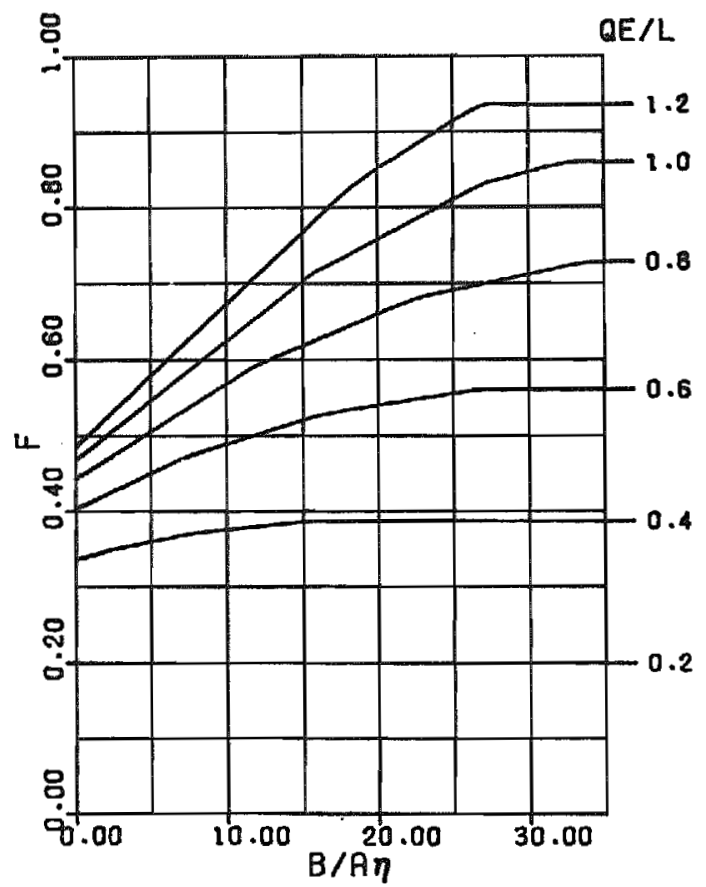

WINTER

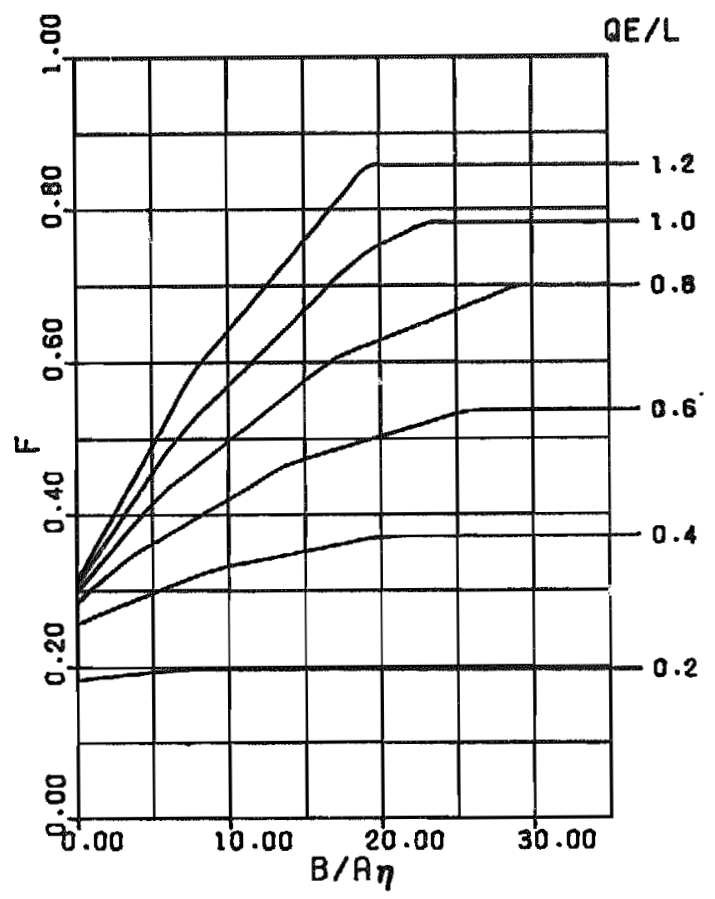


UN I MODAL \# 1

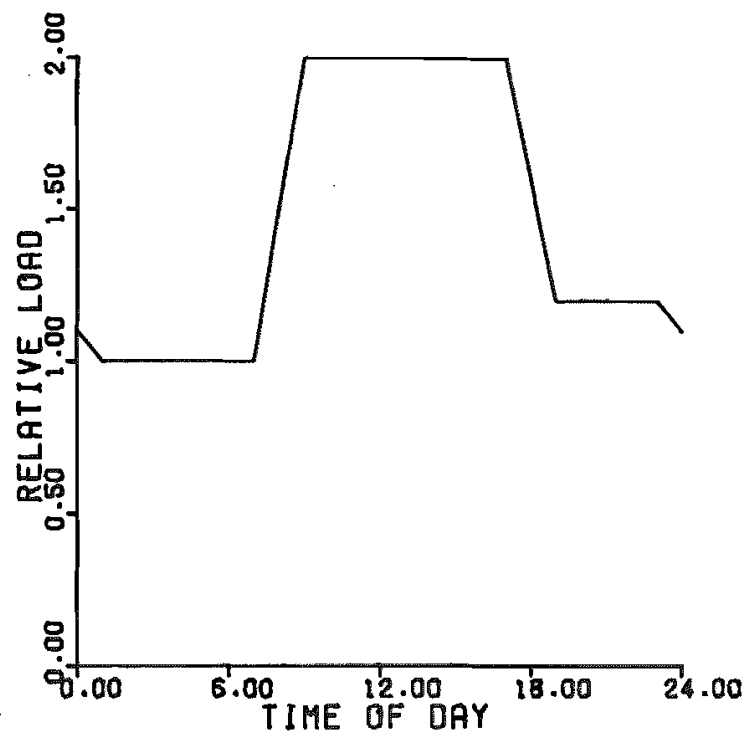

TARLE III SYSTEM PERPORMANCE GRAPHS For Reading Key See Page A-63

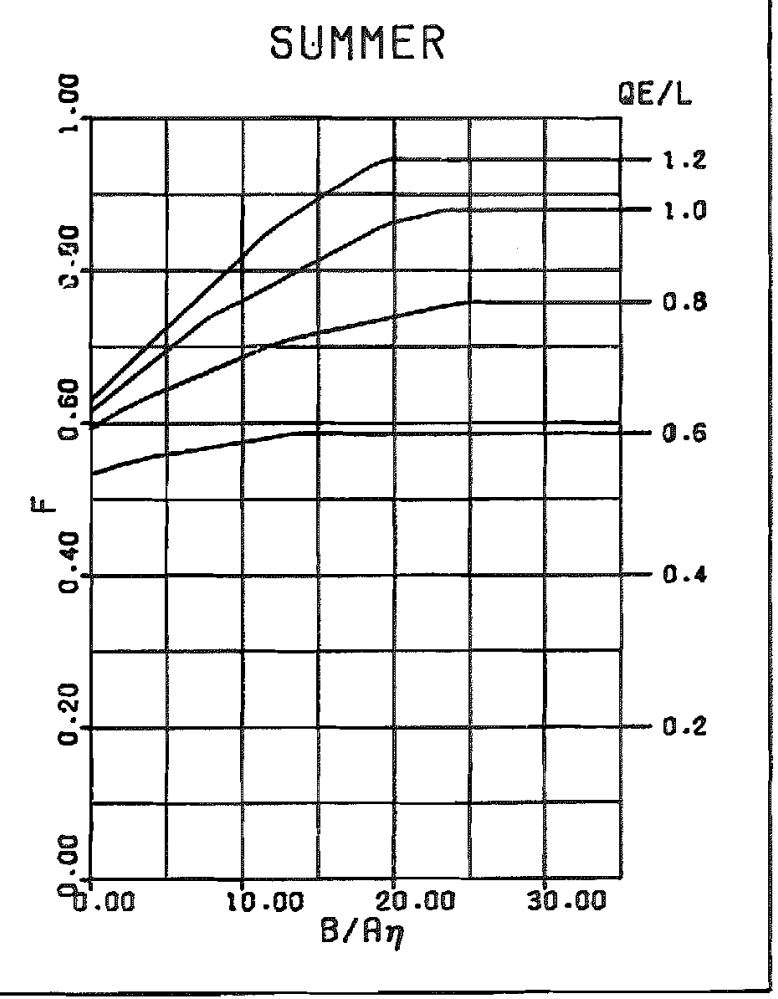

SPRING-FALL

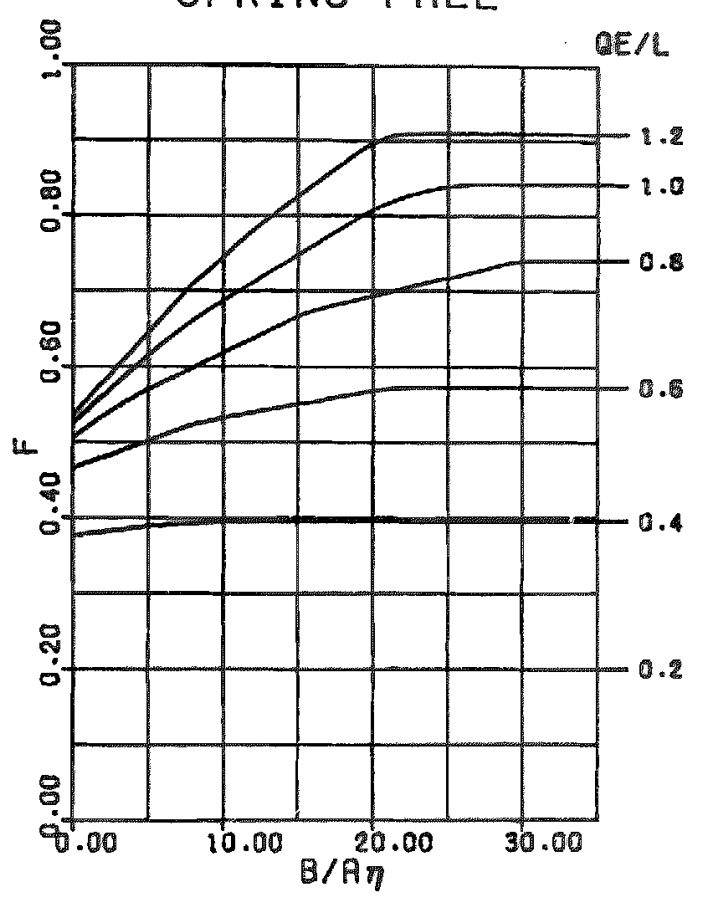

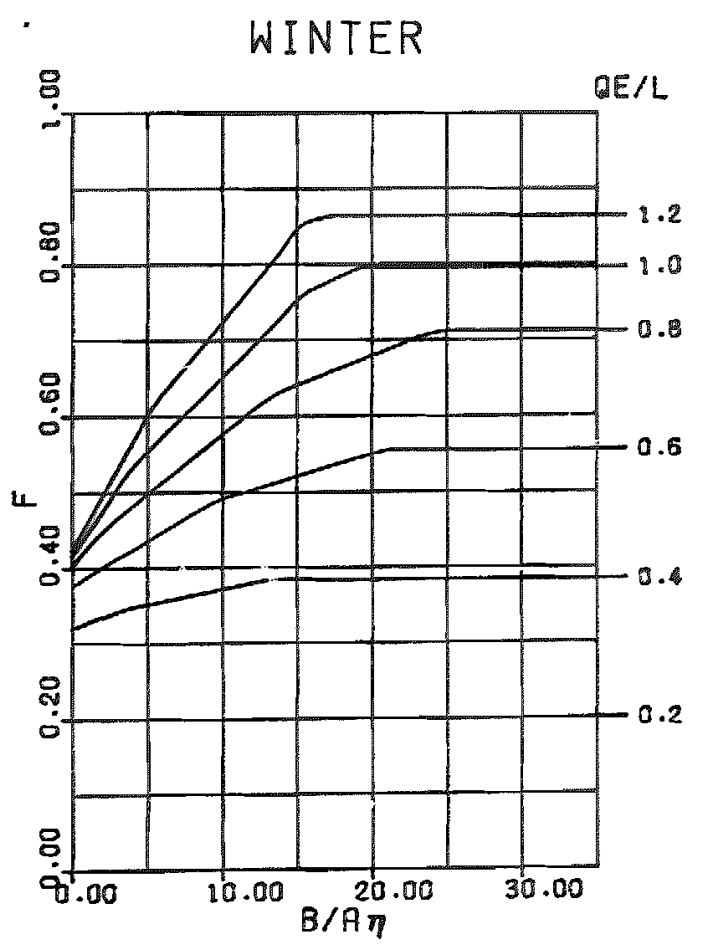




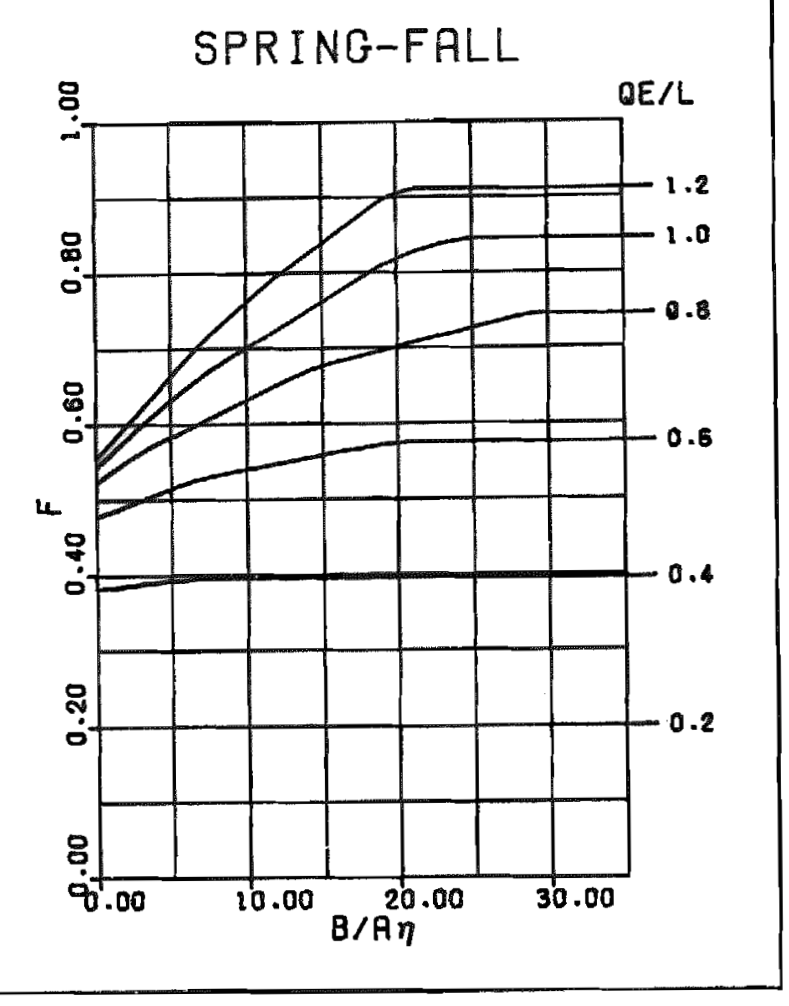

\section{UN I MODAL \#2}

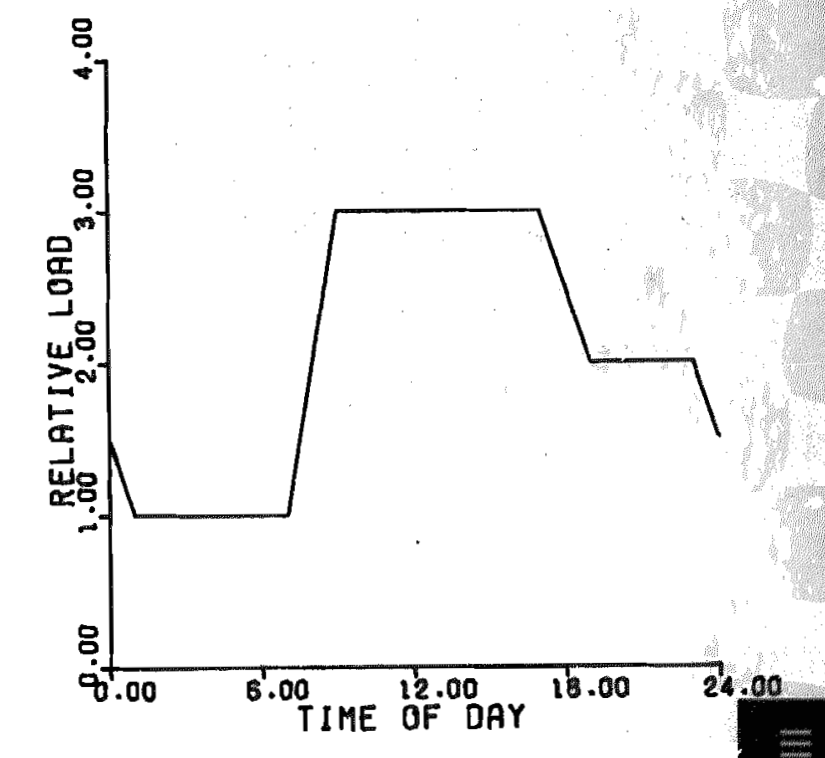

TABLE III SYSTEM PERFORUANCE GRAPAS

For Reading Key See Page A-63

\section{WINTER}

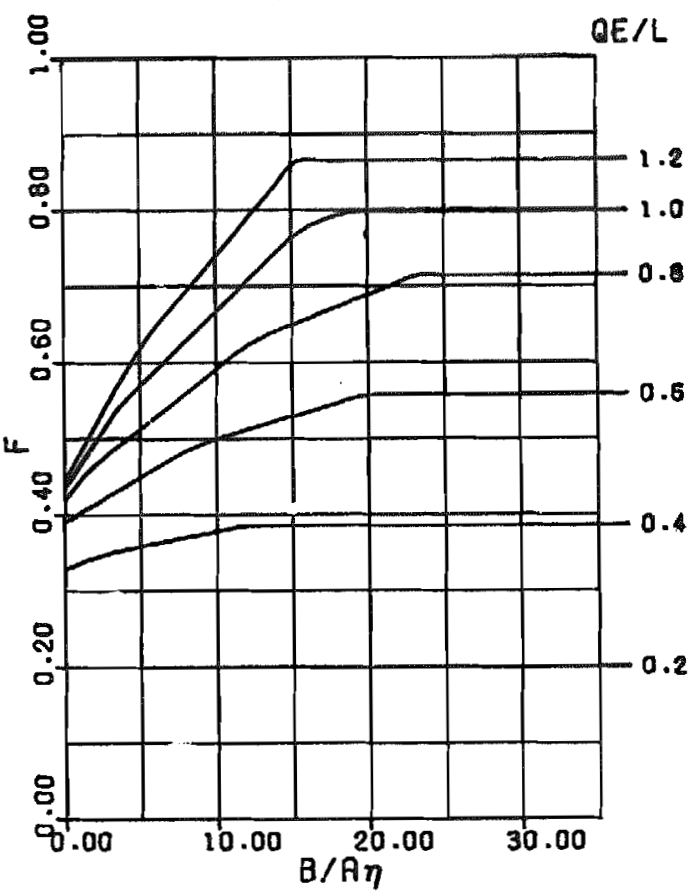


UN I MODAL \#3

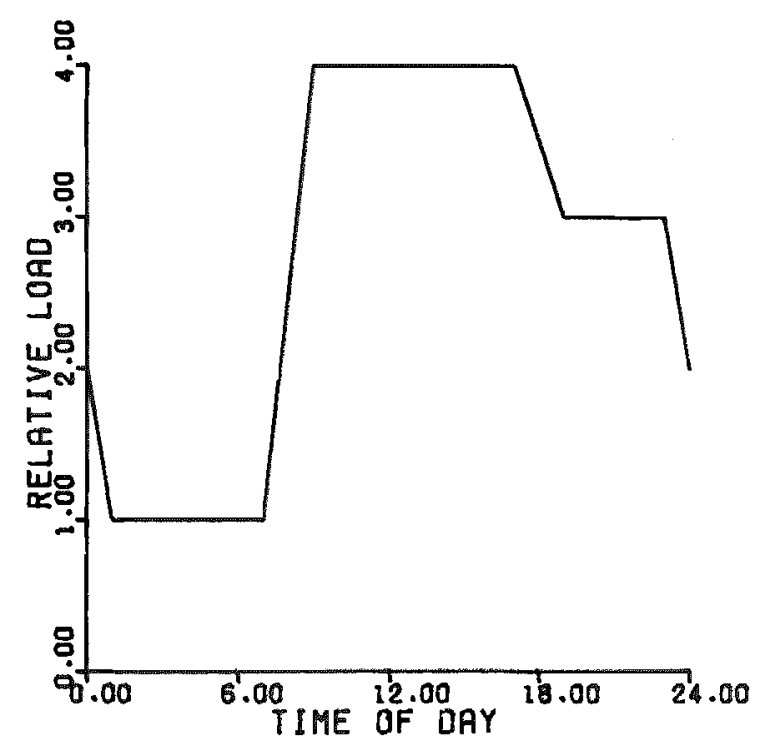

TABLR III SYSTEK PERFORMANCE GRAPIS For Reading roy See Page A-63

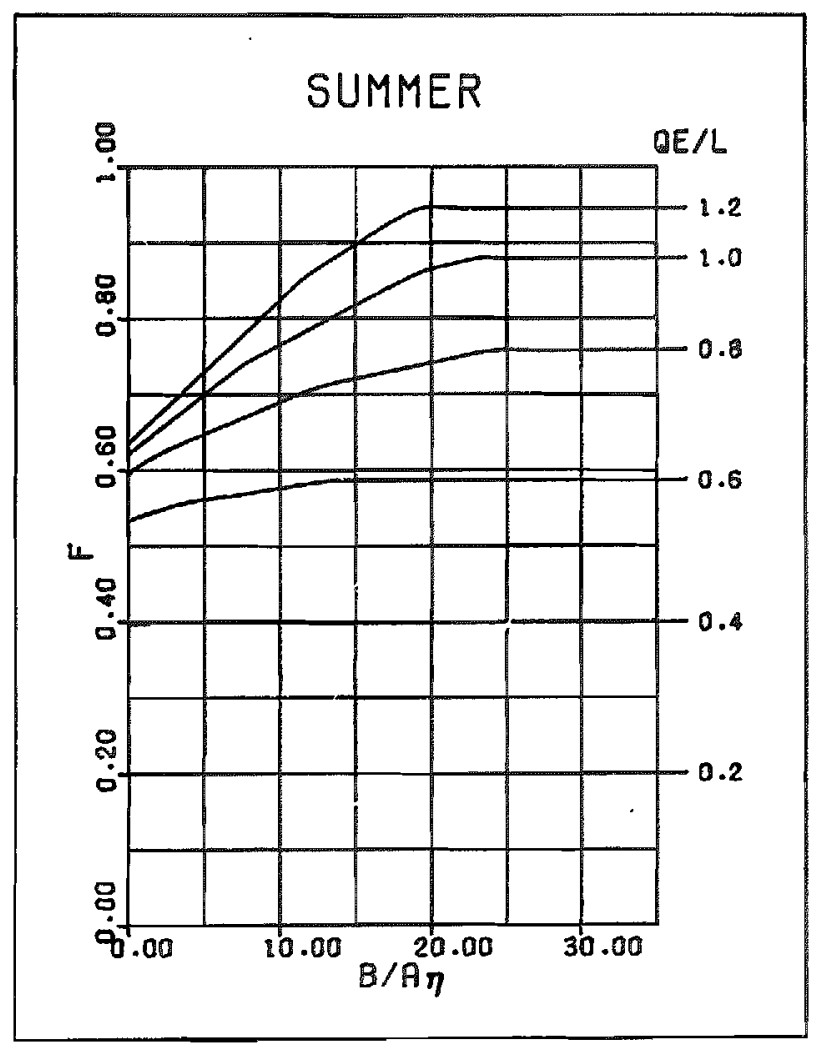

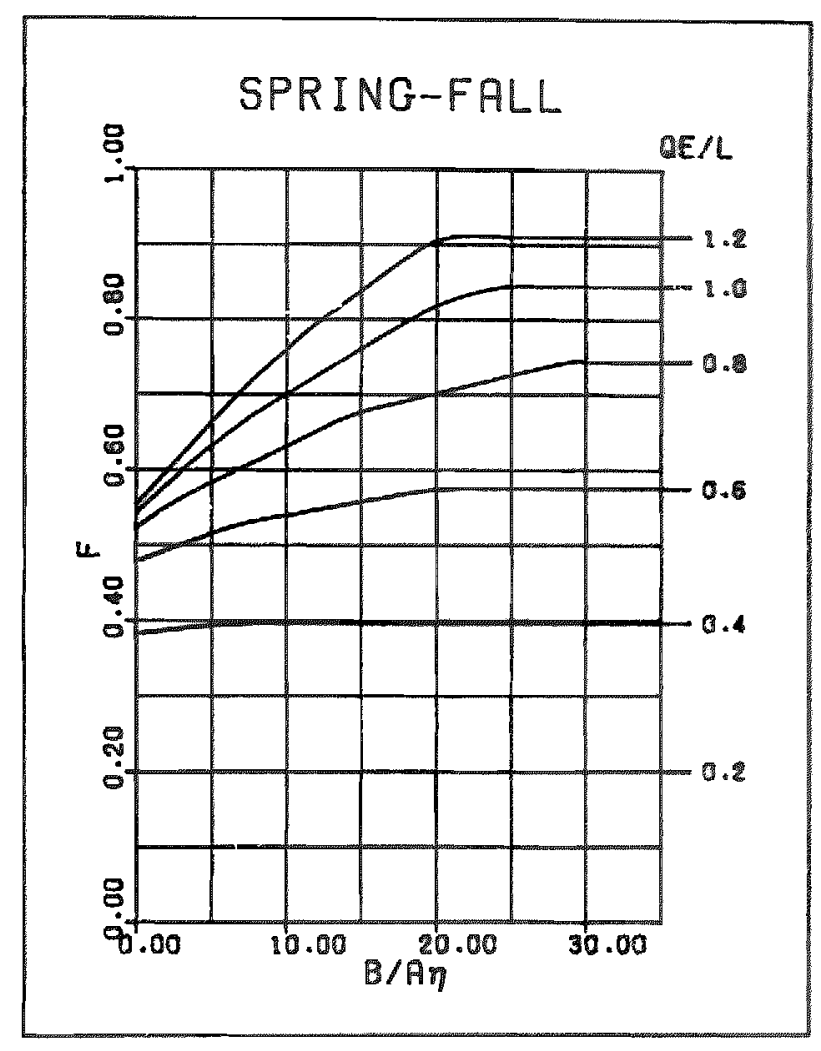

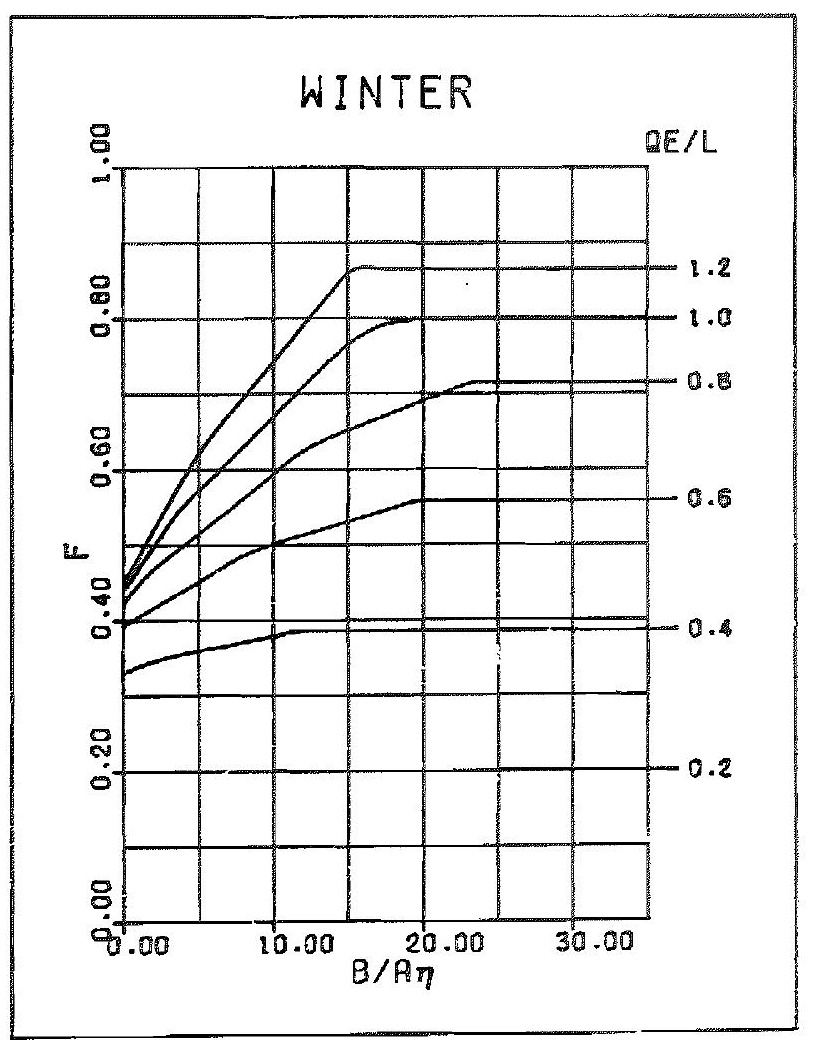




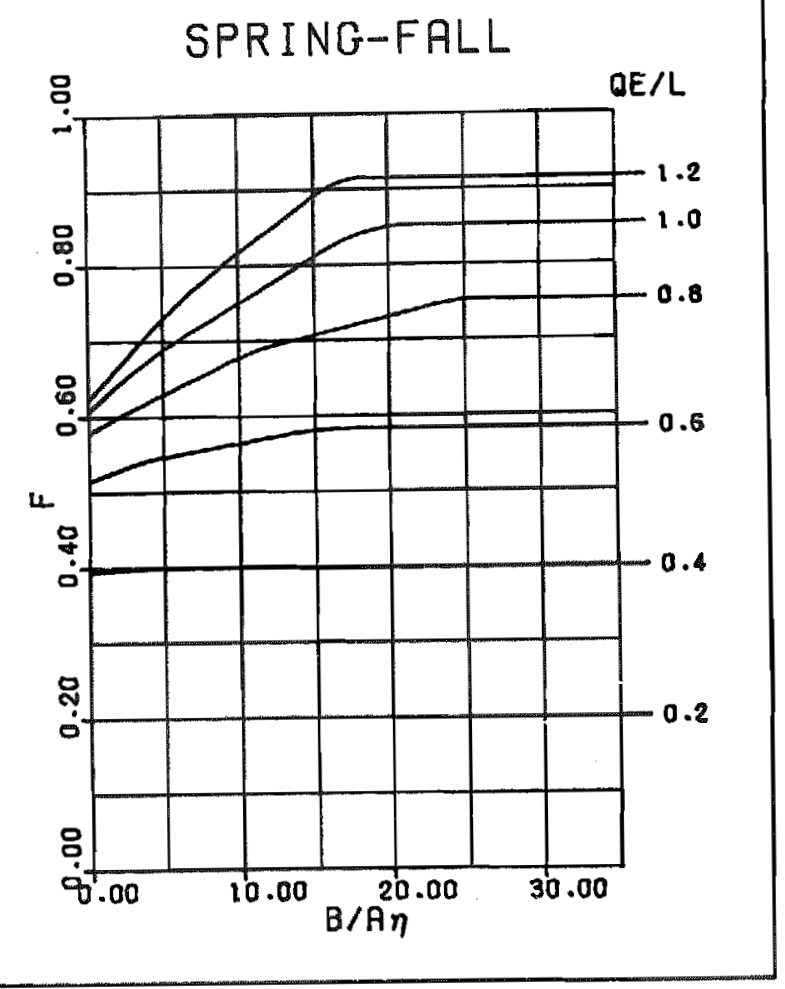

UN IMODAL \# 4

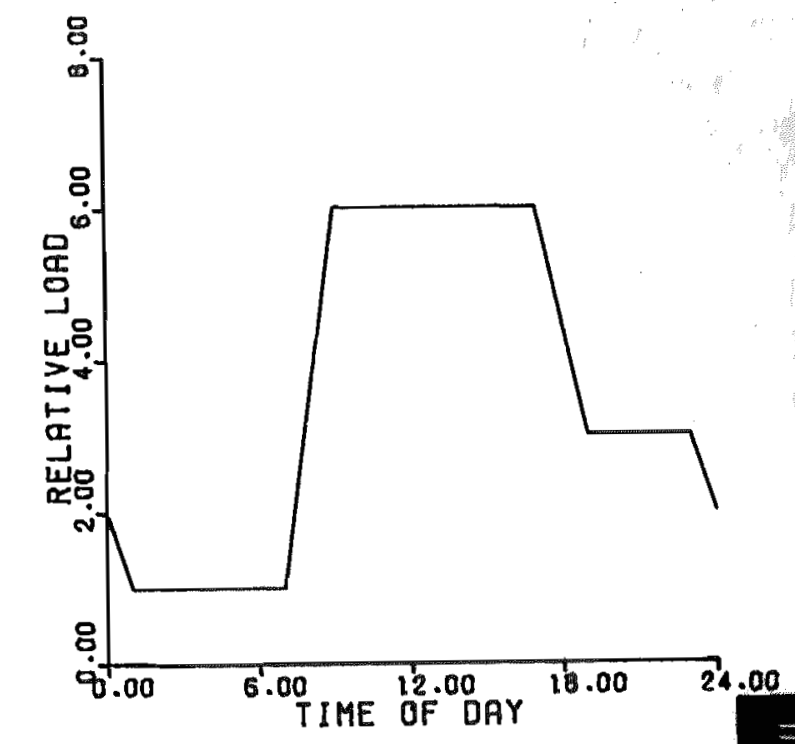

TABLE III SYSTEM PERFORMANCE GRAPHS

For Reading Koy See Page $A-63$

WINTER

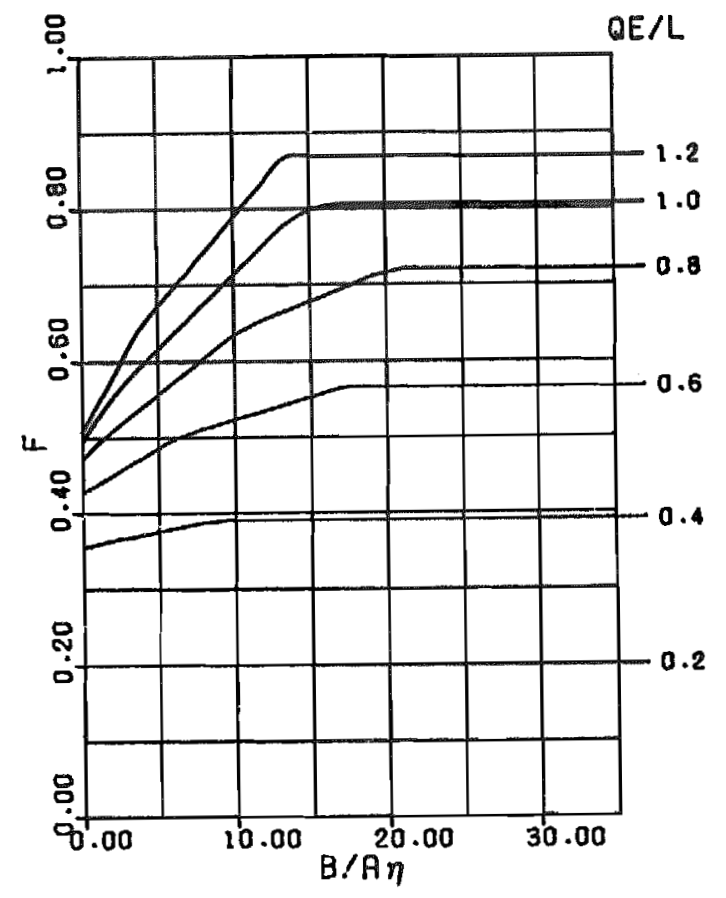


UN IMODAL \#5

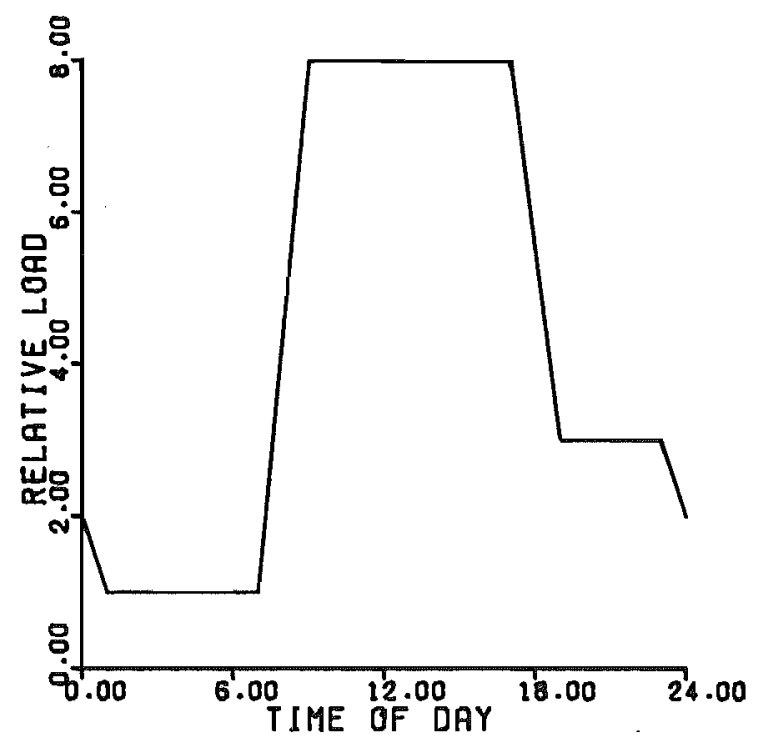

TABLE III SYSTEM PERFORMANCE GRAPHS For Reading Eey See Page A-63
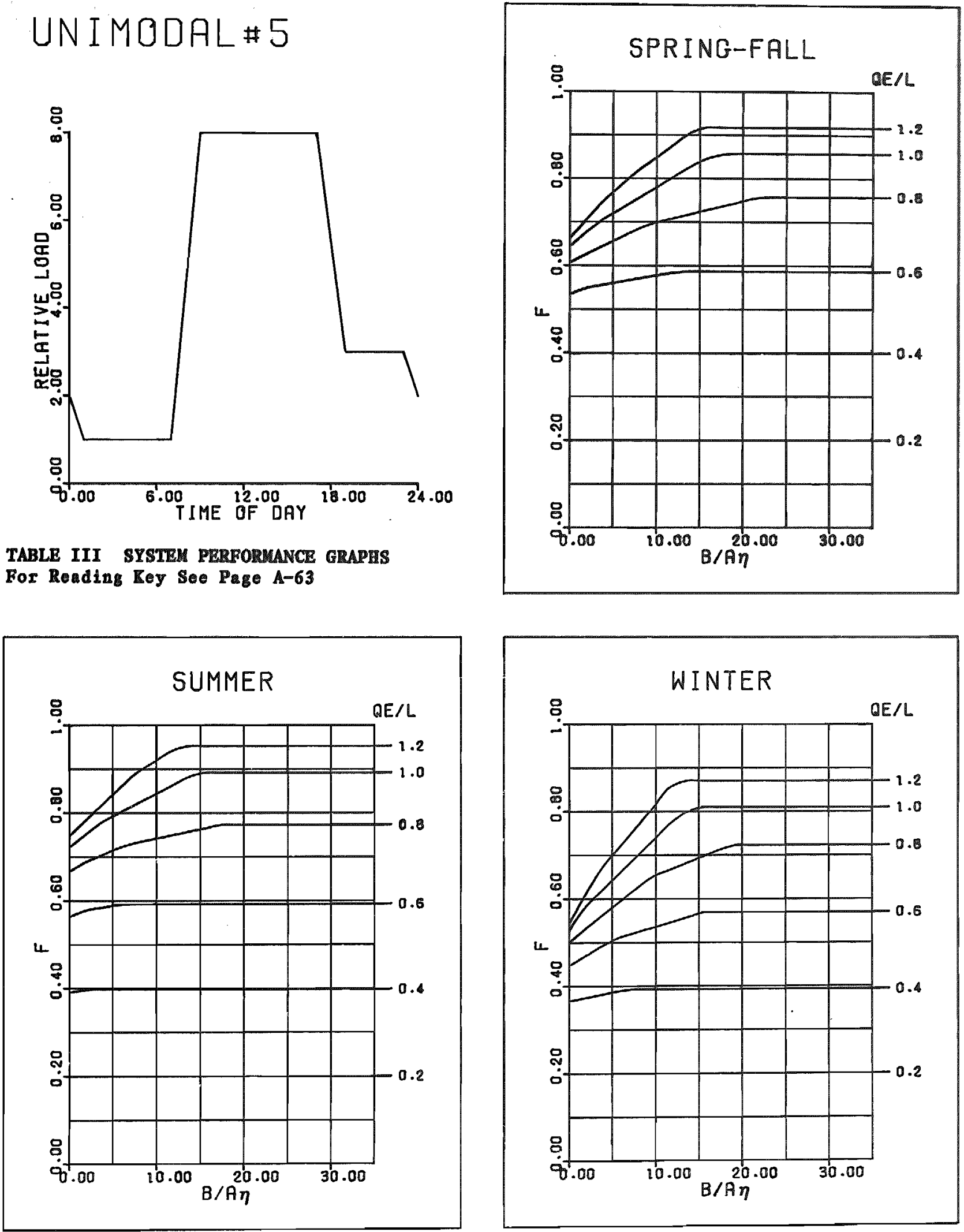


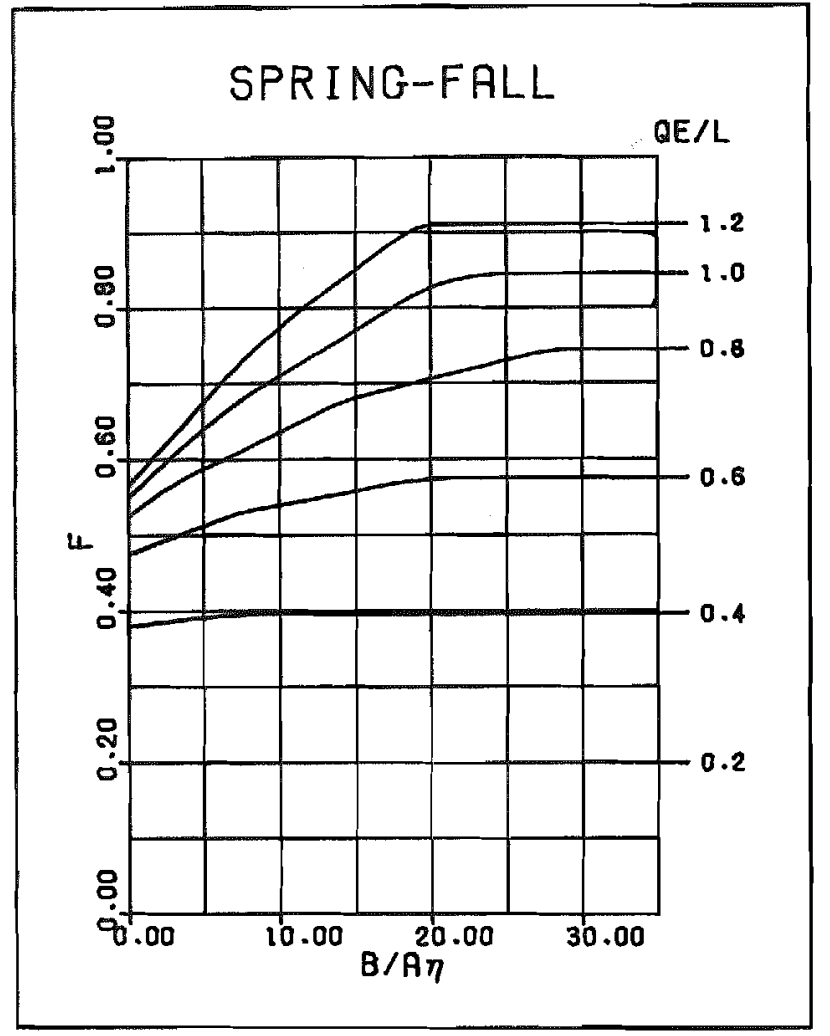

UN I MODAL *6

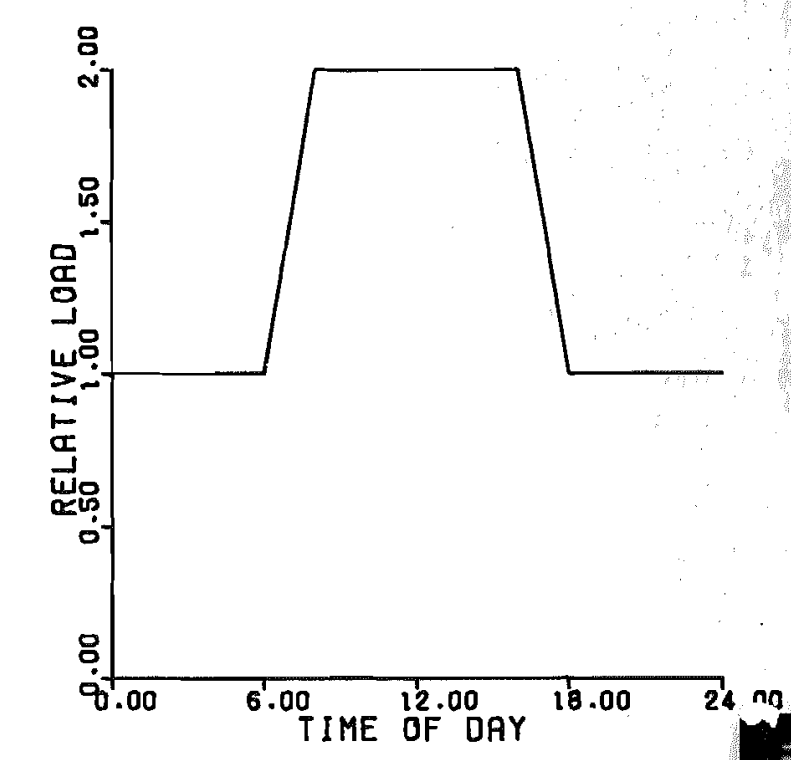

TABLE III SYSTEX PERFORMANCE GRAPHS For Reading Key See Page A-63

SUMMER

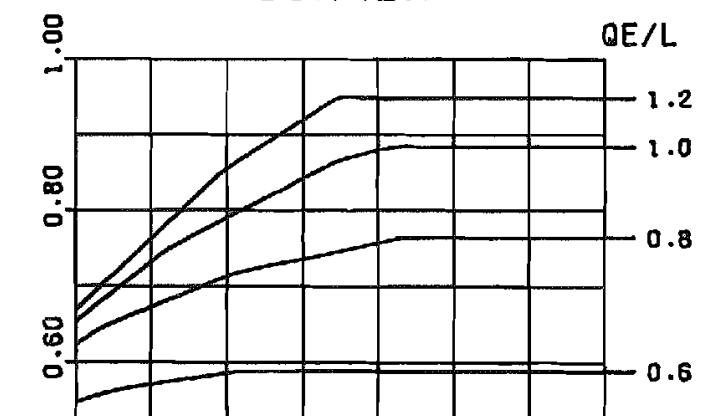

4

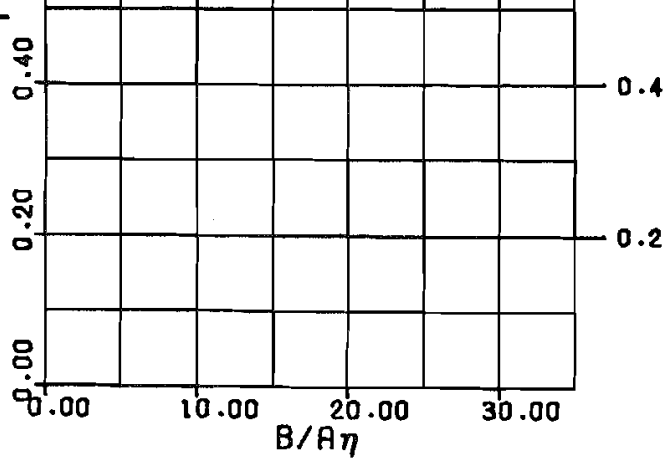

WINTER

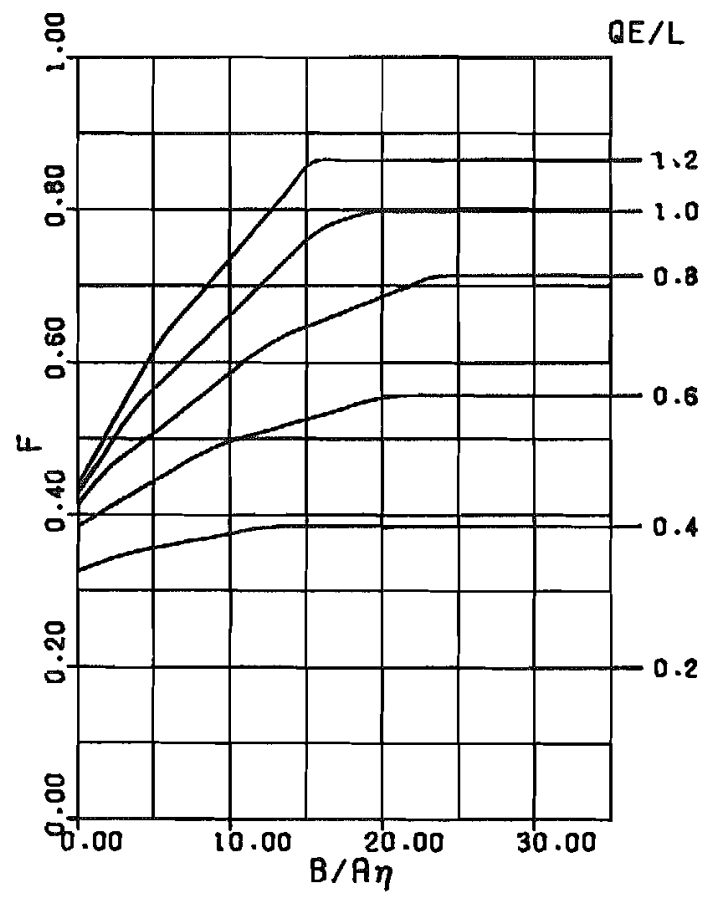


UNIMODAL \# 7

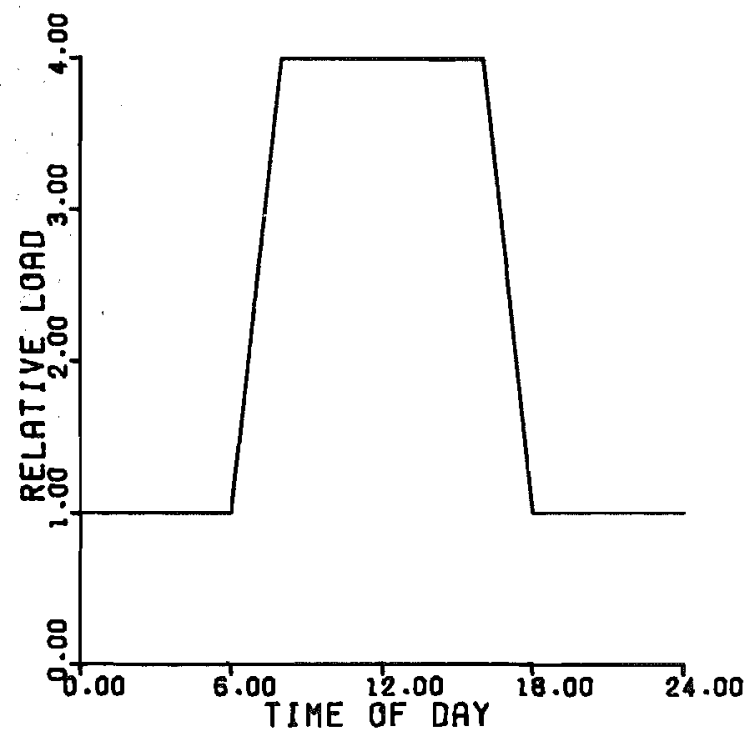

TABLE III SYSTEM PERFORMANCE GRAPHS For Reading Key Soe Page A-63

SUMMER

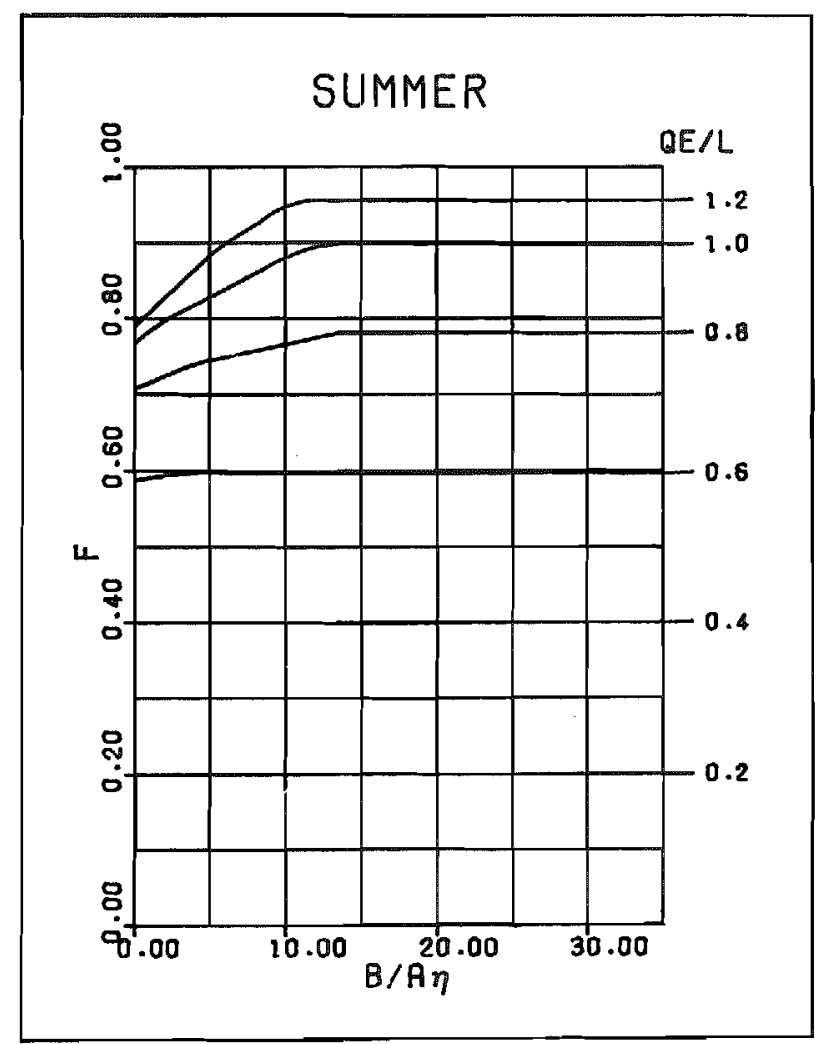

SPR ING-FALL

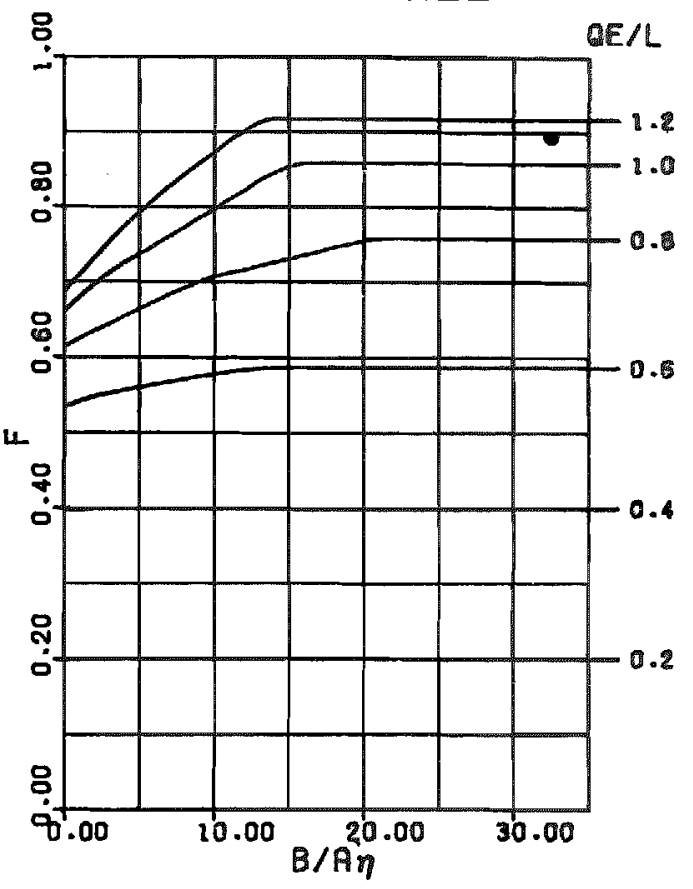

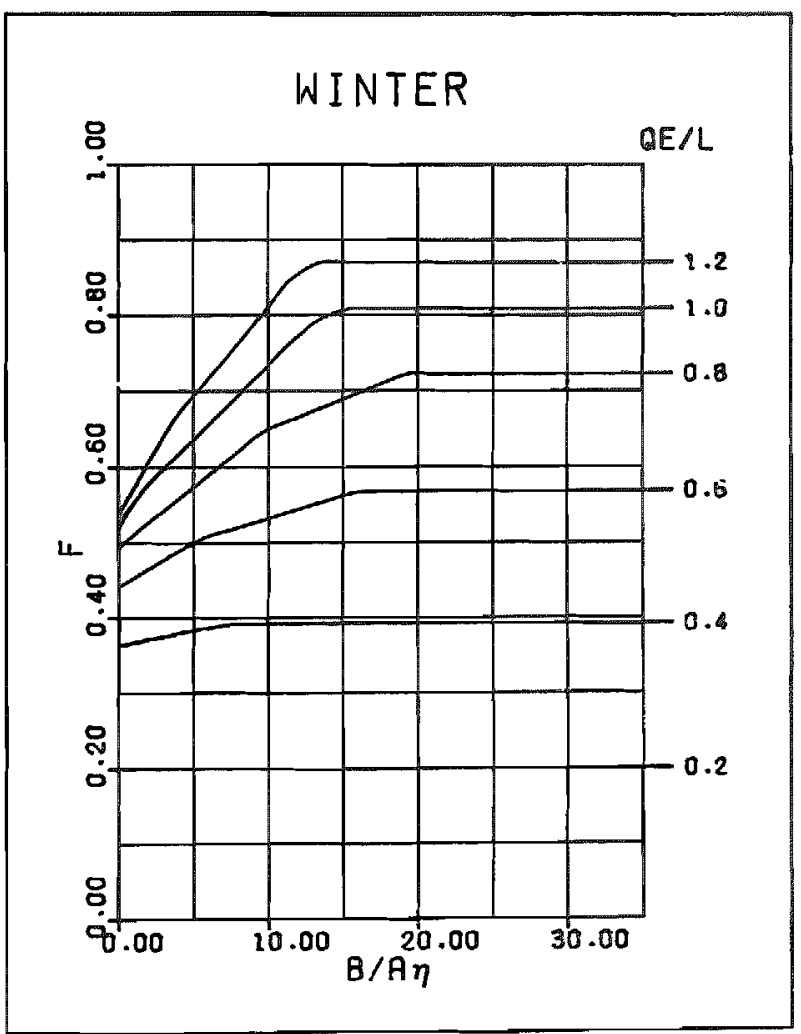




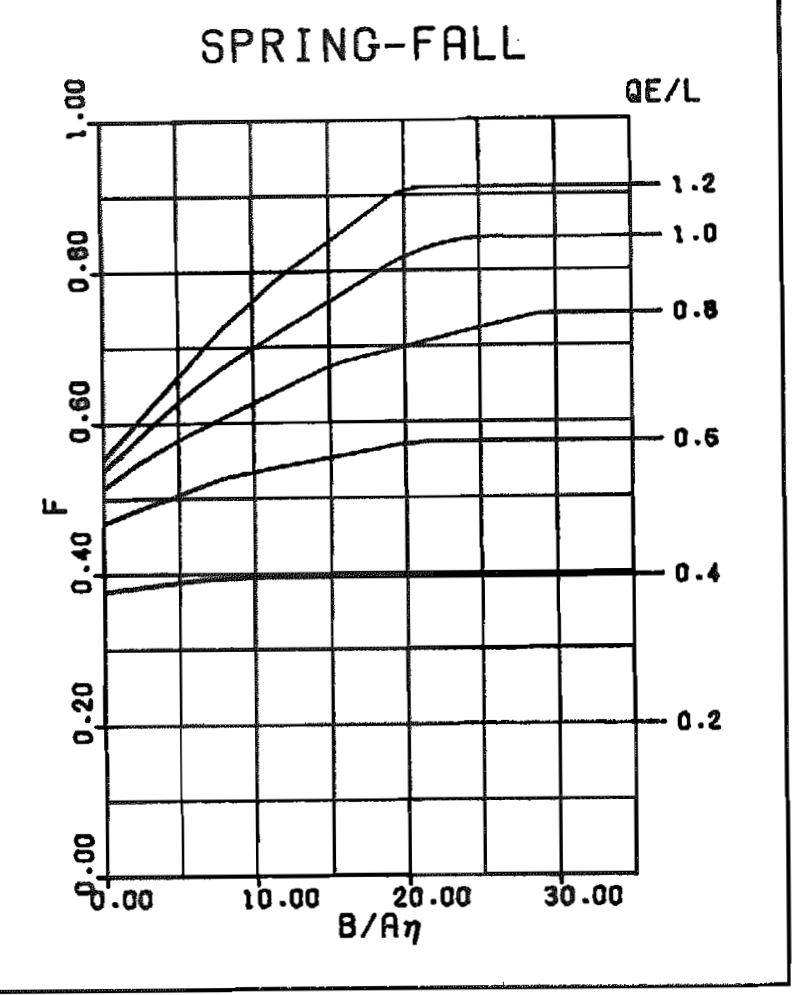

\section{UN I MODAL $* 8$}

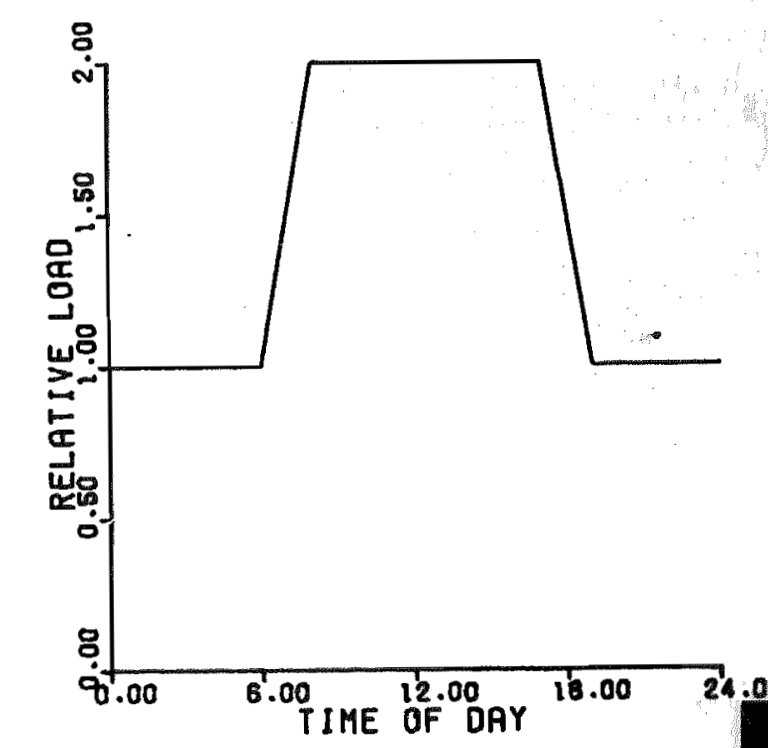

TABLE III SYSTEM PERFORMANCE GRAPHS

For Reading Tey See Pege A-63

\section{SUMMER}

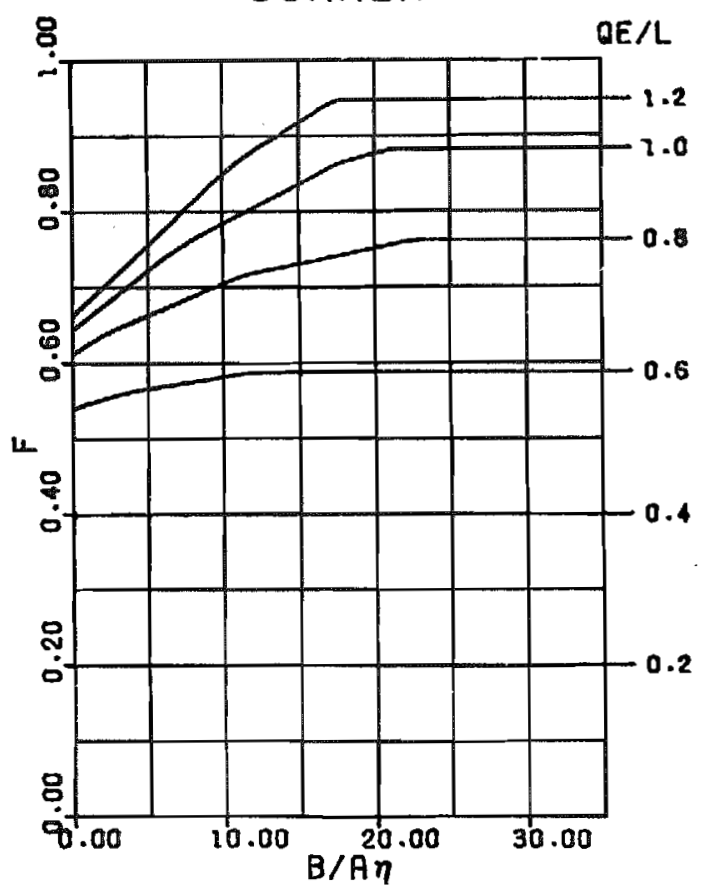

WINTER

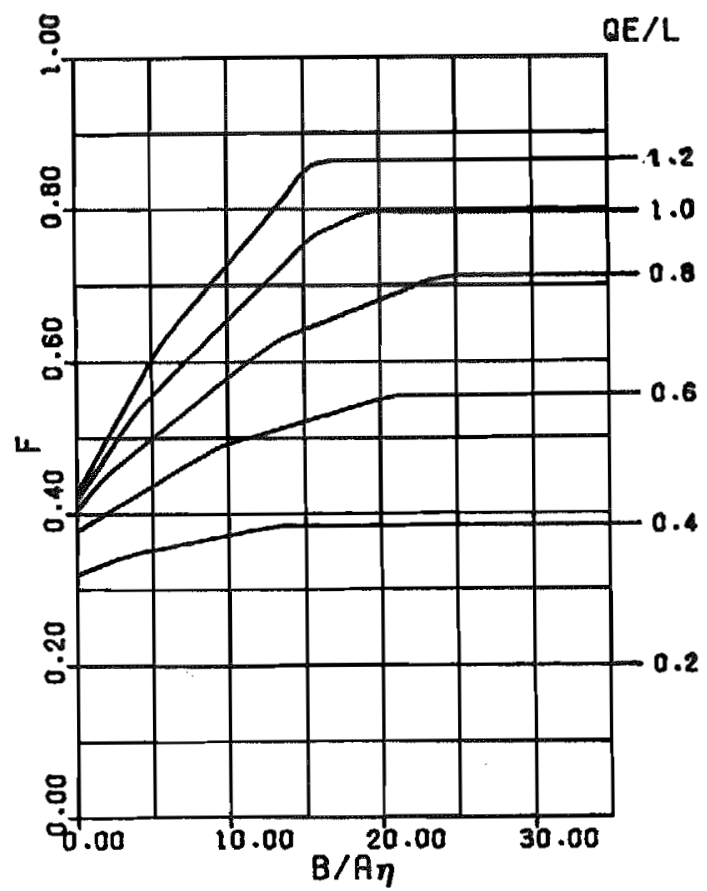


UN I MODAL\# 9

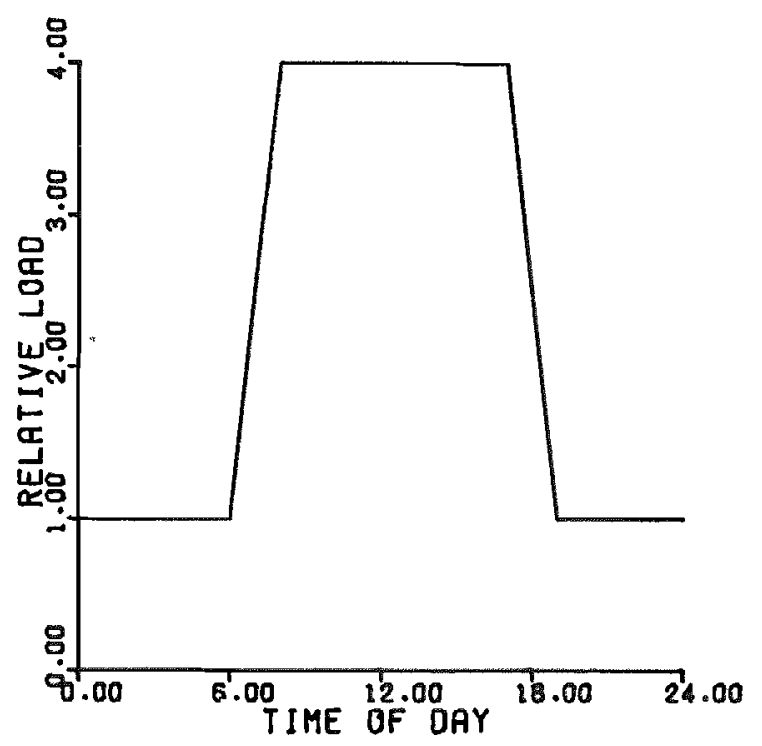

TABLE III SYSTEM PERPORUANCE GRAPHS

For Reading Key See Page A-63

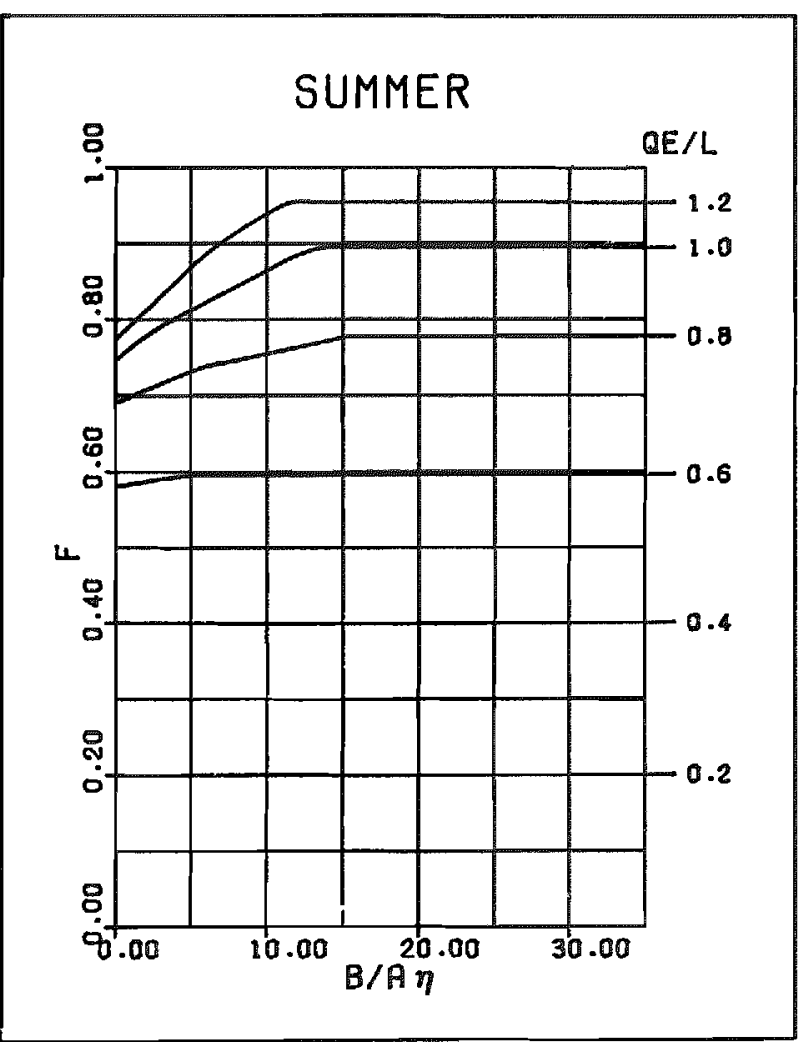

SPR ING-FALL

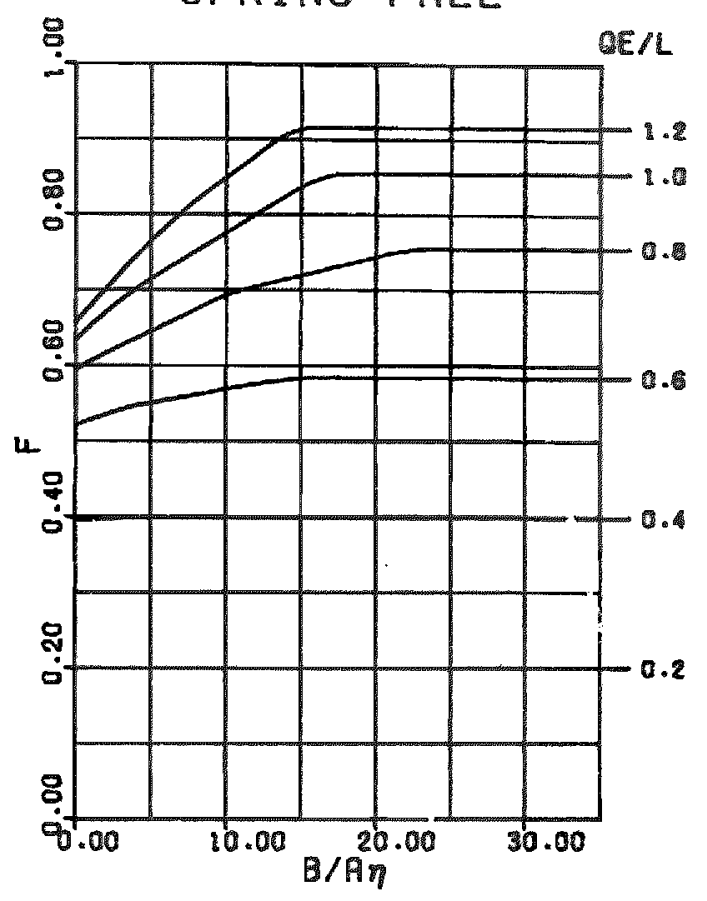

WINTER

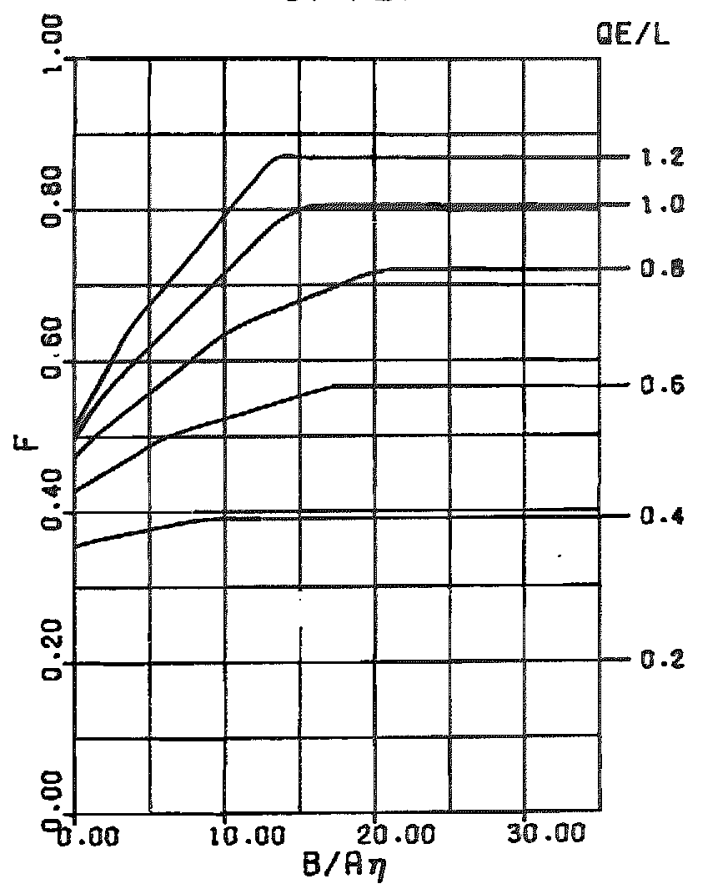


SPR ING-FALL

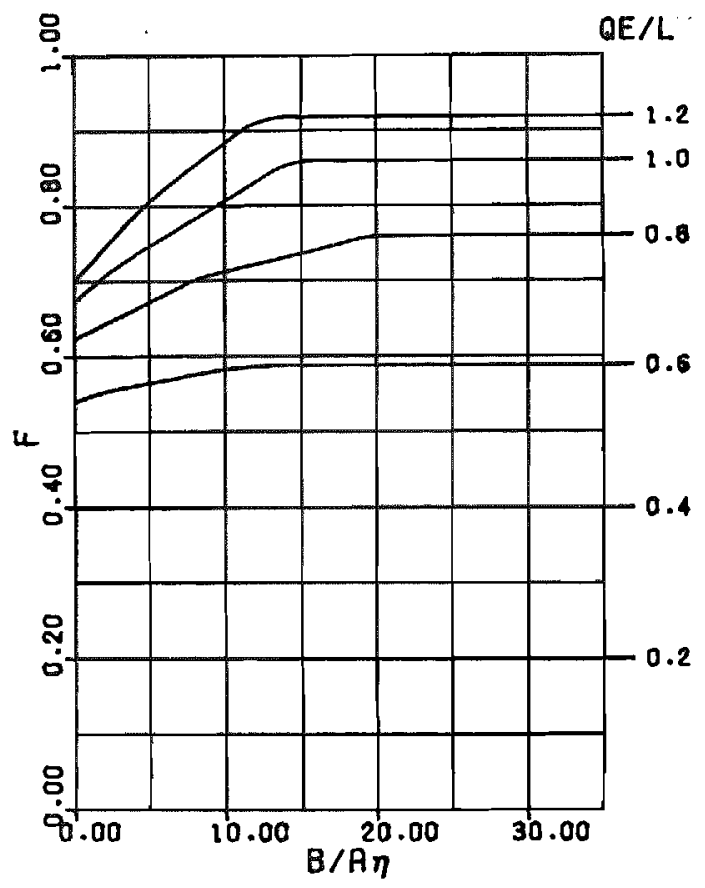

SUMMER

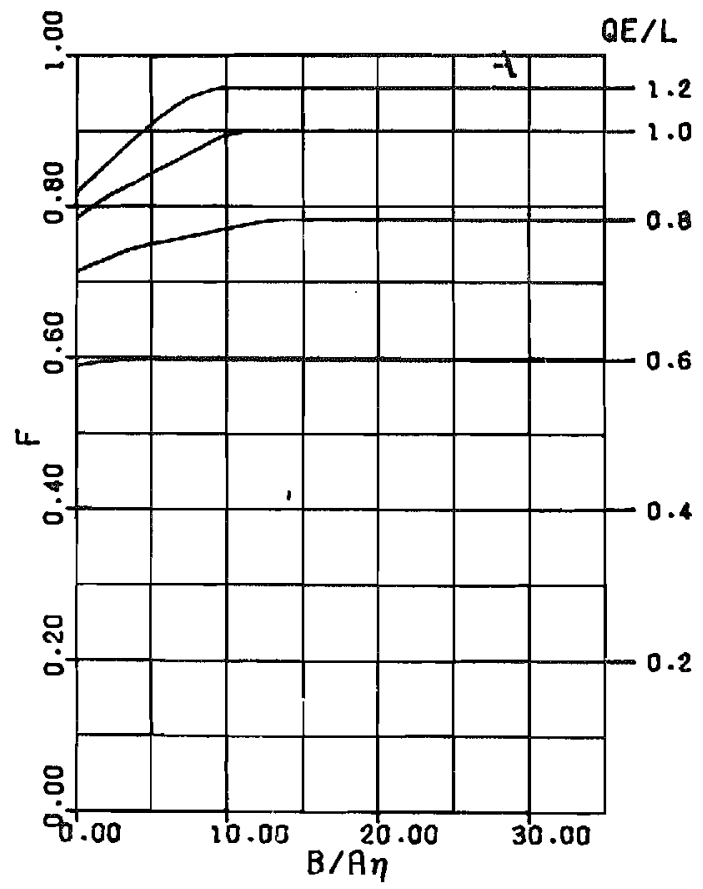

UN I MODAL \#10

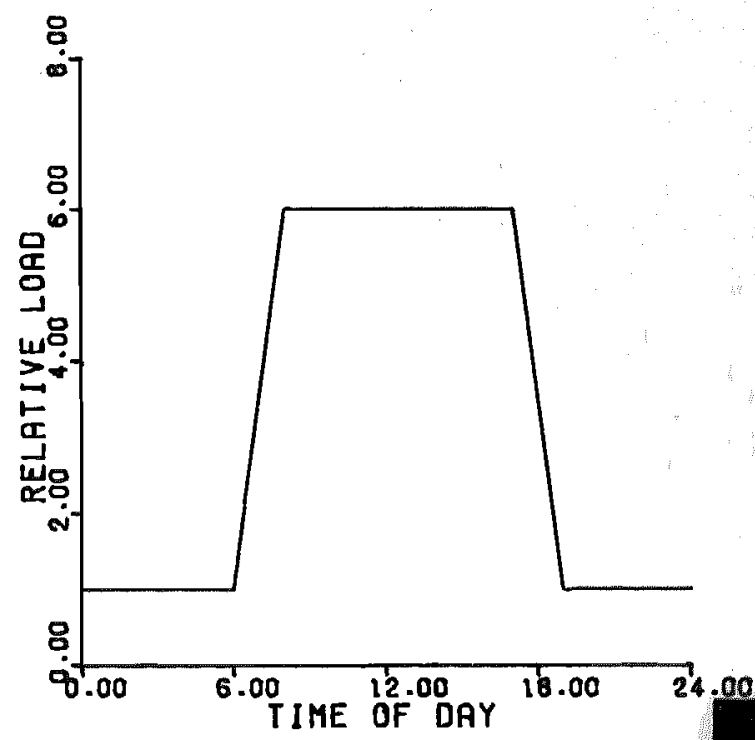

TABLE III SYSTEM PERFORMANCE GRAPHS For Reading Key See Page A-63

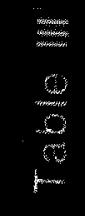

\section{WINTER}

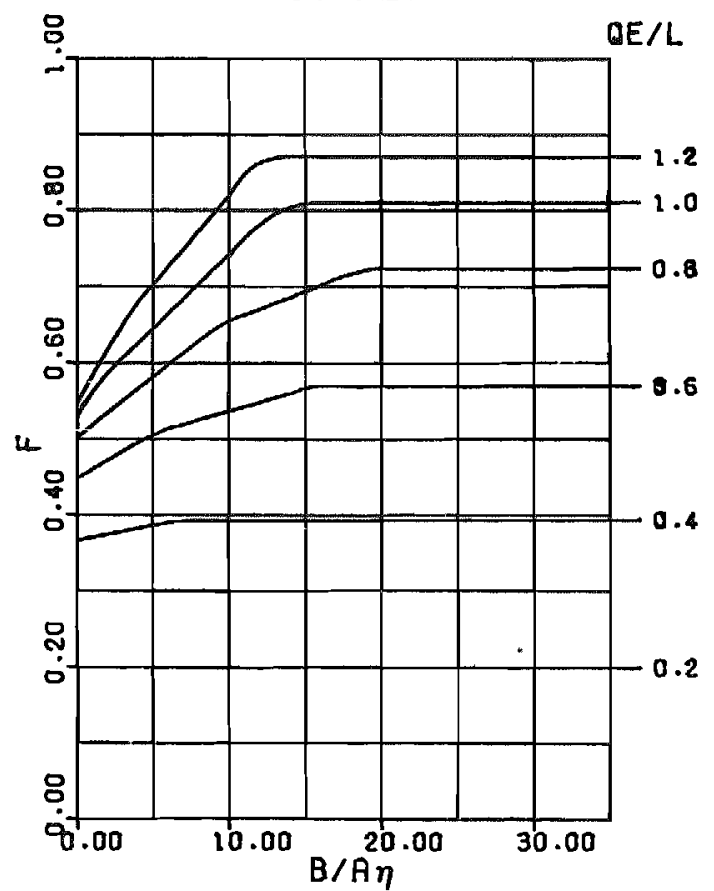


UN I MODAL\# 11

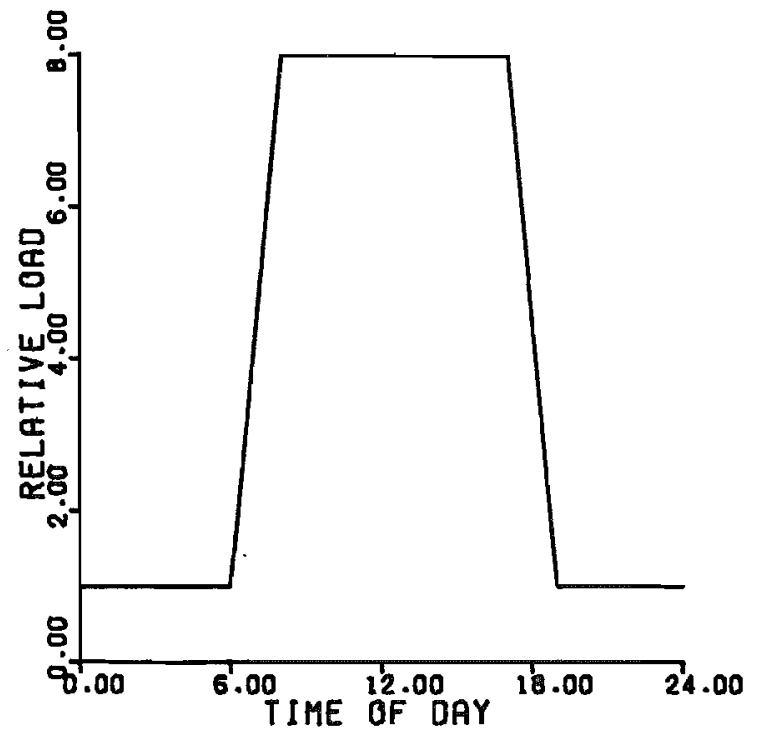

TABLE III SYSTEM PERTORMANCE GRAPIS Bor Reading Key Soe Page A-63

SUMMER

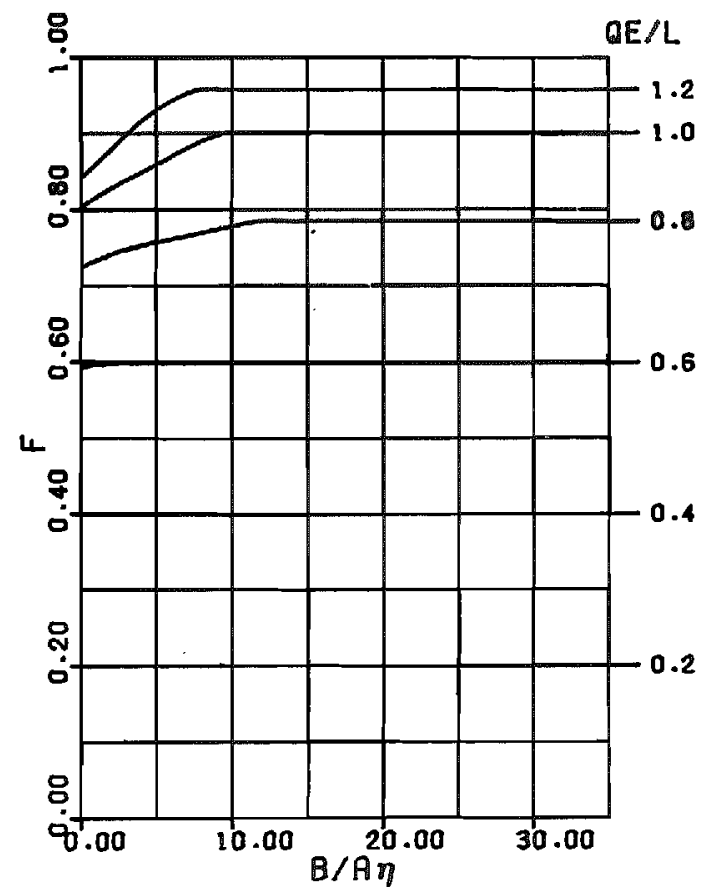

SPRING-FALL

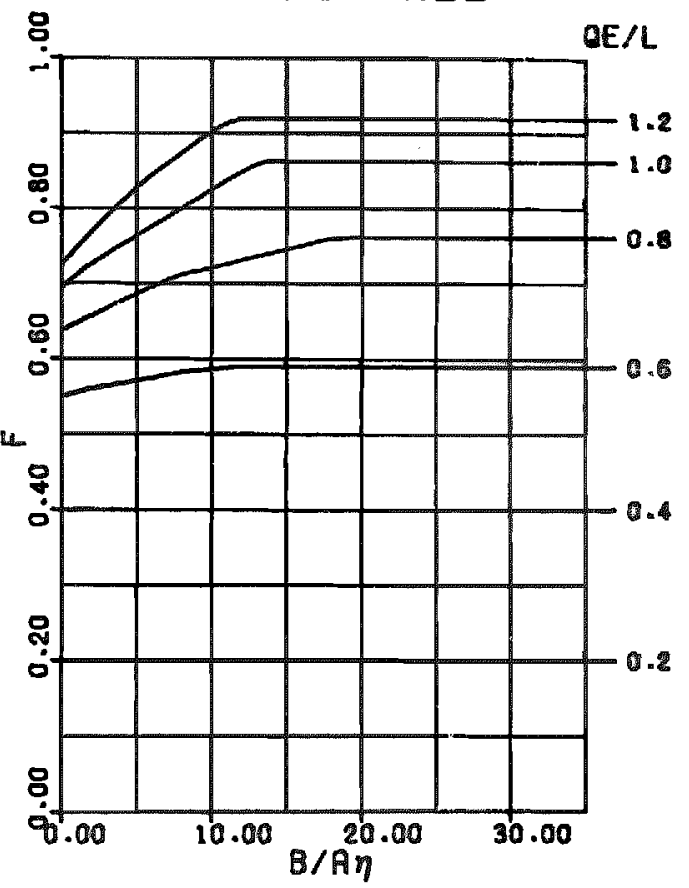

OE/L

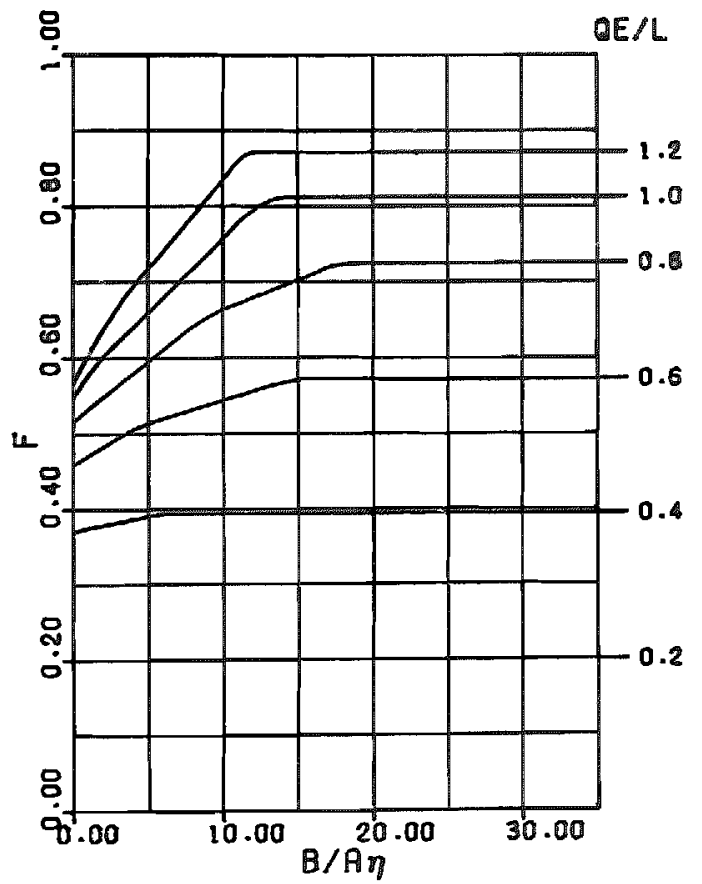




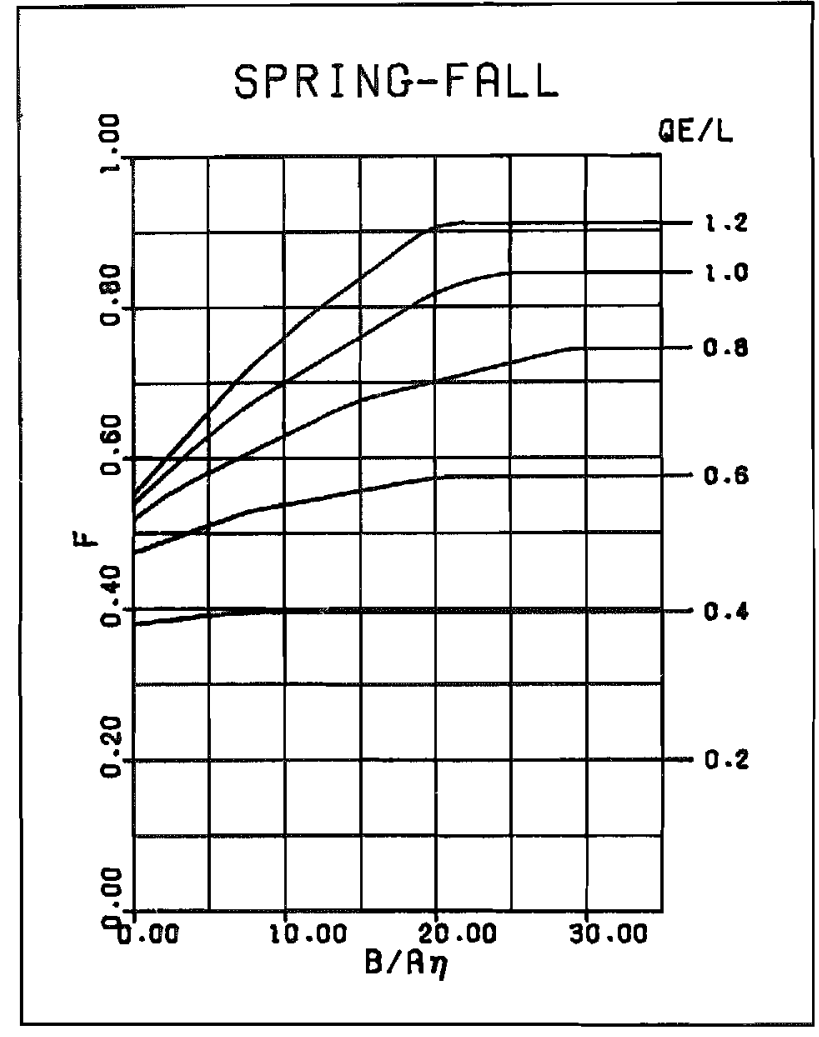

\section{UN I MODAL 12}

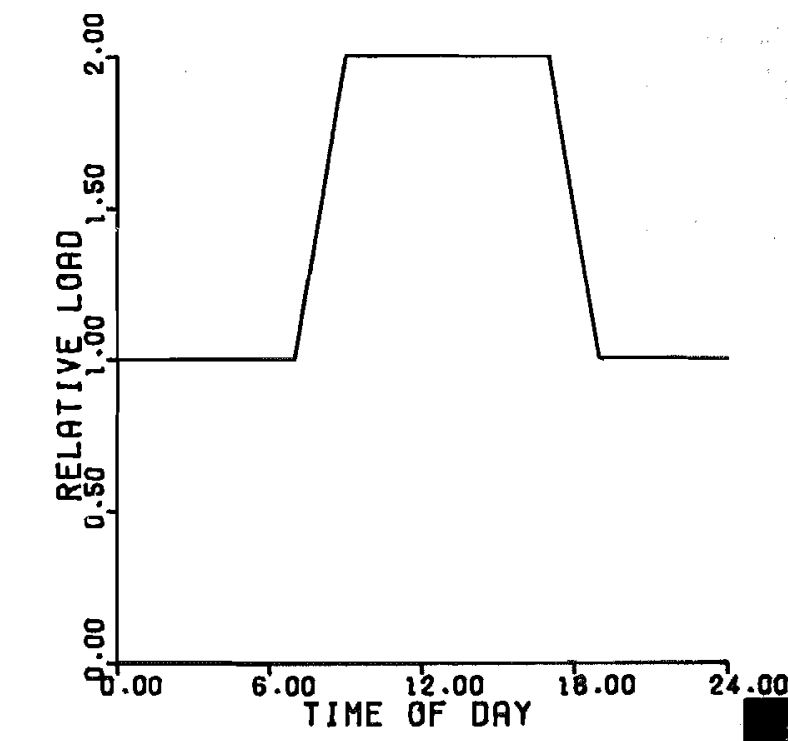

TABLE III SYSTEM PERFORMANCE GRAPHS For Reading Key See Page A-63

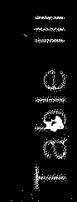

SUMMER

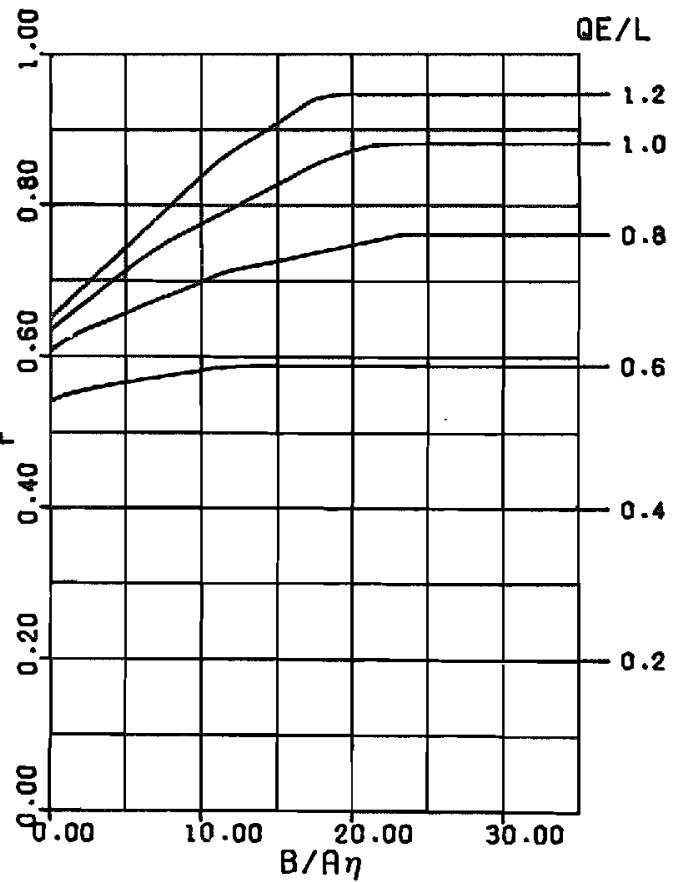

\section{W INTER}

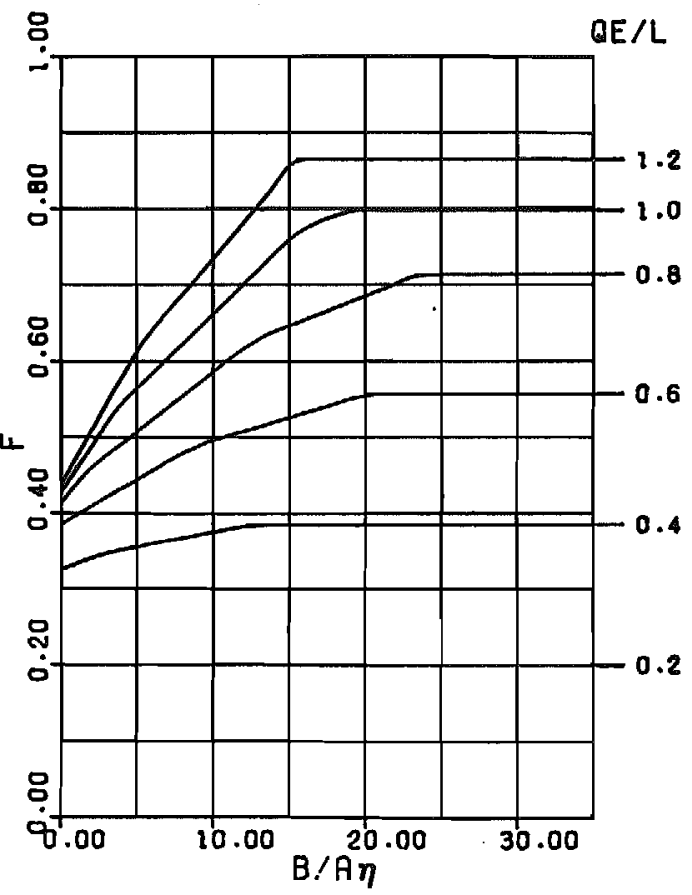


UN I MODAL \#13

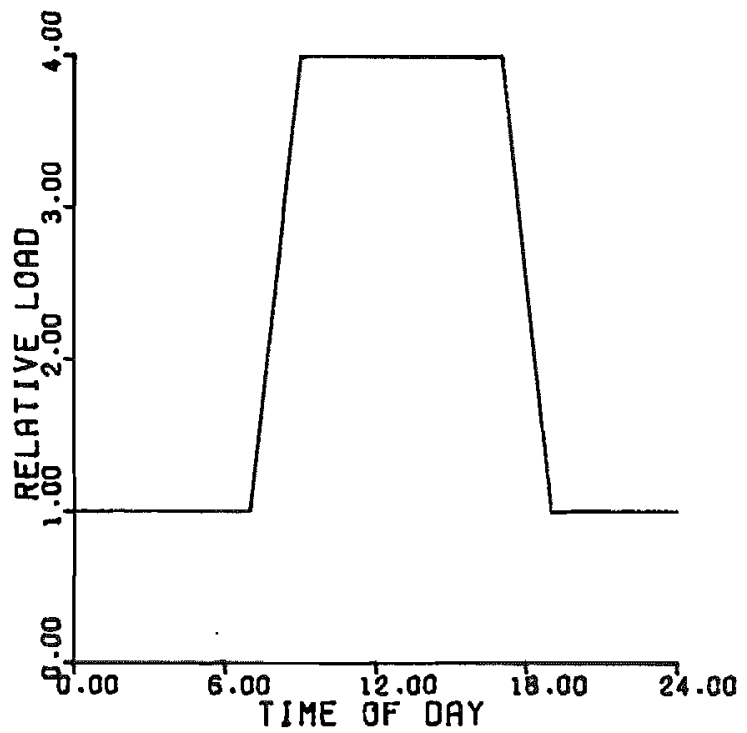

TABLE III SYSTEM PERFORMANCE GRAPHS

For Reading Key Soe Page A-63

SUMMER

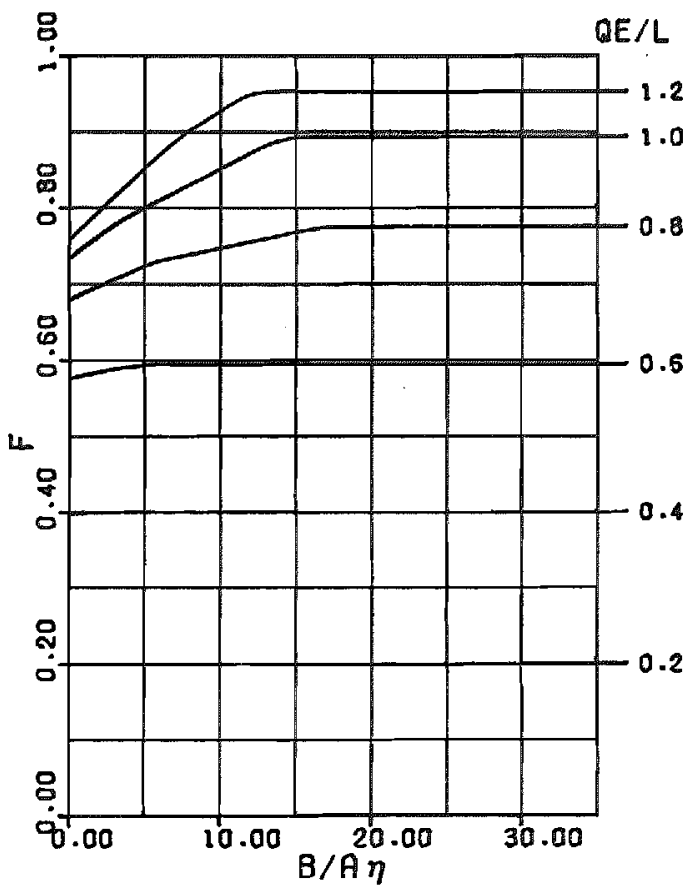

SPRING-FRLL

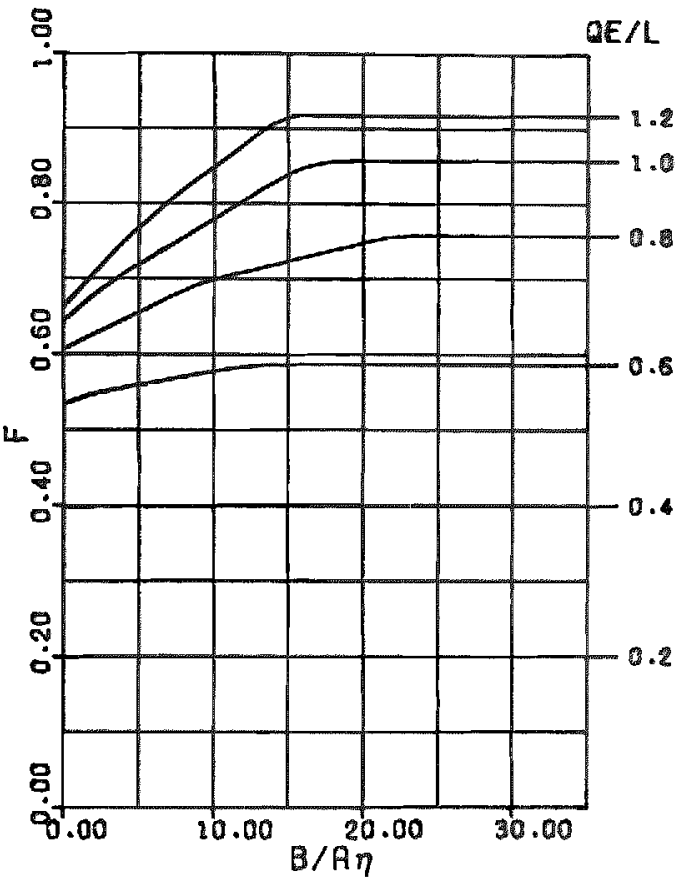

WINTER

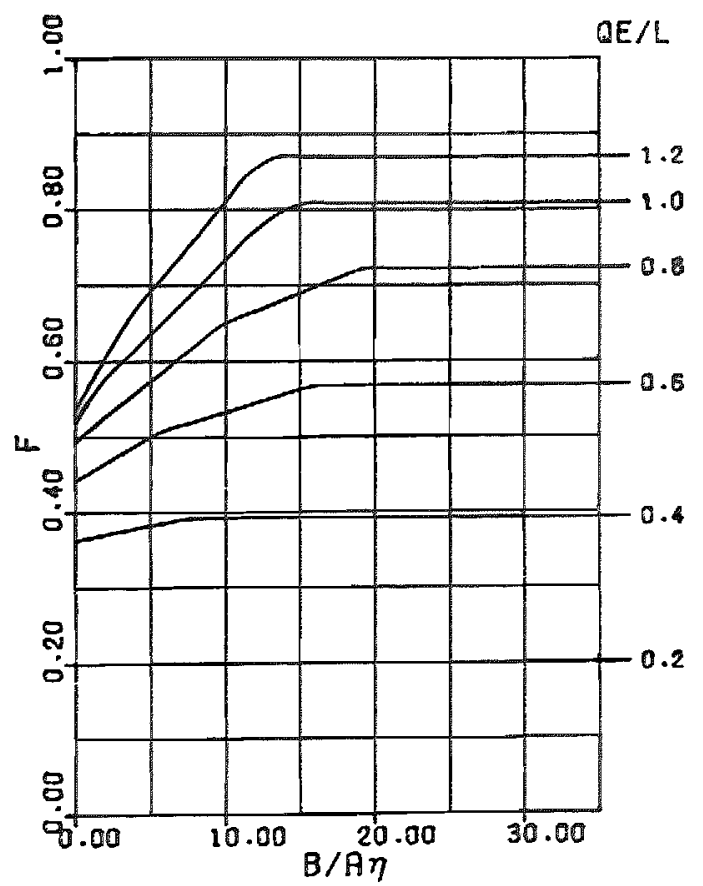




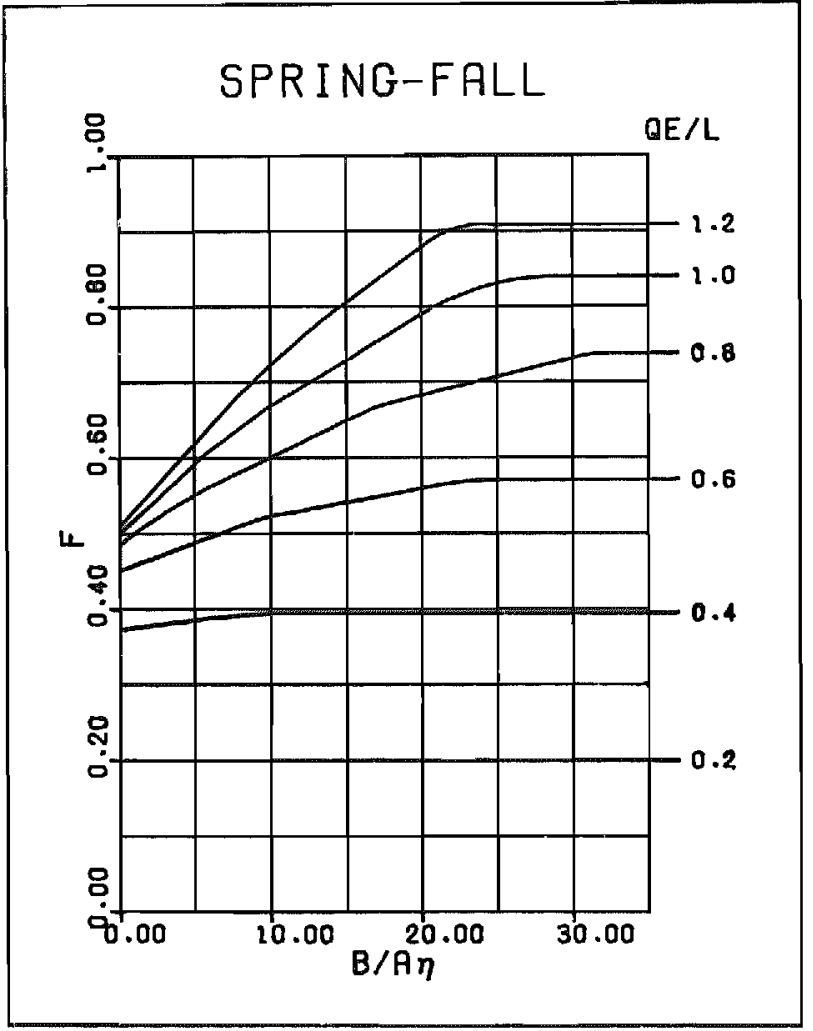

\section{UN IMODAL * 14}

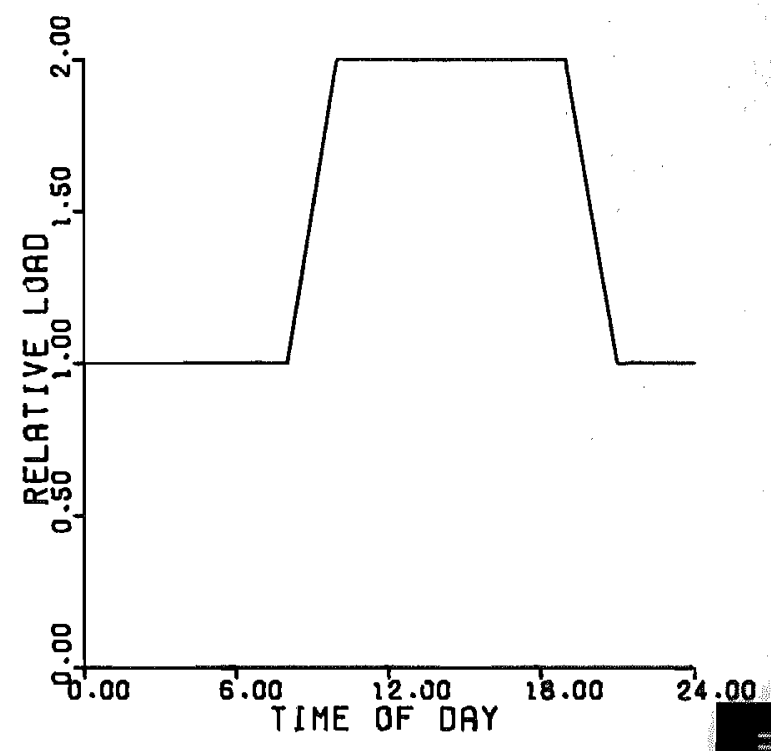

TABLE III SYSTEM PERFORMANCE GRAPHS For Reading Key Soe Page A-63

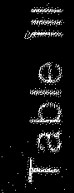

\section{SUMMER}

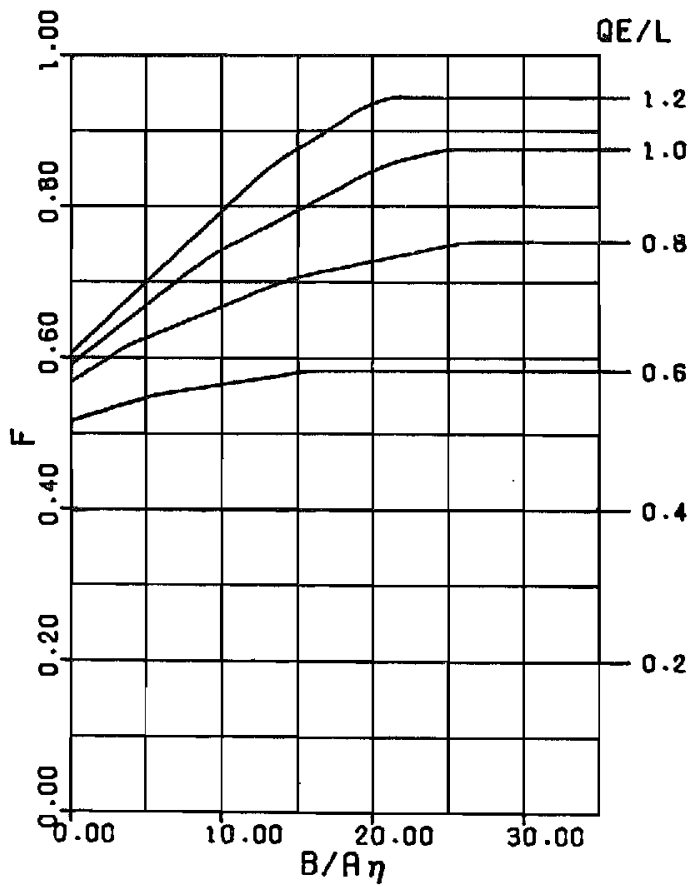

WINTER

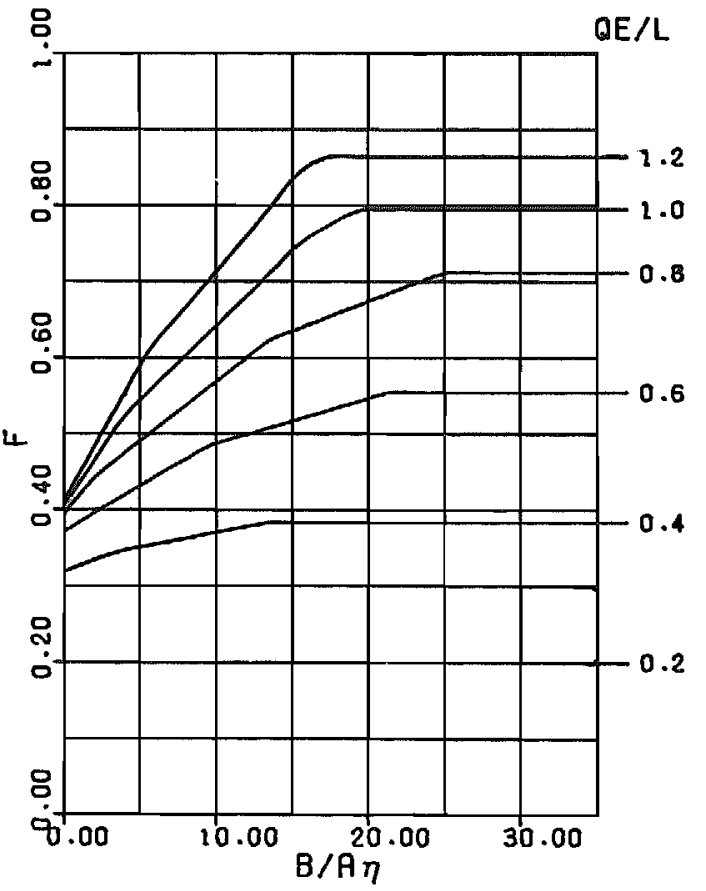


UN I MODAL\# 15

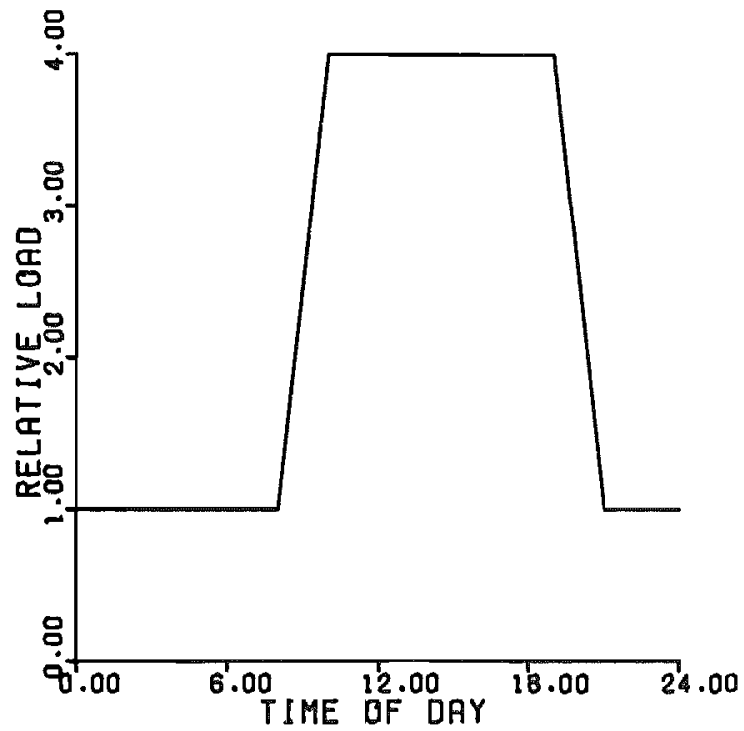

TABLE III SYSTEM PERFORUANCE GRAPHS

For Roading Key Soe Page A-63

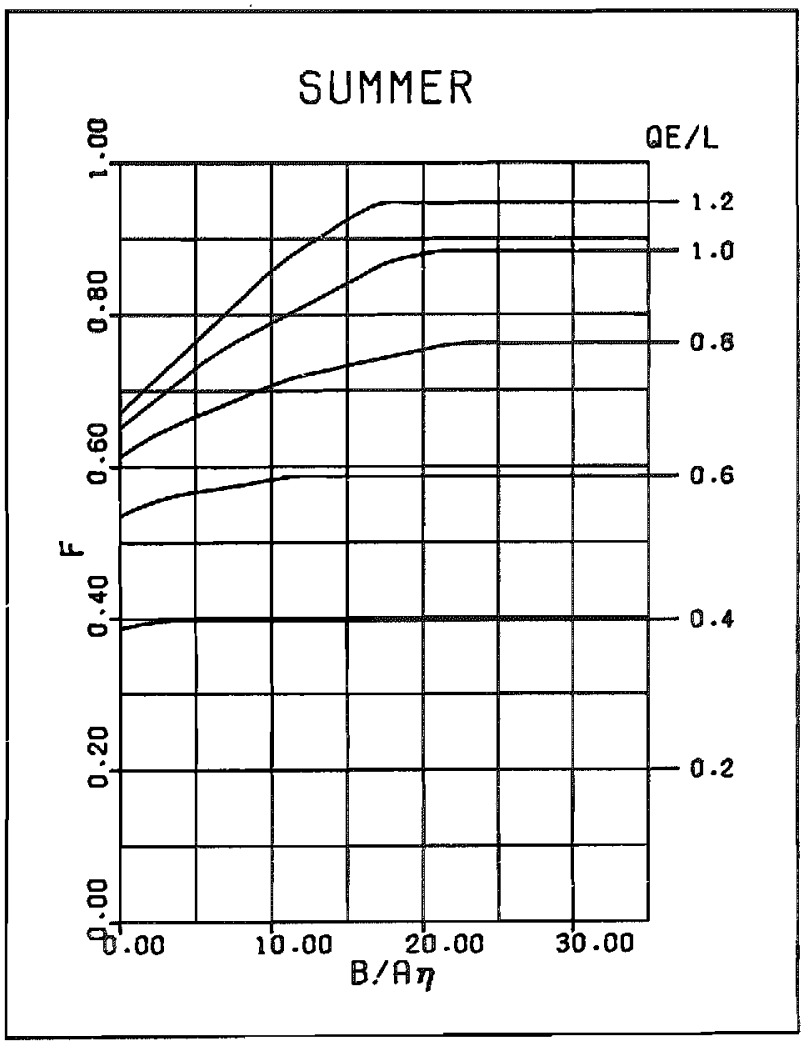




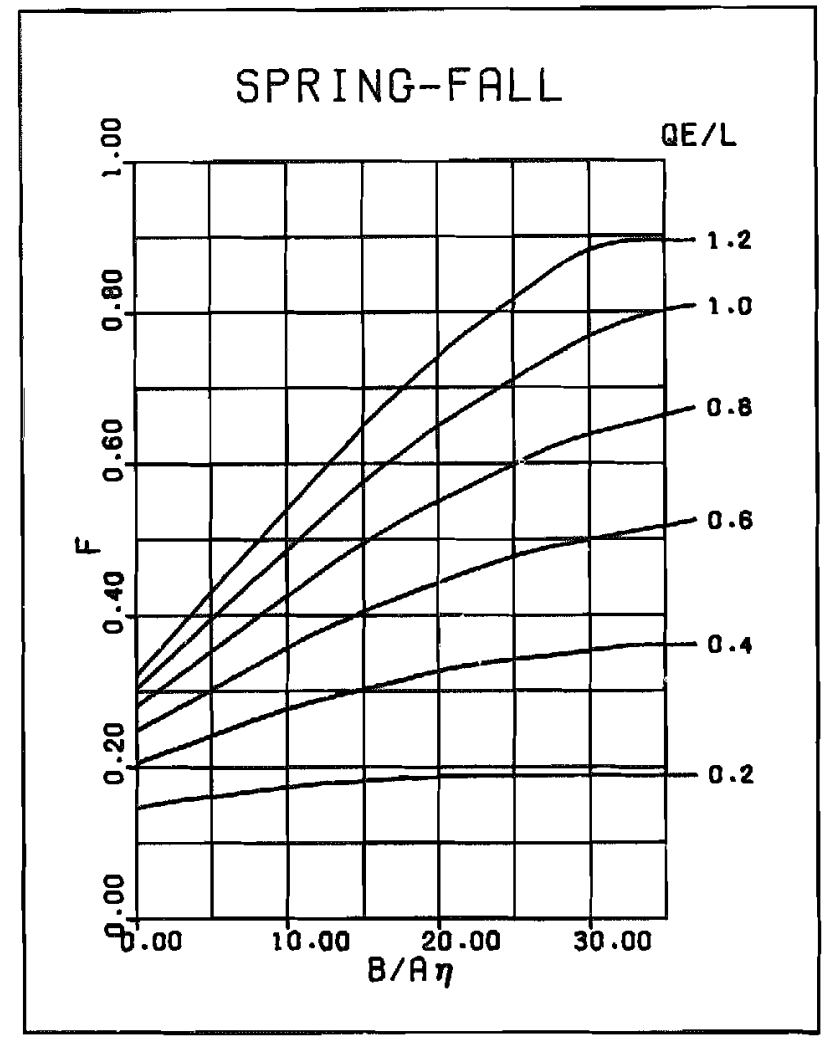

\section{UN I MODAL \#16}

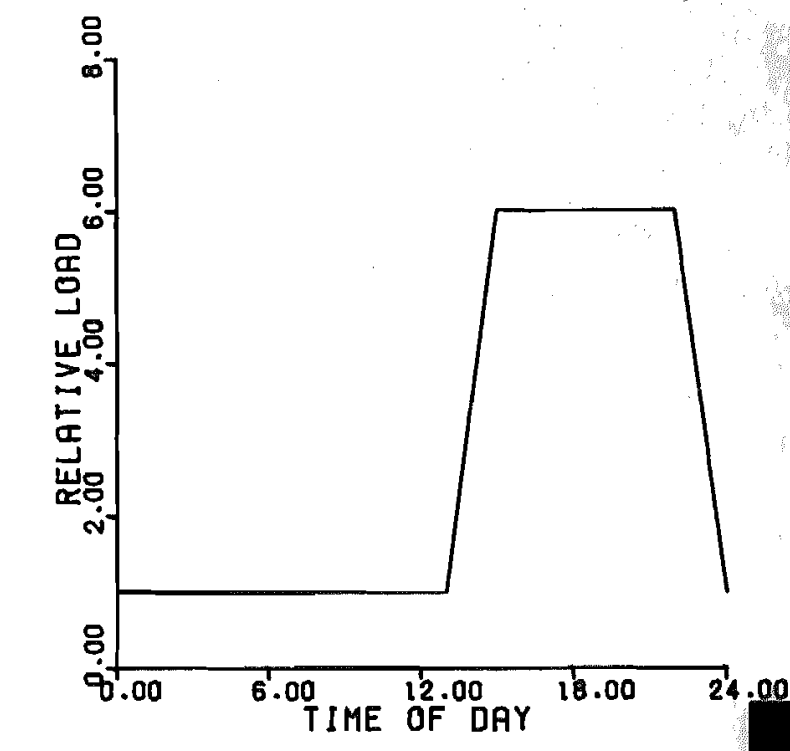

TABLE III SYSTEM PERFORYANCE GRAPHS For Reading Key Soe Page A-63

WINTER

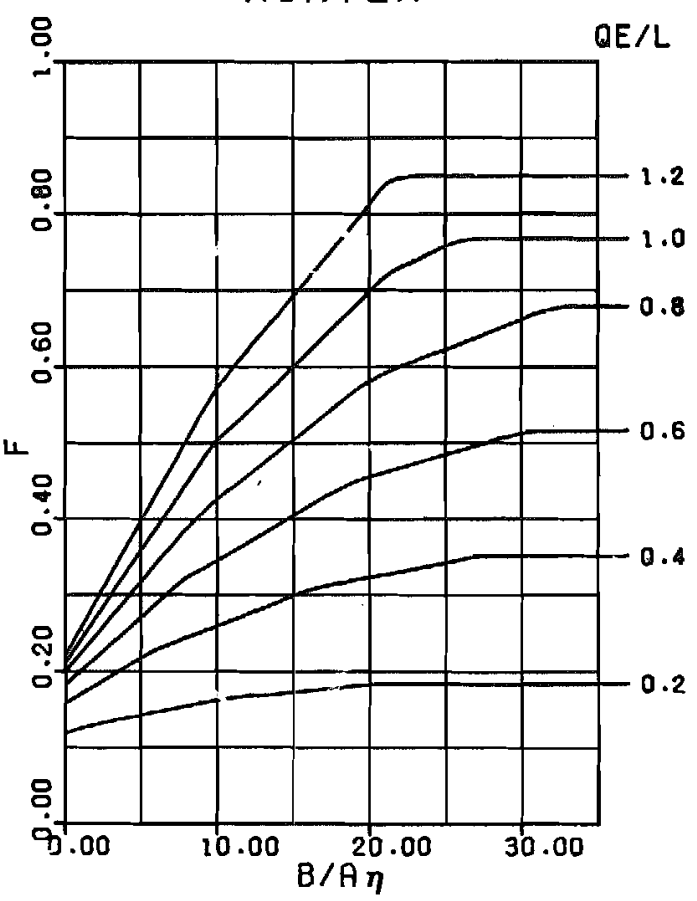


UN I MODAL \#17

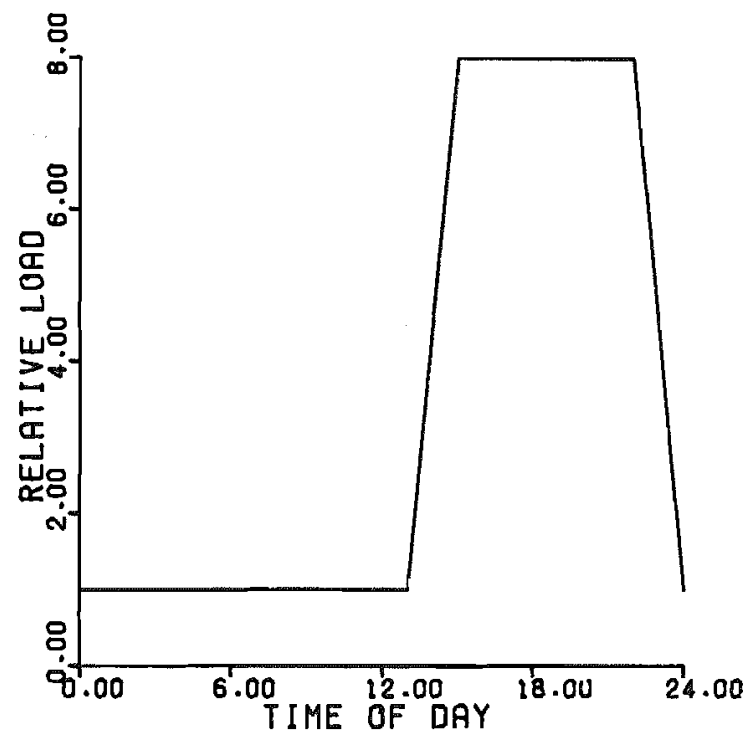

TABLE III SYSTEM PERFORMANCE GRAPHS For Reading Key See Page A-63

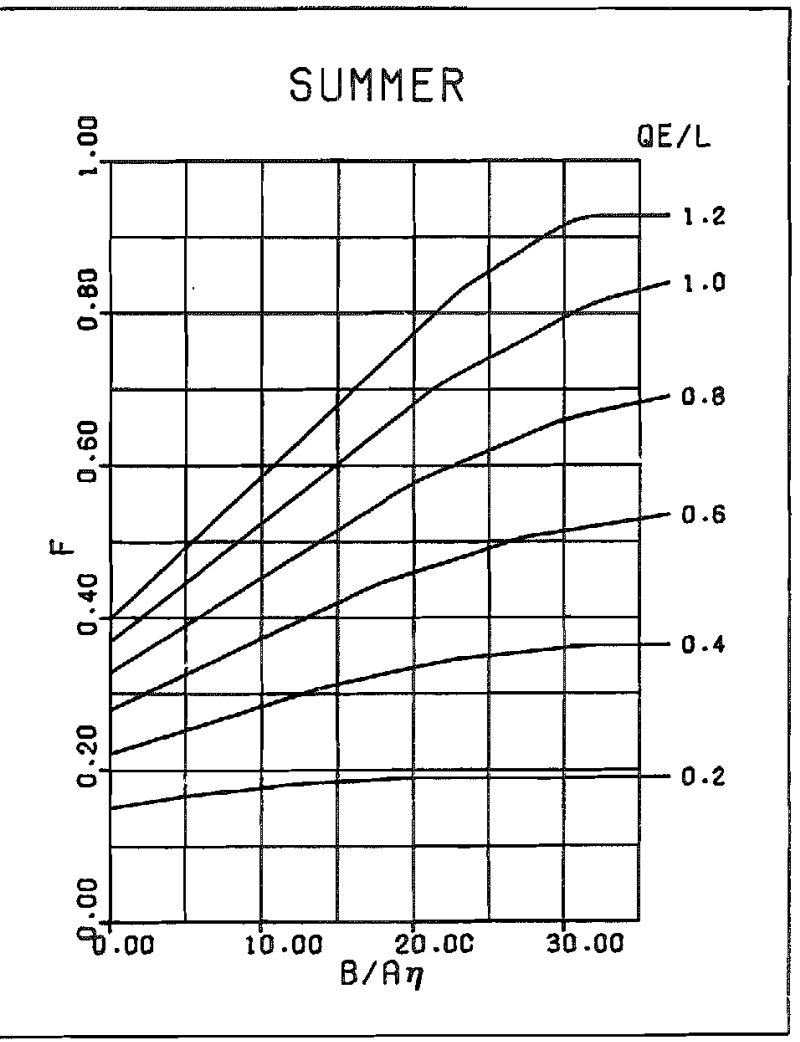

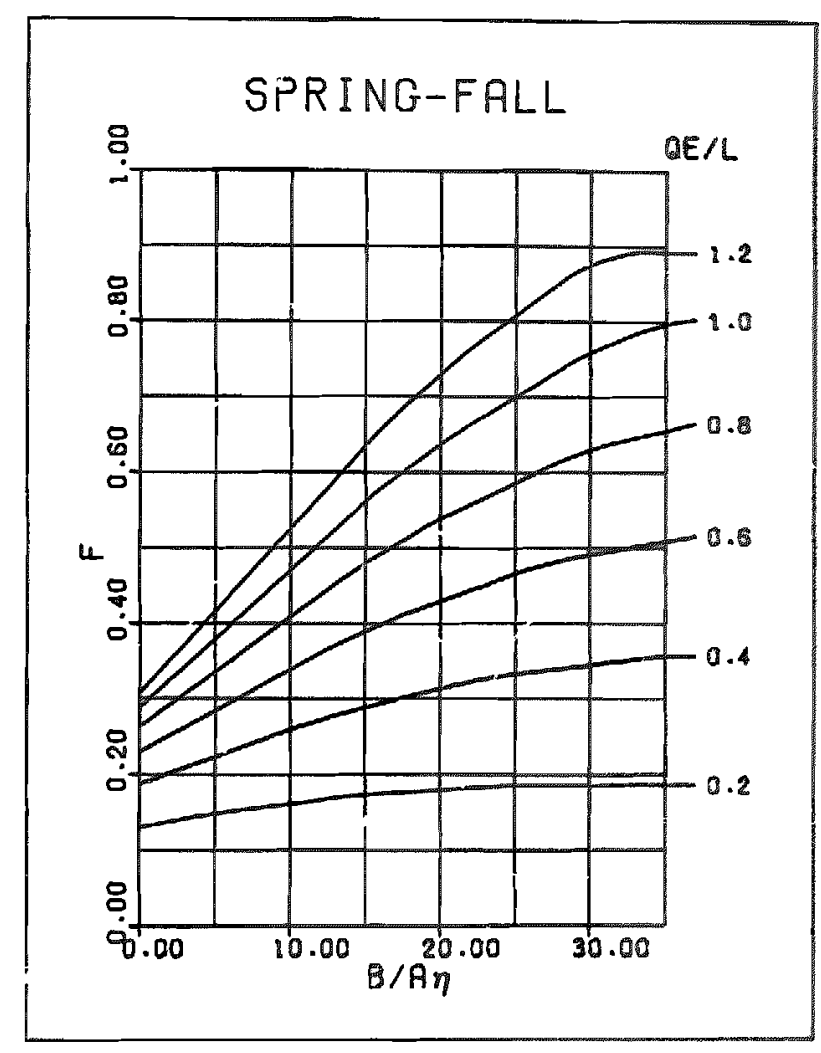

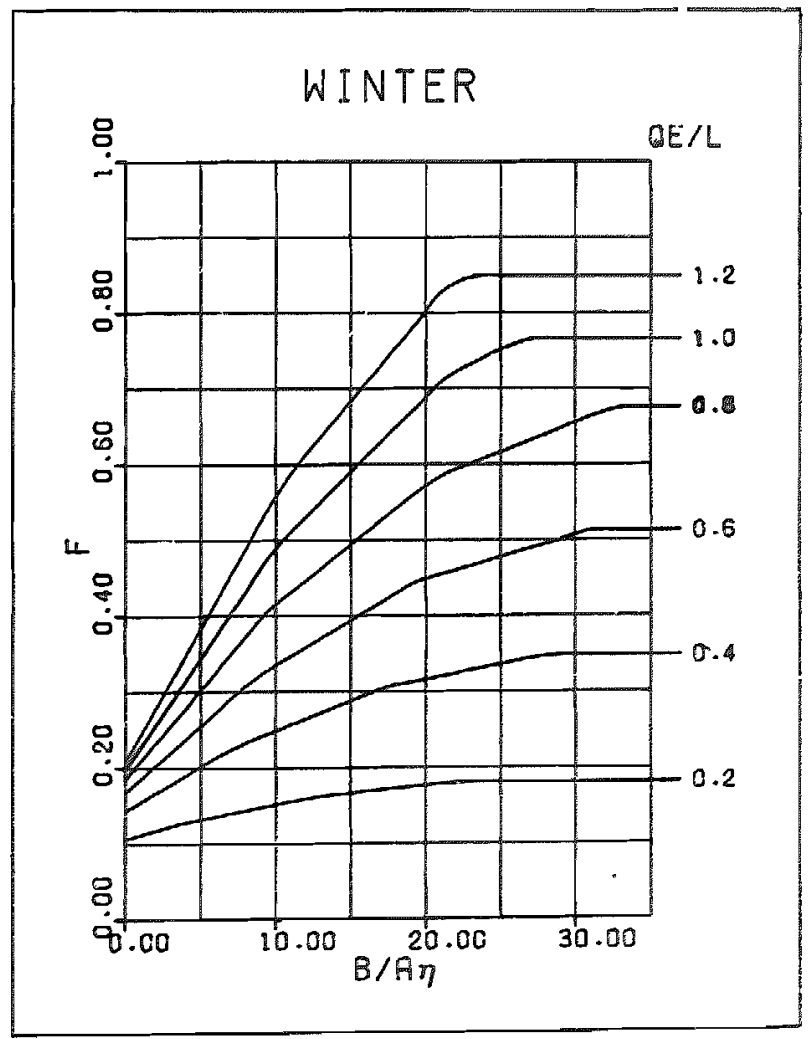



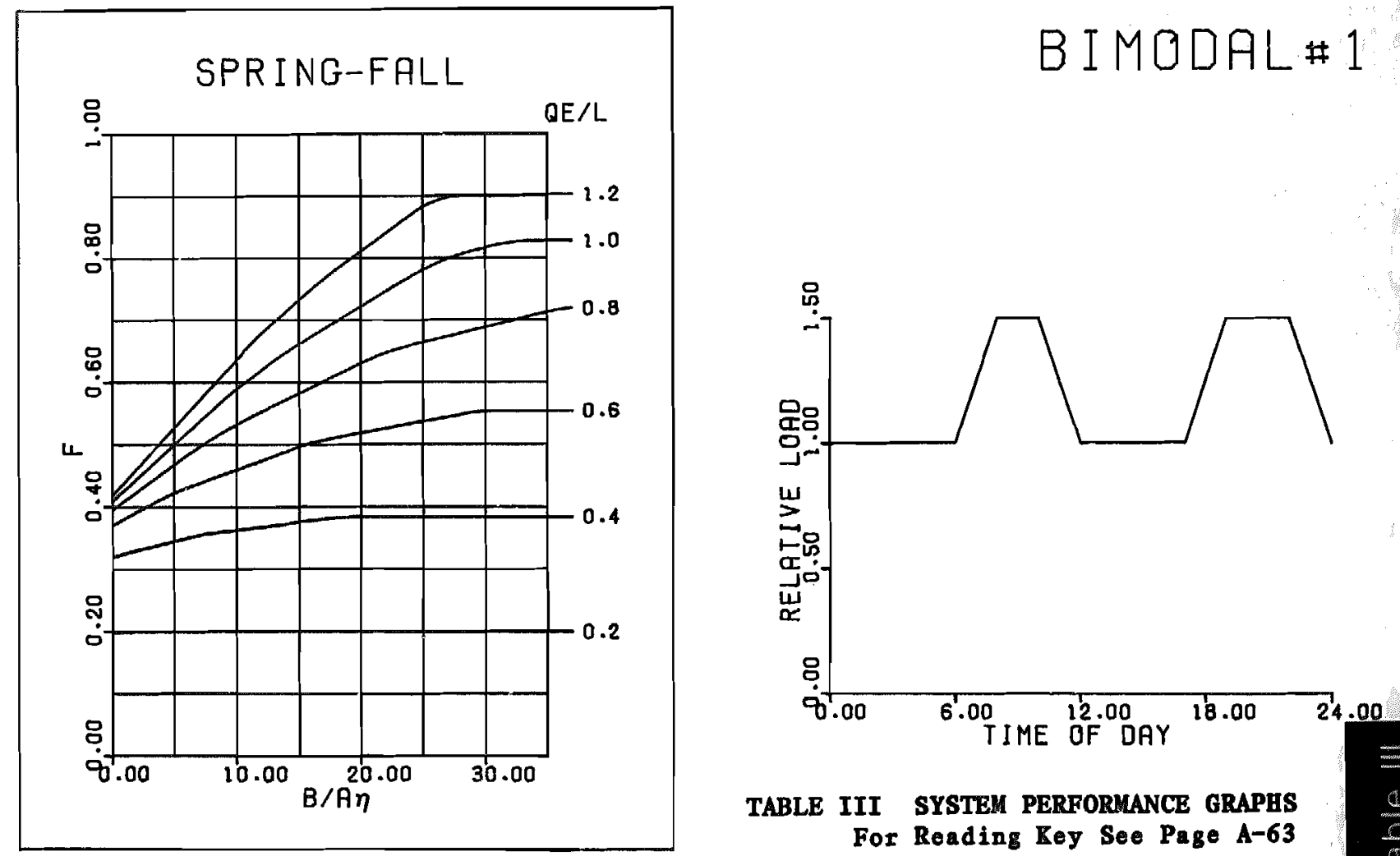

TABLE III SYSTEM PERFORMANCE GRAPHS

For Reading Key See Page A-63
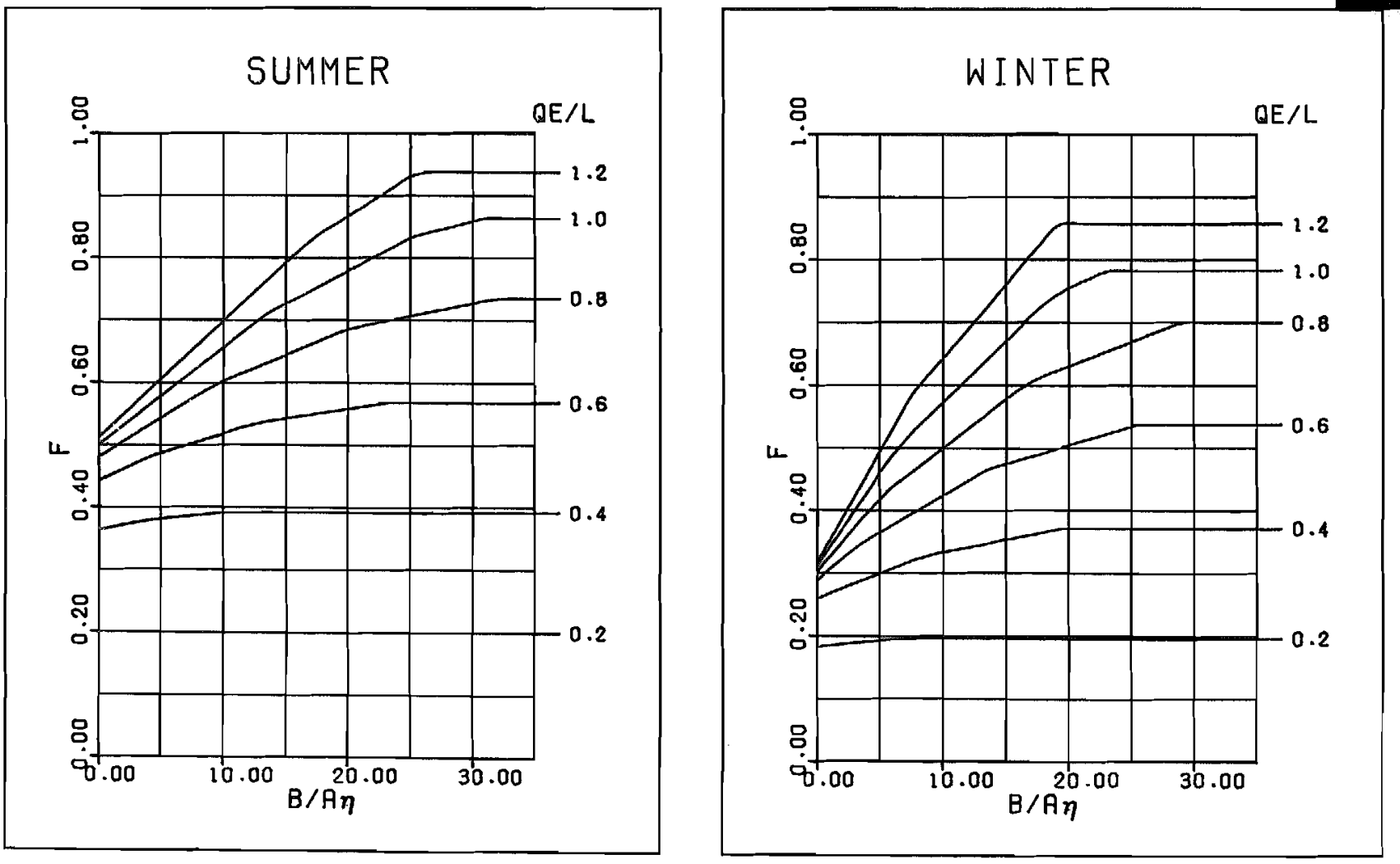
B IMODAL\#2

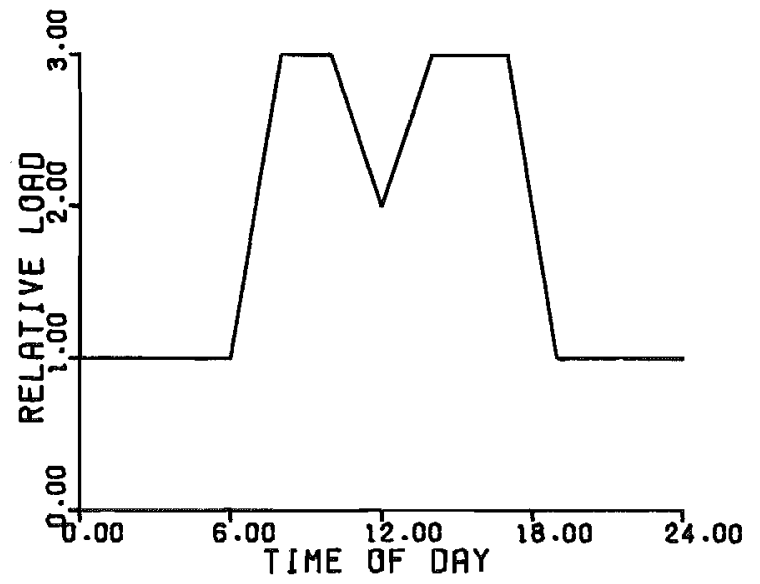

TABLE III SYSTEM PERFORMANCE GRAPHS

For Reading Key See Page A-63

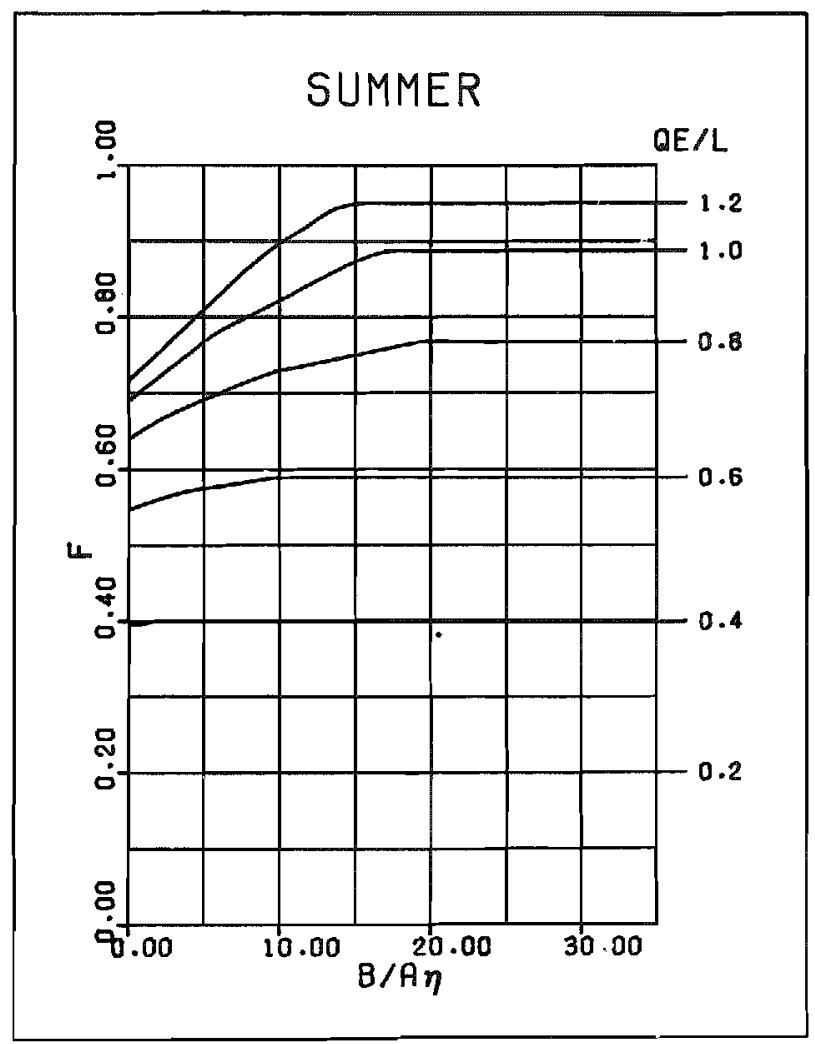

SPR ING-FALL

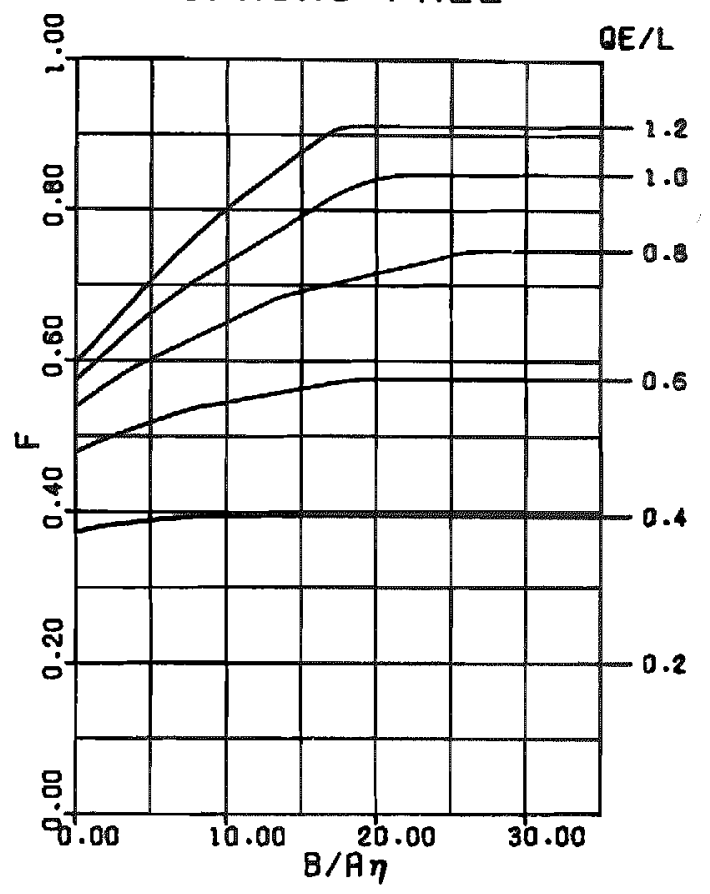

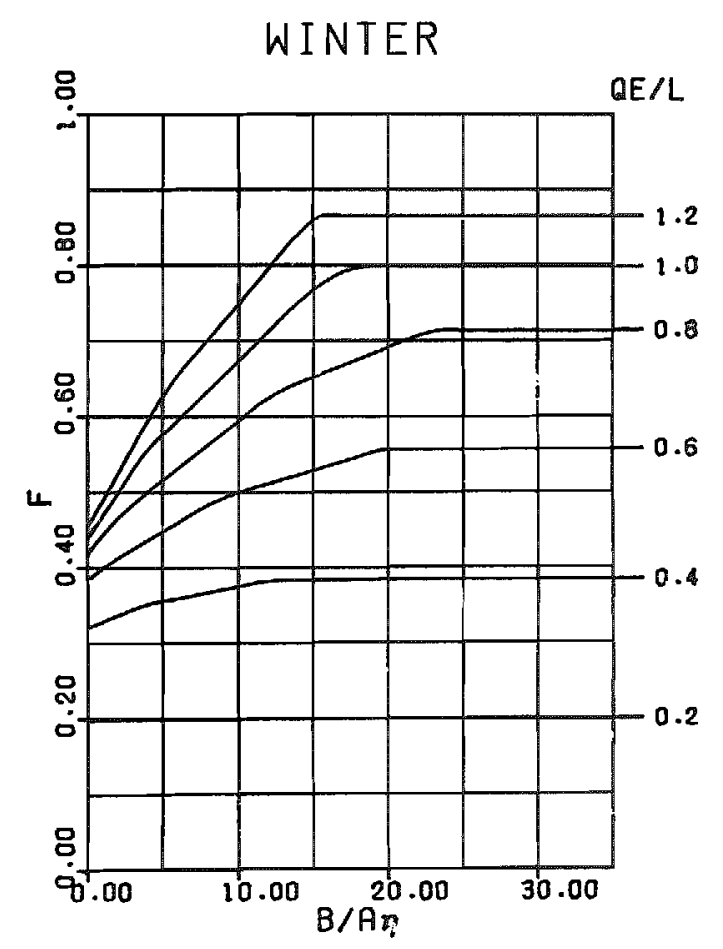



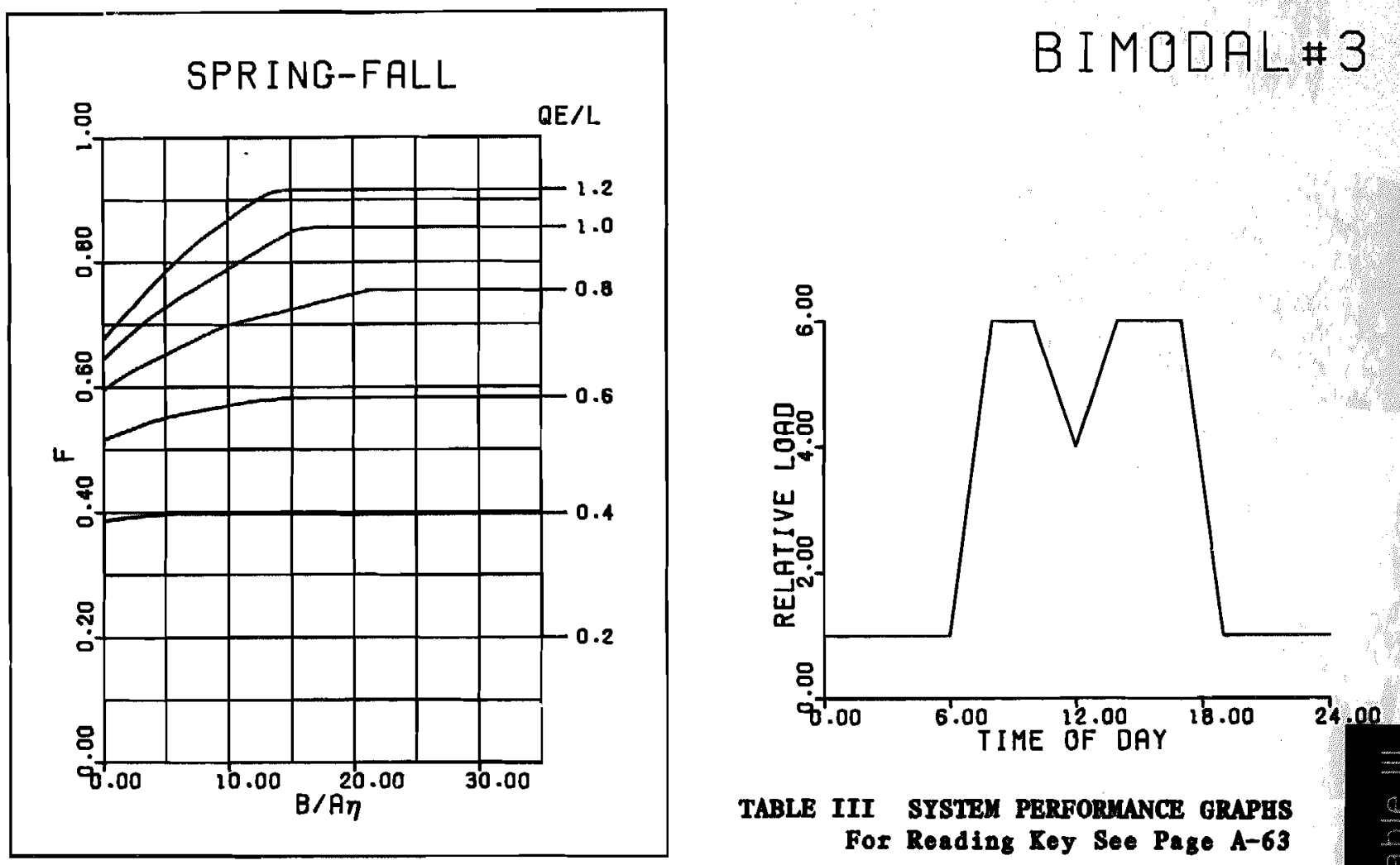

TABLE III SYSTEM PERFORMANCE GRAPHS

For Reading Key See Page A-63
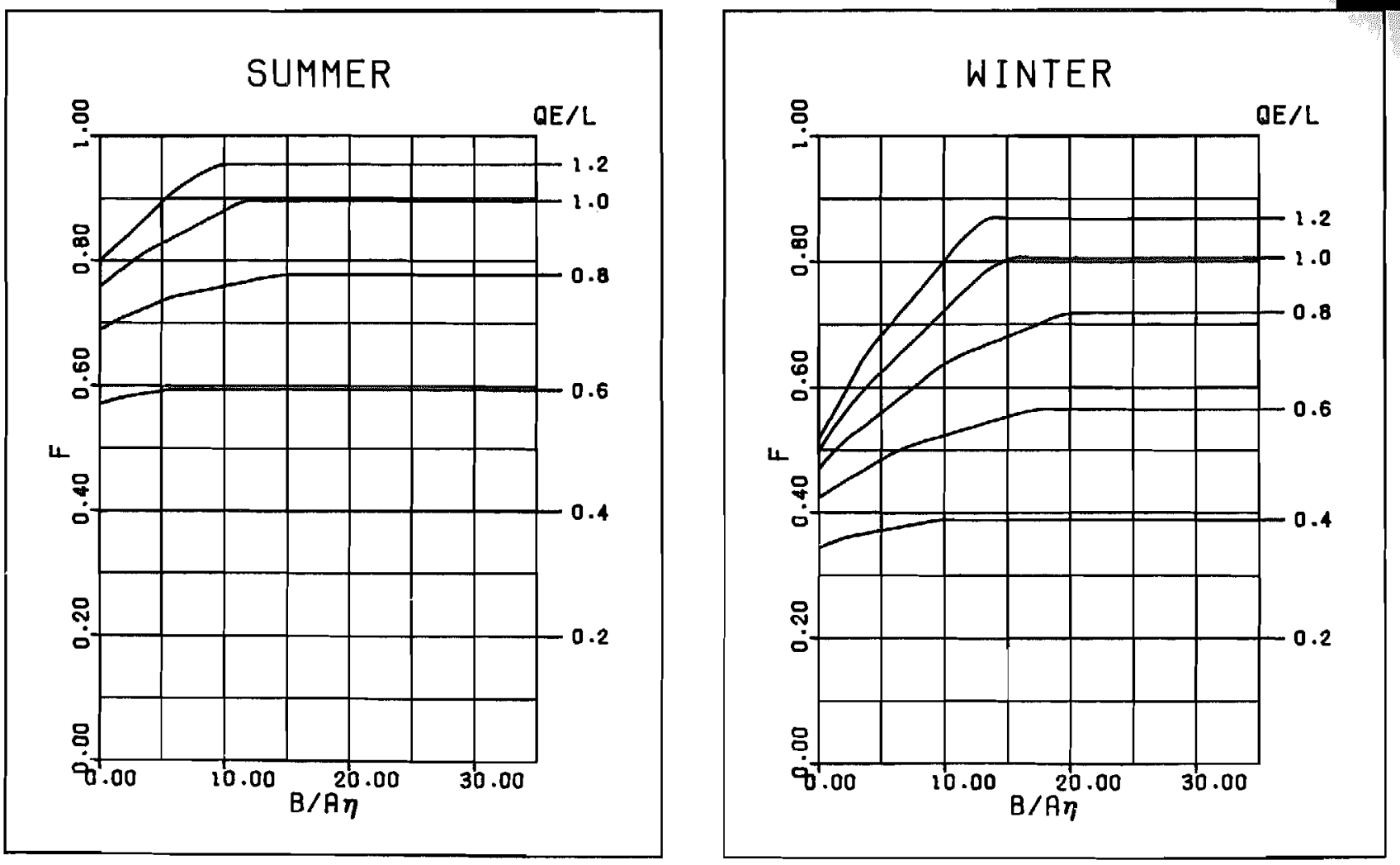
WORESHEET 1

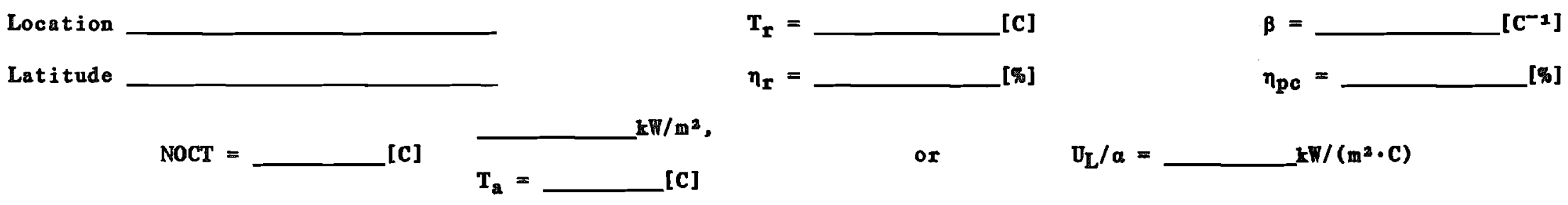

\begin{tabular}{|c|c|c|c|c|c|c|c|c|c|c|}
\hline \multirow[b]{2}{*}{ Month } & $\begin{array}{l}\text { C1 } \\
\text { Ws } \\
{[\mathrm{m} / \mathrm{s}]} \\
\text { from }\end{array}$ & $\begin{array}{c}\text { KT } \\
\text { from }\end{array}$ & $\begin{array}{c}s_{M} \\
\text { from }\end{array}$ & $\frac{C 4}{\text { s }}$ & $=\left|\begin{array}{l}|s-s y| \\
|c 4-c 3|\end{array}\right|$ & $\begin{array}{c}\text { C6 } \\
\underset{T}{T C]} \\
\text { from }\end{array}$ & $\begin{array}{c}\text { C7 } \\
T_{\mathfrak{c}} \\
\text { from }\end{array}$ & $\begin{array}{l}\eta[\$] \\
\text { from }\end{array}$ & $\begin{array}{c}\operatorname{QS} / \mathrm{A} \\
{\left[\mathrm{kWh} / \mathrm{m}^{2}\right]}\end{array}$ & \multirow{2}{*}{$\begin{array}{c}0 \mathrm{E} / \mathrm{A} \\
{\left[\mathrm{kWh} / \mathrm{m}^{2}\right]} \\
\frac{\eta_{\mathrm{pc}}}{\mathrm{Cs} \cdot \mathrm{Cg}} \cdot \frac{\mathrm{Cl}^{2}}{100}\end{array}$} \\
\hline & & & (degrees) & (degrees) & (degrees) & & \multicolumn{3}{|c|}{$\eta_{r}\left[1-\beta\left(C 7-T_{r}\right)\right]$} & \\
\hline JAN & & & & & & & & & & \\
\hline FEB & & & & & & & & & & \\
\hline MAR & & & & & & & & & & \\
\hline APR & & & & & & & & & & \\
\hline MAY & & & & & & & & & & \\
\hline JUN & & & & & & & & & & \\
\hline JUL & & & & & & & & & & \\
\hline AUG & & & & & & & & & & \\
\hline SEP & & & & & & & & & & \\
\hline OCT & & & & & & & & & & \\
\hline Nov & & & & & & & & & & \\
\hline DEC & & & & & & & & & & \\
\hline
\end{tabular}




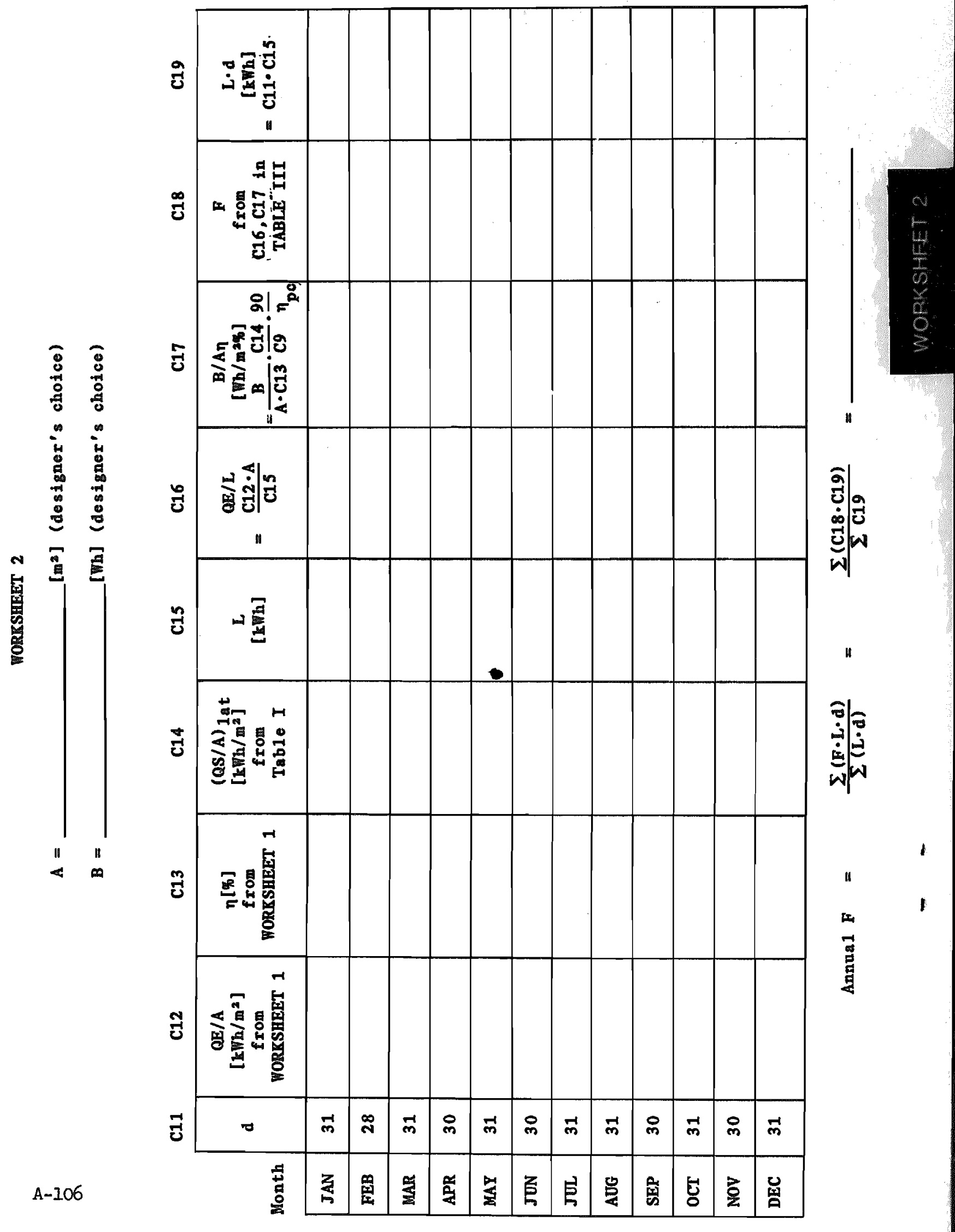


DISTRIBUTION :

TID-4500 R66, UC-63a (304)

Division of Photovoltaic Energy (5)

Systems

U.S. Department of Energy

Washington, DC 20545

Attn: P. D. Maycock, A. S. Clorfeine

A. D. Krantz, L. M. Magid

J. A. Morley

Director, Solar Energy Division

Albuquerque Operations office

U.S. Department of Energy

4710 G. E. Brandvold

4718 E. L. Burgess

4718 K. L. Biringer

4719 D. G. Schueler

(25)

4719 G. J. Jones

8214 P. A. Childers

3141 I. J. Erickson (5)

3151 W. L. Garner (3)

For DOE/TIC (Unlimited Release)

Albuquerque, NM 87115

SERI, Library (2)

1536 Cole Blvd., Bldg. \#4

Golden, CO 80401

Jet Propulsion Laboratory

4800 Oak Grove Drive

Pasadena, CA 91107

Attn: R. Forney, W. Callaghan

R. Powell, R. Ferber

MIT-Lincoln Laboratory

P. O. Box 73

Lexington, MA 02173

Attn: M. Pope

MIT-Energy Laboratory

E40.172

Cambridge, MA 02139

Attn: R. Tabors

The Aerospace Corporation (2)

P.O. Box 92957

Los Angeles, CA 90009

Attn: S. Leonard, B. Siegel

NASA-Lewis Research Center

21000 Brookpark Rd.

Cleveland, OH 44135

Attn: J. Deyo 